\title{
BNL-79252-2007
}

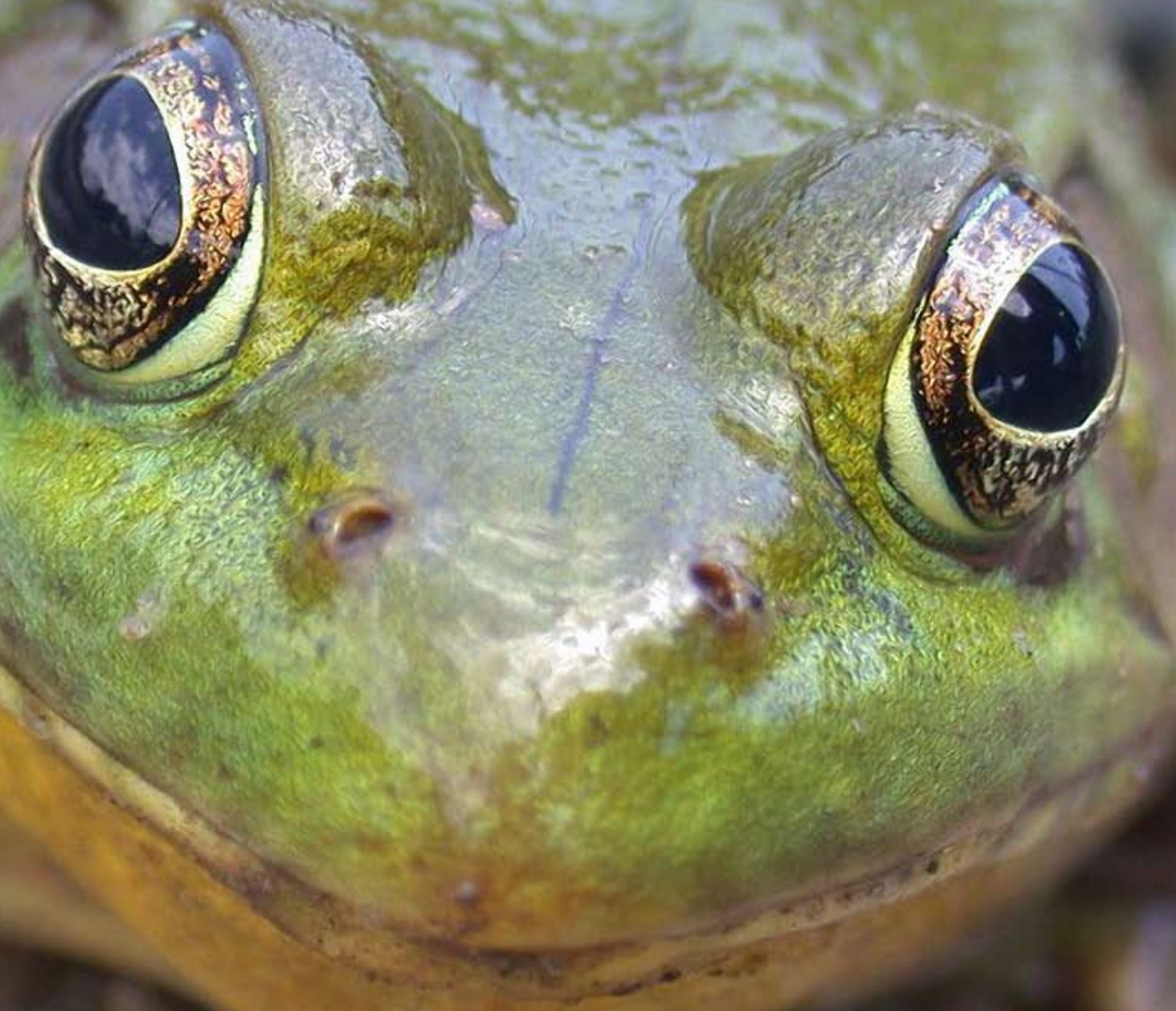

\section{Site Environmental Report}

BROOKHAVEN NATIONAL LABORATORY

Volume I 


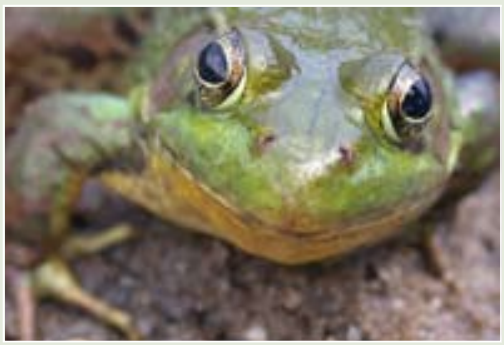

Green frog (Rana clamitans melanota)

\section{ABOUT THE COVER}

The photo on the front cover of the green frog was taken by a student intern working under Dr. Tim Green, BNL's Natural and Cultural Resource Manager. The green frog, wood frog, spring peeper, gray treefrog, and the bullfrog are common species found at $\mathrm{BNL}$ and throughout the Long Island region. The fowler's toad is also commonly found in the area, although numbers have declined in recent years. The pickerel frog, though not as common in all regions of Long Island, is also found at the Laboratory and looks similar to the southern leopard frog.

The southern leopard frog was once regarded as one of the most abundant frog species on Long Island, but has suffered drastic declines over the past 30 to 50 years. They now appear to be extremely rare in this region, if not entirely extinct. Their disappearance has occurred across a variety of landscapes ranging from areas of heavy development to pristine and well-protected natural areas. Many amphibian declines throughout the world today are being linked to global change (e.g. increasing disease outbreaks,

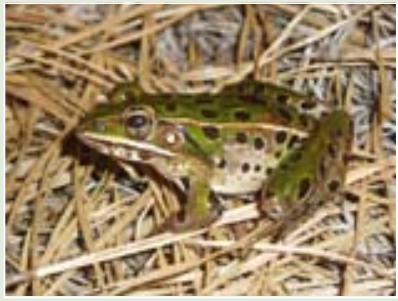

Southern leopard frog

(Rana spehnocephala) invasive species, and contamination).

While working for the U.S. Fish \& Wildlife Services, Jeremy Feinberg gathered three years of baseline information on the southern leopard frog at the Laboratory. He used the information to develop a PhD project at Rutgers University that will test and evaluate the potential negative impacts of four possible negative threats associated with global change and environmental perturbation-disease, contaminants, invasive vegetation, and increased interspecific competition from human subsidized competitors (two closely related frog species). Data will be collected by raising southern leopard frog tadpoles within historic wetland sites on Long Island where the species occurred in the past (including sites at BNL). By using tadpoles as bioindictors within in situ wetland enclosures, he will monitor the development and survivorship of tadpoles and young frogs under various conditions and treatments in an effort to isolate specific causes and trends that may help explain this decline and aid in future amphibian biodiversity conservation.
Gray treefrog (Hyla versicolor)

Fowler's toad (Bufo fowleri)

Pickerel frog (Rana palustris)

Spring peeper (Pseudacris crucifer)

Bullfrog

(Rana catesbeiana)

Wood frog (Rana sylvatica)
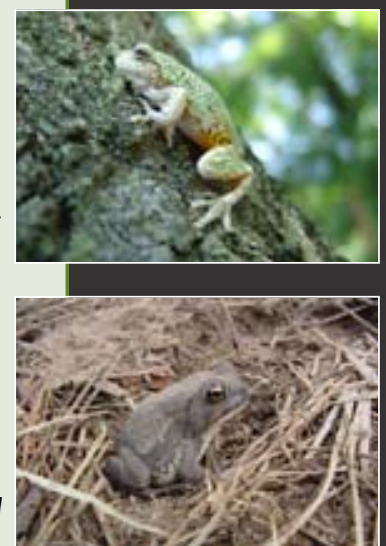

(1)

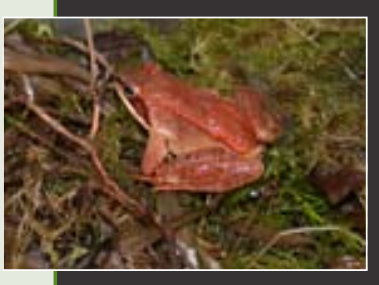

$\mathrm{B}$
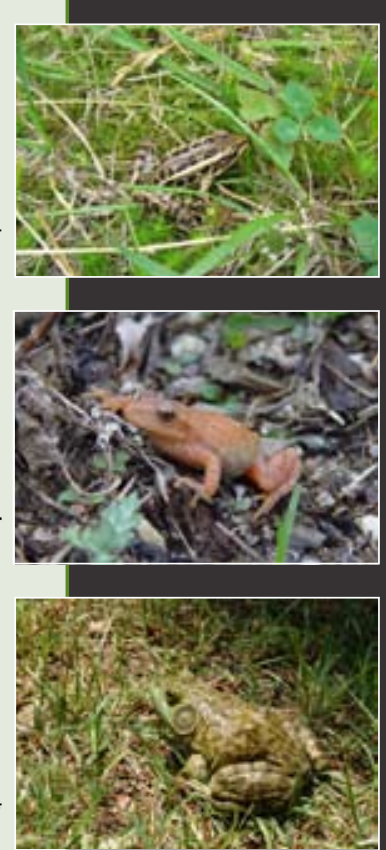

The Brookhaven National Laboratory 2006 Site Environmental Report is a public document that is distributed to various U.S. Department of Energy sites, local libraries, and local regulators and stakeholders. The report is available to the general public on the internet at http://www. bnl. gov/esd/ser.asp. A summary of the report is also available and is accompanied by a compact disk containing the full report. To obtain a copy of the summary and $C D$, please write or call:

Brookhaven National Laboratory

Environmental and Waste Management Services Division

Attention: SER Project Coordinator

Building 120

P.O. Box 5000

Upton, NY I I973-5000

(63I) 344-37II 


\title{
2006
}

\section{Site Environmental Report BROOKHAVEN NATIONAL LABORATORY}

\author{
Volume I
}

October 2007

Prepared by

Brookhaven Science Associates, LLC

For the U.S. Department of Energy

Under Contract No. DE-AC02-98CHI0886

Brookhaven National Laboratory

Brookhaven Science Associates, LLC

P.O. Box 5000

Upton, NY II 1973-5000

EXPLORING EARTH'S MYSTERIES

...PROTECTING ITS FUTURE 


\section{DISCLAIMER}

This report was prepared as an account of work sponsored by an agency of the United States Government. Neither the United States Government nor any agency thereof, nor any of their employees, nor any of their contractors, subcontractors, or their employees, makes any warranty, express or implied, or assumes any legal liability or responsibility for the accuracy, completeness, or usefulness of any information, apparatus, product, or process disclosed, or represents that its use would not infringe on privately owned rights. Reference herein to any specific commercial product, process, or service by trade name, trademark, manufacturer, or otherwise, does not necessarily constitute or imply its endorsement, recommendation, or favoring by the United States Government or any agency, contractor, or subcontractor thereof. The views and opinions of authors expressed herein do not necessarily state or reflect those of the United States Government or any agency, contractor, or subcontractor thereof.

Printed in the United States of America

Available from

National Technical Information Service

U.S. Department of Commerce

5285 Port Royal Road

Springfield, VA 22161

\section{8}

PRINTED ON RECYCLED PAPER 


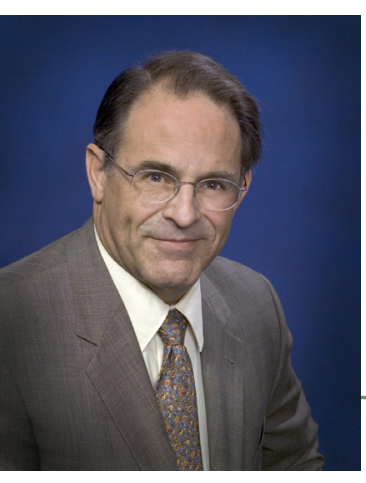

A MESSAGE FROM

THE LABORATORY DIRECTOR

2006 was an exciting year for Brookhaven National Laboratory, and for me as well. In April, I was named Interim Director of the Laboratory, and was fortunate to witness many achievements throughout the year before being named Director that August following a nationwide search. In this new role, I believe the future for scientific research at the Lab looks very bright - with the newly constructed Center for Functional Nanomaterials, the planned National Synchrotron Light Source II project, and proposed enhancements to the Relativistic Heavy Ion Collider, we believe we will have the scientific tools to make some truly special advances in basic and applied science.

Our environmental performance in 2006 continued to be a success. We received three awards from the DOE Office of Science for Best in Class for expanding the envelope of our Environmental Management System through voluntary participation, designing a system to compost animal bedding, and for recycling and reusing waste concrete on site. In addition, BNL was honored with a National Partnership for Environmental Priorities Award for reducing both our mercury waste generation and our inventory of polychlorinated biphenyls. I am proud of these awards, because they show how successful we have been with our pollution prevention and recycling programs.

As we continue to move forward with our scientific enhancements, we also retain our commitment to the environment and our many communities. This book is an annual example of our efforts to remain a good and considerate neighbor whose operations are open and transparent.

Signature on file

Samuel H. Aronson, Laboratory Director 


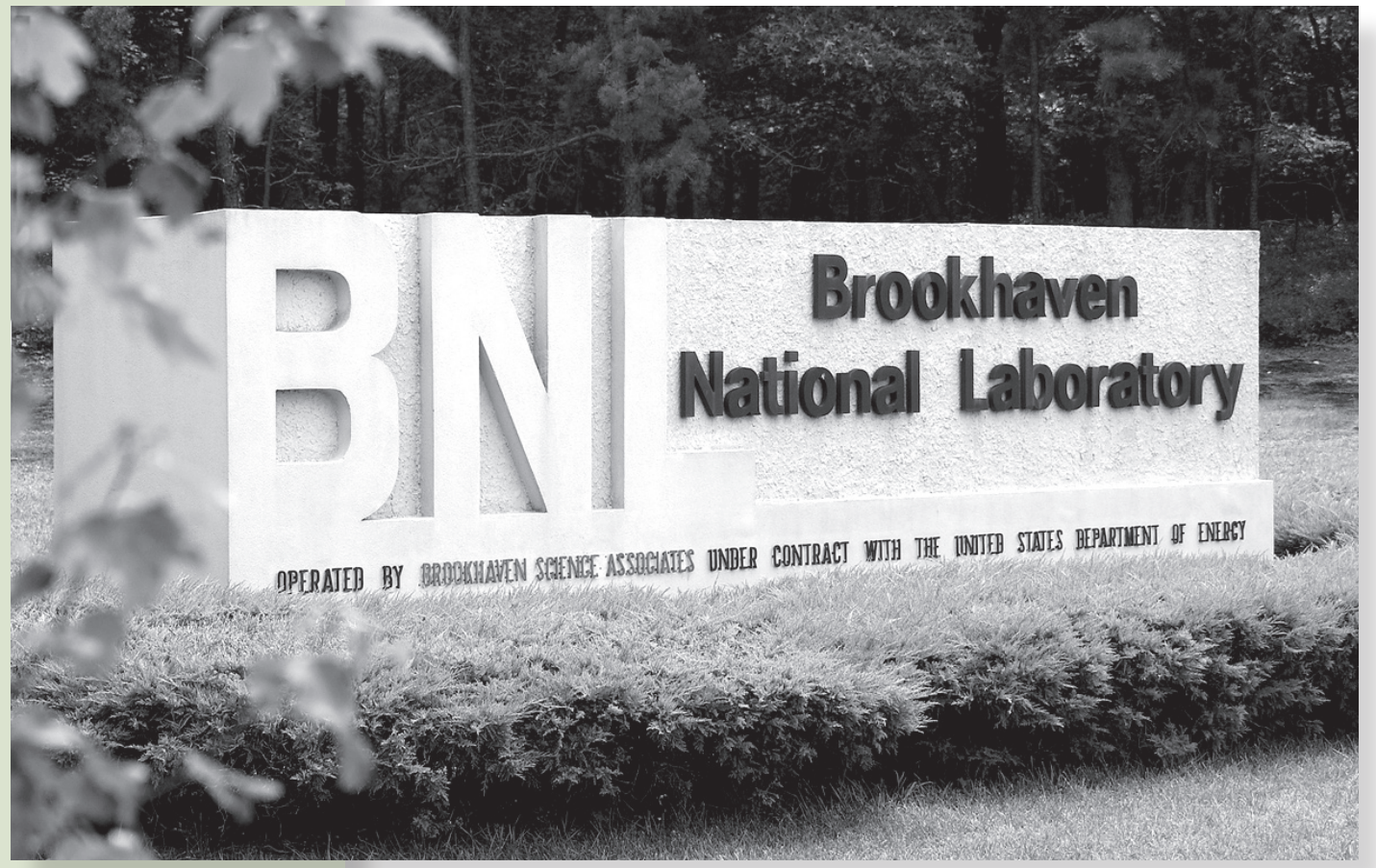

\section{Executive Summary}

Each year, Brookhaven National Laboratory (BNL) prepares an annual Site Environmental Report (SER) in accordance with DOE Order 231.1A, Environment, Safety and Health Reporting of the U.S. Department of Energy. The report is written to inform the public, regulators, employees, and other stakeholders of $B N L$ 's environmental performance during the calendar year in review. The SER summarizes environmental data; environmental management performance; compliance with applicable DOE, federal, state, and local regulations; and compliance, restoration, and surveillance monitoring program performance. BNL has prepared annual SERs since 1971 and has documented nearly all of its environmental history since the Laboratory's inception in 1947.

The report is available in print and as a downloadable file on the BNL web page at http://www.bnl.gov/ewms/serl. A summary of the SER is also prepared each year to provide a general overview of the report, and is distributed with a CD of the full report. 
BNL is operated and managed for DOE's Office of Science by Brookhaven Science Associates (BSA), a nonprofit limited-liability company formed as a 50-50 partnership between Battelle Memorial Institute and The Research Foundation of the State University of New York (SUNY) on behalf of Stony Brook University. For more than 60 years, the Laboratory has played a lead role in the DOE Science and Technology mission and continues to contribute to the DOE missions in Energy Resources, Environmental Quality, and National Security. BNL manages its world-class scientific research with particular sensitivity to environmental issues and community concerns. The Laboratory's motto, "Exploring Life's Mysteries...Protecting its Future," and its Environmental, Safety, Security and Health Policy reflect BNL's management philosophy to fully integrate environmental stewardship into all facets of its missions and operations.

\section{BNL'S INTEGRATED SAFETY MANAGEMENT SYSTEM, ISO I400I, AND OHSAS I800I}

The Laboratory's Integrated Safety Management System (ISMS) integrates environment, safety, and health management into all work planning. The integrated safety processes within ISMS contributed to BNL's Environmental Management System achieving the International Organization for Standardization (ISO) 14001 registration and the Laboratory's Safety and Health Program achieving Occupational Safety and Health Assessment Series (OHSAS) 18001 registration.

One of BNL's highest priorities is ensuring that the Laboratory's environmental performance measures up to its world-class status in science. In 2001, an Environmental Management System (EMS) was established at the Laboratory to ensure that environmental issues are systematically identified, controlled, and monitored. The EMS also provides mechanisms for responding to changing environmental conditions and requirements, reporting on environmental performance, and reinforcing continual environmental improvement. The cornerstone of BNL's EMS is the Laboratory's Environment, Safety, Security, and Health (ESSH) Policy. This policy makes clear BNL's commitments to environmental stewardship, the safety of its employees, and the security of the site. Specific environmental commitments in the policy include compliance, pollution prevention, cleanup, community outreach, and continual improvement. The policy is posted throughout the Laboratory and on the BNL website at http://www.bnl.gov/ESHQ/ESSH.asp and is included in all training programs for new employees, guests, and contractors.

The Laboratory's EMS was designed to meet the rigorous requirements of the globally recognized ISO 14001 Environmental Management Standard. BNL was the first laboratory under the DOE Office of Science to become officially registered to this standard. Annual independent audits, which are required to maintain the registration, are conducted to validate that BNL's EMS is being maintained and to identify evidence of continual improvement. In 2006, an EMS surveillance audit determined that the Laboratory continues to conform to the Standard. During the audit, eight examples of BNL's continual improvement were highlighted, including the Laboratory's commitment to fund pollution prevention and safety projects, improved methods for addressing corrective actions, the use of lessons learned, and management's response to comments and suggestions from employees. There were two minor nonconformances in document control and management review and two opportunities for improvement in "objectives, targets and programs," and "nonconformances." A corrective action plan was prepared to track the minor nonconformances to closure.

The Laboratory's strong Pollution Prevention (P2) Program is an essential element for the successful implementation of BNL's EMS. The P2 Program reflects the national and DOE pollution prevention goals and policies, and represents an ongoing effort to make pollution prevention and waste minimization an integral part of the BNL operating philosophy. Pollution prevention and waste reduction goals have been incorporated into the DOE contract with BSA, into BNL's ESSH Policy, and into critical outcomes associated with the Laboratory's operating contract with DOE. The overall goal of the P2 Program is to create a systems approach that integrates 
pollution prevention and waste minimization, resource conservation, recycling, and affirmative procurement into all planning and decision making. Eighteen P2 proposals were submitted by employees to BNL's P2 Council for funding in 2006. Seven proposals were funded, in addition to four special projects, for a combined investment of approximately $\$ 37,200$. The anticipated annual savings from these projects is estimated at $\$ 74,200$, for an average payback period of less than one year. The four special projects were jointly funded by the P2 Program and other BNL divisions, and significantly limit future environmental and worker safety risks. Initiatives to reduce, recycle, and reuse 13 million pounds of industrial, sanitary, hazardous, and radiological waste through the P2 program saved over $\$ 1.8$ million in 2006.

BNL was accepted into the EPA's Performance Track Program in 2004. This program recognizes top environmental performance among participating U.S. facilities of all types and is considered the "gold standard" for facility-based environmental performance. The program requires that facilities commit to several improvement goals for a 3-year period and report on the progress of these goals annually. In 2006, the Laboratory made significant progress in: increasing BNL's land and habitat conservation, reducing radioactive air emissions, reducing the Laboratory's use of ozone-depleting substances and hazardous materials, and reducing its mercury inventory.

Chapter 2 of this report describes the elements and implementation of BNL's EMS in further detail.

\section{BNL'S ENVIRONMENTAL MANAGEMENT PROGRAM}

BNL's Environmental Management Program consists of several Laboratory-wide and facility-specific environmental monitoring and surveillance programs. These programs identify potential pathways of public and environmental exposure and evaluate the impacts BNL activities may have on the environment. An overview of the Laboratory's environmental programs and a summary of performance for 2006 follows:

\section{Compliance Monitoring Program}

BNL has an extensive program in place to ensure compliance with all applicable environmental regulatory and permit requirements. The Laboratory must comply with more than 100 sets of federal, state, and local environmental regulations, numerous site-specific permits, equivalency permits for the operation of 12 groundwater remediation systems, and several other binding agreements. In 2006, BNL fully complied with the majority of these requirements, and instances of noncompliance were reported to regulatory agencies and corrected expeditiously.

Ten external environmental audits were conducted by regulatory agencies in 2006, including inspections of BNL's potable water system, Sewage Treatment Plant (STP) operations, several State Pollutant Discharge Elimination System (SPDES)-regulated outfalls, Major Petroleum Facility (MPF), Chemical Bulk Storage Facilities, and the hazardous waste program. No formal notices of violation or enforcement actions were issued as a result of these inspections. The Laboratory took immediate corrective actions to address two conditions identified during the New York State Department of Environmental Conservation (NYSDEC) inspection of the MPF. The two conditions that required corrective action included management of vegetative growth in the secondary containment berms at Building 610, and the need to further evaluate the secondary containment system for tanks 5 and 6, based on results of indepth integrity tests performed to ensure that the secondary containment systems will adequately impede the migration of oil in the event of a spill. Two Notices of Violation (NOV) were received in May for excursions of opacity standards reported in 2005. Since corrective actions addressed all future opacity problems, the NOVs were considered closed upon issuance.

Compliance monitoring in 2006 showed that emissions of nitrogen oxides, carbon monoxide, particulate, and sulfur dioxide were all within permit limits. Approximately 132 pounds of ozone-depleting refrigerants were recovered from refrigeration equipment for recycling on site or offered for use by other DOE or federal 
facilities. In addition, one hundred sixteen 17pound and four 13-pound Halon 1211 portable fire extinguishers were removed from service and have been made available to other DOE facilities.

Monitoring of the potable water supply showed that all drinking water quality requirements were met. Groundwater monitoring at the MPF continued to demonstrate that current oil storage and transfer operations are not affecting groundwater quality. With the exception of three minor permit excursions at the STP and one at recharge basins, liquid effluents discharged to surface water and groundwater met all applicable SPDES permit requirements. The three SPDES excursions at the STP included two for total nitrogen, and one for iron. These excursions were investigated by BNL staff, corrected where possible, and reported to NYSDEC and the Suffolk County Department of Health Services (SCDHS). The final excursion at the recharge basin was for non-reporting of oil and grease data for Outfall 002B. The contract analytical laboratory conducting the analysis was unable to report a valid result due to quality control issues.

Efforts to reduce spills continue to be effective. The total number of spills was reduced by 21 percent, from 34 spills in 2005 to 27 in 2006. In addition, reportable spills were reduced by 50 percent, from 14 in 2005 to 7 in 2006 . There were four reportable spills involving very small volumes of ethylene glycol spilled from employee- or Laboratory-owned vehicles, two releases from hydraulic systems on earth-moving equipment, and one spill of diesel fuel from a Fire-Rescue off-road vehicle. All releases were cleaned up or addressed to the satisfaction of NYSDEC.

Chapter 3 of this report describes BNL's Compliance Program and status in further detail.

\section{Air Quality Program}

BNL monitors radioactive emissions at three facilities on site to ensure compliance with the requirements of the Clean Air Act. During 2006, BNL facilities released a total of 4,410 curies of radioactive gases; all with short half-lives of less than 30 minutes. EPA regulations require continuous monitoring of all sources that have the potential to deliver an annual radiation dose greater than 0.1 mrem to a member of the public;all other facilities capable of delivering any radiation dose require periodic confirmatory sampling. Although the dose to the public is less than $0.1 \mathrm{mrem}$ and monitoring is not required by EPA, the Brookhaven Linac Isotope Producer (BLIP) is continuously monitored. Oxygen-15 (half-life: 122 seconds) and carbon-11 (half-life: 20.48 minutes) emitted from the BLIP constituted more than 99.9 percent of radiological air emissions on site in 2006. The combined emissions were approximately 35 percent higher than in 2005 , primarily due to five additional weeks of operation. At BNL, monitoring is conducted at one other active facility, the Target Processing Laboratory (TPL), and one inactive facility, the High Flux Beam Reactor (HFBR). Releases from the TPL in 2006 continued to be very small $(0.0035 \mu \mathrm{Ci})$. Tritium releases from the HFBR in 2006 decreased substantially from releases in 2005 , from $17.9 \mathrm{Ci}$ to $4.03 \mathrm{Ci}$, following the previous downward trend in 2004. An investigation determined that the probable source for the rise in 2005 was the evaporation of residual heavy water through an open drain-tank vent line, which was subsequently closed.

The Laboratory conducts ambient radiological air monitoring to verify local air quality and assess possible environmental and health impacts from BNL operations. Air monitoring stations around the perimeter of the site measure tritium and gross alpha and beta airborne activity. Results for 2006 continued to demonstrate that on-site radiological air quality was consistent with off-site measurements and with results from locations in New York State that are not located near radiological facilities.

Various state and federal regulations governing nonradiological releases require facilities to conduct periodic or continuous emission monitoring to demonstrate compliance with emission limits. The Central Steam Facility (CSF) is the only BNL facility that requires monitoring. Two of the four boilers at the CSF are equipped with continuous emission monitors to measure nitrogen oxide emissions and opacity. In 2006, these monitors measured no periods of excess nitrogen oxide or opacity. 
Because natural gas prices were lower than residual fuel oil prices from June through October in 2006, BNL used natural gas for most heating and cooling needs during these months. As a result, annual facility emissions of particulate matter, nitrogen oxides, and sulfur dioxide were considerably lower than in years when residual fuel oil was predominantly used.

Chapter 4 of this report describes BNL's Air Quality Program and monitoring data in further detail.

\section{Water Quality Surveillance Program}

BNL discharges treated wastewater into the headwaters of the Peconic River via the STP, and non-contact cooling water and storm water runoff to groundwater via recharge basins. Some wastewater may contain very low levels of radiological, organic, or inorganic contaminants. Monitoring, pollution prevention, and careful operation of treatment facilities ensure that these discharges comply with all applicable requirements and that the public, employees, and the environment are protected.

To assess the potential impact of discharges on the water quality of the Peconic River, surface water monitoring is conducted at several locations upstream and downstream of the STP point-source discharge. The Carmans River, located to the west of BNL, is monitored as a geographical control location for comparative purposes, as it is not affected by Laboratory operations. In 2006, the average gross alpha and beta activity levels in the STP discharge were well below drinking water standards. Tritium releases to the Peconic River continued to decline in 2006 and were the lowest ever recorded due to the continued decommissioning and decontaminating at the HFBR. Although tritium was not detected at the influent or effluent for most of 2006, low concentrations were detected in the STP discharge in December. Investigations did not reveal any single source, but did identify several low-concentration sources, which when combined, may have resulted in this slight increase. The maximum concentration of tritium released was approximately 7.5 percent of the drinking water standard. There were no detections of cesium-137 (Cs-137), strontium-90 (Sr-
90), or other gamma-emitting nuclides in the STP effluent.

On-site recharge basins are used for the discharge of "clean" wastewater streams, including once-through cooling water, storm water runoff, and cooling tower blow-down, and are suitable for direct replenishment of the groundwater aquifer. Radiological analyses in 2006 showed that the low levels of gross alpha and beta activity detected in most of the basins were attributable to naturally occurring radionuclides, such as potassium-40, and not to BNL operations. Very low levels of tritium were detected in a single sample collected at one of the recharge basins $(430 \mathrm{pCi} / \mathrm{L})$. Considering the low level of detection and analytical method uncertainties, positive identification of tritium in this sample is questionable.

In 2006, nonradiological analyses of the recharge basins showed low concentrations of volatile organic compounds (VOCs), including disinfection byproducts generated by the use of chlorine for the control of bacteria and algae in cooling water systems. Acetone was also detected above the maximum detection level (MDL) for most recharge basins. Due to the common use of acetone in analytical laboratories and the finding of acetone in the contract analytical laboratory control samples, confirmation of acetone in waste water samples is questionable.

Along the Peconic River, several locations are monitored for radiological and nonradiological parameters to access overall water quality. Radiological data from Peconic River surface water sampling in 2006 showed that, with the exception of a single detection of gross alpha activity at one upstream station, all parameters were less than the detection limit. While single detections of gross beta activity were reported at two downstream stations, average gross beta measurements were indistinguishable from background measurements. Aluminum, copper, iron, and zinc were present at some locations both upstream and downstream of the STP point-source discharge at concentrations that exceeded the NYS Ambient Water Quality Standards. Mercury was found at very low levels in water samples collected downstream of the STP. As part of the follow-up surveillance activi- 
ties for the Peconic River remediation project, mercury concentrations in water samples are being evaluated to determine if the levels impact freshwater organisms. More discussion on mercury in water and sediment samples is found in Chapter 6.

Chapter 5 of this report describes BNL's Water Quality Surveillance Program and monitoring data in further detail.

\section{Natural and Cultural Resource Management Program}

The BNL Natural Resource Management Program was designed to promote stewardship of the natural resources found on site and to integrate natural resource management and protection with BNL's scientific mission. The goals of the program include protecting and monitoring the ecosystem, conducting research, and communicating with the public, stakeholders, and staff members regarding environmental issues. Precautions are taken to protect and enhance habitats and natural resources at the Laboratory. Activities to eliminate or minimize negative effects on sensitive or critical species (such as the eastern tiger salamander, eastern hognose snake, and banded sunfish) are incorporated into BNL procedures or into specific program or project plans. Restoration efforts continue to remove pollutant sources that could contaminate habitats. In some cases, habitats are enhanced to improve survival or increase populations. The Laboratory also monitors and manages other wildlife populations, such as white-tailed deer and wild turkey, to ensure that they are sustained. The Laboratory sponsors a variety of educational and outreach activities involving natural resources. These programs are designed to help participants understand the ecosystem and to foster interest in science.

BNL conducts routine monitoring of flora and fauna to assess the impact, if any, of past and present activities on the Laboratory's natural resources. Generally, deer sampled on site contain higher concentrations of Cs-137 than deer sampled from more than 1 mile off site. This is most likely because on-site deer consume small amounts of contaminated soil and graze on vegetation growing in soil where elevated Cs-137 levels are known to exist. A nine-year trend of on-site and near off-site Cs-137 averages in deer meat showed a statistically significant increase in Cs-137 concentrations in deer meat samples in 2006. The unexplained increase was due to a single sample taken off site along the William Floyd Parkway. While the sample was high compared to samples taken within the recent past, it was still within the historic range of samples taken within the same geographic area. There are no known unremediated sources of Cs-137 in the area. Removal of areas of contaminated soil at BNL began in 2000, and all major areas were remediated by the end of 2005 . The New York State Department of Health (NYS$\mathrm{DOH}$ ) has reviewed the potential public health risk associated with the low levels of Cs-137 in on-site deer and determined that neither hunting restrictions or formal health advisories are warranted. Testing of deer bones for strontium-90 (Sr-90) indicated background levels. BNL will continue to test for Sr-90 in bone to develop baseline information.

In an effort to restore fish populations, the Laboratory suspended most on-site fish sampling in 2001. The reluctance to sample fish continued in 2006, due to impacts of the Peconic River cleanup project and drought conditions in 2005. However, four fish were sampled on site in 2006; although due to the size of the fish, only metals analyses could be performed. Off-site sampling of fish found low levels of Cs137; all levels of Cs-137 appear to be declining, compared with historic values. Cleanup of both on- and off-site portions of the Peconic River in 2004 and 2005 removed approximately 88 percent of Cs-137 in the sediment, and further decreases in Cs-137, as well as mercury, are expected. Low levels of mercury and pesticides were also detected in off-site fish samples, but did not exceed any standards and do not present a health impact to consumers of such fish. Onand off-site aquatic vegetation and sediments contained low levels of Cs-137, metals, pesticides, and PCBs, in amounts that were consistent with levels detected in previous years.

Under the Peconic River remediation project, sediment from the Peconic River was remediated to remove mercury and associated contami- 
nants from the river. This project was completed in the summer of 2005. Sampling results for 2006 showed that 93 percent of samples analyzed at 16 on-site locations and 14 off-site locations met the cleanup goals of $2.0 \mathrm{mg} / \mathrm{kg}$. Two samples exceeded the goal and another was close to exceeding the goal. Additional samples were collected at these locations which confirmed that mercury levels in this area of the Peconic River exceeded the clean-up goal. Additional sampling procedures to characterize the nature and extent of contamination were prepared for implementation in 2007.

Water column sampling for mercury and methyl mercury was performed at 20 Peconic River sampling locations and one reference location on the Connetquot River. Levels were less than 2005 values upstream of Schultz Road, but generally higher than 2004 values down stream of Schultz Road. Effluent from the STP is a potential low-level mercury source that may be contributing to elevated mercury concentrations in these locations. Additional surface water monitoring and monitoring of the STP effluent will be conducted to evaluate its potential contribution.

Wetland monitoring results showed that vegetation restoration along the Peconic River was at 92 percent over 64 monitoring transects with less than 1 percent coverage of invasive species. Monitoring of invasive species will continue until 2008.

In 2006, the Foundation for Ecological Research in the Northeast (FERN) conducted its second year of monitoring under the Forest Health Monitoring program established for the Long Island Pine Barrens. This program was developed to assess the health of the various forest types within the Pine Barrens. Planning for freshwater wetlands monitoring was also initiated.

The goal of BNL's Cultural Resource Management Program (CRMP) is to ensure the proper stewardship of BNL and DOE historic resources. Additional goals include maintaining compliance with various historic preservation and archeological laws and regulations, and ensuring the availability of resources to Laboratory personnel and the public for research and interpretation. In 2006, a National Historic Preservation Act (NHPA) Section 106 review determined that none of Camp Upton era structures remaining on site were eligible for listing on the National Register for Historic Places. A NHPA Section 106 Determination of Effects was performed to address decommissioning of the HFBR, and it was determined that the action would have "Adverse Effects" for its historical status. Also in 2006, an archaeological survey of the National Synchrotron Light Source-II was performed; no further investigations were recommended.

\section{Groundwater Protection Management Program}

BNL's extensive groundwater monitoring well network is used to evaluate progress in restoring groundwater quality, to comply with regulatory permit requirements, and to monitor active research and support facilities. In 2006, the Laboratory collected groundwater samples from 852 on- and off-site monitoring wells during 2,337 individual sampling events. BNL has not detected any new impacts to groundwater quality since 2001 .

Under the environmental surveillance program, 125 groundwater wells at 10 active research and support facilities were monitored during 240 individual sampling events. Although no new impacts to groundwater quality were discovered in 2006, groundwater quality continues to be impacted from past releases at four facilities. Tritium continues to be routinely detected at concentrations above the 20,000 $\mathrm{pCi} / \mathrm{L}$ drinking water standard (DWS) in wells immediately downgradient of the g-2 source area in the Alternating Gradient Synchrotron (AGS) facility, although tritium concentrations have shown a steady decline over the past three years. In January 2006, tritium concentrations exceeded the $20,000 \mathrm{pCi} / \mathrm{L}$ DWS in one well immediately downgradient of BLIP. However, tritium concentrations at BLIP declined to less than the DWS limit for the remainder of the year. Monitoring data suggest that the continued release of tritium from these areas is due to residual tritium being flushed out of the unsaturated zone close to the water table by natural water table fluctuations. The amount of tritium 
available to be flushed out of the deep soils appears to be declining.

As in previous years, VOCs associated with historical petroleum and solvent spills were detected in several monitoring wells directly downgradient of the Motor Pool and Service Station areas. Monitoring of the leak detection systems at both vehicle maintenance facilities indicated that gasoline storage tanks and associated distribution lines were not leaking. Furthermore, BNL's ongoing evaluation of vehicle maintenance operations indicated that all waste oils and used solvents are being properly stored and recycled.

Under the Environmental Restoration Program, on- and off-site contaminant plumes are monitored to track the progress that the groundwater treatment systems are making toward plume remediation. In 2006, 727 groundwater wells were monitored during 2,097 individual sampling events. The Laboratory's groundwater cleanup goals include minimizing plume growth and reducing contaminant concentrations in the Upper Glacial aquifer to below Maximum Contaminant Level (MCL) standards by 2030. For the Sr-90 plumes associated with the Brookhaven Graphite Research Reactor/Waste Concentration Facility MCLs must be reached within 70 years and for the Chemical/Animal Holes area MCLs must be reached within 40 years. VOC levels in the Magothy aquifer must meet MCLs within 65 years. The cleanup objectives will be met by a combination of active treatment and natural attenuation.

The Laboratory continues to make significant progress in restoring groundwater quality on site, with 13 groundwater remediation systems in active operation. During 2006, 372 pounds of VOCs and $5.3 \mathrm{mCi}$ of $\mathrm{Sr}-90$ were removed from the groundwater, and more than 1.5 billion gallons of treated groundwater were returned to the aquifer. To date, approximately 5,592 pounds of VOCs have been removed from the aquifer.

Significant issues associated with the restoration program during 2006 were:

- The Operable Unit (OU) III Record of Decision (ROD) contingency of $20,000 \mathrm{pCi} / \mathrm{L}$ for the HFBR Tritium Plume at Weaver Dive was triggered when tritium was de- tected at $21,000 \mathrm{pCi} / \mathrm{L}$ in a temporary well. A new extraction well will be in operation to treat this area of the plume by the third quarter of 2007.

- Due to the continued presence of high levels of VOCs in the groundwater following three injections of potassium permanganate used to treat the Building 96 source area from December 3004 through January 2006, it appears that additional remedial action will be required in order to meet the cleanup goals. An engineering study to evaluate possible remedial alternatives will be completed by the end of 2007, and one of the existing extraction wells will be restarted to maintain hydraulic control of groundwater contamination in the source area.

- Continued characterization of the downgradient portions of the Chemical/Animal Holes Sr-90 plume indicated that additional extraction wells are needed in order to achieve the cleanup goals specified in the OU III ROD. Two new wells will be operational by the end of 2007.

- Elevated levels of VOCs were observed in one of the western perimeter wells for the Airport treatment system. Based upon additional groundwater characterization of the plume in this area, an additional extraction well will be installed to allow for complete capture of the plume. The new extraction well will be operational by the third quarter of 2007.

- Two of the OU III South Boundary treatment system extraction wells will be placed in standby mode due to consistently low VOC concentrations in these wells. Combined with the two extraction wells previously placed in standby mode, only three of the seven South Boundary extraction wells remain in full-time operation. All wells placed in standby mode continue to be monitored on a quarterly basis and re-started should VOC concentrations rebound.

- Based upon consistently low VOC concentrations in the Industrial Park treatment system area (with concentrations less than the capture goal of $50 \mathrm{ug} / \mathrm{L}$ total VOCs [TVOCs]), pulse pumping of the system 
will begin in 2007, and one of the treatment wells will be placed in standby mode. Only five of the seven Industrial Park treatment wells will remain in full-time operation.

- Based upon consistently low VOC concentrations in two of the Long Island Power Authority (LIPA) treatment system extraction wells and nearby monitoring wells (with concentrations less than the capture goal of $50 \mathrm{ug} / \mathrm{L} \mathrm{TVOCs),} \mathrm{the} \mathrm{two} \mathrm{extrac-}$ tion wells will be placed in standby mode in 2007.

Chapter 7 of this report provides an overview of this program, and the SER Volume II, Groundwater Status Report, provides a detailed description, data, and maps relating to all groundwater monitoring performed in 2006.

\section{Radiological Dose Assessment Program}

BNL routinely assesses its operations to ensure that any potential radiological dose to members of the public, BNL workers, and the environment is "As Low As Reasonably Achievable" (ALARA). The potential radiological dose is calculated as the largest possible dose to a hypothetical Maximally Exposed Individual (MEI) at the BNL site boundary. For dose assessment purposes, the pathways include direct radiation exposure, inhalation, ingestion, immersion, and skin absorption. Radiological dose assessments at the Laboratory have consistently shown that the "effective dose equivalent" from operations is well below the EPA and DOE regulatory dose limits for the public and the environment. The dose impact from all BNL activities in 2006 was found to be insignificantly above natural background radiation levels.

To measure direct radiation from Laboratory operations, thermoluminescent dosimeters (TLDs) are placed on site and in surrounding communities. In 2006, the average doses for all TLDs showed there was no additional contribution to dose from BNL operations above natural background radiation. The annual on-site external dose from all potential sources, including cosmic and terrestrial radiation, was $68 \pm 11$ mrem $(680 \pm 110 \mu \mathrm{Sv})$, and the annual off-site external dose was $63 \pm 9$ mrem $(630 \pm 90 \mu \mathrm{Sv})$.
The effective dose to the MEI from air emissions was $8.14 \mathrm{E}-2 \mathrm{mrem}(0.81 \mu \mathrm{Sv})$. The ingestion pathway dose was estimated as $2.96 \mathrm{mrem}$ $(30 \mu \mathrm{Sv})$ from consumption of deer meat and $0.07 \mathrm{mrem}(0.7 \mu \mathrm{Sv})$ from consumption of fish caught on site. The total annual dose to the MEI from all pathways was estimated as $3.11 \mathrm{mrem}$ $(31 \mu \mathrm{Sv})$. The dose from the air inhalation pathway attributable to BNL operations was less than 1 percent of EPA's annual regulatory dose limit of $10 \mathrm{mrem}(100 \mu \mathrm{Sv})$, and the total dose was less than 4 percent of DOE's annual dose limit of 100 mrem $(1,000 \mu \mathrm{Sv})$ from all pathways. Doses to aquatic and terrestrial biota were also evaluated and found to be well below the regulatory limits.

As a part of the National Emission Standards for Hazardous Air Pollutants (NESHAPs) review process at $\mathrm{BNL}$, any source that has the potential to emit radioactive materials is evaluated for regulatory compliance. In 2006, several NESHAPs compliance reviews were performed, including decontamination activities from removal of the Brookhaven Graphite Research Reactor (BGRR) belowground duct (BGD) liner; a dose assessment to evaluate the potential dose impact (in this case, a firefighter) in the event of an accidental fire at the former Hazardous Waste Management Facility (HWMF); continued decommissioning activities at the HFBR; and a pre-NESHAPS evaluation for emissions of radiological gases from the newly proposed National Synchrotron Light Source-II. All assessments showed there to be no significant dose impacts from these activities.

Chapter 8 of this report describes the BNL Radiological Dose Assessment Program and monitoring data in further detail.

\section{Quality Assurance Program}

The multilayered components of the BNL Quality Assurance (QA) Program ensure that all analytical data reported in this document are reliable and of high quality, and that all environmental monitoring data meet quality assurance and quality control objectives. Samples are collected and analyzed in accordance with EPA methods and standard operating proce- 
dures that are designed to ensure samples are representative and the resulting data are reliable and defensible. Quality control in the analytical laboratories is maintained through daily instrument calibrations, efficiency and background checks, and testing for precision and accuracy. Data are verified and validated as required by project-specific quality objectives before being used to support decision making.

In 2006, the Laboratory used five off-site contract analytical laboratories to analyze environmental samples: General Engineering Lab (GEL), H2M Lab, Severn-Trent Lab (STL), Chemtex Lab, and Brooks Rand. All analytical laboratories were certified by New York State for the tests they performed for BNL, and were subject to oversight that included state and national performance evaluation (PE) testing, review of QA programs, and audits.

Four of the contract analytical laboratories participated in several national and state PE testing programs in 2006. Results of the tests provide information on the quality of a laboratory's analytical capabilities. Testing was conducted by Environmental Resource Associates (ERA), the National Voluntary Laboratory Accreditation Program (NVLAP), the voluntary Mixed Analyte Performance Evaluation Program (MAPEP), and New York State Department of Health (NYSDOH) Environmental Laboratory Accreditation Program (ELAP). GEL and STL participated in the ERA radiological program; 95.7 percent of GEL's tests were in the acceptable range, and 92.9 percent of STL's tests were in the acceptable range. GEL also participated in the MAPEP evaluations; 88.1 percent of GEL's tests on radiological samples were in the acceptable range and 6.7 percent were in the warning (but acceptable range).
H2M and GEL participated in the NYSDOH ELAP evaluations of performance on tests of nonpotable water, potable water, and solid wastes. NYSDOH found 98.1 percent of H2M's nonradiological tests to be in the acceptable range and 92.1 percent of GEL's nonradiological tests to be in the acceptable range.

Also in 2006, H2M, STL, and GEL voluntarily participated in the ERA water supply and water pollution studies, although this evaluation is not required for New York State certification. ERA found that 96.2 percent of H2M's tests were in the acceptable range, 94.7 percent of STL's tests were in the acceptable range, and 95.1 percent of GEL's tests were in the acceptable range. GEL also voluntarily participated in MAPEP evaluations. These evaluations showed that 98.8 percent of GEL's nonradiological tests were in the acceptable range. $\mathrm{H} 2 \mathrm{M}$ also voluntarily participated in NIST-NVLAP evaluations. These evaluations showed that 98.0 percent of H2M's nonradiological tests were in the acceptable range.

STL and GEL were audited as part of DOE's Integrated Contract Procurement Team Program. There was no Priority I ("serious") findings for either laboratory. The STL audit resulted in 14 Priority II findings and the GEL audit resulted in seven Priority II findings. Priority II status indicates problems that do not result in unusable data and do not indicate that the contract analytical laboratory cannot adequately perform services for DOE. Corrective actions plans were submitted to DOE by the contract analytical laboratories to document that procedures were put in place to correct the findings.

Chapter 9 of this report describes the BNL Quality Assurance/Quality Control Program in further detail. 


\section{A Note from the Editor}

Throughout the Site Environmental Report, there are many references to Brookhaven National Laboratory (BNL), the U.S. Department of Energy (DOE), and the U.S. Environmental Protection Agency (EPA). These acronyms, and others that are explained in each chapter, are used interchangeably with their spelled-out forms as an aid to readers. Also, Appendix A opens with a list of acronyms and their meanings. 


\section{Site Environmental Report Team}

The SER Team realizes that many other employees contributed to this report and thanks everyone for their assistance.

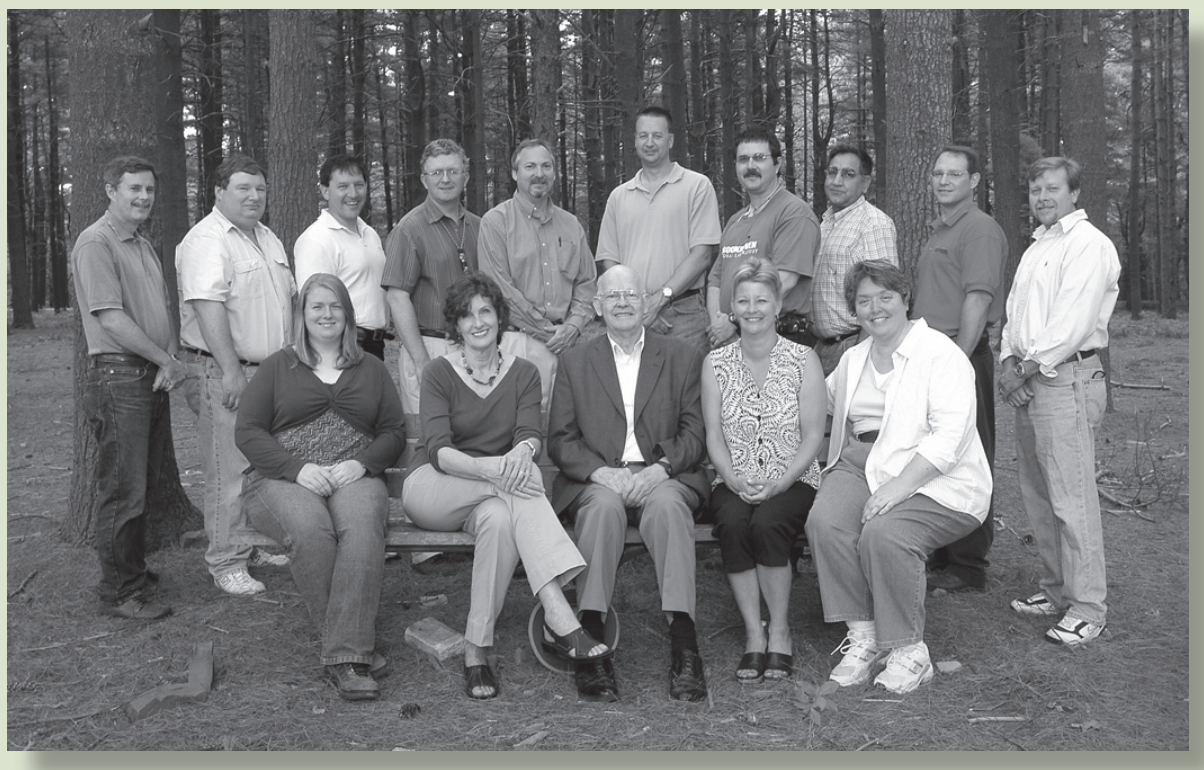

\section{The SER Team}

(Back row) Jeffrey Williams, John Burke, Robert Lee, Douglas Paquette, George Goode, William Dorsch, Timothy Green, Balwan Hooda, Mark Davis, and John Selva (Front row) Jennifer Higbie, Patricia Yalden, Arland Carsten, Karen Ratel, and Kathleen Robinson

(Jason Remien not pictured)

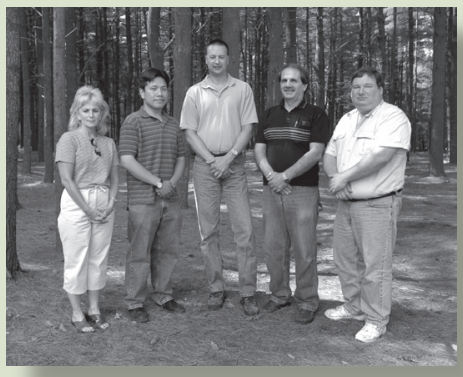

The Environmental Information Management Services Group

(From left to right) Susan Young, Alain Domingo, William Dorsch, Frank Tramontano, and John Burke

The Environmental and Waste Management Services Division Field Sampling Team (From left to right)

Robert Metz, Carlee Ogeka, Richard Lagattolla, and Lawrence Lettieri

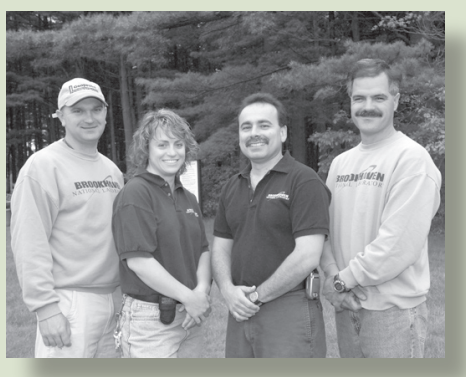




\title{
Acknowledgments
}

The production of the BNL 2006 Site Environmental Report (SER), Volume I, required the knowledge, skill, experience, and cooperation of many people and organizations at the Laboratory. The lead authors, co-authors, and other contributing staff involved in producing the 2006 SER and 2006 SER Summary are listed below.

LEAD CHAPTER AUTHORS

Environmental and Waste Management

Services Division

$\begin{aligned} \text { EXECUTIVE SUMMARY } & \text { Karen Ratel } \\ \text { CHAPTER 1 } & \text { Karen Ratel } \\ \text { CHAPTER 2 } & \text { John Selva } \\ \text { CHAPTER 3 } & \text { Robert Lee } \\ \text { CHAPTER 4 } & \text { Jeffrey Williams } \\ \text { CHAPTER 5 } & \text { Robert Lee }\end{aligned}$

$\begin{aligned} \text { CHAPTER 6 } & \text { Timothy Green } \\ \text { CHAPTER 7 } & \text { Douglas Paquette } \\ & \text { William Dorsch } \\ \text { CHAPTER 8 } & \text { Balwan Hooda } \\ \text { CHAPTER 9 } & \text { John Burke } \\ \text { SER SUMMARY } & \text { Karen Ratel }\end{aligned}$

CO-AUTHORS AND KEY CONTRIBUTORS

Environmental and Waste Management
Services Division
Arland Carsten, Consultant
Mark Davis
George Goode
Jennifer Higbie
Keith Klaus
Richard Lagattolla
Lawrence Lettieri
Robert Metz
Carlee Ogeka
Peter Pohlot
Jason Remien
Glen Todzia

\author{
Biology Department \\ Richard Setlow \\ Community, Education, Government \\ and Public Affairs \\ Jeanne D'Ascoli \\ Peter Genzer \\ Environmental Restoration \\ Robert Howe \\ Plant Engineering Division \\ Edward Phillips \\ Barbara Pierce \\ Mark Toscano \\ Radiological Control Division \\ Charles Schaefer
}

SER PROJECT COORDINATOR

Karen Ratel, Environmental and Waste Management Services Division

\section{EDITOR}

Kathleen Robinson, Information Services Division

DESIGNER

Patricia Yalden, Media \& Communications and Production Services

"Thank you" to the staff and management of the following organizations who assisted the authors in the preparation of this report by providing technical peer reviews, sample and data collection, maps and diagrams, and other support necessary to make this report possible.

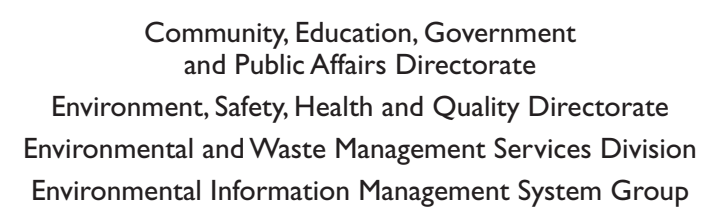

Community, Education, Government and Public Affairs Directorate

Environment, Safety, Health and Quality Directorate

Environmental Information Management System Group

\author{
Environmental Restoration Group \\ Information Services Division \\ Media \& Communications and Production Services \\ Plant Engineering Division \\ Radiological Control Division
}




\section{Contents}

Message from the Laboratory Director .................................................................................................

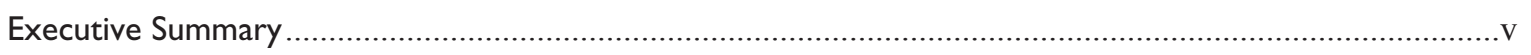

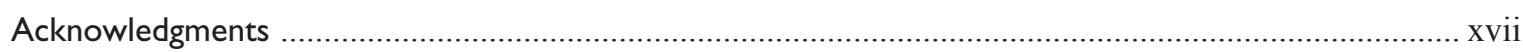

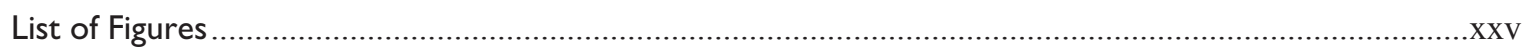

List of Tables ...............................................................................................................................................xxvii

\section{CHAPTER I: INTRODUCTION}

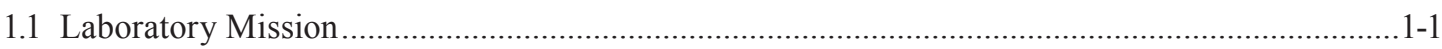

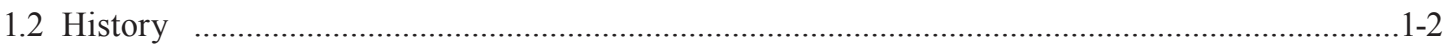

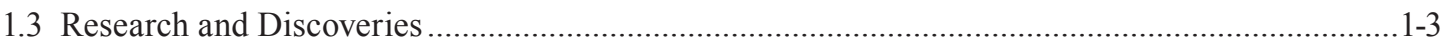

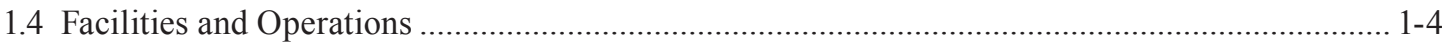

1.5 Location, Local Population, and Local Economy ……............................................................

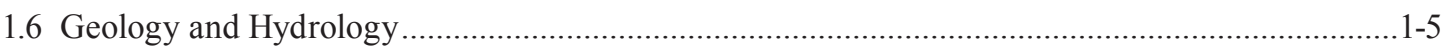

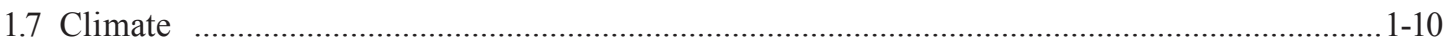

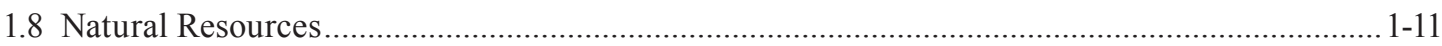

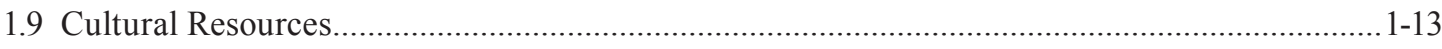

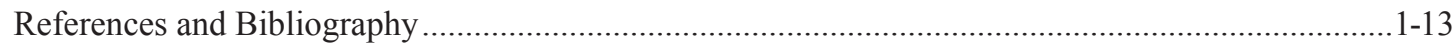

\section{CHAPTER 2: ENVIRONMENTAL MANAGEMENT SYSTEM}

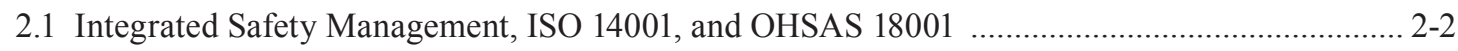

2.2 Environmental, Safety, Security, and Health Policy ................................................................. 2-5

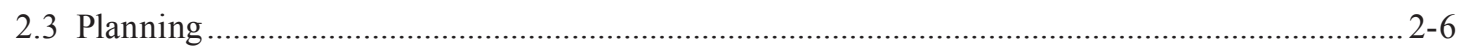

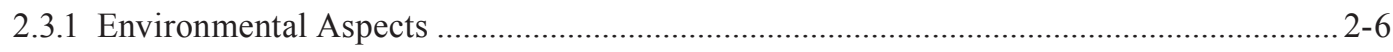

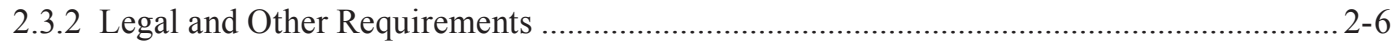

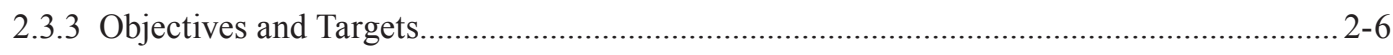

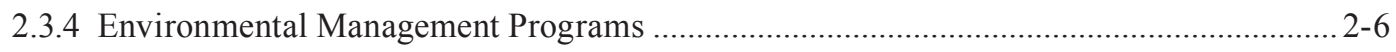

2.3.4.1 Compliance .................................................................................................... 2-7

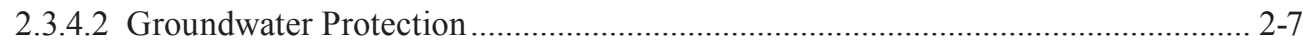

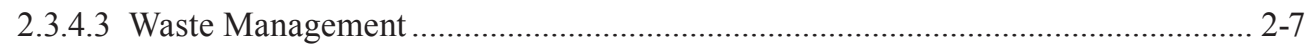

2.3.4.4 Pollution Prevention and Minimization............................................................... 2-9

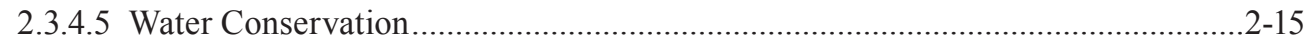

2.3.4.6 Energy Management and Conservation............................................................2-15

2.3.4.7 Natural and Cultural Resource Management Programs......................................2-17

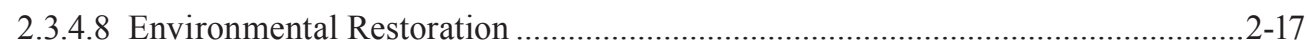

2.3.4.9 EPA Performance Track Program.................................................................... $2-19$

2.4 Implementing the Environmental Management System............................................................2-19

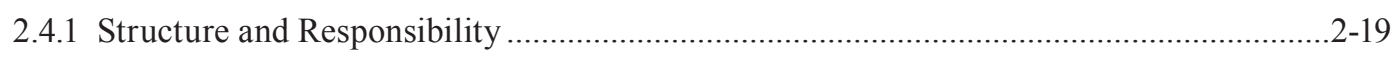

2.4.2 Communication and Community Involvement.............................................................2-21 
2.4.2.1 Communication Forums ………................................................................ 2-21

2.4.2.2 Community Involvement in Cleanup Projects ..................................................2-22

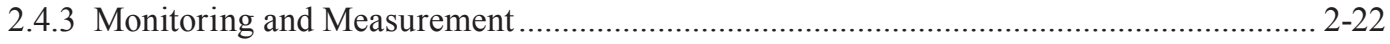

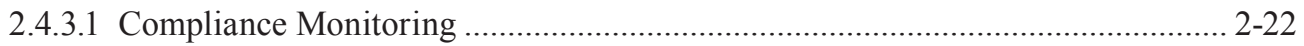

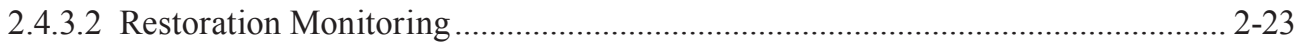

2.4.3.3 Surveillance Monitoring ................................................................................... 2-23

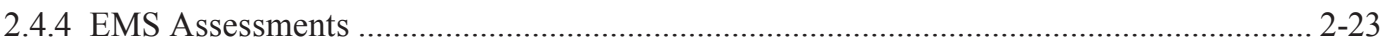

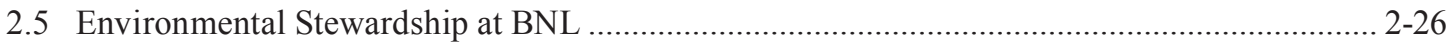

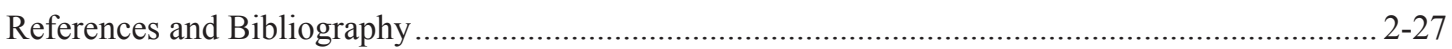

\section{CHAPTER 3: COMPLIANCE STATUS}

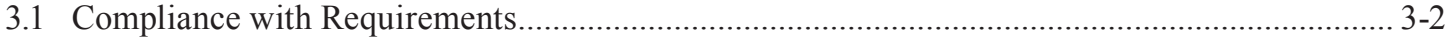

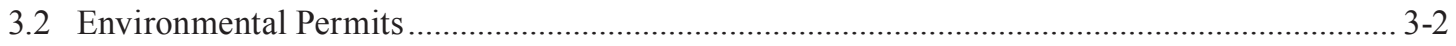

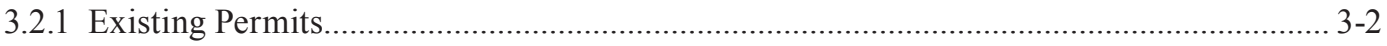

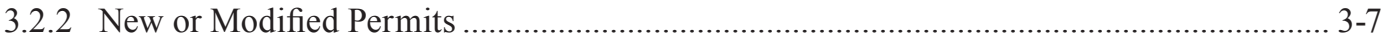

3.2.2.1 Hazardous Waste Management Permit................................................................... 3-7

3.2.2.2 Air Emissions Permits ......................................................................................... 3-7

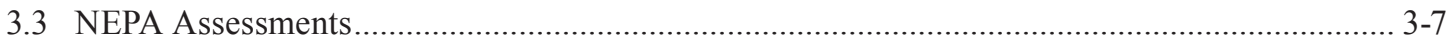

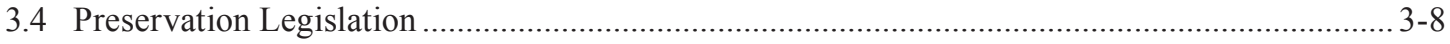

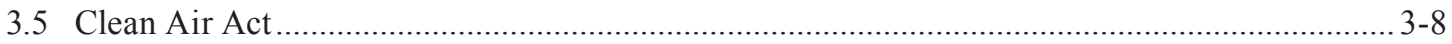

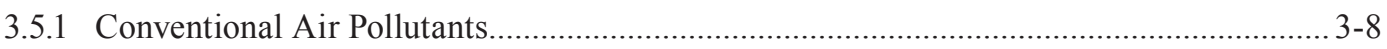

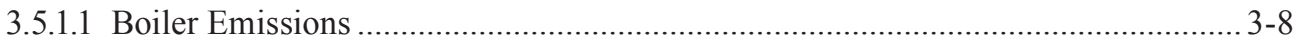

3.5.1.2 Ozone-Depleting Substances........................................................................

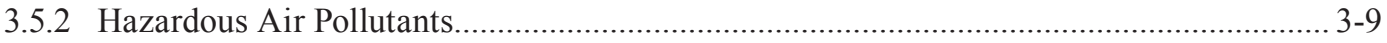

3.5.2.1 Maximum Available Control Technology ........................................................... 3-9

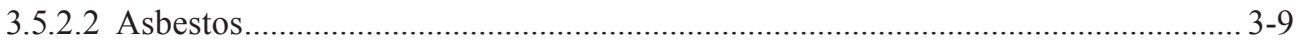

3.5.2.3 Radioactive Airborne Emissions........................................................................ 3-9

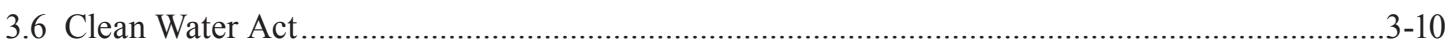

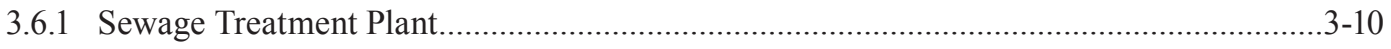

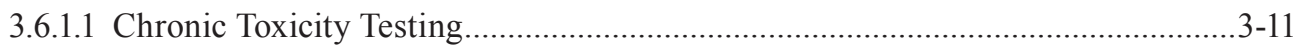

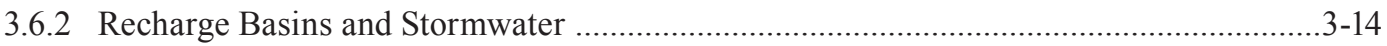

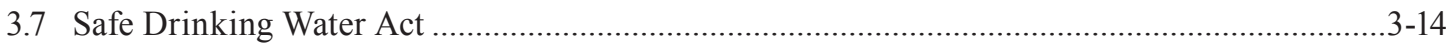

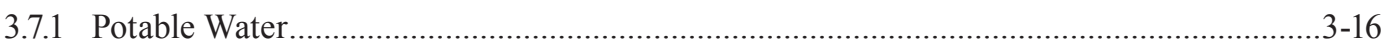

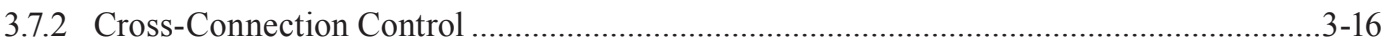

3.7.3 Underground Injection Control....................................................................................

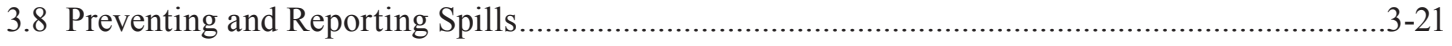

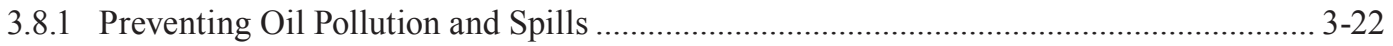

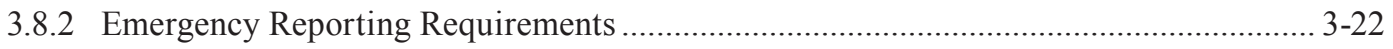

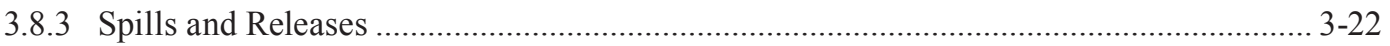

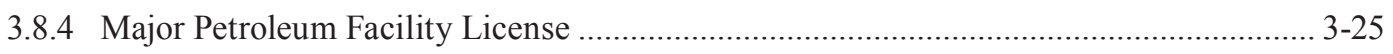

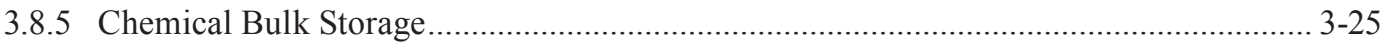

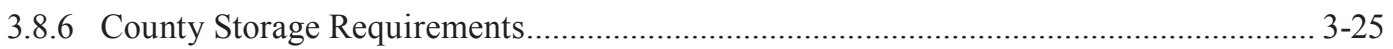




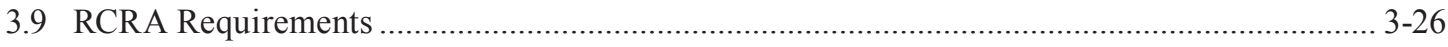

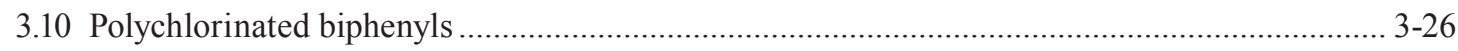

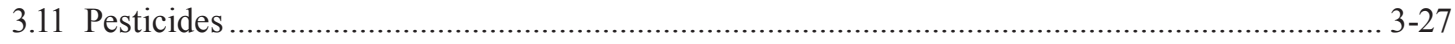

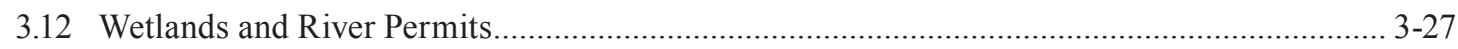

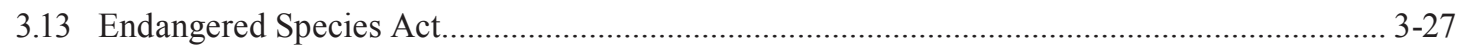

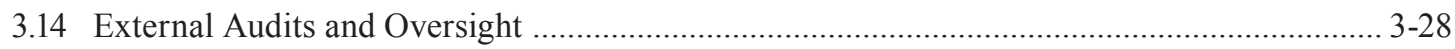

3.14.1 Regulatory Agency Oversight..................................................................... 3-28

3.14.2 DOE Assessments/Inspections ............................................................................. 3-29

3.14.2.1 Environmental Multi-Topic Assessment................................................... 3-29

3.14.2.2 Hazardous Material Transportation............................................................. 3-29

3.14.2.3 EMS Desk Assessment ........................................................................ 3-30

3.14.2.4 Nevada Test Site Inspection ...................................................................... 3-30

3.14.3 Enforcement Actions and Memos............................................................................. 3-31

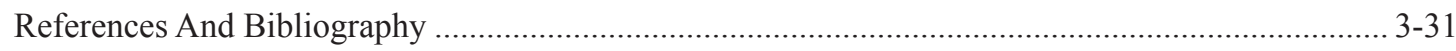

\section{CHAPTER 4: AIR QUALITY}

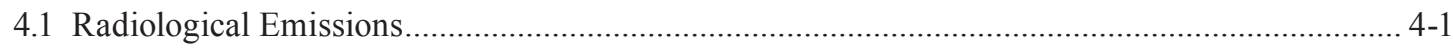

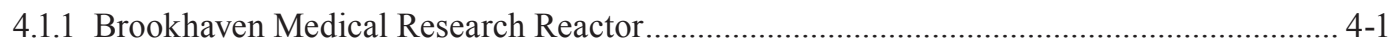

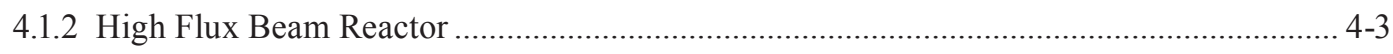

4.1.3 Brookhaven Linac Isotope Producer ............................................................................

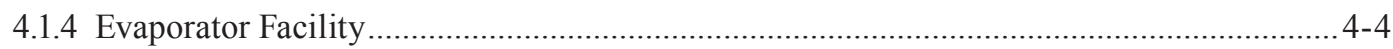

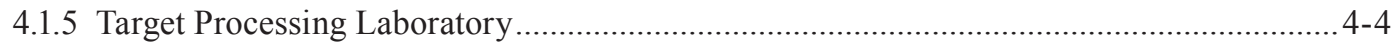

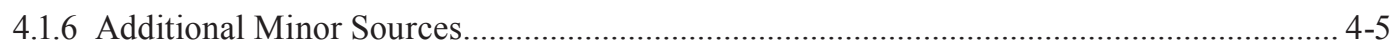

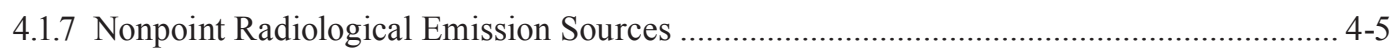

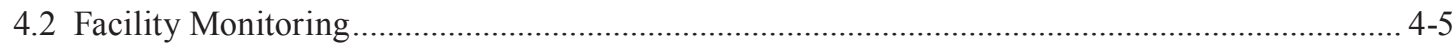

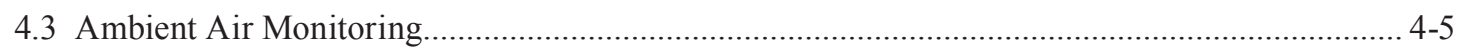

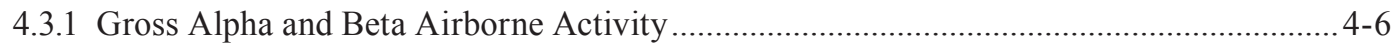

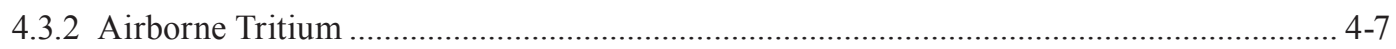

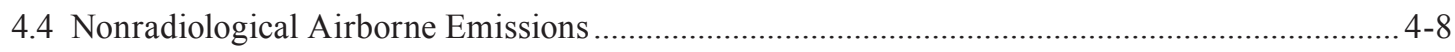

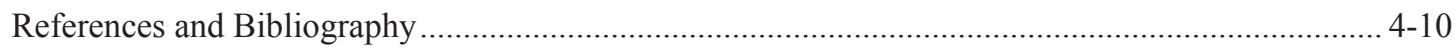

\section{CHAPTER 5: WATER QUALITY}

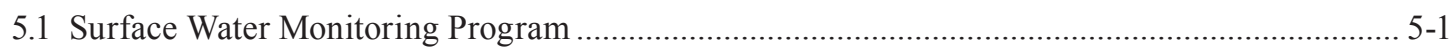

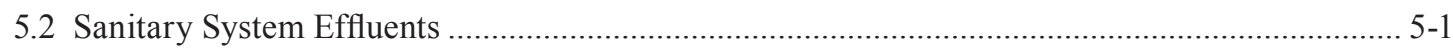

5.2.1 Sanitary System Effluent-Radiological Analyses ........................................................ 5-3

5.2.2 Sanitary System Effluent-Nonradiological Analyses .................................................... 5-5

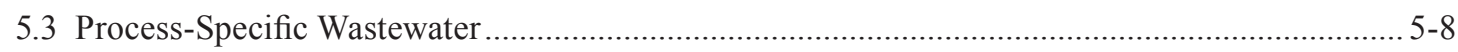

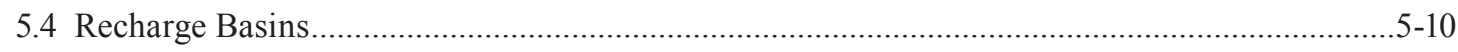

5.4.1 Recharge Basins - Radiological Analyses ..................................................................

5.4.2 Recharge Basins - Nonradiological Analyses ........................................................... 5-12

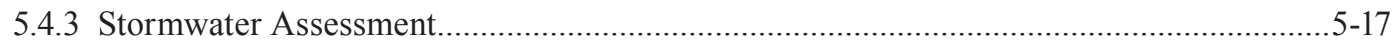

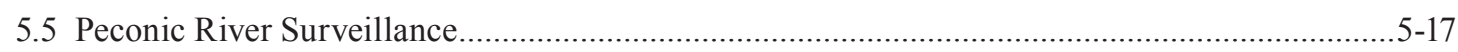

5.5.1 Peconic River - Radiological Analyses......................................................................... 
5.5.2 Peconic River - Nonradiological Analyses..................................................................5-19

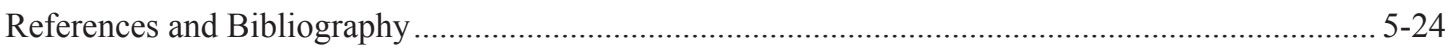

\section{CHAPTER 6: NATURAL AND CULTURAL RESOURCES}

6.1 Natural Resource Management Program …………...................................................................... 6-1

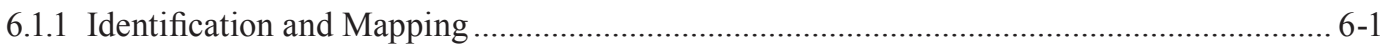

6.1.2 Habitat Protection and Enhancement ……………...................................................... 6-2

6.1.2.1 Salamander Protection Efforts ......................................................................... 6-3

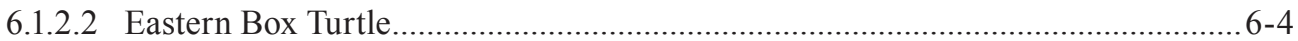

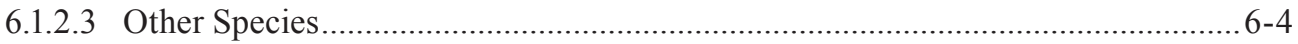

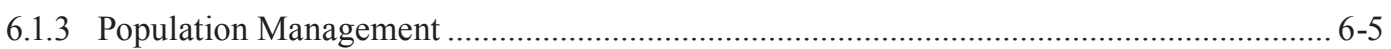

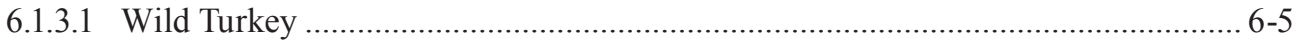

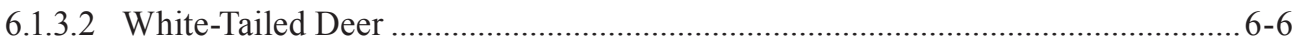

6.1.4 Compliance Assurance and Potential Impact Assessment................................................. 6-6

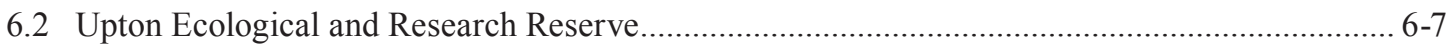

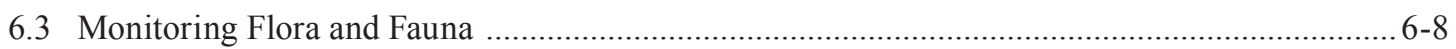

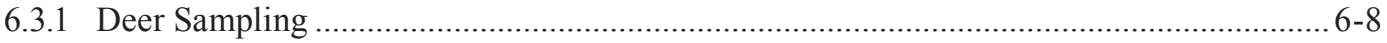

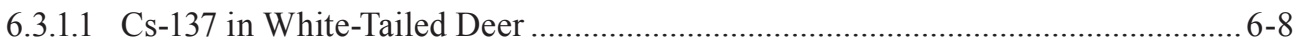

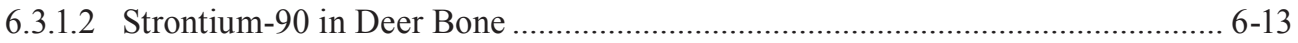

6.3.2 Small Mammal Sampling......................................................................................... 6-15

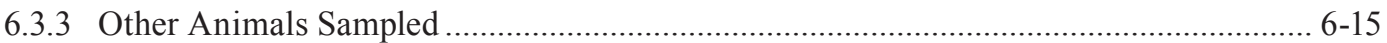

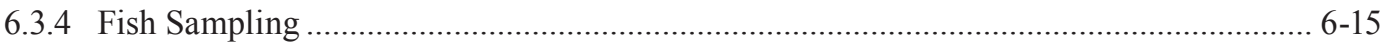

6.3.4.1 Radiological Analysis of Fish...........................................................................6-16

6.3.4.2 Fish Population Assessment ............................................................................6-17

6.3.4.3 Nonradiological Analysis of Fish....................................................................... 6-17

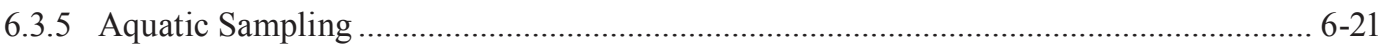

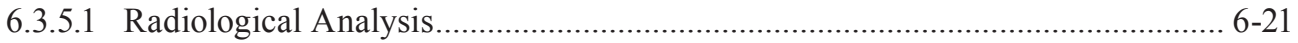

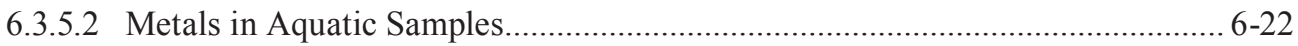

6.3.5.3 Pesticides and PCBs in Aquatic Samples.......................................................... 6-22

6.3.6 Peconic River Post-Cleanup Monitoring ........................................................................ 6-22

6.3.6.1 Sediment Sampling......................................................................................... 6-23

6.3.6.2 Water Column Sampling ..................................................................................... 6-24

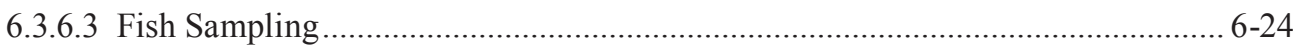

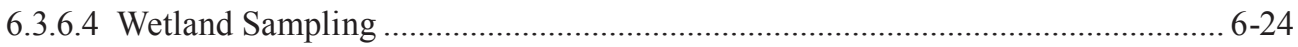

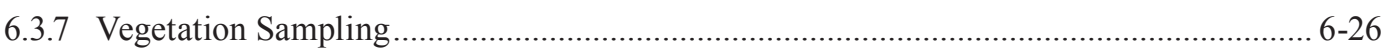

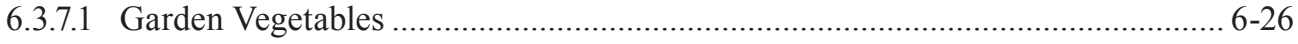

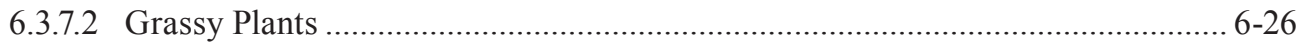

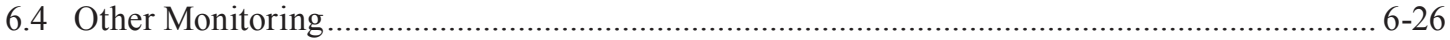

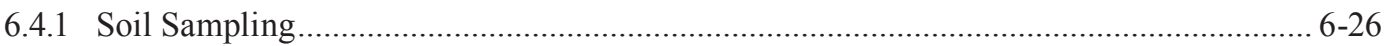

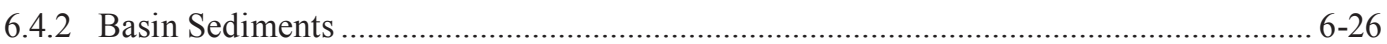

6.4.3 Chronic Toxicity Tests ........................................................................................... 6-26

6.4.4 Radiological Monitoring of Precipitation....................................................................... 6-26 


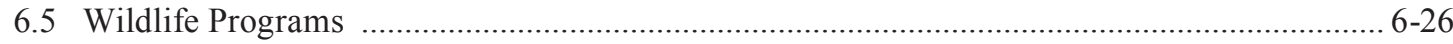

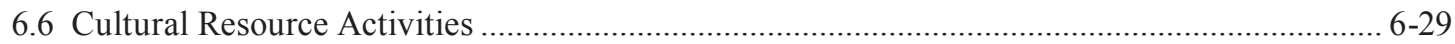

References and Bibliography ............................................................................................ 6-29

\section{CHAPTER 7: GROUNDWATER PROTECTION}

7.1 The BNL Groundwater Protection Management Program.........................................................

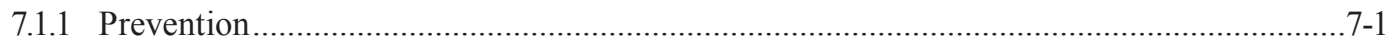

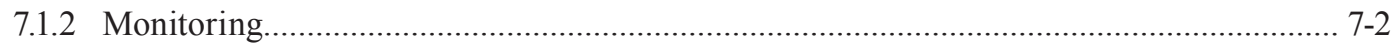

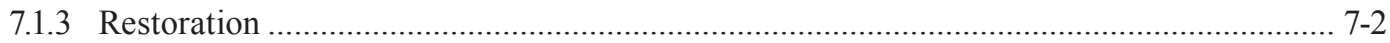

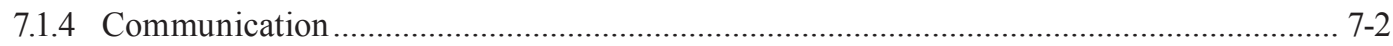

7.2 Groundwater Protection Performance …………….................................................................

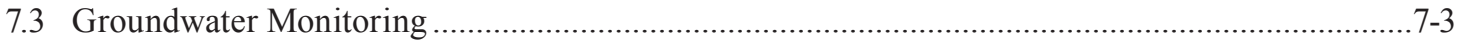

7.4 Supplemental Monitoring of Water Supply Wells ............................................................................ $7-4$

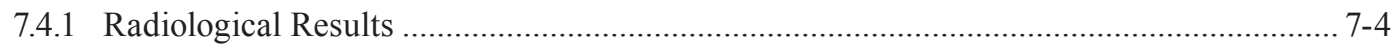

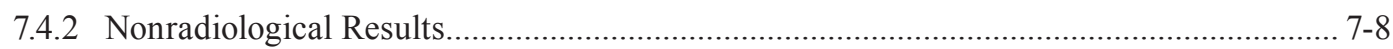

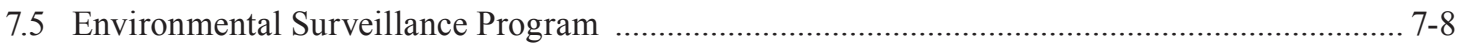

7.6 Environmental Restoration Groundwater Monitoring Program ................................................. 7-9

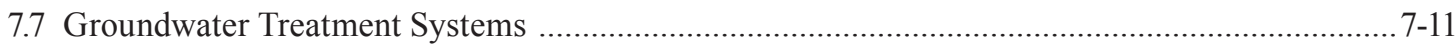

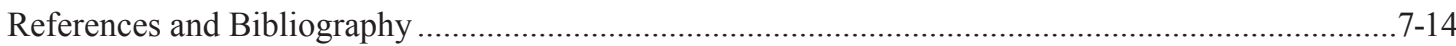

\section{CHAPTER 8: RADIOLOGICAL DOSE ASSESSMENT}

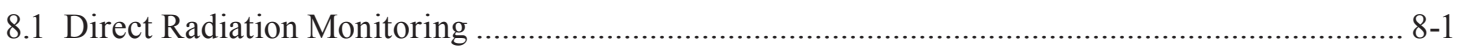

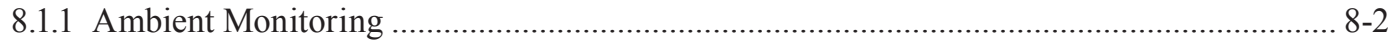

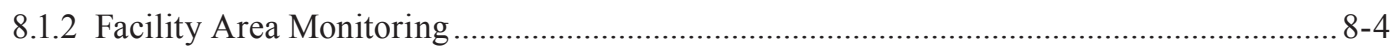

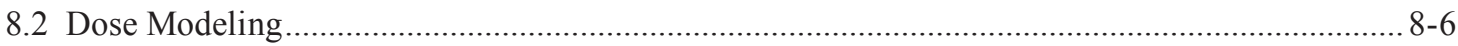

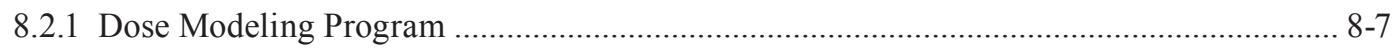

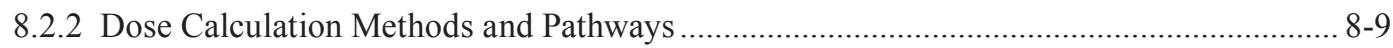

8.2.2.1 Maximally Exposed Individual ……………….............................................. 8-9

8.2.2.2 Effective Dose Equivalent ......................................................................................... 8-9

8.2.2.3 Dose Calculation: Fish Ingestion ...................................................................... 8-9

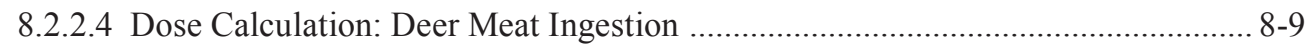

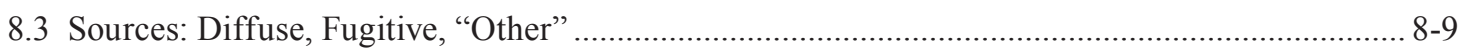

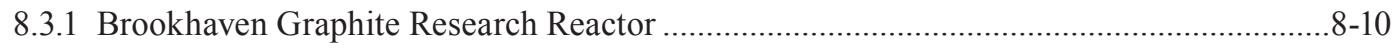

8.3.2 Former Hazardous Waste Management Facility ................................................................

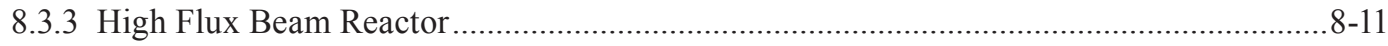

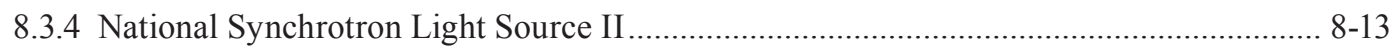

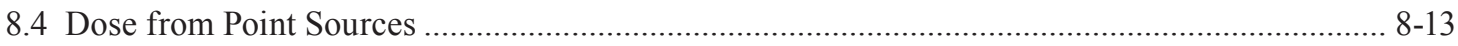

8.4.1 Brookhaven Linac Isotope Producer ................................................................................ 8-13

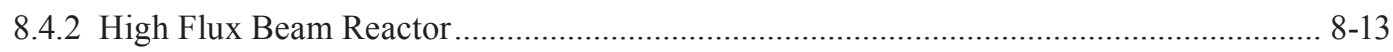

8.4.3 Brookhaven Medical Research Reactor ...................................................................... 8-13

8.4.4 Unplanned Releases................................................................................................

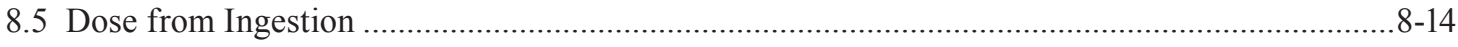

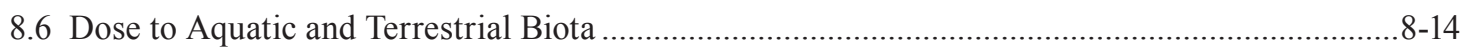




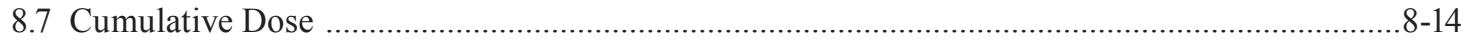

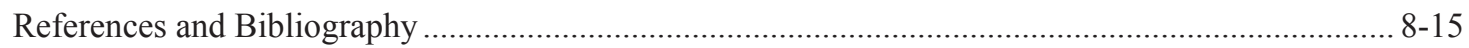

\section{CHAPTER 9: QUALITY ASSURANCE}

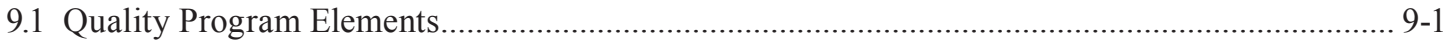

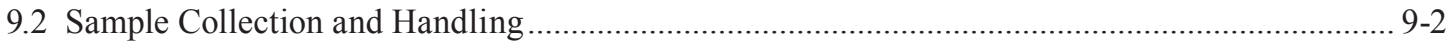

9.2.1 Field Sample Handling....................................................................................... 9-3

9.2.1.1 Custody and Documentation ................................................................. 9-3

9.2.1.2 Preservation and Shipment ......................................................................... 9-3

9.2.2 Field Quality Control Samples ................................................................................ 9-3

9.2.3 Tracking and Data Management ........................................................................... 9-4

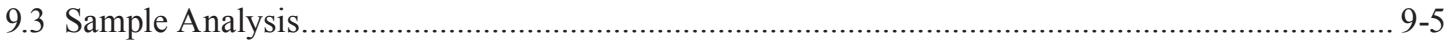

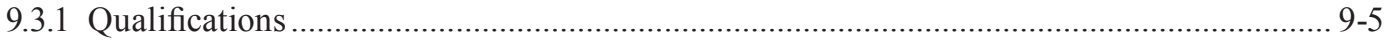

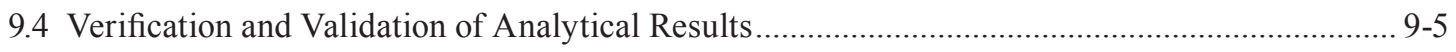

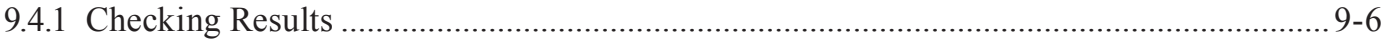

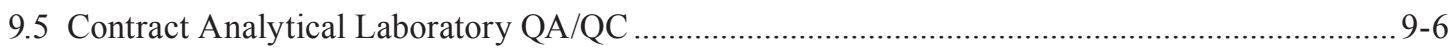

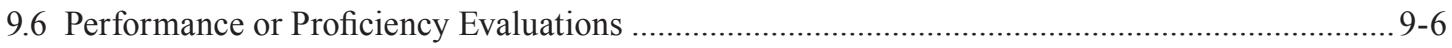

9.6.1 Summary of Test Results ..................................................................................... 9-7

9.6.2.1 Radiological Assessments ...................................................................... 9-7

9.6.2.2 Nonradiological Assessments ............................................................ 9-7

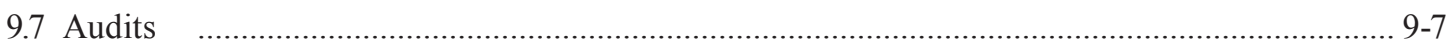

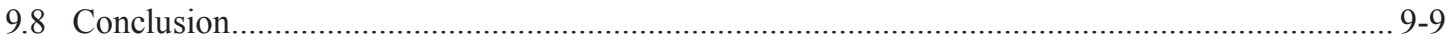

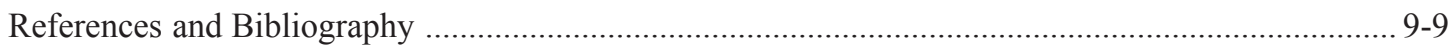

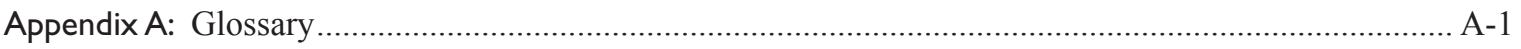

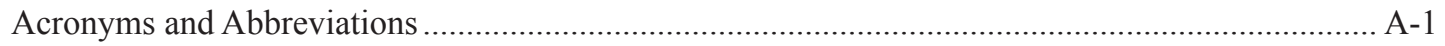

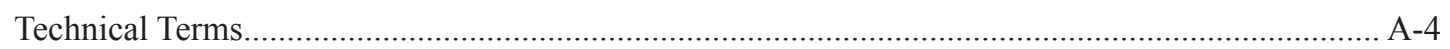

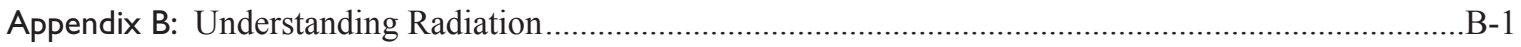

Appendix C: Units of Measure and Half-Life Periods ......................................................................

Appendix D: Federal, State, and Local Laws and Regulations Pertinent to BNL ................................. D-1 


\section{List of Figures}

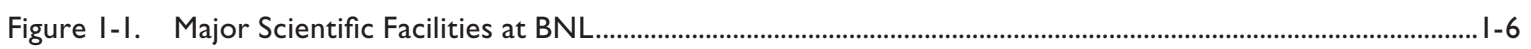

Figure I-2. Major Support and Service Facilities at BNL. ...............................................................................................

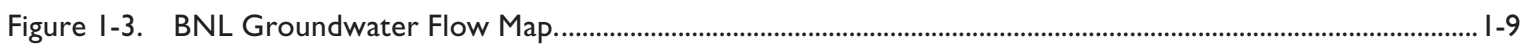

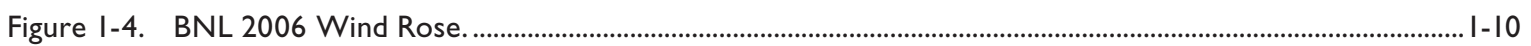

Figure I-5. BNL 2006 Monthly Mean Temperature versus 58-Year Monthly Average. ................................................ I-II

Figure I-6. BNL 2006 Annual Mean Temperature Trend (58 Years)........................................................................... I-II

Figure I-7. BNL 2006 Monthly Precipitation versus 58-Year Monthly Average............................................................. I-I2

Figure I-8. BNL 2006 Annual Precipitation Trend (58 Years) ......................................................................................... I-I2

Figure 2-la. Hazardous Waste Generation from Routine Operations, 1997 - 2006....................................................... 2-8

Figure 2-lb. Mixed Waste Generation from Routine Operations, 1997 - 2006 ............................................................ 2-8

Figure 2-lc. Radioactive Waste Generation from Routine Operations, 1997 - 2006................................................... 2-8

Figure 2-Id. Hazardous Waste Generation from ER and Nonroutine Operations, 1997 - 2006...................................2-9

Figure 2-le. Mixed Waste Generation from ER and Nonroutine Operations, 1997 - 2006...........................................2-9

Figure 2-If. Radioactive Waste Generation from ER and Nonroutine Operations, 1997 - 2006..................................2-9

Figure 2-2. BNL Water Consumption Trend. ....................................................................................................................... 2-17

Figure 2-3. BNL Building Energy Performance, 1985 - 2015.......................................................................................... 2-18

Figure 3-I. Maximum Concentrations of Copper Discharged from the BNL Sewage Treatment Plant, 2002-2006.

Figure 3-2. Maximum Concentrations of Iron Discharged from the BNL Sewage Treatment Plant, 2002-2006

Figure 3-3. Maximum Concentrations of Lead Discharged from the BNL Sewage Treatment Plant, 2002-2006.

Figure 3-4. Maximum Concentrations of Mercury Discharged from the BNL Sewage Treatment Plant, 2002-2006.

Figure 3-5. Maximum Concentrations of Nickel Discharged from the BNL Sewage Treatment Plant, 2002-2006

Figure 3-6. Maximum Concentrations of Silver Discharged from the BNL Sewage Treatment Plant, 2002-2006.

Figure 3-7. Maximum Concentrations of Zinc Discharged from the BNL Sewage Treatment Plant, 2002-2006.

Figure 4-I. Air Emission Release Points Subject to Monitoring. ...4-2

Figure 4-2. High Flux Beam Reactor Tritium Emissions, Ten-Year Trend (1997-2006)................................................. 4-3

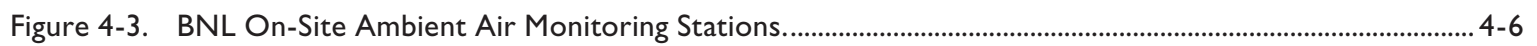

Figure 4-4. Airborne Gross Beta Concentration Trend Recorded at Station P7. ......................................................... 4-8

Figure 5-I. Schematic of BNL's Sewage Treatment Plant (STP). ........................................................................................5-2

Figure 5-2. Tritium Concentrations in Effluent from the BNL Sewage Treatment Plant (2006)................................. 5-5

Figure 5-3. Sewage Treatment Plant/Peconic River Annual Average Tritium Concentrations (1992-2006) .............. 5-6

Figure 5-4. Tritum Released to the Peconic River, 15-Year Trend (1992-2006)............................................................ 5-6

Figure 5-5. Cesium-I37 in the BNL Sewage Treatment Plant Influent and Effluent (1992-2006)................................ 5-6

Figure 5-6. BNL Recharge Basin/Outfall Locations. ...................................................................................................

Figure 5-7. Schematic of Potable Water Use and Flow at BNL. .................................................................................. II

Figure 5-8. Sampling Stations for Surface Water, Fish, and Shellfish. ..................................................................... 5-18 


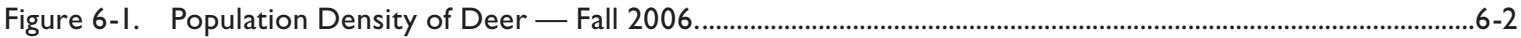

Figure 6-2. Deer Sample Locations, 2002 -2006........................................................................................................... 6-10

Figure 6-3. Comparison of Cs-137 Average Concentrations in Deer, 2006............................................................... 6-14

Figure 6-4. Trend of Cs-137 Concentrations in Deer Meat at BNL and Within I Mile of BNL, $1998-2006 \ldots \ldots . . .6$ 6-14

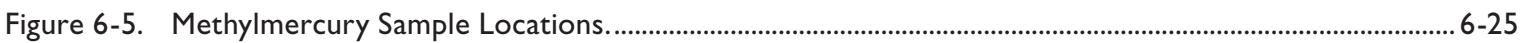

Figure 7-I. Groundwater Protection Performance, 1998 - 2006 .....................................................................................7-3

Figure 7-2. Groundwater Flow and Water Table Elevation (December 2006) with Supply and

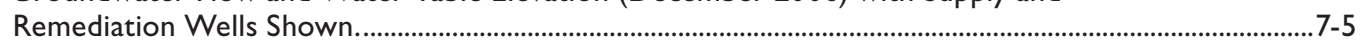

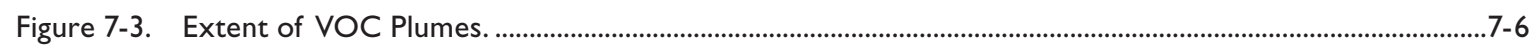

Figure 7-4. Extent of Radionuclide Plumes. ....................................................................................................................... 7-7

Figure 7-5. Locations of BNL Groundwater Remediation Systems.............................................................................. 7-12

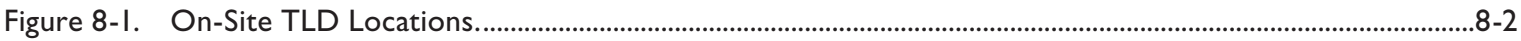

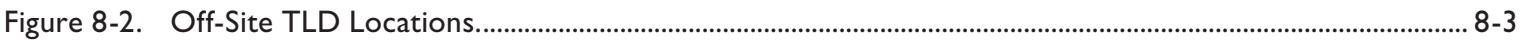

Figure 9-I. Flow of Environmental Monitoring QA/QC Program Elements. ...............................................................9-2

Figure 9-2. Summary of Scores in the Radiological Proficiency Evaluation Programs. .................................................. 9-8

Figure 9-3. Summary of Scores in the Nonradiological Proficiency Evaluation Programs............................................. 9-8 


\section{List of Tables}

Table 2-I. Elements of the Environmental Management System (EMS) and their Relationship to OHSAS I800I and Integrated Safety Management (ISM) - Review of EMS Implementation at BNL...................................2-2

Table 2-2. BNL Pollution Prevention, Waste Reduction, and Recycling Projects............................................................. 2-II

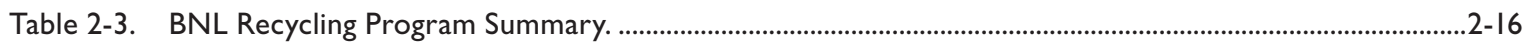

Table 2-4. Summary of BNL 2006 Environmental Restoration Activities. .................................................................. 2-20

Table 2-5. Summary of BNL 2006 Sampling Program Sorted by Media......................................................................2-24

Table 3-I. Federal, State, and Local Environmental Statutes and Regulations Applicable to BNL...............................3-2

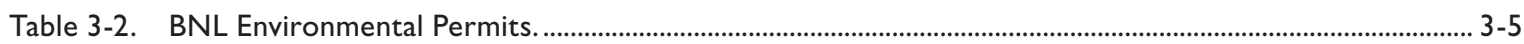

Table 3-3. Analytical Results for Wastewater Discharges to Sewage Treatment Plant Outfall 00I............................3-II

Table 3-4. Analytical Results for Wastewater Discharges to Outfalls 002-008 and 010............................................15

Table 3-5. Potable Water Wells and Potable Distribution System: Analytical Results (Maximum Concentration, Minimum pH Value)

Table 3-6. Potable Water Wells: Analytical Results for Principal Organic Compounds, Synthetic Organic Chemicals, Pesticides, and Micro-Extractables............................................................................... $3-19$

Table 3-7. Summary of Chemical and Oil Spill Reports............................................................................................... 3-23

Table 3-8. Summary of Other Environmental Occurrence Reports................................................................................ 3-24

Table 3-9. Existing Agreements and Enforcement Actions Issued to BNL, with Status. ...........................................3-30

Table 4-I. Airborne Radionuclide Releases from Monitored Facilities............................................................................. 4-3

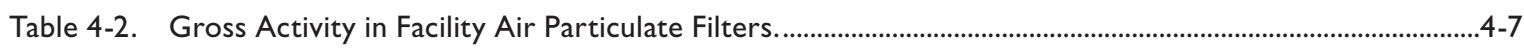

Table 4-3. Gross Activity Detected in Ambient Air Monitoring Particulate Filters. ......................................................4-7

Table 4-4. Ambient Airborne Tritium Measurements in 2006 ................................................................................... 4-8

Table 4-5. Central Steam Facility Fuel Use and Emissions (1996-2006) ........................................................................9

Table 5-I. Tritium and Gross Beta Activity in Water at the BNL Sewage Treatment Plant (STP),.............................5-4

Table 5-2. Gamma-Emitting Radionuclides and Strontium-90 in Water at the BNL Sewage Treatment Plant..........5-7

Table 5-3. BNL Sewage Treatment Plant (STP) Water Quality and Metals Analytical Results....................................5-9

Table 5-4. Radiological Analysis of Samples from BNL On-Site Recharge Basins. .......................................................

Table 5-5. Water Quality Data for BNL On-Site Recharge Basin Samples......................................................................

Table 5-6. Metals Analysis of Water Samples from BNL On-Site Recharge Basins....................................................5-I4

Table 5-7. Radiological Results for Surface Water Samples from the Peconic and Carmans Rivers..........................5-19

Table 5-8. Water Quality Data for Surface Water Samples Collected along the Peconic and Carmans Rivers..... 5-20

Table 5-9. Metals Analysis in Surface Water Samples Collected along the Peconic and Carmans Rivers.................5-2I

Table 6-I. New York State Threatened, Endangered, Exploitably Vulnerable, and Species of Special Concern at BNL.

Table 6-2 Radiological Analyses of Deer Tissue (Flesh, Liver, Bone)..............................................................................

Table 6-3. Radiological Analyses of Small Mammals (Squirrels) and Other Animals. .................................................... 6-I5

Table 6-4. Radiological Analyses of Fish from the Peconic River System and Carmans River, Lower Lake ..............6-17

Table 6-5. Metals Analyses of Fish from the Peconic River System and Carmans River, Lower Lake. ...................... 6-18

Table 6-6. Pesticide and PCB Analyses of Fish from the Peconic River System and Carmans River, Lower Lake.

Table 6-7. Radiological Analyses of Aquatic Vegetation and Sediment from the Peconic River and Carmans River System, Lower Lake.

Table 6-8. Metals Analyses of Aquatic Vegetation and Sediment from the Peconic River System and Carmans River, Lower Lake... 
Table 7-I. Summary of BNL Groundwater Monitoring Program, 2006.......................................................................... 7-2

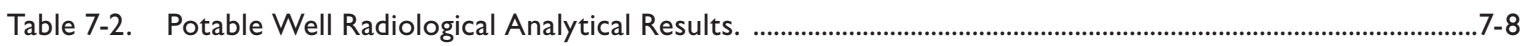

Table 7-3. Portable Water Supply Wells Water Quality Data...........................................................................................7-9

Table 7-4. Total Metals Concentration Data for Potable Water Supply Well Samples..................................................7-10

Table 7-5. BNL Groundwater Remediation Systems Treatment Summary for 1997 through 2006..........................7-13

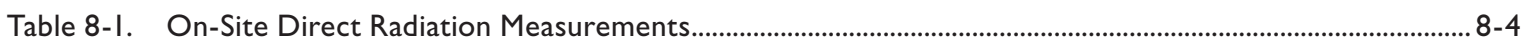

Table 8-2. Off-Site Direct Radiation Measurements. ...........................................................................................................8 8-6

Table 8-3. Facility Area Monitoring. …………….................................................................................................................

Table 8-4. MEI Effective Dose Equivalent From Facilities or Routine Processes........................................................ 8-8

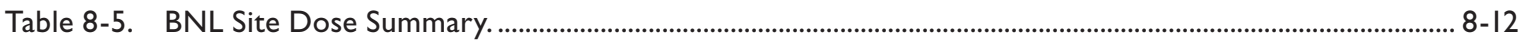




\section{Introduction}

Established in 1947, Brookhaven National Laboratory (BNL) is a multi-program national laboratory managed for the U.S. Department of Energy (DOE) by Brookhaven Science Associates (BSA), a partnership formed by the Research Foundation of State University of New York on behalf of Stony Brook University and Battelle Memorial Institute. BSA has been managing and operating the Laboratory under a performance-based contract with DOE since 1998. From 1947 to 1998, BNL was operated by Associated Universities Incorporated. Prior to 1947, the site operated as Camp Upton, a U.S. Army training camp, which was active from 1917 to 1920 during World War I and from 1940 to 1946 during World War II.

$B N L$ is one of 10 national laboratories under DOE's Office of Science, which provides most of the Laboratory's research dollars and direction. BNL has a history of outstanding scientific achievements. For over 60 years, Laboratory researchers have successfully worked to visualize, construct, and operate large and unique scientific facilities and use the data generated to make advances in many fields. Under BSA's management, new programs in place at BNL emphasize improved environmental, safety, security, and health performance.

\section{I.I LABORATORY MISSION}

BNL's broad mission is to produce excellent science and advanced technology in a safe and environmentally sound manner with the cooperation, support, and appropriate involvement of its scientific and local communities. The fundamental elements of the Laboratory's role in support of DOE's strategic missions in energy resources, environmental quality, and national security are:

- To conceive, design, construct, and operate complex, leading-edge, user-oriented research facilities in response to the needs of DOE and the international community of users.

- To carry out basic and applied research in long-term, high-risk programs at the frontier of science.

- To develop advanced technologies that address national needs and to transfer them to other organizations and to the commercial sector.
- To disseminate technical knowledge to educate future generations of scientists and engineers, to maintain technical currency in the nation's workforce, and to encourage scientific awareness in the general public.

BNL's Environmental, Safety, Security, and Health (ESSH) Policy is the Laboratory's commitment to continual improvement in ESSH performance. Under this policy, the Laboratory's goals are to provide a safe, secure, and healthy workplace; strive to prevent injuries and illnesses; promote healthy lifestyles; and encourage respect for the environment. In 2001, BNL was the first DOE Office of Science National Laboratory to be registered under the prestigious International ISO 14001 environmental management standard. In addition, in December 2006, BNL was the first DOE Laboratory to achieve full registration under the Occupational Health and Safety Assessment Series (OHSAS) 18001 Standard. These programs are described in detail in Chapter 2 of this report. 


\section{I.2 HISTORY}

BNL was founded in 1947 by the Atomic Energy Commission (AEC), which was a predecessor to the present DOE. AEC provided the initial funding for BNL's research into peaceful uses of the atom. The objective was to promote basic research in the physical, chemical, biological, and engineering aspects of the atomic sciences. The result was the creation of a regional laboratory to design, construct, and operate large scientific machines that individual institutions could not afford to develop on their own.

Although BNL no longer operates any research reactors, the Laboratory's first major scientific facility was the Brookhaven Graphite Research Reactor (BGRR), which was the first peace-time reactor to be constructed in the United States following World War II. The reactor's primary mission was to produce neutrons for scientific experimentation in the fields of medicine, biology, chemistry, physics, and nuclear technology. The BGRR operated from 1950 to 1968 and is now being decommissioned. Its research capacity was replaced and surpassed in 1965 by the High Flux Beam Reactor (HFBR), which provided neutrons to researchers in diverse subjects ranging from solid state physics to art history. For more than 30 years, the HFBR was one of the premier neutron beam reactors in the world. In 1997, workers discovered that a leak in the HFBR's spent fuel storage pool had been releasing tritium to the groundwater (see Chapter 7 for further details). In November 1999, the Secretary of Energy decided that the HFBR would be permanently shut down and decommissioned. All spent fuel from the HFBR has been removed and transported off site.

Medical research at BNL began in 1950 with the opening of one of the first hospitals devoted to nuclear medicine. It was followed by the Medical Research Center in 1958 and the Brookhaven Medical Research Reactor (BMRR) in 1959. The BMRR was the first nuclear reactor in the nation to be constructed specifically for medical research. Due to a reduction of research funding, the BMRR was shut down in December 2000. All spent fuel from the BMRR has been removed and transported off site. The Brookhaven Linac Isotope
Producer (BLIP) was built in 1973. It creates radioactive forms of ordinary chemical elements that can be used alone or incorporated into radiotracers for use in nuclear medicine research or for clinical diagnosis and treatment. BNL's Center for Translational Neuroimaging (CTN) uses brain-imaging tools, including positron emission tomography (PET) and magnetic resonance imaging (MRI) equipment, to research causes of, and treatments for, brain diseases such as drug addiction, appetite disorders, attention deficit disorder, and neurodegenerative disease. The development of PET and MRI also has helped facilitate the development of new drugs for physicians worldwide to treat patients for cancer and heart disease. Except for the BMRR, all of the above medical facilities are currently operating.

High-energy particle physics research at BNL began in 1952 with the Cosmotron, the first particle accelerator to achieve billion-electron-volt energies. Work at the Cosmotron resulted in a Noble Prize in 1957. After 14 years of service, the Cosmotron ceased operation and was dismantled due to design limitations that restricted the energies it could achieve. The Alternating Gradient Synchrotron (AGS), a much larger particle accelerator, became operational in 1960. The AGS allowed scientists to accelerate protons to energies that yielded many discoveries of new particles and phenomena, for which BNL researchers were awarded three Nobel Prizes in physics. The AGS receives protons from BNL's linear accelerator (Linac), designed and built in the late 1960s as a major upgrade to the AGS complex. The Linac's purpose is to provide accelerated protons for use at AGS facilities and BLIP. The AGS Booster, constructed in 1991, further enhanced the capabilities of the AGS, enabling it to accelerate protons and heavy ions to even higher energies. The Tandem Van de Graaff accelerator began operating in 1970 and is the starting point of the chain of accelerators that provide ions of gold, other heavy metals, and protons for experiments at the Relativistic Heavy Ion Collider (RHIC).

RHIC began operation in 2000. Inside this two-ringed particle accelerator, two beams of gold ions, heavy metals, or protons circulating at 
nearly the speed of light collide head-on, releasing large amounts of energy. RHIC is used to study what the universe may have looked like in the first few moments after its creation, offering insights into the fundamental forces and properties of matter. Planned upgrades to RHIC will expand the facility's research. The first upgrade, RHIC II, will increase the collider's collision rate and improve the sensitivity of the large detectors it uses. Another planned upgrade, the eRHIC, will add a high-energy electron ring to create the world's only electron-heavy ion collider, which physicists expect will probe a new form of matter.

The NASA Space Radiation Laboratory (NSRL) became operational in 2003. It is jointly managed by DOE's Office of Science and NASA's Johnson Space Center. The NSRL uses heavy ions extracted from the AGS booster to produce beams of radiation similar to radiation that would be encountered by astronauts on long missions. Studies are conducted to assess risks and test protective measures. The NSRL is one of the few facilities in the world that can simulate the harsh cosmic and solar radiation environment found in space.

The National Synchrotron Light Source (NSLS) uses a linear accelerator and booster synchrotron to guide charged particles in orbit inside two electron storage rings for use in a wide range of physical and biological experiments. The NSLS produces beams of very intense light in the $\mathrm{x}$-ray, ultraviolet, and infrared spectra, allowing scientists to study the structure of proteins, investigate the properties of new materials, and understand the fate of chemicals in the environment. Although the current NSLS has been continually updated since its commissioning in 1982, today the practical limits of its performance have been reached. A new synchrotron, NSLS-II, is planned for completion in the next decade and will be the highest resolution light source in the world, further expanding the ability to probe structures on the nanoscale.

Construction of the Center for Functional Nanomaterials (CFN) began in 2005 and is still underway. The CFN will provide researchers with the ability to fabricate and study materials on the order of billionths of a meter. Nanosci- ence has the potential to bring about and accelerate new technologies in energy distribution, drug delivery, sensors, and industrial processes. The possible benefits of nanoscience include faster computers, improved solar energy conversion, stronger and lighter materials, improved chemical and biological sensing, efficient and rapid detection and remediation of pollutants and pathogens in the environment, more efficient catalysts to speed chemical processes, molecular-scale motors, and new pharmaceuticals. The CFN is one of five nanoscience research centers funded by DOE's Office of Science, and supports BNL's goal of leadership in the development of advanced materials and processes for selected energy applications.

The Laboratory's Research Support Building (RSB) was completed in 2006. This building provides administrative and support functions in a single location for employees and visiting scientists. The RSB is rated as "green" or environmentally friendly, according to a scoring system developed by the U.S. Green Building Council's Leadership in Energy \& Environment Design (LEED) Program. The RSB also surpasses New York State requirements for energy efficiency by 15 percent.

Past operations and research at the BNL site dating back to the early 1940s when it was Camp Upton have resulted in localized environmental contamination. As a result, BNL was added to the federal Comprehensive Environmental Response, Compensation and Liability Act (CERCLA) National Priorities List of contaminated sites in 1989. One of 27 such sites on Long Island identified for priority cleanup, BNL has made significant progress toward improving environmental operations and remediating past contamination. DOE continues to fund cleanup projects until such time that the Laboratory is restored and removed from the National Priorities List. Major accomplishments in cleanup activities at BNL are discussed further throughout this report.

\section{I.3 RESEARCH AND DISCOVERIES}

BNL conducts research in nuclear and highenergy physics, the physics and chemistry of materials, environmental science, alternative 
energy sources, nuclear nonproliferation, neurosciences, medical imaging, and structural biology. Approximately 2,700 scientists, engineers, technicians, and support staff work at the Laboratory, and more than 3,500 guest researchers from around the world visit the site each year to participate in scientific collaborations. BNL's world-class research facilities are also available to university, industrial, and government personnel.

To date, six Nobel Prizes have been awarded for discoveries made wholly or partly at BNL. Some important discoveries and developments made at the Laboratory include L-dopa, used to treat Parkinson's disease; magnetically-levitated (maglev) trains; the use of x-rays and neutrons to study biological specimens; the radionuclide thallium-201, used in millions of cardiac stress tests each year; the radionuclide technetium99, also used to diagnose heart disease; x-ray angiography for noninvasive cardiac imaging; and research on solar neutrinos and how they change form on the way to earth.

Examples of current research at the Laboratory include the investigation of new nanostructures and nanoparticles; the development of high-temperature superconductors; novel states of matter being revealed at RHIC; medical imaging techniques to investigate the brain mechanisms underlying drug addiction, psychiatric disorders, and metabolism; new methods of understanding the earth's climate; and research into how infections begin. Further information regarding research and discoveries at BNL can be found at http//www.bnl.gov .

\section{I.4 FACILITIES AND OPERATIONS}

Most of the Laboratory's principal facilities are located near the center of the site. The developed area is approximately 1,650 acres:

- 500 acres originally developed by the Army (as part of Camp Upton) and still used for offices and other operational buildings

- 200 acres occupied by large, specialized research facilities

- 550 acres used for outlying facilities, such as the Sewage Treatment Plant, research agricultural fields, housing facilities, and fire breaks
- 400 acres of roads, parking lots, and connecting areas

The balance of the site, approximately 3,600 acres, is mostly wooded and represents the native pine barrens ecosystem.

The major scientific facilities at BNL are briefly described in Figure 1-1. Additional facilities, shown in Figure 1-2 and briefly described below, support BNL's science and technology mission by providing basic utility and environmental services.

- Central Chilled Water Plant. This facility provides chilled water sitewide for air conditioning and process refrigeration via underground piping. The plant has a large refrigeration capacity and reduces the need for local refrigeration plants and air conditioning.

- Central Steam Facility (CSF). This plant provides high-pressure steam for facility and process heating sitewide. Either natural gas or fuel oil can be used to produce the steam, which is conveyed to other facilities through underground piping. Condensate is collected and returned to the CSF for reuse, to conserve water and energy.

- Fire Station. The Fire Station houses six response vehicles. The BNL Fire Rescue Group provides on-site fire suppression, emergency medical services, hazardous material response, salvage, and property protection. The Fire Rescue Group can respond within 5 minutes to emergencies in the core area of the Laboratory and within 8 minutes to emergencies in the outer areas (RHIC and eastern portions of the site).

- Major Petroleum Facility (MPF). This facility provides reserve fuel for the CSF during times of peak operation. With a total capacity of 2.3 million gallons, the MPF primarily stores No. 6 fuel oil. The 1997 conversion of the CSF boilers to burn natural gas as well as oil has significantly reduced the Laboratory's reliance on oil as a sole fuel source when other fuels are more economical.

- Research Support Building (RSB). This building consolidates frequently visited administrative and support functions in a 
single location for BNL employees and visiting scientists. The 65,000-square-foot building tops New York State Requirements for energy efficiency by 15 percent. The structure is considered "green," or environmentally friendly, based on a rating system by the U.S. Green Building Council's Leadership in Energy \& Environmental Design, also known as LEED. The building also complies with National Environmental Policy Act requirements.

- Sewage Treatment Plant (STP). This facility treats sanitary and certain process wastewater from BNL facilities prior to discharge into the Peconic River, similar to the operations of a municipal sewage treatment plant. The plant has a design capacity of 3 million gallons per day. Effluent is monitored and controlled under a permit issued by the New York State Department of Environmental Conservation.

- Waste Concentration Facility (WCF). This facility was previously used for the receipt, processing, and volume reduction of aqueous radioactive waste. At present, the WCF houses equipment and auxiliary systems required for operation of the liquid lowlevel radioactive waste storage and pump systems.

- Waste Management Facility (WMF). This facility is a state-of-the-art complex for managing the wastes generated from BNL's research and operations activities. The facility was built with advanced environmental protection systems and features, and began operation in December 1997.

- Water Treatment Plant (WTP). The potable water treatment facility has a capacity of 5 million gallons per day. Potable water is obtained from six on-site wells. Three wells located along the western boundary of the site are treated with a lime softening process to remove naturally occurring iron. The plant is also equipped with dual air-stripping towers to ensure that volatile organic compounds (VOCs) are at or below New York State drinking water standards. Three wells located along the eastern section of the developed site are treated with carbon to ensure that VOC levels meet New York State drinking water standards. BNL's potable water met all drinking water standards in 2006.

\section{I.5 LOCATION, LOCAL POPULATION, AND LOCAL ECONOMY}

BNL is located on Long Island, 60 miles east of New York City. The Laboratory's 5,265-acre site is near Long Island's geographic center and is part of the Town of Brookhaven, the largest township (both in area and population) in Suffolk County. The Laboratory is one of five large, high-technology employers on Long Island, with approximately 2,700 employees that include scientists, engineers, technicians, and administrative personnel. More than 75 percent of BNL employees live in Suffolk County. In addition, BNL hosts an estimated 3,500 visiting scientists, more than 30 percent of whom are from New York State universities and businesses. The visiting scientists and their families, as well as visiting students, reside in apartments and dormitories on site or in nearby communities.

An independent Suffolk County Planning Commission report concluded that BNL's spending for operations, procurement, payroll, construction, medical benefits, and technology transfer spreads throughout Long Island's economy, making BNL vital to the local economic health (Kamer 2006). In addition, Laboratory employees do most of their shopping locally, further enhancing the local economy. Some of the Laboratory's currently planned projects, which include the CFN and NSLS-II, are expected to significantly enhance BNL's economic value to Long Island and New York State.

In 2006, BNL's total annual budget was approximately $\$ 490$ million, of which approximately 57 percent, or \$279.5 million, was spent on employees' salaries, wages, and fringe benefits. The Laboratory's total procurement budget in 2006 was approximately $\$ 189$ million, of which 36.5 million was spent on purchases in Nassau County, and \$14.7 million was spent for purchases in Suffolk County.

\section{I.6 GEOLOGY AND HYDROLOGY}

BNL is situated on the western rim of the 


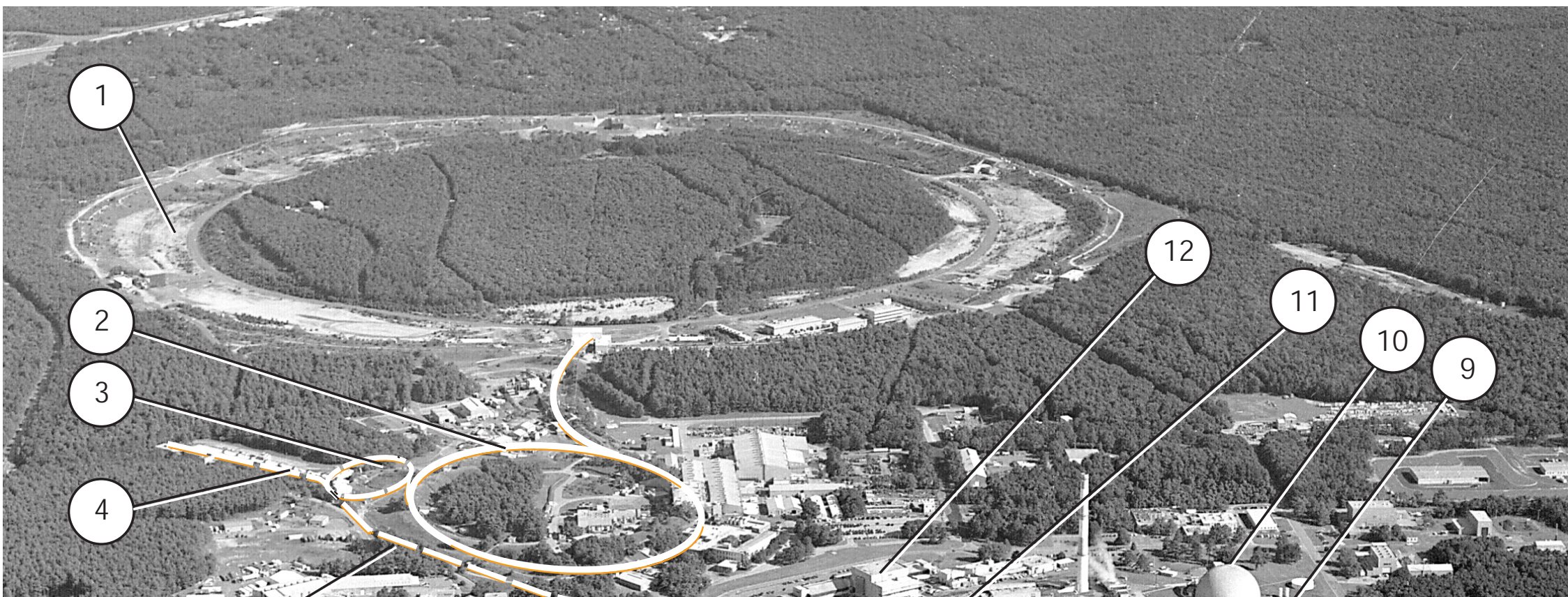

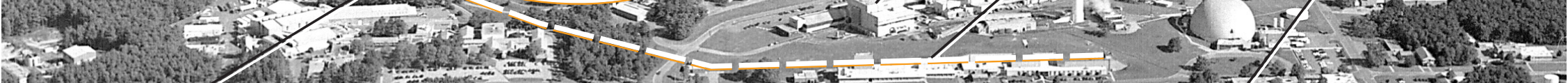

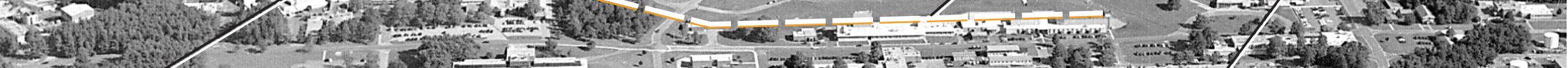

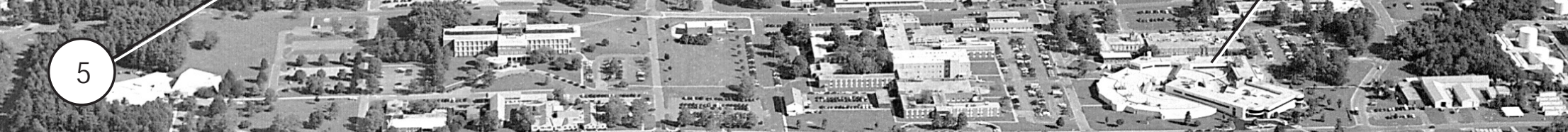

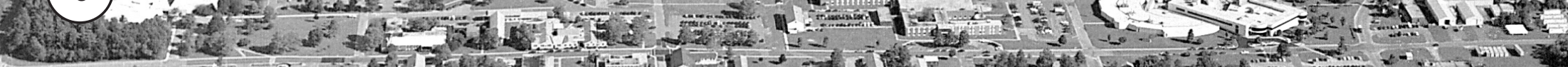

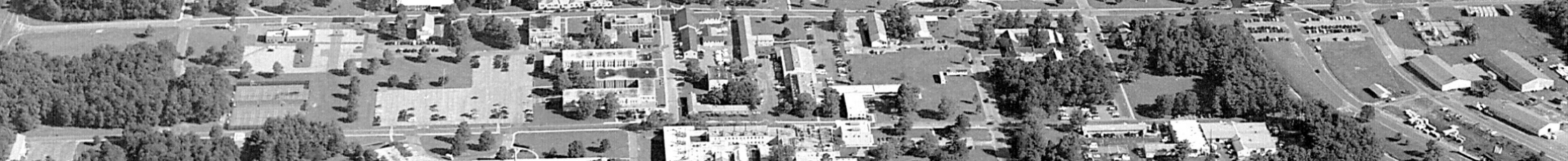

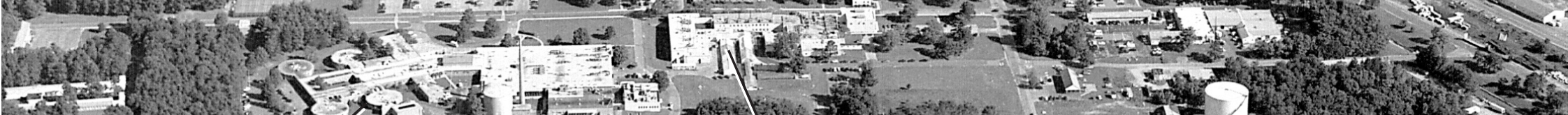

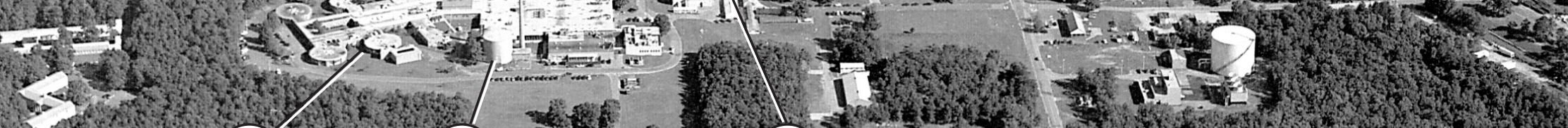
25 (6) (7)

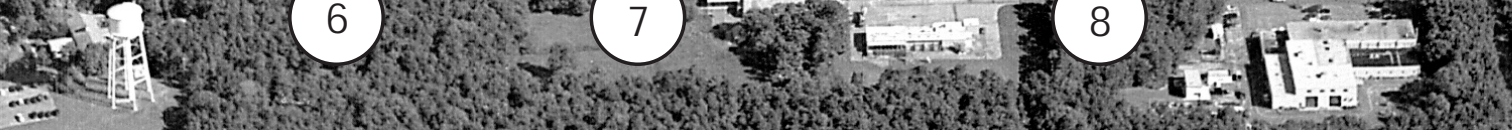

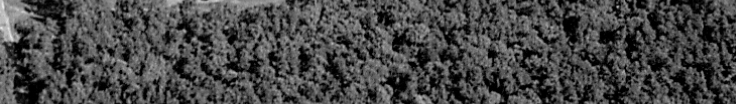
H. 4. Hith 


\section{Relativistic Heavy Ion Collider (RHIC)}

The RHIC is a world-class scientific research facility. The RHIC accelerator drives two intersecting beams of gold ions, other heavy metal ions, and protons head-on to form subatomic collisions. What physicists learn from these collisions may help us understand more about why the physical world works the way it does, from the smallest subatomic particles, to the largest stars. Current RHIC experiments include the Solenoidal Tracker at RHIC (STAR), a detector used to track particles produced by ion collisions; the PHENIX detector, used to record different particles emerging from collisions; the Broad Range Hadron Magnetic Spectrometer (BRAHMS), used to study particles as they pass through detectors; and $\mathrm{PHOBOS}$, an experiment based on the premise that when new collisions occur, new physics will be readily identified.

\section{Alternating Gradient Synchrotron (AGS)}

The AGS is a particle accelerator used to propel protons and heavy ions to high energies for physics research. The AGS is capable of accelerating protons and heavy ions, such as gold and iron. The Linear Accelerator (Linac) serves as a proton injector for the AGS Booster.

\section{AGS Booster}

The AGS Booster is a circular accelerator used for physics research and radiobiology studies. It receives either a proton beam from the Linac or heavy ions from the Tandem Van de Graaff and accelerates these before injecting them into the AGS ring for further acceleration. The Booster also serves as the energetic heavy ion source for the NASA Space Radiation Laboratory. Construction is planned for spring 2005. This new facility will be used to simulate the harsh cosmic and solar radiation environment found in space.

\section{Linear Accelerator (Linac) and Brookhaven Linac Isotope} Producer (BLIP)

The Linac provides beams of polarized protons for the AGS and RHIC. The excess beam capacity is used to produce radioisotopes for research and medical imaging at the BLIP. The BLIP is one of the nation's key production facilities for radioisotopes, which are crucial to clinical nuclear medicine. The BLIP also supports research on new diagnostic and therapeutic radiopharmaceuticals.

\section{Heavy lon Transfer Line (HITL)}

The HITL connects the Tandem Van de Graaff and the AGS Booster. This interconnection enables the transport of ions of intermediate mass to the AGS Booster, where they are accelerated before injection into the AGS. The ions are then extracted and sent to the AGS experimental area for physics research.

\section{Radiation Therapy Facility (RTF)}

Part of the Medical Research Center, the RTF is a high-energy dual x-ray mode linear accelerator used for radiation therapy for cancer patients. This accelerator delivers therapeutically useful beams of $x$-rays and electrons for conventional and advanced medical radiotherapy techniques.

\section{Brookhaven Medical Research Reactor (BMRR)}

The BMRR was the world's first nuclear reactor built exclusively for medical research and therapy. It produced neutrons in an optimal energy range for experimental treatment of a type of brain cancer known as glioblastoma multiforme. The BMRR was shut down in December 2000 due to a reduction in medical research funding.

\section{Scanning Transmission Electron Microscope (STEM)}

The STEM facility includes two microscopes, STEM I and STEM 3, used for biological research. Both devices allow scientists to see the intricate details of living things, from bacteria to human tissue. The images provide a picture and data that are used in Mass Analysis.

\section{National Synchrotron Light Source (NSLS)}

The NSLS uses a linear accelerator and booster synchrotron as an injection system for two electron storage rings that provide intense light spanning the electromagnetic spectrum from the infrared through x-rays. The properties of this light and the 80 specially designed experimental stations, called beamlines, allow scientists to perform a large variety of experiments.

\section{High Flux Beam Reactor (HFBR)}

The HFBR was one of the premier neutron physics research facilities in the world. Neutron beams produced at the HFBR were used to investigate the molecular structure of materials, which aided in pharmaceutical design and materials development and expanded the knowledge base of physics, chemistry, and biology. The HFBR was permanently shut down in November 1999.

\section{Tandem Van de Graaff and Cyclotron}

These accelerators are used in medium energy physics investigations and for producing special nuclides. The Tandem Van de Graff accelerators are used to bombard materials with ions for manufacturing and testing purposes, and to supply RHIC with heavy ions. The cyclotrons, operated by the Chemistry Department, are used for the production of radiotracers for use in Positron Emission Tomography (PET) and Magnetic Resonance Imaging (MRI) studies.

\section{Brookhaven Graphite Research Reactor (BGRR)}

The BGRR was the first peace-time reactor to be constructed in the United States following World War II. It was used for scientific exploration in the fields of medicine, biology, chemistry, physics, and nuclear engineering. The BGRR is currently being decommissioned under the Environmental Restoration Program. 
shallow Peconic River watershed. The marshy areas in the northern and eastern sections of the site are part of the headwaters of the Peconic River. Depending on the height of the water table relative to the base of the riverbed, the Peconic River both recharges to, and receives water from, the underlying upper glacial aquifer. In times of sustained drought, the river water recharges to the groundwater; with normal to above-normal precipitation, the river receives water from the aquifer.

In general, the terrain of the BNL site is gently rolling, with elevations varying between 44 and 120 feet above mean sea level. Depth to groundwater from the land surface ranges from 5 feet near the Peconic River to about 80 feet in the higher elevations of the central and western portions of the site. Studies of Long Island hydrology and geology in the vicinity of the
Laboratory indicate that the uppermost Pleistocene deposits, composed of highly permeable glacial sands and gravel, are between 120 and 250 feet thick (Warren et al. 1968, Scorca et al. 1999). Water penetrates these deposits readily, and there is little direct runoff into surface streams unless precipitation is intense. The sandy deposits store large quantities of water in the Upper Glacial aquifer. On average, about half of the annual precipitation is lost to the atmosphere through evapotranspiration and the other half percolates through the soil to recharge the groundwater (Koppelman 1978).

The Long Island Regional Planning Board and Suffolk County have identified the Laboratory site as overlying a deep-flow recharge zone for Long Island groundwater (Koppelman 1978). Precipitation and surface water that recharge within this zone have the potential to

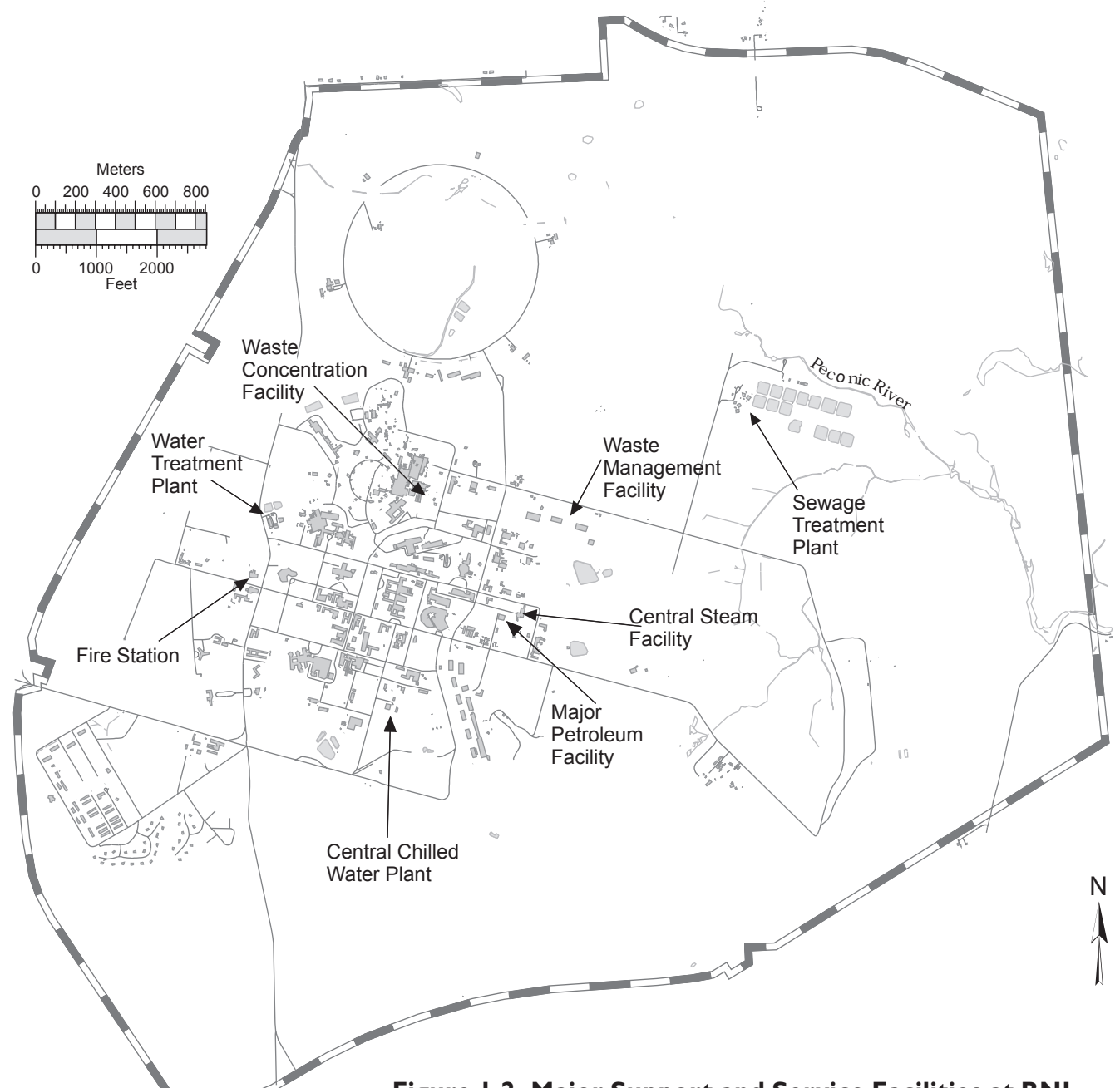

Figure I-2. Major Support and Service Facilities at BNL. 
replenish the Magothy and Lloyd aquifer systems lying below the Upper Glacial aquifer. It has been estimated that up to two-fifths of the recharge from rainfall moves into the deeper aquifers. The extent to which groundwater on site contributes to deep-flow recharge has been confirmed through the use of an extensive network of shallow and deep wells installed at BNL and surrounding areas (Geraghty \& Miller 1996). This groundwater system is the primary source of drinking water for both on- and offsite private and public supply wells and has been designated a sole source aquifer system by the Environmental Protection Agency (EPA).

During 2006, the Laboratory used approximately 1.3 million gallons of groundwater per day to meet potable water needs and heating and cooling requirements. Approximately 75 percent of the water pumped from BNL supply wells is returned to the aquifer through on-site recharge basins and permitted discharges to the Peconic River. Under normal hydrologic conditions, most of the water discharged to the river recharges to the Upper Glacial aquifer before leaving the BNL site. Human consumption, evaporation (cooling tower and wind losses), and sewer line losses account for the remaining 25 percent. An additional 4.9 million gallons of groundwater are pumped each day from remediation wells for treatment and then returned to the aquifer by way of recharge basins.

Groundwater flow directions across the BNL site are influenced by natural drainage systems: eastward along the Peconic River, southeast toward the Forge River, and south toward the Carmans River (Figure 1-3). Pumping from on-site

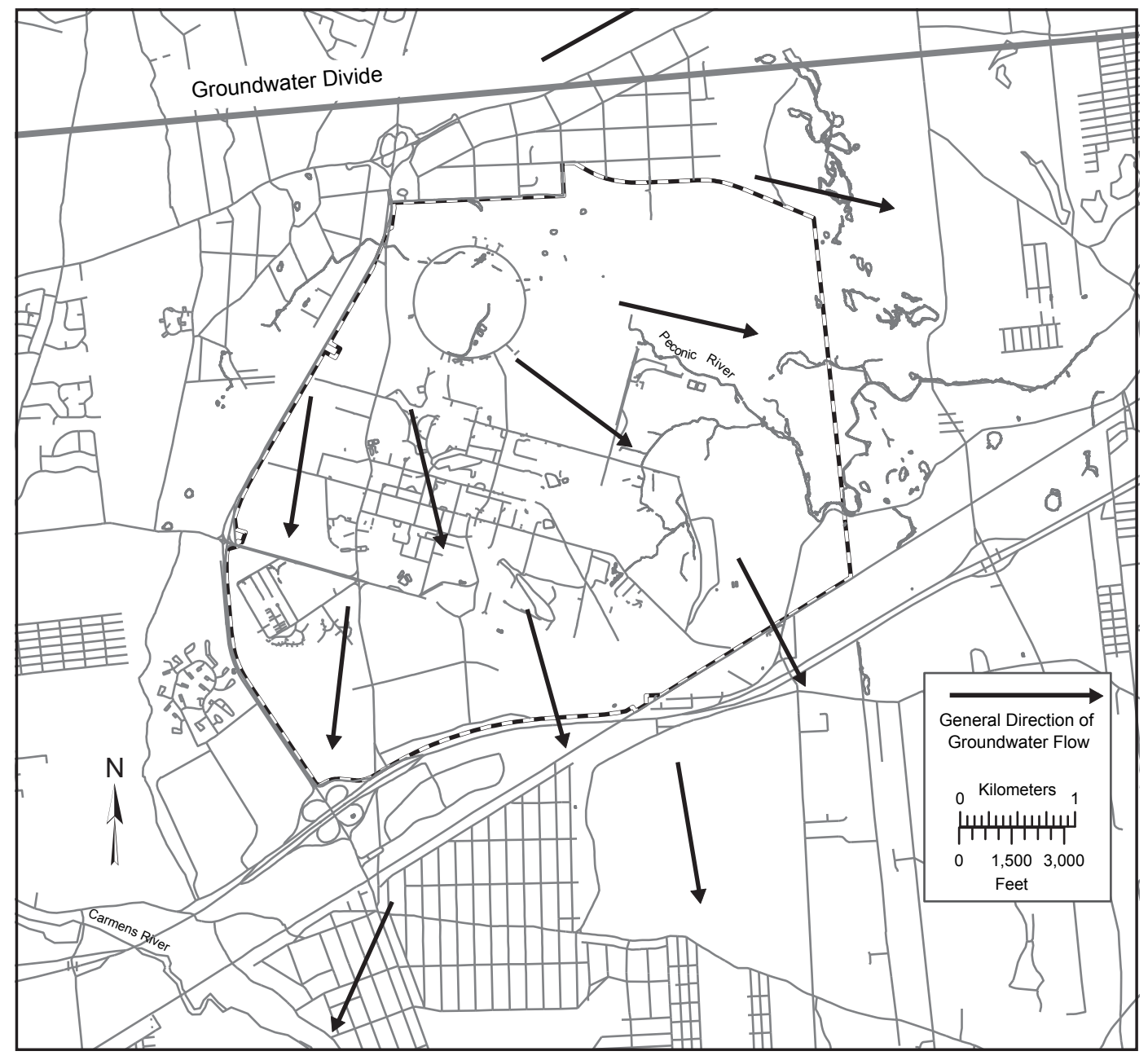

Figure I-3. BNL Groundwater Flow Map. 


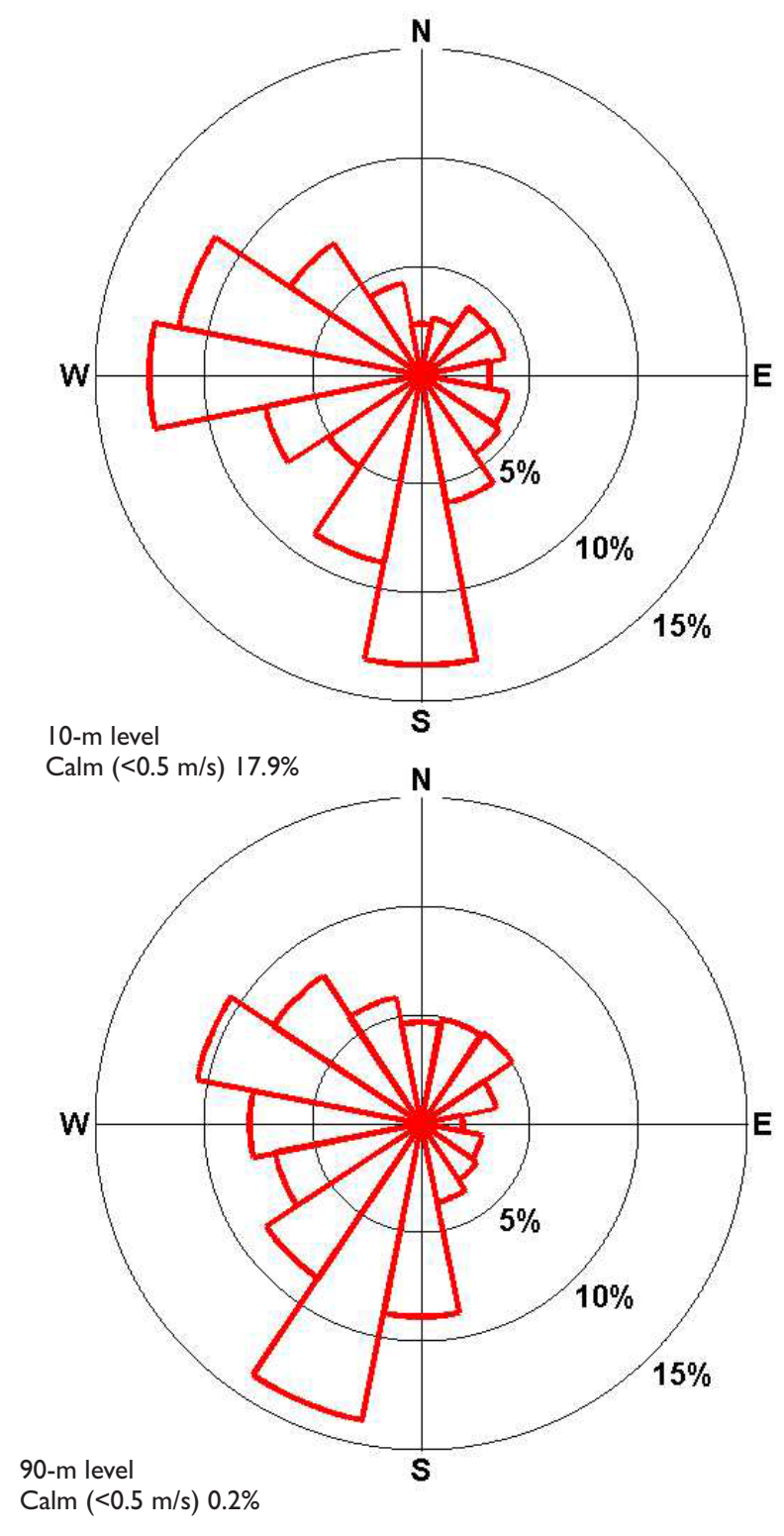

Explanation: The arrows formed by the wedges indicate wind direction. Each concentric circle represents a 5 percent frequency, that is, how often the wind came from that direction. The wind direction was measured at heights of 10 and 90 meters. This diagram indicates that the predominant wind direction was from the south at the $10-\mathrm{m}$ level and south-southwest at the 90-m level.

Figure I-4. BNL 2006 Wind Rose.

supply wells affects the direction and speed of groundwater flow, especially in the central, developed areas of the site. The main groundwater divide on Long Island is aligned generally eastwest and lies approximately one-half mile north of the Laboratory. Groundwater north of the divide flows northward and ultimately discharges to the Long Island Sound. Groundwater south of the divide flows east and south, discharging to the Peconic River, Peconic Bay, south shore streams, Great South Bay, and Atlantic Ocean. The regional groundwater flow system is discussed in greater detail in Stratigraphy and Hydrologic Conditions at the Brookhaven National Laboratory and Vicinity (Scorca et al. 1999). In most areas at BNL, the horizontal velocity of groundwater is approximately 0.75 to 1.2 feet per day (Geraghty \& Miller 1996). In general, this means that groundwater travels for approximately 20 to 22 years as it moves from the central, developed area of the site to the Laboratory's southern boundary.

\section{I.7 CLIMATE}

The Meteorological Group at BNL has been recording weather data on site since 1948 . The Laboratory is broadly influenced by continental and maritime weather systems. Locally, the Long Island Sound, Atlantic Ocean, and associated bays influence wind directions and humidity and provide a moderating influence on extreme summer and winter temperatures. The prevailing ground-level winds at BNL are from the southwest during the summer, from the northwest during the winter, and about equally from those two directions during the spring and fall (Nagle 1975, 1978). Figure 1-4 shows the 2006 annual wind rose for BNL, which depicts the annual frequency distribution of wind speed and direction, measured at an on-site meteorological tower at heights of 33 feet (10 meters) and 300 feet (90 meters) above land surface.

The average monthly temperature for 2006 was $53.9^{\circ} \mathrm{F}$ and the average annual temperature was $53.2^{\circ} \mathrm{F}$, making 2006 the warmest year ever recorded at the Laboratory. Although January was the coldest month recorded, with an average temperature of $28.7^{\circ} \mathrm{F}$, it also beat a record for warmest January day by one degree, when the temperature reached $57^{\circ} \mathrm{F}$. Figures $1-5$ and 1-6 show the 2006 monthly mean temperatures and the historical annual mean temperatures, respectively.

The total snowfall in 2006 was 30.5 inches, slightly below the average yearly snowfall of 31.2 inches. The average yearly precipitation 


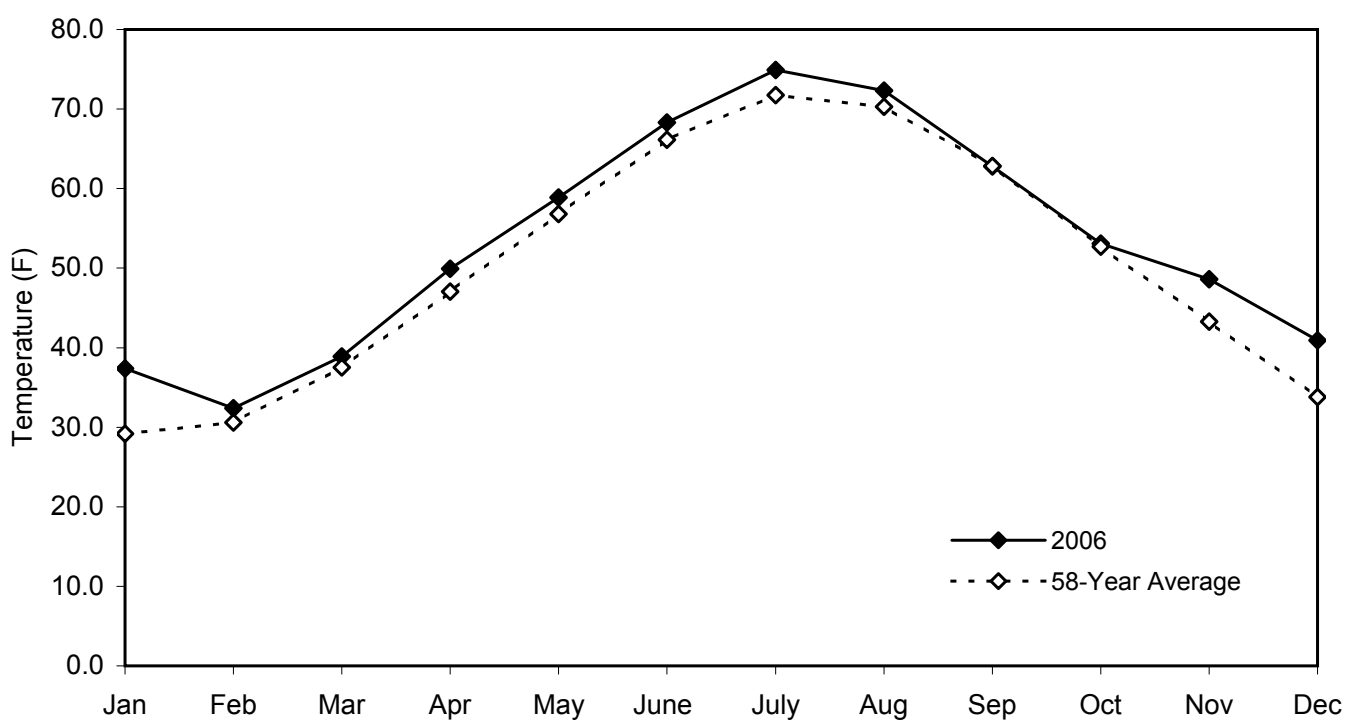

Figure I-5. BNL 2006 Monthly Mean Temperature versus 58-Year Monthly Average.

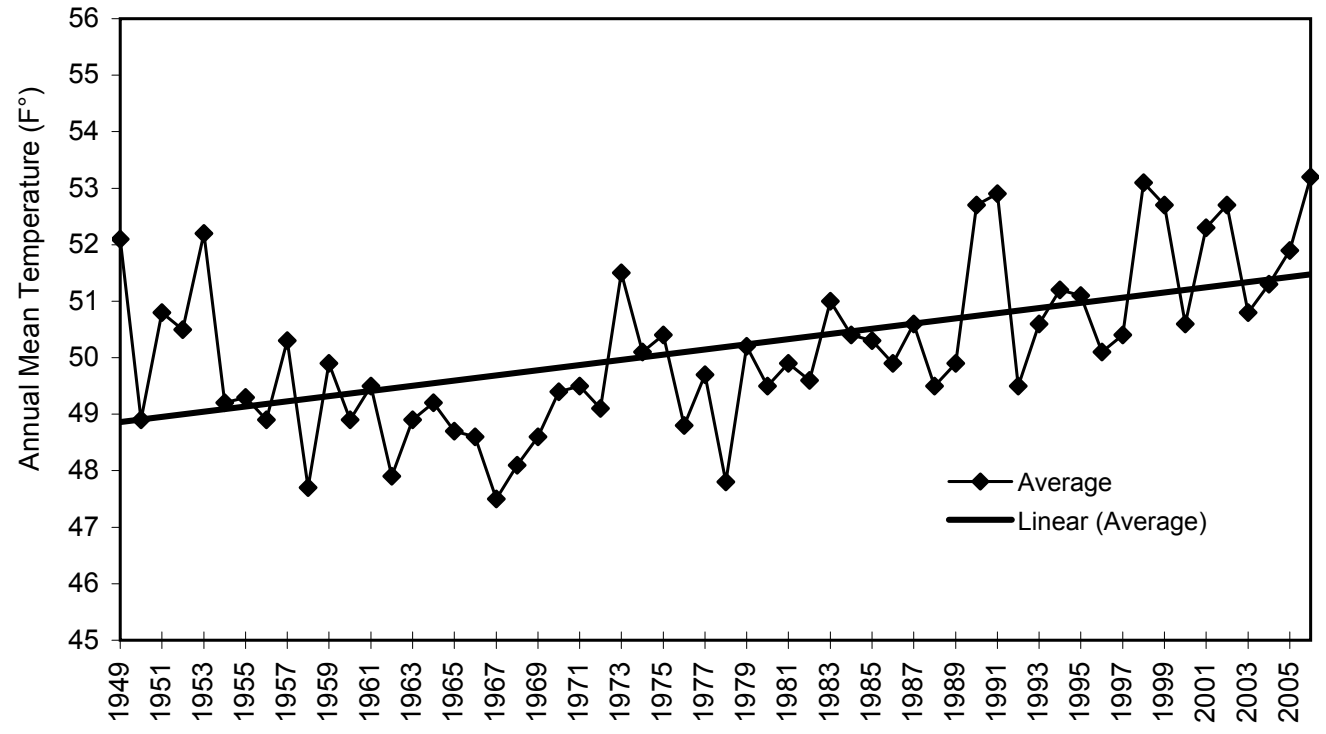

Figure I-6. BNL 2006 Annual Mean Temperature Trend (58 Years).

is 48.5 inches. The total annual precipitation for 2006 was 61.59 inches, making it the fourth wettest year recorded at the Laboratory. Figures 1-7 and 1-8 show the 2006 monthly and the 58year annual precipitation data.

\section{I.8 NATURAL RESOURCES}

The Laboratory is located in the oak/chestnut forest region of the Coastal Plain and constitutes about 5 percent of the 100,000-acre New York State-designated region on Long Island known as the Central Pine Barrens. The section of the Peconic River running through BNL is designated as "scenic" under the New York State Wild, Scenic, and Recreational River System Act of 1972. Due to the general topography and porous soil, the land is very well drained and there is little surface runoff or open standing 


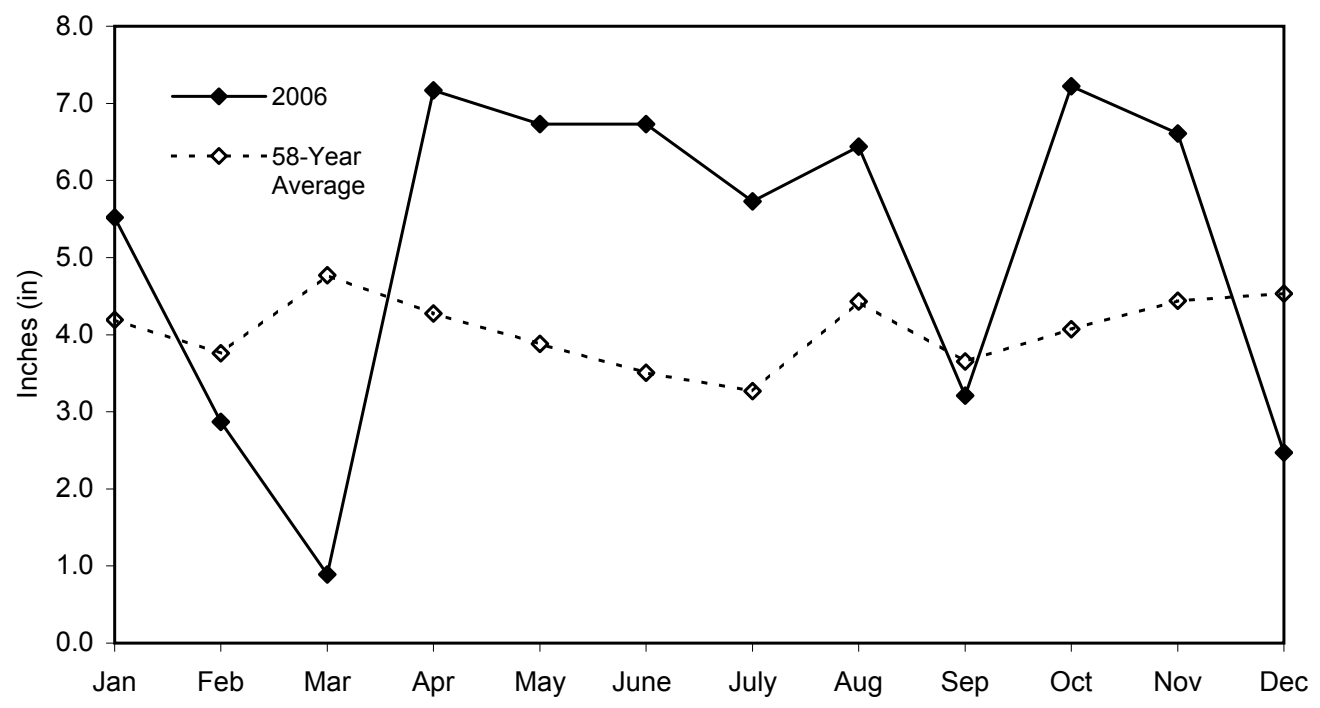

Figure I-7. BNL 2006 Monthly Precipitation versus 58-Year Monthly Average.

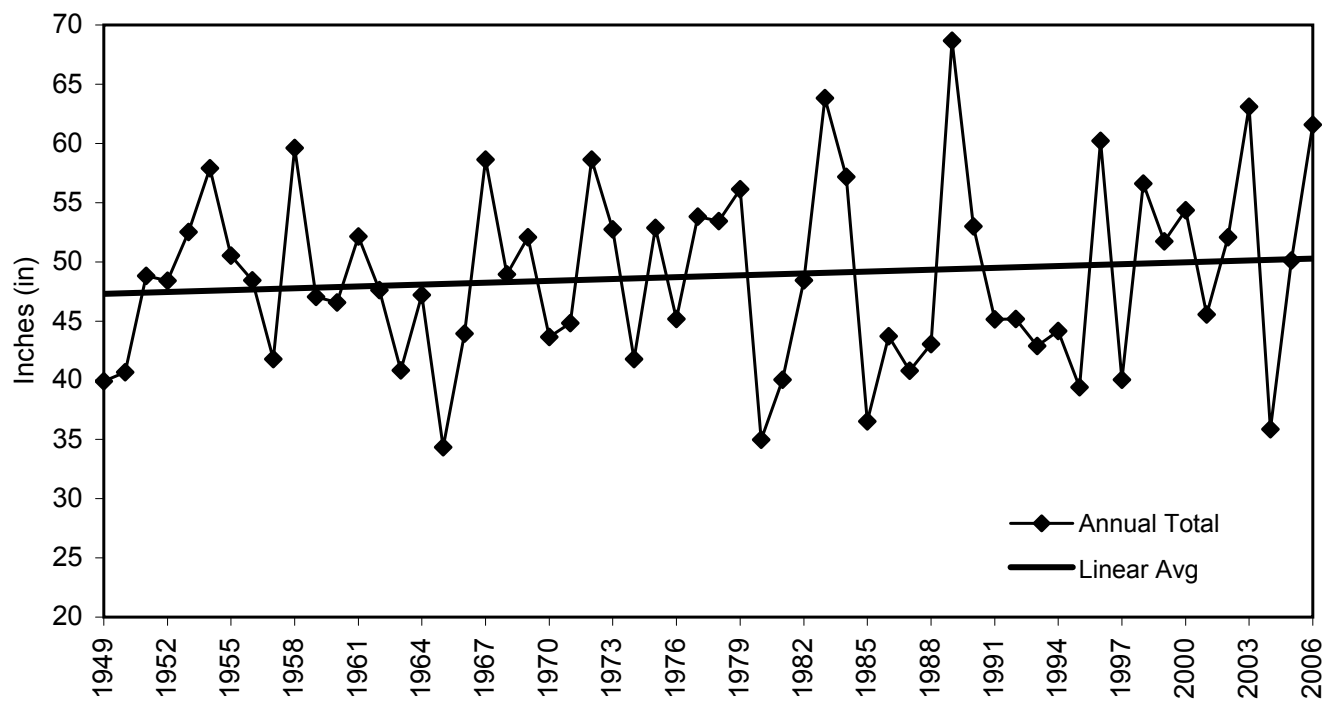

Figure I-8. BNL 2006 Annual Precipitation Trend (58 Years).

water. However, depressions form numerous small, pocket wetlands with standing water on a seasonal basis (vernal pools), and there are six regulated wetlands on site. Thus, a mosaic of wet and dry areas correlates with variations in topography and depth to the water table.

Vegetation on site is in various stages of succession, which reflects a history of disturbances to the area. For example, when Camp Upton was constructed in 1917, the site was entirely cleared of its native pines and oaks. Although portions of the site were replanted in the 1930s, portions were cleared again in 1940 when Camp Upton was reactivated by the U.S. Army. Other past disturbances include fire, local flooding, and draining. Current operations minimize disturbances to the more natural areas of the site.

More than 230 plant species have been identified at the Laboratory, including two species that are threatened in New York State and two 
that are classified as rare. Fifteen animal species identified on site include a number that are protected in New York State, as well as species common to mixed hardwood forests and open grassland habitats. At least 85 species of birds have been observed nesting on site, and more than 200 transitory bird species have been documented visiting the site. (BNL is located within the Atlantic Flyway, with scrub/shrub habitats that offer food and rest to migratory songbirds.) Permanently flooded retention basins and other watercourses support amphibians and aquatic reptiles. Thirteen amphibian and 12 reptile species have been identified at BNL. Recent ecological studies have confirmed 26 breeding sites for the New York State endangered eastern tiger salamander in ponds and recharge basins. Ten species of fish have been identified as endemic to the site, including the banded sunfish and the swamp darter, both of which are threatened in New York State. Two types of butterflies that are protected in New York State are believed to breed on site due to the presence of their preferred habitat and host plants, and a New York State threatened damselfly was found on site in 2005. To eliminate or minimize any negative effects that Laboratory operations might cause to these species, precautions are in place to protect the on-site habitats and natural resources.

In November 2000, DOE established the Upton Ecological and Research Reserve at BNL. The 530-acre Upton Reserve (10 percent of the Laboratory's property) is on the eastern portion of the site, in the Core Preservation Area of the Central Pine Barrens. The Upton Reserve creates a unique ecosystem of forests and wetlands that provides habitats for plants, mammals, birds, reptiles, and amphibians. From 2000 to 2004, funding provided by DOE under an InterAgency Agreement between DOE and the U.S. Fish \& Wildlife Services was used to conduct resource management programs for the conservation, enhancement, and restoration of wildlife and habitat in the reserve. In mid-year 2005, management was transitioned to the Foundation for Ecological Research in the Northeast (FERN). The Laboratory continues to utilize the Upton Reserve Technical Advisory Group, made up of local land management agencies, to assist
BNL and FERN with technical expertise and help determine natural resource management policy for the Laboratory and the Upton Reserve. Management of the Upton Reserve falls within the scope of BNL's Natural Resource Management Plan, and the area will continue to be managed for its key ecological values and as an area for ecological research. Additional information regarding the Upton Reserve and the Laboratory's natural resources can be found in Chapter 6 of this report.

\section{I.9 CULTURAL RESOURCES}

The Laboratory is responsible for ensuring compliance with historic preservation requirements. BNL's Cultural Resource Management Plan was developed to identify, assess, and document the Laboratory's historic and cultural resources. These resources include World War I trenches; Civilian Conservation Corps features; World War II buildings; and historic structures, programs, and discoveries associated with high-energy physics, research reactors, and other science conducted at BNL. The Laboratory currently has three facilities classified as eligible for listing on the National Register of Historic Places: the Brookhaven Graphite Research Reactor complex, the High Flux Beam Reactor complex, and the World War I training trenches associated with Camp Upton.

Kamer, Pearl M. 2006. The Economic Impact of Brookhaven National Laboratory on the New York State. Suffolk County Planning Commission, Suffolk County Department of Planning. October 2005.

Koppelman, L.E. 1978. The Long Island Comprehensive Waste Treatment Management Plan (Long Island 208 Study), Vol. I and II. Long Island Regional Planning Board, Hauppauge, NY. July 1978
} 


\section{CHAPTER I: INTRODUCTION}

Nagle, C.M. 1975. Climatology of Brookhaven National Laboratory: 1949-1973. BNL-50466. Brookhaven National Laboratory, Upton, NY. November 1975.

Nagle, C.M. 1978. Climatology of Brookhaven National Laboratory: 1974-1977. BNL-50857. Brookhaven National Laboratory, Upton, NY. May 1978.

NYCRR. Title 27. Wild, Scenic, and Recreational River Systems Act. Article 15 and subsequent updates. New York State Department of Environmental Conservation, Albany, NY.
Scorca, M.P., W.R. Dorsch, and D.E. Paquette. 1999. Stratigraphy and Hydrologic Conditions at the Brookhaven National Laboratory and Vicinity, Suffolk County, New York, 1994-97. U.S. Geological Survey Water Resources Investigations Report 99-4086. 55 pp.

Warren, M.A., W. deLaguna, and N.J. Lusczynski.1968. Hydrology of Brookhaven National Laboratory and Vicinity, Suffolk County, New York. U.S. Geological Survey Bulletin, II56-C. 


\section{Environmental Management System}

One of Brookhaven National Laboratory's highest priorities is ensuring that its environmental performance measures up to its world-class status in science. The contractor operating the Laboratory on behalf of DOE, Brookhaven Science Associates (BSA), takes environmental stewardship very seriously. As part of their commitment to environmentally responsible operations, they have established the BNL Environmental Management System (EMS). One measure of an effective EMS is recognition of good environmental performance. In 2006, BNL was recognized by DOE 's Office of Science with a "Best in Class" award for expanding the envelope of the Laboratory's EMS through voluntary participation, designing a system to compost animal bedding, and for recycling and reusing waste concrete on site. BNL was also honored with a National Partnership for Environmental Priorities award for reducing both its mercury waste generation and its inventory of polychlorinated biphenyls.

An EMS ensures that environmental issues are systematically identified, controlled, and monitored. Moreover, an EMS provides mechanisms for responding to changing environmental conditions and requirements, reporting on environmental performance, and reinforcing continual improvement. The Laboratory's EMS was designed to meet the rigorous requirements of the globally recognized International Organization for Standardization (ISO) 14001 Environmental Management Standard, with additional emphasis on compliance, pollution prevention, and community involvement.

Annual audits are required to maintain EMS registration. Recertification audits of the entire EMS occur every three years. In 2006, an EMS Surveillance Audit determined that BNL remains in conformance with the ISO 14001: 2004 Standard.

BNL continued its strong support of the Pollution Prevention Program. This program seeks ways to eliminate waste and toxic materials and is the preferred approach to resolving environmental issues at the Laboratory. In 2006, pollution prevention projects saved more than $\$ 1.8$ million and resulted in the reduction or reuse of approximately 13 million pounds of waste. Also in 2006, the BNL Pollution Prevention Council funded 11 new proposals or special projects, investing approximately $\$ 37,000$. Anticipated annual savings from the projects are estimated at approximately $\$ 74,000$, for an average payback period of less than one year. The ISO 14001-registered EMS and the nationally recognized Pollution Prevention Program continue to contribute to the Laboratory's success in promoting pollution prevention.

$B N L$ continues to address legacy issues under the Environmental Restoration Program and openly communicates with neighbors, regulators, employees, and other interested parties on environmental issues and cleanup progress on site. 


\section{I INTEGRATED SAFETY MANAGEMENT, ISO I400I, AND OHSAS I800I}

The Laboratory's Integrated Safety Management System (ISMS) integrates environment, safety, and health management into all work planning. The integrated safety processes within ISMS contributed to BNL's Environmental Management System achieving the International Organization for Standardization (ISO) 14001 registration and the Laboratory's Safety and Health Program achieving Occupational Safety and Health Assessment Series (OHSAS) 18001 Registration.

The ISO 14001 Standard is globally recognized and defines the structure of an organization's EMS for purposes of improving environmental performance. OHSAS 18001 mirrors the ISO14001 structure. The process-based structure of the ISO 14001 and OHSAS 18001 standards are based on the "Plan-Do-Check-Act" improvement cycle. Both standards require an organization to develop a policy, create plans to implement the policy, implement the plans, check progress and take corrective actions, and review the system periodically to ensure its continuing suitability, adequacy, and effectiveness. To gain registration to the ISO 14001 and OHSAS 18001 standards, an organization must comply with the set of requirements listed and described in Table 2-1. Table 2-1 also defines where these requirements fit into the ISMS structure.

BNL's EMS was officially registered to the ISO 14001 Standard in July 2001 and was the first DOE Office of Science Laboratory to obtain third-party registration to this globally recognized environmental standard. Similarly, BNL was offically registered to the OHSAS 18001 Standard in 2006, and was again the first DOE Office of Science Laboratory to achieve this registration. Each certification requires the Laboratory to undergo annual audits by an accredited registrar to assure that the system is maintained.

In 2006, an EMS and OHSAS Surveillance Audit determined that BNL remains in conformance with the ISO 14001 and OHSAS 18001 standards. In their recommendation for continued certification, auditors from NSF-International Strategic Registrations, Ltd. highlighted eight examples of BNL's continual improvement, some of which include the Laboratory's

Table 2-1. Elements of the Environmental Management System (EMS) and their Relationship to OHSAS 18001 and Integrated Safety Management (ISM) - Review of EMS Implementation at BNL.

\begin{tabular}{l|l|l}
\hline ISO 14001 EMS Clause & OHSAS 18001 Clause & ISM Guiding Principle and Core Function \\
\hline 4.2 Environmental policy & 4.2 OH\&S policy & $\begin{array}{l}\text { Core function 1: Define scope of work } \\
\text { Guiding principle 1: Line manager clearly responsible } \\
\text { for ES\&H }\end{array}$ \\
\hline
\end{tabular}

The Environmental, Safety, Security, and Health Policy is a statement of BNL's intentions and principles regarding overall environmental, safety, security, and health performance. It provides a framework for planning and action. In the policy, BNL has reaffirmed its commitment to the environment, safety, security, health, compliance, the community, and continual improvement.

\begin{tabular}{l|l|l}
\hline 4.3.1 Environmental aspects & $\begin{array}{l}\text { 5.3.1 Planning for hazard identification, risk } \\
\text { assessment and risk control }\end{array}$ & $\begin{array}{l}\text { Core function 2: Identify and analyze hazards } \\
\text { associated with the work } \\
\text { Guiding principle 5: Identify ES\&H standards and } \\
\text { requirements }\end{array}$ \\
\hline $\begin{array}{ll}\text { When operations have an environmental aspect, BNL implements the EMS to minimize or eliminate any potential impact. BNL evaluates its operations, } \\
\text { identifies the aspects of operations that can impact the environment, and determines which of those potential impacts are significant. BNL has determined } \\
\text { that the following aspects of its operations have the potential to affect the environment: }\end{array}$ \\
$\begin{array}{ll}\text { - Waste generation } & \text { - Historical and cultural resources } \\
\text { - Atmospheric emissions } & \text { - Environmental noise } \\
\text { - Liquid effluents } & \text { - Disturbances to endangered species/ } \\
\text { - Storage or use of chemicals and } & \text { - Sotected habitats } \\
\text { radioactive materials } & \text { - Historical contamination } \\
\text { - Natural resource usage - power and } & \end{array}$ \\
\begin{tabular}{l} 
water consumption \\
\hline
\end{tabular}
\end{tabular}


Table 2-1. Elements of the Environmental Management System (EMS) and their Relationship to OHSAS 18001 and Integrated Safety Management (ISM) - Review of EMS Implementation at BNL (continued).

\begin{tabular}{l|l|l}
\hline ISO 14001 EMS Clause & OHSAS 18001 Clause & ISM Guiding Principle and Core Function \\
\hline 4.3.2 Legal and other requirements & 4.3 .2 Legal and other requirements & $\begin{array}{l}\text { Core function 2: Identify and analyze hazards } \\
\text { associated with the work } \\
\text { Guiding principle 5: Identify ES\&H standards and } \\
\text { requirements }\end{array}$ \\
\hline
\end{tabular}

BNL has implemented and continues to improve the Standards Based Management System (SBMS), a BNL web-based system designed to deliver Laboratory-level requirements and guidance to all staff. New or revised requirements (e.g., new regulations) are analyzed to determine their applicability, and to identify any actions required to achieve compliance. This may involve developing or revising BNL documents or operating procedures, implementing administrative controls, providing training, installing engineered controls, or increasing monitoring.

\begin{tabular}{l|l|l}
\hline 4.3.3 Objectives Targets and Programs & $\begin{array}{l}4.3 .3 \text { Objectives } \\
4.3 .4 \mathrm{OH} \& S \text { management program(s) }\end{array}$ & $\begin{array}{l}\text { Core function 1: Define the scope of work } \\
\text { Guiding principle 5: Identify ES\&H standards and } \\
\text { requirements }\end{array}$ \\
\hline
\end{tabular}

The Performance Based Management System is designed to develop, align, balance, and implement the Laboratory's strategic objectives, including environmental objectives. Objectives and targets are developed by fiscal year (FY). The following were the objectives and targets in FY 06 :

- Continually improving the EMS

- Improving compliance in targeted areas

- Integrating pollution prevention into work planning

- Improving communications, trust, and relationships with stakeholders on environmental programs and issues
- Fully implementing the BNL Groundwater

Protection Management Program

- Ensuring responsible stewardship of natural and historical resources on site

- Implementing environmental restoration projects efficiently

Organizations within BNL develop action plans detailing how they will achieve their objectives and targets and commit the necessary resources to successfully implement both Laboratory-wide programs and facility-specific programs. The Laboratory has implemented a Pollution Prevention Program to conserve resources and minimize waste generation. BNL also has a budgeting system designed to ensure that priorities are balanced and that resources essential to the implementation and control of the EMS are provided.

\begin{tabular}{l|l|l}
$\begin{array}{l}\text { 4.4.1 Resources, roles, responsibilities and } \\
\text { authority }\end{array}$ & 4.4.1 Structure and responsibility & $\begin{array}{l}\text { Core function 1: Define the scope of work } \\
\text { Guiding principle 1: Line manager clearly responsible } \\
\text { for ES\&H } \\
\text { Guiding principle 2: Clear ES\&H roles and responsibili- } \\
\text { ties } \\
\text { Guiding principle 4: Balanced priorities }\end{array}$ \\
\hline
\end{tabular}

All employees at the Laboratory have specific roles and responsibilities in key areas, including environmental protection. Environmental and waste management technical support personnel assist the line organizations with developing and meeting their environmental responsibilities. Every BNL employee is required to develop a Roles, Responsibilities, Accountabilities, and Authorities document signed by the employee, their supervisor, and the supervisor's manager. Specifics on environment, safety, and health performance expectations are included in these documents.

\begin{tabular}{l|l|l}
\hline 4.4.2 Competence, training and awareness & 4.4.2 Training, awareness and competence & $\begin{array}{l}\text { Core function 4: Perform work within controls } \\
\text { Guiding principle 3: Competence commensurate with } \\
\text { responsibilities }\end{array}$
\end{tabular}

Extensive training on EMS requirements has been provided to staff whose responsibilities include environmental protection. The training program includes general environmental awareness for all employees, regulatory compliance training for selected staff, and specific courses for managers, internal assessors, EMS implementation teams, and operations personnel whose work can impact the environment.

\begin{tabular}{l|l|l}
\hline 4.4.3 Communication & 4.4.3 Consultation and communication & $\begin{array}{l}\text { Core function 4: Perform work within controls } \\
\text { Core function 5: Provide feedback on adequacy of con- } \\
\text { trols and continue to improve safety management } \\
\text { Guiding principle 2: Clear ES\&H roles and responsibili- } \\
\text { ties }\end{array}$ \\
\hline
\end{tabular}

BNL continues to improve processes for internal and external communications on environmental issues. The Laboratory solicits input from interested parties such as community members, activists, civic organizations, elected officials, and regulators. This is accomplished primarily through the Citizens Advisory Committee and the Brookhaven Executive Roundtable. At the core of the communication and community involvement programs are the Environmental Safety, Security, and Health Policy and the Community Involvement Plan.

(continued on next page) 
Table 2-1. Elements of the Environmental Management System (EMS) and their Relationship to OHSAS 18001 and Integrated Safety Management (ISM) - Review of EMS Implementation at BNL (continued).

\begin{tabular}{l|l|l}
\hline ISO 14001 EMS Clause & OHSAS 18001 Clause & ISM Guiding Principle and Core Function \\
\hline 4.4.4 Documentation & 4.4.4 Documentation & $\begin{array}{l}\text { Core function 2: Identify and analyze hazards } \\
\text { associated with the work } \\
\text { Guiding principle 6: Hazard controls tailored to work } \\
\text { Guiding principle 7: Operations authorization }\end{array}$ \\
\hline
\end{tabular}

BNL has a comprehensive, up-to-date set of Laboratory-wide environmental documents describing the EMS. Using the SBMS, staff can access detailed information on regulatory requirements, Laboratory-wide procedures, and manuals on how to control processes and perform their work in a way that protects the environment. The SBMS has improved the quality, usability, and communication of Laboratory-level requirements.

\begin{tabular}{l|l|l}
\hline 4.4.5 Control of documents & 4.4.5 Document and data control & $\begin{array}{l}\text { Core function 4: Perform work within controls } \\
\text { Guiding principle 6: Hazard controls tailored to work }\end{array}$ \\
\hline
\end{tabular}

The SBMS includes a comprehensive document control system to ensure effective management of procedures and other requirements documents. When facilities require additional procedures to control their work, document control protocols are implemented to ensure that workers have access to the most current versions of procedures.

\begin{tabular}{l|l|l}
\hline 4.4.6 Operational control & 4.4.6 Operational control & $\begin{array}{l}\text { Core function 2: Identify and analyze hazards } \\
\text { associated with the work } \\
\text { Core function 3: Develop and implement hazard } \\
\text { controls } \\
\text { Core function 4: Perform work within controls } \\
\text { Guiding principle 5: Identify ES\&H standards and } \\
\text { requirements } \\
\text { Guiding principle 6: Hazard controls tailored to work } \\
\text { Guiding principle 7: Operations authorization }\end{array}$ \\
\hline
\end{tabular}

Operations at the Laboratory are evaluated for the adequacy of current controls to prevent impacts to the environment. As needed, additional administrative or engineered controls are identified, and plans for upgrades and improvements are developed and implemented.

\begin{tabular}{|l|l|l}
\hline 4.4.7 Emergency preparedness and response & 4.4.7 Emergency preparedness and response & $\begin{array}{l}\text { Core function 2: Identify and analyze hazards associ- } \\
\text { ated with the work } \\
\text { Core function 3: Develop and implement hazard } \\
\text { controls } \\
\text { Guiding principle 6: Hazard controls tailored to work }\end{array}$ \\
\hline
\end{tabular}

BNL has an Emergency Preparedness and Response Program and specialized staff to provide timely response to hazardous materials or other environmental emergencies. This program includes procedures for preventing, as well as responding to, emergencies.

\begin{tabular}{l|l|l}
\hline 4.5.1 Monitoring and measurement & $\begin{array}{l}\text { 4.5.1 Performance measurement and monitor- } \\
\text { ing }\end{array}$ & $\begin{array}{l}\text { Core function 5: Provide feedback on adequacy of } \\
\text { controls and continue to improve safety }\end{array}$ \\
\hline
\end{tabular}

Effluent and emission monitoring helps ensure the effectiveness of controls, adherence to regulatory requirements, and timely identification and implementation of corrective measures. BNL has a comprehensive, sitewide Environmental Monitoring Program. Monitoring results are reported to regulatory agencies and are summarized annually in the Site Environmental Report. In addition, BNL tracks and trends its progress and performance in achieving environmental objectives and performance measures.

\begin{tabular}{l|l|l}
\hline 4.4.2 Evaluation of compliance & NA & $\begin{array}{l}\text { Core function 5: Provide feedback on adequacy of } \\
\text { controls and continue to improve safety }\end{array}$ \\
\hline
\end{tabular}

Specific environmental legislation and regulations are evaluated and assessed on a program- or facility-specific basis. BNL has established a documented procedure for periodically evaluating its compliance with relevant environmental regulations. This procedure is often integrated in an organization's environmental, safety, and health inspection process, which is performed in a prioritized fashion by a team of experts including one on environmental regulatory issues. Periodically, the environmental support organizations will perform a regulatory assessment in a particular topical area to verify the compliance status of multiple organizations throughout the Laboratory. Lastly, external regulatory agencies and/or technical experts may conduct independent audits of compliance.

\begin{tabular}{l|l|l}
\hline $\begin{array}{l}\text { 4.5.3 Nonconformance, corrective action and } \\
\text { preventative action }\end{array}$ & $\begin{array}{l}\text { 4.5.2 Accidents, incidents, non-conformances } \\
\text { and corrective and preventative action }\end{array}$ & $\begin{array}{l}\text { Core function 5: Provide feedback on adequacy of } \\
\text { controls and continue to improve safety }\end{array}$
\end{tabular}

BNL continues to improve processes that identify and correct problems. A Lessons Learned Program to prevent recurrences, a sitewide Self-Assessment Program, and an electronic web-based assessment and action tracking system have been implemented. 
Table 2-1. Elements of the Environmental Management System (EMS) and their Relationship to OHSAS 18001 and Integrated Safety Management (ISM) - Review of EMS Implementation at BNL (concluded).

\begin{tabular}{l|l|l}
\hline ISO 14001 EMS Clause & OHSAS 18001 Clause & ISM Guiding Principle and Core Function \\
\hline 4.5.2 Control of records & 4.5 .3 Records and records management & $\begin{array}{l}\text { Core function 2: Identify and analyze hazards associ- } \\
\text { ated with the work } \\
\text { Guiding principle 6: Hazard controls tailored to work } \\
\text { Guiding principle 7: Operations authorization }\end{array}$ \\
\hline
\end{tabular}

EMS-related records, including audit and training records, are maintained to ensure integrity, facilitate retrieval, and protect them from loss.

\begin{tabular}{|c|c|c|}
\hline 4.5.5 Internal audit & 4.5.4 Audit & $\begin{array}{l}\text { Core function 5: Provide feedback on adequacy of } \\
\text { controls and continue to improve safety }\end{array}$ \\
\hline \multicolumn{3}{|c|}{$\begin{array}{l}\text { To periodically verify that the EMS is operating as intended, audits are conducted. These audits, which are part of the sitewide Self-Assessment Pro- } \\
\text { gram, are designed to ensure that any nonconformance to the ISO } 14001 \text { Standard is identified and addressed. An independent accredited registrar also } \\
\text { conducts ISO } 14001 \text { registration audits. In addition, compliance with regulatory requirements is verified through routine inspections, operational evalua- } \\
\text { tions, and periodic audits. }\end{array}$} \\
\hline 4.6 Management review & 4.6 Management review & $\begin{array}{l}\text { Core function 5: Provide feedback on adequacy of } \\
\text { controls and continue to improve safety } \\
\text { Guiding principle 1: Line manager clearly responsible } \\
\text { for ES\&H }\end{array}$ \\
\hline
\end{tabular}

In addition to audits, a management review process has been established to involve top management in the overall assessment of environmental performance, the EMS, and progress toward achieving environmental goals. This review also identifies, as necessary, the need for changes to, and continual improvement of, the EMS.

commitment to fund pollution prevention and safety projects, improved methods for addressing corrective actions, the use of lessons learned, and management's response to comments and suggestions from employees. The auditors also identified two minor nonconformances in document control and management review and two opportunities for improvement in "objectives, targets and programs," and "nonconformances." A corrective action plan was prepared to track minor nonconformances to closure.

\subsection{ENVIRONMENTAL, SAFETY, SECURITY, AND HEALTH POLICY}

The cornerstone of an EMS is a commitment to environmental protection at the highest levels of an organization. BNL's environmental commitments are incorporated into a comprehensive Environmental, Safety, Security, and Health (ESSH) Policy. In 2006, the policy was revised to improve its focus for all employees. The policy, issued and signed by the Laboratory Director, makes clear the Laboratory's commitment to environmental stewardship, the safety of the public and BNL employees, and the security of the site. The policy continues as a statement of the Laboratory's intentions and principles regarding overall environmental performance. It provides a framework for planning and action and is included in employee, guest, and contractor training programs. The ESSH Policy is posted throughout the Laboratory and on the BNL website at http://www.bnl.gov. The goals and commitments focusing on compliance, pollution prevention, community outreach, and continual improvement include:

- ENVIRONMENT: We protect the environment, conserve resources, and prevent pollution.

- SAFETY: We maintain a safe workplace, and we plan our work and perform it safely. We take responsibility for the safety of ourselves, coworkers, and guests.

- SECURITY: We protect people, property, information, computing systems, and facilities.

- HEALTH: We protect human health within our boundaries and in the surrounding community.

- COMPLIANCE: We achieve and maintain compliance with applicable ESSH requirements.

- commUNITY: We maintain open, proactive, and constructive relationships with our em- 
ployees, neighbors, regulators, DOE, and our other stakeholders.

- CONTINUAL IMPROVEMENT: We continually improve ESSH performance.

\subsection{PLANNING}

The planning requirements of the ISO 14001 Standard require BNL to identify the environmental aspects and impacts of its activities, products, and services; to evaluate applicable legal and other requirements; to establish objectives and targets; and to create action plans to achieve the objectives and targets.

\subsection{Environmental Aspects}

An "environmental aspect" is any element of an organization's activities, products, and services that can interact with the environment. As required by the ISO 14001 Standard, BNL evaluates its operations, identifies the aspects that can impact the environment, and determines which of those impacts are significant. The Laboratory's criteria for significance are based on actual and perceived impacts of its operations and on regulatory requirements. BNL utilizes several processes to identify and review environmental aspects. Key among these is the Process Assessment Procedure. This is an evaluation that is documented on a Process Assessment Form, which consists of a written process description, a detailed process flow diagram, a regulatory determination of all process inputs and outputs, identification of pollution prevention opportunities, and identification of any assessment, prevention, and control measures that should be considered. Environmental professionals work closely with Laboratory personnel to ensure that environmental requirements are integrated into each process. Aspects and impacts are evaluated annually to ensure that they continue to reflect stakeholder concerns and changes in regulatory requirements. BNL's list of aspects and significance criteria remained unchanged in 2006.

\subsubsection{Legal and Other Requirements}

To implement the compliance commitments of the ESSH Policy and to meet its legal requirements, BNL has systems in place to review changes in federal, state, or local environmental regulations and to communicate those changes to affected staff. Laboratory-wide procedures for documenting these reviews and recording the actions required to ensure compliance are available to all staff through BNL's web-based Standards-Based Management System (SBMS) subject areas.

\subsubsection{Objectives and Targets}

The establishment of environmental objectives and targets is accomplished through BNL's Performance Based Management System. This system is designed to develop, align, balance, and implement the Laboratory's strategic objectives, including environmental objectives. The system drives BNL's improvement agenda by establishing a prioritized set of key objectives, called the Performance Evaluation Management Plan. The Laboratory and BSA work with DOE to clearly define expectations and performance measures. Factors for selecting environmental priorities include:

- Significant environmental aspects

- Risk and vulnerability (primarily, threat to the environment)

- Legal requirements (laws, regulations, permits, enforcement actions, and memorandums of agreement)

- Commitments (in the ESSH Policy) to regulatory agencies, and to the public

- Importance to DOE, the public, employees, and other stakeholders

Laboratory-level objectives and targets are developed on a fiscal year (FY) schedule. In FY06 (October 1, 2005 through September 30, 2006),

BNL's environmental objectives included:

- Continually improving the EMS

- Improving compliance in targeted areas

- Integrating pollution prevention into all work planning

- Improving communications, trust, and relationships with stakeholders on environmental programs and issues

- Fully implementing the BNL Groundwater Protection Management Program

- Ensuring responsible stewardship of natural and historical resources on site

- Implementing environmental restoration projects efficiently 


\subsubsection{Environmental Management Programs}

Each organization within BNL develops an action plan detailing how they will achieve their environmental objectives and targets and commit the resources necessary to successfully implement both Laboratory-wide and facility-specific programs. BNL has a budgeting system designed to ensure that priorities are balanced and to provide resources essential to the implementation and control of the EMS. The Laboratory has developed and funded several important environmental programs to further integrate environmental stewardship into all facets of BNL's missions.

\subsubsection{Compliance}

BNL has an extensive system to help ensure full compliance with all applicable environmental regulatory requirements and permits. Legislated compliance is outlined by the Clean Air Act, National Emission Standards for Hazardous Air Pollutants (NESHAPs), State Pollutant Discharge Elimination System (SPDES), and the Resource Conservation and Recovery Act (RCRA) and other programs. Other compliance initiatives at the Laboratory involve special projects, such as upgrading petroleum and chemical storage tank facilities, upgrading the sanitary sewer system, closing underground injection control devices, retrofitting or replacing air conditioning equipment refrigerants, and managing legacy waste. See Chapter 3 for a list of regulatory programs to which BNL subscribes, and a thorough discussion of these programs and their status.

\subsubsection{Groundwater Protection}

BNL's Groundwater Protection Management Program is designed to prevent negative impacts to groundwater and to restore groundwater quality by integrating pollution prevention efforts, monitoring groundwater restoration projects, and communicating performance. The Laboratory has also developed a Groundwater Protection Contingency Plan that defines an orderly process for quickly taking corrective actions in response to unexpected monitoring results. Key elements of the groundwater program are full, timely disclosure of any off-normal oc- currences, and regular communication on the performance of the program. In 2005, BNL completed construction of the Strontium-90 Groundwater Treatment system, the last major system scheduled for construction. Chapter 7 and SER Volume II, Groundwater Status Report, provide additional details about this program, its performance, and monitoring results for 2006.

\subsubsection{Waste Management}

As a byproduct of the world-class research it conducts, BNL generates a large range of waste. This includes materials common to many businesses and industries, such as aerosol cans, batteries, paints, and oils. However, the Laboratory's unique scientific activities also generate waste streams that are subject to additional regulation and special handling, including radioactive, hazardous, and mixed waste.

Collecting, storing, transporting, and disposing of waste generated at the Laboratory is the responsibility of BNL's Waste Management Facility (WMF). This modern facility was designed for handling hazardous, industrial, radioactive, and mixed waste and is comprised of three staging areas: a facility for hazardous waste, regulated by RCRA; a mixed-waste building for material that is both hazardous and radioactive; and a reclamation building for radioactive material. The RCRA and mixed-waste buildings are managed under a permit issued by the New York State Department of Environmental Conservation (NYSDEC). These buildings are used for short-term storage of waste before it is packaged or consolidated for off-site shipment to permitted treatment and disposal facilities. In 2006, BNL generated the following types and quantities of waste from routine operations:

- Hazardous waste: 3.9 tons

- Mixed waste: $8.9 \mathrm{ft}^{3}$

- Radioactive waste: $3,678 \mathrm{ft}^{3}$

Hazardous and mixed waste from routine operations in 2006 decreased substantially from 2005, as shown in Figures 2-1a and 2-1b. The decreased mixed waste generation is attributed to reduced activities within the Collider-Accelerator Department. As shown in Figure 2-1c, the radioactive waste quantity for routine op- 
erations in 2006 increased, but remained below quantities typically generated in previous years. This increase is attributed to increased funding and resulting operations within the high-energy nuclear physics program. Wastes generated from nonroutine or one-time events and wastes generated from environmental restoration activities are not included in the figures.

Routine operations are defined as ongoing industrial and experimental operations. $\mathrm{BNL}$ is currently cleaning up facilities and areas containing radioactive and chemical contamination resulting from long-past operations. Waste recovered through restoration and decommissioning activities is managed by the Environmental Restoration (ER) group, with oversight by BNL's Environmental and Waste Management Services Division (EWMSD). In 2006, EWMSD continued surveillance and maintenance operations for the Brookhaven Medical Research Reactor (BMRR) and began working with Plant Engineering staff to prepare the Former Hot Laundry and Decontamination Facility for demolition. Waste generation activity associated with the BMRR and the Decontamination Facility is reflected in the nonroutine waste values. Nonroutine waste typically includes construction and demolition waste, environmental restoration waste, legacy waste, leadpainted debris, lead shielding, and polychlorinated biphenyl

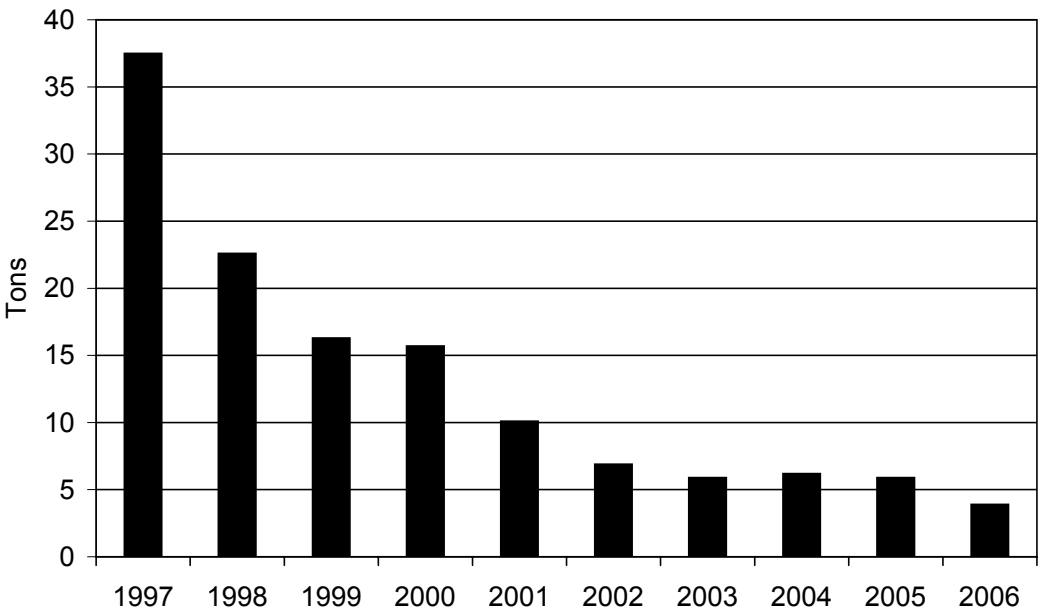

Figure 2-Ia. Hazardous Waste Generation from Routine Operations, 1997 - 2006.

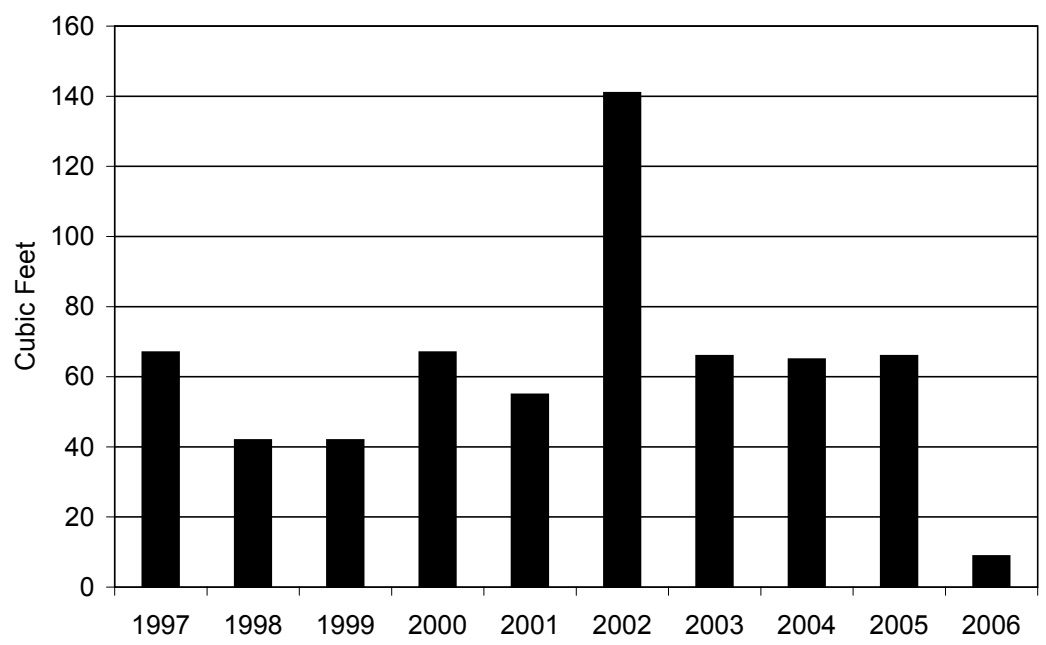

Figure 2-Ib. Mixed Waste Generation from Routine Operations, 1997 - 2006.

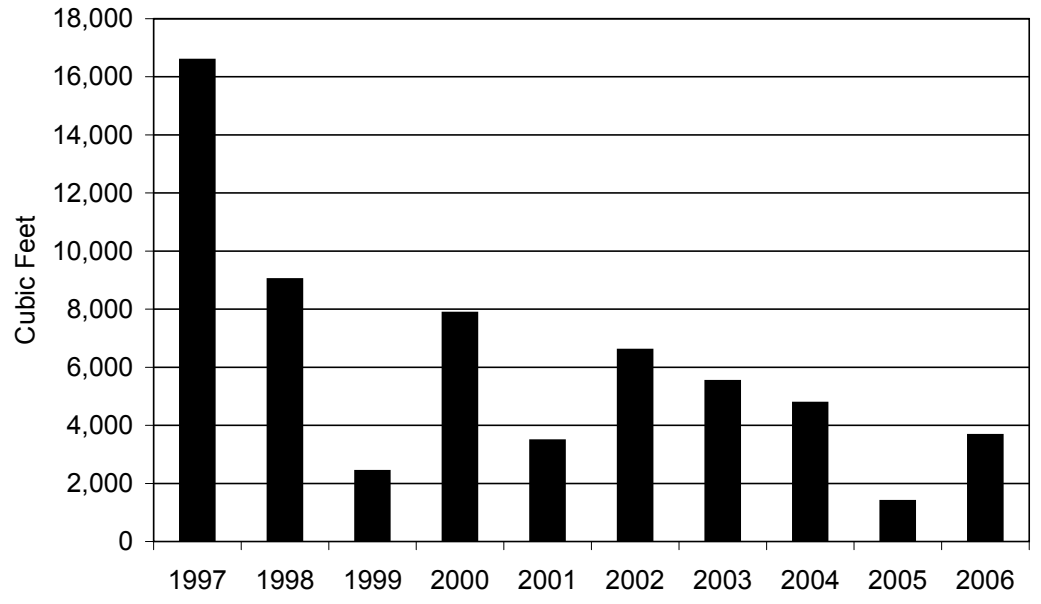

Figure 2-Ic. Radioactive Waste Generation from Routine Operations, 1997 - 2006. 


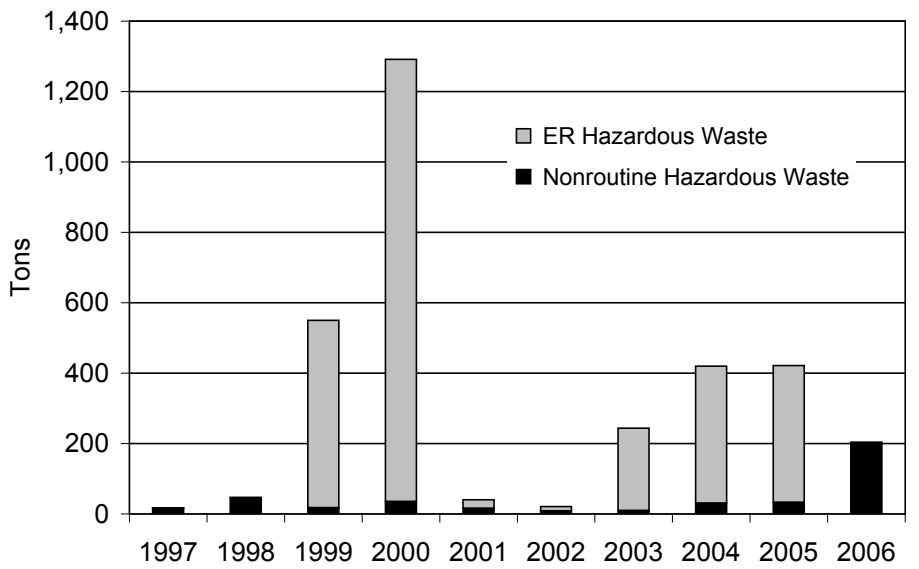

Figure 2-Id. Hazardous Waste Generation from ER and Nonroutine Operations, 1997 - 2006.

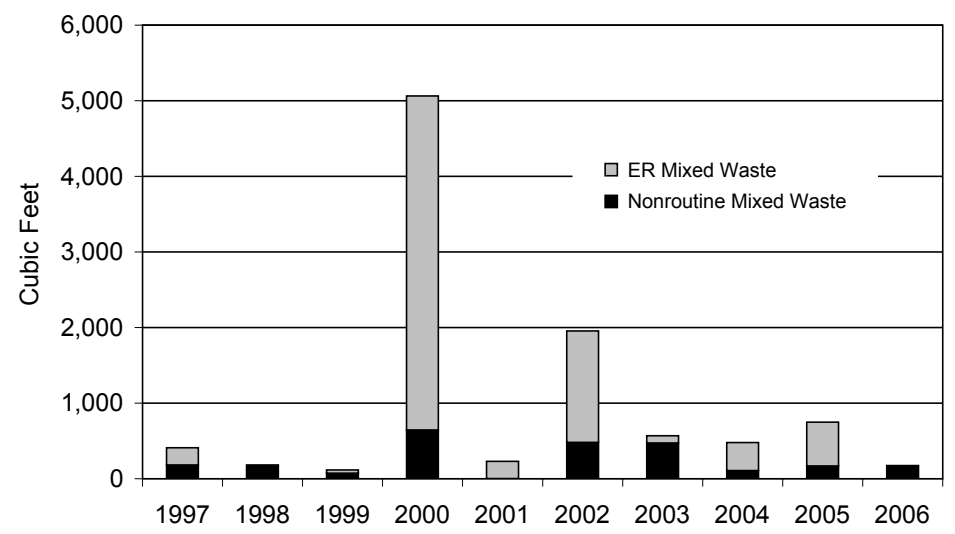

Figure 2-Ie. Mixed Waste Generation from ER and Nonroutine Operations, 1997 - 2006.

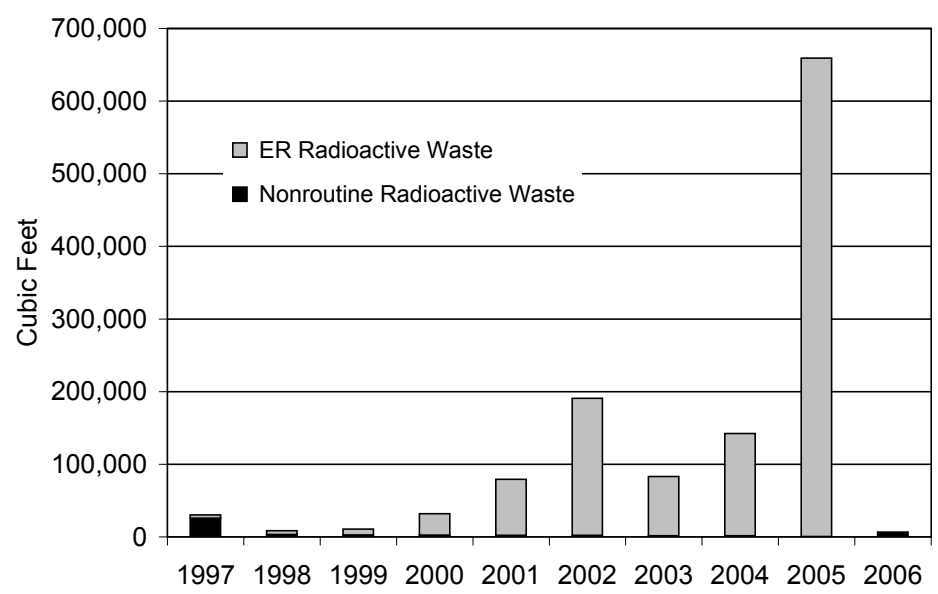

Figure 2-If. Radioactive Waste Generation from ER and Nonroutine Operations, I 997 - 2006.
(PCB) waste. Figures 2-1d through 2-1f show wastes generated under the ER Program, as well as nonroutine operations. Waste generation from these activities has varied significantly from year to year. This was expected, as environmental restoration activities moved from remedial investigations and feasibility studies to remedial actions, which have changed annually based on the progress of BNL's cleanup schedule. With many large-scale remedial operations completed, waste generation decreased significantly and was mainly attributed to housekeeping and surveillance and maintenance activities.

\subsubsection{Pollution Prevention and Minimization}

The Laboratory's Pollution Prevention (P2) Program is an essential element for the successful accomplishment of BNL's broad mission. It reflects the national and DOE pollution prevention goals and policies and represents an ongoing effort to make pollution prevention and waste minimization an integral part of the Laboratory's operating philosophy.

Pollution prevention and waste reduction goals have been incorporated into the DOE contract with BSA, into BNL's ESSH Policy, and into the critical outcomes associated with the Laboratory's operating contract with BSA. Key elements of the P2 Program include:

- Eliminate or reduce emissions, effluents, and waste 
at the source where possible, and ensure that they are as low as reasonably achievable (i.e., uphold the E-ALARA policy)

- Procure environmentally preferable products (known as "affirmative procurement")

- Conserve natural resources and energy

- Reuse and recycle materials

- Achieve or exceed BNL/DOE waste minimization, P2, recycling, and affirmative procurement goals

- Comply with applicable requirements (e.g., New York State Hazardous Waste Reduction Goal, Executive Orders, etc.)

- Reduce waste management costs

- Identify funding mechanisms for evaluating and implementing P2 opportunities

- Implement P2 projects

- Improve employee and community awareness of $\mathrm{P} 2$ goals, plans, and progress

Eighteen P2 proposals were submitted to the BNL P2 Council for funding in FY 2006. Seven proposals were funded, in addition to four special projects, for a combined investment of approximately $\$ 37,200$. The anticipated annual savings from these projects is estimated at $\$ 74,200$, for an average payback period of less than one year. The four special projects were jointly funded with other BNL divisions and significantly limited future environmental and worker safety risks.

The BNL $\mathrm{P} 2$ and recycling programs have achieved significant reductions in waste generated by routine operations, as shown in Figures 2-1a through 2-1c. This continues a positive trend and is further evidence that pollution prevention planning is well integrated into the Laboratory's work planning process. These positive trends are also driven by the EMS emphasis on preventing pollution and establishing objectives and targets to reduce environmental impacts.

Some examples of the Laboratory's P2 accomplishments in 2006 include:

- Three P2 awards from the DOE Office of Science:

- "Best in Class" award for "On-Site Reuse of Concrete from Demolition Projects for New Construction Projects"

- "Noteworthy Practice" for "Environmental Stewardship: Expanding the Envelope of the BNL Environmental Management System (EMS) Through Voluntary Participation"

- "Noteworthy Practice" for "Animal Bedding Composting"

- Several jointly funded P2 projects which greatly decreased both environmental and safety risks to the Laboratory:

- Disposal of a researcher's \#6 fuel oil and BioFuels at the Steam Generating Facility

- On-site recycling of more than 5,500 tons of concrete from building demolition projects for use as base material for parking lots for two new Laboratory buildings

- Replacement of Halogen 1211 fire extinguishers

- Disposal/replacement of BNL's Weather Station mercury barometer

- Purchase of an Animal Bedding Facility dumpster to allow for composting

- A National Partnership for Environmental Priorities (NPEP) Achievement Award for reducing mercury waste generation and reducing the inventory of PCBs. NPEP encourages public and private organizations to form voluntary partnerships with the U.S. Environmental Protection Agency (EPA) to reduce the use or release of any of 31 priority toxic chemicals and metals identified by the EPA. The goal of the program is to reduce the use or release of four million pounds of these toxic substances by 2011 .

Table 2-2 describes the P2 projects implemented through 2006 and indicates the number of pounds of materials reduced, reused, or recycled, as well as the estimated cost benefit of each project. Additional recycling and waste reduction projects are included in the table.

The implementation of pollution prevention opportunities, recycling programs, and conservation initiatives has significantly reduced both waste volumes and management costs. In 2006, these efforts resulted in more than $\$ 1.8$ million in cost avoidance or savings and approximately 13 million pounds of materials being reduced, recycled, or reused.

The Laboratory also has an active and successful solid waste recycling program, which involves all employees. In 2006, BNL collected 
CHAPTER 2: ENVIRONMENTAL MANAGEMENT SYSTEM

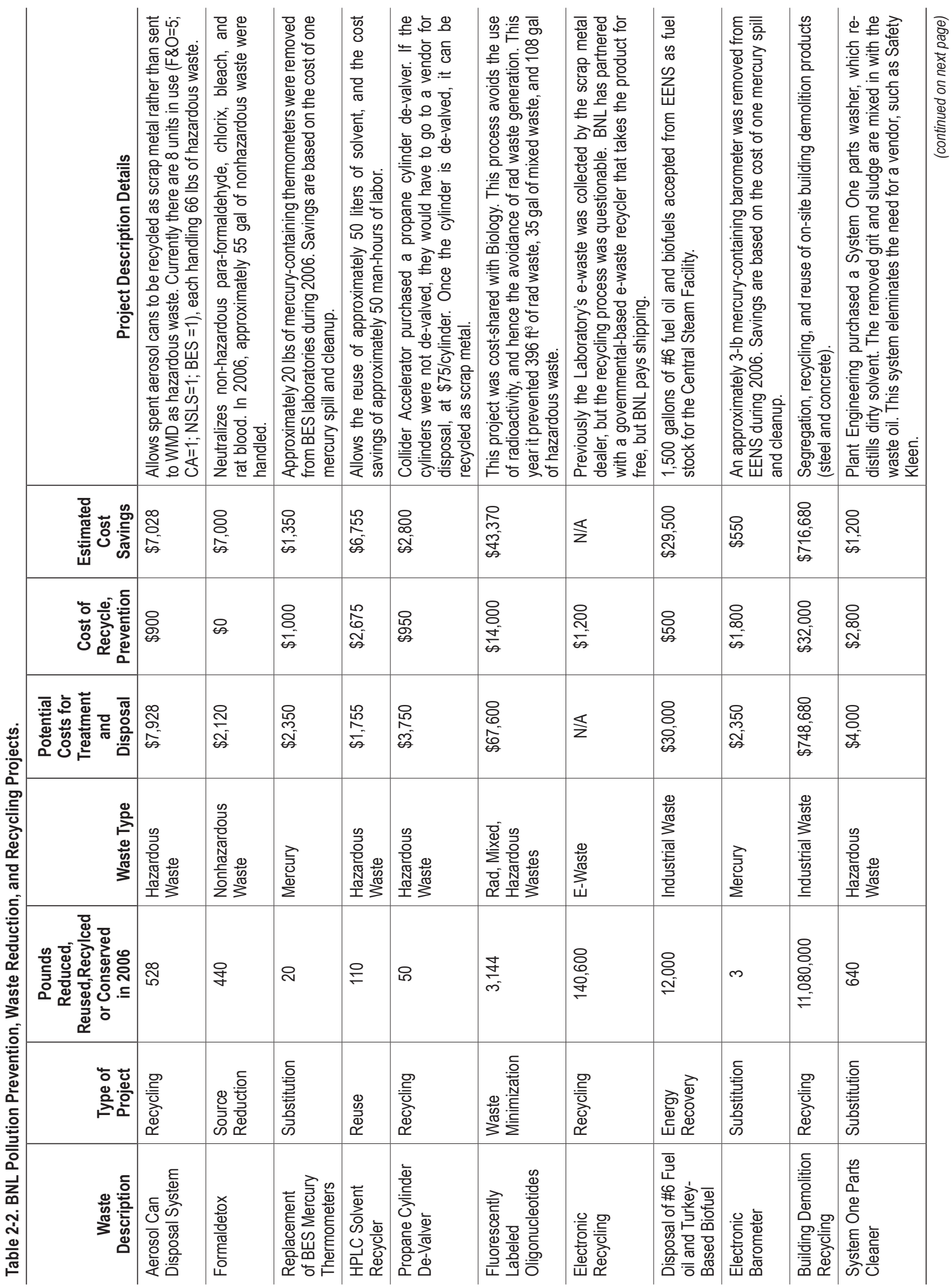


CHAPTER 2: ENVIRONMENTAL MANAGEMENT SYSTEM

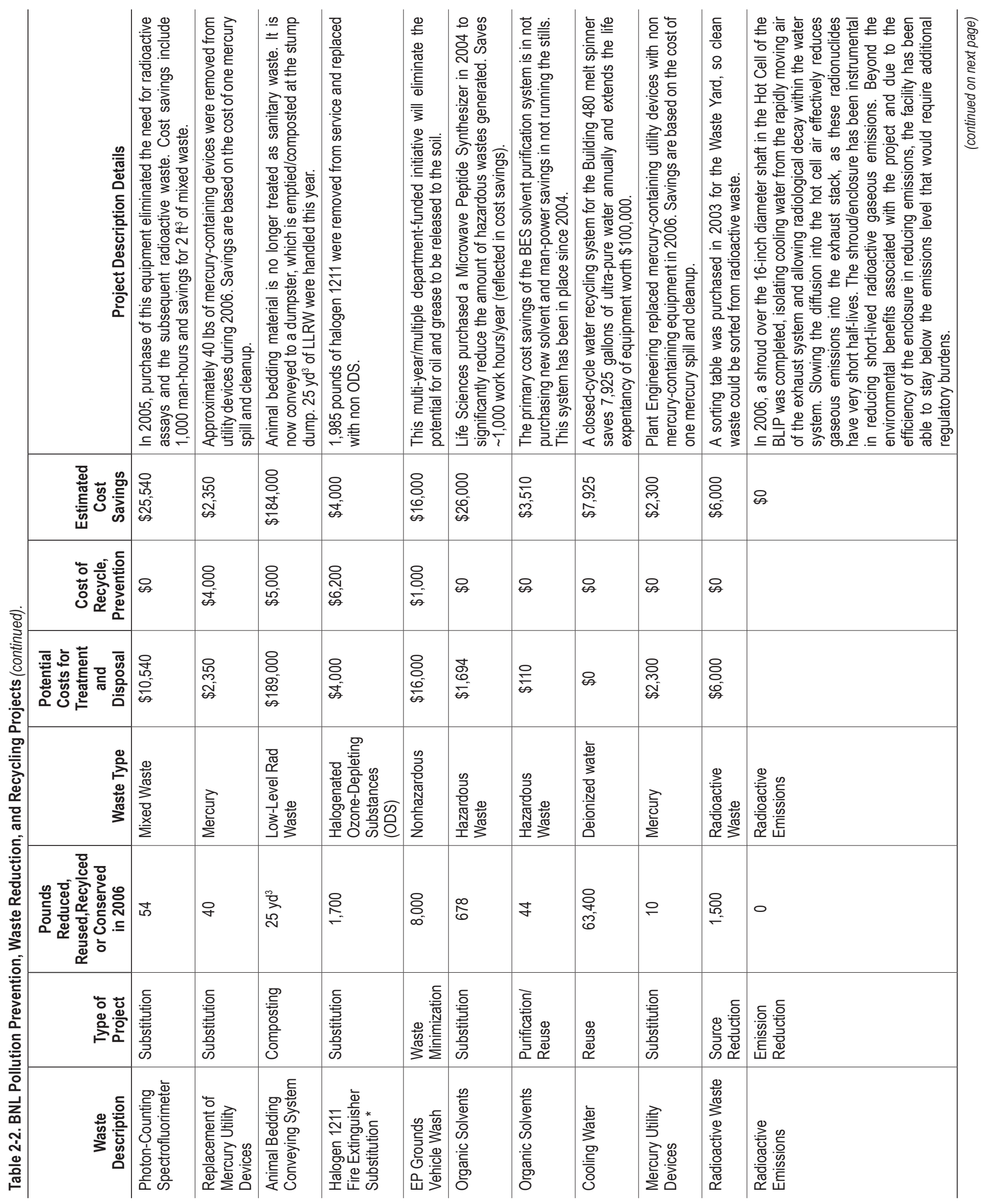


CHAPTER 2: ENVIRONMENTAL MANAGEMENT SYSTEM

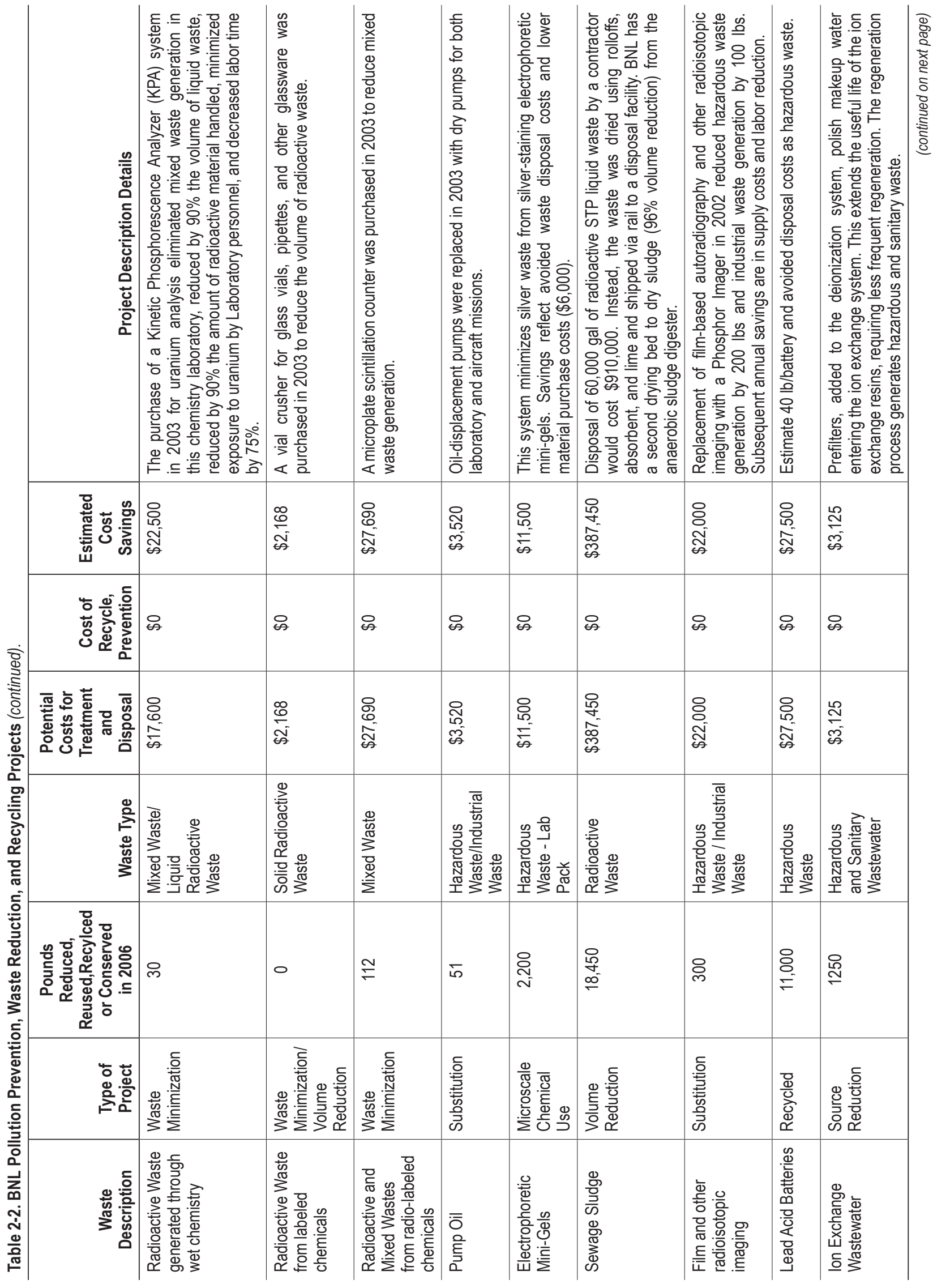


CHAPTER 2: ENVIRONMENTAL MANAGEMENT SYSTEM

\begin{tabular}{|c|c|c|c|c|c|c|c|c|c|c|c|}
\hline 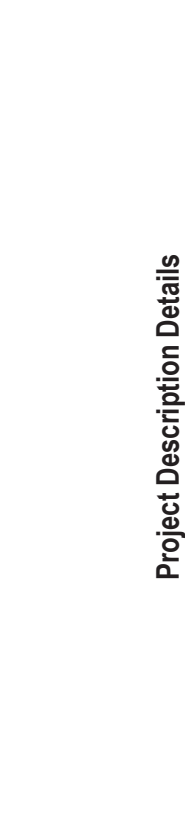 & 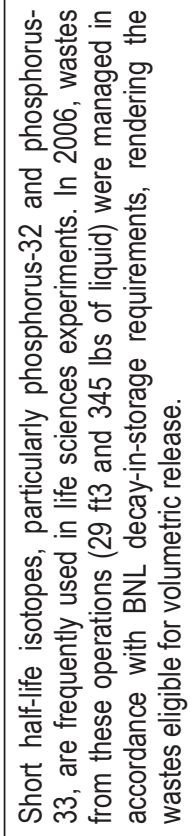 & 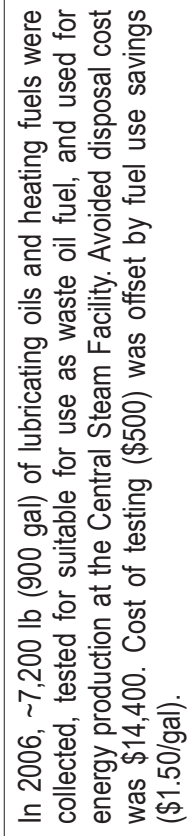 & 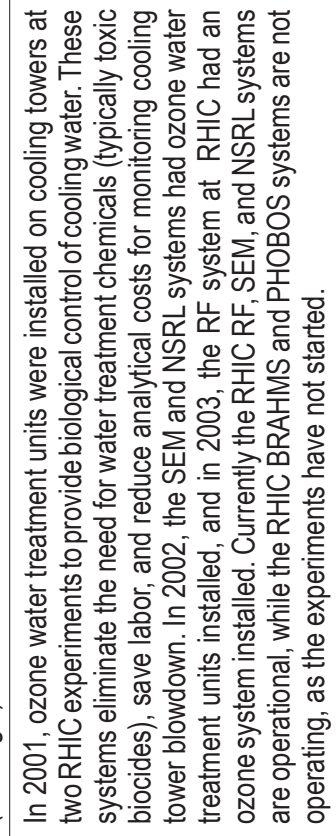 & 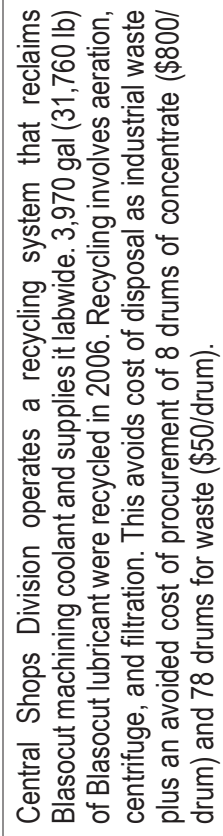 & 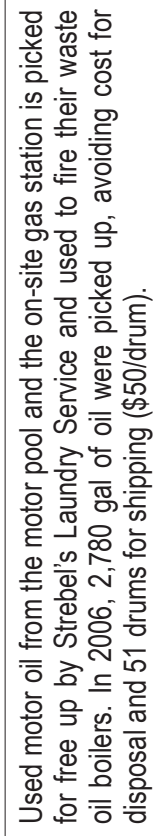 & 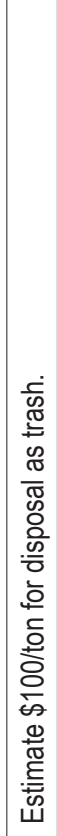 & 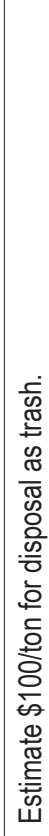 & 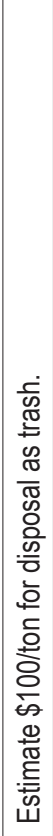 & 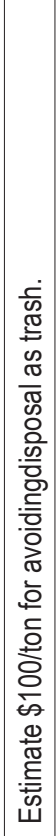 & 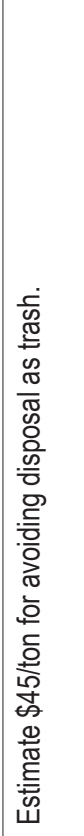 & \\
\hline 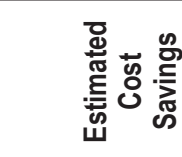 & 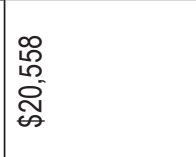 & 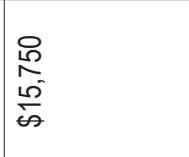 & 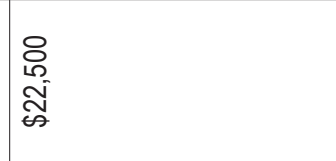 & 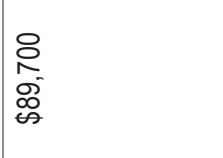 & $\frac{8}{20}$ & $\begin{array}{l}8 \\
\overline{9} \\
\infty \\
\infty \\
\infty\end{array}$ & $\begin{array}{l}8 \\
0 \\
\infty \\
\infty \\
\dot{\infty}\end{array}$ & $\begin{array}{l}8 \\
\infty \\
10 \\
5 \\
6\end{array}$ & $\begin{array}{l}8 \\
\infty \\
\sim \\
\sim \\
\infty\end{array}$ & 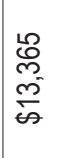 & $\underset{\infty}{\stackrel{5}{\infty}}$ \\
\hline 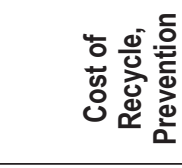 & \& & $\begin{array}{l}8 \\
\text { 员 } \\
\text { 促 }\end{array}$ & \& & ৫) & \& & \& & \& & 吕 & 足 & \& & 苂 \\
\hline 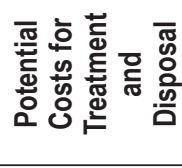 & 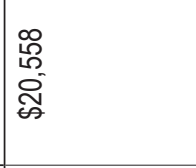 & $\begin{array}{l}8 \\
8 \\
\infty \\
\infty \\
\infty \\
\dot{\infty}\end{array}$ & $\begin{array}{l}\stackrel{8}{0} \\
\text { స̃ } \\
\text { ஸે }\end{array}$ & $\begin{array}{l}\stackrel{8}{0} \\
\tilde{m} \\
\approx \\
\infty \\
\infty\end{array}$ & 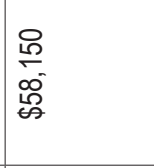 & $\begin{array}{l}8 \\
9 \\
\infty \\
\infty \\
\infty\end{array}$ & 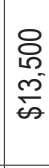 & $\begin{array}{l}8 \\
\infty \\
\infty \\
10 \\
\dot{\infty}\end{array}$ & $\begin{array}{l}8 \\
\text { O } \\
\text { N } \\
\text { S }\end{array}$ & 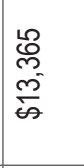 & $\frac{\substack{f \\
-\infty}}{\infty}$ \\
\hline 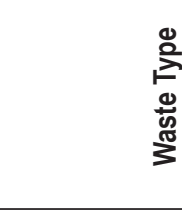 & 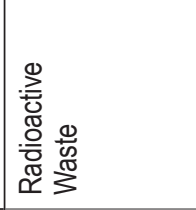 & 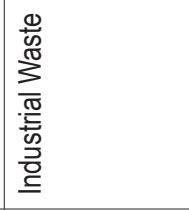 & 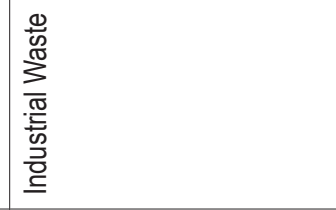 & 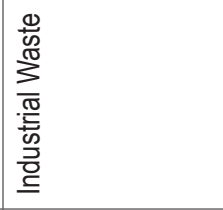 & 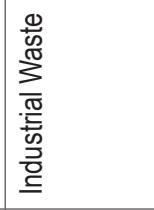 & 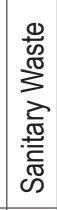 & 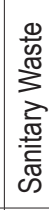 & 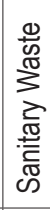 & 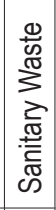 & 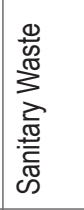 & \\
\hline 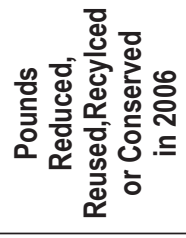 & 官 & 㣽 & $\begin{array}{l}0 \\
0 \\
\infty \\
\infty\end{array}$ & $\frac{\stackrel{8}{\frac{1}{m}}}{\frac{-}{2}}$ & $\begin{array}{l}\stackrel{\mathfrak{d}}{\mathrm{N}} \\
\text { N }\end{array}$ & $\begin{array}{l}8 \\
8 \\
o 0 \\
0 \\
\infty\end{array}$ & 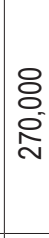 & $\begin{array}{l}8 \\
8 \\
0 \\
\\
m\end{array}$ & $\begin{array}{l}8 \\
80 \\
0 \\
10\end{array}$ & $\begin{array}{l}8 \\
8 \\
\circ \\
\circ \\
\leftrightarrow\end{array}$ & $\begin{array}{l}\text { No } \\
\stackrel{-}{\delta} \\
\stackrel{-}{=}\end{array}$ \\
\hline 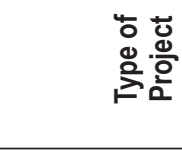 & 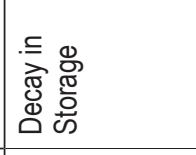 & 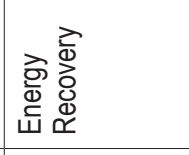 & 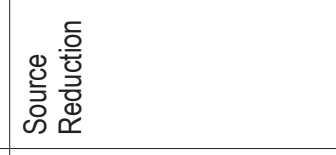 & 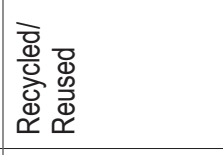 & 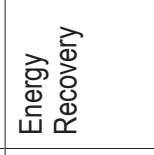 & 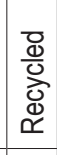 & 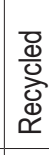 & $\begin{array}{l}\frac{D}{0} \\
\frac{0}{0} \\
\mathbb{d} \\
\mathbb{\Phi}\end{array}$ & 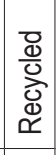 & 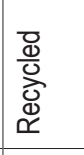 & 足 \\
\hline 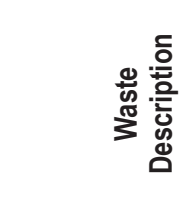 & 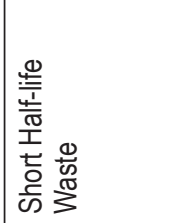 & 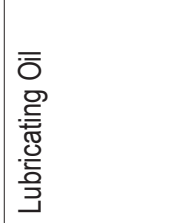 & 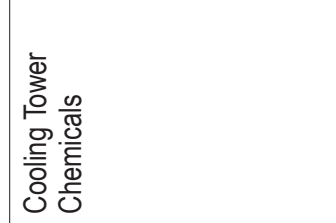 & 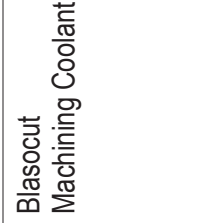 & 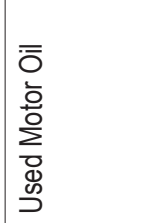 & 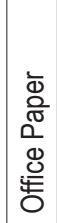 & 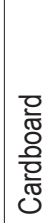 & 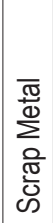 & 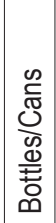 & 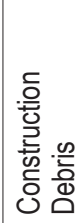 & \\
\hline
\end{tabular}


more than 180 tons of office paper for recycling. Cardboard, bottles and cans, construction debris, motor oil, scrap metals, lead, automotive batteries, electronic scrap, fluorescent light bulbs, drill press machine coolant, and antifreeze were also recycled. Table 2-3 shows the total number of tons (or units) of the materials recycled in 2006.

\subsubsection{Water Conservation}

BNL's strong water conservation program has achieved dramatic reductions in water use since the mid 1990s. The Laboratory continually evaluates water conservation as part of facility upgrades or new construction initiatives. These efforts include more efficient and expanded use of chilled water for cooling and heating/ventilation and air conditioning (HVAC) systems, and reuse of once-through cooling water for other systems such as cooling towers. The goal is to reduce the consumption of potable water and reduce the possible impact of clean water discharges on Sewage Treatment Plant (STP) operations. Figure 2-2 shows the 10-year trend of water consumption. In 2006, BNL used approximately half the water that was used in 1997-a reduction of nearly a half-billion gallons in that one year alone.

\subsubsection{Energy Management and Conservation}

Since 1979, the Laboratory's Energy Management Group has been working to reduce energy use and costs by identifying cost-effective, energy-efficient projects, monitoring energy use and utility bills, and assisting in obtaining the least expensive energy sources possible. The group is responsible for developing, implementing, and coordinating BNL's Energy Management Plan.

The Laboratory has more than 4 million square feet of building space. Many BNL scientific experiments use particle beams generated and accelerated by electricity, with the particles controlled and aligned by large electromagnets. In 2006, the Laboratory used approximately 242 million kilowatt hours ( $\mathrm{kWh}$ ) of electricity, 3.2 million gallons of fuel oil, 36 thousand gallons of propane, and 108 million $\mathrm{ft}^{3}$ of natural gas. Fuel oil and natural gas produce steam at the Central Steam Facility (CSF). Due to market conditions, fuel oil was predominately used in
2006, resulting in a cost savings of approximately $\$ 1,637,000$. (See additional information on natural gas and fuel oil use in Chapter 4.)

BNL is a participant in the New York Independent System Operator (NYISO) Special Case Resource (SCR) Program, which is an electric load reduction curtailment program. Through this program, the Laboratory has agreed to reduce electrical demand during critical days throughout the summer when NYISO expects customer demand to meet or exceed the company's available supply. In return, BNL receives a rebate for each megawatt reduced on each curtailment day. In 2006, there were four curtailment days requested, and participation in this program produced a rebate of $\$ 165,000$, with as much as $6.5 \mathrm{MW}$ of load reduction. The Laboratory also agreed to keep electric loads at a minimum during the summer, in part by curtailing operations at the Relativistic Heavy Ion Collider (RHIC). This scheduling allowed BNL to save more than $\$ 4$ million in electric costs in 2006.

BNL also maintains a contract with the New York Power Authority (NYPA) that resulted in an overall cost avoidance of $\$ 20$ million in 2006. The Laboratory will continue to seek alternative energy sources to meet its future energy needs, support federally required "green" initiatives, and reduce energy costs. In 2007, the Laboratory will purchase a portion of "green energy" for the newly constructed Research Support Building, as well as some biofuels for certain applications.

In 2006, a solar heating system was installed for the BNL swimming pool. This small project is a first step toward meeting the Laboratory's energy needs with renewable sources. Several other activities were also undertaken to reduce energy use at non-research facilities (e.g., replacement of inefficient chiller, demand control, lighting upgrades, etc.):

- $25 \mathrm{MW}$ of demand was rescheduled to avoid coinciding with the utility summer peak, saving several million dollars in electricity charges

- \$486,000 in Federal Energy Management Program funding was obtained to increase the efficiency of a cryogenic cooling sys- 


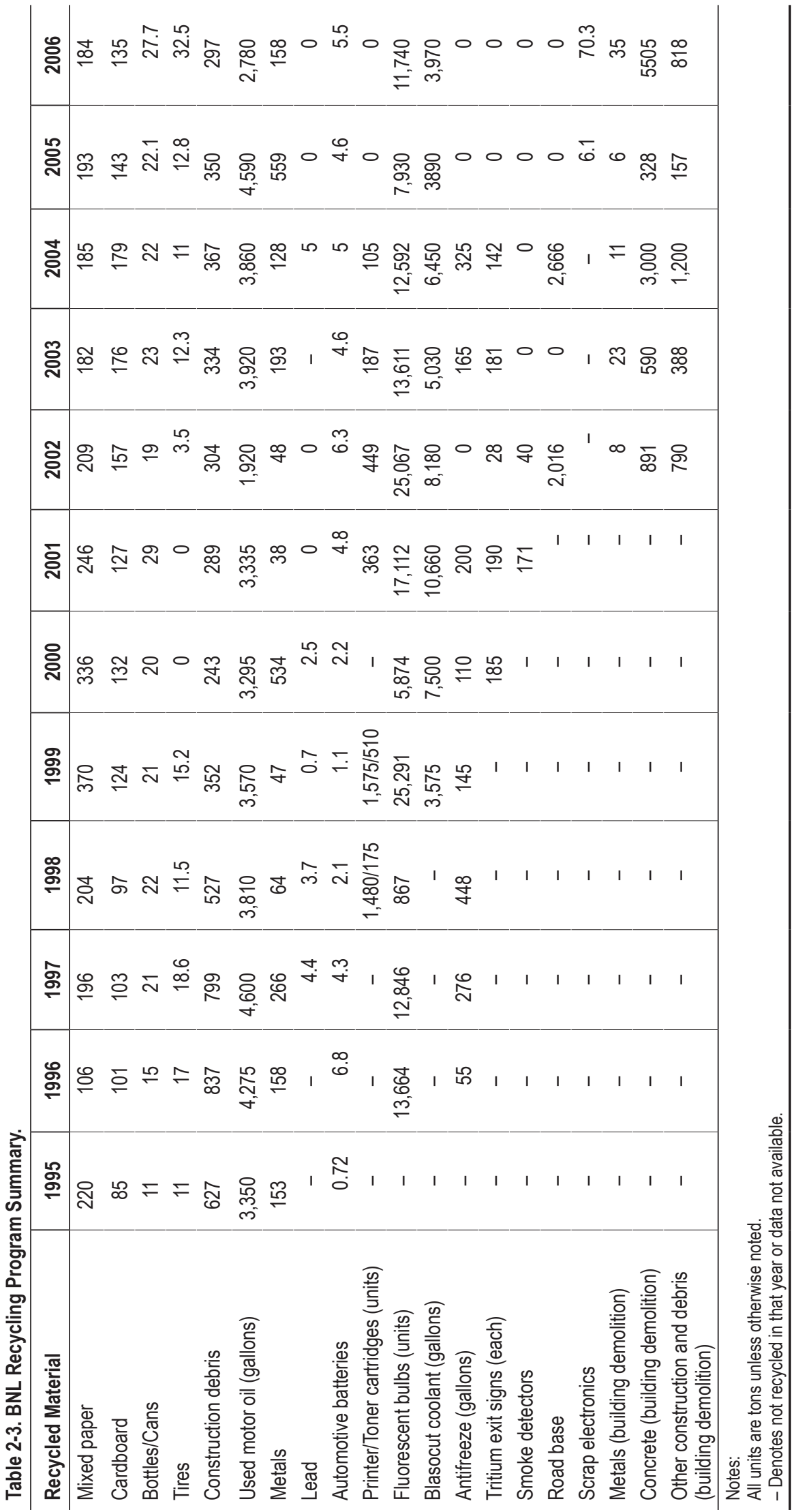

tem; this project reduced the electric demand by $1 \mathrm{MW}$ and will save over 5,000,000 $\mathrm{kWh} /$ year

- Construction of a 1,300-ton satellite chiller was completed, displacing older, less efficient chillers

- Replaced aging, inefficient T-40 fluorescent lighting fixtures with new, efficient T-8 and T-5 units; two to three hundred fixtures are typically replaced annually, saving tens of thousands of kWhs and reducing costs by several thousand dollars

- Due to aggressive conservation in various buildings, BNL's overall facilities energy usage for FY06 was approximately 3.7 percent less than in FY05, saving over $\$ 1.6$ million

- Water consumption for FY06 was 49 million gallons less than in FY05, saving approximately $\$ 15,000$ in operational costs

- Efficient fuel purchasing strategies (buying and storing oil) saved $\$ 109,000$, compared to purchasing oil as it is consumed

- The Laboratory's Research Support Building was completed and will receive Leadership in Energy and Environmental Design (LEED) certification

- The Center for Functional Nanomaterials, nearly completed, is also expected to receive LEED certification

- Nearly 34,000 gge (gas gallon equivalents) of natural gas were used in place of gasoline for the Laboratory's vehicle fleet 


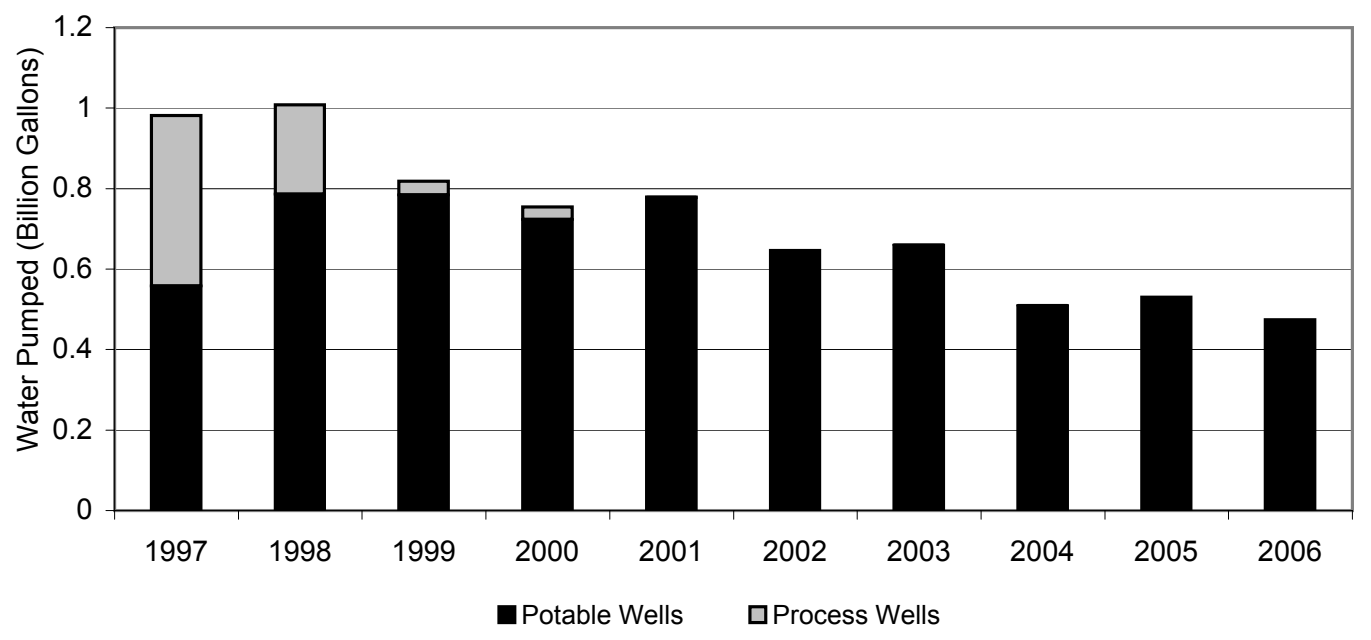

Figure 2-2. BNL Water Consumption Trend.

The National Energy Conservation Policy Act, as amended by the Federal Energy Management Improvement Act of 1988 and the Energy Policy Acts of 1992 and 2005, requires federal agencies to apply energy conservation measures and to improve federal building design to reduce energy consumption per square foot. Current goals are to reduce energy consumption per square foot, relative to 2003 , by 2 percent per year from FY06 - FY15. In 2007, an Executive Order signed by the President will increase the target reduction to 3 percent per year, which is a 30 percent reduction by the end of FY2015. These are very aggressive goals, and go significantly beyond the previous goal of 30 percent reduction by 2005 , compared to 1985. BNL's energy use per square foot in 2006 was 29 percent less than in 1985 (see Figure 2-3) and 8.2 percent less than 2003. It is important to note that energy use for buildings and facilities at the Laboratory is largely weather dependent.

\subsubsection{Natural and Cultural Resource Management Programs}

BNL continues to enhance its Natural Resource Management Program in cooperation with the U.S. Fish \& Wildlife Service, the Upton Ecological and Research Reserve Technical Advisory Group, and the Foundation for Ecological Research in the Northeast (FERN). The Laboratory also continues to enhance its Cultural Resource Management Program. A BNL
Cultural Resource Management Plan has been developed to identify and manage properties that are determined to be eligible or potentially eligible for inclusion on the National Register of Historic Places. See Chapter 6 for further information about these programs.

\subsubsection{Environmental Restoration}

The Comprehensive Environmental Response, Compensation and Liability Act (CERCLA), commonly known as Superfund, was enacted by Congress in 1980. As part of CERCLA, EPA established the National Priorities List, which identifies sites where cleanup of past contamination is required. BNL was placed on the list with 27 other Long Island sites, 12 of which are in Suffolk County (see http://www.epa.gov/superfund/sites/npl/ny.htm).

Each step of the CERCLA cleanup process is reviewed and approved by DOE, EPA, and NYSDEC, under an Interagency Agreement (IAG) contract. This agreement was formalized in 1992. Although not a formal signatory of the IAG, the Suffolk County Department of Health Services also plays a key role in the review process. Most of the contamination at the Laboratory is associated with past accidental spills and outmoded practices for handling, storing, and disposing of chemical and radiological material.

BNL follows the CERCLA process, which includes the following steps:

- Conduct a Remedial Investigation to characterize the nature and extent of contamina- 
tion and assess the associated risks

- Prepare a Feasibility Study and Proposed Plan to identify and evaluate Remedial Action alternatives and present the proposed best alternative

- Issue a Record of Decision (ROD), which is the remedy/corrective action agreed to by DOE, EPA, and NYSDEC

- Perform the Remedial Design/Remedial Action, which includes final design, construction specifications, and carrying out the remedy selected

In 2006, work planning continued for the Brookhaven Graphite Research Reactor (BGRR) and High Flux Beam Reactor (HFBR) decommissioning projects. In accordance with the requirements of 10 CFR 830, BNL completed the development of the Documented Safety Analysis (DSA) and submitted to DOE for review and comment. The DSA is a critical document for the BGRR pile removal. Other progress related to the BGRR project included further characterization of the BGRR pile and finalizing the Remedial Design/Remedial Action Workplan. Progress associated with the
HFBR project included: additional activation analyses to characterize the HFBR and working with regulators to evaluate potential remedial activities. Other progress at the HFBR complex includes the removal of ancillary buildings and structures, and returning previously developed land to an undeveloped state. The Final CERCLA Five-Year Review was issued and is available to the public at http://www.bnl.gov/ ltra/5-year review.asp . EPA concurs that the remedies selected and implemented to date, as reported in this Five-Year Review, are protective of human health and the environment. 2006 was the first full year of long-term operation and maintenance (O\&M) of the groundwater treatment systems following construction completion, as well as post-cleanup monitoring of the Peconic River surface water, sediment, and wetland vegetation. The groundwater systems operate in accordance with the O\&M manuals, while the Peconic and surface soil cleanup areas are monitored via the Operable Unit I Soils and Operable Unit V Long-Term Monitoring and Maintenance Plan. Institutional controls are also monitored and maintained for the cleanup

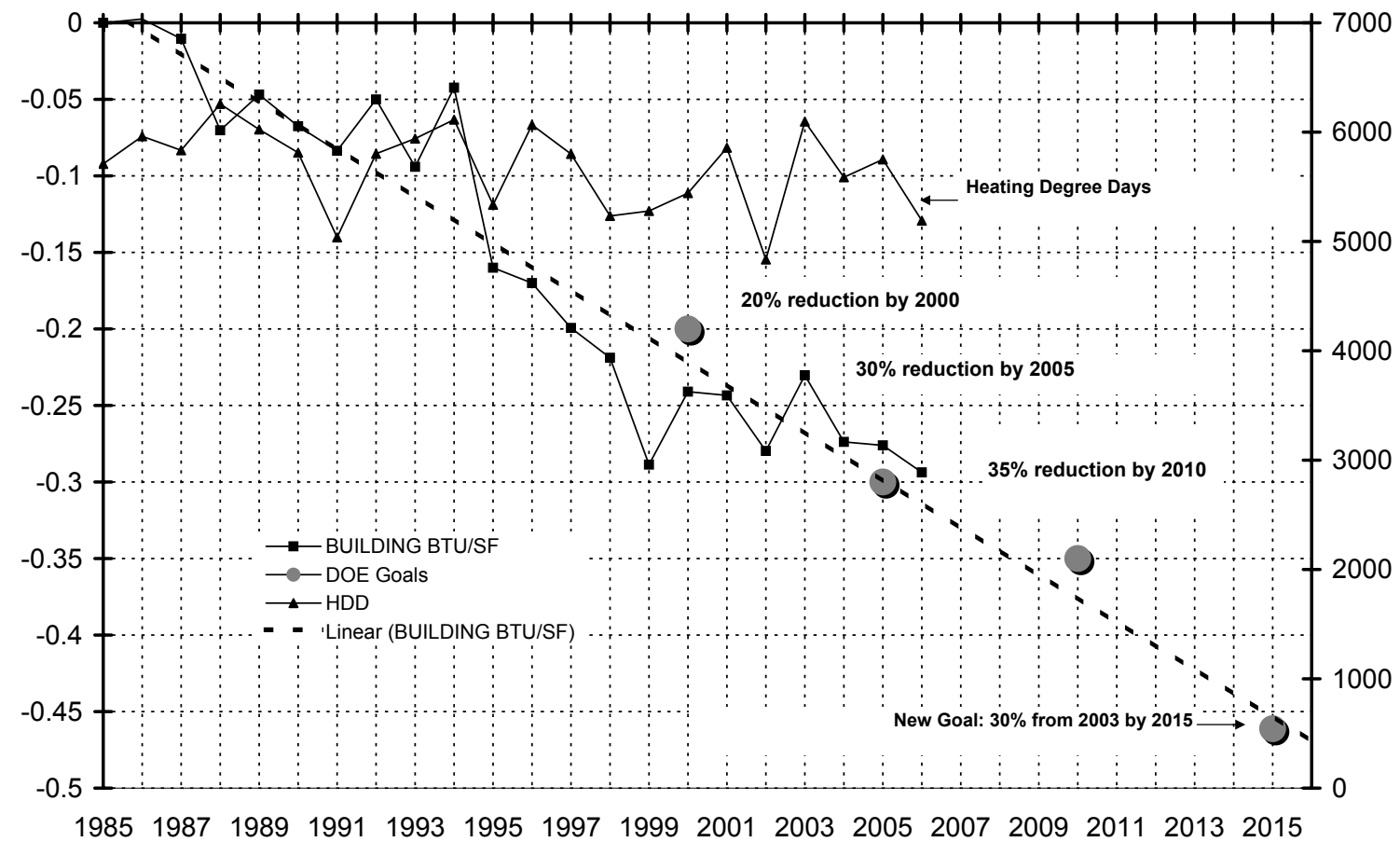

Figure 2-3. BNL Building Energy Performance, I 985 - 20 I5. 
areas in accordance with the RODs to help ensure the remedies remain protective.

A public comment period and public meetings were held for the remedial action plan for the g-2 Tritium Source Area and Groundwater Plume, the Brookhaven LINAC Isotope Producer (BLIP), and the Former Underground Storage Tanks area. The ROD is expected to be signed in the spring of 2007. Table 2-4 provides a description of each operable unit and a summary of environmental restoration actions taken. See Chapter 7 and SER Volume II, Groundwater Status Report, for further details.

\subsubsection{EPA Performance Track Program}

BNL was accepted into the EPA's Performance Track (PTrack) Program in 2004. This program recognizes top environmental performance among participating U.S. facilities of all types, sizes, and complexity, both public and private. It is considered the "gold standard" for facilitybased environmental performance - a standard that participating members strive to attain as they "meet or exceed their performance commitment." Under this program, partners provide leadership in many areas, including preventing pollution at its source. The PTrack Program requires that sites commit to several improvement goals for a three-year period and report on the progress of these goals annually. Below are brief descriptions of the goals and progress for 2006.

- Increase BNL's land and habitat conservation. To date, the Laboratory has recovered a total of 42 acres of land, including 15 acres recovered during a prescribed burn conducted in October 2006. Prescribed burns improve the health of the forest and allow for forest regrowth by removing dead vegetation, eliminating underbrush and leaf litter, and opening the forest floor to new growth. In addition, an acre of land was restored during building demolition.

- Reduce Radioactive Air Emissions. In 2005, the Laboratory made significant progress in achieving a PTrack commitment to reduce radioactive air emissions from the BLIP by 30 percent by 2006 . Construction and testing of a Lucite enclosure was completed in 2005. In 2006, additional evaluation of the
BLIP emissions showed them to be less than the projected performance goal. The emissions data confirmed that the overall reduction in emissions ranged between 29 and 35 percent under normal operating conditions. BNL will continue to evaluate additional measures to reduce emissions.

- Reduce BNL's use of ozone-depleting substances (ODS), specifically Class I ODS. In 2006, BNL continued its commitment to reduce the amount of ODS used at the Laboratory. In total, BNL eliminated 35.5 tons of Class I ODS from 2003 through 2006, which surpassed the original goal by 5.5 tons. In addition, 117 Halon 1211 portable extinguishers were removed from service. The Laboratory's long-term goal is to replace all Halon 1211 portable extinguishers with ABC dry-chemical or with clean agent FE36 extinguishers by the end of 2010 .

- Reduce BNL's hazardous materials use. BNL continued to revise its baseline inventory of mercury and mercury-containing devices in 2006, as new devices were located or identified. The total inventory subject to this commitment was 499 pounds. Of the 499 pounds, 194 pounds were determined to be essential and 305 pounds nonessential. By the end of 2006, BNL had removed and recycled approximately 233 pounds of elemental mercury from the nonessential inventory, resulting in a remaining total inventory of 266 pounds. The removed devices included 87 pounds of elemental mercury from a mercury vacuum pump, more than 450 mercury bulb thermometers, several large barometers and sphygmomanometers, and numerous mercury-wetted relays - some with up to 0.5 pounds of mercury each. In total, 47 percent of the mercury inventory was eliminated. While the goal of 80 percent was not achieved, the reduction effort was notable.

\subsection{IMPLEMENTING THE ENVIRONMENTAL MANAGEMENT SYSTEM}

\subsection{Structure and Responsibility}

All employees at BNL have clearly defined roles and responsibilities in key areas, including 
Table 2-4. Summary of BNL 2006 Environmental Restoration Activities.

\begin{tabular}{|c|c|c|}
\hline Project & Description & Environmental Restoration Program Actions \\
\hline Soil Projects & $\begin{array}{l}\text { OU I } \\
\text { OU II } \\
\text { OU VII }\end{array}$ & $\begin{array}{l}\text { - Issued the Final Operable Unit (OU) I Soils and OU V Long-Term Monitoring and Main- } \\
\text { tenance Plan. } \\
\text { - Performed monitoring and maintenance of institutional controls for cleanup areas. }\end{array}$ \\
\hline \multirow[t]{4}{*}{$\begin{array}{l}\text { Groundwater } \\
\text { Projects }\end{array}$} & OU III & $\begin{array}{l}\text { - Continued operations of } 12 \text { groundwater treatment systems that treat volatile organic } \\
\text { compounds (VOCs) and strontium-90 (Sr-90). } \\
\text { - Three groundwater treatment systems continued pulse pumping due to low VOC con- } \\
\text { centrations in the groundwater near the pumping wells. A fourth VOC system also } \\
\text { began pulse pumping. } \\
\text { - } \\
\text { Two groundwater treatment systems and six individual extraction wells were placed in } \\
\text { standby mode. } \\
\text { - Performed a third and final application of the oxidizer potassium permanganate to } \\
\text { degrade VOC contamination at the Building } 96 \text { groundwater plume. Pending further } \\
\text { review of continued monitoring data, alternative methods for remediating the contami- } \\
\text { nation in the silt zone will be performed. The fourth Building } 96 \text { groundwater treatment } \\
\text { system extraction well was placed on standby in June. } \\
\text { Continued monitoring of the High Flux Beam Reactor (HFBR) tritium plume. The con- } \\
\text { tingency at Weaver Drive was triggered in late } 2006 \text { with a detection of tritium above } \\
\text { the } 20,000 \text { pCi/L drinking water standard. As a result, a fourth groundwater extraction } \\
\text { well will be installed and begin operation in } 2007 \text {. } \\
\text { Began characterization of two existing plumes, one VOC and one Sr-90, to evaluate } \\
\text { the extent of contamination and determine if any additional extraction wells will be } \\
\text { required. } \\
\text { Continued characterization and monitoring of tritium in groundwater from g-2 activated } \\
\text { soil. A public comment period and public meeting were held for the g-2 Tritium Ground- } \\
\text { water Plume, the Brookhaven LINAC Isotope Producer, and former Underground Stor- } \\
\text { age Tanks Proposed Remedial Action Plan. } \\
\text { During } 2006,1.5 \text { billion gallons of groundwater were treated and } 372 \text { pounds of VOCs } \\
\text { were removed. Since the first groundwater treatment system started operating in } \\
\text { December } 1996 \text {, approximately } 5,592 \text { pounds of VOCs have been removed from more } \\
\text { than } 11.6 \text { billion gallons of groundwater. }\end{array}$ \\
\hline & OU IV & - Continued groundwater monitoring. \\
\hline & OU VI & $\begin{array}{l}\text { - Continued operation of a groundwater treatment system to treat ethylene dibromide } \\
\text { that has migrated beyond BNL property in Manorville. }\end{array}$ \\
\hline & $\begin{array}{l}\text { Groundwater Moni- } \\
\text { toring }\end{array}$ & $\begin{array}{l}\text { - Completed the BNL } 2005 \text { Groundwater Status Report. } \\
\text { - Collected and analyzed 2,097 groundwater samples from } 727 \text { monitoring wells. } \\
\text { - Updated the Environmental Monitoring Plan. } \\
\text { - The final sitewide Five-Year Review Report was issued and available to the public at } \\
\text { http://www.bnl.gov/ltra/5-year_review.asp. }\end{array}$ \\
\hline Peconic River & OU V & $\begin{array}{l}\text { - Performed first full year of long-term post-cleanup monitoring of Peconic River surface } \\
\text { water, sediment, fish, and wetland vegetatin. } \\
\text { - Submitted Draft } 2006 \text { Peconic River Monitoring Report to the regulators for review. }\end{array}$ \\
\hline \multirow[t]{3}{*}{ Reactors } & BGRR & $\begin{array}{l}\text { - Characterized the BGRR pile. } \\
\text { - Finalizing Remedial Design/Remedial Action Work Plan. } \\
\text { - Documented Safety Analysis submitted to DOE for review and comment. }\end{array}$ \\
\hline & HFBR & $\begin{array}{l}\text { - } \text { Continued long-term surveillance and maintenance activities. } \\
\text { - Performed additional activation analyses to characterize the HFBR. } \\
\text { - Evaluated potential remedial activities with regulators. } \\
\text { - Removed ancillary buildings and structures, and returned land to an undeveloped } \\
\text { state. }\end{array}$ \\
\hline & $\begin{array}{l}\text { BMRR (Project man- } \\
\text { aged by the BNL } \\
\text { Environmental and } \\
\text { Waste Management } \\
\text { Services Division }\end{array}$ & $\begin{array}{l}\text { - Continued surveillance and maintenance activities at the Brookhaven Medical Research } \\
\text { Reactor (BMRR). } \\
\text { - Removed and disposed of irradiated reactor vessel components, including Hold Down } \\
\text { Grids and Control Rod Blade Guides. } \\
\text { - Removed and disposed of radioactively contaminated lead containers. }\end{array}$ \\
\hline
\end{tabular}


environmental protection. Employees are required to develop their own Roles, Responsibilities, Accountabilities, and Authorities document to sign and be signed by two levels of supervision. BSA has clearly defined expectations for management and staff which must be included in this document. Under the BSA performancebased management model, senior management must communicate their expectation that all line managers and staff take full responsibility for their actions and be held accountable for ESSH performance. Environmental and waste management technical support personnel assist the line organizations with identifying and carrying out their environmental responsibilities. The Environmental Compliance Representative Program, initiated in 1998, is an effective means of integrating environmental planning and pollution prevention into the work planning processes of the line organizations. A comprehensive training program for staff, visiting scientists, and contractor personnel is also in place, thus ensuring that all personnel are aware of their ESSH responsibilities.

\subsubsection{Communication and Community Involvement}

Communication and community involvement are commitments under BNL's EMS. The Laboratory maintains relationships with its employees, key stakeholders, neighbors, elected officials, regulators, and other community members. The goals are to provide an understanding of BNL's science and operations, including environmental stewardship and restoration activities, and to incorporate community input in the Laboratory's decision making.

BNL staff participate in on- and off-site meetings, which include discussions, talks, presentations, roundtables, workshops, canvassing, tours, informal information sessions, and formal public meetings held during public comment periods.

\subsubsection{Communication Forums}

To facilitate effective dialogue between BNL and key stakeholders, several forums for communication and involvement have been established. The Brookhaven Executive Round- table (BER), established in 1997 by DOE's Brookhaven Site Office, meets routinely with BNL and DOE. These meetings enable Laboratory and DOE representatives to update local, state, and federal elected officials and regulatory agencies regarding environmental and operational issues, as well as scientific discoveries and initiatives. The Community Advisory Council (CAC), established by BNL in 1998, advises the Laboratory Director on issues related to the Laboratory that are important to the community. The CAC is composed of approximately 30 member organizations representing business, civic, education, employee, community, and environmental and health organizations. The CAC meets monthly in sessions open to the public, and sets its own agenda in cooperation with the Laboratory.

BNL's Envoy Program educates employee volunteers regarding Laboratory issues and provides a link to local community organizations. Feedback shared by envoys helps BNL gain a better understanding of local community concerns. The Speakers' Bureau provides speakers for educational and other organizations interested in the Laboratory, and the Volunteers in Partnership Program supports employee volunteer efforts for charitable organizations. The BNL Summer Sunday tours enable the Laboratory to educate the public by featuring different facilities and program areas each week. In addition, BNL hosts various events annually in celebration of Earth Day.

To keep employees and the community informed about the Laboratory's research, activities, and issues, including those related to the environment, BNL issues press releases; publishes Laboratory Link, a monthly update on BNL science and events; the Bulletin, a weekly employee newsletter; and discover Brookhaven, BNL's quarterly science magazine. The Laboratory maintains an informative website at http://www.bnl.gov, where these publications are posted, as well as information about BNL's science and operations, past and present. In addition, employees and the community can subscribe to the Laboratory's e-mail update service at http://lists.bnl.gov/mailman/listinfo/bnl-announce-1. 


\subsubsection{Community Involvement in Cleanup Projects}

In 2006, BNL stakeholders participated in the decision-making process for cleaning up the g2 tritium source area and groundwater plume, the BLIP, and eight former underground storage tanks (USTs), and provided early input into the formulation of remediation alternatives for the HFBR complex. Stakeholders were also informed of several environmental compliance initiatives through the public notification process. These initiatives included: a Notice of Complete Application, establishing a public comment period for renewal of BNL's Waste Management Facility; an announcement of the availability of the Five-Year Review report; and a Notice of Availability for the completion of the Environmental Assessment (EA) and Finding of No Significant Impact (FONSI) for the NSLS-II. Stakeholders also were updated on the progress of other issues through presentations given at the monthly CAC and BER meetings, including:

- The Proposed Remedial Act Plan (PRAP) for the g-2 tritium source area called for continued maintenance and monitoring, and outlined contingency plans if unexpected levels of tritium are found in the future. Remedies for BLIP and the USTs also included continued maintenance and monitoring. Stakeholder comments, including those from the CAC, were addressed in a Record of Decision.

- Early input from the CAC on the remediation alternatives being developed for decommissioning and dismantlement of the HFBR highlighted the concerns of some community members regarding the removal and disposal of the highly radioactive control rod blades in the near term.

Working closely with elected officials, regulatory agency representatives, community members, and employees, DOE and BNL openly shared information, extensively solicited input on Laboratory environmental initiatives, and provided feedback on how that input was used.

\subsubsection{Monitoring and Measurement}

The Laboratory monitors effluents and emissions to ensure the effectiveness of controls, adherence to regulatory requirements, and timely identification and implementation of corrective measures. BNL's Environmental Monitoring Program is a comprehensive, sitewide program that identifies potential pathways for exposure of the public and employees, evaluates what impact activities have on the environment, and ensures compliance with environmental permit requirements. The monitoring program is reviewed and revised, as necessary or on an annual basis, to reflect changes in permit requirements, changes in facility-specific monitoring activities, or the need to increase or decrease monitoring based on a review of previous analytical results.

As required under DOE Order 450.1, Environmental Protection Program, BNL prepares an Environmental Monitoring Plan, Triennial Update (BNL 2007), which outlines annual sampling goals by media and frequency. The plan uses the EPA Data Quality Objective approach for documenting the decisions associated with the monitoring program. In addition to the required triennial update, an annual electronic update is also prepared.

As shown in Table 2-5, in 2006 there were 9,766 sampling events of groundwater, potable water, precipitation, air, plants and animals, soil, sediment, and discharges under the Environmental Monitoring Program. Specific sampling programs for the various media are described further in Chapters 3 through 8.

The Environmental Monitoring Program addresses three components: compliance, restoration, and surveillance monitoring.

\subsubsection{Compliance Monitoring}

Compliance monitoring is conducted to ensure that wastewater effluents, air emissions, and groundwater monitoring data comply with regulatory and permit limits issued under the federal Clean Air Act, Clean Water Act, Oil Pollution Act, Safe Drinking Water Act, and the New York State equivalents. Included in compliance monitoring are the following:

- Air emissions monitoring is conducted at reactors, accelerators, and other radiological emission sources, as well as the CSF. Real-time, continuous emission monitoring equipment is installed and maintained 
at some of these facilities, as required by permits and other regulations. At other facilities, samples are collected and analyzed periodically to ensure compliance with regulatory requirements. Analytical data are routinely reported to the permitting authority. See Chapters 3 and 4 for details.

- Wastewater monitoring is performed at the point of discharge to ensure that the effluent complies with release limits in the Laboratory's SPDES permits. Twenty-four point-source discharges are monitored under the BNL program: 12 under the ER Program and 12 under the SPDES permit. As required by permit conditions, samples are collected daily, weekly, monthly, or quarterly and monitored for organic, inorganic, and radiological parameters. Monthly reports that provide analytical results and an assessment of compliance for that reporting period are filed with the permitting agency. See Chapter 3, Section 3.6 for details.

- Groundwater monitoring is also performed in accordance with permit requirements. Specifically, monitoring of groundwater is required under the Major Petroleum Facility License for the CSF and the RCRA permit for the WMF. Extensive groundwater monitoring is also conducted under the ER Program, as required under the Records of Decision for many of the OUs or Areas of Concern (see Chapter 7 and SER Volume II, Groundwater Status Report, for details). Additionally, to ensure that the Laboratory maintains a safe drinking water supply, groundwater is monitored as required by SCDHS.

\subsubsection{Restoration Monitoring}

Restoration monitoring is performed to determine the overall impact of past operations, to delineate the real extent of contamination, and to ensure that Removal Actions are effective and remedial systems are performing as designed under CERCLA and RCRA.

This program typically involves collecting soil and groundwater samples to determine the lateral and vertical extent of the contaminated area. Samples are analyzed for organic, inorganic, and radiological contaminants, and the analytical results are compared with guidance, standards, cleanup goals, or background concentrations. Areas where impacts have been confirmed are fully characterized and, if necessary, remediated to mitigate continuing impacts. Followup monitoring of groundwater is conducted in accordance with a Record of Decision with the regulatory agencies.

\subsubsection{Surveillance Monitoring}

Pursuant to DOE Order 450.1, surveillance monitoring is performed in addition to compliance monitoring, to assess potential environmental impacts that could result from routine facility operations. The BNL Surveillance Monitoring Program involves collecting samples of ambient air, surface water, groundwater, flora, fauna, and precipitation. Samples are analyzed for organic, inorganic, and radiological contaminants. Additionally, data collected using thermoluminescent dosimeters (devices to measure radiation exposure) strategically positioned on and off site are routinely reviewed under this program. Control samples (also called background or reference samples) are collected on and off the site to compare Laboratory results to areas that could not have been affected by BNL operations.

The monitoring programs can be broken down further by the relevant law or requirement (e.g., Clean Air Act) and even further by specific environmental media and type of analysis. The results of monitoring and the analysis of the monitoring data are the subject of the remaining chapters of this report. Chapter 3 summarizes environmental requirements and compliance data, Chapters 4 through 8 give details on media-specific monitoring data and analysis, and Chapter 9 provides supporting information for understanding and validating the data shown in this report.

\subsubsection{EMS Assessments}

To periodically verify that the Laboratory's EMS is operating as intended, audits are conducted as part of BNL's Self-Assessment Program. The audits are designed to ensure that any nonconformance to the ISO 14001 Standard is 
Table 2-5. Summary of BNL 2006 Sampling Program Sorted by Media.

\begin{tabular}{|c|c|c|}
\hline Environmental Media & $\begin{array}{l}\text { No. of } \\
\text { Sampling } \\
\text { Events* }^{*}\end{array}$ & Purpose \\
\hline Groundwater & $\begin{array}{l}2,097 \mathrm{ER} \\
249 \mathrm{ES} / \mathrm{C}\end{array}$ & $\begin{array}{l}\text { Groundwater is monitored to evaluate impacts from past and present operations on groundwater quality, } \\
\text { under the Environmental Restoration, Environmental Surveillance, and Compliance sampling programs. } \\
\text { See Chapter } 7 \text { and SER Volume II, Groundwater Status Report for further detail. }\end{array}$ \\
\hline On-Site Recharge Basins & 78 & $\begin{array}{l}\text { Recharge basins used for wastewater and stormwater disposal are monitored in accordance with discharge } \\
\text { permit requirements and for environmental surveillance purposes. See Chapter } 5 \text { for further detail. }\end{array}$ \\
\hline Potable Water & $\begin{array}{l}38 \mathrm{ES} \\
181 \mathrm{C}\end{array}$ & $\begin{array}{l}\text { Potable water wells and the BNL distribution system are monitored routinely for chemical and radiological } \\
\text { parameters to ensure compliance with Safe Drinking Water Act requirements. In addition, samples are } \\
\text { collected under the Environmental Surveillance Program to ensure the source of the Laboratory's potable } \\
\text { water is not impacted by contamination. See Chapters } 3 \text { and } 7 \text { for further detail. }\end{array}$ \\
\hline $\begin{array}{l}\text { Sewage Treatment Plant } \\
\text { (STP) }\end{array}$ & 455 & $\begin{array}{l}\text { The STP influent and effluent and several upstream and downstream Peconic River stations are monitored } \\
\text { routinely for organic, inorganic, and radiological parameters to assess BNL impacts. The number of samples } \\
\text { taken depends on flow. For example, samples are scheduled for collection at Station HQ monthly, but if there } \\
\text { is no flow, no sample can be collected. See Chapters } 3 \text { and } 5 \text { for further detail. }\end{array}$ \\
\hline Precipitation & 8 & $\begin{array}{l}\text { Precipitation samples are collected from two locations to determine if radioactive emissions have impacted } \\
\text { rainfall, and to monitor worldwide fallout from nuclear testing. The data are also used, along with wind speed, } \\
\text { wind direction, temperature, and atmospheric stability to help model atmospheric transport and diffusion of } \\
\text { radionuclides. See Chapter } 4 \text { for further detail. }\end{array}$ \\
\hline Air - Tritium & 264 & $\begin{array}{l}\text { Silica gel cartridges are used to collect atmospheric moisture for subsequent tritium analysis. These data } \\
\text { are used to assess environmental tritium levels. See Chapter } 4 \text { for further detail. }\end{array}$ \\
\hline Air - Particulate & $\begin{array}{l}441 \mathrm{ES} / \mathrm{C} \\
52 \mathrm{NYSDOH}\end{array}$ & $\begin{array}{l}\text { Samples are collected to assess impacts from BNL operations and to facilitate reporting of emissions to } \\
\text { regulatory agencies. Samples are also collected for the New York State Department of Health Services } \\
\text { (NYSDOH) as part of their program to assess radiological air concentrations statewide. See Chapter } 4 \text { for } \\
\text { further detail. }\end{array}$ \\
\hline Air - Charcoal & 52 & $\begin{array}{l}\text { Samples are collected to assess impacts from BNL operations and to facilitate reporting of emissions to } \\
\text { regulatory agencies. See Chapter } 4 \text { for further detail. }\end{array}$ \\
\hline Fauna & 125 & $\begin{array}{l}\text { Fish, deer, and small mammals are monitored to assess impacts on wildlife associated with past or current } \\
\text { BNL operations. See Chapter } 6 \text { for further detail. }\end{array}$ \\
\hline Flora & 17 & $\begin{array}{l}\text { Vegetation is sampled to assess possible uptake of contaminants by plants and fauna, since the primary } \\
\text { pathway from soil contamination to fauna is via ingestion. See Chapter } 6 \text { for further detail. }\end{array}$ \\
\hline Soils & 401 & $\begin{array}{l}\text { Soil samples are collected as part of the Natural Resource Management Program to assess faunal uptake, } \\
\text { during Environmental Restoration investigative work, during the closure of drywells and underground tanks, } \\
\text { and as part of preconstruction background sampling. }\end{array}$ \\
\hline Miscellaneous & 166 & $\begin{array}{l}\text { Samples are collected periodically from potable water fixtures and dispensers, manholes, spills, to assess } \\
\text { process waters, and to assess sanitary discharges. }\end{array}$ \\
\hline $\begin{array}{l}\text { Groundwater } \\
\text { Treatment Systems and } \\
\text { Remediation Monitoring }\end{array}$ & 2974 & $\begin{array}{l}\text { Samples are collected from groundwater treatment systems and as long-term monitoring after remediation } \\
\text { completion under the Comprehensive Environmental Response, Compensation, and Liability Act program. } \\
\text { The Laboratory has } 14 \text { operating groundwater treatment systems. See discussion in Chapter } 7 .\end{array}$ \\
\hline Vehicle Monitor Checks & 246 & $\begin{array}{l}\text { Materials leaving the Laboratory pass through the on-site vehicle monitor that detects if radioactive materials } \\
\text { are present. Any radioactive material discovered is properly disposed of through the Waste Management } \\
\text { Program. The vehicle monitor is checked on a daily basis. }\end{array}$ \\
\hline $\begin{array}{l}\text { State Pollutant Discharge } \\
\text { Elimination System } \\
\text { (SPDES) }\end{array}$ & 206 & $\begin{array}{l}\text { Samples are collected to ensure that the Laboratory complies with the requirements of the New York State } \\
\text { Department of Environmental Conservation (NYSDEC)- issued SPDES permit. Samples are collected at the } \\
\text { Sewage Treatment Plant (STP), recharge basins, and four process discharge sub-outfalls to the STP. }\end{array}$ \\
\hline Flow Charts & 546 & $\begin{array}{l}\text { Flowcharts are exchanged weekly as part of BNL's SPDES permit requirements to report discharge flow at } \\
\text { the recharge basin outfalls. }\end{array}$ \\
\hline $\begin{array}{l}\text { Floating Petroleum } \\
\text { Checks }\end{array}$ & 102 & $\begin{array}{l}\text { Tests are performed on select petroleum storage facility monitoring wells to determine if floating petroleum } \\
\text { products are present. The number of wells and frequency of testing is determined by NYSDEC licensing } \\
\text { requirements (e.g., Major Petroleum Facility), NYSDEC spill response requirements (e.g., Motor Pool area), } \\
\text { or other facility-specific sampling and analysis plans. }\end{array}$ \\
\hline
\end{tabular}


Table 2-5. Summary of BNL 2006 Sampling Program Sorted by Media.

\begin{tabular}{|c|c|c|}
\hline Environmental Media & $\begin{array}{l}\text { No. of } \\
\text { Sampling } \\
\text { Events* }\end{array}$ & Purpose \\
\hline $\begin{array}{l}\text { Radiological Monitor } \\
\text { Checks }\end{array}$ & 743 & $\begin{array}{l}\text { Daily instrumentation checks are conducted on the radiation monitors located in Buildings } 569 \text { and } 592 . \\
\text { These monitors are located } 30 \text { minutes upstream and at the STP. Monitoring at these locations allows for } \\
\text { diversion of wastes containing radionuclides before they are discharged to the Peconic River. }\end{array}$ \\
\hline $\begin{array}{l}\text { Quality Assurance/ } \\
\text { Quality Control Samples } \\
\text { (QA/QC) }\end{array}$ & 325 & $\begin{array}{l}\text { To ensure that the concentrations of contaminants reported in the Site Environmental Report are accurate, } \\
\text { additional samples are collected. These samples detect if contaminants are introduced during sampling, } \\
\text { transportation, or analysis of the samples. QA/QC samples are also sent to the contract analytical } \\
\text { laboratories to ensure their processes give valid, reproducible results. }\end{array}$ \\
\hline $\begin{array}{l}\text { Total number of } \\
\text { sampling events }\end{array}$ & 9,766 & $\begin{array}{l}\text { The total number of sampling events includes all samples identified in the Environmental Monitoring Plan } \\
\text { (BNL 2006), as well as samples collected to monitor Environmental Restoration projects, air and water } \\
\text { treatment system processes, and by the Environmental and Waste Management Services Division Field } \\
\text { Sampling Team as special requests. The number does not include samples taken by Waste Management } \\
\text { personnel, waste generators, or Environmental Compliance Representatives for waste characterization } \\
\text { purposes. }\end{array}$ \\
\hline \multicolumn{3}{|c|}{$\begin{array}{l}\text { Notes: } \\
\text { *A sampling event is the collection of samples from a single georeferenced location. Multiple samples for different analyses } \\
\text { (i.e..,tritium, gross alpha, gross beta, and volatile organic compounds) can be collected during a single sample event. } \\
C=\text { Compliance } \\
\text { ER = Environmental Restoration } \\
\text { ES = Environmental Surveillance }\end{array}$} \\
\hline
\end{tabular}

identified and addressed. In addition, compliance with regulatory requirements is verified through routine inspections, operational evaluations, and focused compliance audits. BNL's Self-Assessment Program consists of several processes.

- Self-assessment is the systematic evaluation of internal processes and performance. The approach for the environmental self-assessment program includes evaluating programs and processes within organizations that have environmental aspects. Conformance to the Laboratory's EMS requirements is verified, progress toward achieving environmental objectives is monitored, operations are inspected to verify compliance with regulatory requirements, and the overall effectiveness of the EMS is evaluated. BNL environmental staff routinely participate in these assessments. Laboratory management conducts assessments to evaluate BNL environmental performance from a programmatic perspective, to determine if there are Laboratory-wide issues that require attention, and to facilitate the identification and communication of "best management" practices used in one part of the Laboratory that could improve performance in other parts.
BNL management also routinely evaluates progress on key environmental improvement projects. The Laboratory and DOE periodically perform assessments to facilitate the efficiency of assessment activities and ensure that the approach to performing the assessments meets DOE expectations.

- Independent assessments are performed by BNL staff members who do not have line responsibility for the work processes involved, to ensure that operations are in compliance with Laboratory requirements. These assessments verify the effectiveness and adequacy of management processes (including self-assessment programs) at the division, department, directorate, and Laboratory levels. Special investigations are also conducted to identify the root causes of problems, as well as corrective actions and lessons learned.

The Laboratory's Self-Assessment Program is augmented by programmatic, external audits conducted by DOE. BSA staff and subcontractors also perform periodic independent reviews. An independent third party conducts ISO 14001 registration audits of BNL's EMS. BNL is also subject to extensive oversight by external regulatory agencies (see Chapter 3 for details). 
Results of all assessment activities related to environmental performance are included, as appropriate, throughout this report.

\subsection{ENVIRONMENTAL STEWARDSHIP AT BNL}

BNL has unprecedented knowledge of its potential environmental vulnerabilities and current operations due to programs such as the Facility Review Disposition Project, process evaluations, the work planning and control system, and the management systems for groundwater protection, environmental restoration, and information management. Compliance assurance programs have improved the Laboratory's compliance status; pollution prevention projects have reduced costs, minimized waste generation, and reused and recycled significant quantities of materials.

BNL is openly communicating with neighbors, regulators, employees, and other interested parties on environmental issues and progress. To regain and maintain stakeholder trust, the Laboratory will continue to deliver on commitments and demonstrate improvements in environmental performance. The Site Environmental Report is an important communication mechanism, as it summarizes BNL's environmental programs and performance each year. Additional information about the Laboratory's environmental programs is available on BNL's website at http://www.bnl. gov. The Laboratory continues to pursue other ways to communicate timely data in a more user-friendly, visual manner.

BNL's EMS is viewed as exemplary within DOE. Due to external recognition of the Laboratory's knowledge and unique experience implementing the EMS program, several DOE facilities and private universities have invited BNL to extend its outreach activities and share its experiences, lessons learned, and successes. The Laboratory's environmental programs and projects have been recognized with international, national, and regional awards.

Audits have consistently observed a high level of management involvement, commitment, and support for environmental protection and the EMS. Audits and EMS management reviews have noted the following improvements made since BSA began managing BNL:

- The EMS has been strengthened, integrated with other Laboratory management systems, and formalized.

- Line ownership for environmental stewardship has been established, key roles and responsibilities have been identified and clarified, and expectations have been made explicit.

- A comprehensive environmental training program has been implemented.

- From the process evaluation project, BNL has improved its understanding of environmental aspects, waste streams, and applicable requirements.

- There is much greater formality with regard to control of EMS documents, manuals, and procedures. Procedures and requirements have been updated, and environmental management programs have been improved.

- The Laboratory has been very successful in achieving its environmental goals. There have been successes in ISO 14001 registration and recertification, compliance improvements (e.g., facility modifications, implementation of SBMS, enhanced operational controls), and increased environmental knowledge and awareness on the part of management, employees, contractors, and visitors.

- Communication on environmental issues has improved, occurs at the highest levels of management, and reporting is more formal. Managers are better informed about environmental aspects, issues, and performance.

- Core EMS teams representing many organizations have been formed. A consensus process is used to develop the system, improving acceptance and support.

- There has been strong implementation of the EMS throughout the organizations, and cultural change has been notable.

For more than 50 years, the unique, leadingedge research facilities and scientific staff at BNL have made many innovative scientific contributions possible. Today, BNL continues its research mission while focusing on cleaning up and protecting the environment. The Laboratory's environmental motto, which was generated 
in an employee suggestion contest, is "Exploring Earth's Mysteries ... Protecting Its Future," and reflects BNL's desire to balance world-class research with environmentally responsible operations.

\section{REFERENCES AND BIBLIOGRAPHY}

BNL. 1999. Community Involvement Policy and Plan. Brookhaven National Laboratory, Upton, NY.

BNL. 2003a. BNL Energy Management Plan. Brookhaven National Laboratory, Upton, NY.

BNL. 2003b. Natural Resource Management Plan for Brookhaven National Laboratory. BNL-7I 870-2003. Brookhaven National Laboratory, Upton, NY.

BNL. 2003c. Wildland Fire Management Plan for Brookhaven National Laboratory. BNL-7I 629-2003. Brookhaven National Laboratory, Upton, NY.

BNL. 2003d. Facility Review Disposition Project, Final Report. Brookhaven National Laboratory, Upton, NY.
BNL. 2006. BNL Environmental Monitoring Plan 2006, Triennial Update. Brookhaven National Laboratory, Upton, NY.

DOE Order 430.2. 1996. In-House Energy Management. U.S. Department of Energy, Washington, DC. June 13, 1996 (expired June 13, 2000).

DOE Order 435.I. 1999. Radioactive Waste Management. U. S. Department of Energy, Washington, DC. July 7, 1999.

DOE Order 450.I. 2003. Environmental Protection Program. U.S. Department of Energy, Washington, DC. Jan. I 5. 2003.

EPA/DOE. 1998. Memorandum of Agreement by and between the Environmental Protection Agency and the United States Department of Energy. March 23, 1998.

Executive Order 13148. Greening of the Government Through Leadership in Environmental Management. April 22, 2000.

ISO. 2004. ISO I 400 I, Environmental Management Systems Specification with Guidance for Use. First Edition. International Organization for Standardization. Geneva, Switzerland.

Naidu, J.R. 1999. Brookhaven National Laboratory Wildlife Management Plan. BNL-52556. Brookhaven National Laboratory, Upton, NY. 


\section{Compliance Status}

Brookhaven National Laboratory is subject to more than 100 sets of federal, state, and local environmental regulations; numerous site-specific permits; 15 equivalency permits for operation of 12 groundwater remediation systems; and several other binding agreements. In 2006, the Laboratory operated in compliance with most of the requirements defined in these governing documents. Instances of noncompliance were reported to regulatory agencies and corrected expeditiously. Routine inspections conducted during the year found no significant instances of noncompliance; however, minor deficiencies were noted during inspections conducted by the New York State Department of Environmental Conservation (NYSDEC).

Emissions of nitrogen oxides, carbon monoxide, opacity, and sulfur dioxide from the Central Steam facility were all within permit limits. Continued efforts to eliminate opacity excursions in 2006 were successful, and there were no excursions reported for the year. Approximately 2,024 pounds of ozonedepleting refrigerants were recovered for recycling on site or made available for use by other DOE facilities or other federal agencies. These reductions included removal of one hundred sixteen 17pound and four 13-pound Halon 1211 extinguishers. Monitoring BNL's potable water system showed that all drinking water requirements were met. During 2006, most of the liquid effluents discharged to surface water and groundwater met applicable New York State Pollutant Discharge Elimination System permit requirements. Four minor excursions of these permit limits were reported for the year, three at the Sewage Treatment Plant and one at a recharge basin. The permit excursions were reported to NYSDEC and the Suffolk County Department of Health Services. Groundwater monitoring at the Major Petroleum Facility continued to demonstrate that current oil storage and transfer operations are not affecting groundwater quality.

Laboratory efforts to minimize spills of materials continued in 2006. There were seven reportable spills of petroleum products, antifreeze, or chemicals; 50 percent less than in 2005. All releases were two gallons or less. There were four spills of glycol, the most common material spilled, typically due to failed vehicle cooling systems; two spills of hydraulic fluid; and a single spill of diesel fuel. All releases were cleaned up to the satisfaction of NYSDEC.

The Laboratory participated in 10 environmental audits by external regulatory agencies in 2006. These audits included inspections of petroleum and chemical storage, hazardous waste operations, Sewage Treatment Plant operations, other regulated outfalls and recharge basins, and the potable water system. Immediate corrective actions were taken to address all issues raised during these inspections. There were two Notices of Violation issued in 2006 for excess opacity measurements conducted in 2005. These excursions were self-reported and corrective actions were completed in 2005. 


\section{I COMPLIANCE WITH REQUIREMENTS}

The federal, state, and local environmental statutes and regulations that BNL operates under are summarized in Table 3-1, along with a discussion of the Laboratory's compliance status with each. A list of all applicable environmental regulations is found in Appendix D.

\subsection{ENVIRONMENTAL PERMITS}

\subsection{Existing Permits}

Many processes and facilities at BNL operate under permits issued by environmental regula- tory agencies. Table 3-2 provides a complete list of the existing permits, some of which are briefly described below.

- State Pollutant Discharge Elimination System (SPDES) permit, issued by New York State Department of Environmental Conservation (NYSDEC)

- Major Petroleum Facility (MPF) license, issued by NYSDEC

- Resource Conservation and Recovery Act (RCRA) permit issued by NYSDEC for the Waste Management Facility

Table 3-1. Federal, State, and Local Environmental Statutes and Regulations Applicable to BNL.

\begin{tabular}{|c|c|c|c|}
\hline $\begin{array}{l}\text { Regulator: } \\
\text { Codified } \\
\text { Regulation }\end{array}$ & Regulatory Program Description & Compliance Status & $\begin{array}{l}\text { Report } \\
\text { Sections }\end{array}$ \\
\hline $\begin{array}{l}\text { EPA: } \\
40 \text { CFR } 300 \\
40 \text { CFR } 302 \\
40 \text { CFR } 355 \\
40 \text { CFR } 370\end{array}$ & $\begin{array}{l}\text { The Comprehensive Environmental Response, } \\
\text { Compensation \& Liability Act (CERCLA) provides the } \\
\text { regulatory framework for remediation of releases of hazardous } \\
\text { substances and remediation (including decontamination and } \\
\text { decommissioning, D\&D) of inactive hazardous waste disposal } \\
\text { sites. Regulators include EPA, DOE, and the New York State } \\
\text { Depart-ment of Environmental Conservation (NYSDEC). }\end{array}$ & $\begin{array}{l}\text { In 1989, BNL entered into a tri-party agreement with EPA, } \\
\text { NYSDEC, and DOE. BNL site remediation is conducted by } \\
\text { the Environmental Restoration Program in accordance with } \\
\text { milestones established under this agreement. In 2005, BNL } \\
\text { completed the restoration portion of the cleanup project and } \\
\text { entered the surveillance and maintenance mode. Reactor D\&D } \\
\text { will continue under the CERCLA program in } 2007 \text {. }\end{array}$ & 2.3.4.8 \\
\hline $\begin{array}{l}\text { Council for Env. } \\
\text { Quality: } \\
40 \text { CFR } 1500-1508 \\
\text { DOE: } \\
10 \text { CFR } 1021\end{array}$ & $\begin{array}{l}\text { The National Environmental Policy Act (NEPA) requires } \\
\text { federal agencies to follow a prescribed process to anticipate } \\
\text { the impacts on the environment of proposed major federal } \\
\text { actions and alternatives. DOE codified its implementation of } \\
\text { NEPA in } 10 \text { CFR } 1021 .\end{array}$ & $\begin{array}{l}\text { BNL is in full compliance with NEPA requirements. The } \\
\text { Laboratory has established sitewide procedures for } \\
\text { implementing the NEPA requirements. }\end{array}$ & 3.3 \\
\hline $\begin{array}{l}\text { Advisory Council } \\
\text { on Historic } \\
\text { Preservation: } \\
36 \text { CFR } 60 \\
36 \text { CFR } 63 \\
36 \text { CFR } 79 \\
36 \text { CFR } 800 \\
16 \text { USC } 470\end{array}$ & $\begin{array}{l}\text { The National Historic Preservation Act (NHPA) identifies, } \\
\text { evaluates, and protects historic properties eligible for listing in } \\
\text { the National Register of Historic Places, commonly known as } \\
\text { the National Register. Such properties can be archeological } \\
\text { sites or historic structures, documents, records, or objects. } \\
\text { NHPA is administered by state historic preservation offices } \\
\text { (SHPOs; in New York State, NYSHPO). } \\
\text { At BNL, structures that may be subject to NHPA include the } \\
\text { High Flux Beam Reactor (HFBR), the Brookhaven Graphite } \\
\text { Research Reactor (BGRR) complex, World War I training } \\
\text { trenches near the Relativistic Heavy lon Collider project, and } \\
\text { the former Cosmotron Building. }\end{array}$ & $\begin{array}{l}\text { The HFBR, BGRR complex, and World War I trenches are } \\
\text { eligible for inclusion in the National Register. The former } \\
\text { Cosmotron building was identified as potentially eligible in } \\
\text { an April } 1991 \text { letter from NYSHPO. Any proposed activities } \\
\text { involving these facilities must be identified through the NEPA } \\
\text { process and evaluated to determine if the action would affect } \\
\text { the features that make the facility eligible. Some actions } \\
\text { required for D\&D of the BGRR were determined to affect its } \\
\text { eligibility, and mitigative actions are proceeding according to a } \\
\text { Memorandum of Agreement between DOE and NYSHPO. BNL } \\
\text { has a Cultural Resource Management Plan to ensure compli- } \\
\text { ance with cultural resource regulations. }\end{array}$ & 3.4 \\
\hline $\begin{array}{l}\text { EPA: } \\
40 \text { CFR } 50-0 \\
40 \text { CFR } 82 \\
\text { NYSDEC: } \\
6 \text { NYCRR 200-257 } \\
6 \text { NYCRR } 307\end{array}$ & $\begin{array}{l}\text { The Clean Air Act (CAA) and the NY State Environmental } \\
\text { Conservation Laws regulate the release of air pollutants through } \\
\text { permits and air quality limits. Emissions of radionuclides are } \\
\text { regulated by EPA, via the National Emission Standards for } \\
\text { Hazardous Air Pollutants (NESHAPs) authorizations. }\end{array}$ & $\begin{array}{l}\text { All air emission sources are incorporated into the BNL Title V } \\
\text { permit or have been exempted under the New York State air } \\
\text { program, which is codified under the New York Codes, Rules, } \\
\text { and Regulations (NYCRR). }\end{array}$ & 3.5 \\
\hline $\begin{array}{l}\text { EPA: } \\
40 \text { CFR 109-140 } \\
40 \text { CFR 230, } 231 \\
40 \text { CFR 401, } 403 \\
\text { NYSDEC: } \\
6 \text { NYCRR } 700-703 \\
6 \text { NYCRR } 750\end{array}$ & $\begin{array}{l}\text { The Clean Water Act (CWA) and NY State Environmental } \\
\text { Conservation Laws seek to improve surface water quality by } \\
\text { establishing standards and a system of permits. Wastewater } \\
\text { discharges are regulated by NYSDEC permits through the } \\
\text { State Pollutant Discharge Elimination System (SPDES). }\end{array}$ & $\begin{array}{l}\text { BNL permitted discharges include treated sanitary waste, and } \\
\text { cooling tower and stormwater discharges. With the exception } \\
\text { of four excursions, these discharges met the SPDES permit } \\
\text { limits in } 2006 \text {. }\end{array}$ & 3.6 \\
\hline
\end{tabular}


Table 3-1. Federal, State, and Local Environmental Statutes and Regulations Applicable to BNL (continued).

\begin{tabular}{|c|c|c|c|}
\hline $\begin{array}{l}\text { Regulator: } \\
\text { Codified } \\
\text { Regulation }\end{array}$ & Regulatory Program Description & Compliance Status & $\begin{array}{l}\text { Report } \\
\text { Sections }\end{array}$ \\
\hline $\begin{array}{l}\text { EPA: } \\
40 \text { CFR } 141-149 \\
\text { NYSDOH: } \\
10 \text { NYCRR } 5\end{array}$ & $\begin{array}{l}\text { The Safe Drinking Water Act (SDWA) and New York State } \\
\text { Department of Health (NYSDOH) standards for public water } \\
\text { supplies establish minimum drinking water standards and } \\
\text { monitoring requirements. SDWA requirements are enforced by } \\
\text { the Suffolk County Department of Health Services (SCDHS). }\end{array}$ & $\begin{array}{l}\text { BNL maintains a sitewide public water supply. This water supply } \\
\text { met all primary drinking water standards as well as operational } \\
\text { and maintenance requirements. }\end{array}$ & 3.7 \\
\hline $\begin{array}{l}\text { EPA: } \\
40 \text { CFR } 112 \\
40 \text { CFR } 300 \\
40 \text { CFR } 302 \\
40 \text { CFR } 355 \\
40 \text { CFR } 370 \\
40 \text { CFR } 372\end{array}$ & $\begin{array}{l}\text { The Oil Pollution Act, the Emergency Planning and } \\
\text { Community Right-to-Know Act (EPCRA), and the Superfund } \\
\text { Amendment Reauthorization Act (SARA) require facilities with } \\
\text { large quantities of petroleum products or chemicals to prepare } \\
\text { emergency plans and report their inventories to EPA, the state, } \\
\text { and local emergency planning groups. }\end{array}$ & $\begin{array}{l}\text { Since some facilities at BNL store or use chemicals or petroleum } \\
\text { in quantities exceeding threshold planning quantities, BNL } \\
\text { is subject to these requirements. BNL fully complies with all } \\
\text { reporting and emergency planning requirements. }\end{array}$ & $\begin{array}{l}3.8 .1 \\
3.8 .2 \\
3.8 .3\end{array}$ \\
\hline $\begin{array}{l}\text { EPA: } \\
40 \text { CFR } 280 \\
\text { NYSDEC: } \\
6 \text { NYCRR } 595-597 \\
6 \text { NYCRR } 611-613 \\
\text { SCDHS: } \\
\text { SCSC Article } 12\end{array}$ & $\begin{array}{l}\text { Federal, state, and local regulations govern the storage of } \\
\text { chemicals and petroleum products to prevent releases of } \\
\text { these materials to the environment. Suffolk County Safety } \\
\text { Codes (SCSC) are more stringent than the federal and state } \\
\text { regulations. }\end{array}$ & $\begin{array}{l}\text { The regulations require that these materials be managed } \\
\text { in facilities equipped with secondary containment, overfill } \\
\text { protection, and leak detection. BNL complies with all federal } \\
\text { and state requirements and has achieved conformance to } \\
\text { county codes. }\end{array}$ & $\begin{array}{l}3.8 .4 \\
3.8 .5 \\
3.8 .6\end{array}$ \\
\hline $\begin{array}{l}\text { EPA: } \\
\text { 40 CFR 260-280 } \\
\text { NYSDEC: } \\
6 \text { NYCRR } 360-372\end{array}$ & $\begin{array}{l}\text { The Resource Conservation Recovery Act (RCRA) and New } \\
\text { York State Solid Waste Disposal Act govern the generation, } \\
\text { storage, handling, and disposal of hazardous wastes. }\end{array}$ & $\begin{array}{l}\text { BNL is defined as a large-quantity generator of hazard- } \\
\text { ous waste and has a permitted waste management facility. } \\
\text { A hazardous waste regulatory inspection showed that all } \\
\text { operations met regulatory requirements in } 2006 \text {. }\end{array}$ & 3.9 \\
\hline $\begin{array}{l}\text { EPA: } \\
40 \text { CFR } 700-763\end{array}$ & $\begin{array}{l}\text { The Toxic Substances Control Act (TSCA) regulates the } \\
\text { manufacture, use, and distribution of all chemicals. }\end{array}$ & $\begin{array}{l}\text { BNL manages all TSCA-regulated materials, including PCBs, in } \\
\text { compliance with all requirements. }\end{array}$ & 3.10 \\
\hline $\begin{array}{l}\text { EPA: } \\
40 \text { CFR 162-171(f) } \\
\text { NYSDEC: } \\
6 \text { NYCRR } 320 \\
6 \text { NYCRR } 325-329\end{array}$ & $\begin{array}{l}\text { The Federal Insecticide, Fungicide, and Rodenticide Act } \\
\text { (FIFRA) and corresponding NY State regulations govern the } \\
\text { manufacture, use, storage, and disposal of pesticides and } \\
\text { herbicides, as well as the pesticide containers and residuals. }\end{array}$ & $\begin{array}{l}\text { BNL employs NY State-certified pesticide applicators to apply } \\
\text { pesticides and herbicides. Each applicator attends training as } \\
\text { needed to maintain current certification, and files an annual } \\
\text { report to the state detailing the types and quantity of pesticides } \\
\text { applied. }\end{array}$ & 3.11 \\
\hline $\begin{array}{l}\text { DOE: } \\
10 \text { CFR } 1022 \\
\text { NYSDEC: } \\
6 \text { NYCRR } 663 \\
6 \text { NYCRR } 666\end{array}$ & $\begin{array}{l}\text { DOE regulations require its facilities to comply with floodplain/ } \\
\text { wetland review requirements. The New York State Fresh } \\
\text { Water Wetlands and Wild, Scenic, and Recreational Rivers } \\
\text { rules govern development in the state's natural waterways. } \\
\text { Development or projects within a half-mile of regulated waters } \\
\text { must have NYSDEC permits. }\end{array}$ & $\begin{array}{l}\text { BNL is in the Peconic River watershed and has several } \\
\text { jurisdictional wetlands; consequently, development of locations } \\
\text { in the north and east of the site requires NYSDEC permits } \\
\text { and review for compliance under DOE wetland/floodplain } \\
\text { regulations. In 2006, three projects were permitted under the } \\
\text { NYS Fresh Water Program. }\end{array}$ & 3.12 \\
\hline $\begin{array}{l}\text { U.S. Fish \& Wildlife } \\
\text { Service: } \\
50 \text { CFR } 17 \\
\text { NYSDEC: } \\
6 \text { NYCRR } 182\end{array}$ & $\begin{array}{l}\text { The Endangered Species Act and corresponding New York } \\
\text { State regulations prohibit activities that would jeopardize the } \\
\text { continued existence of an endangered or threatened species, } \\
\text { or cause adverse modification to a critical habitat. }\end{array}$ & $\begin{array}{l}\text { BNL is host to numerous species of flaura and fauna, many } \\
\text { categorized by NYS as endangered, threatened, or of special } \\
\text { concern. BNL's Natural Resource Management Plan outlines } \\
\text { activities to protect these vulnerable species and protect their } \\
\text { habitats (see Chapter 6). }\end{array}$ & 3.13 \\
\hline $\begin{array}{l}\text { DOE: } \\
\text { Manual 231.1-1A }\end{array}$ & $\begin{array}{l}\text { The Environment, Safety, and Health Reporting program } \\
\text { objective is to ensure timely collection, reporting, analysis, } \\
\text { and dissemination of information on environment, safety, and } \\
\text { health issues as required by law or regulations or as needed } \\
\text { to ensure that DOE is kept fully informed on a timely basis } \\
\text { about events that could adversely affect the health and safety } \\
\text { of the public, workers, environment, intended purpose of } \\
\text { DOE facilities, or credibility of the Department. Included in the } \\
\text { order are the requirements for the Occurrence Reporting and } \\
\text { Processing of Operations Program (ORPS). }\end{array}$ & $\begin{array}{l}\text { BNL prepares an annual Site Environmental Report and } \\
\text { provides data for DOE to prepare annual NEPA summaries } \\
\text { and other Safety, Fire Protection, and Occupational Health } \\
\text { and Safety Administration (OSHA) reports. BNL developed the } \\
\text { ORPS Subject Area for staff and management who perform } \\
\text { specific duties related to discovery, response, notification, } \\
\text { investigation, and reporting of occurrences to BNL and DOE } \\
\text { management. The ORPS Subject Area is supported by: } \\
\text { Occurrence Reporting Program Description, Critiques Subject } \\
\text { Area, Occurrence Categorizer's Procedure, and the ORPS } \\
\text { Office Procedure. }\end{array}$ & $\begin{array}{l}\text { All } \\
\text { chapters }\end{array}$ \\
\hline
\end{tabular}


Table 3-1. Federal, State, and Local Environmental Statutes and Regulations Applicable to BNL (concluded).

\begin{tabular}{|c|c|}
\hline $\begin{array}{l}\text { Regulator: } \\
\text { Codified } \\
\text { Regulation }\end{array}$ & Regulatory Program Description \\
\hline $\begin{array}{l}\text { DOE: } \\
\text { Order } 414.1 \\
10 \text { CFR } 830 \text {, } \\
\text { Subpart A } \\
\text { Policy } 450.5\end{array}$ & $\begin{array}{l}\text { The Quality Assurance (QA) program objective is to establish } \\
\text { an effective management system using the performance } \\
\text { requirements of this Order, coupled with technical standards, } \\
\text { where appropriate, to ensure: senior management provides } \\
\text { planning, organization, direction, control, and support to } \\
\text { achieve DOE objectives; line organizations achieve and } \\
\text { maintain quality while minimizing safety and health risks } \\
\text { and environmental impacts and maximizing reliability and } \\
\text { performance; line organizations have a basic management } \\
\text { system in place supporting this Order; and each DOE element } \\
\text { reviews, evaluates, and improves its overall performance and } \\
\text { that of its contractors using a rigorous assessment process } \\
\text { based on an approved QA Program. }\end{array}$ \\
\hline
\end{tabular}

Compliance Status

BNL has a Quality Management (QM) system to implement Chapter quality management methodology throughout its management 9 systems and associated processes to:

1) plan and perform Laboratory operations reliably and effectively to minimize the impact on the safety and health of humans and on the environment; 2) standardize processes and support continuous improvement in all aspects of Laboratory operations; and 3) enable the delivery of products and services that meet customers' requirements and expectations. Having a comprehensive program ensures that all environmental monitoring data meet QA and quality control requirements. Samples are collected and analyzed using standard operating procedures, to ensure representative samples and reliable, defensible data. Quality control in the analytical labs is maintained through daily instrument calibration, efficiency and background checks, and testing for precision and accuracy. Data are verified and validated according to project-specific quality objectives before they are used to support decision making.

The BNL Waste Certification Program Plan (WCPP) in the RWMB Program Description defines the radioactive waste management program's structure, logic, and methodology for waste certification. New or modified operations or activities that do not fall within the scope of the RWMB Program Description must be documented and approved before implementation. BNL's RWMB Program Description describes the BNL policies, procedures, plans, and controls demonstrating that BNL has the management systems, administrative controls, and physical controls to comply with DOE Order 435.1.

BNL's EMS was officially registered to the ISO 14001:1996 Chapter standard in 2001 and recertified to the revised standard in 2004. 2 In June 2006, a surveillance audit was conducted that found the BNL EMS to be robust. The BNL ISMS Program Description presents the Laboratory's approach to integrating environment, safety, and health (ES\&H) requirements into the processes for planning and conducting work at BNL. It describes BNL's programs, including the SBMS, for accomplishing work safely and provides the road map of the systems and processes. mental Management System (EMS) that is part of an Integrated Safety Management System (ISMS). Other components include establishing sound environmental monitoring programs to comply with former DOE Order 5400.1. The Site Based Management System (SBMS) provides staff with procedural guidance.

DOE:
Order 5400.5,
Change 2

To protect members of the public and the environment against undue risk from radiation, the Radiation Protection of the Public and Environment Program establishes standards and requirements for operations of DOE and DOE contractors.
BNL uses the guidance values provided in DOE Order Chapters 5400.5 to ensure that effluents and emissions do not affect $4,5,6$, the environment or public and worker safety and health, and and 8 to ensure that all doses meet the "As Low As Reasonably Achievable" (ALARA) policy.

Notes:

CFR $=$ Code of Federal Regulations

NYCRR = New York Codes, Rules, and Regulations

SCSC $=$ Suffolk County Sanitary Code 
Table 3-2. BNL Environmental Permits.

\begin{tabular}{|c|c|c|c|c|c|c|}
\hline Issuing Agency & $\begin{array}{l}\text { Bldg. } \\
\text { or } \\
\text { Facility }\end{array}$ & Process/Permit Description & Permit ID No. & $\begin{array}{c}\text { Expiration or } \\
\text { Completion }\end{array}$ & $\begin{array}{l}\text { Emission } \\
\text { Unit ID }\end{array}$ & Source ID \\
\hline EPA - NESHAPS & 510 & Calorimeter Enclosure & BNL-689-01 & None & NA & NA \\
\hline EPA - NESHAPS & 705 & Building Ventilation & BNL-288-01 & None & NA & NA \\
\hline EPA - NESHAPS & 820 & Accelerator Test Facility & BNL-589-01 & None & NA & NA \\
\hline EPA - NESHAPS & AGS & AGS Booster - Accelerator & BNL-188-01 & None & NA & NA \\
\hline EPA - NESHAPS & $\mathrm{RHIC}$ & Accelerator & BNL-389-01 & None & NA & NA \\
\hline EPA - SDWA & BNL & Underground Injection Control & NYU500001 & $11-F e b-11$ & NA & NA \\
\hline NYSDEC - Air Equivalency & 517 & Middle Road System & $1-51-009$ & NA & NA & NA \\
\hline NYSDEC - Air Equivalency & 518 & South Boundary System & $1-51-009$ & NA & NA & NA \\
\hline NYSDEC - Air Equivalency & 598 & OU I Remediation System & $1-52-009$ & NA & NA & NA \\
\hline NYSDEC - Air Equivalency & 539 & Western South Boundary System & $1-52-009$ & NA & NA & NA \\
\hline NYSDEC - Air Equivalency & TR 867 & T-96 Remediation System & NA & NA & NA & NA \\
\hline NYSDEC - SPDES Equivalency & 517 & Middle Road System & $1-51-009$ & NA & NA & NA \\
\hline NYSDEC - SPDES Equivalency & 518 & South Boundary System & $1-51-009$ & NA & NA & NA \\
\hline NYSDEC - SPDES Equivalency & 539 & W. South Boundary System & $1-52-009$ & NA & NA & NA \\
\hline NYSDEC - SPDES Equivalency & 598 & OU I Remediation System & $1-52-009$ & 31-Oct-06 & NA & NA \\
\hline NYSDEC - SPDES Equivalency & 598 & Tritium Remediation System & $1-52-009$ & NA & NA & NA \\
\hline NYSDEC - SPDES Equivalency & 670 & Sr-90 Treatment System & None & NA & NA & NA \\
\hline NYSDEC - SPDES Equivalency & TR 829 & Carbon Tetrachloride System & None & NA & NA & NA \\
\hline NYSDEC - SPDES Equivalency & OS-4 & Airport/LIPA Treatment System & None & NA & NA & NA \\
\hline NYSDEC - SPDES Equivalency & OS-2 & Industrial Park East Treatment System & None & NA & NA & NA \\
\hline NYSDEC - SPDES Equivalency & OS-5 & North St./North St. East Treatment System & None & NA & NA & NA \\
\hline NYSDEC - SPDES Equivalency & OS-6 & Ethylene Di-Bromide Treatment System & None & 1-Aug-09 & NA & NA \\
\hline NYSDEC - SPDES Equivalency & 855 & Sr-90 Treatment System - BGRR/WCF & None & 1-Jan-10 & NA & NA \\
\hline NYSDEC - Hazardous Substance & BNL & Bulk Storage Registration Certificate & $1-000263$ & 27-Jul-07 & NA & NA \\
\hline NYSDEC - LI Well Permit & BNL & Domestic Potable/Process Wells & $1-4722-00032 / 00113$ & 13-Sep-08 & NA & NA \\
\hline NYSDEC - Air Quality & 197 & Lithographic Printing Presses & $1-4722-00032 / 00115$ & 06-Jan-07 & U-LITHO & $19709-10$ \\
\hline NYSDEC - Air Quality & 423 & Metal Parts Cleaning Tanks & $1-4722-00032 / 00115$ & 06-Jan-07 & U-METAL & 42308 \\
\hline NYSDEC - Air Quality & 423 & Gasoline Storage and Fuel Pumps & $1-4722-00032 / 00115$ & 06-Jan-07 & U-FUELS & $42309-10$ \\
\hline NYSDEC - Air Quality & 423 & Motor Vehicle A/C Servicing & $1-4722-00032 / 00115$ & 06-Jan-07 & U-MVACS & MVAC1\&2 \\
\hline NYSDEC - Air Quality & 244 & Paint Spray Booth & $1-4722-00032 / 00115$ & 06-Jan-07 & U-45801 & $244-02$ \\
\hline NYSDEC - Air Quality & 244 & Flammable Liquid Storage Cabinet & $1-4722-00032 / 00115$ & 06-Jan-07 & U-45801 & $244 \mathrm{AE}$ \\
\hline NYSDEC - Air Quality & 479 & Metal Parts Cleaning Tank & $1-4722-00032 / 00115$ & 06-Jan-07 & U-METAL & 47908 \\
\hline NYSDEC - Air Quality & 479 & Metal Parts Cleaning Tank & $1-4722-00032 / 00115$ & 06-Jan-07 & U-METAL & $47906^{* *}$ \\
\hline NYSDEC - Air Quality & 490 & Milling Machine/Block Cutter & $1-4722-00032 / 00115$ & 06-Jan-07 & U-49003 & $49003^{* *}$ \\
\hline NYSDEC - Air Quality & 490 & Lead Alloy Melting & $1-4722-00032 / 00115$ & 06-Jan-07 & U-49003 & $49004^{* *}$ \\
\hline NYSDEC - Air Quality & 498 & Aqueous Cleaning Facility & $1-4722-00032 / 00115$ & 06-Jan-07 & U-METAL & 49801 \\
\hline NYSDEC - Air Quality & $535 B$ & Plating Tanks & $1-4722-00032 / 00115$ & 06-Jan-07 & U-INSIG & 53501 \\
\hline NYSDEC - Air Quality & $535 B$ & Etching Machine & $1-4722-00032 / 00115$ & 06-Jan-07 & U-INSIG & 53502 \\
\hline NYSDEC - Air Quality & $535 \mathrm{~B}$ & Printed Circuit Board Process & $1-4722-00032 / 00115$ & 06-Jan-07 & U-INSIG & 53503 \\
\hline NYSDEC - Air Quality & 610 & Combustion Unit & $1-4722-00032 / 00115$ & 06-Jan-07 & U-61005 & 61005 \\
\hline
\end{tabular}


Table 3-2. BNL Environmental Permits (concluded).

\begin{tabular}{|c|c|c|c|c|c|c|}
\hline Issuing Agency & $\begin{array}{l}\text { Bldg. } \\
\text { or } \\
\text { Facility }\end{array}$ & Process/Permit Description & Permit ID No. & $\begin{array}{l}\text { Expiration or } \\
\text { Completion }\end{array}$ & $\begin{array}{l}\text { Emission } \\
\text { Unit ID }\end{array}$ & Source ID \\
\hline NYSDEC - Air Quality & 610 & Combustion Unit & $1-4722-00032 / 00115$ & 06-Jan-07 & U-61006 & 61006 \\
\hline NYSDEC - Air Quality & 610 & Combustion Unit & $1-4722-00032 / 00115$ & 06-Jan-07 & U-61007 & 61007 \\
\hline NYSDEC - Air Quality & 610 & Metal Parts Cleaning Tray & $1-4722-00032 / 00115$ & 06-Jan-07 & U-METAL & 61008 \\
\hline NYSDEC - Air Quality & 610 & Combustion Unit & $1-4722-00032 / 00115$ & 06-Jan-07 & U-61005 & $6101 \mathrm{~A}$ \\
\hline NYSDEC - Air Quality & 630 & Gasoline Storage \& Fuel Pumps & $1-4722-00032 / 00115$ & 06-Jan-07 & U-FUELS & $63001-03$ \\
\hline NYSDEC - Air Quality & 820 & Metal Parts Cleaning Tank & $1-4722-00032 / 00115$ & 06-Jan-07 & U-METAL & $82001^{* *}$ \\
\hline NYSDEC - Air Quality & 902 & Epoxy Coating/Curing Exhaust & $1-4722-00032 / 00115$ & 06-Jan-07 & U-COILS & 90206 \\
\hline NYSDEC - Air Quality & 903 & Metal Parts Cleaning Tank & $1-4722-00032 / 00115$ & 06-Jan-07 & U-METAL & 90304 \\
\hline NYSDEC - Air Quality & 919B & Electroplating Operation & $1-4722-00032 / 00115$ & 06-Jan-07 & U-INSIG & 91904 \\
\hline NYSDEC - Air Quality & 922 & Metal Parts Cleaning Tank & $1-4722-00032 / 00115$ & 06-Jan-07 & U-METAL & $92202-03^{* *}$ \\
\hline NYSDEC - Air Quality & 922 & Electroplating Operation & $1-4722-00032 / 00115$ & 06-Jan-07 & U-INSIG & 92204 \\
\hline NYSDEC - Air Quality & 923 & Electronic Equipment Cleaning & $1-4722-00032 / 00115$ & 06-Jan-07 & U-METAL & $9231 \mathrm{~A}$ \\
\hline NYSDEC - Air Quality & 923 & Parts Drying Oven & $1-4722-00032 / 00115$ & 06-Jan-07 & U-METAL & 9231B \\
\hline NYSDEC - Air Quality & 924 & Magnet Coil Production Press & $1-4722-00032 / 00115$ & 06-Jan-07 & U-INSIG & 92402 \\
\hline NYSDEC - Air Quality & 924 & Vapor/Ultrasonic Degreasing Unit & $1-4722-00032 / 00115$ & 06-Jan-07 & U-METAL & 92404 \\
\hline NYSDEC - Air Quality & Site & Halon 1211 Portable Extinguishers & $1-4722-00032 / 00115$ & 06-Jan-07 & U-HALON & $\mathrm{H} 1211$ \\
\hline NYSDEC - Air Quality & Site & Halon 1301 Fire Suppression Systems & $1-4722-00032 / 00115$ & 06-Jan-07 & U-HALON & H1301 \\
\hline NYSDEC - Air Quality & Site & Packaged A/C Units & $1-4722-00032 / 00115$ & 06-Jan-07 & U-RFRIG & PKG01-02 \\
\hline NYSDEC - Air Quality & Site & Reciprocating Chillers & $1-4722-00032 / 00115$ & 06-Jan-07 & U-RFRIG & REC01-52 \\
\hline NYSDEC - Air Quality & Site & Rotary Screw Chillers & $1-4722-00032 / 00115$ & 06-Jan-07 & U-RFRIG & ROT01-11 \\
\hline NYSDEC - Air Quality & Site & Split A/C Units & $1-4722-00032 / 00115$ & 06-Jan-07 & U-RFRIG & SPL01-02 \\
\hline NYSDEC - Air Quality & Site & Centrifugal Chillers & $1-4722-00032 / 00115$ & 06-Jan-07 & U-RFRIG & CEN01-24 \\
\hline NYSDEC - Hazardous Waste & WMF & Waste Management & $1-4722-00032 / 00102$ & 19-Nov-16 & NA & NA \\
\hline NYSDEC - Natural Resources & AGS & Construction of AGS Storage Facility & $1-4722-00032 / 00133$ & 23-Mar-06 & NA & NA \\
\hline NYSDEC - Natural Resources & $\mathrm{RHIC}$ & Construction of New Recharge Basin & $1-4722-00032 / 00129$ & 17-May-07 & NA & NA \\
\hline NYSDEC - Natural Resources & $\mathrm{RHIC}$ & Construct 9C/7C Alcove Building & $1-4722-00032 / 00137$ & 08-Sep-08 & NA & NA \\
\hline NYSDEC - NESHAPS & REF & Radiation Effects/Neutral Beam & BNL-789-01 & None & NA & NA \\
\hline NYSDEC - NESHAPS & RTF & Radiation Therapy Facility & BNL-489-01 & None & NA & NA \\
\hline NYSDEC - Water Quality & CSF & Major Petroleum Facility & $1-1700$ & 31-Mar-07 & NA & NA \\
\hline NYSDEC - Water Quality & STP & Sewage Plant and Recharge Basins & NY-0005835 & 01-Mar-10 & NA & NA \\
\hline \multicolumn{3}{|c|}{$\begin{array}{l}\text { AGS = Alternating Gradient Synchrotron } \\
\text { CSF = Central Steam Facility } \\
\text { EPA = Environmental Protection Agency } \\
\text { NESHAPs = National Emission Standards for Hazardous Air Pollutants } \\
\text { NYSDEC = New York State Department of Environmental Conservation } \\
\text { NA=Not Applicable } \\
\text { OU = Operable Unit }\end{array}$} & \multicolumn{4}{|c|}{$\begin{array}{l}\text { RTF = Radiation Therapy Facility } \\
\text { RHIC = Relativistic Heavy lon Collider } \\
\text { SDWA = Safe Drinking Water Act } \\
\text { SPDES = State Pollutant Discharge Elimination System } \\
\text { STP = Sewage Treatment Plant } \\
\text { WMF = Waste Management Facility }\end{array}$} \\
\hline
\end{tabular}

- Registration certificate from NYSDEC for tanks storing bulk quantities of hazardous substances

- Seven radiological emission authorizations issued by the United States Environmental
Protection Agency (EPA) under the National Emission Standards for Hazardous Air Pollutants (NESHAPs)

- Air emissions permit issued by NYSDEC under Title V of the Clean Air Act Amend- 
ments authorizing the operation of 39 facilities

- Three permits issued by NYSDEC for construction activities within the Peconic River corridor

- An EPA Underground Injection Control (UIC) Area permit for the operation of 90 UIC wells

- Permit for the operation of six domestic water supply wells, issued by NYSDEC

- Fifteen equivalency permits for the operation of 12 groundwater remediation systems installed under the Interagency Agreement (Federal Facility Agreement under the Comprehensive Environmental Response, Compensation and Liability Act [CERCLA])

\subsubsection{New or Modified Permits}

\subsubsection{Hazardous Waste Management Permit}

The RCRA Part B permit authorizes BNL to store, prepare for shipment, and ship hazardous wastes generated by site operations. This permit expired in July 2005, but remained in force while NYSDEC reviewed BNL's renewal application. The permit was re-issued in November 2006 and remains in effect for a period of 10 years.

\subsubsection{Air Emissions Permits}

Air emissions permits are granted by NYSDEC. The Title V permit consolidates all applicable federal and state requirements for BNL's regulated emission sources into a single document. The Laboratory has a variety of nonradioactive air emission sources covered under the permit that are subject to federal or state regulations. Section 3.5 describes the more significant sources and the methods used by BNL to comply with the applicable regulatory requirements. In June 2006, an application to renew the Laboratory's Title V operating permit was submitted to NYSDEC. The application included numerous changes to reflect the removal of certain processes previously included in the permit, as well as the addition of new processes.

Air emissions permits are also issued as "equivalency" permits for the installation and operation of groundwater remediation systems under CERCLA, or as changes to the BNL
Title V operating permit. During 2006, no CERCLA air equivalency permits were issued.

\subsection{NEPA ASSESSMENTS}

The National Environmental Policy Act (NEPA) regulations require federal agencies to evaluate the effects of proposed major federal activities on the environment. The prescribed evaluation process ensures that the proper level of environmental review is performed before an irreversible commitment of resources is made.

An Environmental Assessment (EA) of the proposed construction and operation of the National Synchrotron Light Source II (NSLSII) was prepared in 2006. NSLS-II will be an advanced synchrotron light source designed to study the properties and functions of materials, primarily in the nanoscale range (1 to 100 nanometers). This new state-of-the-art facility will consist of a medium energy ( 3 billion electron volt) electron storage ring, estimated at 2,560 feet ( 780 meters) in circumference, with beamlines 200 feet long (60 meters). NSLS-II will replace the existing NSLS, which has been operational and producing world-class science for more than 24 years. The EA analyzed the potential environmental consequences of the facility and compared them to the consequences of a "No Action" alternative. The assessment included detailed analysis of all potential environmental, safety and health hazards anticipated in the design, construction, and operation of the facility. Based on information and analysis in the EA, DOE determined that the proposed action would not significantly affect the quality of the human environment within the meaning of the National Environmental Policy Act of 1969, and issued a Finding of No Significant Impact (FONSI) in October 2006.

During 2006, environmental evaluations were completed for 81 additional proposed projects. Of these, 75 were considered minor actions requiring no additional documentation. The six remaining projects were addressed by submitting notification forms to DOE, which determined that they were covered by existing Categorical Exclusions as per 10 CFR 1021 or fell within the scope of a previous environmental assessment. 


\subsection{PRESERVATION LEGISLATION}

The Laboratory is subject to several cultural resource laws, most notably the National Historic Preservation Act and the Archeological Resource Protection Act. These laws require agencies to consider the effects of proposed federal actions on historic structures, objects, and documents, as well as cultural or natural places important to Native Americans or other ethnic groups.

BNL has three structures or sites that are eligible for listing on the National Register of Historic Places: the Brookhaven Graphite Research Reactor complex, the High Flux Beam Reactor complex, and the World War I Army training trenches associated with Camp Upton. An annual Department of Interior questionnaire regarding historic and cultural resources was submitted in March 2006. Additional activities associated with historic preservation compliance are described in Chapter 6.

\subsection{CLEAN AIR ACT}

The objectives of the Clean Air Act (CAA), which is administered by EPA and NYSDEC, are to improve or maintain regional ambient air quality through operational and engineering controls on stationary or mobile sources of air pollution. Both conventional and hazardous air pollutants are regulated under the CAA.

\subsection{Conventional Air Pollutants}

The Laboratory has a variety of conventional, nonradioactive air emission sources that are subject to federal or state regulations. The following subsections describe the more significant sources and the methods used by BNL to comply with the applicable regulatory requirements.

\subsubsection{Boiler Emissions}

BNL has four boilers (Nos. 1A, 5, 6, and 7) at the Central Steam Facility (CSF) that are subject to NYSDEC Reasonably Available Control Technology requirements. Three of the boilers can burn either residual fuel oil or natural gas; Boiler $1 \mathrm{~A}$ burns fuel oil only. In 2006, low nitrogen residual fuel oil (i.e., below 0.3 percent) was the predominant fuel burned in all four boilers. For boilers with maximum operating heat inputs greater than or equal to 50 MMBtu/hr (14.6 MW), the requirements establish emissions standards for oxides of nitrogen $\left(\mathrm{NO}_{\mathrm{x}}\right)$. Boilers with a maximum operating heat input between 50 and $250 \mathrm{MMBtu} / \mathrm{hr}$ (14.6 and 73.2 MW) can demonstrate compliance using periodic emission tests or by using continuous emission monitoring equipment. Emission tests conducted in 1995 and again in 2006 confirmed that boilers $1 \mathrm{~A}$ and 5, both in this size category, met the $\mathrm{NO}_{\mathrm{x}}$ emission standards when burning residual fuel oil with low nitrogen content. To ensure continued compliance, an outside contract analytical laboratory analyzes composite samples (collected quarterly) of fuel deliveries. The analyses conducted in 2006 confirmed that the fuel-bound nitrogen content met these requirements. Compliance with the $0.30 \mathrm{lbs} /$ MMBtu $\mathrm{NO}_{\mathrm{x}}$ emission standards for boilers 6 and 7 was demonstrated by continuous emission monitoring of the flue gas. In 2006, $\mathrm{NO}_{\mathrm{x}}$ emissions from Boilers 6 and 7 averaged 0.210 lbs/MMBtu and 0.162 lbs/MMBtu, respectively, and there were no known exceedances of the $\mathrm{NO}_{\mathrm{x}}$ emission standard for either boiler.

The Laboratory also maintains continuous opacity monitors for boilers 6 and 7 . These monitors measure the transmittance of light through the exhaust gas and report this measurement in percent attenuated. Opacity limitations state that no facility may emit particulates such that the opacity exceeds 20 percent, calculated in 6-minute averages, except for one period not to exceed 27 percent in any one hour. To maintain boiler efficiency, soot that accumulates on the boiler tubes must be removed. This is accomplished by passing a mixture of high-pressure steam and air through the boiler using a series of blowers. In 2006, BNL reported no periods where opacity exceeded the 6-minute, 20 percent average due to soot blowing operations. The only deviations from the opacity standard occurred during boiler startup and shutdown or during required opacity monitor calibration error testing. Both EPA and NYSDEC recognize these periods as permissible.

\subsubsection{Ozone-Depleting Substances \\ Refrigerants. The Laboratory's preventative}


maintenance program requires regular inspection and maintenance of refrigeration and air conditioning equipment that contains ozonedepleting substances such as R-11, R-12, and $\mathrm{R}-22$. All refrigerant recovery and recycling equipment is certified to meet refrigerant evacuation levels specified by 40 CFR 82.158 . As a matter of standard practice at BNL, if a refrigerant leak is found, technicians will either immediately repair the leak or isolate it and prepare a work order for the needed repairs. This practice exceeds the leak repair provisions of 40 CFR 82.156. In 2006, approximately 132 pounds of R-22 were recovered and recycled from refrigeration equipment that was serviced.

Halon. Halon 1211 and 1301 are extremely efficient fire suppressants, but are being phased out due to their effect on the Earth's ozone layer. In 1998, the Laboratory purchased equipment to comply with the halon recovery and recycling requirements of the CAA, $40 \mathrm{CFR}$ 82 Subpart $\mathrm{H}$. When portable fire extinguishers or fixed systems are removed from service and when halon cylinders are periodically tested, BNL technicians use halon recovery and recycling devices, to comply with the CAA provisions.

In 2006, BNL declared one hundred sixteen 17-pound and four 13-pound Halon 1211 portable fire extinguishers as excess property. The Laboratory is making arrangements for their transfer to another DOE facility or to another federal agency, in accordance with the Class I Ozone Depleting Substances Disposition Guidelines of the DOE Office of Environmental Policy and Guidance. The portable extinguishers became excess property after they were removed from areas they served, due to changes in operations, or when they were replaced by $\mathrm{ABC}$ dry-chemical or clean agent FE-36 extinguishers.

\subsubsection{Hazardous Air Pollutants}

In 1970, the CAA established standards to protect the general public from hazardous air pollutants that may lead to death or an increase in irreversible or incapacitating illnesses. The National Emission Standards for Hazardous Air Pollutants (NESHAPs) program was established in 1977 and the governing regulations were updated significantly in 1990. EPA developed this program to limit the emission of 189 toxic air pollutants. This program includes a list of regulated contaminants, a schedule for implementing control requirements, aggressive technologybased emission standards, industry-specific requirements, special permitting provisions, and a program to address accidental releases. The following subsections describe BNL's compliance with NESHAPs regulations.

\subsubsection{Maximum Available Control \\ Technology}

Based on the Laboratory's review of existing state and federal CAA regulations, no proposed or promulgated Maximum Available Control Technology (MACT) standards apply to BNL operations. In 2006, additional evaluations were performed during the preparation of BNL's Title $\mathrm{V}$ operating permit renewal application and during assessments of proposed activities and operations. The evaluations verified that no MACT standards apply to the emissions from existing permitted operations or the anticipated emissions from proposed activities and operations.

\subsubsection{Asbestos}

In 2006, the Laboratory notified the EPA Region II office regarding removal of materials containing asbestos. During the year, 1,100 linear feet and $1,450 \mathrm{ft}^{2}$ of asbestos-containing pipe and duct insulation, and $9,900 \mathrm{ft}^{2}$ of asbestos-containing surface material (siding, roofing, and vinyl asbestos floor tile) were removed and disposed of in accordance with EPA requirements.

\subsubsection{Radioactive Airborne Emissions}

Emissions of radiological contaminants are evaluated and, if necessary, monitored to ensure that they do not impact the environment or people working or residing at or near the Laboratory. A full description of this monitoring conducted in 2006 is provided in Chapter 4. BNL transmitted all data pertaining to radioactive air emissions and dose calculations to EPA in fulfillment of the June 30 annual reporting requirement. As in past years, the maximum off- 
site dose due to airborne radioactive emissions from the Laboratory continued to be far below the $10 \mathrm{mrem}(100 \mu \mathrm{Sv})$ annual dose limit specified in 40 CFR 61 Subpart H. See Chapters 4 and 8 for more information on the estimated air dose. Using EPA's modeling software, the dose to the hypothetical maximally exposed individual resulting from BNL's airborne emissions was 0.08 mrem $(0.8 \mu \mathrm{Sv})$.

\subsection{CLEAN WATER ACT}

The disposal of wastewater generated by Laboratory operations is regulated under the Clean Water Act (CWA) as implemented by NYSDEC and under DOE Order 5400.5, Radiation Protection of the Public and the Environment. The goals of the CWA are to achieve a level of water quality that promotes the propagation of fish, shellfish, and wildlife; to provide waters suitable for recreational purposes; and to eliminate the discharge of pollutants into surface waters. New York State was delegated CWA authority in 1975. NYSDEC has issued a SPDES permit to regulate wastewater effluents at the Laboratory. This permit was renewed in May 2005, and specifies monitoring requirements and effluent limits for nine of 12 outfalls, as described below. See Figure 5-7 in Chapter 5 for the locations of BNL outfalls.

- Outfall 001 is used for the discharge of the treated effluent from the STP to the Peconic River.

- Outfalls 002, 002B, 003, 005, 006A, 006B, 008, 010, 011, and 012 are recharge basins used to discharge cooling tower blowdown, once-through cooling water, and/or stormwater. NYSDEC does not require BNL to monitor Outfalls 003, 011, and 012.

- Outfall 007 receives backwash water from the potable Water Treatment Plant filter building.

- Outfall 009 consists of numerous subsurface and surface wastewater disposal systems (e.g., drywells) that receive predominantly sanitary waste and steam- and air-compressor condensate discharges. NYSDEC does not require monitoring of this outfall.

Each month, the Laboratory prepares Dis- charge Monitoring Reports that describe monitoring results, evaluate compliance with permit limitations, and identify corrective measures taken to address permit excursions. These reports are submitted to the NYSDEC central and regional offices and the Suffolk County Department of Health Services (SCDHS). Details of the monitoring program conducted for the groundwater treatment systems and SPDES equivalency permit performance are provided in SER Volume II, Groundwater Status Report.

\subsection{Sewage Treatment Plant}

Sanitary and process wastewater generated by BNL operations is conveyed to the Sewage Treatment Plant (STP) for processing before discharge to the Peconic River. The STP provides tertiary treatment of this wastewater (settlement/sedimentation, biological reduction of organic matter, and reduction of nitrogen). Chapter 5 provides a detailed description of the treatment process.

A summary of the SPDES monitoring results for the STP discharge at Outfall 001 is provided in Table 3-3. The relevant SPDES permit limits are also shown. The Laboratory monitors the STP discharge for more than 100 parameters monthly and more than 200 parameters quarterly. BNL's overall compliance with effluent limits was greater than 99 percent. In 2006, there were three excursions of the SPDES permit limits: two for total nitrogen and one for iron. Each of these excursions was investigated.

In August and September, effluent concentrations for total nitrogen were just above the Laboratory's SPDES limit of $10 \mathrm{ppm}$ with discharges of 10.8 and 10.5 , respectively. The slight increase in nitrogen levels was attributed to ineffective denitrification of the effluent by the biological organisms during treatment due to limited nutrients in the waste. To increase the nutrient load to the secondary treatment process, the primary clarifier was bypassed and the raw influent was directed into the modular aeration system. Based on data for October through December, the change in operation appeared to resolve the problem. In September, iron was detected in a single sample. Sporadic iron excursions are typically associated with increased 
Table 3-3. Analytical Results for Wastewater Discharges to Sewage Treatment Plant Outfall 001.

\begin{tabular}{|c|c|c|c|c|c|c|}
\hline Analyte & Low Report & $\begin{array}{l}\text { High } \\
\text { Report }\end{array}$ & Min. Monitoring. Freq. & $\begin{array}{l}\text { SPDES } \\
\text { Limit }\end{array}$ & Exceedances & $\begin{array}{c}\% \\
\text { Compliance* }\end{array}$ \\
\hline Max. temperature $\left({ }^{\circ} \mathrm{F}\right)$ & 52 & 81 & Daily & 90 & 0 & 100 \\
\hline $\mathrm{pH}(\mathrm{SU})$ & 6.0 & 7.4 & Continuous Recorder & Min. 5.8 & 0 & 100 \\
\hline Avg. 5-day BOD (mg/L) & $<1$ & $<1$ & Twice Monthly & 10 & 0 & 100 \\
\hline Max. 5-day BOD (mg/L) & $<2$ & $<2$ & Twice Monthly & 20 & 0 & 100 \\
\hline$\%$ BOD removal & $>93$ & $>99$ & Monthly & 85 & 0 & 100 \\
\hline Avg. TSS (mg/L) & $<0.3$ & $<1.0$ & Twice Monthly & 10 & 0 & 100 \\
\hline Max. TSS (mg/L) & $<0.6$ & $<2.9$ & Twice Monthly & 20 & 0 & 100 \\
\hline$\%$ TSS removal & $>96$ & $>99$ & Monthly & 85 & 0 & 100 \\
\hline Settleable solids (ml/L) & 0.0 & 0.0 & Daily & 0.1 & 0 & 100 \\
\hline Ammonia nitrogen (mg/L) & $<0.10$ & $2.2(\mathrm{a})$ & Twice Monthly & 2 & 0 & 100 \\
\hline Total nitrogen (mg/L) & 2.6 & $10.8(b)$ & Twice Monthly & 10 & 2 & 93 \\
\hline Total phosphorus (mg/L) & 0.8 & 1.6 & Twice Monthly & NA & 0 & 100 \\
\hline Cyanide $(\mu \mathrm{g} / \mathrm{L})$ & $<1.5$ & 3.1 & Twice Monthly & 100 & 0 & 100 \\
\hline Copper (mg/L) & 0.02 & 0.09 & Twice Monthly & 0.15 & 0 & 100 \\
\hline Iron (mg/L) & 0.11 & $0.45(c)$ & Twice Monthly & 0.37 & 1 & 96 \\
\hline Lead (mg/L) & $<0.001$ & 0.003 & Twice Monthly & 0.019 & 0 & 100 \\
\hline Nickel (mg/L) & 0.007 & 0.024 & Twice Monthly & 0.11 & 0 & 100 \\
\hline Silver (mg/L) & $<0.001$ & 0.003 & Twice Monthly & 0.015 & 0 & 100 \\
\hline Zinc (mg/L) & 0.021 & 0.09 & Twice Monthly & 0.1 & 1 & 100 \\
\hline Mercury (mg/L) & $<0.00005$ & 0.0002 & Twice Monthly & 0.0008 & 0 & 100 \\
\hline Toluene $(\mu \mathrm{g} / \mathrm{L}$ & $<1.0$ & $<1.0$ & Twice Monthly & 5 & 0 & 100 \\
\hline Methylene chloride ( $\mu \mathrm{g} / \mathrm{L})$ & $<2.00$ & $<2.0$ & Twice Monthly & 5 & 1 & 100 \\
\hline 1,1,1-trichloroethane ( $\mu \mathrm{g} / \mathrm{L})$ & $<1.0$ & $<1.0$ & Twice Monthly & 5 & 0 & 100 \\
\hline 2-butanone ( $\mu \mathrm{g} / \mathrm{L})$ & $<5.0$ & $<5.0$ & Twice Monthly & 50 & 0 & 100 \\
\hline PCBs $(\mu g / L)$ & $<0.0565$ & $<0.056$ & Quarterly & NA & 0 & 100 \\
\hline Max. flow (MGD) & 0.24 & 0.56 & Continuous Recorder & 2.3 & 0 & 100 \\
\hline Avg. flow (MGD) & 0.20 & 0.41 & Continuous Recorder & NA & 0 & 100 \\
\hline Avg. fecal coliform (MPN/100 mL) & $<1$ & 10.7 & Twice Monthly & 200 & 0 & 100 \\
\hline Max. fecal coliform (MPN/100 mL) & $<2$ & $<30$ & Twice Monthly & 400 & 0 & 100 \\
\hline \multicolumn{3}{|c|}{$\begin{array}{l}\text { Notes: } \\
\text { See Chapter } 5 \text {, Figure } 5-6 \text { for location of Outfall } 001 \text {. } \\
\text { *\% Compliance = total no. samples }- \text { total no. exceedances/total no. of } \\
\text { samples } \times 100 \\
\text { BOD = Biological Oxygen Demand } \\
\text { MGD = Million Gallons per Day } \\
\text { MPN = Most Probable Number } \\
\text { NA = Not Applicable } \\
\text { SU = Standard Unit } \\
\text { TSS = Total Suspended Solids }\end{array}$} & \multicolumn{4}{|c|}{$\begin{array}{l}\text { (a) Although one sample had an ammonia concentration of } 2.2 \mathrm{mg} / \mathrm{L} \text {, a violation } \\
\text { was not reported, due to mathematical rounding. } \\
\text { (b) Two permit exceedances of the total nitrogen limits were reported, one in Augus } \\
\text { and one in September. } \\
\text { (c) A single sample collected in September exhibited an iron concentration of } 0.45 \\
\text { ppm, which exceeded the permit limit of } 0.37 \mathrm{ppm} \text {. } \\
\text { Please refer to Section } 3.6 .1 \text { for explanations of these permit exceedances. }\end{array}$} \\
\hline
\end{tabular}

sediment in the discharge caused by surface runoff during rain events. Figures 3-1 through 3-7 plot 5-year trends for the monthly concentrations of copper, iron, lead, mercury, nickel, silver, and zinc in the STP discharge.

\subsubsection{Chronic Toxicity Testing}

The Laboratory's SPDES permit requires that "whole effluent toxicity" (WET) tests be conducted to ensure that chemicals present in the STP effluent are not toxic to aquatic organisms. 
Figure 3-I. Maximum Concentrations of Copper Discharged from the BNL Sewage Treatment Plant, 2002-2006.

Figure 3-2. Maximum Concentrations of Iron Discharged from the BNL Sewage Treatment Plant, 2002-2006.

Figure 3-3. Maximum Concentrations of Lead Discharged from the BNL Sewage Treatment Plant, 2002-2006.
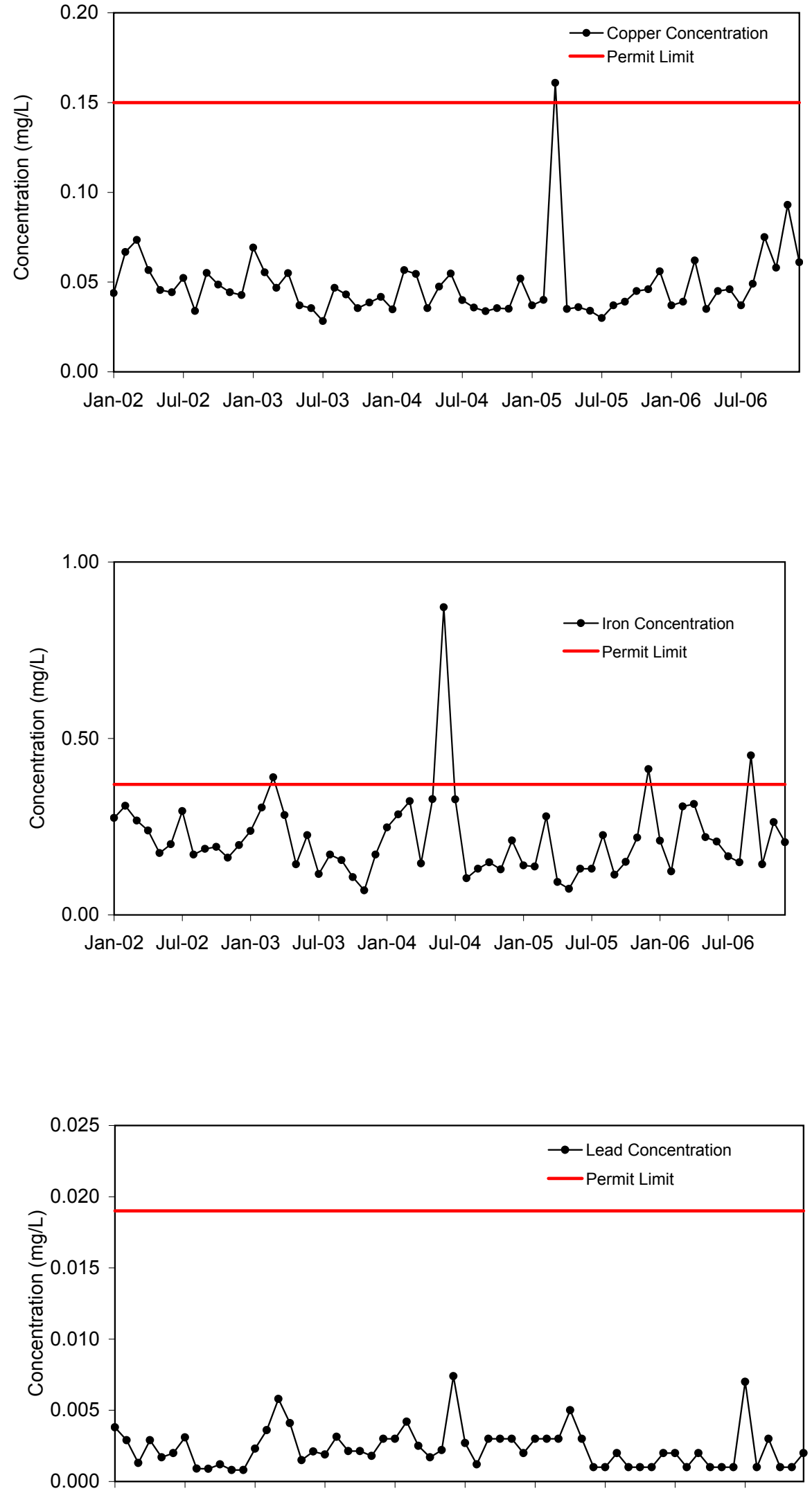

Jan-02 Jul-02 Jan-03 Jul-03 Jan-04 Jul-04 Jan-05 Jul-05 Jan-06 Jul-06 


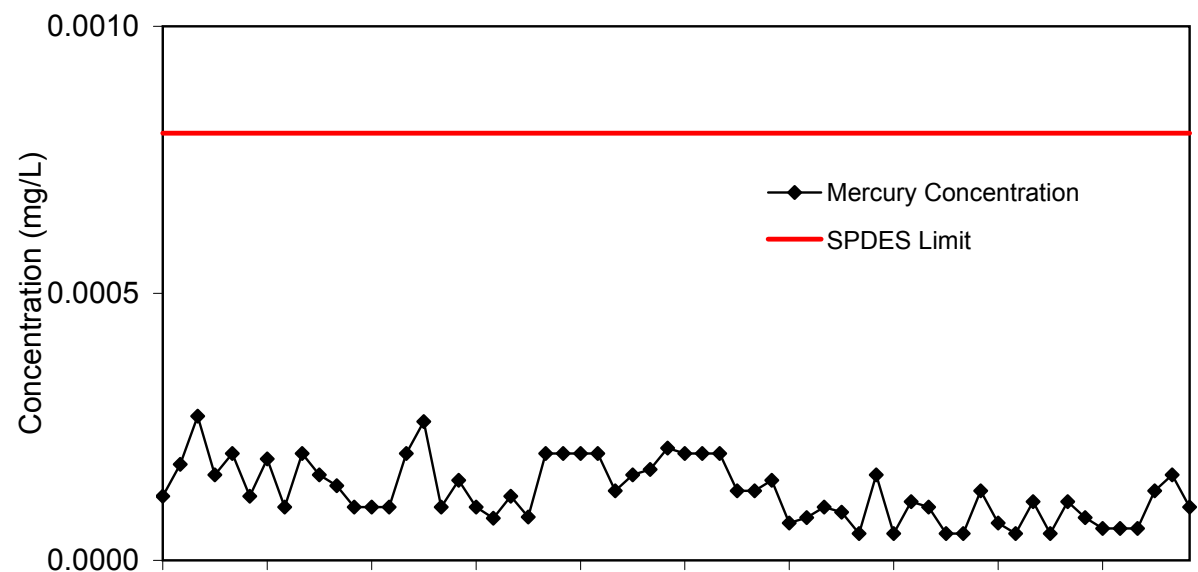

Jan-02 Jul-02 Jan-03 Jul-03 Jan-04 Jul-04 Jan-05 Jul-05 Jan-06 Jul-06

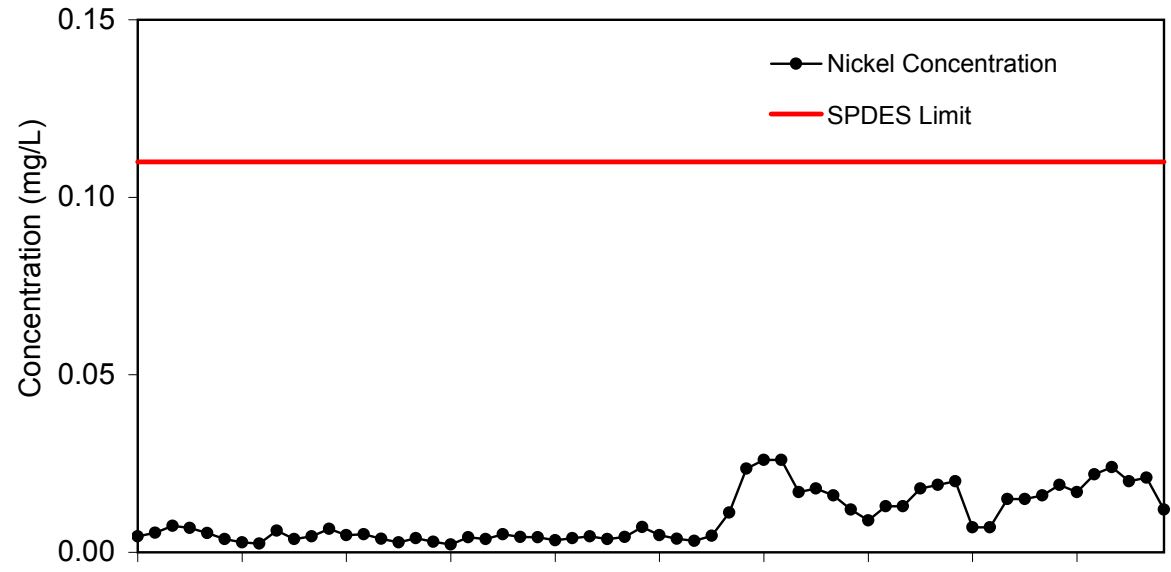

Jan-02 Jul-02 Jan-03 Jul-03 Jan-04 Jul-04 Jan-05 Jul-05 Jan-06 Jul-06

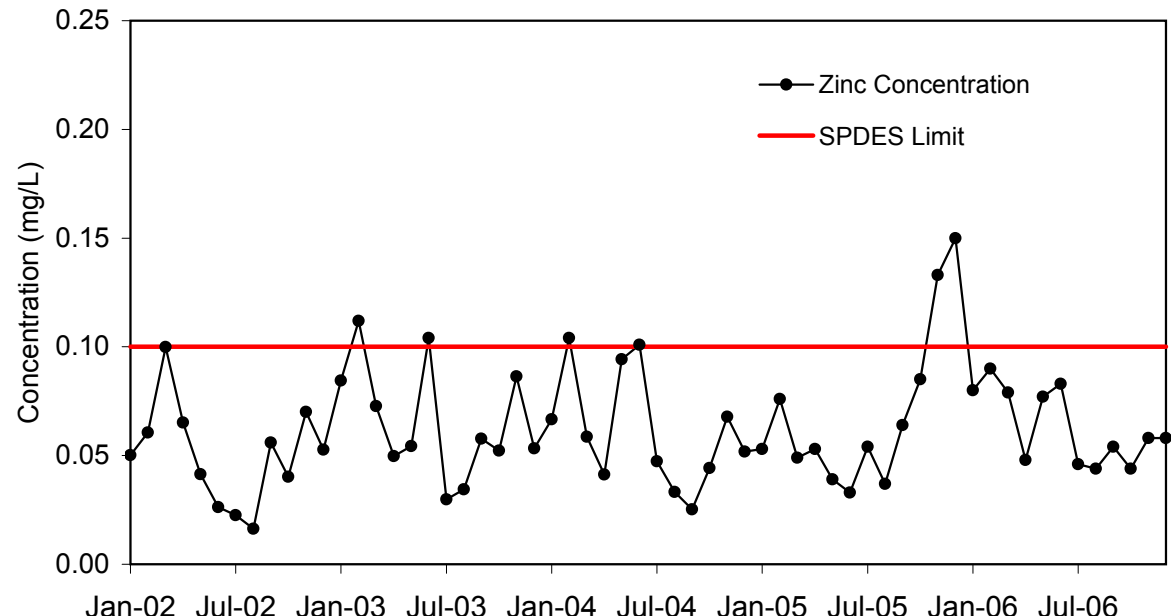

Figure 3-4. Maximum Concentrations of Mercury Discharged from the BNL Sewage Treatment Plant, 2002-2006.
Figure 3-5. Maximum Concentrations of Nickel Discharged from the BNL Sewage Treatment Plant, 2002-2006.

Figure 3-6. Maximum Concentrations of Silver Discharged from the BNL Sewage Treatment Plant, 2002-2006. 
Note:

Per New York State Department of Environmental Conservation guidance, the concentration of zinc exhibited in the effluent during February and June of 2003 and 2004 and November 2005 was not considered in violation of the State Pollutant Discharge Elimination System effluent limit of 0.1 $\mathrm{mg} / \mathrm{L}$, due to rounding off of significant figures.

Figure 3-7. Maximum Concentrations of Zinc Discharged from the BNL Sewage Treatment Plant, 2002-2006.

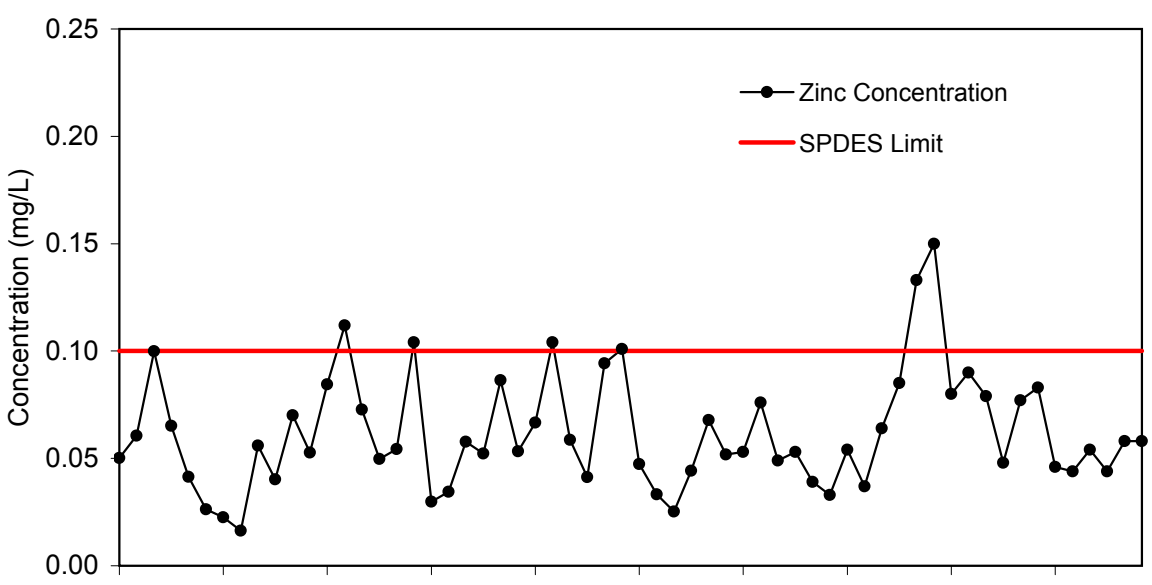

Jan-02 Jul-02 Jan-03 Jul-03 Jan-04 Jul-04 Jan-05 Jul-05 Jan-06 Jul-06
BNL's chronic toxicity testing program began in 1993 and continued through 2003. Toxicity testing was postponed in 2004, but was restarted in March 2005 as stipulated in the 2005 SPDES permit renewal. Under the WET testing provisions, samples are collected and tested quarterly. The program consists of 7-day chronic toxicity testing on two freshwater organisms, water fleas and fathead minnows. In each test, sets of 10 of these organisms are exposed to varying concentrations of the STP effluent $(100,50,25,12.5$, and 6.25 percent) for 7 days. During testing, the growth rate of the fish and rate of reproduction for the water flea are measured and compared to untreated organisms (i.e., controls). The test results are submitted to NYSDEC for review.

Since tests conducted in 2005 were inconclusive to determine the toxic effects on freshwater organisms, testing was continued in 2006. To evaluate the role of additional calcium in the potable water system, testing continued in 2006 using potable water from the Water Treatment Plant as a dilution water and control source. Tests were performed in March, June, September, and December. Minnows exhibited no acute or chronic toxicity in all tests conducted in 2006. For the water flea, minor impacts on reproduction rates were observed in one of the four tests conducted (June). Because the observed impacts were minor (only evident in one of the four test concentrations tested), no further toxicity reduction was required. Testing will continue in 2007.

\subsubsection{Recharge Basins and Stormwater}

Water discharged to Outfalls 002 through 008 and Outfalls 010 through 012 recharges to groundwater, replenishing the underlying aquifer. Monitoring requirements for each of these discharges vary, depending on the type of wastewater received and the type of cooling water treatment reagents used. Table 3-4 summarizes the monitoring requirements and performance results for 2006. Due to quality control problems at the contract analytical laboratory, sample results were not available for January 2006, resulting in a deviation for Outfall 002B (non-report of data). During the analysis, a quality control sample failed to meet expected performance criteria; consequently all results for samples analyzed as part of this batch were rejected. To mitigate future problems of this nature, additional sample volume is being collected during sample collection periods.

\subsection{SAFE DRINKING WATER ACT}

The extraction and distribution of drinking water is regulated under the federal Safe Drinking Water Act (SDWA). In New York State, implementation of the SDWA is delegated to the New York State Department of Health (NYSDOH) and administered locally by SCDHS. Because BNL provides potable water to "more than 25 full-time residents," it is subject to the same requirements as a municipal water supplier. Monitoring requirements are prescribed annually by SCDHS, and a Potable 


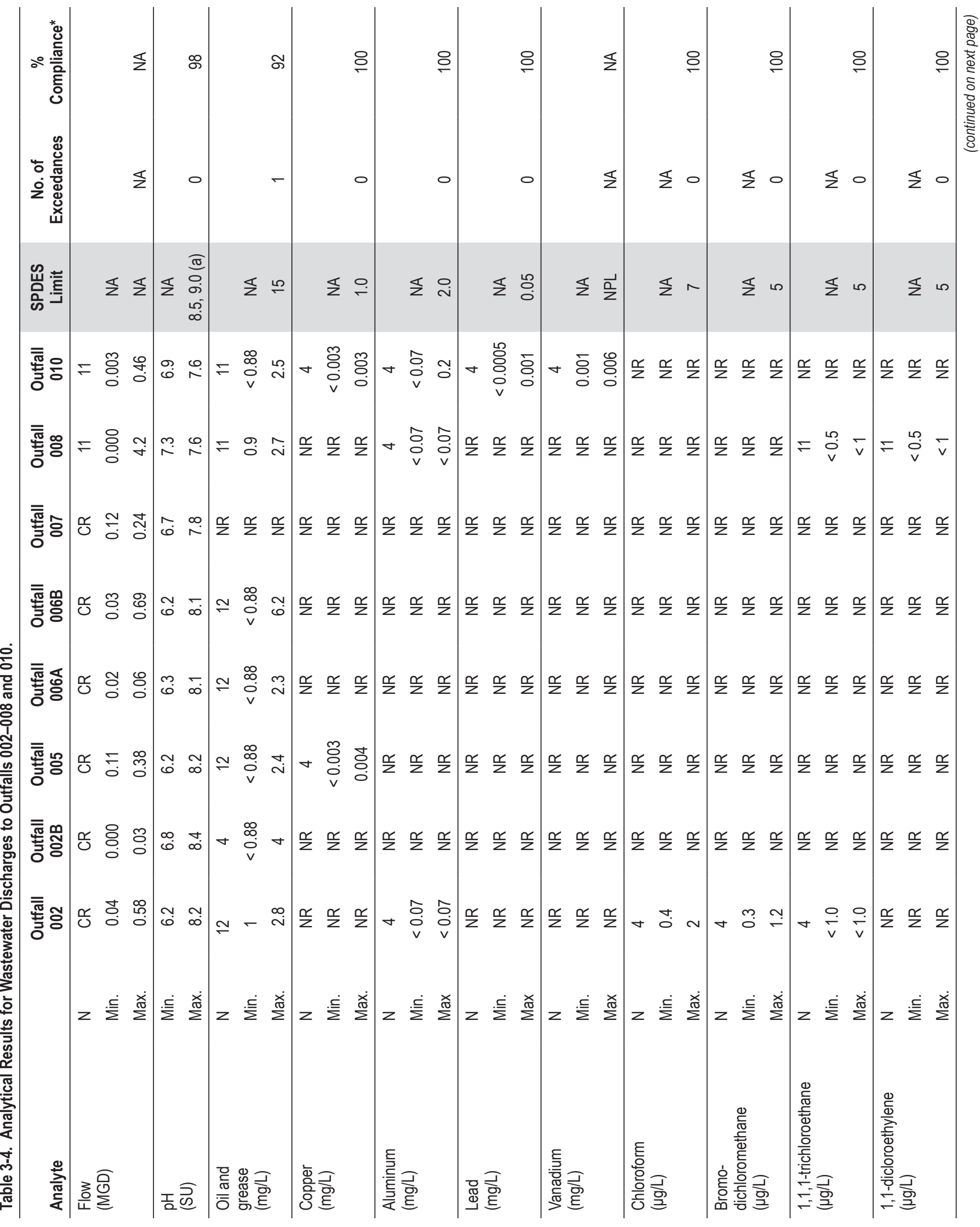




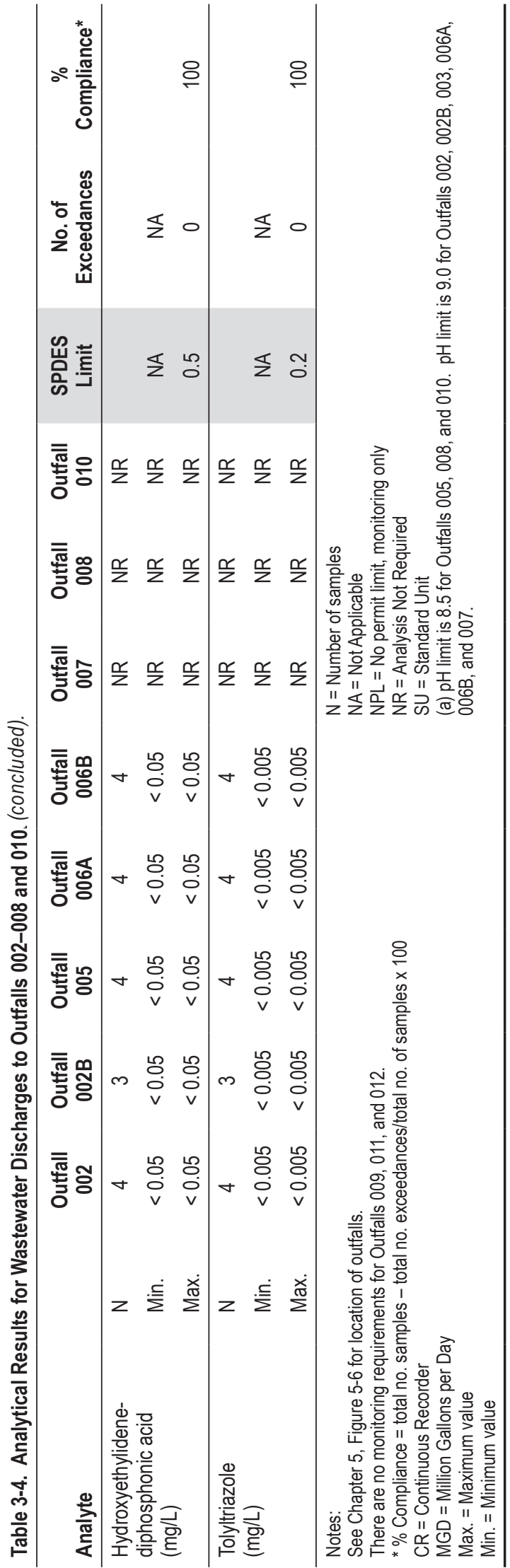

Water Sampling and Analysis Plan (Chaloupka 2006) is prepared by BNL to comply with these requirements.

\subsection{Potable Water}

The Laboratory maintains six water supply wells for on-site distribution of potable water. As required by NYSDOH regulations, BNL monitors the potable wells regularly for bacteria, inorganics, organics, and pesticides. The Laboratory also voluntarily monitors drinking water supplies for radiological contaminants yearly. Tables 3-5 and 3-6 provide the potable water supply monitoring data for 2006. In 2006, only iron exceeded New York State Drinking Water Standards (NYS DWS) in samples collected from two of the wells (wells 6 and 7) before distribution. Groundwater from three of the six wells is treated to reduce naturally occurring iron. Treatment at the Water Treatment Plant effectively reduces these levels to below DWS limits. To ensure that BNL's water supply continually meets NYS DWS, groundwater is also treated with activated carbon or air stripping to remove volatile organic compounds (VOCs). At the point of consumption, drinking water complied with all DWS during 2006.

Chapter 7 provides additional data on environmental surveillance tests performed on potable wells. This additional testing goes beyond the minimum SDWA testing requirements.

\subsubsection{Cross-Connection Control}

The SDWA requires that public water suppliers implement practices to protect the water supply from sanitary hazards. One of the safety requirements is to rigorously prevent crossconnections between the potable water supply and facility piping systems that may contain hazardous substances. Cross-connection control is the installation of control devices (e.g., double-check valves, reduced pressure zone valves, etc.) at the interface between a facility and the domestic water main. Cross-connection control devices are required at all facilities where hazardous materials are used in a manner that could result in their introduction into the domestic water system, especially under low-pressure conditions. In addition, secondary 
Table 3-5. Potable Water Wells and Potable Distribution System: Analytical Results (Maximum Concentration, Minimum pH Value).

\begin{tabular}{|c|c|c|c|c|c|c|c|c|}
\hline Compound & $\begin{array}{c}\text { Well } \\
\text { No. } 4\end{array}$ & $\begin{array}{c}\text { Well } \\
\text { No. } 6\end{array}$ & $\begin{array}{l}\text { Well } \\
\text { No. } 7\end{array}$ & $\begin{array}{c}\text { Well } \\
\text { No. } 10\end{array}$ & $\begin{array}{c}\text { Well } \\
\text { No. } 11\end{array}$ & $\begin{array}{c}\text { Well } \\
\text { No. } 12\end{array}$ & $\begin{array}{c}\text { Potable } \\
\text { Distribution } \\
\text { Sample }\end{array}$ & $\begin{array}{l}\text { NYS } \\
\text { DWS }\end{array}$ \\
\hline \multicolumn{9}{|l|}{ Water Quality Indicators } \\
\hline Total coliform & ND & ND & ND & ND & ND & ND & ND & Negative \\
\hline Color (units) & NA & 5 & 5 & $<5$ & $<5$ & $<5$ & $<5$ & 15 \\
\hline Odor (units) & NA & 0 & 0 & 0 & 0 & 0 & 0 & 3 \\
\hline Cyanide ( $\mu \mathrm{g} / \mathrm{L})$ & NA & $<10$ & $<10$ & $<10$ & $<10$ & $<10$ & $<10$ & SNS \\
\hline Conductivity ( $\mu \mathrm{mhos} / \mathrm{cm})$ & 118 & 168 & 189 & 152 & 199 & 221 & 168 & SNS \\
\hline Chlorides (mg/L) & NA & 26.5 & 23.1 & 15.4 & 18 & 21.6 & 31.4 & 250 \\
\hline Sulfates (mg/L) & NA & 9.4 & 10.4 & 6.2 & 8.6 & 10.2 & 9.7 & 250 \\
\hline Nitrates (mg/L) & NA & 0.2 & 0.24 & 0.35 & 0.27 & 0.43 & 0.29 & 10 \\
\hline Nitrites (mg/L) & NA & $<0.10$ & $<0.10$ & $<0.10$ & $<0.10$ & $<0.10$ & $<0.10$ & 1.0 \\
\hline Ammonia (mg/L) & NA & $<0.10$ & $<0.10$ & $<0.10$ & $<0.10$ & $<0.10$ & $<0.10$ & SNS \\
\hline pH (Standard Units) & 6.0 & 6.1 & 6.0 & 6.4 & 6.3 & 6.2 & 7.2 & SNS \\
\hline MBAS (mg/L) & NA & $<0.08$ & $<0.08$ & $<0.08$ & $<0.08$ & $<0.08$ & $<0.08$ & SNS \\
\hline \multicolumn{9}{|l|}{ Metals } \\
\hline Antimony $(\mu \mathrm{g} / \mathrm{L})$ & NA & $<5.90$ & $<5.90$ & $<5.90$ & $<5.90$ & $<5.90$ & $<5.90$ & 6.0 \\
\hline Arsenic $(\mu \mathrm{g} / \mathrm{L})$ & NA & $<3.00$ & $<3.00$ & $<3.00$ & $<3.00$ & $<3.00$ & $<3.00$ & 50 \\
\hline Barium (mg/L) & NA & $<0.2$ & $<0.2$ & $<0.2$ & $<0.2$ & $<0.2$ & $<0.2$ & 2.0 \\
\hline Beryllium ( $\mu \mathrm{g} / \mathrm{L})$ & NA & $<3.0$ & $<3.0$ & $<3.0$ & $<3.0$ & $<3.0$ & $<3.0$ & 4.0 \\
\hline Cadmium ( $\mu \mathrm{g} / \mathrm{L})$ & NA & $<5.0$ & $<5.0$ & $<5.0$ & $<5.0$ & $<5.0$ & $<5.0$ & 5.0 \\
\hline Chromium (mg/L) & NA & $<0.010$ & $<0.010$ & $<0.010$ & $<0.010$ & $<0.010$ & $<0.010$ & 0.1 \\
\hline Fluoride (mg/L) & NA & $<0.10$ & $<0.10$ & $<0.10$ & $<0.10$ & $<0.10$ & $<0.10$ & 2.2 \\
\hline Iron (mg/L) & NA & $3.77^{*}$ & $2.19^{*}$ & 0.024 & $<0.02$ & $<0.02$ & 0.124 & 0.3 \\
\hline Lead $(\mu \mathrm{g} / \mathrm{L})$ & NA & $<1.0$ & $<1.0$ & $<1.0$ & $<1.0$ & 1.72 & $<1.0$ & 15 \\
\hline Manganese (mg/L) & NA & 0.082 & 0.079 & $<0.010$ & $<0.010$ & $<0.010$ & 0.127 & 0.3 \\
\hline Mercury ( $\mu \mathrm{g} / \mathrm{L})$ & NA & $<0.20$ & $<0.20$ & $<0.20$ & $<0.20$ & $<0.20$ & $<0.20$ & 2.0 \\
\hline Nickel (mg/L) & NA & $<0.040$ & $<0.040$ & $<0.040$ & $<0.040$ & $<0.040$ & $<0.040$ & SNS \\
\hline Selenium $(\mu \mathrm{g} / \mathrm{L})$ & NA & $<5.00$ & $<5.00$ & $<5.00$ & $<5.00$ & $<5.00$ & $<5.00$ & 50.0 \\
\hline Sodium (mg/L) & NA & 14.0 & 14.6 & 10.1 & 12.1 & 14.1 & 17.5 & SNS \\
\hline Silver ( $\mu g / L)$ & NA & $<10$ & $<10$ & $<10$ & $<10$ & $<10$ & $<10$ & 100 \\
\hline Thallium ( $\mu \mathrm{g} / \mathrm{L})$ & NA & $<1.90$ & $<1.90$ & $<1.90$ & $<1.90$ & $<1.90$ & $<1.90$ & 2.0 \\
\hline Zinc (mg/L) & NA & $<0.020$ & $<0.020$ & $<0.020$ & $<0.020$ & $<0.020$ & 0.022 & 5.0 \\
\hline \multicolumn{9}{|l|}{ Radioactivity } \\
\hline Gross alpha activity (pCi/L) & $<1.07$ & $<1.2$ & $<1.7$ & $<0.88$ & $<1.94$ & $<1.7$ & $\mathrm{NR}$ & 15.0 \\
\hline Gross beta activity (pCi/L) & $1.69 \pm 0.44$ & $<2.65$ & $<2.54$ & $<0.64$ & $<3.33$ & $<2.69$ & NR & (a) \\
\hline
\end{tabular}


Table 3-5. Potable Water Wells and Potable Distribution System: Analytical Results (Maximum Concentration, Minimum pH Value)(concluded).

\begin{tabular}{|c|c|c|c|c|c|c|c|c|}
\hline Compound & $\begin{array}{l}\text { Well } \\
\text { No. } 4\end{array}$ & $\begin{array}{l}\text { Well } \\
\text { No. } 6\end{array}$ & $\begin{array}{l}\text { Well } \\
\text { No. } 7\end{array}$ & $\begin{array}{c}\text { Well } \\
\text { No. } 10\end{array}$ & $\begin{array}{c}\text { Well } \\
\text { No. } 11\end{array}$ & $\begin{array}{c}\text { Well } \\
\text { No. } 12\end{array}$ & $\begin{array}{c}\text { Potable } \\
\text { Distribution } \\
\text { Sample }\end{array}$ & $\begin{array}{l}\text { NYS } \\
\text { DWS }\end{array}$ \\
\hline Tritium (pCi/L) & $<547$ & $<653$ & $<553$ & $<544$ & $<549$ & $<554$ & NR & 20,000 \\
\hline Strontium-90 (pCi/L) & $<0.41$ & $<0.69$ & $<0.69$ & $<0.34$ & $<0.68$ & $<0.76$ & NR & 8.0 \\
\hline \multicolumn{9}{|l|}{ Other } \\
\hline $\begin{array}{l}\text { Asbestos } \\
\text { (M. fibers/L) }\end{array}$ & NR & NR & NR & NR & NR & NR & $<0.41$ & 7 \\
\hline Calcium (mg/L) & 4.3 & 5.3 & 5.9 & 5.9 & 5.5 & 8.2 & 8.6 & SNS \\
\hline Alkalinity (mg/L) & 4.8 & 10.6 & 13.6 & 20.1 & 15.6 & 20.9 & 54.4 & SNS \\
\hline Residual chlorine - MRDL (mg/L) & NR & NR & NR & NR & NR & NR & 0.6 & 4.0 \\
\hline TTHM (mg/L) & NR & NR & NR & NR & NR & NR & 0.013 & $0.08^{* *}$ \\
\hline HAA5 (mg/L) & NR & NR & NR & NR & NR & NR & $<0.002$ & $0.06^{* *}$ \\
\hline \multicolumn{4}{|c|}{$\begin{array}{l}\text { Notes: } \\
\text { See Figure } 7-3 \text { for well locations. } \\
\text { HAA5 = Five Haloacetic Acids } \\
\text { MBAS = Methylene Blue Active Substances } \\
\text { MRDL = Maximum Residual Disinfectant Level } \\
\text { NA = Not Analyzed due to well shutdown } \\
\text { ND = Not Detected } \\
\text { NR = Analysis Not Required } \\
\text { NYS DWS = New York State Drinking Water Standard } \\
\text { SNS = Drinking Water Standard Not Specified } \\
\text { TTHM = Total Trihalomethanes }\end{array}$} & \multicolumn{5}{|c|}{$\begin{array}{l}\text { * Water from these wells is treated at the Water Treatment Plant for color and } \\
\text { iron reduction prior to site distribution. } \\
\text { ** Limit imposed on distribution samples only. } \\
\text { (a) The drinking water standard was changed from } 50 \mathrm{pCi} / \mathrm{L} \text { (concentration based) } \\
\text { to } 4 \text { mrem/yr (dose based) in late } 2003 \text {. Because gross beta activity does not } \\
\text { identify specific radionuclides, a dose equivalent cannot be calculated. Since } \\
\text { there were no specific nuclides detected, compliance with the requirement is } \\
\text { demonstrated. }\end{array}$} \\
\hline
\end{tabular}

cross-connection controls at the point of use are recommended, to protect users within a specific facility from hazards that might be posed by intra-facility operations.

The Laboratory maintains approximately 200 cross-connection control devices at interfaces to the potable water main, and secondary control devices at the point of use. Approximately 160 cross-connection control units were tested at BNL in 2006, including primary and secondary devices. If a problem with a cross-connection device is encountered during testing, the device is repaired and retested to ensure proper function. Copies of the cross-connection device test reports are filed with the SCDHS annually.

\subsubsection{Underground Injection Control}

Underground Injection Control (UIC) wells are regulated under the SDWA. At the Laboratory, UICs include drywells, cesspools, septic tanks, and leaching pools, all of which are classified by EPA as Class V injection wells. Proper management of UIC devices is vital for protect- ing underground sources of drinking water. In New York State, the UIC program is implemented through EPA, because NYSDEC has not adopted UIC regulatory requirements. (Note: New York State regulates discharges of pollutants to cesspools under the SPDES program.) Under EPA's UIC program, all Class V injection wells must be included in an inventory maintained with the agency. In 2006, a single UIC that was not in BNL's original permit was found outside the north side of Building 912. Inspection of the cesspool showed it to be dry and apparently unused for many years. The cesspool was sampled and will be closed, assuming the analytical data show no impacts to underlying soils.

In addition to the UICs maintained for routine Laboratory discharges of sanitary waste and stormwater, UICs also are maintained at several on- and off-site treatment facilities used for groundwater remediation. Contaminated groundwater is treated and then returned to the aquifer via drywells, injection wells, or recharge basins. Discharges to these UICs are "autho- 
Table 3-6. Potable Water Wells: Analytical Results for Principal Organic Compounds, Synthetic Organic Chemicals, Pesticides, and Micro-Extractables.

\begin{tabular}{|c|c|c|c|c|c|c|c|c|}
\hline & $\begin{array}{l}\text { WTP } \\
\text { Effluent }\end{array}$ & $\begin{array}{l}\text { Well } \\
\text { No. } 4\end{array}$ & $\begin{array}{l}\text { Well } \\
\text { No. } 6\end{array}$ & $\begin{array}{l}\text { Well } \\
\text { No. } 7\end{array}$ & $\begin{array}{l}\text { Well } \\
\text { No. } 10\end{array}$ & $\begin{array}{l}\text { Well } \\
\text { No. } 11\end{array}$ & $\begin{array}{c}\text { Well } \\
\text { No. } 12\end{array}$ & $\begin{array}{l}\text { NYS } \\
\text { DWS }\end{array}$ \\
\hline Compound & & & & $-\mu \mathrm{g} / \mathrm{L}$ & & & & \\
\hline Dichlorodifluoromethane & $<M D L$ & $<M D L$ & $<M D L$ & $<M D L$ & $<M D L$ & $<M D L$ & $<M D L$ & 5 \\
\hline Chloromethane & $<\mathrm{MDL}$ & $<M D L$ & $<\mathrm{MDL}$ & $<M D L$ & $<M D L$ & $<M D L$ & $<M D L$ & 5 \\
\hline Vinyl Chloride & $<M D L$ & $<M D L$ & $<M D L$ & $<M D L$ & $<M D L$ & $<M D L$ & $<M D L$ & 2 \\
\hline Bromomethane & $<M D L$ & $<\mathrm{MDL}$ & $<\mathrm{MDL}$ & $<M D L$ & $<M D L$ & $<M D L$ & $<M D L$ & 5 \\
\hline Chloroethane & $<M D L$ & $<M D L$ & $<M D L$ & $<M D L$ & $<M D L$ & $<M D L$ & $<M D L$ & 5 \\
\hline Trichlorofluoromethane & $<M D L$ & $<M D L$ & $<\mathrm{MDL}$ & $<M D L$ & $<M D L$ & $<M D L$ & $<M D L$ & 5 \\
\hline 1,1-dichloroethene & $<M D L$ & $<M D L$ & $<M D L$ & $<M D L$ & $<M D L$ & $<M D L$ & $<M D L$ & 5 \\
\hline Methylene Chloride & $<\mathrm{MDL}$ & $<M D L$ & $<\mathrm{MDL}$ & $<M D L$ & $<M D L$ & $<M D L$ & $<M D L$ & 5 \\
\hline trans-1,2-dichloroethene & $<M D L$ & $<M D L$ & $<M D L$ & $<M D L$ & $<M D L$ & $<M D L$ & $<M D L$ & 5 \\
\hline 1,1-dichloroethane & $<M D L$ & $<\mathrm{MDL}$ & $<\mathrm{MDL}$ & $<M D L$ & $<M D L$ & $<M D L$ & $<M D L$ & 5 \\
\hline cis-1,2-dichloroethene & $<M D L$ & $<M D L$ & $<M D L$ & $<M D L$ & $<\mathrm{MDL}$ & $<M D L$ & $<M D L$ & 5 \\
\hline 2,2-dichloropropane & $<M D L$ & $<M D L$ & $<\mathrm{MDL}$ & $<M D L$ & $<M D L$ & $<M D L$ & $<M D L$ & 5 \\
\hline Bromochloromethane & $<M D L$ & $<M D L$ & $<M D L$ & $<\mathrm{MDL}$ & $<M D L$ & $<M D L$ & $<\mathrm{MDL}$ & 5 \\
\hline 1,1,1-trichloroethane & $<\mathrm{MDL}$ & $<M D L$ & $<\mathrm{MDL}$ & $<M D L$ & $<M D L$ & $<M D L$ & 0.74 & 5 \\
\hline Carbon Tetrachloride & $<M D L$ & $<M D L$ & $<M D L$ & $<M D L$ & $<M D L$ & $<M D L$ & $<M D L$ & 5 \\
\hline 1,1-dichloropropene & $<\mathrm{MDL}$ & $<M D L$ & $<\mathrm{MDL}$ & $<M D L$ & $<\mathrm{MDL}$ & $<M D L$ & $<M D L$ & 5 \\
\hline 1,2-dichloroethane & $<M D L$ & $<M D L$ & $<M D L$ & $<M D L$ & $<M D L$ & $<M D L$ & $<M D L$ & 5 \\
\hline Trichloroethene & $<\mathrm{MDL}$ & $<M D L$ & $<\mathrm{MDL}$ & $<M D L$ & $<M D L$ & $<M D L$ & $<M D L$ & 5 \\
\hline 1,2-dichloropropane & $<M D L$ & $<M D L$ & $<\mathrm{MDL}$ & $<M D L$ & $<M D L$ & $<M D L$ & $<M D L$ & 5 \\
\hline Dibromomethane & $<M D L$ & $<M D L$ & $<M D L$ & $<\mathrm{MDL}$ & $<M D L$ & $<M D L$ & $<M D L$ & 5 \\
\hline trans-1,3-dichloropropene & $<M D L$ & $<M D L$ & $<\mathrm{MDL}$ & $<M D L$ & $<M D L$ & $<M D L$ & $<M D L$ & 5 \\
\hline cis-1,3-dichloropropene & $<M D L$ & $<M D L$ & $<\mathrm{MDL}$ & $<M D L$ & $<\mathrm{MDL}$ & $<M D L$ & $<M D L$ & 5 \\
\hline 1,1,2-trichloroethane & $<M D L$ & $<M D L$ & $<\mathrm{MDL}$ & $<M D L$ & $<M D L$ & $<M D L$ & $<M D L$ & 5 \\
\hline 1,3-dichloropropane & $<\mathrm{MDL}$ & $<\mathrm{MDL}$ & $<\mathrm{MDL}$ & $<\mathrm{MDL}$ & $<M D L$ & $<\mathrm{MDL}$ & $<\mathrm{MDL}$ & 5 \\
\hline Chlorobenzene & $<M D L$ & $<M D L$ & $<\mathrm{MDL}$ & $<M D L$ & $<M D L$ & $<M D L$ & $<M D L$ & 5 \\
\hline 1,1,1,2-tetrachloroethane & $<\mathrm{MDL}$ & $<M D L$ & $<\mathrm{MDL}$ & $<\mathrm{MDL}$ & $<M D L$ & $<\mathrm{MDL}$ & $<\mathrm{MDL}$ & 5 \\
\hline Bromobenzene & $<M D L$ & $<M D L$ & $<\mathrm{MDL}$ & $<M D L$ & $<M D L$ & $<M D L$ & $<M D L$ & 5 \\
\hline 1,2,3-trichloropropane & $<M D L$ & $<M D L$ & $<\mathrm{MDL}$ & $<\mathrm{MDL}$ & $<M D L$ & $<M D L$ & $<M D L$ & 5 \\
\hline 2-chlorotoluene & $<M D L$ & $<M D L$ & $<\mathrm{MDL}$ & $<M D L$ & $<M D L$ & $<M D L$ & $<M D L$ & 5 \\
\hline 4-chlorotoluene & $<M D L$ & $<M D L$ & $<\mathrm{MDL}$ & $<M D L$ & $<M D L$ & $<M D L$ & $<M D L$ & 5 \\
\hline 1,3-dichlorobenzene & $<M D L$ & $<M D L$ & $<\mathrm{MDL}$ & $<M D L$ & $<M D L$ & $<M D L$ & $<M D L$ & 5 \\
\hline 1,4-dichlorobenzene & $<\mathrm{MDL}$ & $<M D L$ & $<M D L$ & $<\mathrm{MDL}$ & $<M D L$ & $<\mathrm{MDL}$ & $<\mathrm{MDL}$ & 5 \\
\hline 1,2-dichlorobenzene & $<M D L$ & $<M D L$ & $<\mathrm{MDL}$ & $<M D L$ & $<M D L$ & $<M D L$ & $<M D L$ & 5 \\
\hline 1,2,4-trichlorobenzene & $<\mathrm{MDL}$ & $<\mathrm{MDL}$ & $<\mathrm{MDL}$ & $<\mathrm{MDL}$ & $<\mathrm{MDL}$ & $<\mathrm{MDL}$ & $<\mathrm{MDL}$ & 5 \\
\hline Hexachlorobutadiene & $<\mathrm{MDL}$ & $<\mathrm{MDL}$ & $<\mathrm{MDL}$ & $<\mathrm{MDL}$ & $<\mathrm{MDL}$ & $<M D L$ & $<\mathrm{MDL}$ & 5 \\
\hline Tetrachloroethene & $<\mathrm{MDL}$ & $<\mathrm{MDL}$ & $<\mathrm{MDL}$ & $<\mathrm{MDL}$ & $<\mathrm{MDL}$ & $<\mathrm{MDL}$ & $<\mathrm{MDL}$ & 5 \\
\hline 1,1,2,2-Tetrachloroethane & $<M D L$ & $<M D L$ & $<\mathrm{MDL}$ & $<M D L$ & $<M D L$ & $<M D L$ & $<M D L$ & 5 \\
\hline 1,2,3-trichlorobenzene & $<M D L$ & $<M D L$ & $<M D L$ & $<M D L$ & $<M D L$ & $<M D L$ & $<M D L$ & 5 \\
\hline
\end{tabular}


Table 3-6. Potable Water Wells: Analytical Results for Principal Organic Compounds, Synthetic Organic Chemicals, Pesticides, and Micro-Extractables (continued).

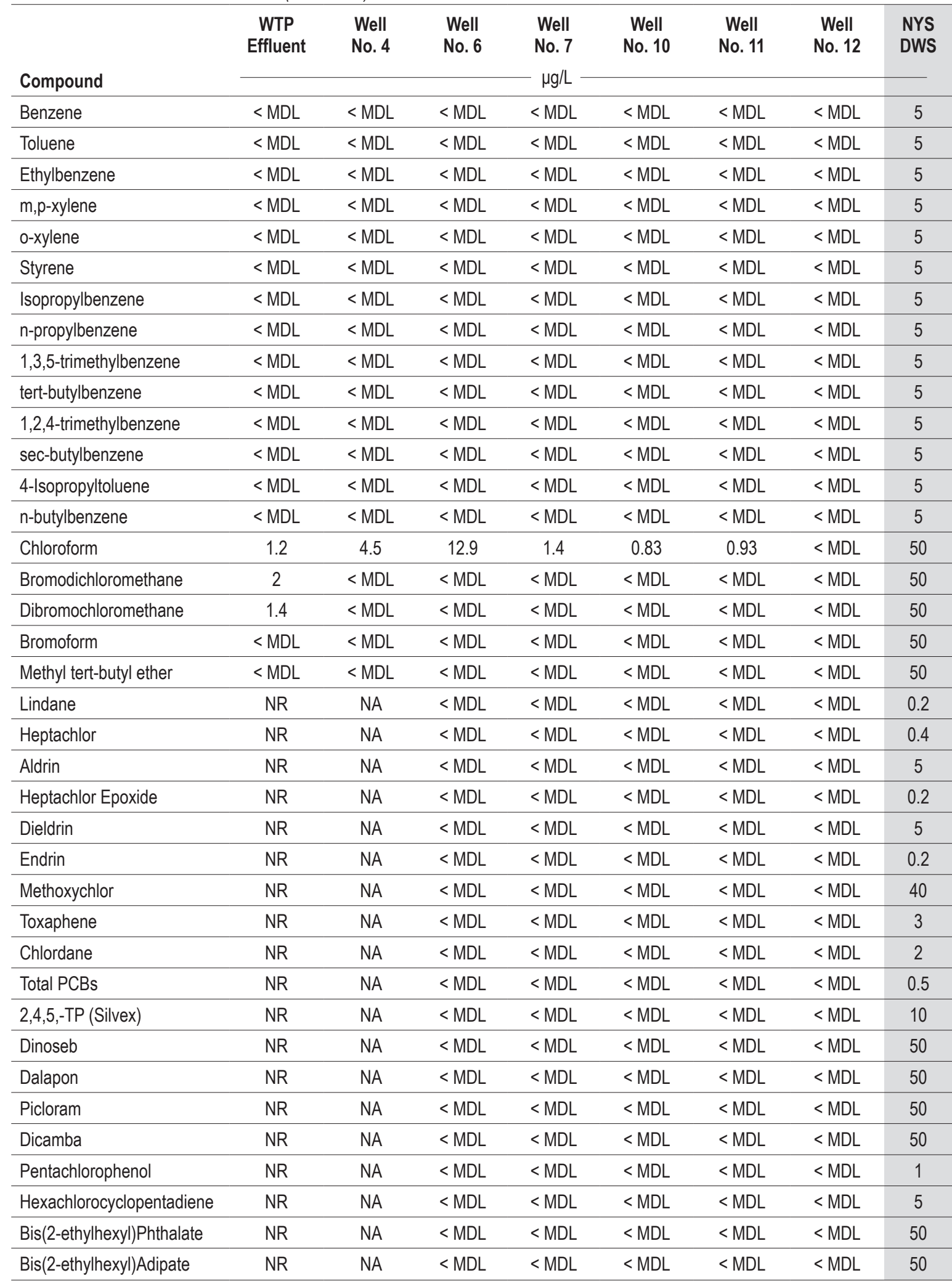


Table 3-6. Potable Water Wells: Analytical Results for Principal Organic Compounds, Synthetic Organic Chemicals, Pesticides, and Micro-Extractables (concluded).

\begin{tabular}{|c|c|c|c|c|c|c|c|c|}
\hline \multirow[b]{2}{*}{ Compound } & $\begin{array}{c}\text { WTP } \\
\text { Effluent }\end{array}$ & $\begin{array}{l}\text { Well } \\
\text { No. } 4\end{array}$ & $\begin{array}{l}\text { Well } \\
\text { No. } 6\end{array}$ & $\begin{array}{l}\text { Well } \\
\text { No. } 7\end{array}$ & $\begin{array}{l}\text { Well } \\
\text { No. } 10\end{array}$ & $\begin{array}{l}\text { Well } \\
\text { No. } 11\end{array}$ & $\begin{array}{c}\text { Well } \\
\text { No. } 12\end{array}$ & \multirow[t]{2}{*}{$\begin{array}{l}\text { NYS } \\
\text { DWS }\end{array}$} \\
\hline & \multicolumn{7}{|c|}{$-\mu g / L$} & \\
\hline Hexachlorobenzene & NR & NA & $<M D L$ & $<\mathrm{MDL}$ & $<M D L$ & $<M D L$ & $<M D L$ & 5 \\
\hline Benzo(A)Pyrene & NR & NA & $<\mathrm{MDL}$ & $<M D L$ & $<M D L$ & $<\mathrm{MDL}$ & $<M D L$ & 50 \\
\hline Aldicarb Sulfone & NR & NA & $<M D L$ & $<\mathrm{MDL}$ & $<\mathrm{MDL}$ & $<\mathrm{MDL}$ & $<M D L$ & SNS \\
\hline Aldicarb Sulfoxide & NR & NA & $<\mathrm{MDL}$ & $<\mathrm{MDL}$ & $<\mathrm{MDL}$ & $<\mathrm{MDL}$ & $<M D L$ & SNS \\
\hline Aldicarb & NR & NA & $<M D L$ & $<\mathrm{MDL}$ & $<\mathrm{MDL}$ & $<\mathrm{MDL}$ & $<\mathrm{MDL}$ & SNS \\
\hline Oxamyl & NR & NA & $<\mathrm{MDL}$ & $<\mathrm{MDL}$ & $<\mathrm{MDL}$ & $<\mathrm{MDL}$ & $<\mathrm{MDL}$ & 50 \\
\hline 3-Hydroxycarbofuran & NR & NA & $<\mathrm{MDL}$ & $<M D L$ & $<M D L$ & $<\mathrm{MDL}$ & $<M D L$ & 50 \\
\hline Carbofuran & NR & NA & $<M D L$ & $<\mathrm{MDL}$ & $<M D L$ & $<M D L$ & $<\mathrm{MDL}$ & 40 \\
\hline Carbaryl & NR & NA & $<\mathrm{MDL}$ & $<\mathrm{MDL}$ & $<\mathrm{MDL}$ & $<\mathrm{MDL}$ & $<\mathrm{MDL}$ & 50 \\
\hline Methomyl & NR & NA & $<\mathrm{MDL}$ & $<\mathrm{MDL}$ & $<\mathrm{MDL}$ & $<\mathrm{MDL}$ & $<M D L$ & 50 \\
\hline Glyphosate & NR & NA & $<\mathrm{MDL}$ & $<\mathrm{MDL}$ & $<M D L$ & $<M D L$ & $<M D L$ & 50 \\
\hline Diquat & NR & NA & $<\mathrm{MDL}$ & $<M D L$ & $<M D L$ & $<\mathrm{MDL}$ & $<M D L$ & 50 \\
\hline 1,2-dibromoethane (EDB) & NR & NA & $<\mathrm{MDL}$ & $<\mathrm{MDL}$ & $<M D L$ & $<\mathrm{MDL}$ & $<M D L$ & 0.05 \\
\hline $\begin{array}{l}\text { 1,2-dibromo-3- } \\
\text { chloropropane }\end{array}$ & NR & NA & $<\mathrm{MDL}$ & $<\mathrm{MDL}$ & $<M D L$ & $<M D L$ & $<M D L$ & 0.2 \\
\hline $2,4,-D$ & NR & NA & $<M D L$ & $<\mathrm{MDL}$ & $<M D L$ & $<M D L$ & $<M D L$ & 50 \\
\hline Alachlor & NR & NA & $<M D L$ & $<M D L$ & $<M D L$ & $<\mathrm{MDL}$ & $<M D L$ & 2 \\
\hline Simazine & NR & NA & $<\mathrm{MDL}$ & $<\mathrm{MDL}$ & $<M D L$ & $<M D L$ & $<M D L$ & 50 \\
\hline Atrazine & NR & NA & $<\mathrm{MDL}$ & $<M D L$ & $<M D L$ & $<M D L$ & $<M D L$ & 3 \\
\hline Metolachlor & NR & NA & $<M D L$ & $<M D L$ & $<M D L$ & $<\mathrm{MDL}$ & $<M D L$ & 50 \\
\hline Metribuzin & NR & NA & $<M D L$ & $<\mathrm{MDL}$ & $<M D L$ & $<\mathrm{MDL}$ & $<\mathrm{MDL}$ & 50 \\
\hline Butachlor & NR & NA & $<\mathrm{MDL}$ & $<\mathrm{MDL}$ & $<\mathrm{MDL}$ & $<\mathrm{MDL}$ & $<\mathrm{MDL}$ & 50 \\
\hline Endothall & NR & NA & $<\mathrm{MDL}$ & $<\mathrm{MDL}$ & $<M D L$ & $<M D L$ & $<M D L$ & 100 \\
\hline Propachlor & NR & NA & $<\mathrm{MDL}$ & $<\mathrm{MDL}$ & $<M D L$ & $<M D L$ & $<M D L$ & 50 \\
\hline \multicolumn{4}{|c|}{$\begin{array}{l}\text { See Chapter 7, Figure 7-3 for well locations. } \\
\text { For compliance determination with New York State Department of Health } \\
\text { standards, potable water samples were analyzed quarterly for principal } \\
\text { organic compounds and annually for other organics by H2M Labs Inc., a } \\
\text { New York State-certified contractor laboratory. } \\
\text { The minimum detection limits for principal organic compound analytes are } \\
0.5 \mu \mathrm{g} / \mathrm{L} \text {. Minimum detection limits for synthetic organic chemicals, and } \\
\text { micro-extractables are compound specific, and in all cases are less than } \\
\text { the New York State Department of Health drinking water standard. }\end{array}$} & \multicolumn{5}{|c|}{$\begin{array}{l}<\text { MDL = Less than the Minimum Detection Limit for the a } \\
\text { question } \\
\text { NA = Not available } \\
\text { NR = Analysis Not Required } \\
\text { SNS = Drinking Water Standard Not Specified } \\
\text { NYS DWS = New York State Drinking Water Standard } \\
\text { WTP = Water Treatment Plant }\end{array}$} \\
\hline
\end{tabular}

rized by rule" rather than by permit. Under the "authorized by rule" requirements, a separate inventory is maintained for these treatment facilities and periodically updated whenever a new device is added or closed.

\subsection{PREVENTING AND REPORTING SPILLS}

Federal, state, and local regulations are in place to address the management of storage facilities containing chemicals, petroleum, and other hazardous materials. The regulations include specifications for the design of storage facilities, requirements for written plans relating to unplanned releases, and requirements for reporting any releases that do occur. BNL's compliance with these regulations is described below. 


\subsection{Preventing Oil Pollution and Spills} As required by the Oil Pollution Act, BNL must maintain a Spill Prevention Control and Countermeasures (SPCC) Plan as a condition of its license to store petroleum fuel. The SPCC Plan is part of the Laboratory's emergency preparedness program and outlines mitigating and remedial actions that would be taken in the event of a major petroleum release. The plan also provides information regarding release prevention measures, the design of storage facilities, and maps detailing their locations. The SPCC Plan is filed with NYSDEC, EPA, and DOE, and was last updated in December 2000 (Chaloupka 2000). BNL remained in full compliance with the SPCC requirements in 2006.

In July 2002, EPA adopted significant changes to the SPCC regulations that extended the requirements to previously unregulated facilities and provided some relief to existing covered facilities. These changes, among others, included extending the plan update deadline from 3 to 5 years, and specifying that containers smaller than 55 gallons need not be counted toward reaching SPCC applicability. In February 2006, EPA extended the timeline for updating and implementing BNL's SPCC plan to incorporate these and other changes to October 2007, although the Laboratory is proceeding with updates to the plan and expects the changes to be completed before that date. Additional pending legislation may extend the deadline for updating the SPCC to 2009.

BNL also maintains a Facility Response Plan (FRP) (Lee 2006) that outlines emergency response procedures to be implemented in the event of a worst-case discharge of oil. In October 2005, EPA reviewed the Laboratory's FRP and responded with numerous comments. The FRP was revised in February 2006 to address EPA's comments. In July 2006, EPA conducted a site visit at BNL's request to review the changes and review the Laboratory's response procedures; the FRP was approved by EPA in September 2006 .

\subsubsection{Emergency Reporting Requirements}

The Emergency Planning and Community Right-to-Know Act (EPCRA) and Title III of the Superfund Amendments and Reauthorization Act (SARA) require that facilities report inventories (i.e., Tier II Report) and releases (i.e., Tier III Report) of certain chemicals that exceed specific release thresholds. These reports are submitted to the local emergency planning committee and the state emergency response commission. Community Rightto-Know requirements are codified under 40 CFR Parts 355, 370, and 372. Table 3-1 summarizes the applicability of the regulations to BNL. The Laboratory complied with these requirements in 2006 through the submittal of reports under EPCRA Sections 302, 303, 311 , and 312. In 2006, through the Tier III report, BNL reported releases of lead $(\sim 84,750$ pounds), mercury ( $\sim 101$ pounds), PCBs ( $\sim 93$ pounds), benzo(g,h,i)perylene ( $<1$ pound), and polycyclic aromatic compounds ( $<1$ pound). "Releases" of lead, PCBs, and mercury were predominantly in the form of shipments of waste for off-site recycling or disposal. Releases of benzo(g,h,i)perylene and polycyclic aromatic compounds were as byproducts of the combustion of fuel oils. In 2006, there were no releases of "extremely hazardous substances" that are reportable under Part 304.

\subsubsection{Spills and Releases}

When a spill of hazardous material occurs, Laboratory and contractor personnel are required to immediately notify the on-site Fire Rescue Group, whose members are trained to

\begin{tabular}{|l|l|c|c|c|}
\hline \multicolumn{5}{|c|}{ Applicability of EPCRA to BNL } \\
\hline EPCRA 302-303 & Planning Notification & YES [X] & NO [ ] & NOT REQUIRED [ ] \\
\hline EPCRA 304 & EHS Release Notification & YES [ ] & NO [ ] & NOT REQUIRED [X] \\
\hline EPCRA 3II-3I2 & MSDS/Chemical Inventory & YES [X] & NO [ ] & NOT REQUIRED [ ] \\
\hline EPCRA 3।3 & TRI Reporting & YES [X] & NO [ ] & NOT REQUIRED [ ] \\
\hline
\end{tabular}


respond to such releases. The initial step in spill response is to contain and control any release and to notify additional response personnel (i.e., BNL environmental professionals, industrial hygienists, etc.). Environmental professionals reporting to the scene assess the spill for environmental impact and determine if it is reportable to regulatory agencies. Any release of petroleum products to soil must be reported to both NYSDEC and SCDHS, and any release impacting surface water must also be reported to the EPA National Response Center. In addition, a release of more than 5 gallons of petroleum product to impermeable surfaces or containment areas must be reported to NYSDEC and SCDHS. Spills of chemicals in quantities greater than the CERCLA-reportable limits must be reported to the EPA National Response Center, NYSDEC, and SCDHS. Remediation of the spill is conducted, as necessary, to prevent impacts to the environment, minimize human health exposures, and restore the site.

During 2006, there were 27 spills, seven of which met regulatory agency reporting criteria. The remaining 20 spills were small-volume releases either to containment areas or to other impermeable surfaces that did not exceed a reportable quantity. Four of the seven reported releases involved very small volumes $(<2$ gallons) of ethylene glycol spilled from employeeor Laboratory-owned vehicles. Two releases

Table 3-7. Summary of Chemical and Oil Spill Reports.

\begin{tabular}{|c|c|c|c|}
\hline $\begin{array}{l}\text { Spill No. } \\
\text { and Date }\end{array}$ & $\begin{array}{l}\text { Material and } \\
\text { Quantity }\end{array}$ & $\begin{array}{l}\text { ORPS } \\
\text { Report }\end{array}$ & Source/Cause and Corrective Actions \\
\hline $\begin{array}{l}06-09 \\
07 / 18 / 06\end{array}$ & $\begin{array}{l}\text { ethylene } \\
\text { glycol/water } \\
1 \text { gallon }\end{array}$ & No & $\begin{array}{l}\text { A Laboratory visitor was at the main gate trailer when the radiator in his vehicle failed, spilling approxi- } \\
\text { mately } 1 \text { gallon of antifreeze to the asphalt parking lot. Roads and Grounds personnel responded and } \\
\text { cleaned up the release with speedy dry, and containerized the waste for off-site disposal. }\end{array}$ \\
\hline $\begin{array}{l}06-10 \\
07 / 19 / 06\end{array}$ & $\begin{array}{l}\text { hydraulic fluid } \\
1 \text { gallon }\end{array}$ & No & $\begin{array}{l}\text { A front-end loader was being used to move a fallen tree off the north gate access road. As it was pushing } \\
\text { the tree off the road, a branch ripped the hydraulic hose, releasing approximately } 1 \text { gallon of hydraulic } \\
\text { fluid to the ground. The majority of the fluid leaked onto the road, but approximately } 1 \text { quart reached soil. } \\
\text { Emergency Services applied speedy dry, Security closed off the road (at William Floyd Parkway), and } \\
\text { Roads and Grounds staff cleaned up and containerized the spill debris for off-site disposal. }\end{array}$ \\
\hline $\begin{array}{l}06-15 \\
09 / 06 / 06\end{array}$ & $\begin{array}{l}\text { ethylene } \\
\text { glycol/water } \\
2 \text { gallons }\end{array}$ & No & $\begin{array}{l}\text { During grading and application of recycled concrete aggregate on a dirt road (east of Buildings } 610 \text { and } \\
\text { 528), a hose clamp broke on the dump truck radiator, causing the hose to come loose and spill approxi- } \\
\text { mately } 2 \text { gallons of antifreeze to the ground. Roads and Ground personnel excavated and containerized } \\
\text { the impacted soil for off-site disposal. }\end{array}$ \\
\hline $\begin{array}{l}06-17 \\
09 / 22 / 06\end{array}$ & $\begin{array}{l}\text { diesel fuel } \\
1 / 2 \text { gallon }\end{array}$ & No & $\begin{array}{l}\text { A fuel line leak from BNL's Fire Brush truck occurred while Emergency Services personnel were prac- } \\
\text { ticing the use of equipment (the Brush Truck). Release was to sand. Emergency Services personnel } \\
\text { removed most of affected sand and Roads and Grounds cleaned up residual material that was stained. } \\
\text { The contaminated soil was placed into a plastic drum (10-gal) for off-site disposal. }\end{array}$ \\
\hline $\begin{array}{l}06-21 \\
09 / 27 / 06\end{array}$ & $\begin{array}{l}\text { ethylene } \\
\text { glycol/water } \\
1 \text { gallon }\end{array}$ & No & $\begin{array}{l}\text { Upon exiting the vehicle, the driver of a BNL step van noticed it was leaking antifreeze and notified ap- } \\
\text { propriate staff. Fire Rescue responded and applied speedy dry. The vehicle was towed away, and the } \\
\text { material was containerized for off-site disposal. }\end{array}$ \\
\hline $\begin{array}{l}06-24 \\
10 / 26 / 06\end{array}$ & $\begin{array}{l}\text { hydraulic fluid } \\
1 / 2 \text { gallon }\end{array}$ & No & $\begin{array}{l}\text { A tractor trailer being used to transport excavated soils for off-site disposal experienced a small leak of } \\
\text { hydraulic fluid while dumping some of its payload on the ground. The prime contractor for the excavation } \\
\text { project had spill equipment handy (i.e., absorbent pads) and was able to capture most of the leak. Some } \\
\text { of the hydraulic fluid was released to the soil on the dirt road. The contractor's front-end loader was used } \\
\text { to immediately clean up the impacted area and the material was placed on plastic for ultimate disposal. } \\
\text { The impacted soil and absorbent pads ( } 1 / 2 \text { drum) were containerized and disposed of off-site. }\end{array}$ \\
\hline $\begin{array}{l}06-25 \\
11 / 20 / 06\end{array}$ & $\begin{array}{l}\text { ethylene } \\
\text { glycol/water } \\
2 \text { gallons }\end{array}$ & No & $\begin{array}{l}\text { An unknown vehicle developed a leak of ethylene glycol after entering the site. The vehicle started leak- } \\
\text { ing at the traffic light at Upton Road and Princeton Avenue, traveled to the Vehicle Monitoring Station } \\
\text { turnaround area, turned around, and then left the site. BNL Fire Rescue personnel applied speedy dry to } \\
\text { the spill and Roads and Grounds containerized the material for off-site disposal. }\end{array}$ \\
\hline \multicolumn{4}{|l|}{ Note: } \\
\hline & & & cessing System (ORPS) established by the requirements of DOE Order $231.1 \mathrm{~A}$ \\
\hline
\end{tabular}


were from hydraulic systems on earth-moving equipment. In both cases the releases were 1 gallon or less, but because they reached the soil they were reportable in New York State, which has a "zero tolerance" level for releases of petroleum products to soil or water. There was one spill of diesel fuel, less than a half gallon, from a Fire/Rescue off-road vehicle, during a field exercise. Table 3-7 summarizes each of the reportable incidents, including a description of the cause and corrective actions taken. There were no spills reportable through the DOE Occurrence Reporting and Processing System (ORPS), a system for identifying, categorizing, notifying, investigating, analyzing, and reporting to DOE events or conditions discovered on site.

The Laboratory has been very successful in reducing the number and severity of spills on site. In 2006, the total number of spills was reduced by 21 percent, from 34 spills in 2005 to 27 in 2006. Reportable spills were reduced by 50 percent, from 14 in 2005 to 7 in 2006 . Measures employed to achieve this reduction included: replacing petroleum-based lubricants and fluids with vegetable-based products, installing stainless steel-reinforced hydraulic lines on various pieces of equipment, and training staff in proper spill-response techniques.

\section{Table 3-8. Summary of Other Environmental Occurrence Reports.}

ORPS* ID: SC-BHSO-BNL-BNL-2006-0003

A Potentially Inadequate Safety Evaluation (PISA) was noted for several ventilation stacks serving the Radioactive Waste Storage and Handling Facility that were found to be corroding. While there was no threat of release, the PISA was issued due to the degraded stacks. All stacks have been repaired.

ORPS* ID: SC-BHSO-BNL-BNL-2006-0007

During a routine radiological contamination control survey of a Radioactive Material Area, tritium contamination was discovered. The maximum level of contamination was $209,000 \mathrm{dpm}$. The contaminated areas were covered with plastic to prevent the spread of contamination, and the floor tiles were removed and replaced. All corrective actions have been completed.

ORPS* ID: SC-BHSO-BNL-BNL-2006-0012

A dumpster containing debris collected from the High Flux Beam Reactor activated the radiation alarm at the Laboratory's vehicle monitor. An external survey identified the source as a small piece of metal, approximately $0.2 \mathrm{sq}$. in. that registered 5 $\mathrm{mrem} / \mathrm{hour}$. The activated metal was recovered.

ORPS* ID: SC-BHSO-BNL-BNL-2006-0016

While exiting a Controlled Area at the Brookhaven Graphite Research Reactor, a staff member alarmed the personnel contamination monitor. Upon investigation, a small area of contamination was found on the heel of the worker's shoe. Examination of the worker's footpath showed some loose contamination on a hallway mat and several areas of fixed contamination. There was no other loose contamination discovered, and a survey of staff shoes showed all to be clean.

\section{ORPS ID: SC-BHSO-BNL-PE-2006-0003}

A Notice of Violation (NOV) was issued on May 16, 2006 by the New York State Department of Conservation for opacity violations that were self-reported for the Central Steam facility. The NOV cites a period of non-compliance beginning on April 1, 2005 and ending on September 30, 2005. The cause was routine soot blowing performed at the Central Steam Facility to maintain boiler efficiency. Reprogramming of the soot blowers has resolved the issue. There have been no opacity excursions reported since August 2005.

\section{ORPS ID: SC-BHSO-BNL-NSLS-2006-0001}

Although the release of 1 liter of acetonitrile did not exceed a reportable quantity, management concern over exposures to staff cleaning up the release and potential release to the sanitary sewer necessitated this report. Evaluation of this incident showed that staff was not exposed and there was a small release to the BNL sanitary sewer. Diversion of the plant effluent precluded a release to the Peconic River. All action items have been completed.

\section{ORPS ID: EM-BHSO-BNL-HFBR-2006-0001}

During routine inspections of the High Flux Beam Reactor (HFBR), a field engineer noticed that the HVAC cooling tower had no water flowing through it. Upon investigation, the engineer noticed water on the equipment level floor due to leaking water from the circulation pump. In total, 26,000 gallons of water was lost to the floor. The water became tritiated due to the high levels of absorbed tritium in the HFBR structure and components. The water was recovered and transferred to the Waste Concentration Facility for storage prior to off-site disposal.

Note:

${ }^{*}$ Reportable under the Occurrence Reporting and Processing System (ORPS), established by the requirements of DOE Order 231.1A.
Date: $01 / 23 / 06$

Status: Closed. All corrective actions have been completed.

Date: 03/09/06

Status: Closed.

All corrective actions have been completed.

Date: 08/08/06

Status: Closed.

All corrective actions have been completed.

Date: 09/27/06

Status: Closed. All corrective actions have been completed.

Date: 05/22/06

Status: Closed.

All corrective actions have been completed.

\section{Date: $07 / 19 / 06$}

Status: Closed. All corrective actions have been completed.

Date: 09/25/06

Status: Open. One action remains open. 
While there were no spills reported through ORPS in 2006, there were seven ORPS reports that were environmental in nature. These events have been summarized in Table 3-8. All incidents were addressed through the identification and implementation of corrective actions addressing the root cause. No off-site or on-site permanent environmental impacts arose from the ORPS-reported incidents.

\subsubsection{Major Petroleum Facility License}

The storage of 2.3 million gallons of fuel oil (principally No. 6 oil) subjects the Laboratory to Major Petroleum Facility (MFP) licensing by NYSDEC. The fuel is used at the CSF to produce high pressure steam to heat and cool BNL facilities. During 2006, the Laboratory remained in full compliance with the MPF license requirements, which include monitoring groundwater in the vicinity of the six active, aboveground storage tanks that range in capacity from 300,000 to 600,000 gallons. The license also requires BNL to inspect the storage facilities monthly and test the systems for leak detection, high-level monitoring, and secondary containment. Tank integrity is also checked periodically. Groundwater monitoring consists of monthly checks for the presence of floating products and twice-yearly analyses for VOCs and semi-volatile organic compounds (SVOCs). In 2006, no VOCs, SVOCs, or floating products attributable to MPF activities were detected. See SER Volume II, Groundwater Status Report, for additional information on groundwater monitoring results.

In 2006, upgrades and/or inspections were performed at the MPF. In July, in-depth integrity tests of the secondary containment berms at the MPF were conducted to ensure that they will adequately impede the migration of oil in the event of a spill. The berms for tanks 3, 4, 9, and 10 were found to be in substantial compliance with secondary containment requirements. However, one small area in the secondary containment berm for tanks 5 and 6 did not meet the permeability requirements of the MPF License. Additional testing was performed in December 2006, which confirmed the original results. Engineering plans will be prepared and implemented in 2007 to address this deficiency.

In September, NYSDEC conducted its annual inspection. Two conditions that required corrective action were noted: the management of vegetative growth in the secondary containment berms at Building 610, and the need for further evaluation of the secondary containment system for tanks 5 and 6 , based on the results of the indepth integrity tests performed in July.

\subsubsection{Chemical Bulk Storage}

Title 6 of the Official Compilation of the Codes, Rules and Regulations of the State of New York (NYCRR), Part 597, requires that all aboveground tanks larger than 185 gallons and all underground tanks that store specific chemicals be registered with NYSDEC. The Laboratory holds a Hazardous Substance Bulk Storage Registration Certificate for eight tanks. Seven of the tanks store treatment chemicals for potable water (sodium hydroxide and sodium hypochlorite) and one tank stores gallium trichloride, formerly required in physics experiments. The tanks range in capacity from 200 to 1,200 gallons. These tanks are also regulated under Suffolk County Sanitary Code (SCSC) Article 12 (SCDHS 1993) and are managed in accordance with BNL procedures designed to conform to Suffolk County requirements.

NYSDEC conducted an inspection of the Chemical Bulk Storage (CBS) facilities in September 2006. During this inspection, one issue was identified that required corrective action: the need to add open/close position signs for several control valves associated with caustic tanks at Well Houses 10 and 12. This issue was immediately corrected in accordance with the NYSDEC directive.

\subsubsection{County Storage Requirements}

Article 12 of the SCSC regulates the storage and handling of toxic and hazardous materials in aboveground or underground storage tanks, drum storage facilities, piping systems, and transfer areas. Article 12 specifies design criteria to prevent environmental impacts resulting from spills or leaks and specifies administrative requirements such as identification, registration, and spill reporting procedures. In 1987, the Lab- 
oratory entered into a voluntary Memorandum of Agreement with SCDHS, in which DOE and BNL agreed to conform to the environmental requirements of Article 12.

Currently, there are 357 active storage facilities at BNL for wastewater, chemicals, and fuel (some fuel facilities are regulated under the MPF license), as well as storage facilities used to support BNL research. An additional 33 storage facilities are temporarily out of service. The Laboratory has five active storage facilities associated with environmental restoration activities conducted under the CERCLA program; these are not regulated under Article 12.

BNL has an ongoing program to upgrade or replace existing storage facilities, to ensure that the information provided to SCDHS for all registered storage facilities is accurate, and to ensure that new or modified storage facilities are designed and reviewed for full conformance with Article 12 regulations. In 2006, the Laboratory continued to provide SCDHS with updated information regarding several registered tanks, including a request to abandon the Building 801 F-Tanks and Building 510 Source Tubes. The request was approved by SCDHS. In addition, one of the last single-walled underground storage tanks was removed in September 2006 and replaced with an aboveground tank that complies with SCSC Article 12.

\subsection{RCRA REQUIREMENTS}

The Resource Conservation and Recovery Act (RCRA) regulates hazardous wastes that, if mismanaged, could present risks to human health or the environment. The regulations are designed to ensure that hazardous wastes are managed from the point of generation to final disposal. In New York State, EPA delegates the RCRA program to NYSDEC, with EPA retaining an oversight role. The Laboratory is considered a large-quantity generator because it may generate greater than $1,000 \mathrm{Kg}$ (2,200 pounds) of hazardous waste in a month, and has a RCRA permit to store hazardous wastes for up to one year before shipping them off site to licensed treatment and disposal facilities. As noted in Chapter 2, BNL also has a number of satellite accumulation and 90-day waste storage areas.
Mixed wastes are materials that are both hazardous (under RCRA guidelines) and radioactive. The Federal Facilities Compliance Act (1992) requires that DOE work with local regulators to develop a site treatment plan to manage mixed waste. Development of the plan has two purposes: to identify available treatment technologies and disposal facilities (federal or commercial) that are able to manage mixed waste produced at federal facilities, and to develop a schedule for treating and disposing of these waste streams.

BNL's Site Treatment Plan is updated annually and submitted to NYSDEC for review. The updated plan documents the current mixed waste inventory and describes efforts undertaken to seek new commercial treatment and disposal outlets for various waste streams. Treatment options for all of the mixed waste now in storage have been identified. The Laboratory anticipates that it will continue to manage mixed wastes within its permitted one-year storage limitation, and will continue to maintain and update its Site Treatment Plan as a reporting mechanism, should waste types or treatment facility availability change in the future

\section{I0 POLYCHLORINATED BIPHENYLS}

The storage, handling, and use of polychlorinated biphenyls (PCBs) are regulated under the Toxic Substances Control Act (TSCA). Capacitors manufactured before 1970 that are believed to be oil filled are handled as if they contain PCBs, even when that cannot be verified from the manufacturer's records. All equipment containing PCBs must be inventoried, except for capacitors containing less than 3 pounds of dielectric fluid and items with a concentration of PCB source material of less than 50 parts per million. Certain PCB-containing articles or PCB containers must be labeled. The inventory is updated by July 1 of each year. The Laboratory responds to any PCB spill in accordance with standard emergency response procedures. BNL was in compliance with the regulatory requirements in 2006.

The Laboratory has aggressively approached reductions in its PCB inventory. By replacing and disposing of 128 large capacitors from the 
Collider-Accelerator Department in 2006, the inventory was reduced an additional 51 percent. Since 2003, BNL has reduced its PCB inventory by more than 90 percent.

\section{II PESTICIDES}

The storage and application of pesticides (insecticides, rodenticides, herbicides, and algicides) are regulated under the Federal Insecticide, Fungicide and Rodenticide Act (FIFRA). Pesticides are used at the Laboratory to control undesirable insects, mice, and rats; bacteria in cooling towers; and to maintain certain areas free of vegetation (e.g., around fire hydrants and inside secondary containment berms). Insecticides are also applied to agricultural research fields and in greenhouses on site. Herbicide use is minimized wherever possible (e.g., through spot treatment of weeds). All pesticides are applied by BNL-employed, New York State-certified applicators. By February 1, each applicator files an annual report with NYSDEC detailing insecticide, rodenticide, algicide, and herbicide use for the previous year. The Laboratory was in full compliance with the legislated requirements in 2006.

\section{I2 WETLANDS AND RIVER PERMITS}

As noted in Chapter 1, portions of the BNL site are situated on the Peconic River floodplain. Portions of the Peconic River are listed by NYSDEC as "scenic" under the Wild, Scenic, and Recreational River Systems Act. The Laboratory also has six areas regulated as wetlands and a number of vernal (seasonal) pools. Construction or modification activities performed within these areas require permits from NYSDEC.

Activities that could require review under the BNL Natural and Cultural Resource Management Programs are identified during the NEPA process (see Section 3.3). In the preliminary design stages of a construction project, design details required for the permit application process are specified. These design details ensure that the construction activity will not negatively affect the area, or if it does, that the area will be restored to its original condition. When design is near completion, permit applications are filed. During and after construction, the Laboratory must comply with the permit conditions.

In 2006, three projects that were started in 2005 were granted permits under this program. These projects included constructing a new recharge basin, a storage facility at the Alternating Gradient Synchrotron (AGS), and ancillary structures at Buildings 1007 and 1009. All projects have been completed except for new structures at Buildings 1007 and 1009, which are no longer planned; the permit will be cancelled in 2007. Final photos and completed project notifications for construction of the AGS storage facility were submitted in 2006, and this permit was closed. Final photos for the recharge basin will be submitted in 2007, along with the permit completion notice to close this permit.

\section{I3 ENDANGERED SPECIES ACT}

In 2006, the Laboratory updated its list of endangered, threatened, and species of special concern (see Table 6-1 in Chapter 6). Although the tiger salamander is no longer the only state endangered species found at BNL, it is the most notable and best-studied species on site. Tiger salamanders are listed as endangered in New York State because populations have declined due to habitat loss through development, road mortality during breeding migration, introduction of predatory fish into breeding sites, historical collection for the bait and pet trade, water level fluctuations, pollution, and general disturbance of breeding sites. The Laboratory adopted and implemented the BNL Natural Resource Management Plan (NRMP) in December 2003. One component of the plan formalizes the strategy and actions needed to protect 22 confirmed tiger salamander breeding locations on site. The strategy includes identifying and mapping habitats, monitoring breeding conditions, improving breeding sites, and controlling activities that could negatively affect breeding. A multi-year study of three ponds was begun in 2004 to gain a better understanding of the habitat requirements and salamander movement.

The banded sunfish and swamp darter are found in the Peconic River drainage areas at BNL. Both are listed as threatened species within New York State. Eastern Long Island has the only known remaining populations of these fish 
in New York. Measures taken or being taken by the Laboratory to protect the banded sunfish and swamp darter and their habitat include: eliminating, reducing, or controlling pollutant discharges; reducing nitrogen loading in the Peconic River; monitoring populations and water quality to ensure that habitat remains viable; maintaining adequate flow to the river to enable the fish to survive drought; and minimizing disturbances to the river and adjacent banks.

Three butterfly species that are endangered, threatened, or of special concern have been historically documented at the Laboratory; these include the frosted elfin, persius duskywing, and mottled duskywing. None have been documented in recent surveys. Habitat for the frosted elfin and persius duskywing exists on Laboratory property and mottled duskywing is likely to exist on site; therefore, the management of habitat and surveys for the three butterflies has been added to the NRMP.

Surveys for damselffies and dragonflies conducted annually during the summer months confirmed the presence of one of the three threatened species of damselflies expected to be found on site. In June 2005, the pine-barrens bluet (Enallagma recurvatum), a threatened species, was documented at one of the many coastal plain ponds located at BNL.

The Laboratory is also home to 14 species that are listed as species of special concern. Such species have no protection under the state endangered species laws, but may be protected under other state and federal laws (e.g., Migratory Bird Treaty Act). New York State monitors species of special concern and manages their populations and habitats, where practical, to ensure that they do not become threatened or endangered. Species of special concern found at BNL include the mottled duskywing butterfly, marbled salamander, eastern spadefoot toad, spotted turtle, eastern box turtle, eastern hognose snake, worm snake, horned lark, whip-poor-will, vesper sparrow, grasshopper sparrow, and Cooper's hawk. The management efforts for the tiger salamander also benefit the marbled salamander. At present, no additional protective measures are planned for the eastern box turtle or spotted turtle, as little activity oc- curs within their known habitat at the Laboratory. Radio telemetry work on the spotted turtle was carried out in $2004-2006$, and a basic understanding of their movement and habitat needs was developed. A radio telemetry study on the eastern hognose snake was completed in 2005, resulting in greater understanding of this species' habitat needs and its movement between habitats. BNL continues to evaluate bird populations as part of the management strategy outlined in the NRMP. In addition to the bird species mentioned above, 18 other bird species listed as species of special concern and two federally threatened species have been observed during spring and fall migrations.

The Laboratory has 20 plant species that are protected under state law. One is an endangered plant, the crested fringed orchid; two are threatened plants, the stiff goldenrod and stargrass; and two are rare plants, the narrow-leafed bush clover and long-beaked bald-rush. The other 15 species are considered to be "exploitably vulnerable," meaning that they may become threatened or endangered if factors that result in population declines continue. These plants are currently sheltered at BNL due to the large areas of undeveloped pine-barren habitat on site. As outlined in the NMRP, locations of these rare plants must be determined, populations estimated, and management requirements established. See Chapter 6 for further details.

\subsection{EXTERNAL AUDITS AND OVERSIGHT}

\subsection{Regulatory Agency Oversight}

A number of federal, state, and local agencies oversee BNL activities. In 2006, BNL was inspected by federal, state, or local regulators on 10 occasions and SCDHS continued to maintain a part-time, on-site inspector who provided periodic oversight of BNL activities. In addition to external audits and oversight, the Laboratory has a comprehensive self-assessment program, as described in Chapter 2.

These inspections included:

- Air Compliance. Although NYSDEC observed several air emissions tests, there was no formal air inspection in 2006, and no issues identified during testing observations.

- Potable Water. In September, SCDHS col- 
lected samples and conducted its annual inspection of the BNL potable water system. No issues were identified.

- Sewage Treatment Plant. SCDHS conducts quarterly inspections of the Laboratory's STP, to evaluate operations and sample the effluent. In 2006, no performance or operational issues were identified. NYSDEC also conducted an annual inspection of the STP and other SPDES-regulated outfalls; no issues were identified.

- Recharge Basins. SCDHS inspected several of the SPDES-regulated outfalls and collected samples. No issues were identified.

- Major Petroleum Facility. The annual NYSDEC inspection of the MPF was conducted in August. See Section 3.8.4 for a discussion of the issues identified.

- Chemical Bulk Storage Facilities. The CBS facilities are inspected periodically by NYSDEC. This inspection was conducted in August (see Section 3.8.5).

- Hazardous Waste. NYSDEC conducted a comprehensive inspection of BNL's hazardous waste program in November, including BNL's permitted storage facility and 90-day storage areas. No issues were identified.

\subsubsection{DOE Assessments/Inspections}

Although DOE Headquarters (EH-10) and the Chicago Support Center did not conduct assessments of BNL's environmental programs in 2006, the DOE Brookhaven Site Office (BHSO) continued to oversee Laboratory programs and observed BNL's multi-topic programmatic assessment. The Environmental and Waste Management Services Division adopted a different approach to conducting its annual assessments. Rather than perform several individual assessments during the year, a single multi-topic assessment was conducted. The rationale for this change was to reduce the impact in time and resources, on both the assessors and assesses. In addition, the Laboratory also underwent an inspection by the Nevada Test Site in order to maintain its waste shipment certification. The results of these assessments and the inspection are summarized below.

\subsubsection{Environmental Multi-Topic Assessment}

The multi-topic assessment included a field review of Process Assessments Forms (PAFs) and Experimental Safety Reviews (ESRs), Universal and Industrial Wastes, and Quality Assurance practices for sampling by non-environmental and waste management organizations.

In general, descriptions in the PAFs and ESRs are reflective of actual field observations and many were very accurate and required no additional information. There were two minor non conformances identified in the management of universal and industrial wastes; both related to the labeling of waste containers. With regard to sampling practices, the field practices and other activities reviewed during the assessment were of good quality; however, the lack of formal sample collection and data review procedures leaves the opportunity for future errors. Corrective actions were identified and completed in 2006.

\subsubsection{Hazardous Material Transportation}

The BNL Triennial Transportation Assessment was performed in accordance with the Transportation Safety and Operations Compliance Assurance Process (TCAP). TCAP ensures compliance with applicable regulations, policies, and orders at sites involved in transportation operations, including DOE Field oversight; identifies opportunities for process improvements in all aspects of transportation operations; and shares transportation safety and operations best practices and lessons learned throughout the DOE complex. The TCAP evaluation process is designed to assist site line personnel in identifying the cause(s) of deficiencies where they exist, and to foster the development of site management systems that continually maximize regulatory compliance, increase efficiency, and enhance worker safety.

The results of this assessment were based on the documentation provided and followed the definition of terms as established by the BHSOOA-01, Conduct of Environmental, Safety and Health (ESH) Assessments (i.e., noteworthy items, concerns, findings, and observations). No concerns or programmatic breakdowns 
Table 3-9. Existing Agreements and Enforcement Actions Issued to BNL, with Status.

\begin{tabular}{|c|c|c|c|c|}
\hline Number & Title & Parties & $\begin{array}{l}\text { Effective } \\
\text { Date }\end{array}$ & Status \\
\hline \multicolumn{5}{|l|}{ Agreements } \\
\hline No Number & Suffolk County Agreement & $\begin{array}{l}\text { SCDHS, } \\
\text { DOE, } \\
\text { and BNL }\end{array}$ & $\begin{array}{l}\text { Originally } \\
\text { signed on } \\
09 / 23 / 87\end{array}$ & $\begin{array}{l}\text { This Agreement was developed to ensure that the storage and } \\
\text { handling of toxic and hazardous materials at BNL conform with } \\
\text { the environmental and technical requirements of Suffolk County } \\
\text { codes. }\end{array}$ \\
\hline No Number & $\begin{array}{l}\text { Federal Facilities Compliance Agreement } \\
\text { on Mixed Wastes }\end{array}$ & $\begin{array}{l}\text { NYS- } \\
\text { DEC } \\
\text { and } \\
\text { DOE }\end{array}$ & $\begin{array}{l}1992 \\
\text { (updated } \\
\text { annually) }\end{array}$ & $\begin{array}{l}\text { The Federal Facilities Compliance Act (FFCA) requires that a site } \\
\text { treatment plan to manage mixed wastes be written and updated } \\
\text { annually. BNL is in compliance with this requirement. }\end{array}$ \\
\hline $\begin{array}{l}\text { II-CERCLA- } \\
\text { FFA-00201 }\end{array}$ & $\begin{array}{l}\text { Federal Facility Agreement under the } \\
\text { Comprehensive Environmental Response, } \\
\text { Compensation and Liability Act (CERCLA) } \\
\text { Section } 120 \text { (also known as the Interagen- } \\
\text { cy Agreement or "IAG" of the Environmen- } \\
\text { tal Restoration Program) }\end{array}$ & $\begin{array}{l}\text { EPA, } \\
\text { DOE, } \\
\text { and } \\
\text { NYSDEC }\end{array}$ & $05 / 26 / 92$ & $\begin{array}{l}\text { Provides the framework, including schedules, for assessing the } \\
\text { extent of contamination and conducting the BNL cleanup. Work is } \\
\text { performed either as an Operable Unit or a Removal Action. The } \\
\text { IAG integrates the requirements of CERCLA, Resource Conserva- } \\
\text { tion and Recovery Act (RCRA), and the National Environmental } \\
\text { Policy Act (NEPA). All IAG-scheduled milestones were met in } \\
2006 \text {. }\end{array}$ \\
\hline \multicolumn{5}{|c|}{ Notices of Violation/Enforcement Actions } \\
\hline None & $\begin{array}{l}\text { Notice of Violation: Title V Facility } \\
\text { Exceedance of 6-minute opacity standards: } \\
\text { 04/01/05 - 06/30/05 }\end{array}$ & $\begin{array}{l}\text { NYS- } \\
\text { DEC } \\
\text { and } \\
\text { DOE }\end{array}$ & $\begin{array}{l}12 / 05 / 05 \\
\text { Received } \\
\text { 05/16/06 }\end{array}$ & $\begin{array}{l}\text { The NOV cites violation of Condition } 62 \text { of BNL's Title V permit } \\
\text { and documents } 60 \text { exceedances of BNL's 6-minute average opac- } \\
\text { ity limit. }\end{array}$ \\
\hline None & $\begin{array}{l}\text { Notice of Violation: Title V Facility } \\
\text { Exceedance of 6-minute opacity standards: } \\
\text { 07/01/05 - 9/30/05 }\end{array}$ & $\begin{array}{l}\text { NYS- } \\
\text { DEC } \\
\text { and } \\
\text { DOE }\end{array}$ & $\begin{array}{l}\text { 12/05/05 } \\
\text { Received } \\
\text { 05/16/06 }\end{array}$ & $\begin{array}{l}\text { The NOV cites violation of Condition } 62 \text { of BNL's Title V permit } \\
\text { and documents } 36 \text { exceedances of BNL's 6-minute average opac- } \\
\text { ity limit. }\end{array}$ \\
\hline \multicolumn{5}{|c|}{$\begin{array}{l}\text { Notes: } \\
\text { EPA = Environmental Protection Agency } \\
\text { NYSDEC = New York State Department of Environmental Conservation } \\
\text { SCDHS = Suffolk County Department of Health Services }\end{array}$} \\
\hline
\end{tabular}

were found. There were four "significant findings" in the performance objectives of: General Management of Transportation and Packaging Programs, Hazardous and Radioactive Materials Packaging, Transportation Emergency Response, and HAZMAT Employee Training. In addition, nine "observations" were noted. Although the Laboratory met all the performance objectives of this review, no noteworthy or best-in-class items were identified. The TCAP team provides technical assistance to Brookhaven Science Associates (BSA) management and personnel throughout the evaluation process by offering recommendations based on recognized transportation and business practices and by identifying additional information and/or training sources. Nineteen recommendations were made by the team to assist BSA in improving transportation operations at BNL. A corrective action plan was prepared and is currently underway.

\subsubsection{EMS Desk Assessment}

BHSO conducted a desk audit of the Laboratory's Environmental Management System to ensure it met the requirements of Executive Order 13148, Greening the Government Through Leadership in Environmental Management. The assessment looked at five functional areas which covered all 17 elements for the implementation of the International Organization for Standardization (ISO) 14001 Standard at BNL. There were no findings or deficiencies identified during this audit.

\subsubsection{Nevada Test Site Inspection}

In order to ship low-level waste to the Ne- 
vada Test Site (NTS) for disposal, BNL must be certified as a waste generator by the NTS Maintenance and Operations contractor. The Laboratory performed a gap analysis of the BNL Waste Management Program (WMP) and the NTS Waste Acceptance Criteria (WAC). Based on the analysis, WMP modified and created standard operating procedures to comply with NTS WAC requirements. The inspection team from NTS issued one Corrective Action Report. BNL corrected the deficiency and was certified as a waste generator in March of 2006.

\subsubsection{Enforcement Actions and Memos}

No new consent orders were issued to the Laboratory in 2006. As previously discussed, in May two Notices of Violation (NOVs) were issued for opacity excursions that were selfreported in 2005. Since all corrective actions were completed in 2005, the NOVs were considered resolved upon issuance. All existing enforcement actions and memoranda are listed in Table 3-9, along with a summary of their status. BNL and DOE have determined that the Laboratory has fully complied with the terms and conditions listed in these actions, and have submitted supporting documentation to the regulatory agencies.
REFERENCES AND BIBLIOGRAPHY

BNL. 1997. BNL Site Treatment Plan. Brookhaven National Laboratory, Upton, NY.

BNL. 2000. Brookhaven National Laboratory Site Master Plan. Brookhaven National Laboratory, Upton, NY.

BNL. 2003. Natural Resource Management Plan for Brookhaven National Laboratory. Brookhaven National Laboratory, Upton, NY

Chaloupka, W. 2000. Brookhaven National Laboratory Spill Prevention Control and Countermeasure Plan. Brookhaven National Laboratory, Upton, NY.

Chaloupka, W. 2006. Brookhaven National Laboratory 2006 Annual Potable Water Sampling Plan. Brookhaven National Laboratory, Upton, NY.

DOE Order 5400.5. 1990. Radiation Protection of the Public and the Environment. U.S. Department of Energy, Washington, DC. Change 2: I-7-93.

DOE Policy 450.4. 1996. Safety Management System Policy. U.S. Department of Energy, Washington, DC. 10- $15-96$.

EPA. 2000. Federal Facilities Agreement under CERCLA 120. Administrative Docket Number II-CERCLA-FFA-0020I .

Lee, R. 2006. Brookhaven National Laboratory, Facility Response Plan. Brookhaven National Laboratory, Upton, NY.

Lee, R. Brookhaven National Laboratory, Programmatic SelfAssessment Report for 2006, Multi-Topic Environmental Assessment, February 2006, Brookhaven National Laboratory, Upton, NY.

SCDHS. 1993. Suffolk County Sanitary Code Article 12:Toxic and Hazardous Material Storage and Handling Controls. Suffolk County Department of Health Services, NY. 


\section{Air Quality}

Brookhaven National Laboratory monitors both radioactive and nonradioactive emissions at several facilities on site to ensure compliance with the requirements of the Clean Air Act. In addition, $B N L$ conducts ambient air monitoring to verify local air quality and assess possible environmental impacts from Laboratory operations.

During 2006, BNL facilities released a total of 4,410 curies of short-lived radioactive gases. Oxygen-15 and carbon-11 emitted from the Brookhaven Linac Isotope Producer constituted more than 99.9 percent of the site's radiological air emissions.

Since natural gas prices were comparatively lower than residual fuel prices from June through October in 2006, the Central Steam Facility used natural gas to meet most of the heating and cooling needs of the Laboratory's major facilities during this period. As a result, annual facility emissions of particulate matter, nitrogen oxides, and sulfur dioxide were considerably lower in 2006 than in the prior two years, when residual fuel satisfied more than 99.9 percent of BNL major facility heating and cooling needs.

\section{I RADIOLOGICAL EMISSIONS}

Federal air quality laws and DOE regulations that govern the release of airborne radioactive material include 40 CFR 61 Subpart H: National Emission Standards for Hazardous Air Pollutants (NESHAPs) - part of the Clean Air Act, and DOE Order 5400.5, Radiation Protection of the Public and the Environment. Under NESHAPs Subpart H, facilities that have the potential to deliver an annual radiation dose of greater than $0.1 \mathrm{mrem}(1 \mu \mathrm{Sv})$ to a member of the public must be continuously monitored for emissions. Facilities capable of delivering radiation doses below that limit require periodic, confirmatory monitoring. Although not required, BNL has one facility that is continuously monitored, the Brookhaven Linac Isotope Producer (BLIP). Periodic monitoring is conducted at one active facility, the Target Processing Laboratory (TPL), and one inactive facility, the High Flux Beam Reactor (HFBR). Figure 4-1 indicates the locations of these monitored facilities, and Table 4-1 presents the airborne release data from each of these facilities during 2006. Annual emissions from monitored facilities are discussed in the following sections of this chapter. Also discussed is a fourth inactive facility, the Evaporator Facility, which was periodically monitored in past years. The associated radiation dose estimates are presented in Chapter 8, Table 8-4.

\section{I.I Brookhaven Medical Research Reactor}

In August 2000, DOE announced that the Brookhaven Medical Research Reactor (BMRR) would be permanently shut down due to a reduction of research funding. Until it stopped operating in late December 2000, the BMRR was fueled with enriched uranium, moderated and cooled by "light" (ordinary) water, and was operated intermittently at power levels up to $3 \mathrm{MW}$, thermal. Air from the interior of the containment building was used to cool the neutron reflector surrounding the core of the reactor vessel. As air was drawn through the reflector, it was exposed to a neutron field, resulting in activation of the argon fraction of the air. This produced argon-41 (Ar-41), an inert, radioactive gas (half-life 1.8 hours). After passage through the reflector, the air was routed through a roughing filter and a high-efficiency 


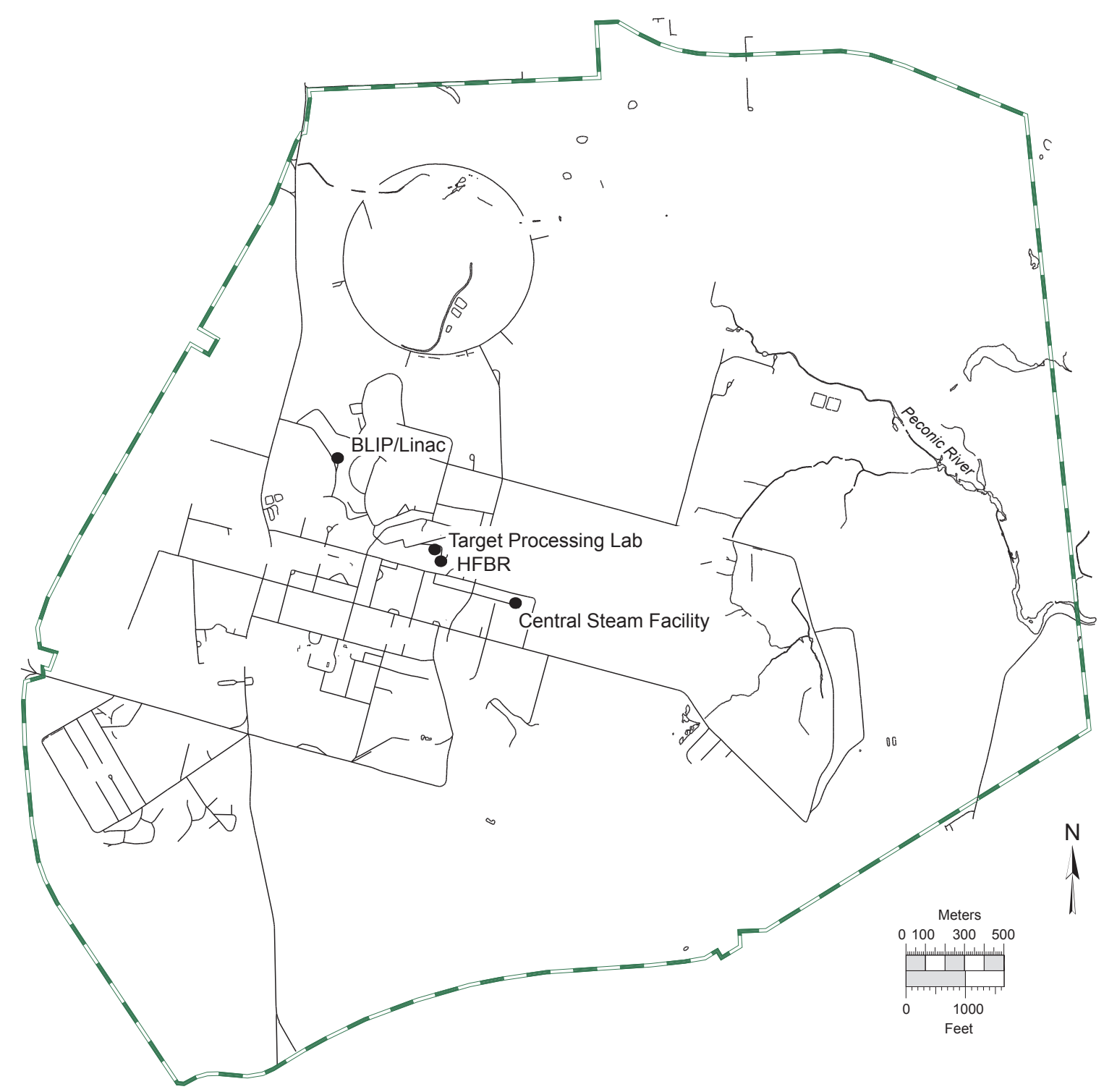

Figure 4-I. Air Emission Release Points Subject to Monitoring.

particulate air (HEPA) filter to remove any particulate matter. Charcoal filters were also used to remove radioiodines produced during the fission process. Following filtration, the air was exhausted to the atmosphere through a $150-\mathrm{ft}$ stack adjacent to the reactor containment building. This air was continuously monitored for Ar-41 emissions.

After the BMRR stopped operating, continuous Ar-41 monitoring was reduced to periodic, semi-annual monitoring to confirm that radionuclide concentrations remained below detection limits. In January 2003, the remaining fuel was removed from the BMRR reactor vessel, eliminating the last significant source for radionuclide emissions. The sole remaining BMRR emission source was evaporation of the cooling water, which contained the radioactive isotope tritium (H-3, half-life 12.3 years) produced by neutron activation when the BMRR operated. In January 2005, EPA approved BNL's petition to discontinue emissions monitoring at the BMRR. As a result, samples are no longer collected.

In 2006, the facility was managed as a radiological facility. During the year, all removable radioactive equipment in the reactor vessel was retrieved and shipped to a DOE-approved disposal facility. 


\subsubsection{High Flux Beam Reactor}

When the HFBR operated, "heavy" water was used as a neutron moderator and fuel coolant. Heavy water, or $\mathrm{D}_{2} \mathrm{O}$, is water composed of a nonradioactive isotope of hydrogen known as deuterium. When exposed to neutron fields generated inside a reactor vessel, deuterium becomes activated and produces radioactive tritium. As a result of the transfer of fuel elements from the reactor, tritiated heavy water (HTO) from the HFBR system was contained in the spent fuel storage pool. In 1997, a leak in the pool was discovered when a plume of tritiated groundwater was traced back to it. The HFBR was put in standby mode, the pool was pumped out, and the HTO from the pool was properly disposed of as radioactive waste. The pool was then repaired and double lined, in accordance with Suffolk County Article 12 regulations (SCDHS 1993) and remained empty while the facility was in a standby mode.

The HFBR continued in standby mode until November 1999, when DOE declared that it was to be permanently shut down. Residual tritium in water in the reactor vessel and piping systems continues to diffuse into the building's air through valve seals and other system penetrations, though emission rates are much lower than during the years of operation (Figure 4-2).
Table 4-1. Airborne Radionuclide Releases from Monitored Facilities.

\begin{tabular}{|c|c|c|c|}
\hline Facility & Nuclide & Half-Life & Ci Released \\
\hline HFBR & Tritium & 12.3 years & $4.03 E+0$ \\
\hline \multirow[t]{3}{*}{ BLIP } & Carbon-11 & 20.4 minutes & $1.28 \mathrm{E}+3$ \\
\hline & Oxygen-15 & 122 seconds & $3.12 E+3$ \\
\hline & Tritium & 12.3 years & $6.78 \mathrm{E}-2$ \\
\hline $\begin{array}{l}\text { TPL - } \\
\text { Bldg. } 801\end{array}$ & Germanium-68 & 270.8 days & $3.47 \mathrm{E}-9$ \\
\hline Total & & & $4.41 \mathrm{E}+3$ \\
\hline \multicolumn{4}{|c|}{$\begin{array}{l}\text { Notes: } \\
\mathrm{Ci}=3.7 \mathrm{E}+10 \mathrm{~Bq} \\
\mathrm{BLIP}=\text { Brookhaven Linac Isotope Producer } \\
\text { HFBR = High Flux Beam Reactor (operations were terminated in } \\
\text { November 1999) } \\
\text { TPL = Target Processing Laboratory }\end{array}$} \\
\hline
\end{tabular}

The increase in emissions in 2003 was attributed to evaporative losses when HTO remaining in the reactor core was pumped out for approved disposal. In 2004, the downward trend in emissions resumed: the level dropped from $9.0 \mathrm{Ci}$ (the 2003 value) to $3.94 \mathrm{Ci}$. In 2005 , tritium emissions climbed to $17.9 \mathrm{Ci}$, apparently due to evaporation of residual heavy water through an open drain-tank vent line. In 2006, tritium emissions dropped to $4.03 \mathrm{Ci}$, a level consistent with 2004 emissions. The air emissions from the HFBR facility have been

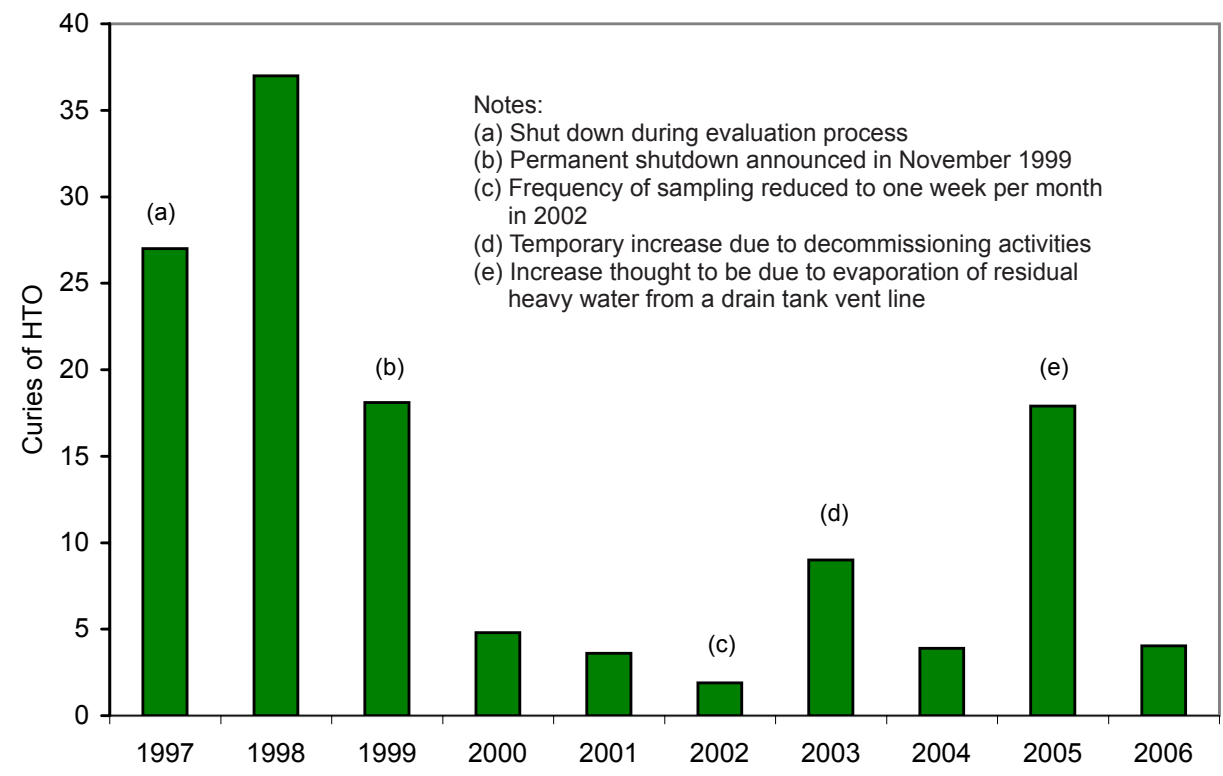

Figure 4-2. High Flux Beam Reactor Tritium Emissions, Ten-Year Trend (1997-2006). 
monitored since 2002 via air sampling of the building at a frequency of one week per month.

\section{I.3 Brookhaven Linac Isotope Producer}

Protons from the Linear Accelerator (Linac) are sent via an underground beam tunnel to the BLIP, where they strike various metal targets to produce new radionuclides for medical diagnostics. The activated metal targets are transferred to the TPL in Building 801 for separation and shipment to various radiopharmaceutical research laboratories. During irradiation, the targets become hot and are cooled by a continuously recirculating water system. The cooling water also becomes activated during the process, producing secondary radionuclides. The most significant of these radionuclides are oxygen- 15 (O-15, half-life 122 seconds) and carbon-11 (C-11, half-life 20.48 minutes). Both of these isotopes are released as gaseous, airborne emissions through the facility's 33-ft stack. Emissions of these radionuclides are dependent upon the current and energy of the proton beam used to manufacture the radioisotopes.

In 2006, BLIP operated over a period of 22 weeks. During this period, 1,284 Ci of C-11 and 3,122 $\mathrm{Ci}$ of $\mathrm{O}-15$ were released. Tritium produced from activation of the target cooling water was also released, but in a much smaller quantity, 6.78E-02 Ci. Combined emissions of $\mathrm{C}-11$ and $\mathrm{O}-15$ were roughly 35 percent higher than in 2005 , primarily due to five additional weeks of operation. The combined emissions, normalized to the same number of micro-amphours of production, were 31 percent lower than the total in 2003. This drop in emissions was facilitated by the installation of a lucite enclosure over the continuously recirculating water system. Section 8.4.1 provides more details on the enclosure's effectiveness.

\subsubsection{Evaporator Facility}

In the past, liquid waste generated on site that contained residual radioactivity was accumulated at the Waste Concentration Facility (WCF) in Building 811. At this facility, reverse osmosis was used to remove suspended solids and a high percentage of radionuclides from the liquid. Because tritium is an isotope of hydrogen, it could not be removed from aqueous wastes. The tritiated water that remained following waste concentration was transferred to the Evaporator Facility in Building 802B, where it was converted to steam and released as an airborne emission. The Evaporator Facility was constructed primarily to reduce the amount of tritiated water released to the Peconic River through the BNL Sewage Treatment Plant. Emissions from the Evaporator Facility were previously directed to the same stack used by the HFBR to exhaust building air. This method was preferable to releases to surface water because there was virtually no potential for the airborne emissions to influence groundwater (the primary drinking water source on Long Island), and the potential for the released tritium to contribute to an off-site dose was minimized by atmospheric dispersion.

No aqueous waste has been processed at the WCF since 2001. As a result, the Evaporator Facility has not been used and has produced no emissions of tritiated water vapor. Because generation rates of aqueous wastes containing residual radioactivity are expected to remain low, it is no longer cost effective to process the waste in the same manner. Wastes are now processed through solidification and disposed of off site. As a result, planning is underway to decommission the Evaporator Facility. Subject to funding availability, the plans also call for demolishing the Building 802B stack and decontaminating the WCF.

\section{1.5 Target Processing Laboratory}

As mentioned in Section 4.1.3, the metal targets irradiated at the BLIP are transported to the TPL in Building 801, where isotopes are chemically extracted for radiopharmaceutical production. Airborne radionuclides released during the extraction process are drawn through multistage HEPA and activated charcoal filters and then vented to the HFBR stack. The types of radionuclides that are released depend on the isotopes chemically extracted from the irradiated metal targets, which may change from year to year. Annual radionuclide quantities released from this facility are very small, 
typically in the $\mu \mathrm{Ci}$ to $\mathrm{mCi}$ range. In 2006 , the total release from the TPL was $0.0035 \mu \mathrm{Ci}$. See Table 4-1 for details of the radionuclides released in 2006.

\section{I.6 Additional Minor Sources}

Several research departments at BNL use designated fume hoods for work that involves small quantities of radioactive materials (in the $\mu \mathrm{Ci}$ to $\mathrm{mCi}$ range). The work typically involves labeling chemical compounds and transferring material between containers using pipettes. Due to the use of HEPA filters and activated charcoal filters, the nature of the work conducted, and the small quantities involved, these operations have a very low potential for atmospheric releases of any significant quantities of radioactive materials. Compliance with NESHAPs Subpart H is demonstrated through the use of an inventory system that allows an upper estimate of potential releases to be calculated. Facilities that demonstrate compliance in this way include Buildings 463, 490, 490A, $510,535,555,725$, and 801 , where research is conducted in the fields of biology, medicine, high energy physics, chemistry, applied and materials science, and advanced technology. See Table 8-4 in Chapter 8 for the calculated dose from these facility emissions.

\section{I.7 Nonpoint Radiological Emission Sources}

Nonpoint radiological emissions from a variety of diffuse sources were evaluated in 2006 for compliance with NESHAPs Subpart H. Diffuse sources evaluated included planned research, environmental restoration, and waste management activities. The EPA-approved CAP88-PC dose modeling computer program was used to calculate the possible dose to members of the public from each of the planned activities. The evaluations determined whether NESHAPs permitting and continuous monitoring requirements were applicable, or whether periodic confirmatory sampling was needed to ensure compliance with Subpart H standards for radionuclide emissions. Chapter 8 discusses the NESHAPs evaluations of the research, environmental restoration, and waste management activities that occurred in 2006.

\subsection{FACILITY MONITORING}

In the past, potential sources of radioactive emissions have been monitored at the BMRR, HFBR, Evaporator Facility, TPL, and BLIP. Because the BMRR and HFBR are permanently shut down and the Evaporator Facility has not processed any aqueous wastes since 2001, no particulate sampling was conducted at these facilities in 2006.

The samplers in the TPL exhaust duct and the exhaust stack for BLIP are equipped with glassfiber filters that capture samples of airborne particulate matter generated at these facilities (see Figure 4-3 for locations). The filters are collected and analyzed weekly for gross alpha and beta activity. Particulate filter analytical results for gross alpha and beta activity are reported in Table 4-2. The average gross alpha and beta airborne activity levels for samples collected from the BLIP exhaust stack were 0.1320 and 1.2226 $\mathrm{pCi} / \mathrm{m}^{3}$, respectively. Annual average gross alpha and beta airborne activity levels for samples collected from the TPL were 0.0053 and 0.0451 $\mathrm{pCi} / \mathrm{m}^{3}$, respectively.

\subsection{AMBIENT AIR MONITORING}

As part of the Environmental Monitoring Program, air monitoring stations are in place around the perimeter of the BNL site. Samples are collected using sampling equipment at six blockhouse stations and three pole-mounted samplers (see Figure 4-3 for locations). The blockhouses are fenced to control access and protect costly sampling equipment. In 2003, the number of pole-mounted, battery-powered silica-gel samplers used for airborne tritium monitoring was reduced from 16 to 3 . The elimination of redundant samplers was justified on the basis that historical air surveillance data after the shutdown of the HFBR and the BMRR revealed that, at most of the sampling stations, the tritium concentrations were below minimum detection limits (MDL) obtained on the day of analysis.

At each blockhouse, vacuum pumps draw air through columns, where particulate matter is captured on a glass-fiber filter and water vapor for tritium analysis is collected on silica-gel absorbent material. Particulate filters are col- 


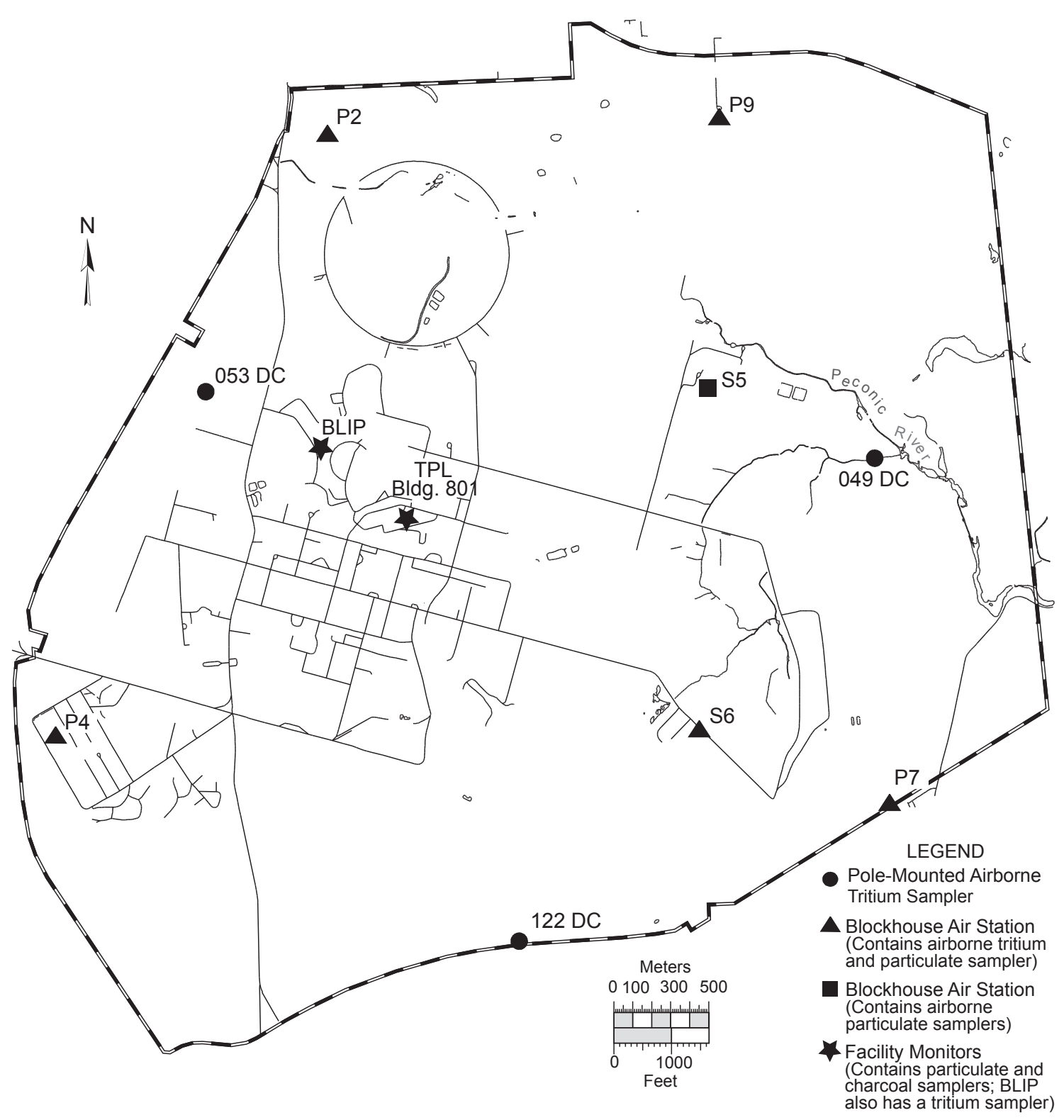

Figure 4-3. BNL On-Site Ambient Air Monitoring Stations.

lected weekly and are analyzed for gross alpha and beta activity using a gas-flow proportional counter. In 2006, silica-gel samples were collected every two weeks for processing by liquid scintillation analysis.

\subsection{Gross Alpha and Beta Airborne Activity}

Particulate filter analytical results for gross alpha and beta airborne activity are reported in Table 4-3. Validated samples are those not rejected due to equipment malfunction or other factors (e.g., sample air volumes were not acceptable). The annual average gross alpha and beta airborne activity levels for the six monitoring stations were 0.0016 and $0.0147 \mathrm{pCi} / \mathrm{m}^{3}$, respectively. Annual gross beta activity trends recorded at Station P7 are plotted in Figure 4-4. The results for this location are typical for the site. The trend shows seasonal variation in activity within a range that is representative of natural background levels. The New York State Department of Health (NYSDOH) received duplicate filter samples that were collected at Station P7 using a sampler they provided. These samples were collected weekly and analyzed by the NYSDOH laboratory for gross beta activ- 
Table 4-2. Gross Activity in Facility Air Particulate Filters.

\begin{tabular}{|c|c|c|c|}
\hline \multirow{2}{*}{\multicolumn{2}{|c|}{ Facility Monitor }} & Gross Alpha & Gross Beta \\
\hline & & \multicolumn{2}{|c|}{$-\left(\mathrm{pCi} / \mathrm{m}^{3}\right)-$} \\
\hline \multirow[t]{4}{*}{ BLIP } & $\mathrm{N}$ & 51 & 51 \\
\hline & Max. & $0.5080 \pm 0.2050$ & $2.6100 \pm 0.3650$ \\
\hline & Avg. & $0.1320 \pm 0.1167$ & $1.2226 \pm 0.2485$ \\
\hline & MDL & $0.1823^{*}$ & $0.3046^{*}$ \\
\hline \multirow[t]{4}{*}{ TPL - Bldg. 801} & $\mathrm{~N}$ & 50 & 50 \\
\hline & Max. & $0.0279 \pm 0.0145$ & $0.2110 \pm 0.0291$ \\
\hline & Avg. & $0.0053 \pm 0.0030$ & $0.0451 \pm 0.0064$ \\
\hline & MDL & $0.0040^{*}$ & $0.0067^{*}$ \\
\hline
\end{tabular}

Notes:

See Figure 4-3 for sampling station locations.

All values shown with a $95 \%$ confidence interval.

$\mathrm{BLIP}=$ Brookhaven Linac Isotope Producer

$\mathrm{MDL}=$ Minimum Detection Limit

$\mathrm{N}=$ Number of validated samples collected

TPL = Target Processing Laboratory

*Average MDL for all samples taken at this location

ity only. The analytical results NYSDOH found were comparable to the Station P7 samples analyzed by GEL Laboratories, an analytical laboratory contracted by BNL. New York State's analytical results for gross beta activity at BNL were between 0.0028 and $0.0232 \mathrm{pCi} / \mathrm{m}^{3}$, with an average concentration of $0.0100 \mathrm{pCi} / \mathrm{m}^{3}$. BNL results ranged from 0.0002 to 0.0248 $\mathrm{pCi} / \mathrm{m}^{3}$, with an average concentration of 0.0141 $\mathrm{pCi} / \mathrm{m}^{3}$. As part of a statewide monitoring program, NYSDOH also collects air samples in Albany, New York, a control location with no potential to be influenced by nuclear facility emissions. In 2006, NYSDOH reported that airborne gross beta activity at that location varied between 0.0030 and $0.0157 \mathrm{pCi} / \mathrm{m}^{3}$, and the average concentration was $0.0089 \mathrm{pCi} / \mathrm{m}^{3}$. Sample results measured at the Laboratory generally fell within this range, demonstrating that on-site radiological air quality was consistent with that observed at locations in New York State not located near radiological facilities.

\subsubsection{Airborne Tritium}

Airborne tritium in the form of HTO is monitored throughout the BNL site. In addition to the five blockhouses containing tritium samplers, three pole-mounted monitors used for tritium sampling are located at or near the
Table 4-3. Gross Activity Detected in Ambient Air Monitoring Particulate Filters.

\begin{tabular}{|c|c|c|c|}
\hline \multicolumn{2}{|c|}{$\begin{array}{l}\text { Sample } \\
\text { Station }\end{array}$} & \multirow{2}{*}{$\begin{array}{c}\text { Gross Alpha } \\
46\end{array}$} & \multirow{2}{*}{$\frac{\text { Gross Beta }}{}$} \\
\hline P2 & $\mathrm{N}$ & & \\
\hline & Max & $0.0030 \pm 0.0008$ & $0.0241 \pm 0.0019$ \\
\hline & Avg. & $0.0012 \pm 0.0005$ & $0.0119 \pm 0.0012$ \\
\hline & MDL & $0.0005^{\star}$ & $0.0009^{*}$ \\
\hline \multirow[t]{4}{*}{ P4 } & $\mathrm{N}$ & 39 & 39 \\
\hline & Max & $0.0133 \pm 0.0019$ & $0.0256 \pm 0.0016$ \\
\hline & Avg. & $0.0019 \pm 0.0007$ & $0.0150 \pm 0.0014$ \\
\hline & MDL & $0.0006^{*}$ & $0.0010^{*}$ \\
\hline \multirow[t]{4}{*}{ P7 } & $\mathrm{N}$ & 46 & 46 \\
\hline & Max & $0.0045 \pm 0.0009$ & $0.0248 \pm 0.0018$ \\
\hline & Avg. & $0.0016 \pm 0.0006$ & $0.0141 \pm 0.0013$ \\
\hline & MDL & $0.0006^{*}$ & $0.0010^{*}$ \\
\hline \multirow[t]{4}{*}{ P9 } & $\mathrm{N}$ & 46 & 46 \\
\hline & Max & $0.0038 \pm 0.0009$ & $0.0287 \pm 0.0028$ \\
\hline & Avg. & $0.0012 \pm 0.0006$ & $0.0125 \pm 0.0013$ \\
\hline & MDL & $0.0006^{*}$ & $0.0011^{*}$ \\
\hline \multirow[t]{4}{*}{ S5 } & $\mathrm{N}$ & 46 & 46 \\
\hline & Max & $0.0034 \pm 0.0009$ & $0.0294 \pm 0.00223$ \\
\hline & Avg. & $0.0016 \pm 0.0006$ & $0.0161 \pm 0.0015$ \\
\hline & MDL & $0.0006^{*}$ & $0.0010^{*}$ \\
\hline \multirow[t]{4}{*}{ S6 } & $\mathrm{N}$ & 48 & 48 \\
\hline & Max & $0.0170 \pm 0.0062$ & $0.1200 \pm 0.0124$ \\
\hline & Avg. & $0.0019 \pm 0.0008$ & $0.0184 \pm 0.0017$ \\
\hline & MDL & $0.0008^{*}$ & $0.0013^{*}$ \\
\hline \multicolumn{2}{|c|}{ Grand Average } & $0.0016 \pm 0.0002$ & $0.0147 \pm 0.0010$ \\
\hline \multicolumn{4}{|c|}{$\begin{array}{l}\text { Notes: } \\
\text { See Figure 4-3 for sampling station locations. } \\
\text { All values shown with a } 95 \% \text { confidence interval. } \\
M D L=\text { Minimum Detection Limit } \\
N=\text { Number of validated samples collected } \\
{ }^{*} \text { Average MDL for all samples taken at this location }\end{array}$} \\
\hline
\end{tabular}

property boundary (see Figure 4-3 for locations). Observed concentrations of tritium at the sampling stations in 2006 were comparable to concentrations observed in 2005. Table 4-4 lists the number of validated samples collected at each location, the maximum value observed, and the annual average concentration. Validated samples are those not rejected due to equipment malfunction or other factors (e.g., a battery failure in the sampler, frozen or supersaturated silica gel, insufficient sample volumes, or the 


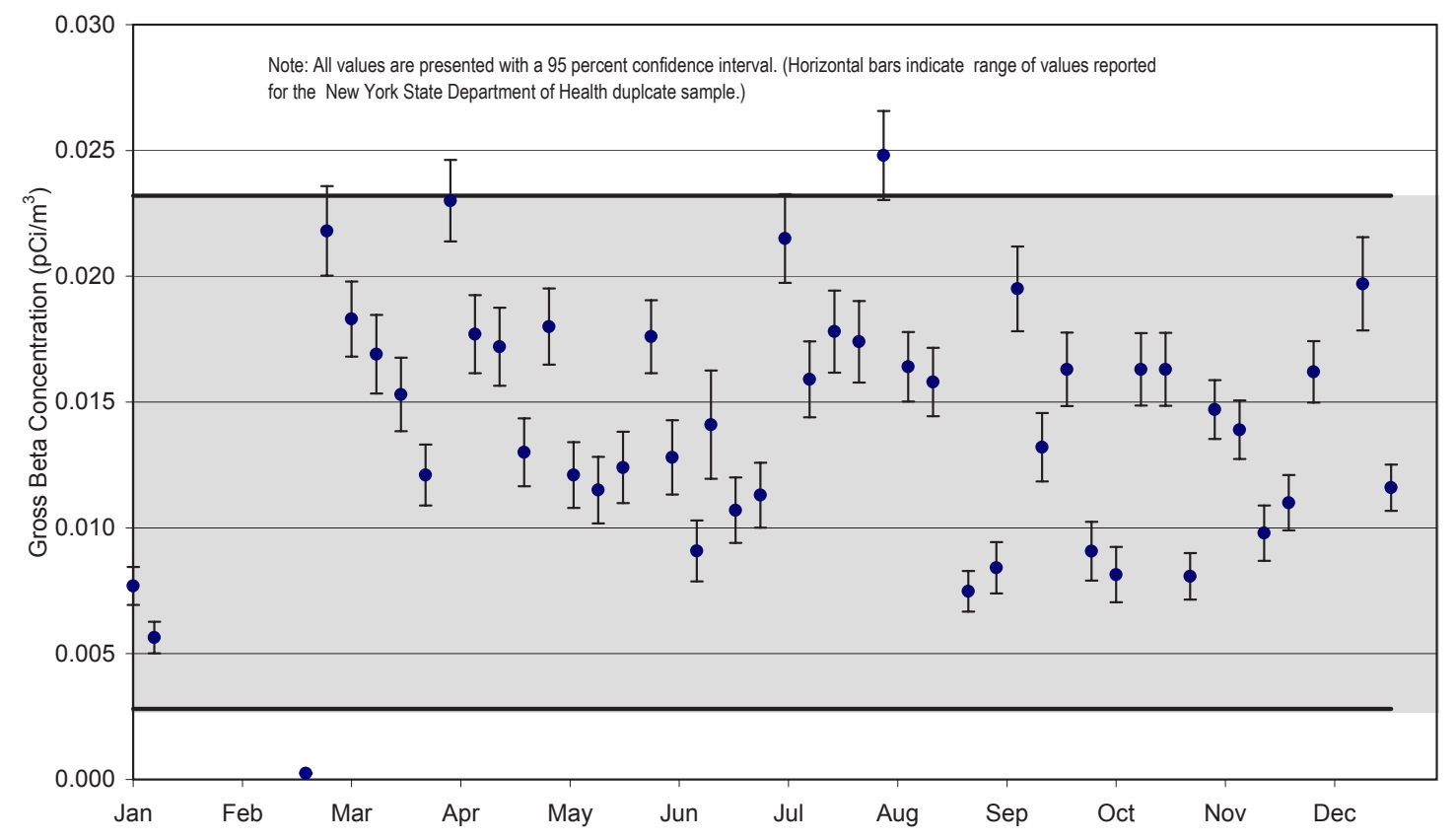

Figure 4-4. Airborne Gross Beta Concentration Trend Recorded at Station P7.

loss of sample during preparation at the contract analytical laboratory). Airborne tritium samples were collected every two weeks from each sampling station during 2006. The average tritium concentrations at all of the sampling locations were less than the typical MDL, which ranged from 1.0 to $9.0 \mathrm{pCi} / \mathrm{m}^{3}$. The collected data demonstrate that there were no significant differences in ambient tritium concentrations on site or at the site boundary.

\subsection{NONRADIOLOGICAL AIRBORNE EMISSIONS}

Various state and federal regulations governing nonradiological releases require facilities to conduct periodic or continuous emission monitoring to demonstrate compliance with emission limits. The Central Steam Facility (CSF) is the only BNL facility that requires monitoring for nonradiological emissions. The Laboratory has several other emission sources subject to state and federal regulatory requirements that do not require emission monitoring (see Chapter 3 for more details). The CSF supplies steam for heating and cooling to major BNL facilities through an underground steam distribution and condensate grid. The location of the CSF is shown in Figure 4-1. The combustion units at the CSF are designated as Boilers 1A, 5, 6, and 7. Boiler 1A, which was installed in 1962, has a heat input of 16.4 MW (56.7 million British thermal units [MMBtu] per hour). Boiler 5, installed in 1965, has a heat input of 65.3 MW (225 MMBtu/hr). The newest units, Boilers 6 and 7, were installed in 1984 and 1996, and each has a heat input of

Table 4-4. Ambient Airborne Tritium Measurements in 2006.

\begin{tabular}{|c|c|c|c|c|}
\hline $\begin{array}{l}\text { Sample } \\
\text { Station }\end{array}$ & $\begin{array}{l}\text { Wind } \\
\text { Sector }\end{array}$ & $\begin{array}{l}\text { Validated } \\
\text { Samples }\end{array}$ & \multicolumn{2}{|c|}{$-\left(\mathrm{pCi} / \mathrm{m}^{3}\right)-$} \\
\hline 049 & $E$ & 21 & $59.9 \pm 7.1$ & $3.1 \pm 6.1$ \\
\hline 053 & NW & 18 & $10.3 \pm 6.5$ & $1.3 \pm 1.7$ \\
\hline 122 & SSE & 20 & $4.1 \pm 4.6$ & $-0.7 \pm 1.4$ \\
\hline P2 & NNW & 22 & $12.3 \pm 3.5$ & $0.7 \pm 1.7$ \\
\hline P4 & WSW & 21 & $11.4 \pm 3.9$ & $-0.4 \pm 2.0$ \\
\hline P7 & ESE & 22 & $14.4 \pm 2.8$ & $0.9 \pm 1.7$ \\
\hline P9 & NE & 21 & $27.8 \pm 5.9$ & $2.0 \pm 2.7$ \\
\hline S6 & SE & 23 & $10.5 \pm 3.3$ & $0.6 \pm 1.5$ \\
\hline \multicolumn{4}{|c|}{ Grand Average } & $0.9 \pm 1.0$ \\
\hline \multicolumn{5}{|c|}{$\begin{array}{l}\text { Notes: } \\
\text { See Figure } 4-3 \text { for sampling station locations. } \\
\text { Wind sector is the downwind direction of the sample station from the } \\
\text { HFBR stack. } \\
\text { All values reported with a } 95 \% \text { confidence interval. } \\
\text { Typical minimum detection limit for tritium is between } 1.0 \text { and } 9.0 \\
\mathrm{pCi} / \mathrm{m}^{3} \text {. } \\
\text { DOE Order } 5400.5 \text { Air Derived Concentration Guide is } 100,000 \mathrm{pCi} / \mathrm{m}^{3} \text {. }\end{array}$} \\
\hline
\end{tabular}


42.6 MW (147 MMBtu/hr). For perspective, Keyspan's Northport, New York power station has four utility-sized turbine/generator boilers, each with a maximum rated heat input of 1,082 MW (3,695 MMBtu/hr).

Because of their design, heat inputs, and dates of installation, Boilers 6 and 7 are subject to Title 6 of the New York Code, Rules, and Regulations (NYCRR) Part 227-2, and the Federal New Source Performance Standard (40 CFR 60 Subpart Db: Standards of Performance for Industrial-Commercial-Institutional Steam Boilers). Therefore, these boilers are equipped with continuous emission monitors to measure nitrogen oxides $\left(\mathrm{NO}_{\mathrm{x}}\right)$. Boiler 7 was already equipped with a continuous opacity monitor to comply with Subpart Db opacity monitoring requirements, and after a new continuous opacity monitor for Boiler 6 was voluntarily brought online in 2004, emissions on both boilers are now continuously monitored for opacity. To measure combustion efficiency, the boilers are also monitored for carbon dioxide $\left(\mathrm{CO}_{2}\right)$. Continuous emission monitoring results from the two boilers are reported quarterly to EPA and the New York State Department of Environmental Conservation.

From May 1 to September 15 (the peak ozone period), compliance with the $0.30 \mathrm{lbs} / \mathrm{MMBtu}$ $(129 \mathrm{ng} / \mathrm{J}) \mathrm{NO}_{\mathrm{x}}$ emission standard for No. 6 oil and the $0.20 \mathrm{lbs} / \mathrm{MMBtu}(86 \mathrm{ng} / \mathrm{J}) \mathrm{NO}_{\mathrm{x}}$ emission standard for No. 2 oil and natural gas is demonstrated by calculating the 24-hour average emission rate from continuous emission monitoring system readings and comparing the value to the emission standard. The remainder of the year, the calculated 30-day rolling average emission rate is used to establish compliance. Boiler 7 opacity levels are recorded as 6-minute averages. Measured opacity levels cannot exceed 20 percent opacity, except for one 6-minute period per hour of not more than 27 percent opacity. In 2006, there were no measured exceedances of the $\mathrm{NO}_{\mathrm{x}}$ emission standards for either boiler. During the year, all of the Boiler 6 and Boiler 7 opacity measurements that exceeded the opacity limit occurred during boiler startups or shutdowns, or during necessary calibrations of the monitoring system. Changes in the sequence of the soot blowing cycle for Boiler 6 that were

Table 4-5. Central Steam Facility Fuel Use and Emissions (1996 - 2006).

\begin{tabular}{|c|c|c|c|c|c|c|c|c|c|c|}
\hline \multicolumn{7}{|c|}{ Annual Fuel Use and Fuel Heating Values } & \multicolumn{4}{|c|}{ Emissions } \\
\hline Year & $\begin{array}{l}\text { No. } 6 \text { Oil } \\
\text { (103 gals) }\end{array}$ & $\begin{array}{l}\text { Heating } \\
\text { Value } \\
\text { (MMBtu) }\end{array}$ & $\begin{array}{l}\text { No. } 2 \text { Oil } \\
\text { (103 gals) }\end{array}$ & $\begin{array}{l}\text { Heating } \\
\text { Value } \\
\text { (MMBtu) }\end{array}$ & $\begin{array}{c}\text { Natural Gas } \\
\qquad\left(106 \mathrm{ft}^{3}\right)\end{array}$ & $\begin{array}{l}\text { Heating Value } \\
\text { (MMBtu) }\end{array}$ & TSP & $\mathrm{NO}_{\mathrm{x}}$ & s) & VOCs \\
\hline 1996 & $4,782.55$ & 703,991 & 52.77 & 7,388 & 0.00 & 0 & 14.0 & 104.9 & 109.0 & 0.7 \\
\hline 1997 & $3,303.43$ & 484,613 & 10.23 & 1,432 & 190.65 & 194,463 & 13.7 & 83.5 & 75.1 & 1.0 \\
\hline 1998 & 354.28 & 52,283 & 9.44 & 1,322 & 596.17 & 608,093 & 2.7 & 75.1 & 8.9 & 1.7 \\
\hline 1999 & 682.76 & 78,335 & 2.77 & 388 & 614.98 & 627,280 & 5.1 & 53.5 & 16.7 & 1.8 \\
\hline 2000 & $2,097.32$ & 309,317 & 0.82 & 115 & 342.40 & 349,248 & 9.5 & 81.6 & 45.0 & 1.2 \\
\hline 2001 & $3,645.10$ & 538,847 & 3.40 & 476 & 103.96 & 106,039 & 17.5 & 80.4 & 77.8 & 0.8 \\
\hline 2002 & $2,785.04$ & 407,518 & 0.29 & 41 & 220.62 & 225,030 & 15.4 & 62.4 & 53.8 & 1.0 \\
\hline 2003 & $4,290.94$ & 628,765 & 402.06 & 56,288 & 0.98 & 1,000 & 22.8 & 75.3 & 107.1 & 0.6 \\
\hline 2004 & $4,288.76$ & 628,063 & 2.45 & 343 & 0.11 & 109 & 16.4 & 81.9 & 104.7 & 2.4 \\
\hline 2005 & $4,206.12$ & 618,590 & 0.87 & 122 & 0.00 & 0 & 15.2 & 80.4 & 93.1 & 2.4 \\
\hline 2006 & $2,933.00$ & 432,430 & 0.22 & 30 & 191.35 & 195,177 & 11.8 & 66.9 & 66.3 & 2.2 \\
\hline \multicolumn{3}{|c|}{ Permit Limit (in tons) } & & & & & 113.3 & 159.0 & 445.0 & 39.7 \\
\hline \multicolumn{11}{|c|}{$\begin{array}{l}\text { Notes: } \\
\mathrm{NO}_{x}=\text { Oxides of Nitrogen } \\
\mathrm{SO}_{2}=\text { Sulfur Dioxide } \\
\text { TSP = Total Suspended Particulates } \\
\text { VOCs = Volatile Organic Compounds }\end{array}$} \\
\hline
\end{tabular}


made in August 2005 have proven effective in eliminating opacity exceedances due to soot blowing. Similar changes made to the soot blowing cycle on Boiler 7 after the installation of a new soot blowing controller in March 2006 have been successful in eliminating soot blowing opacity exceedances on that boiler, as well. While there are no regulatory requirements to continuously monitor opacity for Boilers $1 \mathrm{~A}$ and 5, surveillance monitoring of visible stack emissions is a condition of BNL's Title V operating permit. Daily observations of stack gases recorded by CSF personnel throughout the year showed no visible emissions with opacity levels exceeding the regulatory limits established for these boilers.

To satisfy periodic testing requirements of the Laboratory's Title V operating permit, emission tests of Boilers 1A, 6, and 7 were completed in October 2006, and required emission tests of Boiler 5 were conducted in December 2006. The purpose of the tests was to certify compliance of Boilers 1A and 5 with Part 227-2 emission standards for $\mathrm{NO}_{x}$ and to certify compliance of all four boilers with Part 227.2(b)(1) emission standards for particulates. Results of the $\mathrm{NO}_{\mathrm{x}}$ emission tests of Boiler $1 \mathrm{~A}$ and $5 \mathrm{dem}-$ onstrated that flue gas emissions of $\mathrm{NO}_{\mathrm{x}}$ from both boilers while combusting residual fuel at low, moderate, and high load conditions were well below the Part 227-2 $\mathrm{NO}_{\mathrm{x}}$ standard of 0.3 lbs/MMBtu. Similarly, results of separate tests of Boiler 5 while burning natural gas at low, medium, and high operating loads showed flue gas emissions of $\mathrm{NO}_{\mathrm{x}}$ to be less than the corresponding Part 227-2 emission standard of 0.2 lbs/MMBtu. Meanwhile, the average particulate emissions from three test runs of Boilers 1A, 5,6 , and 7 at low, medium, and high operating loads while burning residual fuel were 0.063 , $0.084,0.026$, and $0.051 \mathrm{lbs} / \mathrm{MMBtu}$, respec- tively; all readings are less than the emission standard of $0.1 \mathrm{lbs} / \mathrm{MMBtu}$.

In 2006, residual fuel prices from June to October exceeded those of natural gas. As a result, natural gas was used to supply more than 84 percent of the heating and cooling needs of BNL's major facilities during these months. Throughout the year, natural gas supplied approximately 31 percent of major facility heating and cooling needs. By comparison, in 2004 and 2005, residual fuel satisfied more than 99.9 percent of the major facility heating and cooling needs. Consequently, 2006 emissions of particulates, $\mathrm{NO}_{\mathrm{x}}$, and sulfur dioxide $\left(\mathrm{SO}_{2}\right)$ were 3.4 , 13.5, and 26.8 tons less than the respective totals for 2005. All emissions were well below the respective permit limits of $113.3,159$, and 445 tons. Table 4-5 shows fuel use and emissions since 1996.

\section{REFERENCES AND BIBLIOGRAPHY}

40 CFR 60 Subpart Db. Standards of Performance for IndustrialCommercial-Institutional Steam Boilers. 52 FR 47842, Dec. 16, 1987, as amended 7I FR 33400, June 9, 2006.

40 CFR 6 I Subpart H. National Emission Standards for Emissions of Radionuclides OtherThan Radon From Department of Energy Facilities. 54 FR 51695, Dec. 15, 1989, as amended at 67 FR 57|66, Sept. 9, 2002

DOE Order 5400.5. 1990. Radiation Protection of the Public and the Environment. U.S. Department of Energy, Washington, DC. Change 2: 1-7-93.

NYCRR Part 227-2. Title 6. Reasonably Available Control Technology for Oxides of Nitrogen. New York State Department of Environmental Conservation, Albany, NY. Amended I-2804.

Shlein, Bernard, et al., eds. 1998. Handbook of Health Physics and Radiological Health, Third Edition. Williams and Wilkins, Baltimore, MD.

SCDHS. 1993. Suffolk County Sanitary Code Article 12: Toxic and Hazardous Material Storage and Handling Controls. Suffolk County Department of Health Services, New York.

USC Title 42, Chapter 85. Air Pollution Prevention and Control (Clean Air Act), 1990. 


\section{Water Quality}

Wastewater generated from Brookhaven National Laboratory operations is discharged to surface waters via the Sewage Treatment Plant and to groundwater via recharge basins. Some wastewater may contain very low levels of radiological, organic, or inorganic contaminants. Monitoring, pollution prevention, and vigilant operation of treatment facilities ensure that these discharges comply with all applicable requirements and that the public, employees, and environment are protected.

Analytical data for 2006 show that the average gross alpha and beta activity levels in the Sewage Treatment Plant discharge were within the typical range of historical levels and were well below drinking water standards. Tritium releases to the Peconic River continued to decline and were the lowest ever recorded. The maximum concentration of tritium released was approximately 7.5 percent of the drinking water standard. Analysis of the Sewage Treatment Plant effluent continued to show no detection of cesium-137, strontium-90, or other gamma-emitting nuclides attributable to BNL operations. For most of the year, tritium was not detected at the influent or effluent. However, from December 1 -December 15, low concentrations of tritium were detected at both the influent and effluent. Tritium was not detected downstream of the Sewage Treatment Plant discharge for all of 2006.

Nonradiological monitoring of effluent showed that, except for isolated incidents of noncompliance, organic and inorganic parameters were within State Pollutant Discharge Elimination System effluent limitations or other applicable standards. Inorganic data from Peconic River samples collected upstream, downstream, and at control locations demonstrated that elevated amounts of aluminum and iron detected in the river are associated with natural sources.

\section{I SURFACE WATER MONITORING PROGRAM}

Treated wastewater from the BNL Sewage Treatment Plant (STP) is discharged into the headwaters of the Peconic River. This discharge is permitted under the New York State Department of Environmental Conservation (NYSDEC) State Pollutant Discharge Elimination System (SPDES) Program. Effluent limits are based on the water quality standards established by NYSDEC, as well as historical operational data. To assess the impact of wastewater discharge on the quality of the river, surface water is monitored at several locations upstream and downstream of the discharge point. Monitoring Station HY (see Figure 5-8), on site but upstream of all Laboratory operations, provides information on the "background" water quality of the Peconic River. The Carmans River is monitored as a geographic control location for comparative purposes, as it is not affected by operations at BNL.

On the Laboratory site, the Peconic River is an intermittent stream. Off-site flow occurs only during periods of sustained precipitation, typically in the spring. Due to the unusually wet fall of 2005, flow was consistent throughout 2006. The following sections describe BNL's surface water monitoring and surveillance program.

\subsection{SANITARY SYSTEM EFFLUENTS}

The STP effluent (Outfall 001) is a discharge point operated under a SPDES permit issued by NYSDEC. Figure 5-1 shows a schematic of the 


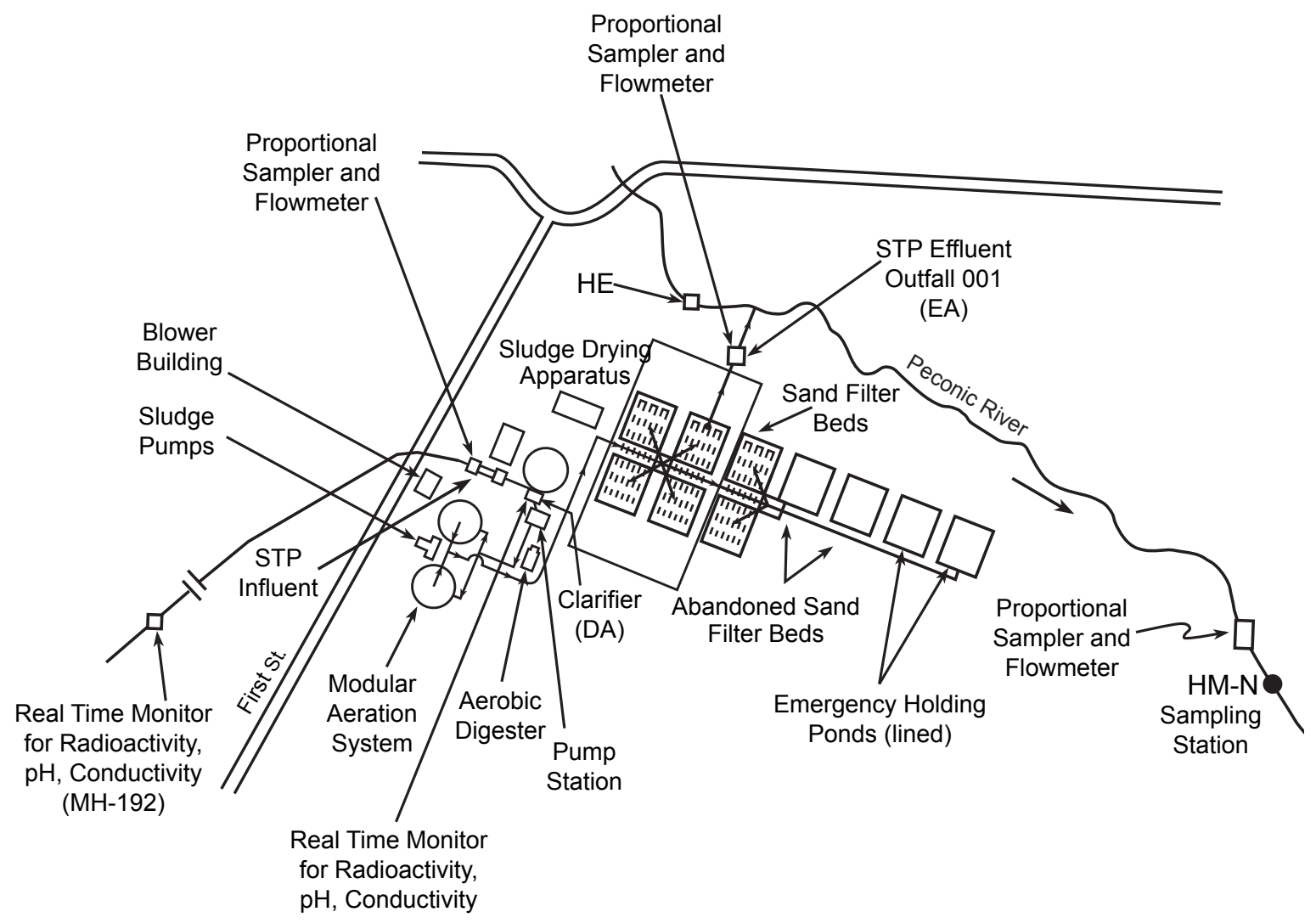

Figure 5-I. Schematic of BNL's Sewage Treatment Plant (STP).

STP and its sampling locations. The Laboratory's STP treatment process includes five steps: 1) primary clarification to remove settleable solids and floatable materials, 2) aerobic oxidation for secondary removal of biological matter and nitrification of ammonia, 3) secondary clarification, 4) sand filtration for final solids removal, and 5) ultraviolet disinfection for bacterial control prior to discharge to the Peconic River. Tertiary treatment for nitrogen removal is also provided by controlling the oxygen levels in the aeration tanks. During the aeration process (Step 2), the oxygen levels are allowed to drop to the point where microorganisms use nitrate-bound oxygen for respiration; this liberates nitrogen gas and consequently reduces the concentration of nitrogen in the STP discharge. In October 2006, changes were made to the treatment process. The primary clarifier was removed from the treatment sequence to permit the entry of all waste products into the aeration process. This change was necessary to enhance nitrogen removal by providing more nutrients for the biological organisms to be used during the denitrification step. Data collected in November and December showed this change to be effective.

Nitrogen is an essential nutrient in biological systems that, in high concentrations, can cause excessive aquatic vegetation growth. During the night (when photosynthesis does not occur), aquatic plants use oxygen in the water. Too much oxygen uptake by aquatic vegetation deprives a water system of oxygen needed by fish and other aquatic organisms for survival. Limiting the concentration of nitrogen in the STP discharge helps keep plant growth in the Peconic River in balance with the nutrients provided by natural sources.

Real-time monitoring of the sanitary waste stream for radioactivity, $\mathrm{pH}$, and conductivity takes place at two locations. The first site (MH-192, see Figure 5-1) is approximately 1.1 miles upstream of the STP, providing at least 30 minutes' warning to the STP operators if wastewater is en route that may exceed SPDES 
limits or BNL effluent release criteria (which are more stringent than DOE-specified levels). The second site is at the point where the STP influent enters the primary clarifier, as shown in Figure 5-1.

Based on the data collected by the real-time monitoring systems, any influent to the clarifier that may not meet SPDES limits or BNL effluent release criteria (whichever is more stringent) is diverted to two double-lined holding ponds. The total combined capacity of the two holding ponds exceeds 7 million gallons, or approximately 21 days of flow. Diversion continues until the effluent's water quality meets the permit limits or release criteria. If wastewater is diverted to the holding ponds, it is tested and evaluated against the requirements for release. If necessary, the wastewater is treated and then reintroduced into the STP at a rate that ensures compliance with SPDES permit limits for nonradiological parameters or BNL effluent release criteria for radiological parameters. In 2006, the STP influent was diverted once in July in response to a release of acetonitrile from a research facility. This release could have resulted in a violation of the Laboratory's SPDES permit. The diverted wastewater was reintroduced to the plant after analytical results showed the concentration of acetonitrile to be less than New York State water quality standards.

Solids separated in the clarifiers are pumped to an aerobic digester for solids reduction. Sludge is periodically emptied into solar/heat lamp-powered drying beds, where it is dried to a semisolid cake. The dried sludge contains extremely low levels (less than $0.5 \mathrm{pCi} / \mathrm{g}$ ) of radioactivity, such as residual levels of cobalt- 60 (Co-60: half-life 5.2 years) from historic sewage releases. The dried sludge is put into containers for off-site disposal at an authorized facility.

\subsection{Sanitary System Effluent-Radiological Analyses}

Wastewater at the STP is sampled at the output of the primary clarifier, Station DA (see Figure 5-2) and at the Peconic River Outfall (Station EA). At each location, samples are collected on a flow-proportional basis; that is, for every 1,000 gallons of water treated, ap- proximately 4 fluid ounces of sample are collected and composited into a 5-gallon collection container. These samples are analyzed for gross alpha and gross beta activity and for tritium concentrations. Samples were collected three times weekly. Samples collected from these locations are also composited and analyzed monthly for gamma-emitting radionuclides and strontium-90 (Sr-90: half-life 29 years).

Although the Peconic River is not used as a direct source of potable water, the Laboratory applies the stringent Safe Drinking Water Act (SDWA) standards for comparison purposes when monitoring the effluent, in lieu of DOE wastewater criteria. Under the SDWA, water standards are based on a 4 mrem $(40 \mu \mathrm{Sv})$ dose limit. The SDWA specifies that no individual may receive an annual dose greater than 4 mrem from radionuclides that are beta or photon emitters. Beta/photon emitters include up to 168 individual radioisotopes. The Laboratory performs radionuclide-specific gamma analysis to ensure compliance with this standard. The SDWA annual average gross alpha activity limit is $15 \mathrm{pCi} / \mathrm{L}$, including radium-226 ( $\mathrm{Ra}-226$ : half-life 1,600 years) but excluding radon and uranium. Other SDWA-specified drinking water limits are 20,000 pCi/L for tritium (H-3: halflife 12.3 years), $8 \mathrm{pCi} / \mathrm{L}$ for $\mathrm{Sr}-90,5 \mathrm{pCi} / \mathrm{L}$ for Ra-226 and radium-228 (Ra-228: half-life 5.75 years), and $30 \mu \mathrm{g} / \mathrm{L}$ for uranium. Gross activity (alpha and beta) measurements are used as a screening tool for detecting the presence of radioactivity. Table 5-1 shows the monthly gross alpha and beta activity data and tritium concentrations for the STP influent and effluent during 2006. Annual average gross alpha and beta activity levels in the STP effluent were $0.5 \pm 0.1$ $\mathrm{pCi} / \mathrm{L}$ and $5.0 \pm 0.2 \mathrm{pCi} / \mathrm{L}$, respectively. Control location data (Carmans River Station HH; see Figure 5-8 for location) show average gross alpha and beta levels of $0.34 \pm 0.47 \mathrm{pCi} / \mathrm{L}$ and $1.3 \pm 0.31 \mathrm{pCi} / \mathrm{L}$, respectively (see Table $5-7$ ).

Tritium detected at the STP originates from either High Flux Beam Reactor (HFBR) sanitary system releases, or from small, infrequent batch releases that meet BNL discharge criteria from other facilities. Although the HFBR is no longer operating, tritium continues to be 
Table 5-1. Tritium and Gross Beta Activity in Water at the BNL Sewage Treatment Plant (STP).

\begin{tabular}{|c|c|c|c|c|c|c|c|c|}
\hline & & Flow (a) & Trit & (pCi/L) & Gross A & $\mathrm{a}(\mathrm{pCi} / \mathrm{L})$ & Gross B & (pCi/L) \\
\hline & & (Liters) & $\max$. & avg. & $\max$. & avg. & max. & avg. \\
\hline January & influent & $4.33 E+7$ & $<340$ & $18.6 \pm 97.3$ & $<1.7$ & $0.6 \pm 0.3$ & $11.9 \pm 1.9$ & $5.2 \pm 1.5$ \\
\hline & effluent & $3.94 \mathrm{E}+7$ & $<360$ & $-55 \pm 96.4$ & $<1.4$ & $0.2 \pm 0.2$ & $6.9 \pm 1.4$ & $4.1 \pm 0.8$ \\
\hline February & influent & $3.58 \mathrm{E}+7$ & $<420$ & $1.7 \pm 65.7$ & $<1.1$ & $0.3 \pm 0.2$ & $7.2 \pm 1.6$ & $4.8 \pm 0.6$ \\
\hline & effluent & $3.16 \mathrm{E}+7$ & $<330$ & $-1.5 \pm 86.3$ & $<1.0$ & $0.2 \pm 0.2$ & $5.7 \pm 1.5$ & $4.2 \pm 0.4$ \\
\hline March & influent & $4.33 \mathrm{E}+7$ & $<300$ & $7.9 \pm 88.9$ & $2.0 \pm 1.2$ & $0.5 \pm 0.3$ & $8.8 \pm 1.8$ & $6.1 \pm 0.8$ \\
\hline & effluent & $3.58 \mathrm{E}+7$ & $<300$ & $-19.9 \pm 76.9$ & $<1.1$ & $0.3 \pm 0.2$ & $6.7 \pm 1.5$ & $5.3 \pm 0.4$ \\
\hline April & influent & $4.21 \mathrm{E}+7$ & $<340$ & $-69.7 \pm 48.4$ & $3.6 \pm 1.2$ & $1.3 \pm 0.6$ & $16.4 \pm 2.5$ & $7.1 \pm 1.9$ \\
\hline & effluent & $3.46 \mathrm{E}+7$ & $<340$ & $-49.2 \pm 75.8$ & $2.0 \pm 1.2$ & $0.6 \pm 0.3$ & $12.1 \pm 2.0$ & $5.6 \pm 1.3$ \\
\hline May & influent & $4.21 \mathrm{E}+7$ & $<360$ & $-113 \pm 59.9$ & $<2.0$ & $0.6 \pm 0.2$ & $6.9 \pm 1.7$ & $5.4 \pm 0.6$ \\
\hline & effluent & $3.93 E+7$ & $<360$ & $-92.1 \pm 67.1$ & $<1.4$ & $0.4 \pm 0.2$ & $11.6 \pm 2.0$ & $5.7 \pm 1.2$ \\
\hline June & influent & 4.44E+7 & $<350$ & $-77.7 \pm 51.9$ & $1.8 \pm 1.0$ & $0.8 \pm 0.2$ & $7.4 \pm 1.6$ & $5.1 \pm 0.8$ \\
\hline & effluent & $4.71 \mathrm{E}+7$ & $<350$ & $-42.6 \pm 72.1$ & $1.3 \pm 0.9$ & $0.5 \pm 0.2$ & $8.8 \pm 1.7$ & $5.5 \pm 0.8$ \\
\hline July & influent & $4.95 \mathrm{E}+7$ & $<370$ & $31.3 \pm 83.8$ & $4.3 \pm 1.4$ & $1.2 \pm 0.7$ & $8.7 \pm 1.7$ & $5.6 \pm 0.8$ \\
\hline & effluent & $4.09 \mathrm{E}+7$ & $<340$ & $41.1 \pm 62.3$ & $1.2 \pm 0.8$ & $0.6 \pm 0.2$ & $6.1 \pm 1.5$ & $4.9 \pm 0.3$ \\
\hline August & influent & $4.89 \mathrm{E}+7$ & $<330$ & $8.7 \pm 62.3$ & $2.5 \pm 1.3$ & $1.0 \pm 0.3$ & $6.8 \pm 1.5$ & $4.4 \pm 0.8$ \\
\hline & effluent & $4.00 \mathrm{E}+6$ & $<350$ & $44.3 \pm 70.7$ & $<1.3$ & $0.6 \pm 0.1$ & $11.5 \pm 1.8$ & $5.1 \pm 1.1$ \\
\hline September & influent & $2.95 \mathrm{E}+7$ & $<360$ & $64.3 \pm 37.6$ & $1.7 \pm 1.1$ & $0.7 \pm 0.3$ & $8.6 \pm 1.7$ & $5.4 \pm 0.6$ \\
\hline & effluent & $3.08 \mathrm{E}+7$ & $<220$ & $37.8 \pm 33.5$ & $1.6 \pm 1.2$ & $0.4 \pm 0.3$ & $5.7 \pm 1.4$ & $4.9 \pm 0.3$ \\
\hline October & influent & $3.13 E+7$ & $380 \pm 220$ & $-0.8 \pm 79.8$ & $2.3 \pm 1.2$ & $0.5 \pm 0.4$ & $7.6 \pm 1.7$ & $4.6 \pm 0.8$ \\
\hline & effluent & $2.93 E+7$ & $<380$ & $-12.4 \pm 35$ & $<1.3$ & $0.2 \pm 0.2$ & $6.2 \pm 1.5$ & $4.5 \pm 0.5$ \\
\hline November & influent & $3.60 \mathrm{E}+7$ & $<340$ & $-69.2 \pm 96.9$ & $11.0 \pm 3.3$ & $3.0 \pm 1.6$ & $11.2 \pm 2.5$ & $6.1 \pm 1.1$ \\
\hline & effluent & $3.40 \mathrm{E}+7$ & $<300$ & $-38.3 \pm 66.6$ & $2.0 \pm 1.2$ & $0.7 \pm 0.4$ & $6.2 \pm 1.5$ & $4.6 \pm 0.5$ \\
\hline December & influent & $2.45 E+7$ & $3430 \pm 630$ & $722.3 \pm 559.1$ & $38.0 \pm 11.0$ & $7.4 \pm 5.6$ & $25.0 \pm 5.4$ & $8.6 \pm 3.2$ \\
\hline & effluent & $2.42 \mathrm{E}+7$ & $1470 \pm 330$ & $587.7 \pm 298.4$ & $2.3 \pm 1.8$ & $0.8 \pm 0.4$ & $6.5 \pm 1.5$ & $5.0 \pm 0.6$ \\
\hline Annual Avg. & influent & & & $44.1 \pm 59.5$ & & $1.5 \pm 0.6$ & & $5.7 \pm 0.4$ \\
\hline & effluent & & & $33.3 \pm 41.1$ & & $0.5 \pm 0.1$ & & $5.0 \pm 0.2$ \\
\hline Total Release & & $4.31 \mathrm{E}+8$ & & $6.1 \mathrm{mCi}$ & & $0.2 \mathrm{mCi}$ & & $2 \mathrm{mCi}$ \\
\hline Average MDL & & & & 353 & & 1.4 & & 1.9 \\
\hline SDWA Limit ( & & & & 20,000 & & 15 & & (b) \\
\hline $\begin{array}{l}\text { Notes: } \\
\text { All values are re } \\
\text { Negative numbe } \\
\text { To convert value } \\
\text { MDL = Minimum } \\
\text { SDWA = Safe D } \\
\text { (a) Effluent val } \\
\text { (b) The drinkin } \\
\text { specific rad }\end{array}$ & $\begin{array}{l}\text { with a } 95 \% \\
\text { r when the } \\
\text { oCi to Bq, d } \\
\text { ion Limit } \\
\text { Water Act } \\
\text { ter than inf } \\
\text { standards w } \\
\text { s, a dose } 6\end{array}$ & $\begin{array}{l}\text { nce interval. } \\
\text { ed value is lo } \\
27.03 \text {. } \\
\text { lues occur w } \\
\text { nged from } 5 \\
\text { nt cannot be }\end{array}$ & $\begin{array}{l}\text { water that had } \\
\mathrm{i} / \mathrm{L} \text { (concentrati } \\
\text { culated for the }\end{array}$ & $\begin{array}{l}\text { Appendix B for } \\
\text { diverted to the h } \\
\text { ased) to } 4 \mathrm{mrem} / \mathrm{y} \\
\text { s in the table. }\end{array}$ & $\begin{array}{l}\text { scription). } \\
\text { gg ponds is test } \\
\text { lose based) in le }\end{array}$ & $\begin{array}{l}\text { treated (if ne } \\
003 \text {. As gros }\end{array}$ & $\begin{array}{l}\text { y), and releas } \\
\text { activity does }\end{array}$ & dentify \\
\hline
\end{tabular}


released from the facility at very low concentrations, due to off-gassing. When the HFBR was operating, air within the reactor building contained higher levels of tritium in the form of water vapor. The water was absorbed by many porous surfaces and materials, which slowly liberate the tritiated moisture as it is replaced by untritiated water. Once tritium is in the air stream, it condenses as a component of water vapor in the air conditioning or air compressor units and is discharged in these wastewater streams. To minimize the quantity of tritium released to the STP, efforts have been made to capture most of the air conditioning condensate collected on the equipment level of the HFBR. A plot of the 2006 tritium concentrations recorded in the STP effluent is presented in Figure 5-2. A 15-year trend plot of annual average tritium concentrations measured in the STP discharge is shown in Figure 5-3. The annual average concentration trend has been declining since 1995.

In 2006, a total of $0.006 \mathrm{Ci}(6 \mathrm{mCi})$ of tritium was released during the year (see Figure 5-4). The annual average tritium concentration, as measured in the STP effluent (EA, Outfall 001), was $33 \pm 41 \mathrm{pCi} / \mathrm{L}$; more than 50 percent less than that recorded for 2005 and well below the drinking water standard (DWS) of 20,000 $\mathrm{pCi} / \mathrm{L}$. The 2006 average value is approximately one-tenth of the average minimum detec- tion limit (MDL) of $307 \mathrm{pCi} / \mathrm{L}$. The maximum concentration detected in the STP discharge (see Figure 5-2) was $1,470 \pm 330 \mathrm{pCi} / \mathrm{L}$. The maximum release occurred in December, which was unusual because summer-time evaporative losses typically produce the highest results. An investigation was conducted to ascertain the tritium source. The investigation did not reveal any single source of high concentration tritium, but did identify several low-concentration sources, which when combined, may have resulted in this observation. Low concentration releases of this magnitude are expected to continue as facilities such as the HFBR and BMRR are placed into routine surveillance mode and piping and tank systems are drained and dried out.

Table 5-2 presents the gamma spectroscopy analytical data for anthropogenic radionuclides historically detected in the monthly STP wastewater composite samples. During 2006, there were no gamma-emitting nuclides detected in the STP effluent, which is consistent with the data reported for 2003 - 2005 (see Figure 5-5). Sr-90 also was not detected in 2006.

\subsubsection{Sanitary System Effluent-Nonradiological Analyses}

In addition to the compliance monitoring discussed in Chapter 3, effluent from the STP is also monitored for nonradiological

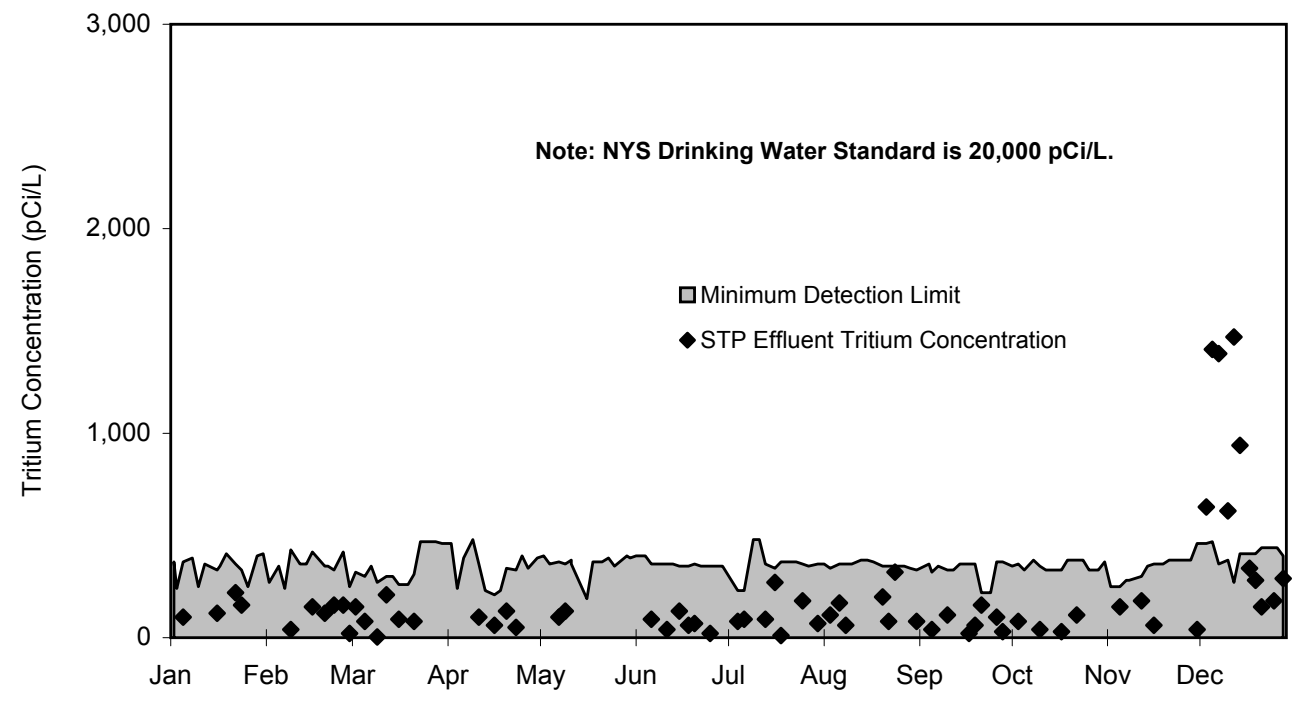

Figure 5-2. Tritium Concentrations in Effluent from the BNL Sewage Treatment Plant (2006). 
Figure 5-3.

Sewage Treatment

Plant/Peconic

River Annual

Average Tritium

Concentrations

(1992-2006)

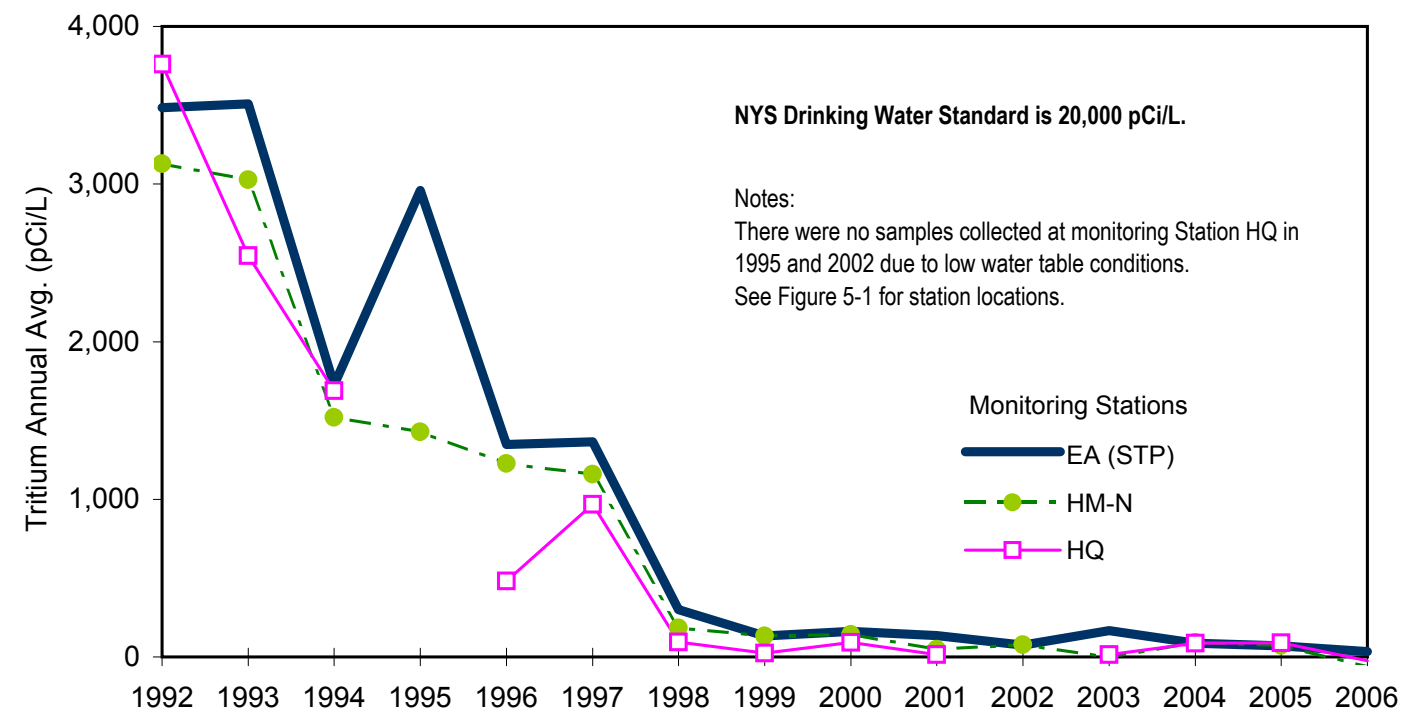

Figure 5-4. Tritum Released to the Peconic River,

I 5-Year Trend (1992-2006).

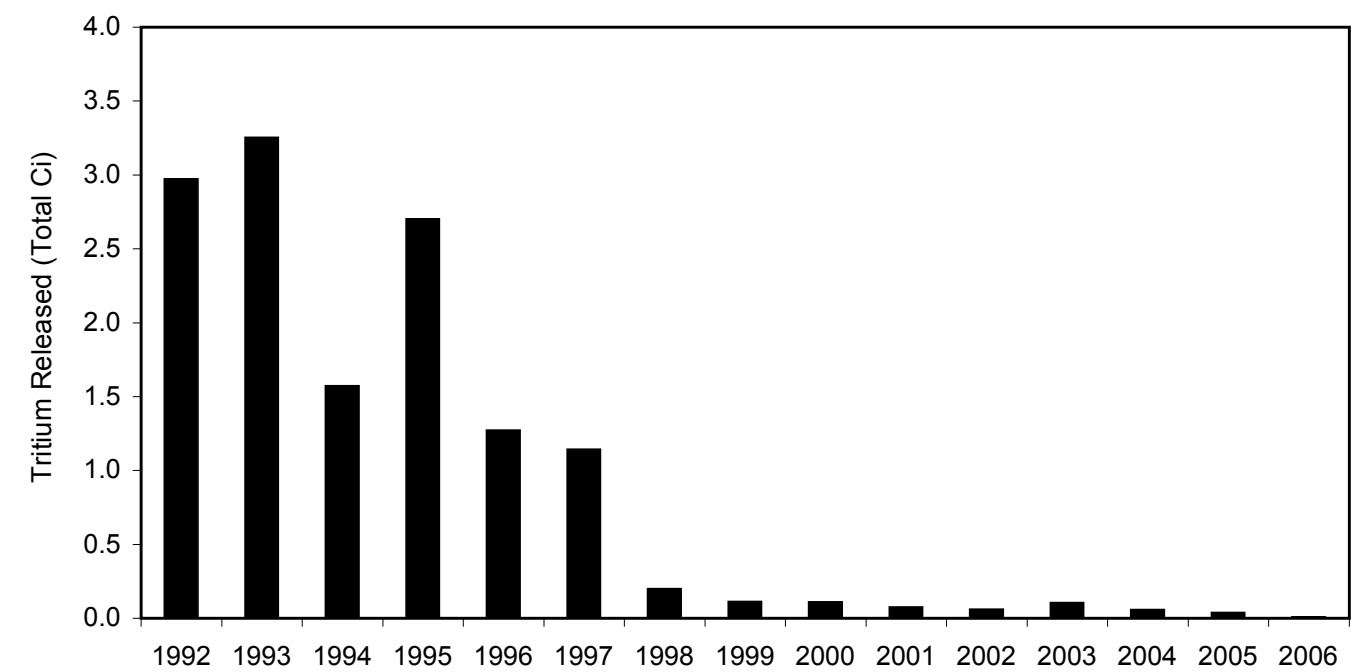

Figure 5-5. Cesium- 137 in the BNL Sewage

Treatment Plant Influent and Effluent (1992-2006).

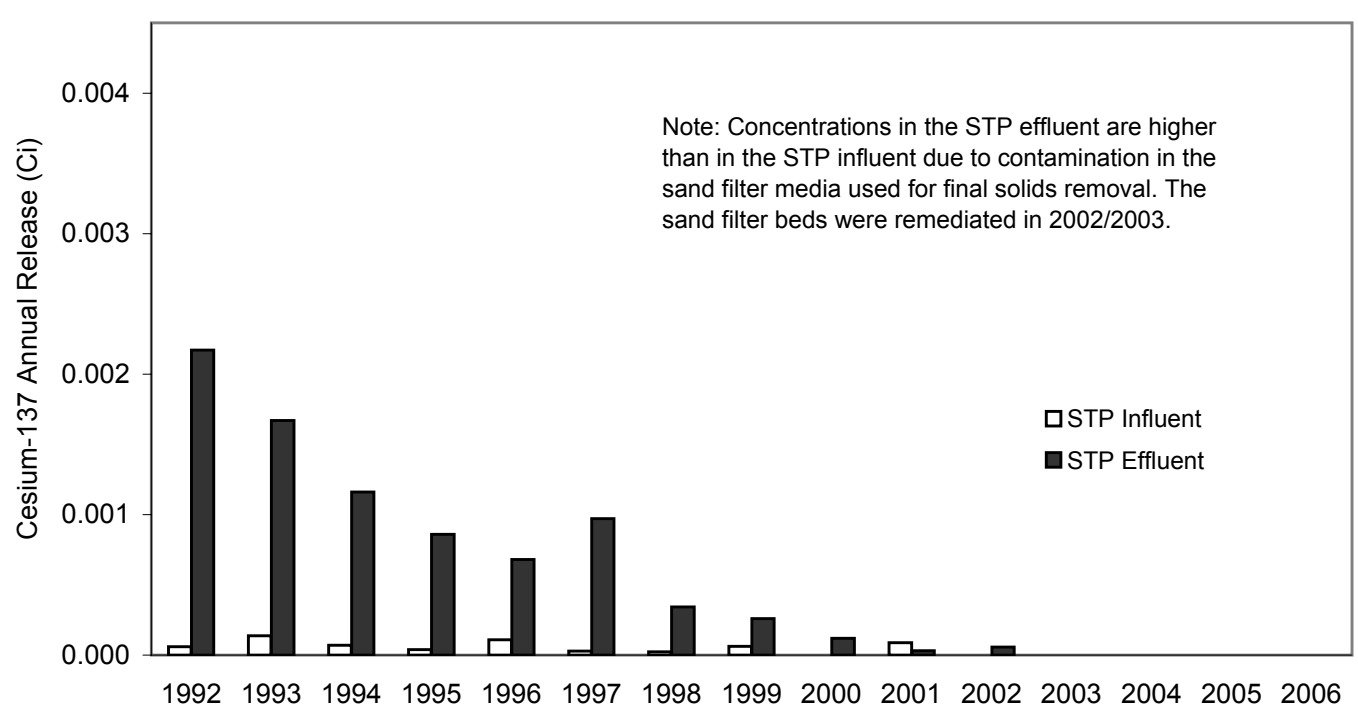


Table 5-2. Gamma-Emitting Radionuclides and Strontium-90 in Water at the BNL Sewage Treatment Plant.

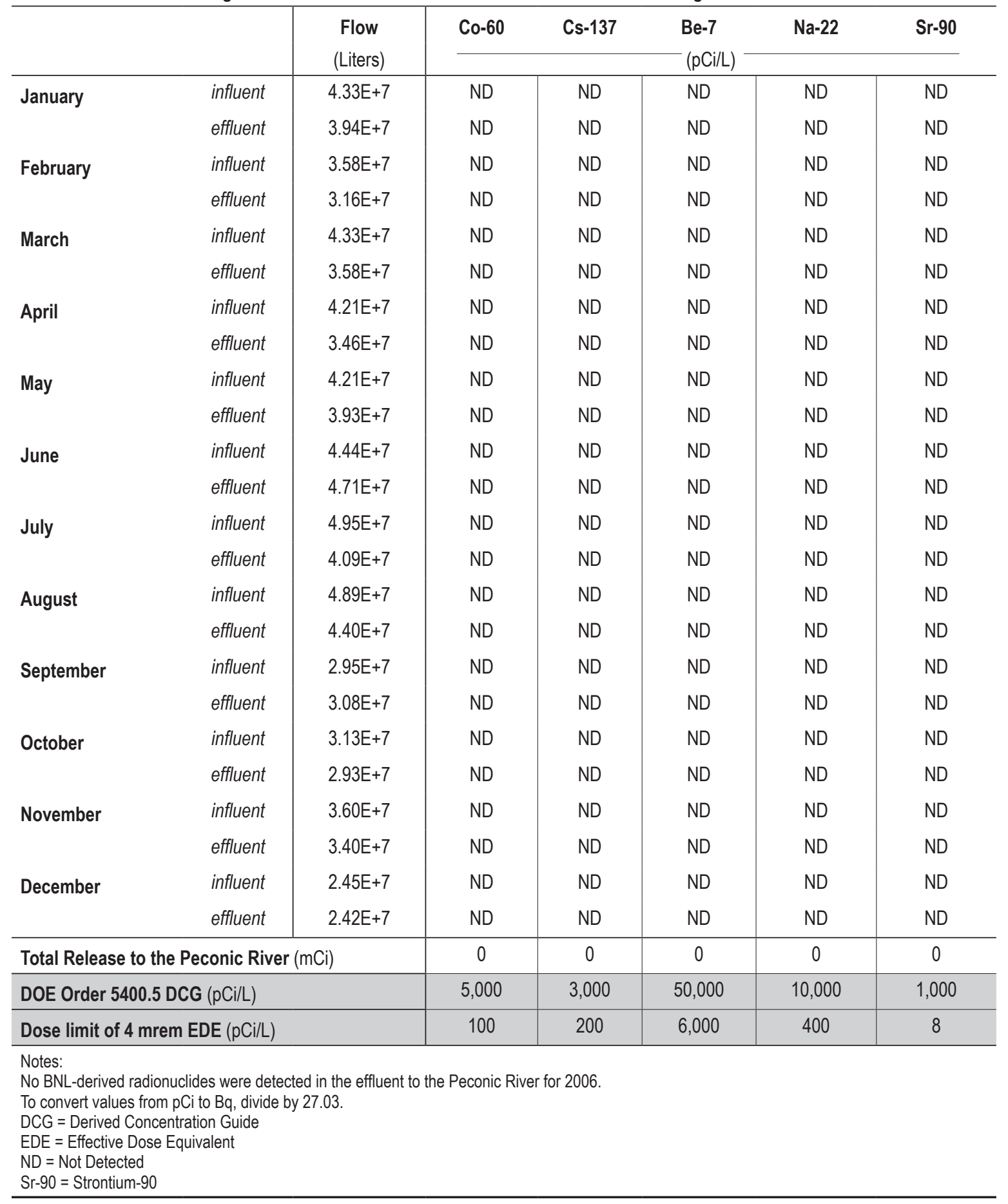

contaminants under the BNL Environmental Surveillance Program. Data are collected for field-measured parameters such as temperature, specific conductivity, $\mathrm{pH}$, and dissolved oxygen, as well as inorganic parameters such as chlorides, nitrates, sulfates, and metals. Composite samples of the STP effluent are collected using a flow-proportional refrigerated sampling device (ISCO Model 3700RF) and are then analyzed by contract analytical laboratories. Samples are analyzed for 23 inorganic elements, anions, semivolatile organic compounds 
(SVOCs), pesticides, and herbicides. In addition, grab samples are collected monthly from the STP effluent and analyzed for 38 different volatile organic compounds (VOCs). Daily influent and effluent logs are maintained by the STP operators for flow, $\mathrm{pH}$, temperature, and settleable solids as part of routine monitoring of STP operations.

Table 5-3 summarizes the water quality and inorganic analytical results for the STP samples. Comparing the effluent data to the SPDES effluent limits (or New York State Ambient Water Quality Standards [NYS AWQS], as appropriate) shows that most of the analytical parameters were within SPDES effluent permit limits (see also the compliance data in Chapter 3). There were several parameters detected at concentrations just above SPDES limits. In January, zinc and iron were detected at $114 \mathrm{ppb}$ and $0.4 \mathrm{ppm}$, respectively, which exceed the permit limits of $100 \mathrm{ppb}$ and $0.37 \mathrm{ppm}$. These excursions were likely associated with the decant of water from the aerobic digesters that occurred in December 2005. The decant was analyzed and found to have high concentrations of iron, zinc, and nitrate.

Vanadium was detected in June, July, and August at levels above the NYS AWQS of 14 $\mathrm{ppb}$. The annual average concentration was approximately $11 \mathrm{ppb}$. Analysis of digester waste has shown elevated levels of vanadium in sludges and associated decant. Vanadium is found in soils and especially shales from which petroleum is extracted. Discharges of boiler blowdown and historical discharges of boiler wash water may be a source of the higher vanadium levels.

In 2006, acetone was the only VOC detected in the STP effluent at concentrations at or near the detection limit. Other VOCs were sporadically detected at concentrations much less than the method detection limit (typically $<1 \mathrm{ppb}$ ) and much less than the NYS AWQS. Acetone is a common solvent used in the contract analytical laboratory and is typically found in background levels in laboratories. The maximum concentration detected was $7.6 \mu \mathrm{g} / \mathrm{L}$. Although there are no SPDES limits or AWQS specified for acetone, NYSDEC imposes a generic limit of $50 \mu \mathrm{g} / \mathrm{L}$ for unlisted organic compounds. The amounts detected in BNL samples were approximately 15 percent of that generic limit.

\subsection{PROCESS-SPECIFIC WASTEWATER}

Wastewater that may contain constituents above SPDES permit limits or ambient water quality discharge standards must be held by the generating facility and be characterized to determine the appropriate means of disposal. The analytical results are compared with the appropriate discharge limit, and the wastewater is released to the sanitary system only if the volume and concentration of contaminants in the discharge would not jeopardize the quality of the STP effluent and, subsequently, the Peconic River.

The Laboratory's SPDES permit includes requirements for quarterly sampling and analysis of process-specific wastewater discharged from printed-circuit-board fabrication operations conducted in Building 535B, metal cleaning operations in Building 498, cooling tower discharges from Building 902, and boiler blowdown from satellite boilers in Buildings 244 and 423. These operations are monitored for contaminants such as metals, cyanide, VOCs, and SVOCs. In 2006, analyses of these waste streams showed that, although several operations contributed contaminants to the STP in concentrations exceeding SPDES-permitted levels, these discharges did not affect the quality of the STP effluent.

Process wastewaters that were not expected to be of consistent quality because they were not routinely generated were held for characterization before release to the site sewer system. The process wastewaters typically included purge water from groundwater sampling, heat exchanger cleaning wastewater, wastewater generated as a result of restoration activities, and other industrial wastewaters. To determine the appropriate disposal method, samples were analyzed for contaminants specific to the process. The analyses were then reviewed and the concentrations were compared to the SPDES effluent limits and BNL's effluent release criteria. If the concentrations were within limits, authorization for sewer system discharge was 
Table 5-3. BNL Sewage Treatment Plant (STP) Water Quality and Metals Analytical Results.

\begin{tabular}{|c|c|c|c|c|c|c|c|c|c|c|c|}
\hline \multirow[b]{2}{*}{ ANALYTE } & \multirow[b]{2}{*}{ Units } & \multicolumn{4}{|c|}{ STP Influent } & \multicolumn{4}{|c|}{ STP Effluent } & \multirow{2}{*}{$\begin{array}{l}\text { SPDES Limit } \\
\text { or AWQS (1) }\end{array}$} & \multirow{2}{*}{$\begin{array}{l}\text { Comment or } \\
\text { Qualifier }\end{array}$} \\
\hline & & $\mathrm{N}$ & Min. & Max. & Avg. & $\mathrm{N}$ & Min. & Max. & Avg. & & \\
\hline pH & SU & $\mathrm{CM}$ & 5.2 & 7.7 & NA & $\mathrm{CM}$ & 5.8 & 7.4 & NA & $5.8-9.0$ & \\
\hline Conductivity & $\mu S / \mathrm{cm}$ & $\mathrm{CM}$ & NR & NR & NR & 173 (a) & 5 & 473 & 310.6 & SNS & \\
\hline Temperature & ${ }^{\circ} \mathrm{C}$ & $\mathrm{CM}$ & NR & NR & NR & 173 (a) & 4.1 & 27.2 & 15.4 & SNS & \\
\hline Dissolved Oxygen & $\mathrm{mg} / \mathrm{L}$ & NM & NM & NM & NM & 173 (a) & 7 & 20.3 & 10 & SNS & \\
\hline Chlorides & $\mathrm{mg} / \mathrm{L}$ & 12 & 39.2 & 118.0 & 57.5 & 12 & 37.2 & 56.4 & 47.0 & SNS & \\
\hline Nitrate (as N) & $\mathrm{mg} / \mathrm{L}$ & 12 & 1.2 & 5.7 & 2.8 & 12 & 3.6 & 11.2 & 7.1 & 10 & Total N \\
\hline Sulfates & $\mathrm{mg} / \mathrm{L}$ & 12 & 10.5 & 21.2 & 16.4 & 12 & 14.8 & 18.7 & 16.6 & 250 & GA \\
\hline Aluminum & $\mu g / L$ & 14 & 121.0 & 5470.0 & 878.3 & 14 & 23.0 & $<250$ & $<250$ & 100 & Ionic \\
\hline Antimony & $\mu g / L$ & 14 & 0.5 & 6.2 & $<5$ & 14 & 0.5 & $<5$ & $<5$ & 3 & GA \\
\hline Arsenic & $\mu g / L$ & 15 & 2.5 & 20.1 & $<5$ & 15 & 2.3 & $<5$ & $<5$ & 150 & Dissolved \\
\hline Barium & $\mu g / L$ & 15 & 32.7 & 693.0 & 120.0 & 15 & 9.7 & 24.2 & 17.4 & 1000 & GA \\
\hline Beryllium & $\mu g / L$ & 14 & 0.1 & $<2$ & $<2$ & 14 & $<2$ & $<2$ & $<2$ & 11 & Acid Soluble \\
\hline Cadmium & $\mu g / L$ & 15 & 0.2 & 3.4 & 0.8 & 15 & 0.2 & 0.4 & 0.3 & 1.1 & Dissolved \\
\hline Calcium & $\mathrm{mg} / \mathrm{L}$ & 14 & 10.4 & 21.0 & 13.2 & 14 & 8.0 & 17.3 & 13.0 & SNS & \\
\hline Chromium & $\mu g / L$ & 15 & 1.7 & 58.5 & 9.3 & 15 & 1.9 & $<25$ & $<25$ & 34.4 & Dissolved \\
\hline Cobalt & $\mu g / L$ & 14 & 0.7 & 15.1 & 3.9 & 14 & 0.3 & $<5$ & $<5$ & 5 & Acid Soluble \\
\hline Copper & $\mu g / L$ & 14 & 70.3 & 2820.0 & 441.6 & 14 & 27.5 & 53.0 & 39.5 & 150 & SPDES \\
\hline Iron & $\mathrm{mg} / \mathrm{L}$ & 14 & 0.8 & 64.0 & 9.8 & 14 & 0.1 & 0.4 & 0.2 & 0.37 & SPDES \\
\hline Mercury & $\mu g / L$ & 16 & 0.1 & 7.0 & 1.1 & 15 & 0.1 & $<0.2$ & $<0.2$ & 0.8 & SPDES \\
\hline Manganese & $\mu g / L$ & 14 & 17.6 & 221.0 & 63.1 & 14 & 2.0 & 14.5 & 4.4 & 300 & GA \\
\hline Magnesium & $\mathrm{mg} / \mathrm{L}$ & 14 & 3.3 & 6.5 & 4.3 & 14 & 2.6 & 3.9 & 3.4 & SNS & \\
\hline Nickel & $\mu g / L$ & 14 & 5.9 & 228.0 & 58.6 & 14 & 7.7 & 21.3 & 14.5 & 110 & SPDES \\
\hline Lead & $\mu g / L$ & 15 & 3.8 & 375.0 & 53.4 & 15 & 0.6 & 5.6 & 1.5 & 19 & SPDES \\
\hline Potassium & $\mathrm{mg} / \mathrm{L}$ & 14 & 3.0 & 10.0 & 6.4 & 14 & 3.4 & 5.8 & 4.5 & SNS & \\
\hline Selenium & $\mu g / L$ & 15 & 0.6 & 8.2 & $<5$ & 15 & 0.7 & $<25$ & $<25$ & 4.6 & Dissolved \\
\hline Silver & $\mu g / L$ & 15 & 0.7 & 27.3 & 4.1 & 15 & 0.8 & 2.8 & $<2$ & 15 & SPDES \\
\hline Sodium & $\mathrm{mg} / \mathrm{L}$ & 14 & 29.6 & 86.1 & 45.6 & 14 & 27.7 & 55.8 & 36.4 & SNS & \\
\hline Thallium & $\mu g / L$ & 14 & 0.4 & $<5$ & $<5$ & 14 & 0.5 & $<5$ & $<5$ & 8 & Acid Soluble \\
\hline Vanadium & $\mu g / L$ & 14 & 1.8 & 223.0 & 50.7 & 14 & 2.2 & 25.0 & $<25$ & 14 & Acid Soluble \\
\hline Zinc & $\mu g / L$ & 14 & 56.3 & 1380.0 & 422.0 & 14 & 22.9 & 114.0 & 63.8 & 100 & SPDES \\
\hline
\end{tabular}

Notes:

See Figure 5-2 for locations of the STP influent and effluent monitoring locations.

All analytical results were generated using total recoverable analytical techniques.

$\mathrm{N}=$ Number of Samples

For Class C Ambient Water Quality Standards (AWQS), the solubility state for the metal

$\mathrm{NA}=$ Not Applicable

is provided.

(1) Unless otherwise provided, the reference standard is NYSDEC Class C Surface Water AWQS.

(a) The conductivity, temperature, and dissolved oxygen values reported are based on analyses of daily grab samples.

$\mathrm{CM}=$ Continuously monitored

GA = Class GA (groundwater) Ambient Water Quality Standard

$\mathrm{NM}=$ Not Monitored

$\mathrm{NR}=$ Not Recorded

NYSDEC = New York State Department of Environmental

Conservation

SNS = Standard Not Specified

SPDES = State Pollutant Discharge Elimination System

SU = Standard Units 
granted; if not, alternate means of disposal were used. Any waste that contained elevated levels of hazardous or radiological contaminants in concentrations that exceeded Laboratory effluent release criteria was sent to the BNL Waste Management Facility for proper management and off-site disposal.

\subsection{RECHARGE BASINS}

Recharge basins are used for the discharge of "clean" wastewater streams, including oncethrough cooling water, stormwater runoff, and cooling tower blowdown. With the exception of elevated temperature and increased natural sediment content, these wastewaters are suitable for direct replenishment of the groundwater aquifer. Figure 5-6 shows the locations of the Laboratory's discharges to recharge basins (also called "outfalls" under BNL's SPDES permit). Figure 5-7 presents an overall schematic of potable water use at the Laboratory. Ten recharge basins are used for managing once-through cooling water, cooling tower blowdown, and stormwater runoff:

- Basins HN, HT-W, and HT-E receive oncethrough cooling water discharges generated at the Alternating Gradient Synchrotron (AGS) and Relativistic Heavy Ion Collider (RHIC), as well as cooling tower blowdown and stormwater runoff.

- Basin HS receives predominantly stormwater runoff, once-through cooling water from

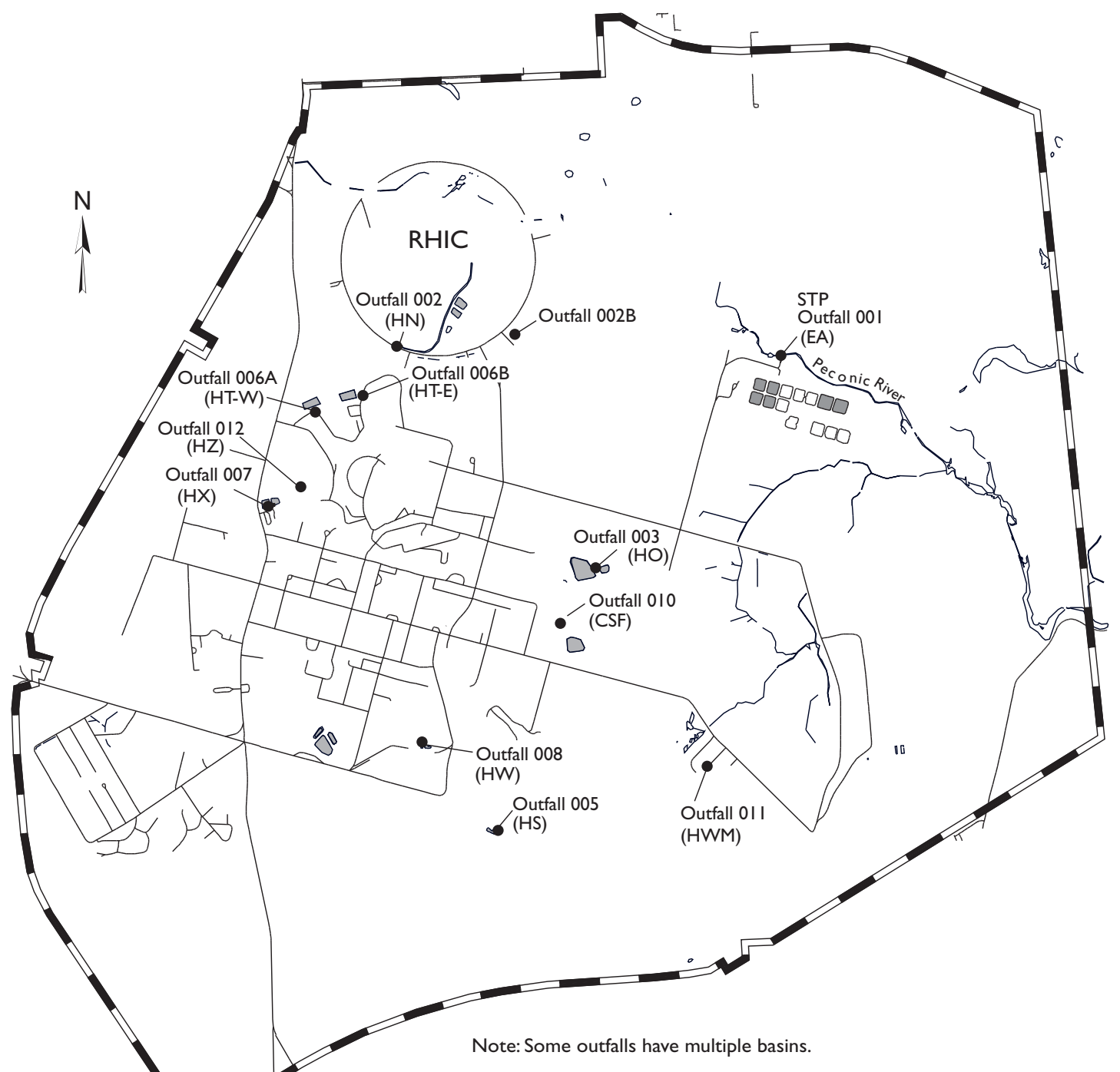

Figure 5-6. BNL Recharge Basin/Outfall Locations. 
Building 555 (Chemistry Department), and minimal cooling tower blowdown from the National Synchrotron Light Source (NSLS).

- Basin HX receives Water Treatment Plant filter backwash water.

- Basin HO receives cooling water discharges from the AGS and stormwater runoff from the area surrounding the HFBR.

- Several other recharge areas are used exclusively for discharging stormwater runoff. These areas include Basin HW in the warehouse area, Basin CSF at the Central Steam Facility (CSF), Basin HW-M at the former Hazardous Waste Management Facility (HWMF), and Basin HZ near Building 902. Each of the recharge basins is a permitted point-source discharge under the Laboratory's SPDES permit. Where required by the permit, the discharge to the basin is equipped with a flow monitoring station; weekly recordings of flow are collected, along with measurements of $\mathrm{pH}$. The specifics of the SPDES compliance monitoring program are provided in Chapter 3. To supplement that monitoring pro- gram, samples are also routinely collected and analyzed under BNL's Environmental Monitoring Program for radioactivity, VOCs, metals, and anions. During 2006, water samples were collected from all basins listed above, except recharge basin HX at the Water Treatment Plant (exempted by NYSDEC from sampling due to documented non-impact to groundwater) and the recharge basin at the former HWMF, as there are no longer any operations that could lead to contamination of run-off.

\subsection{Recharge Basins - Radiological Analyses}

Discharges to the recharge basins were sampled throughout the year for subsequent analyses for gross alpha and beta activity, gamma-emitting radionuclides, and tritium. These results are presented in Table 5-4. These data show that low levels of alpha and beta activity were detected in most of the basins. Activities ranged from nondetectable to $1.9 \pm 0.9 \mathrm{pCi} / \mathrm{L}$ for gross alpha activity, and from nondetectable to $7.2 \pm 1.8 \mathrm{pCi} / \mathrm{L}$ for gross beta activity. Lowlevel detections of gross alpha and beta activity

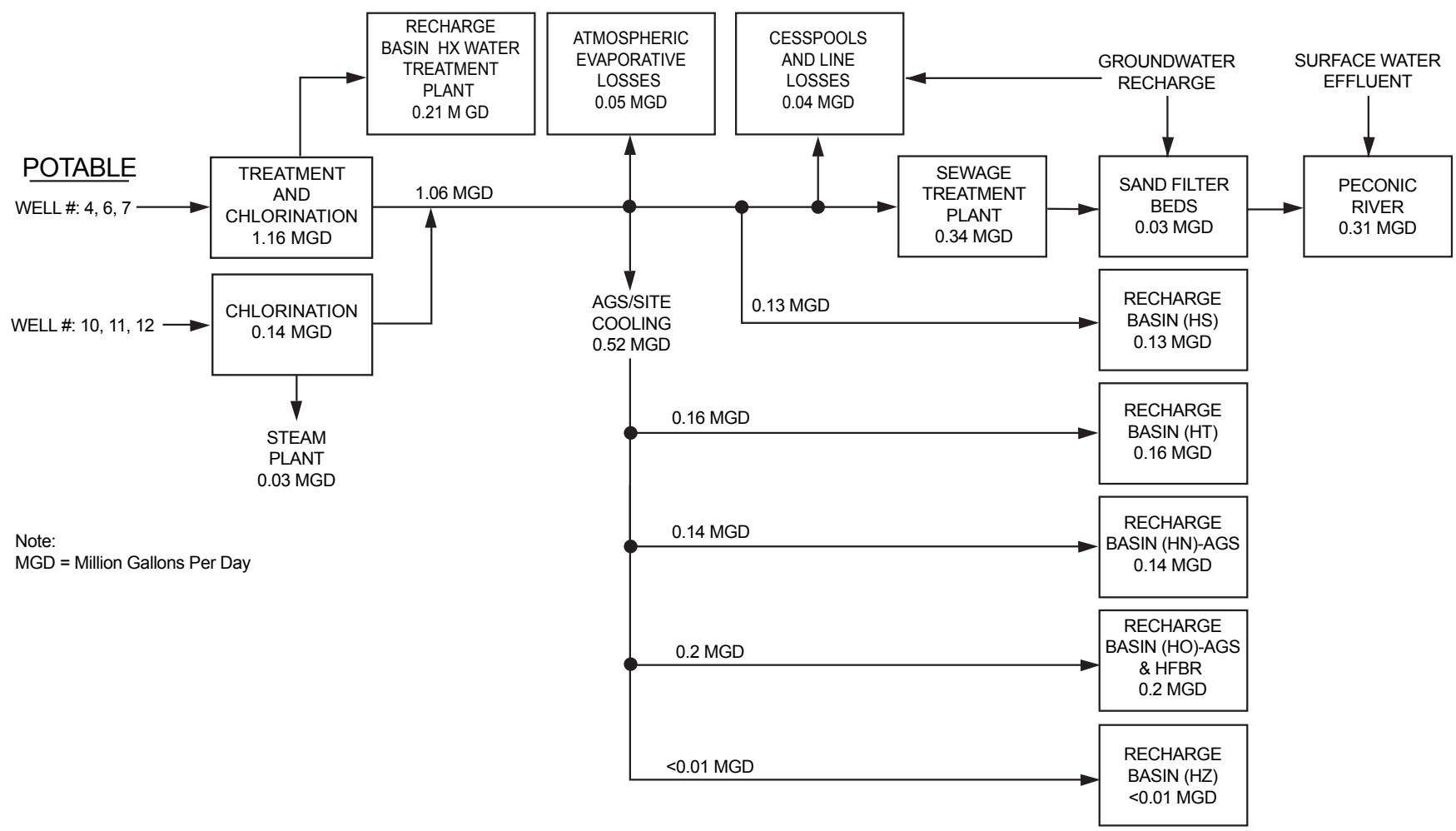

Figure 5-7. Schematic of Potable Water Use and Flow at BNL. 
Table 5-4. Radiological Analysis of Samples from BNL On-Site Recharge Basins.

\begin{tabular}{|c|c|c|c|c|}
\hline \multirow{2}{*}{\multicolumn{2}{|c|}{ Basin }} & Gross Alpha & Gross Beta & Tritium \\
\hline & & & $-(\mathrm{pCi} / \mathrm{L})$ & \\
\hline \multicolumn{2}{|c|}{ No. of samples } & 4 & 4 & 4 \\
\hline \multirow[t]{2}{*}{ HN } & $\max$ & $<1.9$ & $3.4 \pm 1.4$ & $<300$ \\
\hline & avg. & $0.8 \pm 0.5$ & $2.8 \pm 0.5$ & $23.5 \pm 55.4$ \\
\hline \multirow[t]{2}{*}{$\mathrm{HO}$} & max. & $<1.2$ & $<2.0$ & $<350$ \\
\hline & avg. & $0.1 \pm 0.2$ & $1.4 \pm 0.5$ & $-12.5 \pm 211.9$ \\
\hline \multirow[t]{2}{*}{ HS } & $\max$. & $<1.5$ & $2.5 \pm 1.2$ & $<300$ \\
\hline & avg. & $0.7 \pm 0.5$ & $1.6 \pm 0.8$ & $7.5 \pm 188.9$ \\
\hline \multirow[t]{2}{*}{ HT-E } & $\max$ & $<1.7$ (b) & $5.7 \pm 1.5$ & $<300$ \\
\hline & avg. & $0.4 \pm 0.5$ & $5.8 \pm 6.5$ & $-69 \pm 127.6$ \\
\hline \multirow[t]{2}{*}{ HT-W } & $\max$. & $<1.4$ & $2.2 \pm 1.0$ & $430 \pm 230$ \\
\hline & avg. & $0.1 \pm 1.2$ & $0.8 \pm 2.0$ & $112 \pm 246.5$ \\
\hline \multirow[t]{2}{*}{ HW } & $\max$ & $1.9 \pm 0.9$ & $3.7 \pm 1.3$ & $<350$ \\
\hline & avg. & $1.1 \pm 0.5$ & $2.5 \pm 0.9$ & $-127.5 \pm 32.4$ \\
\hline \multirow[t]{2}{*}{$\mathrm{HZ}$} & $\max$. & $<0.9$ & $7.2 \pm 1.8$ & $<350$ \\
\hline & avg. & $0.1 \pm 0.3$ & $2.9 \pm 2.9$ & $-65.2 \pm 81.6$ \\
\hline \multicolumn{2}{|c|}{ SDWA Limit } & 15 & (a) & 20,000 \\
\hline $\begin{array}{l}\text { Notes: } \\
\text { See Fig } \\
\text { All value } \\
\text { Negative } \\
\text { (see A } \\
\text { To conve } \\
\text { The drin } \\
\text { (dose } \\
\text { a dose } \\
\text { One dat } \\
\text { MDL = } \\
\text { SDWA }\end{array}$ & $\begin{array}{l}-7 \text { for the } \\
\text { orted wit } \\
\text { nbers oce } \\
\text { dix B for } \\
\text { lues fron } \\
\text { water sta } \\
\text { d) in } 200 \\
\text { valent ca } \\
\text { nt was di } \\
\text { um Dete } \\
\text { Drinking }\end{array}$ & $\begin{array}{l}\text { ations of recharg } \\
95 \% \text { confidence } \\
\text { when the measur } \\
\text { scription). } \\
\text { Ci to } \mathrm{Bq} \text {, divide by } \\
\text { ard was changed } \\
\text { 3ecause gross bet } \\
\text { ot be calculated fo } \\
\text { unted due to high } \\
n \text { Limit } \\
\text { later Act }\end{array}$ & $\begin{array}{l}\text { s/outfalls. } \\
\text { e is lower than t } \\
\text { pCi/L (concent } \\
\text { ity does not iden } \\
\text { alues in this tabl } \\
\text { content and hig }\end{array}$ & $\begin{array}{l}\text { ound } \\
\text { pased) to } 4 \mathrm{mrem} / \mathrm{yr} \\
\text { ecific radionuclides, }\end{array}$ \\
\hline
\end{tabular}

are attributable to very low levels of naturally occurring radionuclides, such as potassium-40 (K-40: half-life $1.3 \mathrm{E}+09$ years). The contract analytical laboratory reported no gamma-emitting nuclides attributable to BNL operations in any discharges to recharge basins in 2006. Tritium was detected in a single sample collected at Ba- sin HT-W at very low levels $(430 \pm 230 \mathrm{pCi} / \mathrm{L})$ and with high levels of uncertainty (53 percent). This basin receives discharges from the Collider-Accelerator complex.

\subsubsection{Recharge Basins - Nonradiological Analyses}

To determine the overall impact of the recharge basin discharges on the environment, the nonradiological analytical results were compared to groundwater discharge standards promulgated under Title 6 of the New York Codes, Rules, and Regulations (NYCRR), Part 703.6. Samples were collected quarterly for water quality parameters, metals, and VOCs, and analyzed by a contract analytical laboratory. Field-measured parameters ( $\mathrm{pH}$, conductivity, and temperature) were routinely monitored and recorded. The water quality and metals analytical results are summarized in Tables 5-5 and 5-6, respectively.

Low concentrations of disinfection byproducts are periodically detected. Sodium hypochlorite and bromine, used to control algae in cooling towers, lead to the formation of VOCs including bromoform, chloroform, dibromochloromethane, and dichlorobromomethane. In 2006 , concentrations ranged from nondetectable to a maximum of $6.2 \mu \mathrm{g} / \mathrm{L}$. Acetone was the only other analyte detected above the MDL for most recharge basins, ranging from nondetectable to a maximum of $9.2 \mu \mathrm{g} / \mathrm{L}$. In most instances, acetone was also found as a contaminant in the contract analytical laboratory, as evidenced by detections in blank samples.

The analytical data in Tables 5-5 and 56 show that all parameters, except for iron, complied with the respective water quality or groundwater discharge standards (GDS). Aluminum was also found at detectable levels in most discharges. Chlorides were found to be higher in discharge samples collected during the winter and are attributed to road salt used to control snow and ice buildup. Iron and aluminum are natural components of soil and readily dissolve when water samples are acidified for preservation. Iron is also naturally present in Long Island groundwater at concentrations that exceed the New York State GDS. Filtration of samples resulted in aluminum and iron concen- 
Table 5-5. Water Quality Data for BNL On-Site Recharge Basin Samples.

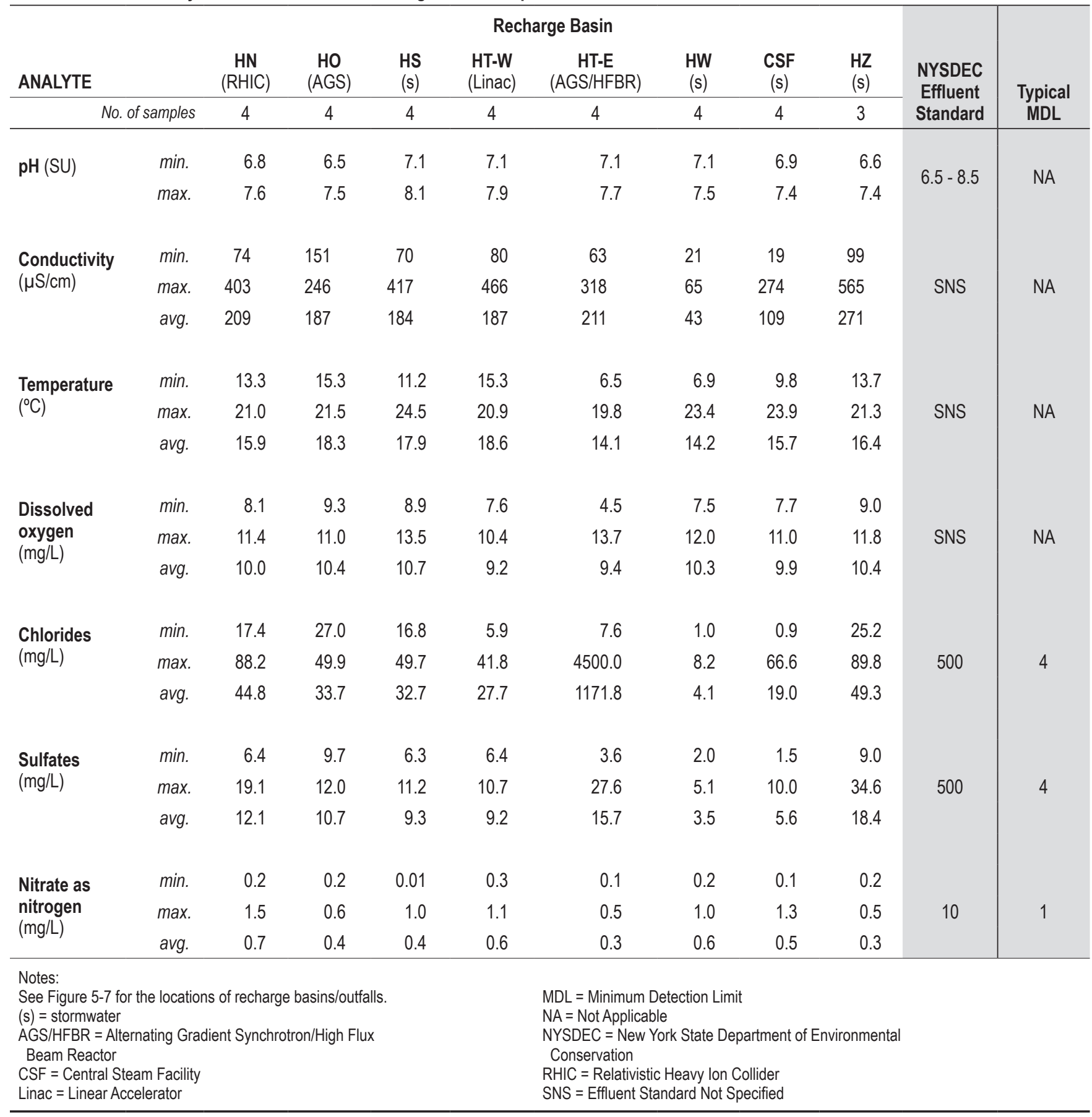

trations that were less than the NYS AWQS or GDS, as appropriate. As the aluminum and iron are in particulate form, they pose no threat to groundwater quality, because the recharge basin acts as a natural filter, trapping the particles before they reach groundwater. Cobalt was detected in most filtered water samples and is being attributed to the filter media since it was absent in the unfiltered water samples.

Remediation of lead-contaminated soils at the CSF outfall was completed in 2006. Post-excavation soil samples showed all areas to have levels lower than the clean-up goal of $400 \mathrm{ppm}$. The area will be restored in 2007. The clean-up 


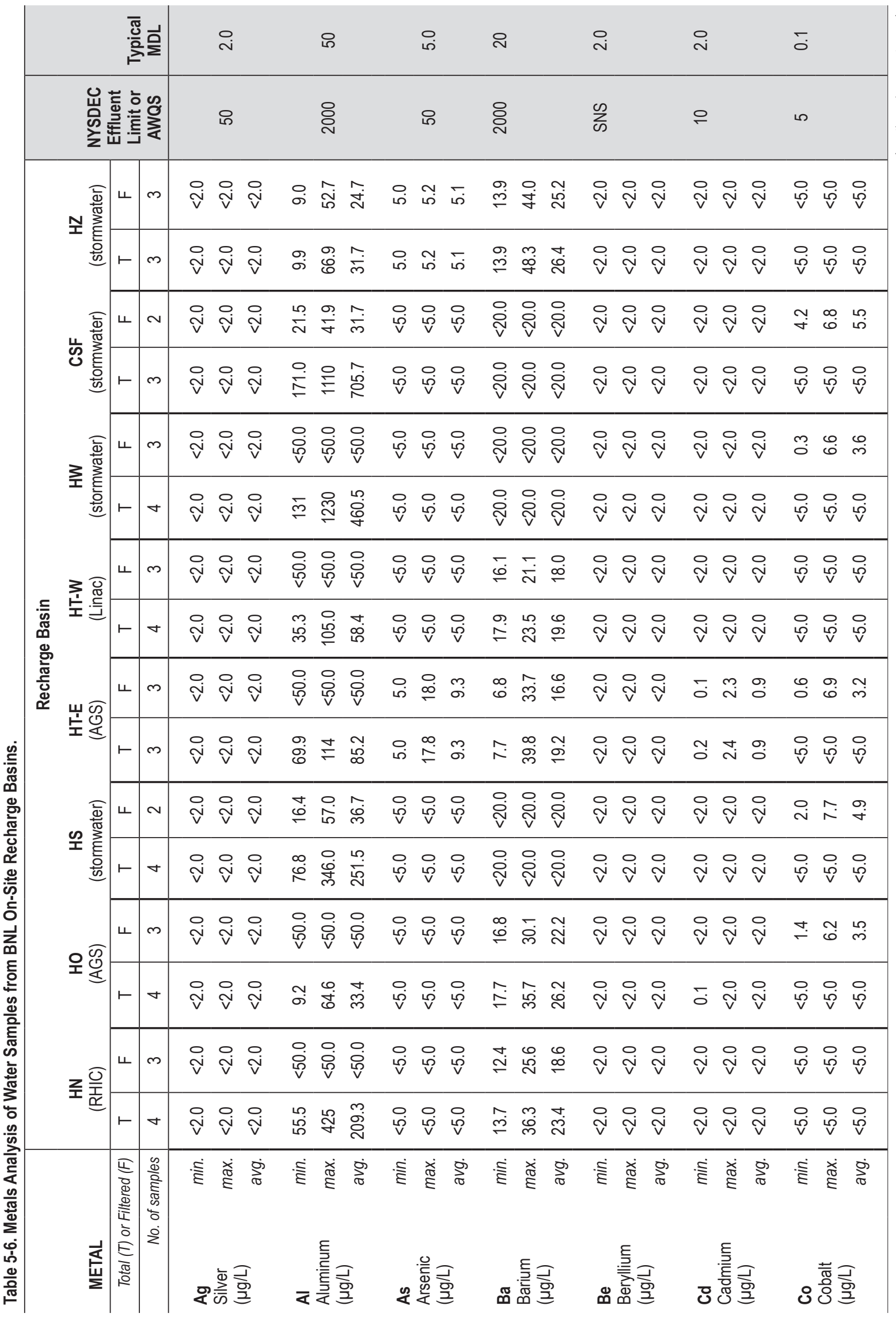




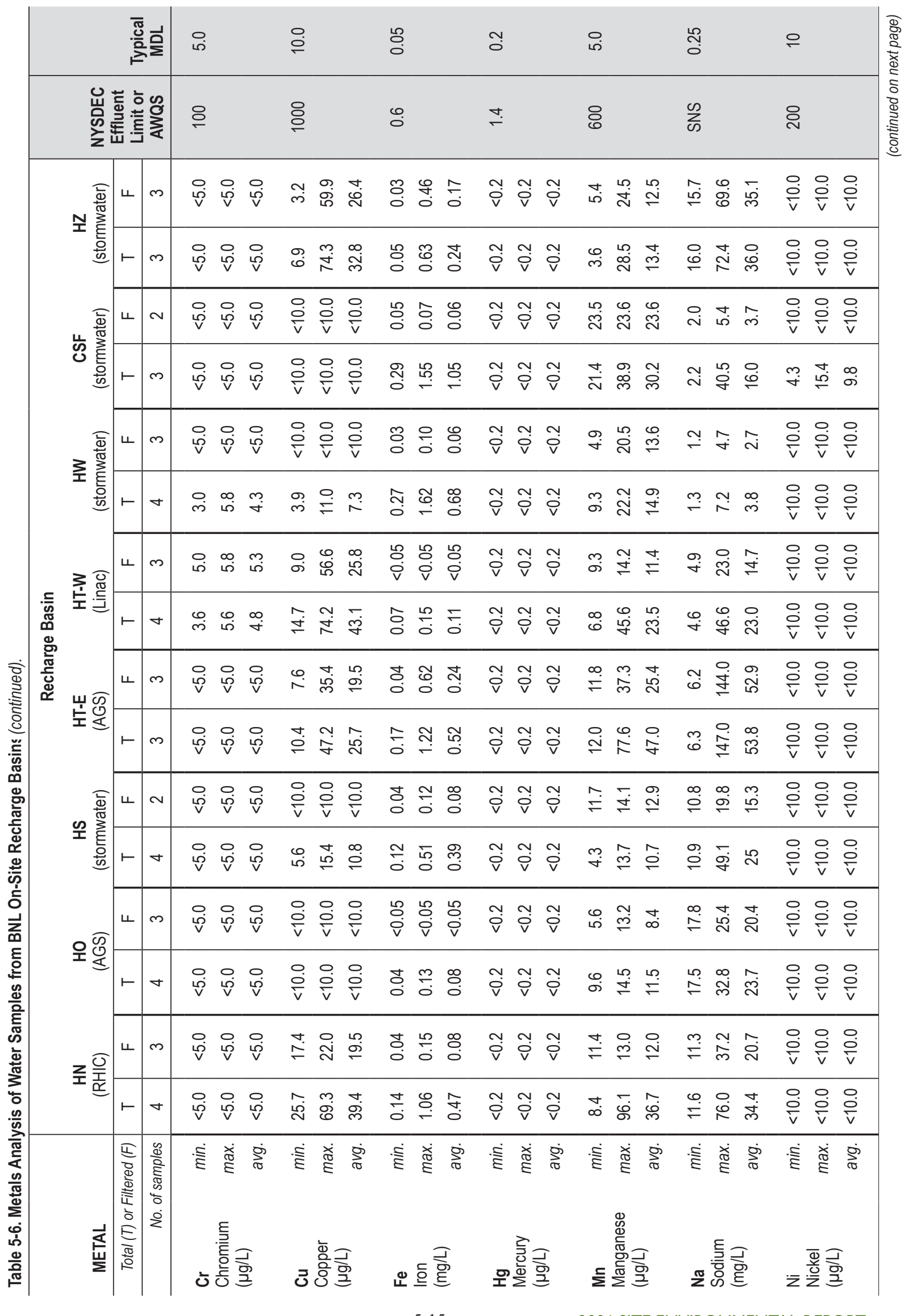




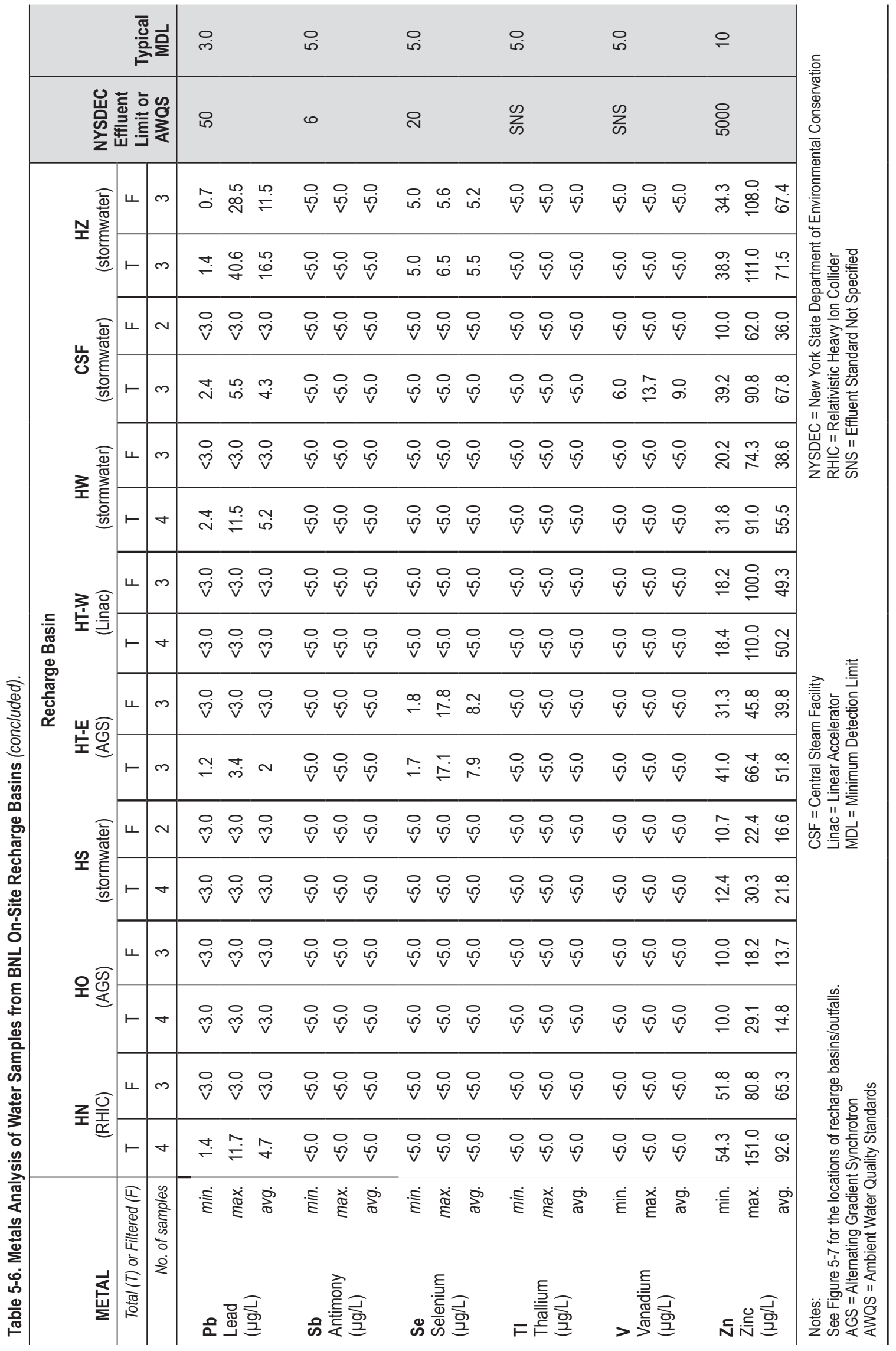


was documented in the "Central Steam Facility Storm Water Outfall Remediation Closeout Report," dated February 21, 2007 (Remien, 2007).

\subsubsection{Stormwater Assessment}

All recharge basins receive stormwater runoff. Stormwater at BNL is managed by collecting runoff from paved surfaces, roofs, and other impermeable surfaces and directing it to recharge basins via underground piping and abovegrade vegetated swales. Recharge Basin HS receives most of the stormwater runoff from the central, developed portion of the Laboratory site. Basins HN, HZ, HT-W, and HT-E receive runoff from the Collider-Accelerator complex. Basin $\mathrm{HO}$ receives runoff from the Brookhaven Graphite Research Reactor (BGRR) and HFBR areas. Basin CSF receives runoff from the Central Steam Facility area and along Cornell Avenue east of Railroad Avenue. Basin HW receives runoff from the warehouse area, and HW-M receives runoff from the fenced area at the former HWMF.

Stormwater runoff at the Laboratory typically has elevated levels of inorganics and low $\mathrm{pH}$. The inorganics are attributable to high sediment content and the natural occurrence of these elements in native soil. In an effort to further protect the quality of stormwater runoff, BNL has finalized formal procedures for managing and maintaining outdoor work and storage areas. The requirements include covering areas to prevent contact with stormwater, conducting an aggressive maintenance and inspection program, and restoring these areas when operations cease.

\subsection{PECONIC RIVER SURVEILLANCE}

Several locations are monitored along the Peconic River to assess the overall water quality of the river and assess any impact from BNL discharges. Sampling points along the Peconic River are identified in Figure 5-8. In total, 10 stations (three upstream and seven downstream of the STP) were regularly sampled in 2006. A sampling station along the Carmans River $(\mathrm{HH})$ was also monitored as a geographic control location, not affected by Laboratory operations. All locations were routinely monitored for ra- diological and nonradiological parameters. The sampling stations are located as follows:

Upstream sampling stations

- HY, on site immediately east of the William Floyd Parkway

- HV, on site just east of the 10:00 o'clock Experimental Hall in the RHIC Ring

- HE, on site approximately $20 \mathrm{ft}$ upstream of the STP outfall (EA)

Downstream sampling stations

- HM-N, on site 0.5 mile downstream of the STP outfall

- HM-S, on site on a typically dry tributary of the Peconic River

- HQ, on site 1.2 miles downstream of the STP outfall at the site boundary

- HA, first station downstream of the BNL boundary, 3.1 miles from the STP outfall

- Donahue's Pond, off site, 4.3 miles downstream of the STP outfall. (Note: In 2006, one of the four samples was collected at former station $\mathrm{HC}$, due to access problems at Donahue's Pond. The two sites are very near one another, one within the pond and the other at the outflow from the pond.)

- Forge Pond, off site

- Swan Pond, off site not within the influence of BNL discharges

Control location

- HH, Carmans River

\subsection{Peconic River - Radiological Analyses}

Radionuclide measurements were performed on surface water samples collected from the Peconic River at all 10 locations. Routine samples at Stations HM-N and HQ were collected once per month; all other stations were sampled quarterly unless conditions (such as no water flow) prevented collection. Stations HE, HM$\mathrm{N}$, and HQ have been equipped with Parshall flumes that allow automated flow-proportional sampling and volume measurements. All other sites were sampled by collecting instantaneous grab samples, as flow allowed.

The radiological data from Peconic River surface water sampling in 2006 are summarized in Table 5-7. Radiological analysis of upstream 


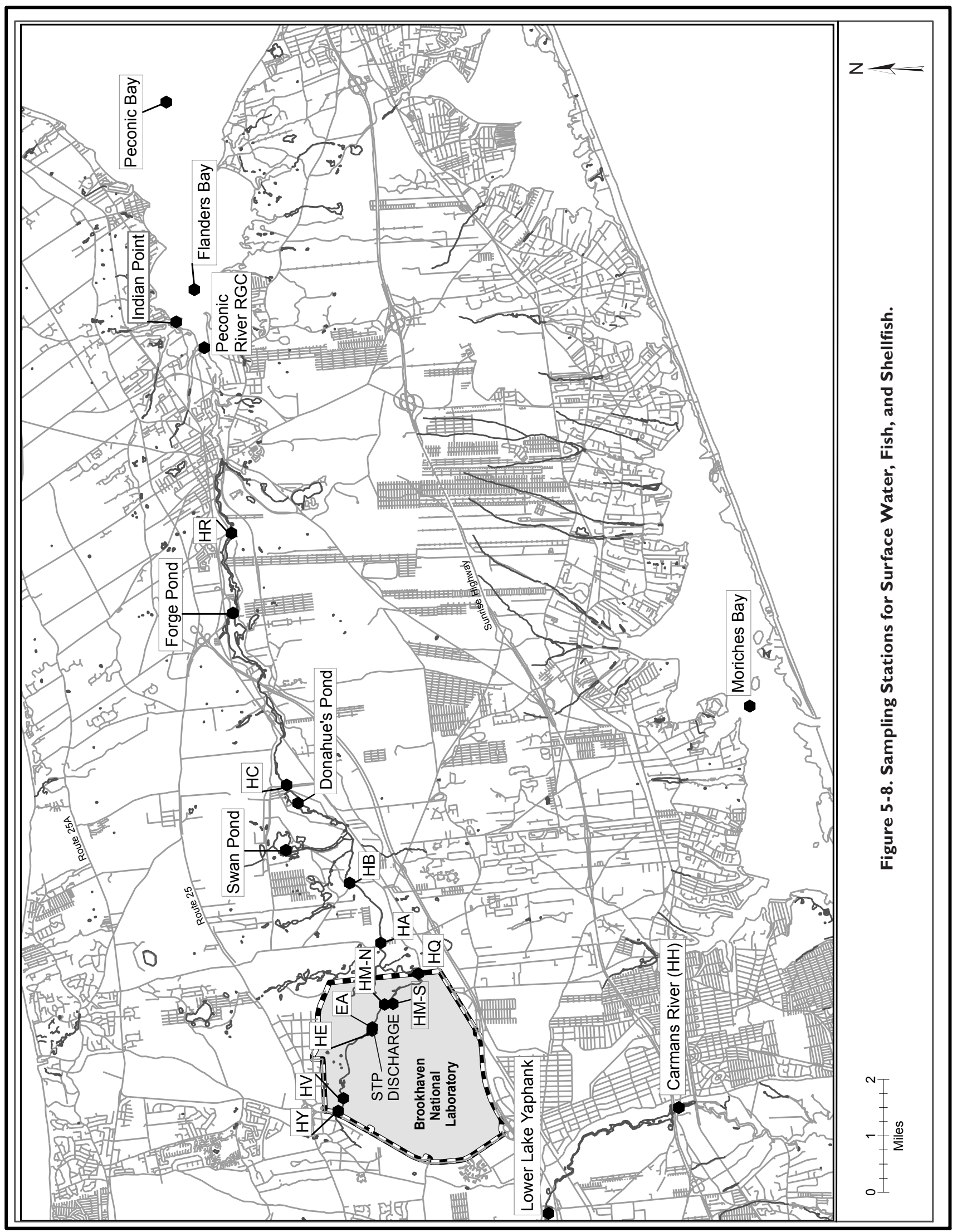


water samples showed that, with the exception of a single detection of gross alpha activity at Station HV, all radiological parameters were less than the detection limit. Downstream, single detections of beta activity were noted at Stations HM-N and HQ. The highest concentration of gross beta activity was detected at Station HQ, located downstream of the STP Outfall and just before the river leaves the BNL site. The average concentrations from off-site and control locations were indistinguishable from BNL onsite levels. The beta activity for all locations is therefore attributed to natural sources. Samples collected downstream of the STP discharge showed concentrations typical of STP releases and historical values. All detected levels were below the applicable DWS. No gamma-emitting radionuclides attributable to Laboratory operations were detected either upstream or downstream of the STP. Similarly, tritium was not detected in water samples collected upstream and downstream of the STP discharge.

Monitoring for Sr-90 was performed at nine of the ten Peconic River stations in 2006. Strontium-90 was detected in single samples collected at Stations HQ and Swan Pond at levels of 3.29 and $0.9 \mathrm{pCi} / \mathrm{L}$, respectively. All concentrations detected were much less than the drinking water standard of $8 \mathrm{pCi} / \mathrm{L}$. The concentration at Swan Pond is consistent with historical levels and is attributed to worldwide fallout from nuclear testing. The levels detected at HQ are likely attributed to residual contaminants in Peconic River sediment.

\subsubsection{Peconic River - Nonradiological Analyses}

Peconic River samples collected in 2006 were analyzed for water quality parameters $(\mathrm{pH}$, temperature, conductivity, and dissolved oxygen), anions (chlorides, sulfates, and nitrates), metals, and VOCs. No VOCs above the MDL were detected in river water samples. The inorganic analytical data for the Peconic River and Carmans River samples are summarized in Tables 5-8 (water quality) and 5-9 (metals).

Peconic River water quality data collected upstream and downstream showed that water quality was consistent throughout the river system. These data were also consistent with those
Table 5-7. Radiological Results for Surface Water Samples from the Peconic and Carmans Rivers.

\begin{tabular}{|c|c|c|c|c|c|}
\hline \multirow{2}{*}{ Sampling Station } & & $\begin{array}{l}\text { Gross } \\
\text { Alpha }\end{array}$ & $\begin{array}{l}\text { Gross } \\
\text { Beta }\end{array}$ & \multirow[b]{2}{*}{$(\mathrm{pCi} / \mathrm{L})$} & \multirow{2}{*}{ Sr-90 } \\
\hline & & & -1 & & \\
\hline \multicolumn{6}{|l|}{ PECONIC RIVER } \\
\hline $\begin{array}{l}\text { HY } \\
\text { (headwaters) } \\
\text { on site, west of } \\
\text { the RHIC ring }\end{array}$ & $\begin{array}{l}N \\
\max . \\
\text { avg. }\end{array}$ & $\begin{array}{c}4 \\
<1.2 \\
0.63 \pm 0.48\end{array}$ & $\begin{array}{c}4 \\
2.7 \pm 1.2 \\
1.65 \pm 0.73\end{array}$ & $\begin{array}{c}4 \\
<350 \\
7.5 \pm 68.54\end{array}$ & $\begin{array}{c}4 \\
<0.51 \\
0.16 \pm 0.07\end{array}$ \\
\hline $\begin{array}{l}\text { HV } \\
\text { (headwaters) } \\
\text { on site, inside } \\
\text { the RHIC ring } \\
\end{array}$ & $\begin{array}{l}N \\
\max . \\
\text { avg. }\end{array}$ & $\begin{array}{c}4 \\
3 \pm 1.2 \\
1.58 \pm 0.93\end{array}$ & $\begin{array}{c}4 \\
3.4 \pm 1.3 \\
2.12 \pm 0.86\end{array}$ & $\begin{array}{c}5 \\
<300 \\
10.2 \pm 106.73\end{array}$ & NS \\
\hline $\begin{array}{l}\text { HE } \\
\text { upstream of } \\
\text { STP outfall } \\
\end{array}$ & $\begin{array}{l} \\
\max . \\
\text { avg. }\end{array}$ & $\begin{array}{c}4 \\
1.53 \pm 0.76 \\
0.8 \pm 0.49 \\
\end{array}$ & $\begin{array}{c}4 \\
<1.9 \\
0.96 \pm 0.31 \\
\end{array}$ & $\begin{array}{c}4 \\
<350 \\
-20 \pm 131.72\end{array}$ & $\begin{array}{c}4 \\
<0.71 \\
0.22 \pm 0.14 \\
\end{array}$ \\
\hline $\begin{array}{l}\mathrm{HM}-\mathrm{N} \\
\text { downstream of } \\
\text { STP, on site } \\
\end{array}$ & $\begin{array}{l}N \\
\max . \\
\text { avg. }\end{array}$ & $\begin{array}{c}12 \\
1.6 \pm 1 \\
0.79 \pm 0.26 \\
\end{array}$ & $\begin{array}{c}12 \\
4.5 \pm 1.3 \\
2.79 \pm 0.71 \\
\end{array}$ & $\begin{array}{c}12 \\
<320 \\
-62.25 \pm 92.68 \\
\end{array}$ & $\begin{array}{c}4 \\
<0.77 \\
-0.008 \pm 0.06 \\
\end{array}$ \\
\hline $\begin{array}{l}\text { HM-S } \\
\text { tributary, on site }\end{array}$ & $\begin{array}{l}N \\
\max . \\
\text { avg. }\end{array}$ & $\begin{array}{c}4 \\
0.86 \pm 0.6 \\
0.52 \pm 0.23 \\
\end{array}$ & $\begin{array}{c}4 \\
2.7 \pm 1.3 \\
1.47 \pm 0.85 \\
\end{array}$ & $\begin{array}{c}4 \\
<300 \\
10 \pm 80.02 \\
\end{array}$ & $\begin{array}{c}4 \\
<0.54 \\
0.09 \pm 0.14 \\
\end{array}$ \\
\hline $\begin{array}{l}\text { HQ } \\
\text { downstream of } \\
\text { STP,at BNL site } \\
\text { boundary }\end{array}$ & $\begin{array}{l}N \\
\max . \\
\text { avg. }\end{array}$ & $\begin{array}{c}12 \\
1.16 \pm 0.72 \\
0.47 \pm 0.19\end{array}$ & $\begin{array}{c}12 \\
5 \pm 1.4 \\
2.64 \pm 0.66\end{array}$ & $\begin{array}{c}12 \\
<370 \\
-23.33 \pm 86.83\end{array}$ & $\begin{array}{c}5 \\
3.29 \pm 0.71 \\
0.7 \pm 1.27\end{array}$ \\
\hline $\begin{array}{l}\mathrm{HA} \\
\text { off site }\end{array}$ & $\begin{array}{l}N \\
\max . \\
\text { avg. }\end{array}$ & $\begin{array}{c}4 \\
<0.84 \\
0.26 \pm 0.08 \\
\end{array}$ & $\begin{array}{c}4 \\
2.2 \pm 1.2 \\
1.65 \pm 0.51 \\
\end{array}$ & $\begin{array}{c}4 \\
<360 \\
-26.75 \pm 174.98 \\
\end{array}$ & $\begin{array}{c}4 \\
<0.74 \\
0.22 \pm 0.09 \\
\end{array}$ \\
\hline $\begin{array}{l}\mathrm{HC} \\
\text { off site }\end{array}$ & $\begin{array}{l}N \\
\max . \\
\text { avg. }\end{array}$ & $\begin{array}{c}1 \\
0.66 \pm 0.69 \\
N A \\
\end{array}$ & $\begin{array}{c}1 \\
2.1 \pm 1.3 \\
\text { NA } \\
\end{array}$ & $\begin{array}{c}1 \\
<360 \\
\text { NA } \\
\end{array}$ & $\begin{array}{c}1 \\
<0.35 \\
N A \\
\end{array}$ \\
\hline $\begin{array}{l}\text { Donahue's Pond } \\
\text { off site }\end{array}$ & $\begin{array}{l}N \\
\text { max. } \\
\text { avg. }\end{array}$ & $\begin{array}{c}3 \\
<0.99 \\
0.01 \pm 0.83 \\
\end{array}$ & $\begin{array}{c}3 \\
<2 \\
0.8 \pm 1.76 \\
\end{array}$ & $\begin{array}{c}3 \\
<420 \\
-6.67 \pm 203.16 \\
\end{array}$ & $\begin{array}{c}3 \\
<0.84 \\
0.25 \pm 0.14 \\
\end{array}$ \\
\hline $\begin{array}{l}\text { Forge Pond } \\
\text { off site }\end{array}$ & $\begin{array}{l}N \\
\max . \\
\text { avg. }\end{array}$ & $\begin{array}{c}4 \\
<1 \\
0.2 \pm 0.31 \\
\end{array}$ & $\begin{array}{c}4 \\
2.4 \pm 1.2 \\
0.62 \pm 1.69 \\
\end{array}$ & $\begin{array}{c}4 \\
<430 \\
-96.4 \pm 112.26\end{array}$ & $\begin{array}{c}4 \\
<0.64 \\
0.36 \pm 0.19 \\
\end{array}$ \\
\hline $\begin{array}{l}\text { Carmans River } \\
\text { Swan Pond } \\
\text { control location, } \\
\text { off site }\end{array}$ & $\begin{array}{l}N \\
\max . \\
\text { avg. }\end{array}$ & $\begin{array}{c}\quad 4 \\
<0.98 \\
0.3 \pm 0.19\end{array}$ & $\begin{array}{c}4 \\
2.7 \pm 1.4 \\
2.47 \pm 0.22\end{array}$ & $\begin{array}{c}4 \\
<380 \\
-102.5 \pm 151.27\end{array}$ & $\begin{array}{c}4 \\
0.9 \pm 0.53 \\
0.31 \pm 0.39\end{array}$ \\
\hline $\begin{array}{l}\mathrm{HH} \\
\text { control location, } \\
\text { off site } \\
\end{array}$ & $\begin{array}{l}N \\
\max . \\
\text { avg. }\end{array}$ & $\begin{array}{c}4 \\
1.03 \pm 0.72 \\
0.34 \pm 0.47 \\
\end{array}$ & $\begin{array}{c}4 \\
<1.9 \\
1.3 \pm 0.31 \\
\end{array}$ & $\begin{array}{c}4 \\
<340 \\
-60 \pm 185.42\end{array}$ & $\begin{array}{c}4 \\
<0.67 \\
0.16 \pm 0.11 \\
\end{array}$ \\
\hline SDWA Limit (pCi/ & & 15 & (a) & 20,000 & 8 \\
\hline $\begin{array}{l}\text { Notes: } \\
\text { See Figure } 5-1 \text { for lo } \\
\text { All values reported w } \\
\text { Negative numbers oc } \\
\text { lower than backgro } \\
\text { To convert values fro } \\
\text { The drinking water st } \\
\text { (concentration base } \\
2003 \text {. Because gro } \\
\text { specific radionuclid } \\
\text { calculated for the v }\end{array}$ & $\begin{array}{l}\text { cations } \\
\text { vith a } 95^{\circ} \\
\text { ccur whe } \\
\text { und (see } \\
\text { m pCi to } \\
\text { tandard } \\
\text { ed) to } 4 \\
\text { ss beta } \\
\text { les, a do } \\
\text { alues in }\end{array}$ & $\begin{array}{l}\text { of sampling stat } \\
\% \text { confidence in } \\
\text { en the measurec } \\
\text { e Appendix B). } \\
\text { Bq, divide by } 2 \\
\text { was changed fr } \\
\text { mrem/yr (dose } \\
\text { activity does no } \\
\text { se equivalent c } \\
\text { this table. }\end{array}$ & $\begin{array}{l}\text { ations. } \\
\text { interval. } \\
\text { ed values are } \\
27.03 . \\
\text { from } 50 \mathrm{pCi} / \mathrm{L} \\
\text { based) in } \\
\text { ot identify } \\
\text { cannot be }\end{array}$ & $\begin{array}{l}\mathrm{N}=\text { Number of sam } \\
\text { NS = Not Sampled } \\
\text { RHIC = Relativistic } \\
\text { Collider } \\
\text { SDWA = Safe Drink } \\
\text { STP = Sewage Trea }\end{array}$ & $\begin{array}{l}\text { mples analyzed } \\
\text { for this analyte } \\
\text { Heavy lon } \\
\text { king Water Act } \\
\text { eatment Plant }\end{array}$ \\
\hline
\end{tabular}




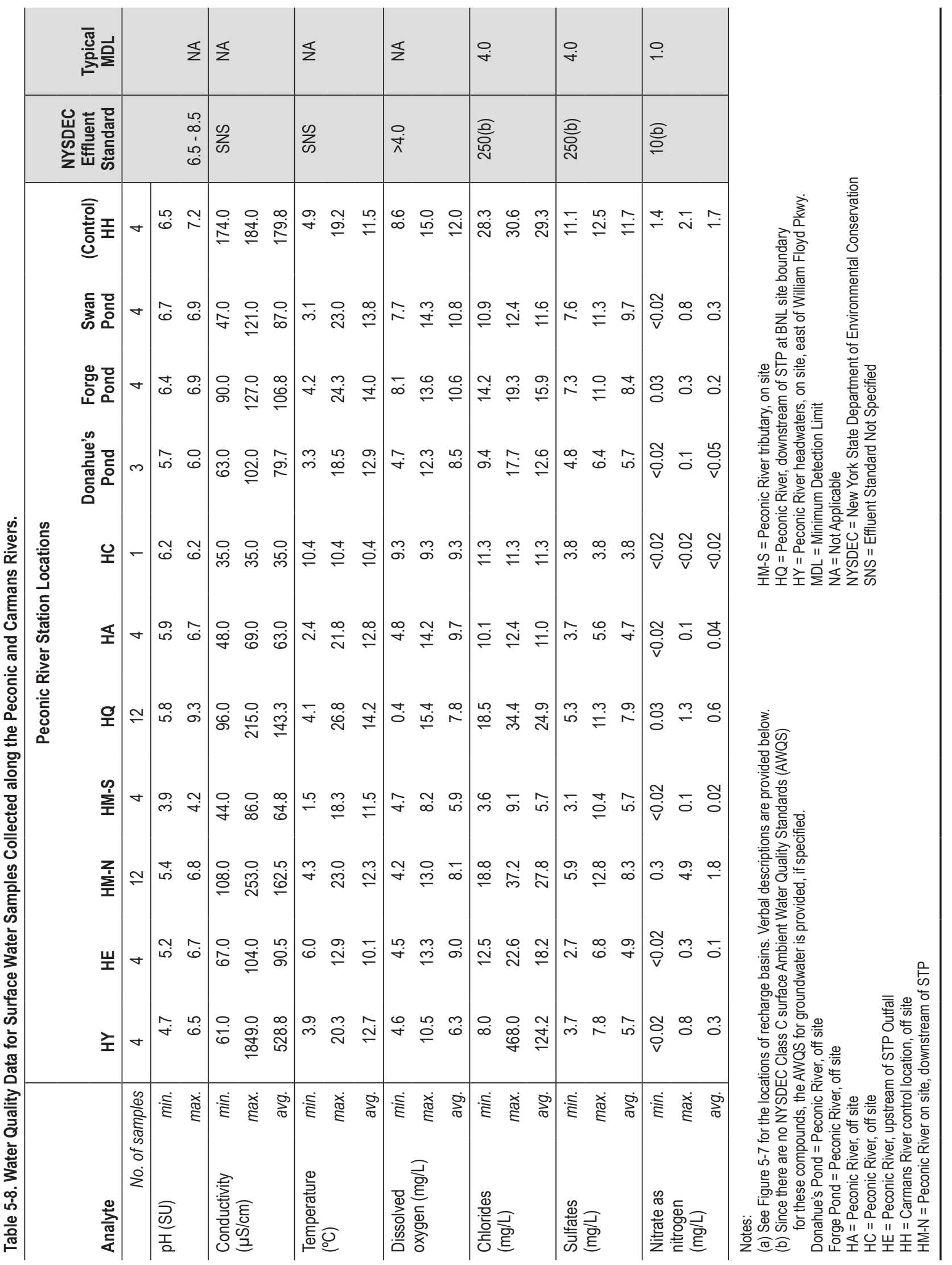




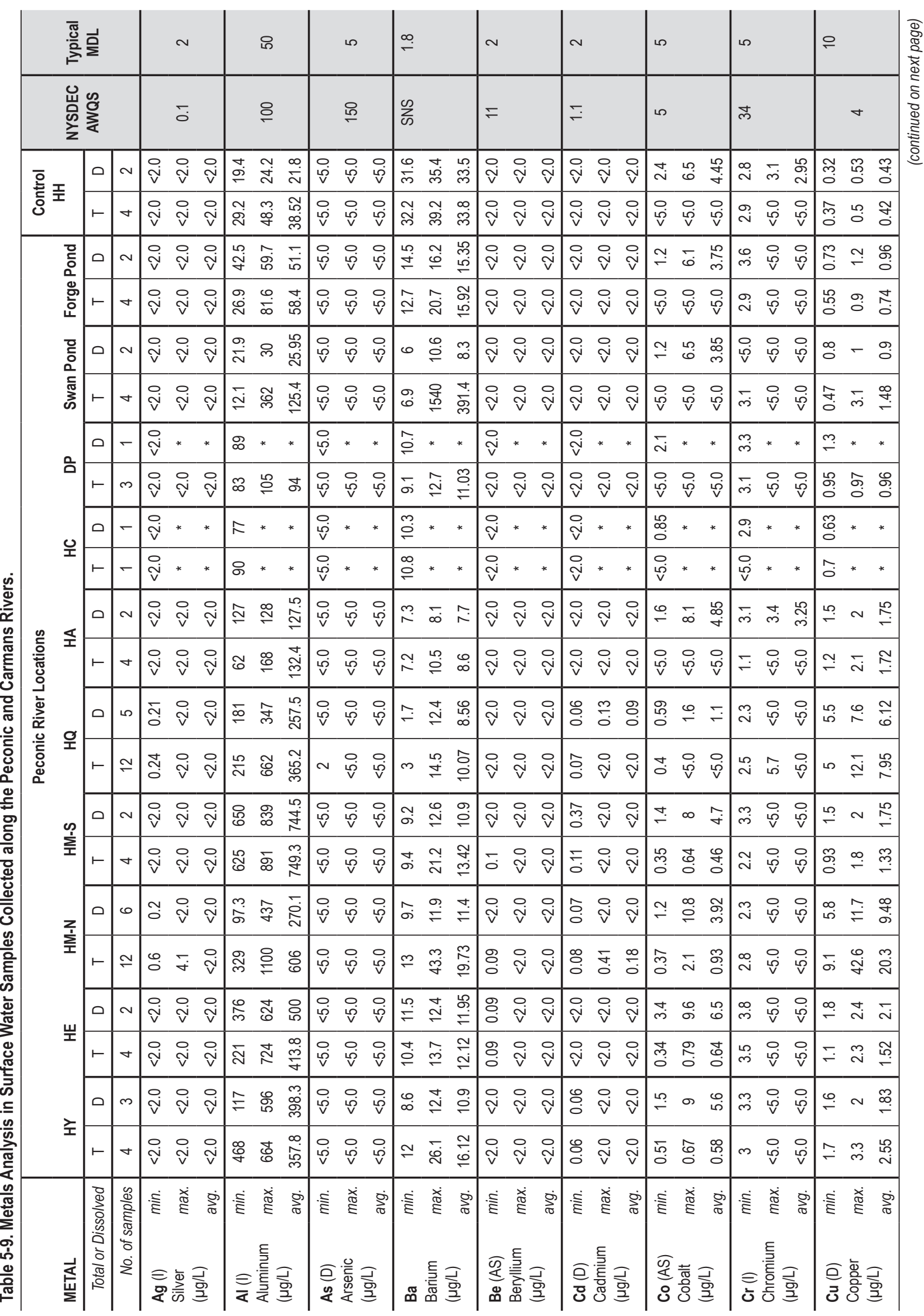




\begin{tabular}{|c|c|c|c|c|c|c|c|c|c|c|c|c|}
\hline \multicolumn{3}{|c|}{ 吾 } & 응 & ̃̃ & $\sim$ & - & 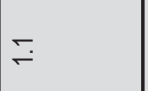 & $m$ & مـ & مـ & L & \\
\hline \multicolumn{3}{|c|}{ 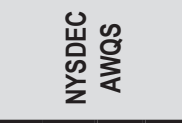 } & $\stackrel{m}{0}$ & ฮี & $\sum_{\infty}^{\infty}$ & $\sum_{\infty}^{\infty}$ & $\mathscr{N}$ & $\stackrel{+}{\leftarrow}$ & $\sum_{\omega}^{\infty}$ & $\stackrel{\circ}{+}$ & $\infty$ & \\
\hline \multirow{2}{*}{ 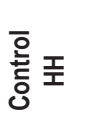 } & 0 & $\sim$ & $\left|\begin{array}{ccc}\frac{0}{0} & \frac{1}{0} & \multirow{0}{0}{}\end{array}\right|$ & $\left|\begin{array}{ccc}\tilde{O} & \tilde{Q} & \tilde{Q} \\
\bar{v} & \bar{v}\end{array}\right|$ & 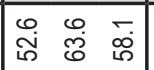 & 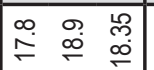 & $\bar{\sigma}=\bar{\sigma}$ & $\left|\begin{array}{lll}0 & 0 & 0 \\
\tilde{v} & \stackrel{\tilde{v}}{v} & 0\end{array}\right|$ & 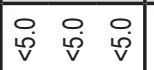 & 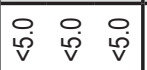 & 悹 $\begin{array}{ll}0 \\
\dot{v}\end{array}$ & \\
\hline & $\vdash$ & $\nabla$ & $\begin{array}{ccc}\bar{m} & \hat{m} & \stackrel{m}{0} \\
0 & 0 & 0\end{array}$ & 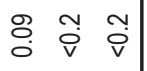 & 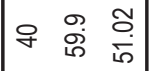 & $\left|\begin{array}{lll}\infty & m & \stackrel{\infty}{\sim} \\
\stackrel{\sim}{\sim} & \stackrel{\infty}{\leftarrow}\end{array}\right|$ & 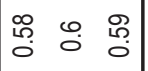 & 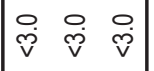 & 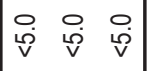 & 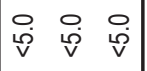 & 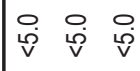 & \\
\hline \multirow{2}{*}{ 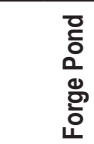 } & $\circ$ & $\sim$ & \begin{tabular}{|lll|}
\multirow{2}{*}{} & $\Re$ & $\stackrel{9}{0}$ \\
0 & 0 & 0 \\
0
\end{tabular} & 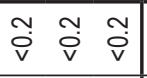 & 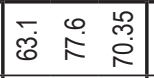 & \begin{tabular}{|lll|}
\multirow{\sigma}{*}{} & $\bar{\delta}$ & $\infty$ \\
$\sigma$ & $\stackrel{\sigma}{\circ}$ \\
\end{tabular} & 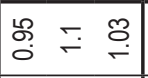 & 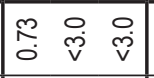 & 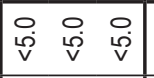 & 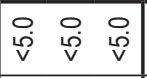 & 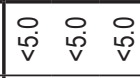 & \\
\hline & $\vdash$ & 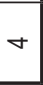 & 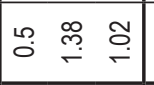 & 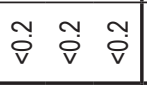 & $\begin{array}{|ccc|}\dot{m} & \infty & \stackrel{\circ}{\circ} \\
\end{array}$ & 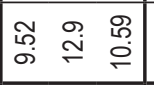 & 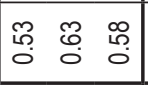 & $\left|\begin{array}{lll}0 & 0 & 0 \\
\hdashline & \stackrel{\widetilde{v}}{v} & \mathrm{v}\end{array}\right|$ & 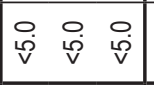 & $\begin{array}{lll}\circ & 0 & 0 \\
\stackrel{\rho}{v} & \stackrel{\rho}{v} & \stackrel{\rho}{v}\end{array}$ & 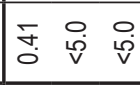 & \\
\hline \multirow{3}{*}{ 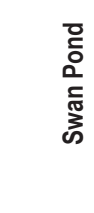 } & $\circ$ & $\sim$ & $\mid \begin{array}{lll}\qquad & 0 & 0 \\
0 & 0 & 0 \\
0 & 0 & 0 \\
\end{array}$ & 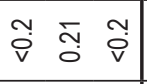 & 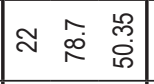 & 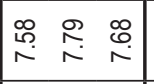 & 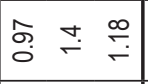 & 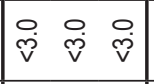 & $\begin{array}{ccc}0 & 0 & 0 \\
\stackrel{\leftrightarrow}{\vee} & \stackrel{v}{v} & \vee\end{array}$ & 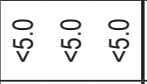 & 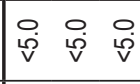 & \\
\hline & $\vdash$ & 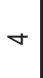 & 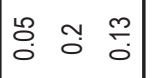 & 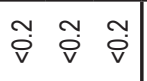 & 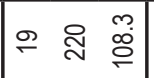 & 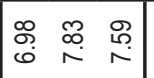 & 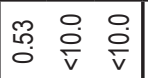 & $=\begin{array}{lll}= & 0 & 0 \\
\dot{v} & \dot{v}\end{array}$ & $\mid \begin{array}{lll}0 & 0 & 0 \\
\stackrel{v}{v} & \stackrel{v}{v} & \vee\end{array}$ & $\left|\begin{array}{ccc}0 & 0 & 0 \\
\stackrel{v}{v} & \stackrel{v}{v} & \stackrel{v}{v}\end{array}\right|$ & $\mid \begin{array}{lll}\infty & 0 & 0 \\
0 & \stackrel{v}{0} & \stackrel{v}{v}\end{array}$ & \\
\hline & 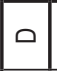 & - & $\begin{array}{ll}0 \\
0 \\
0\end{array}$ & 원 * * & 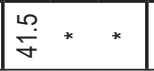 & 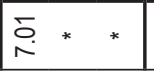 & $-* *$ & $\stackrel{0}{\circ} * *$ & 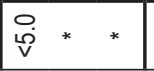 & 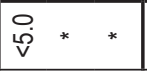 & 㝒 * & \\
\hline \multirow{2}{*}{ a } & $\vdash$ & $m$ & 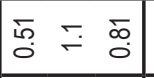 & 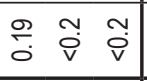 & 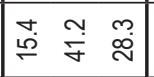 & 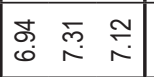 & $\begin{array}{|lll|}\infty & \infty & 0 \\
0 & 0 & 0 \\
0 & 0 & 0 \\
\end{array}$ & 足 & 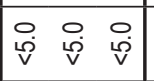 & \begin{tabular}{lll|}
0 & 0 & 0 \\
$\stackrel{v}{v}$ & $\stackrel{v}{v}$ & $\stackrel{v}{v}$
\end{tabular} & 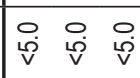 & \\
\hline & $\circ$ & - & 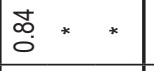 & 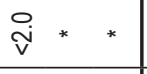 & $\underset{f}{\mathcal{Z}} * *$ & $\underset{\sim}{\stackrel{\Xi}{\sim}} * *$ & 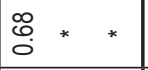 & $\stackrel{O}{\stackrel{\rho}{v}}{ }^{*} \quad *$ & 㝒* * * & $\stackrel{\circ}{\stackrel{\rho}{v}} *^{*} *$ & 官 & \\
\hline \multirow{5}{*}{ 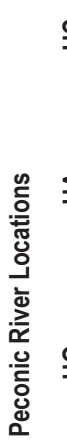 } & $\vdash$ & - & $\digamma * *$ & 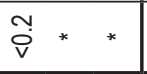 & $\widehat{\hat{g}} * *$ & $\underset{\sim}{8} *{ }^{\circ} *$ & : * * & 兽 * * & 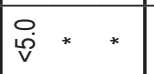 & $\stackrel{\stackrel{O}{\vee}}{\vee} *$ * & 嶽 * & \\
\hline & 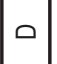 & $\sim$ & $\left|\begin{array}{lll}\forall & \hat{A} & \overline{0} \\
0 & 0 & 0\end{array}\right|$ & 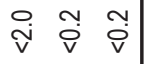 & 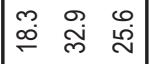 & 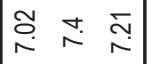 & $\stackrel{\leftrightarrow}{\longrightarrow} \sim \stackrel{\infty}{\rightarrow}$ & $\left|\begin{array}{lll}0 & 0 & 0 \\
0 & 0 & 0 \\
0 & 0 & 0\end{array}\right|$ & $\mid \begin{array}{ccc}0 & 0 & 0 \\
\stackrel{v}{v} & \stackrel{v}{v} & \stackrel{v}{v}\end{array}$ & 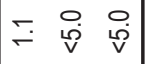 & $\mid \begin{array}{lll}0 & 0 & 0 \\
\dot{v} & \stackrel{v}{v} & \stackrel{\leftrightarrow}{v}\end{array}$ & \\
\hline & $\vdash$ & $\nabla$ & 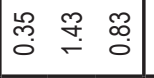 & 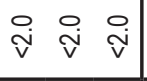 & 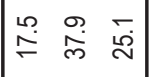 & 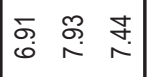 & 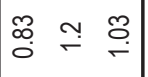 & $\left|\begin{array}{lll}\bar{\Xi} & 0 & 0 \\
\hdashline & \stackrel{\vartheta}{v} & \stackrel{v}{v}\end{array}\right|$ & $\begin{array}{lll}0 & 0 & 0 \\
\stackrel{\rho}{v} & \stackrel{v}{v} & \vee\end{array}$ & $\begin{array}{lll}\circ & 0 & 0 \\
\stackrel{\omega}{\varphi} & \stackrel{v}{v} & \stackrel{v}{v}\end{array}$ & m & \\
\hline & 0 & م & 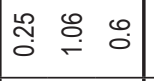 & $\begin{array}{ccc}\tilde{v} & \tilde{v} & \tilde{v} \\
\bar{v} & \bar{v} & v\end{array} \mid$ & 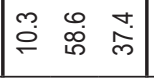 & 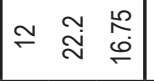 & 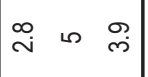 & 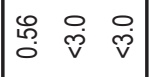 & $\mid \begin{array}{ccc}\bar{\delta} & 0 & 0 \\
\dot{0} & \stackrel{v}{v} & \stackrel{v}{v}\end{array}$ & 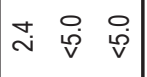 & 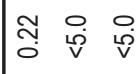 & \\
\hline & $\vdash$ & $\simeq$ & 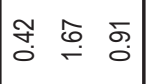 & $\left|\begin{array}{lll}0 & m & \tilde{0} \\
0 & 0 & \bar{v}\end{array}\right|$ & 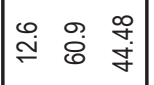 & 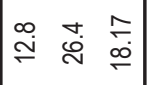 & 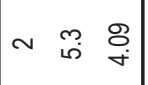 & 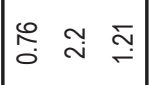 & 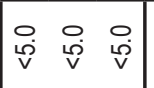 & 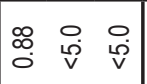 & 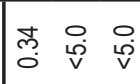 & \\
\hline \multirow{2}{*}{$\sum_{i=1}^{0}$} & $\circ$ & $\sim$ & 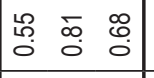 & 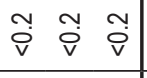 & 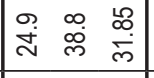 & 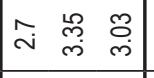 & $\cong \bar{\sim} \stackrel{\oplus}{\leftarrow}$ & $\stackrel{m}{\rightarrow} \stackrel{m}{\sim} \stackrel{m}{\sim}$ & 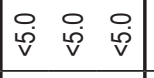 & 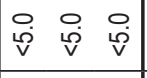 & $\begin{array}{lll}0 & 0 & 0 \\
\stackrel{v}{v} & \stackrel{v}{v} & \stackrel{\rho}{v}\end{array}$ & \\
\hline & $\vdash$ & $\nabla$ & $\mid \begin{array}{lll}m & \overline{0} & 0 \\
0 & 0 & 0 \\
0 & 0\end{array}$ & 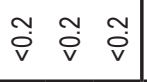 & 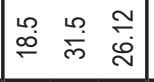 & 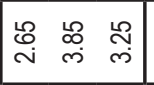 & 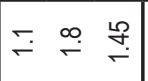 & 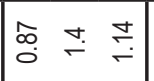 & 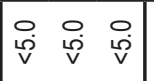 & 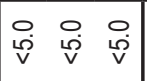 & 守 & \\
\hline \multirow{2}{*}{$\sum_{i}^{z}$} & 0 & 0 & 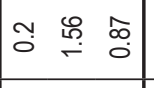 & 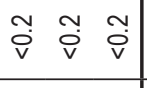 & 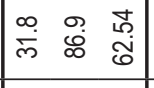 & 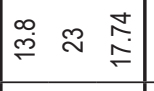 & \begin{tabular}{lll}
0 & $\cong$ & $\infty$ \\
& $\nwarrow$ & $\infty$ \\
\hdashline
\end{tabular} & $\left|\begin{array}{lll}\bar{i} & 0 & 0 \\
0 & \stackrel{v}{v} & \stackrel{v}{v}\end{array}\right|$ & 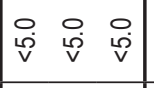 & 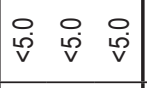 & 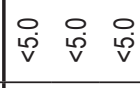 & \\
\hline & $\vdash$ & $\simeq$ & 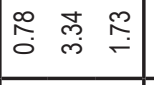 & 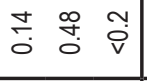 & 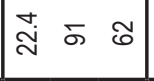 & 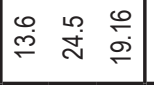 & 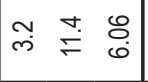 & 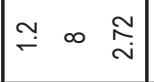 & 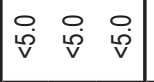 & 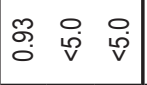 & 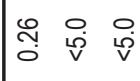 & \\
\hline \multirow{2}{*}{ 岌 } & 0 & $\sim$ & 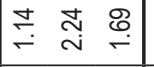 & $\left|\begin{array}{ccc}\tilde{N} & \tilde{v} & \tilde{v} \\
\dot{v} & \tilde{v} & 0\end{array}\right|$ & $\mid \begin{array}{lll}\mathscr{\infty} & m & - \\
\infty & \stackrel{8}{\infty} & \infty \\
\end{array}$ & 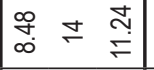 & 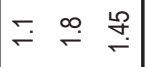 & 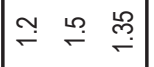 & $\mid \begin{array}{lll}0 & 0 & 0 \\
\stackrel{v}{v} & \stackrel{v}{v} & \stackrel{v}{v}\end{array}$ & $\begin{array}{lll}0 & 0 & 0 \\
\stackrel{\rho}{v} & \stackrel{v}{v} & \stackrel{v}{v}\end{array}$ & 郘 & \\
\hline & $\vdash$ & + & 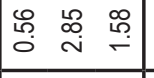 & 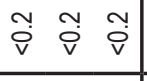 & 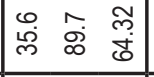 & 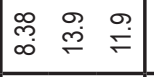 & 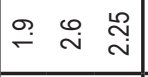 & $\tilde{\overbrace{}}$ & $\mid \begin{array}{ccc}0 & 0 & 0 \\
ن & \stackrel{v}{v} & \stackrel{v}{v}\end{array}$ & 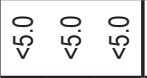 & 莡 & \\
\hline \multirow{2}{*}{ 文 } & ه & $m$ & 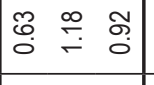 & 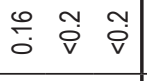 & 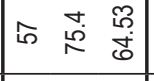 & 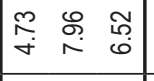 & 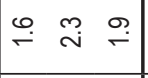 & $-\underset{⿱ 亠 乂}{\stackrel{9}{\leftarrow}}$ & 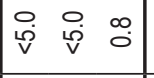 & 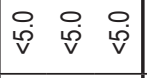 & 悹 & \\
\hline & $\vdash$ & 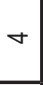 & 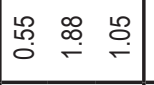 & \begin{tabular}{ccc|}
$\tilde{v}$ & $\widetilde{Q}$ & $\widetilde{v}$ \\
$\stackrel{\nabla}{v}$ & $\bar{v}$ \\
\end{tabular} & 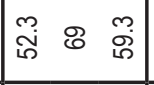 & 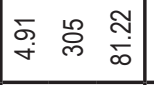 & 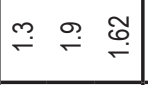 & 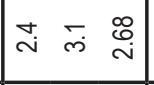 & $\mid \begin{array}{ccc}0 & 0 & 0 \\
ن & \stackrel{\rho}{v} & \stackrel{b}{v}\end{array}$ & 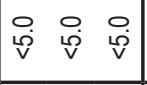 & 突 & \\
\hline $\begin{array}{l}\overrightarrow{\overleftarrow{E}} \\
\stackrel{\mathrm{w}}{\Sigma}\end{array}$ & 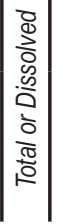 & 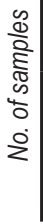 & 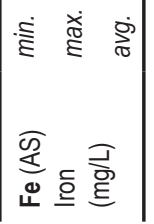 & 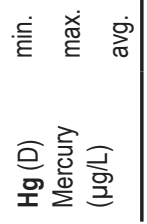 & 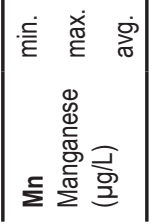 & 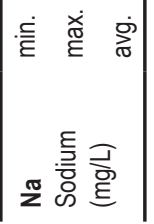 & 可产 & 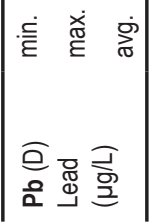 & 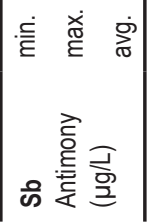 & 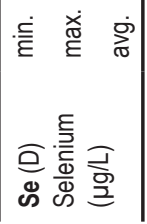 & 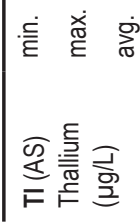 & \\
\hline
\end{tabular}




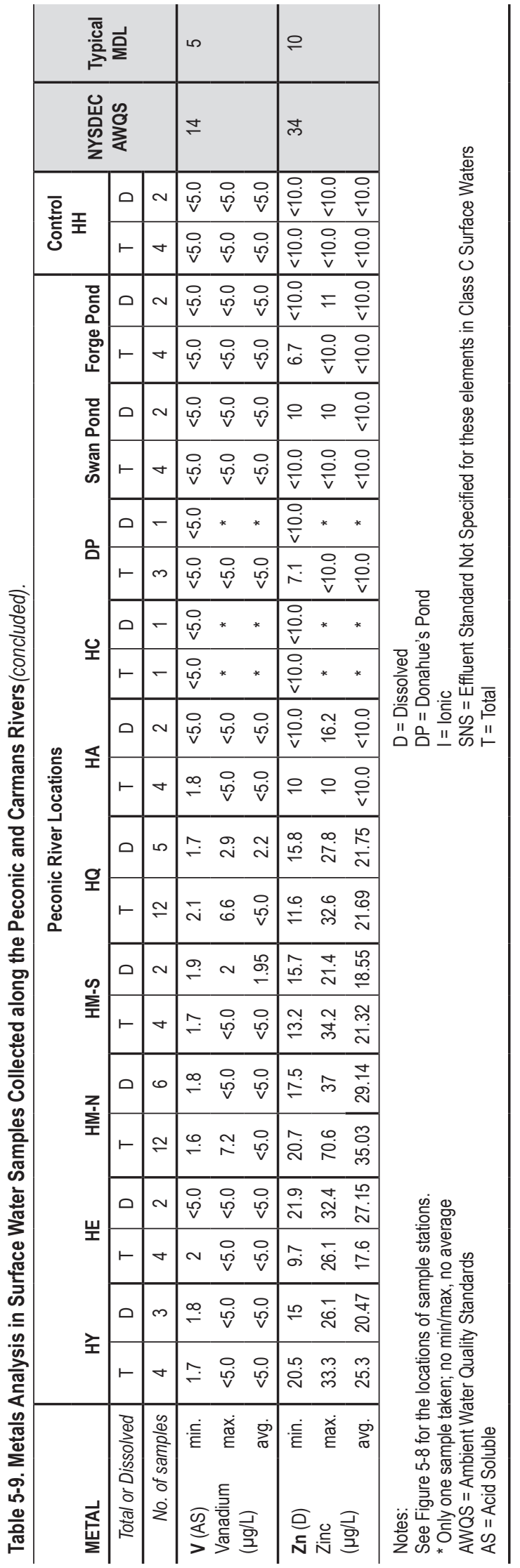

from the Carmans River control location (HH). Sulfates, and nitrates tend to be slightly higher in samples collected immediately downstream of the STP discharge (Stations HM-N and HQ) and were consistent with the concentrations in the STP discharge. All nitrate levels were less than $10 \mathrm{mg} / \mathrm{L}$. Chlorides were highest at Station HY, which is immediately east of William Floyd Parkway and likely impacted by road salting operations. There are no AWQS imposed for chloride or sulfates in discharges to surface water; however, NYSDEC imposes a limit of $500 \mathrm{mg} / \mathrm{L}$ for discharges to groundwater.

The $\mathrm{pH}$ measured at several locations was very low, due to the low $\mathrm{pH}$ of precipitation, groundwater, and the formation of humic acids from decaying organic matter. As spring rains mix with decaying matter, these acids decrease the already low $\mathrm{pH}$ of precipitation, resulting in a pH as low as 3.9 Standard Units. A discussion of precipitation monitoring is provided in Chapter 6 (see Section 6.7 for more detail).

Ambient water quality standards for metallic elements are based on their solubility state. Certain metals are only biologically available to aquatic organisms if they are in a dissolved or ionic state, whereas other metals are toxic in any form (i.e., dissolved and particulate combined). In 2006, the BNL monitoring program continued to assess water samples for both the dissolved and particulate form. Dissolved concentrations were determined by filtering the samples prior to acid preservation and analysis. Examination of the metals data showed that aluminum, copper, iron, lead, and zinc were present in concentrations at some locations that exceeded AWQS both upstream and downstream of the STP discharge. Aluminum and iron are detected throughout the Peconic and Carmans Rivers at concentrations that exceed the NYS AWQS in both the filtered and unfiltered fractions. Both are found in high concentrations in native Long Island soil and, for iron, at high levels in groundwater. The low $\mathrm{pH}$ of groundwater and precipitation contribute to the dissolution of these elements. Although most metals were detected in upstream samples (indicating a natural presence), the highest levels for copper, lead, and zinc were detected in 
samples collected immediately downstream of the Laboratory's STP discharge (HM-N). The concentrations detected were consistent with the concentrations found in the STP discharge and, in most instances, were within the BNL SPDES permit limits. The NYS AWQS limits for copper, lead, and zinc are extremely restrictive; consequently, the NYS-granted SPDES permit allows higher limits provided toxicity testing shows no impact to aquatic organisms. Filtration of the samples reduced concentrations of most metals to below the NYS AWQS, indicating that most detections were due to sediment carryover.

Mercury was detected sporadically in samples collected from Station HM-N and in a single sample collected at Station HQ, both downstream of the Laboratory's STP discharge. Metals such as mercury can pose a risk for human consumption when they enter the food chain. In 2005, BNL completed an extensive project to remove contaminants from the Peconic River by excavating 6 to 12 inches of sediment from the river bottom. Remediation began immediately downstream of the STP discharge and continued off site into the County Parks east of the BNL boundary. Once remediation was completed, monitoring of river water, sediment, vegetation, and fish samples was performed to determine the project's effectiveness. Mercury levels in the water initially rose, most likely due to disturbances of mercury deposits within the buried sediments. While the mercury levels in the sediments are lower than the pre-cleanup levels, suspension of the sediments due to erosion likely resulted in the detections noted at these locations. All filtered results were less than detection levels.

\section{REFERENCES AND BIBLIOGRAPHY}

BNL. 1998. Operable Unit V: Remedial Investigation and Risk Assessment of the Eastern Area of the Laboratory. Brookhaven National Laboratory, Upton, NY.

BNL. 200I. Standards Based Management System Subject Area: Liquid Effluents. Brookhaven National Laboratory, Upton, NY. May 2001.

DOE Order 5400.5 1990. Radiation Protection of the Public and the Environment. U.S. Department of Energy, Washington, DC. Change 2: 1-7-93.

NYCRR Part 703.6. Title 6. 1999. Surface Water and Groundwater Quality Standards and Groundwater Effluent Limitations. New York State Department of Environmental Conservation. Albany, NY. Change 8-4-99.

Remien, J. 2007. Central Steam Facility Storm Water Outfall Remediation Closeout Report, Brookhaven National Laboratory, Upton, NY. February 21, 2007. 


\section{Natural and Cultural Resources}

The Brookhaven National Laboratory Natural Resource Management Program is designed to protect and manage flora and fauna and the ecosystems in which they exist. The Laboratory's natural resource management strategy is based on understanding the site's resources and on maintaining compliance with applicable regulations. The goals of the program include protecting and monitoring the ecosystem, conducting research, and communicating with staff and the public on ecological issues. BNL focuses on protecting New York State threatened and endangered species on site, as well as continuing the Laboratory's leadership role within the greater Long Island Central Pine Barrens ecosystem.

Monitoring to determine whether current or historical activities are affecting natural resources is also part of this program. In 2006, deer and fish sampling results were consistent with previous years. Vegetables grown in the BNL garden plot continue to support historical analyses that there are no Laboratory-generated radionuclides in produce.

The Foundation for Ecological Research in the Northeast conducted a second year of monitoring under the Forest Health Monitoring program established for the Long Island Central Pine Barrens, and planning for freshwater wetlands monitoring was initiated. This work is discussed in greater detail in this chapter.

The overriding goal of the Cultural Resource Management Program is to ensure that proper stewardship of BNL and DOE historic resources is established and maintained. Additional goals of the program include maintaining compliance with various historic preservation and archeological laws and regulations, and ensuring the availability of identified resources to on-site personnel and the public for research and interpretation. Under the BNL Cultural Resource Management Plan, an archeological survey was completed of a 30-acre area where the proposed National Synchrotron Light Source II is to be placed. Additional details are discussed within this chapter.

\section{I NATURAL RESOURCE MANAGEMENT PROGRAM}

The purpose of the Natural Resource Management Program at BNL is to promote stewardship of the natural resources found at the Laboratory, as well as to integrate natural resource management and protection with BNL's scientific mission. To meet this purpose, the Laboratory prepared and issued the Natural Resource Management Plan (NRMP) (BNL 2003a). The NRMP describes the program strategy, elements, and planned activities for managing the various resources found on site.

\section{I.I Identification and Mapping}

An understanding of the environmental baseline is the foundation of natural resource management planning. BNL uses digital global positioning systems (GPS) and geographic information systems (GIS) to clearly relate various "layers" of geographic information (e.g., vegetation types, soil condition, habitat, forest health, etc.). This is done to gain insight into interrelationships between the biotic systems and physical conditions at the Laboratory. In 2005, efforts were initiated to better understand the distribution of deer on site. A model of deer 
density was developed (Figure 6-1) using the mapping and spatial analysis tools. This model enables resource managers to track changes in deer density over time, detect interactions between components of the ecosystem, and identify locations for management activities.

A wide variety of vegetation, birds, reptiles, amphibians, and mammals inhabit the site. Through implementation of the NRMP, additional endangered, threatened, and species of special concern have been identified as having been resident at BNL during the past 30 years. The only New York State endangered species confirmed as now inhabiting Laboratory property is the eastern tiger salamander (Ambystoma t. tigrinum). Additionally, the New York State endangered Persius duskywing butterfly (Erynnis $p$. persius) and the crested fringed orchid (Plantathera cristata) have been identified on the site in the past. Five New York State threatened species have been positively identified on site and two other species are considered likely to be present. The banded sunfish (Enneacanthus obesus), the swamp darter fish (Etheostoma fusiforme), and the stiff goldenrod plant (Solidago rigida) have been previously reported (BNL 2000). The northern harrier (Circus cyaneus) was seen hunting over open fields in November 2003. In 2005, the Pine Barrens bluet (Enallagma recurvatum) damselfly was confirmed at one of the many coastal plain ponds located on site. The frosted elfin butterfly (Callophrys irus) has been identified as possibly being at BNL, based on historic documentation and the presence of its preferred habitat and host plant (wild lupine). In addition, stargrass (Aletris farinosa) was reconfirmed to exist at BNL. Several other species that inhabit the site, visit during migration, or have historically been identified, are listed as rare, species of special concern, or exploitably vulnerable by New York State (Table 6-1).

\subsubsection{Habitat Protection and Enhancement}

BNL has precautions in place to protect on-site habitats and natural resources. Activities to eliminate or minimize negative effects on sensitive or critical species are either incorporated into Laboratory procedures or into specific program or
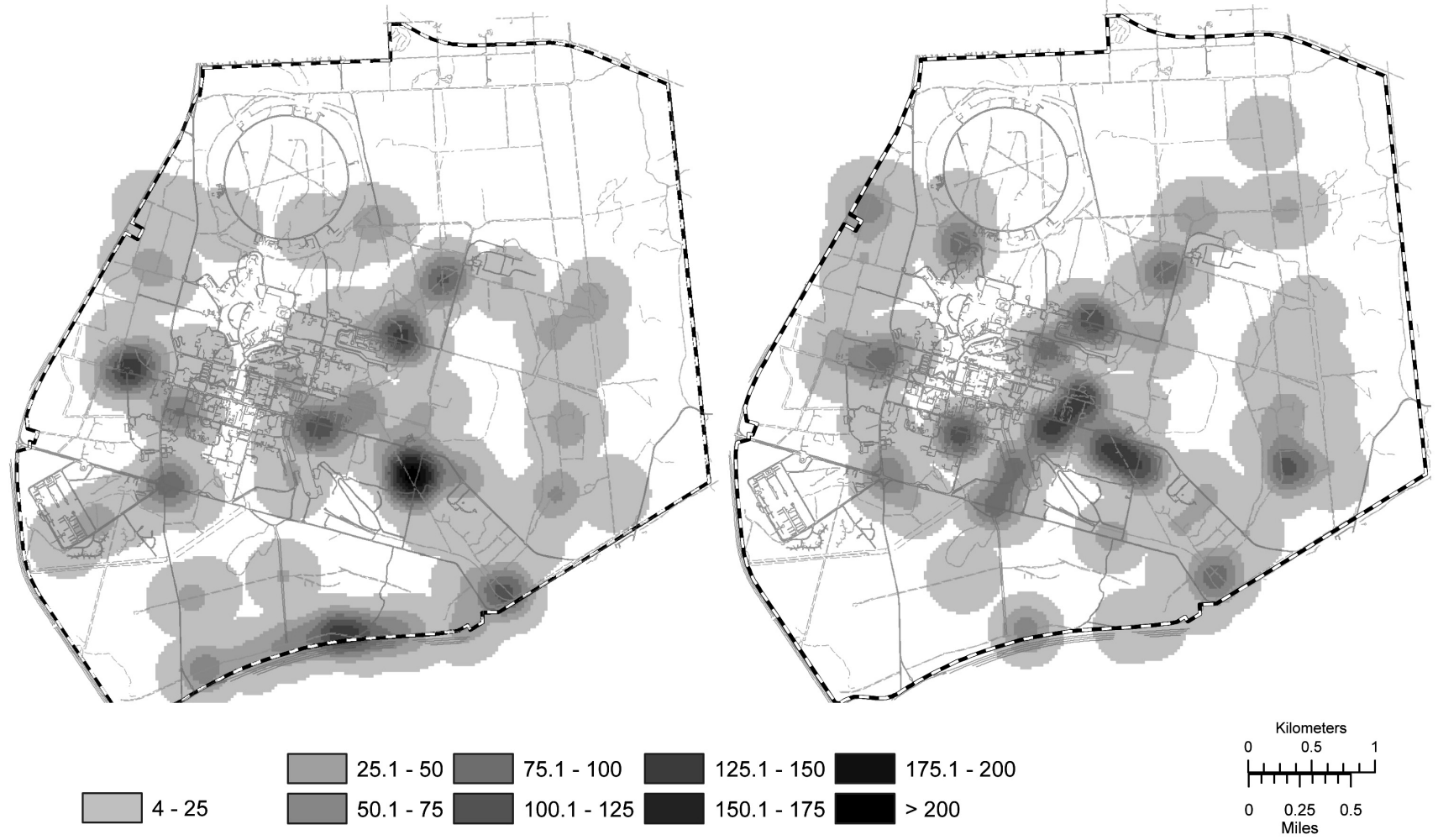

$4-25$

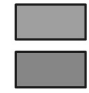

$25.1-50 \square$
$50.1-75$

75.1 - 100

100.1 - 125

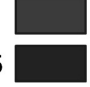

150.1 - 175

$>200$

Figure 6-I. Population Density of Deer — Fall 2006. 
project plans. Environmental restoration efforts remove pollutant sources that could contaminate habitats. Human access to critical habitats is limited. In some cases, habitats are enhanced to improve survival or increase populations. Even routine activities such as road maintenance are not performed until they have been duly evaluated and determined to be unlikely to affect habitat.

\subsubsection{Salamander Protection Efforts}

To safeguard eastern tiger salamander breeding areas, a map of these locations is reviewed when new projects are proposed. Distribution of the map is limited, to protect the salamander from exploitation by collectors and the pet trade. The map is routinely updated as new information concerning the salamanders is generated through research and monitoring. Other efforts to protect this state endangered species include determining when adult salamanders are migrating toward breeding locations, when metamorphosis has been completed, and when juveniles are migrating after metamorphosis. During these times, construction and maintenance activities near their habitats are postponed. BNL environmental protection staff must review any project planned near eastern tiger salamander habitats, and every effort is made to minimize impacts.

Water quality testing is conducted as part of the routine monitoring of recharge basins, as discussed in Chapter 5. In cooperation with the New York State Department of Environmental Conservation (NYSDEC), habitat surveys have been conducted annually since 1999 . Biologists conducting egg mass and larval surveys have increased the number of confirmed sites from 17 on-site ponds to 26 ponds that are used by eastern tiger salamanders. The study procedure calls for all ponds that had egg masses during the spring surveys to be surveyed again in June and July to check for the presence of larval salamanders. Egg mass surveys of 26 ponds plus additional flooded depressions at the Laboratory were conducted in 2006. A PhD candidate and students working through the intern programs offered by DOE and BNL's Office of Education conducted surveys of tiger salamander ponds, drift fence surveys, and radio telemetry tracking
Table 6-1. New York State Threatened, Endangered, Exploitably Vulnerable, and Species of Special Concern at BNL.

\begin{tabular}{|c|c|c|c|}
\hline Common Name & Scientific Name & $\begin{array}{l}\text { State } \\
\text { Status }\end{array}$ & $\begin{array}{l}\text { BNL } \\
\text { Status }\end{array}$ \\
\hline \multicolumn{4}{|l|}{ Insects } \\
\hline Frosted elfin & Callophrys iris & $\mathrm{T}$ & Likely \\
\hline Mottled duskywing & Erynnis martialis & SC & Likely \\
\hline Persius duskywing & Erynnis persius persius & $E$ & Likely \\
\hline Pine Barrens Bluet & Enallagma recurvatum & $\mathrm{T}$ & Confirmed \\
\hline \multicolumn{4}{|l|}{ Fish } \\
\hline Banded sunfish & Enniacanthus obesus & $\mathrm{T}$ & Confirmed \\
\hline Swamp darter & Etheostoma fusiforme & $\mathrm{T}$ & Confirmed \\
\hline \multicolumn{4}{|l|}{ Amphibians } \\
\hline Eastern tiger salamander & Ambystoma tigrinum tigrinum & $E$ & Confirmed \\
\hline Marbled salamander & Ambystoma opacum & SC & Confirmed \\
\hline Eastern spadefoot toad & Scaphiopus holbrookii & SC & Confirmed \\
\hline \multicolumn{4}{|l|}{ Reptiles } \\
\hline Spotted turtle & Clemmys guttata & SC & Confirmed \\
\hline Eastern hognose snake & Heterodon platyrhinos & SC & Confirmed \\
\hline ox turtle & Terrapene carolina & SC & Confirmed \\
\hline Worm snake & Carphophis amoenus & SC & Confirmed \\
\hline \multicolumn{4}{|c|}{ Birds (nesting, transient, or potentially present) } \\
\hline Horned lark & Eremophila alpestris & SC & Likely \\
\hline Whip-poor-will & Caprimulgus vociferus & SC & Likely \\
\hline Vesper sparrow & Pooecetes gramineus & SC & Likely \\
\hline Grasshopper sparrow & Ammodramus savannarum & SC & Confirmed \\
\hline Northern harrier & Circus cyaneus & $\mathrm{T}$ & Confirmed \\
\hline Cooper's hawk & Accipiter cooperii & SC & Confirmed \\
\hline Osprey & Pandion haliaetus & SC & Confirmed \\
\hline Shap-shinned hawk & Accipiter striatus & SC & Confirmed \\
\hline \multicolumn{4}{|l|}{ Plants } \\
\hline Stargrass & Aletris farinosa & $\mathrm{T}$ & Confirmed \\
\hline Butterfly & Asclepias tuberosa & V & Confirmed \\
\hline Spotted wintergreen & Chimaphila maculata & V & Confirmed \\
\hline Flowering dogwood & Cornus florida & V & Confirmed \\
\hline Pink lady's slipper & Cypripedium acaule & V & Confirmed \\
\hline Winterberry & Ilex verticillata & V & Confirmed \\
\hline Sheep laurel & Kalmia angustifolia & V & Confirmed \\
\hline Narrow-leafed bush clover & Lespedeza augustifolia & $\mathrm{R}$ & Confirmed \\
\hline Ground pine & Lycopodium obscurum & V & Confirmed \\
\hline Bayberry & Myrica pensylvanica & V & Confirmed \\
\hline Cinnamon fern & Osmunda cinnamomera & V & Confirmed \\
\hline Clayton's fern & Osmunda claytoniana & V & Confirmed \\
\hline Royal fern & Osmunda regalis & V & Confirmed \\
\hline Crested fringed orchid & Plantathera cristata & $E$ & Likely \\
\hline Swamp azalea & Rhododendron viscosum & V & Confirmed \\
\hline Long-beaked bald-rush & Rhynchospora scirpoides & $\mathrm{R}$ & Confirmed \\
\hline Stiff goldenrod & Solidago rigida & $\mathrm{T}$ & Confirmed \\
\hline New York fern & Thelypteris novaboracensis & V & Confirmed \\
\hline Marsh fern & Thelypteris palustris & V & Confirmed \\
\hline Virginia chain-fern & Woodwardia virginica & V & Confirmed \\
\hline \multicolumn{4}{|c|}{$\begin{array}{l}\text { Notes: } \\
\text { * Table information is based on } 6 \text { NYCRR Part 182, } 6 \text { NYCRR Part 193, and BNL survey data. } \\
\text { No federally listed Threatened or Endangered Species are known to inhabit the BNL site. } \\
\text { E = Endangered } \\
R=\text { Rare } \\
\text { SC = Species of Special Concern } \\
T=\text { Threatened } \\
V=\text { Exploitably Vulnerable }\end{array}$} \\
\hline
\end{tabular}


around four ponds. The results of these studies show the extent of egg mass production, the importance of precipitation as a trigger for metamorphic salamanders leaving ponds, and the extent of movements by both adults and metamorphic tiger salamanders. Work toward a comprehensive understanding of eastern tiger salamander movements and habitat needs began in 2004, with funding provided to SUNY Binghamton by NYSDEC. Continued research consistently adds to the understanding of the needs of this state endangered species. Information acquired from all research is entered into a database, and portions of the data are linked to a GIS. These data are used to visualize distributions, track reproductive success, and identify areas for focused management or study.

\subsubsection{Eastern Box Turtle}

A radio telemetry study of the eastern box turtle (Terrapene carolina) was initiated in 2006 to investigate the amount of territory overlap between individual turtles. This study was initiated after repeatedly finding turtles with ear infections and the discovery of three sick turtles simultaneously in 2005. Two of the three turtles died and were subsequently necropsied, with tissues sent to a laboratory for virus isolation. Results confirmed the presence of an iridovirus known to affect turtles and amphibians, which was of greater concern, given their endangered status. As the three turtles were found in a primary breeding pond for tiger salamanders, further study was warranted. The radiotelemetry study confirmed significant amounts of overlap within the territories of five turtles outfitted with transmitters. This overlap provides an indication of the likelihood of disease transmission between turtles. Additionally, all five turtles spent some time near the pond and could have released the virus to the water, where it could infect amphibians. The telemetry work is scheduled to continue in 2007.

Associated with the radiotelemetry study was a study to isolate and identify the iridovirus within eastern box turtles found at BNL. Routine transects of various areas of the Laboratory were established and traversed in order to capture eastern box turtles. When a turtle was found, it was given a unique identification mark and samples from the mouth and cloaca were taken using cotton swabs. The samples were later tested for iridovirus. Unfortunately, due to difficulties at the contract analytical laboratory, iridovirus could not be isolated. The study will continue with revisions in 2007 in order to assess the potential for turtles to carry iridovirus and infect other reptiles or amphibians. Revisions will include improved procedures for obtaining swab samples and alterations of lab procedures to improve the genetic analysis of samples.

\subsubsection{Other Species}

As part of the eastern tiger salamander and herpetological surveys, information is being gathered on other species found on site. Including the tiger salamander (see Section 6.1.2.1), sightings of 26 species of reptiles and amphibians have been recorded over the past several years. The species observed include the northern red-back salamander (Plethodon c. cinereus), marbled salamander (Ambystoma opacum), four-toed salamander (Hemidactylium scutatum), red-spotted newt (Notophthalmus viridescens), spring peeper (Pseudacris crucifer), wood frog (Rana sylvatica), gray tree frog (Hyla versicolor), bullfrog (Rana catesbiana), green frog (Rana clamitans), pickerel frog (Rana palustris), Fowler's toad (Bufo woodhousei fowleri), eastern spadefoot toad (Scaphiopus holbrooki), snapping turtle (Chelydra serpentine), painted turtle (Chrysemys p. picta), musk turtle (Sternotherus odoratus), spotted turtle (Clemmys guttata), eastern box turtle (Terrapene c. Carolina), northern black racer (Coluber constrictor), eastern ribbon snake (Thamnophis s. sauritus), eastern garter snake (Thamnophis $s$. sirtalis), northern water snake (Nerodia s. sipedon), northern ring-necked snake (Diadophis puctatus edwardsi), brown snake (Storeria d. dekayi), the northern red-bellied snake (Storeria occiptiomaculata), and the eastern wormsnake (Carphophis amoenus). This listing indicates that BNL has one of the most diverse herpetofaunal assemblages on Long Island.

Banded sunfish protection efforts include observing whether adequate flow in the Peconic 
River is maintained within areas currently identified as sunfish habitat, ensuring that existing vegetation in their habitat is not disturbed, and evaluating all activities taking place on the river for potential impacts on these habitats. A population estimate of reproductive success of the banded sunfish in a protected pond was scheduled for 2006 after the pond nearly dried in 2005. However, due to cool springtime temperatures, fish reproduction was delayed. An attempt at assessing the population was made, but because the fish were so small, concerns were that studies would damage the population. Plans for the population assessment were rescheduled for 2007. The likelihood of a successful population estimate in 2007 is high because the hydrologic conditions of the pond remained in satisfactory condition in late 2005 . Conservative estimates are that the pond held 3,000 fish at that time. If even a portion of the fish survived to successfully breed in 2006, the resulting population should be significant.

A total of 216 species of birds have been identified at BNL since 1948; at least 85 species are known to nest on site. Some of these nesting birds have shown declines in their populations nationwide over the past 30 years. The Laboratory conducts routine monitoring of songbirds along six permanent bird survey routes in various habitats at BNL. In 2006, monthly surveys were conducted starting at the end of March and extending through the end of September. These surveys identified 70 songbird species, compared to 67 species in 2005 and 68 species during 2004. Two new species were identified during the 2006 surveys. A total of 110 songbird species have been identified during surveys in the past seven years; 45 of these species were present each year. Variations in the number and species identified reflect the time of sampling, variations in weather patterns between years, or actual changes in the environment. The two most diverse transects pass near wetlands by the Biology Fields and the Peconic River. The four transects passing through the various forest types (white pine, moist pine barrens, and dry pine barrens) showed a less diverse bird community. Data are stored in an electronic database that is linked to the Laboratory's GIS.
Canada geese (Branta canadensis) are a protected species under the Migratory Bird Treaty Act. BNL has a resident, year-round (non migrating) flock of approximately 120 birds that occasionally create problems due to their droppings, choice of nesting areas, and assertive defense of nests and offspring. When questions regarding migratory birds arise, BNL consults NYSDEC, U.S. Fish \& Wildlife Services (FWS), and the United States Department of Agriculture - Animal Plant Health Inspection Service - Wildlife Services Division. Because Canada geese have protected status, they were allowed to finish nesting while action plans took shape to prevent their use of the same areas in the future. The Laboratory began looking into control methods in 2006 and will likely begin some form of population management in 2007.

The eastern bluebird (Sialia sialis) has been identified as one of the declining species of migratory birds in North America. This decline is due to loss of habitat and to nest site competition from European starlings (Sturnus vulgaris) and house sparrows (Passer domesticus). BNL's NRMP includes habitat enhancement for the eastern bluebird. Since 2000, the Laboratory has installed 56 nest boxes around open grassland areas on site to enhance their population. In 2006, the boxes were monitored approximately every 3 weeks during the breeding season to determine use and nesting success. Thirty-nine bluebird nests were observed. Other birds using the houses included house wrens (Troglodytes aedon), black-capped chickadees (Poecile atricapilla), tufted titmouse (Baeolophus bicolor), and tree swallows (Tachycineta bicolor). Bluebirds produced 38 broods in 2006, compared to 19 broods in 2002.

\subsubsection{Population Management}

The Laboratory also monitors and manages other populations, including species of interest, to ensure that they are sustained and to control invasive species.

\subsubsection{Wild Turkey}

The forested areas of BNL provide good nesting and foraging habitat for wild turkey (Meleagris gallapavo). The on-site population 
was estimated at 60 to 80 birds in 1999 and had grown to approximately 500 birds in 2004 . Since 2004, the population appears to have stabilized at approximately 300 birds. The population across Suffolk County, Long Island, is now sufficiently large for NYSDEC to consider establishing a hunting season to maintain the population at a reasonable number.

\subsubsection{White-Tailed Deer}

BNL consistently updates information on the resident population of white-tailed deer (Odocoileus virginianus). As there are no natural predators on site and hunting is not permitted at the Laboratory, there are no significant pressures on the population to migrate beyond their typical home range of approximately 1 square mile. Normally, a population density of 10 to 30 deer per square mile is considered an optimum sustainable level for a given area. This would equate to approximately 80 to 250 deer inhabiting the BNL property, under normal circumstances. This was the approximate density in 1966, when the Laboratory reported an estimate of 267 deer on site (Dwyer 1966). BNL has been conducting population surveys of the whitetailed deer since 2000. In February and March 2004, an aerial infrared survey was conducted of three properties, including Wertheim National Wildlife Refuge (south of BNL), Brookhaven National Laboratory, and Rocky Point Wildlife Area (northwest of BNL). The results indicated a population of 412 deer on site and immediately off site. When a correction for survey accuracy was applied, the on-site population was estimated at 446 animals. This value was much lower than a ground-based estimate of 1,302, made at the same time using the existing methodology. Because there was a large discrepancy between methods, a review of the ground-based methodology was conducted and the method of estimating was refined. The new method uses the Laboratory's vegetation map and estimates the deer population based on the habitat in which deer are sighted during surveys. The result of this revised method indicated that the deer population was approximately 497 , which is considered to be reasonably comparable to the aerial survey results. The next step taken was to apply the new population model to historic survey data. Most of the data resulted in a much lower estimate, with ranges from approximately 1,000 deer in 2001 to approximately 400 deer in 2005 . The current population estimate is 466 deer, based on surveys conducted in November and December 2006. Note that the current estimate is still higher than the optimal range of 80 to 250 deer on an area the size of BNL.

Deer overpopulation can affect animal and human health (e.g., animal starvation, Lyme disease from deer ticks, collision injuries - both human and animal), species diversity (songbird species reduction due to selective grazing and destruction of habitat by deer), and property values (auto damage and browsing damage to ornamental plantings). In 2006, 10 deer-related collisions occurred on site, compared to six accidents in 2005 and 25 accidents documented in 2004. This downward trend in accidents is attributed to a major effort by BNL Safeguards and Security personnel to enforce the 30-mph speed limit on site. Additional emphasis on vehicle-deer safety is also thought to have helped reduce this type of accident. Deer health continues to be affected due to lack of food. Deer damage to vegetation around buildings continues to be a problem, but varies depending on the severity of the winter and the availability of browse in the lawns.

Because the high deer population is a regional problem, the Laboratory is working on the issue with other local jurisdictions. BNL is represented on a deer advisory panel for the hamlet of Lloyd Harbor. Environmental biologists at the Laboratory would like to see a regional approach to deer management in place before attempting large-scale deer management on site. Options for deer management are limited, and most are controversial. A regional approach would benefit the community, land managers, and the health of the deer population.

\section{I.4 Compliance Assurance and Potential Impact Assessment}

The National Environmental Policy Act (NEPA) review process at BNL is key to ensuring that environmental impacts of a proposed action or activity are adequately evaluated 
and addressed. The Laboratory will continue to use NEPA (or NEPA-like) processes under the Comprehensive Environmental Response, Compensation and Liability Act (CERCLA) Environmental Restoration Program when identifying potential environmental impacts associated with site activities - especially with physical alterations. As appropriate, stakeholders such as EPA, NYSDEC, Suffolk County Department of Health Services (SCDHS), BNL's Community Advisory Council, and the Brookhaven Roundtable are involved in reviewing major projects that have the potential for significant environmental impacts. Formal NEPA reviews are coordinated with the State of New York.

\subsection{UPTON ECOLOGICALAND RESEARCH RESERVE}

On November 9, 2000, then-Secretary of Energy Bill Richardson and Susan MacMahon, Acting Regional Director of Region 5 FWS, dedicated 530 acres of Laboratory property as an ecological research reserve. The property was designated by DOE as the Upton Ecological and Research Reserve (Upton Reserve) and was managed by FWS under an Interagency Agreement (DOE-FWS 2000). The Upton Reserve, on the eastern boundary of BNL, is home to a wide variety of flora and fauna. It contains wetlands and is largely within the core preservation area of the Long Island Central Pine Barrens. Based on information from the 1994-1995 biological survey of the Laboratory, experts believe the reserve is home to more than 200 plant species and at least 162 species of mammals, birds, fish, reptiles, and amphibians (LMS 1995).

A transition from FWS management of the Upton Reserve to management by BNL and the Foundation for Ecological Research in the Northeast (FERN) occurred in 2005. During that year, FERN initiated its first pine barrenswide monitoring program to assess the health of the various forest types within the Pine Barrens. FERN established 91 permanent plots over the 2 year period of the monitoring program and is currently analyzing the data. One significant finding from the monitoring is the lack of forest regeneration. In virtually every forest type, there is a lack of survival of trees from seedlings through to saplings. This is likely a result of either deer over-abundance or lack of sunlight penetrating to the understory. Further information on the forest health initiative, as well as other activities of FERN, are available on the FERN website, at www.fern-li.org.

The Interagency Agreement that established the Upton Reserve specified the formation of a Technical Advisory Group (TAG), which includes the supervisory biologist for FWS and representatives from NYSDEC, Suffolk County Parks Department, the Central Pine Barrens Joint Policy and Planning Commission, DOE, BNL's Community Advisory Council, Brookhaven Executive Roundtable, Brookhaven Science Associates, and The Nature Conservancy. The TAG's primary responsibility was to develop a comprehensive NRMP for BNL. The TAG also developed criteria for soliciting and reviewing proposals and awarding funds for research that is conducted within the Upton Reserve. While most of the TAG's responsibilities have been met, the Laboratory intends to periodically ask for assistance in reviewing annual reports required under the NRMP, and to support the five-year update of the plan.

Research on oak tree defoliators that was initiated by FWS and the Upton Reserve is continuing at the Laboratory. Much of the oak forest on site and immediately east of BNL has been subject to repeated defoliation by gypsy moth and orange-striped oak moth. This double defoliation, if it occurs year after year, can kill large sections of oak forest. Beginning in 2003, death of tree oaks was documented. Due to continued defoliation, oak mortality is now estimated at greater than 25 percent in many areas in the northeast quadrant of the Laboratory. The amount of defoliation increased in 2006, with a second year of defoliation by a geometrid moth that became established in 2005 .

Research supported by FERN in 2006 included an investigation into the microbial world of soils located within the former Gamma Forest. Microbial research carried out by a scientist at Dowling College identified several new species of fungus and bacteria that had not previously 
been known. Future work in the area of microbial diversity is expected to identify additional new species across the Pine Barrens.

\subsection{MONITORING FLORA AND FAUNA}

The Laboratory routinely monitors flora and fauna to determine the effects of past and present Laboratory activities. Because soil contaminated with cesium-137 (Cs-137), a radioactive isotope of cesium, was used in some BNL landscaping projects in the past, traces have now been found in deer and in other animals and plants. Most radionuclide tables in this chapter list data for both potassium-40 (K-40), a naturally occurring radioisotope of potassium, and $\mathrm{Cs}-137$. Because $\mathrm{K}-40$ occurs naturally in the environment, it is not uncommon in flora and fauna. It is presented as a comparison to Cs- 137 because Cs-137 competes with potassium at a cellular level. General trends indicate that Cs-137 will out-compete potassium when potassium salts are limited in the environment, which is the typical case on Long Island. In general, K-40 values do not receive significant discussion in the scientific literature due to this relationship and the fact that K-40 occurs naturally. The results of the annual sampling conducted under the flora and fauna monitoring program follow.

\subsection{Deer Sampling}

White-tailed deer in New York State typically are large, with males weighing, on average, about 150 pounds; females typically weigh one-third less, approximately 100 pounds. However, white-tailed deer on Long Island tend to be much smaller, weighing an average of 80 pounds. The available meat on local deer ranges from 20 to 40 pounds per deer. This fact has implications for calculating the potential radiation dose to consumers of deer meat containing Cs-137, because smaller deer do not provide sufficient amounts of venison to support the necessary calculations.

In 2006, as in recent years, an off-site deersampling program was conducted with the NYSDEC Wildlife Branch and FWS. While most off-site samples are from road-killed deer at and near the Laboratory, NYSDEC provides a few samples that result in data on deer that move beyond BNL boundaries, where they can be legally hunted. The samples provide control data on deer living 1 mile or more from BNL. In addition, FWS occasionally informs Laboratory staff of deer that have died in or near the Wertheim National Wildlife Refuge and other FWS properties on Long Island. In all, 11 deer were obtained on site and 13 were from off-site locations, ranging from adjacent to BNL along the William Floyd Parkway, to approximately 3 miles away (Ridge, New York).

BNL sampling technicians collect the samples and process them for analysis. Samples of meat, liver, and bone are taken from each deer, when possible. The meat and liver are analyzed for Cs-137, and the bone is analyzed for strontium-90 (Sr-90).

\subsubsection{Cs-137 in White-Tailed Deer}

White-tailed deer sampled at the Laboratory contain higher concentrations of Cs-137 than deer from greater than 1 mile off site (BNL 2000), probably because they graze on vegetation growing in soil where elevated Cs-137 levels are known to exist. Cs-137 in soil can be transferred to aboveground plant matter via root uptake, where it then becomes available to browsing animals.

Removal of contaminated soil areas at BNL has occurred under the Laboratory's Environmental Restoration (ER) Program. All major areas of contaminated soil were remediated in September 2005. In addition, all buildings at the former Hazardous Waste Management Facility (HWMF) were removed in 2003, and the cleanup of the remainder of the facility was completed by fall 2005. Subsequent to the completion of cleanup at the former HWMF, additional minor contamination outside the facility was found and is currently being characterized.

The number of deer taken for sampling steadily increased between 1996 and 2004. However, the numbers of deer taken in 2005 and 2006 were significantly down. As mentioned above, the number of deer killed on-site and available for sampling has decreased, most likely due to increased safety awareness and better enforcement of speed restrictions. In 1998, a statistical analysis based on existing data suggested that 
40 deer from off site and 25 deer from on site were needed to achieve a statistically sound data set. Since that analysis was completed, BNL has attempted to obtain the required number of deer. The number taken each year has varied due to the sampling method, which depends on vehicle and deer accidents and people reporting dead deer. The number of deer hit by vehicles varies widely from year to year, depending on the population of deer present near major roadways and the traffic density. Figure 6-2 shows the location of all deer samples taken within a 5-mile radius of the Laboratory since 2002. Most of the offsite samples are concentrated along the William Floyd Parkway on the west boundary of BNL, whereas the concentration on site is near the front gate area and the constructed portions of the Laboratory. This distribution is most likely due to the fact that people on their way to work see and report dead deer. Vehicle collisions with deer on site occur primarily early or late in the day, when deer are more active.

In 2006, Cs-137 concentrations in deer meat samples taken at BNL ranged from nondetectable to $4.27 \mathrm{pCi} / \mathrm{g}$ wet weight. The "wet weight" concentration is before a sample is dried for analysis, and is the form most likely to be consumed. Dry weight concentrations are typically higher than wet weight values. The maximum 2006 on-site concentration $(4.27 \mathrm{pCi} / \mathrm{g}$ wet weight) was eight times higher than the highest level reported in 2005 ( $0.52 \mathrm{pCi} / \mathrm{g}$ wet weight), but is significantly lower than the highest level ever reported (11.74 pCi/g wet weight, in 1996). The arithmetic average concentration in on-site meat samples was $0.82 \mathrm{pCi} / \mathrm{g}$ (see Table 6-2).

Cs-137 concentrations in off-site deer meat samples were separated into two groups: samples taken within 1 mile of BNL (nine samples) and samples taken farther away (four samples) (see Table 6-2). Concentrations in meat samples taken within 1 mile ranged from 0.08 to 9.51 $\mathrm{pCi} / \mathrm{g}$ wet weight, with an average of $2.04 \mathrm{pCi} / \mathrm{g}$ wet weight; concentrations in meat taken from greater than 1 mile ranged from 0.79 to 4.00 $\mathrm{pCi} / \mathrm{g}$ wet weight, with an average of $2.17 \mathrm{pCi} / \mathrm{g}$ wet weight. Because deer on site may routinely travel up to 1 mile off site, the average for deer taken both on site and within 1 mile of the Lab- oratory is also calculated and for 2006 was 1.37 $\mathrm{pCi} / \mathrm{g}$ wet weight.

Figure 6-3 compares the average values of Cs-137 concentrations in meat samples collected in 2006 from four different location groupings. Although the figure does not show this, 58 percent of all samples taken both on and off site are below $1 \mathrm{pCi} / \mathrm{g}$ wet weight (see Table 6-2).

Figure 6-4 presents the nine-year trend of onsite and near off-site Cs-137 averages in deer meat. 2006 sampling is the first year since 2001 that showed a statistically significant increase in Cs-137 concentrations. The unexplained increase was due to a single sample taken off site along the William Floyd Parkway $(9.51 \mathrm{pCi} / \mathrm{g}$ wet weight). While the sample was high compared to samples taken within the recent past, it was within the historic range of samples taken within the same geographic area. The area was scanned in aerial radiological surveys in 1981 and 1990; no unremediated sources are known to be in the area.

In 2003, a seasonal pattern in Cs-137 concentrations in deer meat was noticed. This seasonality was present in earlier years and occurred again in 2006 (see Table 6-2). During the summer of 2004, a student in the Community College Intern Program reviewed all data from 2000-2003, analyzed it statistically, and determined that there was a statistical seasonal variation in values for deer both on site as well as far off site (Florendo 2004). This seasonality is likely due to diet and the biological processing of Cs-137. From January through May, deer have a limited food supply - mostly dry vegetation from the previous year's growth (with a fixed concentration of Cs-137 because plants are dormant). In the summer and fall, deer eat more and the vegetation is constantly growing, taking up nutrients and contaminants from the soil. In summer and fall, deer feeding on vegetation growing in soil containing Cs-137 are more likely to obtain a continuous supply, which is incorporated into their tissues. This increased concentration of Cs-137 in tissues is evidenced by the three highest values seen in deer in 2006 (3.06, 4.00, and $9.51 \mathrm{pCi} / \mathrm{g}$ wet weight) from samples taken in October and November. By January or February, the Cs-137 in their tissues 


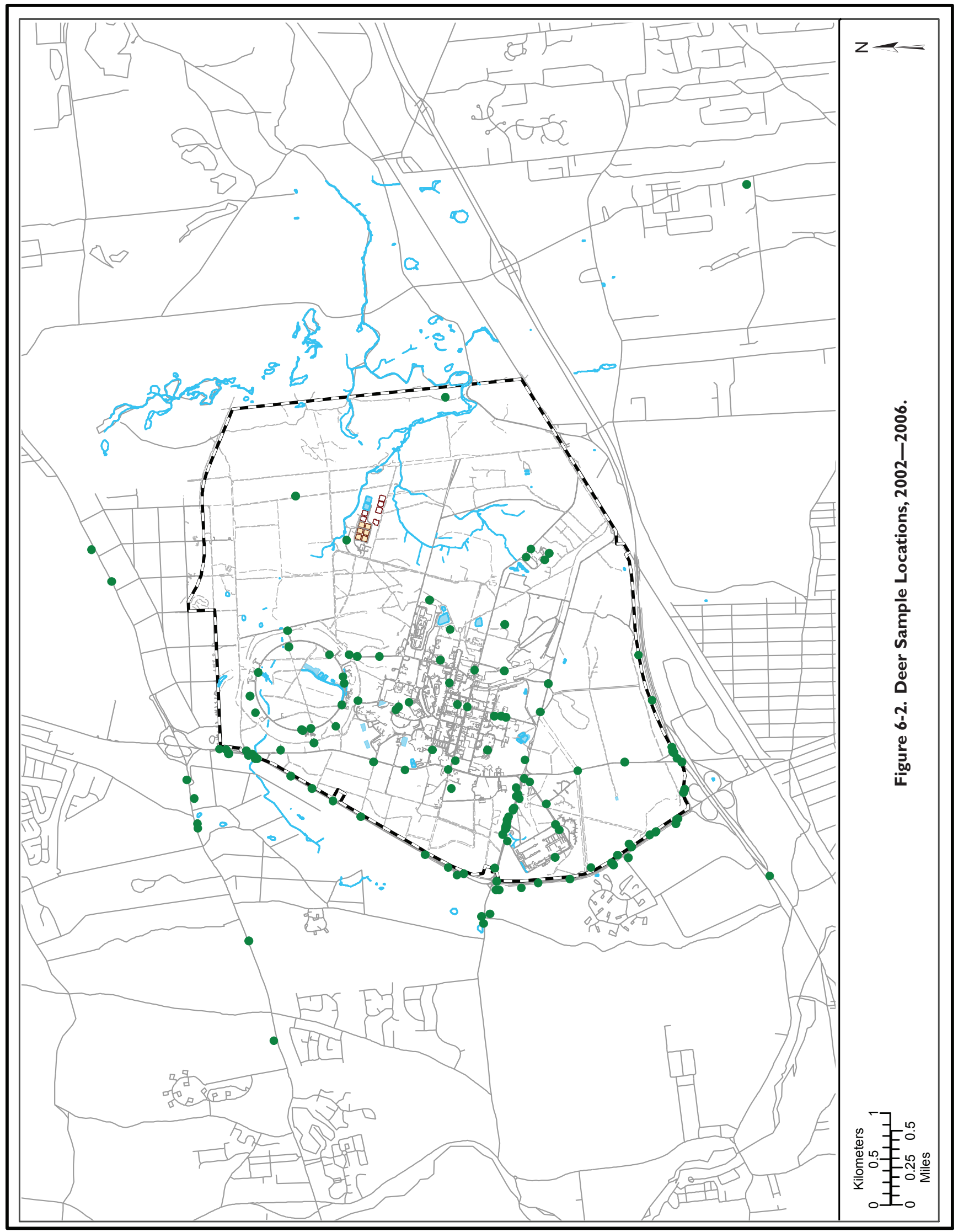


Table 6-2 Radiological Analyses of Deer Tissue (Flesh, Liver, Bone).

\begin{tabular}{|c|c|c|c|c|c|}
\hline Sample Location & $\begin{array}{l}\text { Collection } \\
\text { Date }\end{array}$ & $\begin{array}{l}\text { Tissue } \\
\text { Type }\end{array}$ & $\begin{array}{c}\text { K-40 } \\
\mathrm{pCi} / \mathrm{g} \text { Wet Weight }\end{array}$ & $\begin{array}{c}\text { Cs-137 } \\
\text { pCi/g Wet Weight }\end{array}$ & $\begin{array}{c}\text { Sr-90 } \\
\text { pCi/g Dry Weight }\end{array}$ \\
\hline \multicolumn{6}{|l|}{ BNL, On Site } \\
\hline \multirow[t]{3}{*}{ North of Cafeteria } & 01/06/06 & Flesh & $3.07 \pm 0.37$ & ND & \\
\hline & & Liver & $2.14 \pm 0.33$ & ND & \\
\hline & & Bone & & & $1.53 \pm 0.18$ \\
\hline \multirow[t]{3}{*}{ Princeton Ave. } & 02/01/06 & Flesh & $4.05 \pm 0.50$ & $0.41 \pm 0.04$ & \\
\hline & & Liver* & $2.29 \pm 0.35$ & $0.13 \pm 0.02$ & \\
\hline & & Bone & & & $1.83 \pm 0.24$ \\
\hline \multirow[t]{3}{*}{ Bldg. 650 Sump } & $03 / 14 / 06$ & Flesh* & $2.60 \pm 0.35$ & $0.07 \pm 0.02$ & \\
\hline & & Liver* & $2.37 \pm 0.37$ & $0.08 \pm 0.02$ & \\
\hline & & Bone & & & $2.36 \pm 0.23$ \\
\hline \multirow[t]{3}{*}{ Upton Rd. and Bldg. 50} & 03/29/06 & Flesh & $3.87 \pm 0.55$ & ND & \\
\hline & & Liver & $3.24 \pm 0.70$ & ND & \\
\hline & & Bone & & & $2.19 \pm 0.28$ \\
\hline \multirow[t]{3}{*}{ Bldg. 750, East Side } & 04/06/06 & Flesh & $3.62 \pm 0.49$ & ND & \\
\hline & & Liver & $2.74 \pm 0.51$ & ND & \\
\hline & & Bone & & & $2.42 \pm 0.23$ \\
\hline \multirow[t]{2}{*}{ North Gate } & $05 / 02 / 06$ & Flesh & $3.90 \pm 0.59$ & $0.27 \pm 0.04$ & \\
\hline & & Bone & & & $2.69 \pm 0.24$ \\
\hline \multirow[t]{3}{*}{ Cornell Ave. and Rutherford Drive } & 09/16/06 & Flesh & $3.28 \pm 0.54$ & $0.28 \pm 0.04$ & \\
\hline & & Liver* & $2.47 \pm 0.60$ & $0.11 \pm 0.03$ & \\
\hline & & Bone** & & & $0.61 \pm 0.21$ \\
\hline \multirow[t]{3}{*}{ Back of Paint Shop, Bldg. 244} & $10 / 23 / 06$ & Flesh & $3.87 \pm 0.42$ & $4.27 \pm 0.10$ & \\
\hline & & Liver & $2.47 \pm 0.35$ & $1.18 \pm 0.06$ & \\
\hline & & Bone & & & $1.61 \pm 0.27$ \\
\hline \multirow[t]{2}{*}{ Inbound lane of Main Gate } & $11 / 01 / 06$ & Flesh & $3.31 \pm 0.40$ & $2.00 \pm 0.17$ & \\
\hline & & Bone & & & $5.27 \pm 0.48$ \\
\hline \multirow[t]{2}{*}{ Inbound lane of Main Gate } & $11 / 27 / 06$ & Flesh & $4.12 \pm 0.54$ & $1.04 \pm 0.09$ & \\
\hline & & Bone & & & $1.43 \pm 0.29$ \\
\hline \multirow[t]{3}{*}{ Upton Rd., across from Bldg. 50} & $12 / 11 / 06$ & Flesh & $3.41 \pm 0.55$ & $0.64 \pm 0.07$ & \\
\hline & & Liver* & $2.61 \pm 0.37$ & $0.10 \pm 0.02$ & \\
\hline & & Bone $^{* *}$ & & & $0.94 \pm 0.21$ \\
\hline \multicolumn{6}{|l|}{$<1$ Mile from BNL } \\
\hline \multirow[t]{3}{*}{ William Floyd Pkwy., south of main gate } & $01 / 20 / 06$ & Flesh & $3.92 \pm 0.32$ & $0.27 \pm 0.02$ & \\
\hline & & Liver* & $2.99 \pm 0.47$ & $0.04 \pm 0.02$ & \\
\hline & & Bone & & & $3.32 \pm 0.33$ \\
\hline \multirow[t]{2}{*}{ Rte. 25, Ridge } & 07/20/06 & Flesh & $4.25 \pm 0.56$ & $0.08 \pm 0.02$ & \\
\hline & & Bone & & & $2.53 \pm 0.25$ \\
\hline \multirow[t]{2}{*}{ Rte. 25 and William Floyd Pkwy. } & $08 / 11 / 06$ & Flesh & $3.75 \pm 0.44$ & $1.59 \pm 0.07$ & \\
\hline & & Bone & & & $1.01 \pm 0.14$ \\
\hline William Floyd Pkwy., south of main gate & 10/13/06 & Flesh & $3.47 \pm 0.40$ & $1.86 \pm 0.06$ & \\
\hline
\end{tabular}


Table 6-2 Radiological Analyses of Deer Tissue (Flesh, Liver, Bone) (continued).

\begin{tabular}{|c|c|c|c|c|c|}
\hline Sample Location & $\begin{array}{l}\text { Collection } \\
\text { Date }\end{array}$ & $\begin{array}{l}\text { Tissue } \\
\text { Type }\end{array}$ & $\begin{array}{c}\text { K-40 } \\
\text { pCi/g Wet Weight }\end{array}$ & $\begin{array}{c}\text { Cs-137 } \\
\mathrm{pCi} / \mathrm{g} \text { Wet Weight }\end{array}$ & $\begin{array}{c}\text { Sr-90 } \\
\text { pCi/g Dry Weight }\end{array}$ \\
\hline William Floyd Pkwy. and Long Island & $10 / 25 / 06$ & Flesh & $3.76 \pm 0.44$ & $9.51 \pm 0.16$ & \\
\hline \multirow[t]{2}{*}{ Expressway } & & Liver & $2.47 \pm 0.39$ & $2.67 \pm 0.09$ & \\
\hline & & Bone & & & $2.35 \pm 0.49$ \\
\hline William Floyd Pkwy., southbound $1 / 4$ mile & $10 / 31 / 06$ & Flesh & $3.39 \pm 0.41$ & $0.56 \pm 0.04$ & \\
\hline \multirow[t]{2}{*}{ north of Long Island Expressway ramp } & & Liver ${ }^{*}$ & $3.30 \pm 0.57$ & $0.10 \pm 0.04$ & \\
\hline & & Bone ${ }^{* *}$ & & & $0.75 \pm 0.20$ \\
\hline Long Island Expressway, 1 mile east of & $11 / 07 / 06$ & Flesh & $3.27 \pm 0.38$ & $1.85 \pm 0.13$ & \\
\hline of William Floyd Pkwy. & & Bone & & & $2.89 \pm 0.38$ \\
\hline \multirow[t]{2}{*}{ William Floyd Pkwy. and Rte. 25} & $11 / 13 / 06$ & Flesh & $3.25 \pm 0.38$ & $0.61 \pm 0.04$ & \\
\hline & & Bone & & & $2.66 \pm 0.37$ \\
\hline William Floyd Pkwy. at Colonial Pine light & $11 / 16 / 06$ & Flesh & $3.99 \pm 0.40$ & $2.02 \pm 0.07$ & \\
\hline \multicolumn{6}{|l|}{$>1$ Mile from BNL } \\
\hline \multirow{3}{*}{$\begin{array}{l}100 \text { ' east of McDonald's Restaurant, } \\
\text { Rte. } 25\end{array}$} & $01 / 27 / 06$ & Flesh & $2.96 \pm 0.43$ & $0.79 \pm 0.06$ & \\
\hline & & Liver* & $3.08 \pm 0.47$ & $0.17 \pm 0.03$ & \\
\hline & & Bone & & & $2.15 \pm 0.22$ \\
\hline \multirow[t]{3}{*}{ Smith Rd., Ridge } & $11 / 01 / 06$ & Flesh & $3.22 \pm 0.47$ & $4.00 \pm 0.39$ & \\
\hline & & Liver & $1.43 \pm 0.25$ & $1.03 \pm 0.10$ & \\
\hline & & Bone & & & $3.89 \pm 0.44$ \\
\hline William Floyd Pkwy., 1 mile north of & $11 / 08 / 06$ & Flesh & $3.30 \pm 0.43$ & $3.06 \pm 0.09$ & \\
\hline \multirow[t]{2}{*}{ Whiskey Road } & & Liver & $2.57 \pm 0.30$ & $0.62 \pm 0.06$ & \\
\hline & & Bone & & & $2.62 \pm 0.37$ \\
\hline \multirow[t]{3}{*}{ Woodlot Rd. and Rte. 25} & $11 / 27 / 06$ & Flesh & $3.38 \pm 0.34$ & $0.85 \pm 0.04$ & \\
\hline & & Liver & $2.82 \pm 0.39$ & $0.22 \pm 0.03$ & \\
\hline & & Bone & & & $1.99 \pm 0.32$ \\
\hline \multicolumn{6}{|l|}{ Averages by Tissue } \\
\hline \multicolumn{6}{|l|}{ Flesh } \\
\hline Average for all samples (24) & & & $3.54 \pm 2.21$ & $1.50 \pm 0.53$ & \\
\hline BNL on-site average (11) & & & $3.55 \pm 1.61$ & $0.82 \pm 0.24$ & \\
\hline $\begin{array}{l}\text { BNL on- and off-site }<1 \text { mile average } \\
\text { (20) }\end{array}$ & & & $3.61 \pm 2.05$ & $1.37 \pm 0.34$ & \\
\hline Off-site average (13) & & & $3.53 \pm 1.51$ & $2.08 \pm 0.47$ & \\
\hline Off-site $<1$ mile average (9) & & & $3.67 \pm 1.26$ & $2.04 \pm 0.25$ & \\
\hline Off-site > 1 mile average (4) & & & $3.22 \pm 0.84$ & $2.17 \pm 0.41$ & \\
\hline \multicolumn{6}{|l|}{ Liver } \\
\hline Average for all samples (15) & & & $2.60 \pm 2.05$ & $0.45 \pm 0.24$ & \\
\hline BNL on-site average (8) & & & $2.54 \pm 1.32$ & $0.20 \pm 0.08$ & \\
\hline $\begin{array}{l}\text { BNL on- and off-site }<1 \text { mile average } \\
\text { (11) }\end{array}$ & & & $2.64 \pm 1.56$ & $0.40 \pm 0.13$ & \\
\hline Off-site average (7) & & & $2.67 \pm 1.11$ & $0.69 \pm 0.16$ & \\
\hline
\end{tabular}


Table 6-2 Radiological Analyses of Deer Tissue (Flesh, Liver, Bone) (concluded).

\begin{tabular}{|c|c|c|c|c|c|}
\hline Sample Location & $\begin{array}{l}\text { Collection } \\
\text { Date }\end{array}$ & $\begin{array}{c}\text { Tissue } \\
\text { Type }\end{array}$ & $\begin{array}{c}\text { K-40 } \\
\text { pCi/g Wet Weight }\end{array}$ & $\begin{array}{c}\text { Cs-137 } \\
\text { pCi/g Wet Weight }\end{array}$ & $\begin{array}{c}\text { Sr-90 } \\
\text { pCi/g Dry Weight }\end{array}$ \\
\hline Off-site < 1 mile average (3) & & & $2.92 \pm 0.84$ & $0.94 \pm 0.10$ & \\
\hline Off-site > 1 mile average (4) & & & $2.48 \pm 0.72$ & $0.51 \pm 0.12$ & \\
\hline \multicolumn{6}{|l|}{ Bone } \\
\hline Average for all samples (21) & & & & & $2.29 \pm 1.41$ \\
\hline BNL on-site average (10) & & & & & $2.19 \pm 0.87$ \\
\hline $\begin{array}{l}\text { BNL on- and off-site }<1 \text { mile average } \\
\text { (17) }\end{array}$ & & & & & $2.20 \pm 1.23$ \\
\hline Off-site average (11) & & & & & $2.38 \pm 1.11$ \\
\hline Off-site $<1$ mile average $(7)$ & & & & & $2.22 \pm 0.86$ \\
\hline Off-site > 1 mile average (4) & & & & & $2.66 \pm 0.69$ \\
\hline \multicolumn{6}{|c|}{$\begin{array}{l}\text { Notes: } \\
\text { All values are shown with a } 95 \% \text { confidence interval. } \\
\text { K-40 occurs naturally in the environment and is presented as a comparison to cesium-137 (Cs-137). } \\
\text { All averages are the arithmetic average and utilize estimated values for ND. Confidence limits are } 2 \sigma \text { sigma (95\%) propogated error. } \\
\text { Cs- } 137=\text { cesium- } 137 \\
\text { K-40 }=\text { potassium- } 40 \\
\text { ND }=\text { Not Detected } \\
\text { Sr-90 - strontium-90 } \\
{ }^{*}=\text { estimated value for Cs-137 } \\
{ }^{* *}=\text { estimated value for Sr-90 }\end{array}$} \\
\hline
\end{tabular}

has been eliminated through biological processes. The levels of Cs-137 in deer tissue during June through early August are not well known, as there are few vehicle-deer accidents at this time of year.

When possible, liver samples are taken concurrently with meat samples. Liver generally accumulates Cs-137 at a lower rate than muscle tissue (meat). The typically lower values in liver allow the results to be used as a validity check for meat values (i.e., if liver values are higher than meat values, results can be considered questionable and should be confirmed). In liver samples collected on site in 2006, Cs-137 concentrations ranged from nondetectable to 1.18 $\mathrm{pCi} / \mathrm{g}$ wet weight, with an average of $0.20 \mathrm{pCi} / \mathrm{g}$ wet weight. The off-site Cs-137 concentration in liver ranged from 0.04 to $2.67 \mathrm{pCi} / \mathrm{g}$ wet weight, with an average for all off-site liver samples of $0.69 \mathrm{pCi} / \mathrm{g}$ wet weight.

The potential radiological dose resulting from deer meat consumption is discussed in Chapter 8. The New York State Department of Health (NYSDOH) has formally considered the potential public health risk associated with elevated Cs-137 levels in on-site deer and determined that neither hunting restrictions nor formal health advisories are warranted (NYSDOH 1999).

With respect to the health of on-site deer based on their exposure to radionuclides, the International Atomic Energy Agency (IAEA) has concluded that chronic dose rates of 100 millirad per day to even the most radiosensitive species in terrestrial ecosystems are unlikely to cause detrimental effects in animal populations (IAEA 1992). A deer containing a uniform distribution of Cs-137 within muscle tissue at the highest levels observed to date $(11.74 \mathrm{pCi} / \mathrm{g}$ wet weight, reported in 1996) would carry a total amount of about $0.2 \mu \mathrm{Ci}$. That animal would receive an absorbed dose of approximately 3 millirad per day, which is only 3 percent of the threshold evaluated by the IAEA. The deer observed and sampled on site appear to have no health effects from the level of Cs-137 found in their tissues.

\subsubsection{Strontium-90 in Deer Bone}

BNL began testing deer bones for Sr-90 content in 2000, and continued this analysis in 2006. Sr-90 content ranged from 0.61 to 5.27 $\mathrm{pCi} / \mathrm{g}$ dry weight in on-site samples. Sr-90 in off-site samples ranged from 0.75 to $3.32 \mathrm{pCi} / \mathrm{g}$ 


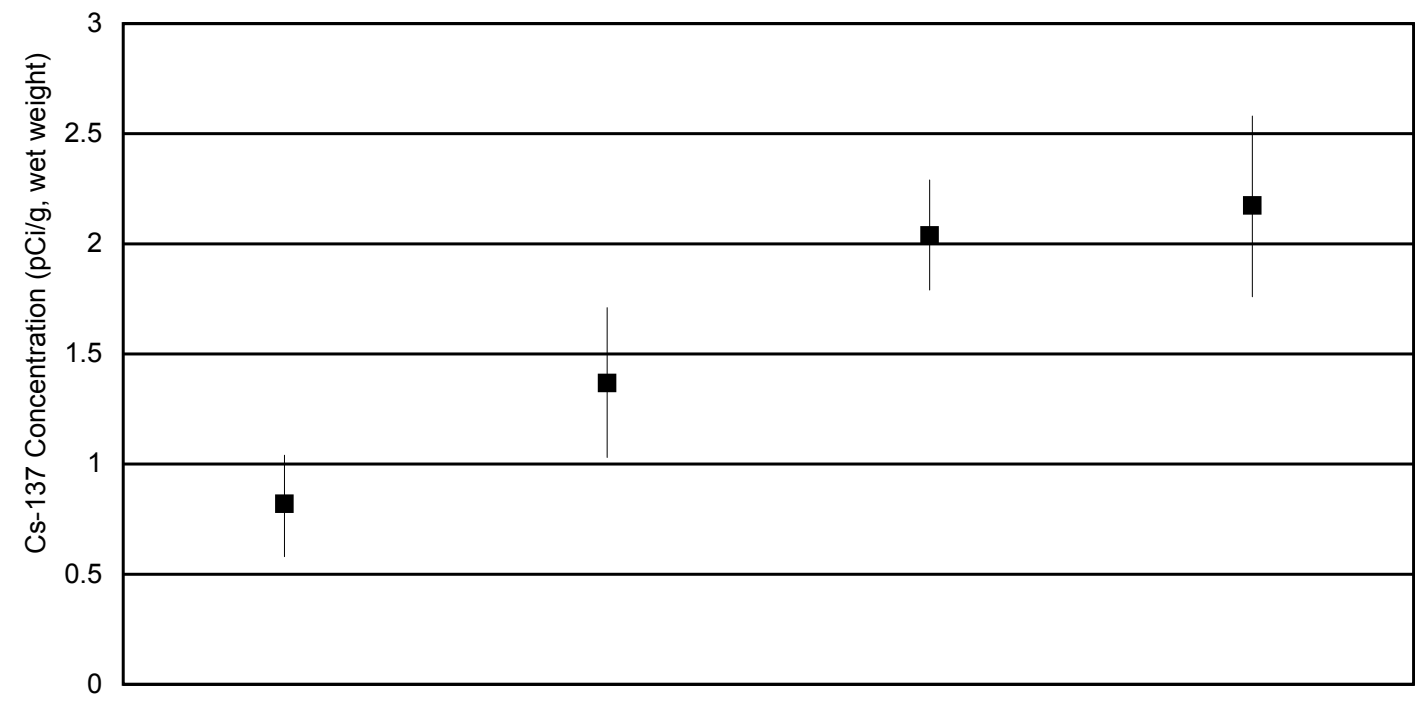

BNL (11) BNL and off-site $<1 \mathrm{mi} . \quad$ Off-site $<1 \mathrm{mi} .(9) \quad$ Off-site $>1 \mathrm{mi}$. (4)

(20)

Notes: Averages are shown for samples collected at BNL, on site and off site within 1-mile, off site but within a 1-mile radius, and off site greater than a 1 -mile radius.

Numbers in parentheses indicate the number of samples in that data set.

All values are presented with a $95 \%$ confidence interval.

Cs-137 = cesium- 137

Figure 6-3. Comparison of Cs- 137 Average Concentrations in Deer, 2006.

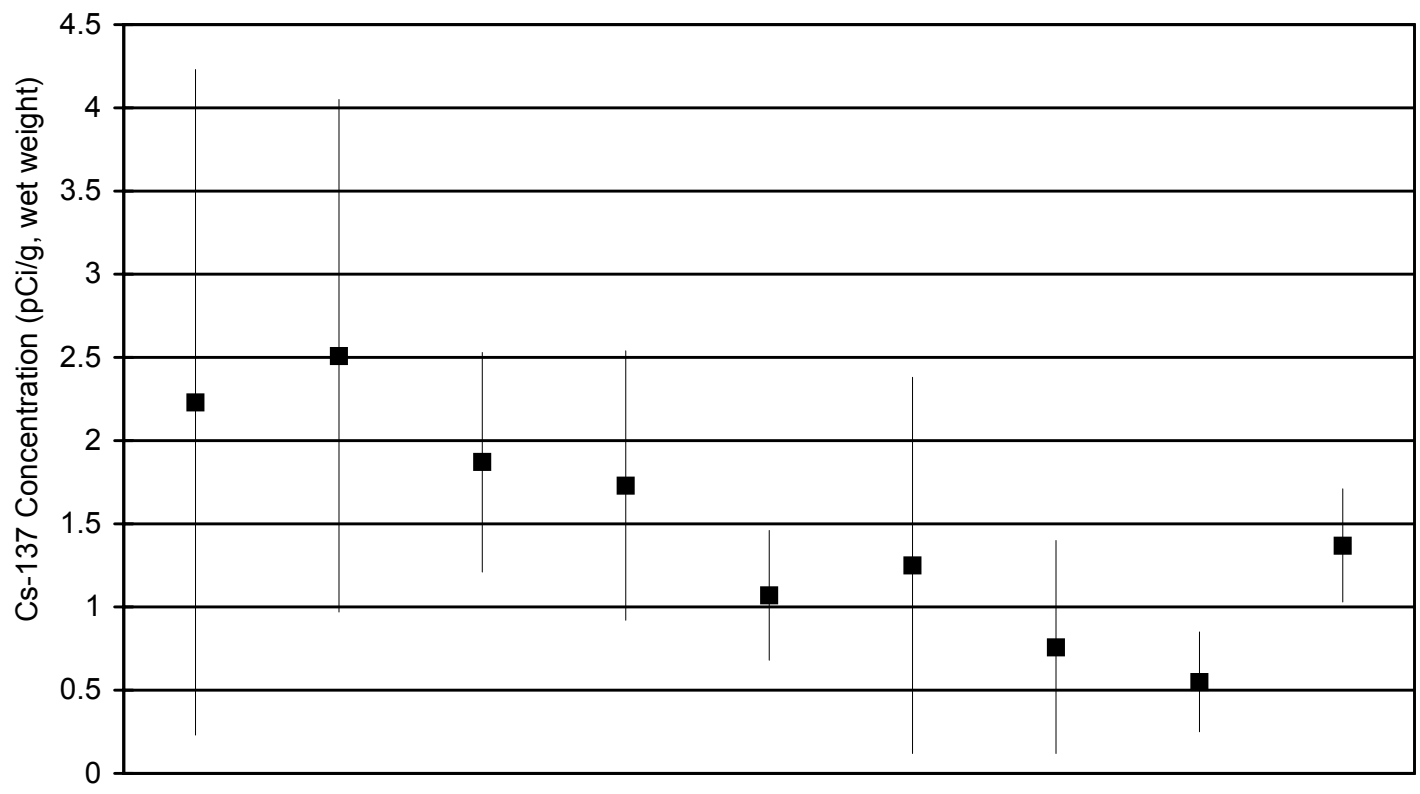

1998 (9) 1999 (13) 2000 (37) 2001 (20) 2002 (36) 2003 (45) 2004 (34) 2005 (16) 2006 (20)

Notes: Averages are shown for samples collected at BNL, and within 1 mile.

Numbers in parentheses indicate the number of samples in that data set.

All values are presented with a $95 \%$ confidence interval.

Figure 6-4. Trend of Cs-I 37 Concentrations in Deer Meat at BNL and Within I Mile of BNL, 1998 - 2006. 
dry weight in samples taken within 1 mile of BNL, and 1.99 to $3.89 \mathrm{pCi} / \mathrm{g}$ dry weight in samples taken more than a mile from BNL. This overlap in values between all samples suggests that $\mathrm{Sr}-90$ is present in the environment at background levels, probably as a result of worldwide fallout from nuclear weapons testing. Sr-90 is present at very low levels in the environment, is readily incorporated into bone tissue, and may concentrate over time. BNL will continue to test for Sr-90 in bone to develop baseline information on this radionuclide and its presence in white-tailed deer.

\subsubsection{Small Mammal Sampling}

BNL continued small mammal sampling in 2006. The original goal of this sampling was to determine the suitability of small mammals, primarily squirrels, as a surrogate for deer sampling. Squirrels are usually readily trapped and tend to eat similar food as deer, but have a much more restricted range and therefore can indicate areas where low levels of contamination may be present. Squirrels were sent to an off-site contract analytical laboratory for dissection and analysis. Meat was separated from the bone and tested for gamma-emitting radionuclides, and the bone was tested for Sr-90. Results of the analyses are presented in Table 6-3. No off-site samples were obtained in 2006. On-site samples contained Cs-137 ranging from 0.12 to $0.86 \mathrm{pCi} / \mathrm{g}$ dry weight. $\mathrm{Sr}-90$ values ranged from nondetectable to $0.99 \mathrm{pCi} / \mathrm{g}$ dry weight in on-site squirrels. While squirrels appear to be suitable for looking at localized areas, monitoring deer is more appropriate for the larger BNL area. Therefore, continued sampling of small mammals will be assessed and potentially removed from surveillance monitoring.

\subsubsection{Other Animals Sampled}

Occasionally, other animals such as wild turkey or Canada geese are found dead along the roads of the Laboratory and the immediate vicinity due to road mortality and are tested. In 2006, a single goose was sampled (see Table 6-3). Muscle from the goose was analyzed for Cs-137 content, with a value reported at nondetectable levels.

\subsubsection{Fish Sampling}

In collaboration with the NYSDEC Fisheries Division, BNL maintains an ongoing program for collecting and analyzing fish from the Peconic River and surrounding freshwater bodies. Annual on-site sampling has depleted the number of large fish. To obtain a sample large enough to complete all analyses desired, multiple small fish would be needed. The Laboratory suspended most on-site sampling in 2001, and population surveys continue to indicate that population levels on site are still insufficient to conduct full-

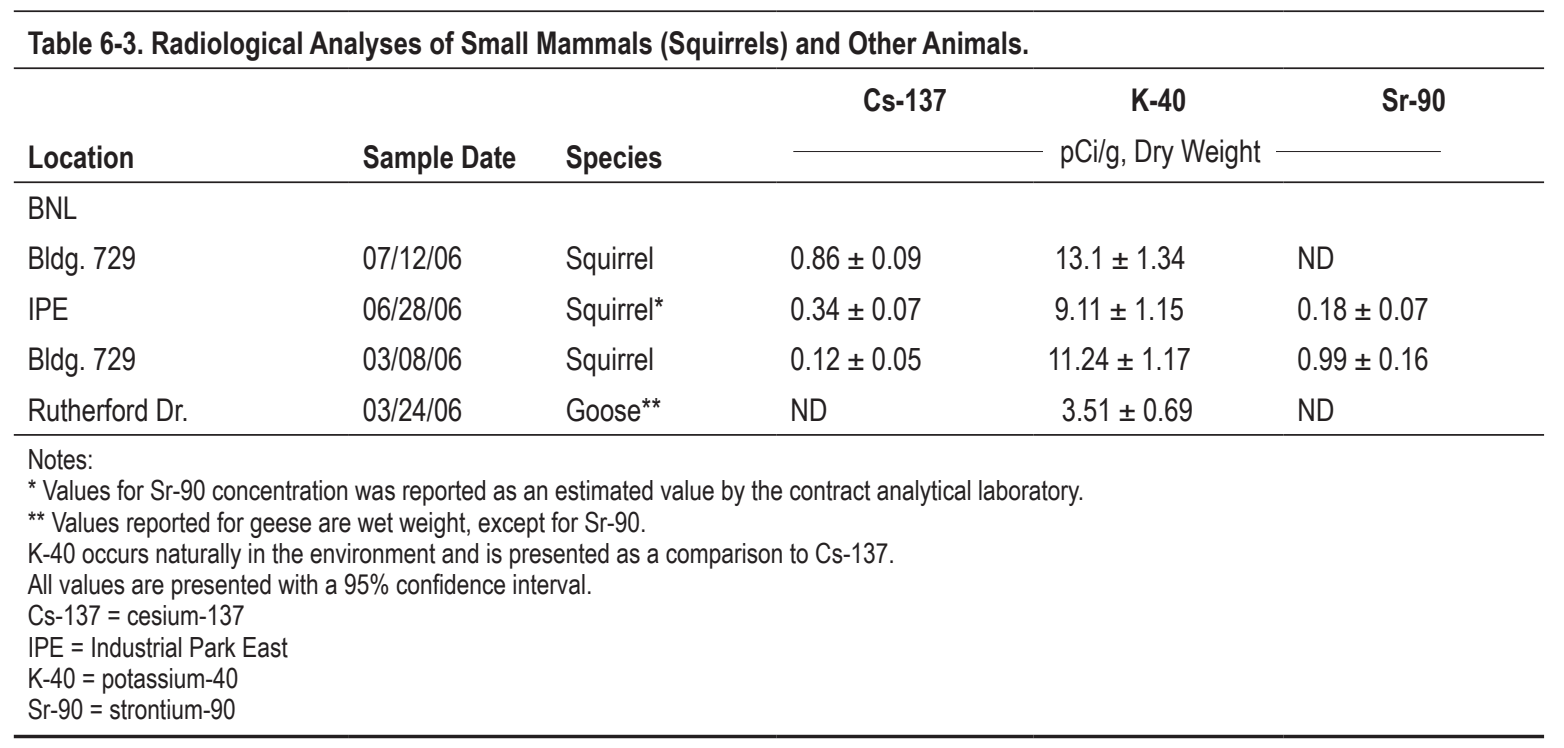


scale annual sampling and analysis. On-site fish were sampled in 2004 when the river was dewatered for the Peconic River cleanup project. Flow was returned to the river in the spring of 2005 , but the area experienced drought conditions toward the end of the summer. Natural flow to the river resumed after heavy rains in October 2005. Four fish were sampled on site in 2006 near gauging station HQ, adjacent to North Street. However, due to the size of the fish, not all requested analyses could be obtained. One reason for the lack of fish population growth is likely due to low levels of dissolved oxygen within slow-moving stretches of the Peconic River. Low dissolved oxygen levels during summer months force fish to move to other locations where oxygen is more abundant. The on-site population of fish will be reassessed in 2007, and samples will be taken if the fish populations have sufficiently recovered. BNL is assessing the need to move fish sampling to either earlier or later in the year, to periods when dissolved oxygen levels are higher and will support the presence of fish.

As in the past, off-site fish sampling continued in 2006. All samples were analyzed for edible (fillet) content of each of the analytes reported. In 2006, various species of fish were collected off site from Swan Pond, Donahue's Pond, Forge Pond, Manor Road, and Lower Lake on the Carmans River (see Figure 5-8 for sampling stations). Swan Pond is a semi-control location on the Peconic River system (a tributary of the Peconic not connected to the BNL branch), and Lower Lake on the Carmans River is the nonPeconic control site. Sampling is carried out in cooperation with NYSDEC and through a contract with Cold Spring Harbor Fish Hatchery and Museum. Eighty-five samples were taken, representing eight species of fish.

\subsubsection{Radiological Analysis of Fish}

The species collected for radiological analysis in 2006 by the Laboratory and through contract labor included brown bullhead (Ictalurus nebulosus), chain pickerel (Esox niger), largemouth bass (Micropterus salmoides), bluegill (Lepomis macrochirus), golden shiner (Notemigonus crysoleucas), brown trout (Salmo trutta), and black crappie (Pomoxis nigromaculatus). Gamma spectroscopy analysis was performed on all samples. Table 6-4 presents specific information on the sampling location, species collected, and analytical results. All sample results are presented as wet weight concentrations. Because Sr-90 is deposited only in bone, and only fillets were tested, no $\mathrm{Sr}-90$ data is presented. Information on the natural radioisotope $\mathrm{K}-40$ is included as a comparison.

Cs-137 was detected at low levels in all samples from the Peconic River system, ranging from nondectable levels in golden shiners, chain pickerel, and largemouth bass, to $0.38 \mathrm{pCi} / \mathrm{g}$ wet weight in chain pickerel from Donahue's Pond. In 2006, all fish taken from Lower Lake on the Carmans River (the non-Peconic control location) had estimated levels of Cs-137 below the minimum detection limit (MDL) and are shown in Table 6-4 as ND (nondetectable).

To account for the different feeding habits and weights of various species, it is important to compare species with similar feeding habits (i.e., bottom feeders such as brown bullhead should be compared to other bottom feeders). Cs-137 concentrations in brown bullhead collected at all locations along the Peconic River had values less than $0.21 \mathrm{pCi} / \mathrm{g}$ wet weight; values for brown bullhead at the control location had nondetectable levels of Cs-137. Largemouth bass from the Peconic River showed Cs-137 levels of 0.19 $\mathrm{pCi} / \mathrm{g}$ wet weight or less; Cs-137 was nondetetable in largemouth bass from the control location. Levels of Cs-137 in all fish species appear to be declining, compared with historic values.

Though it is clear from discharge records and sediment sampling that past BNL operations have contributed to anthropogenic (human-caused) radionuclide levels in the Peconic River system, most of these radionuclides were released between the late 1950s and early 1970s. Concentrations continue to decline over time through natural decay. Cs-137 has a half-life of 30 years. No Cs-137 was released from the BNL Sewage Treatment Plant (STP) to the Peconic River between 2003 and 2006 (see Figure 5-4 for a trend of Cs-137 discharges). Additionally, the cleanup of both on- and off-site portions of the Peconic River in 2004 and 2005 removed 
Table 6-5. Metals Analyses of Fish from the Peconic River System and Carmans River, Lower Lake.

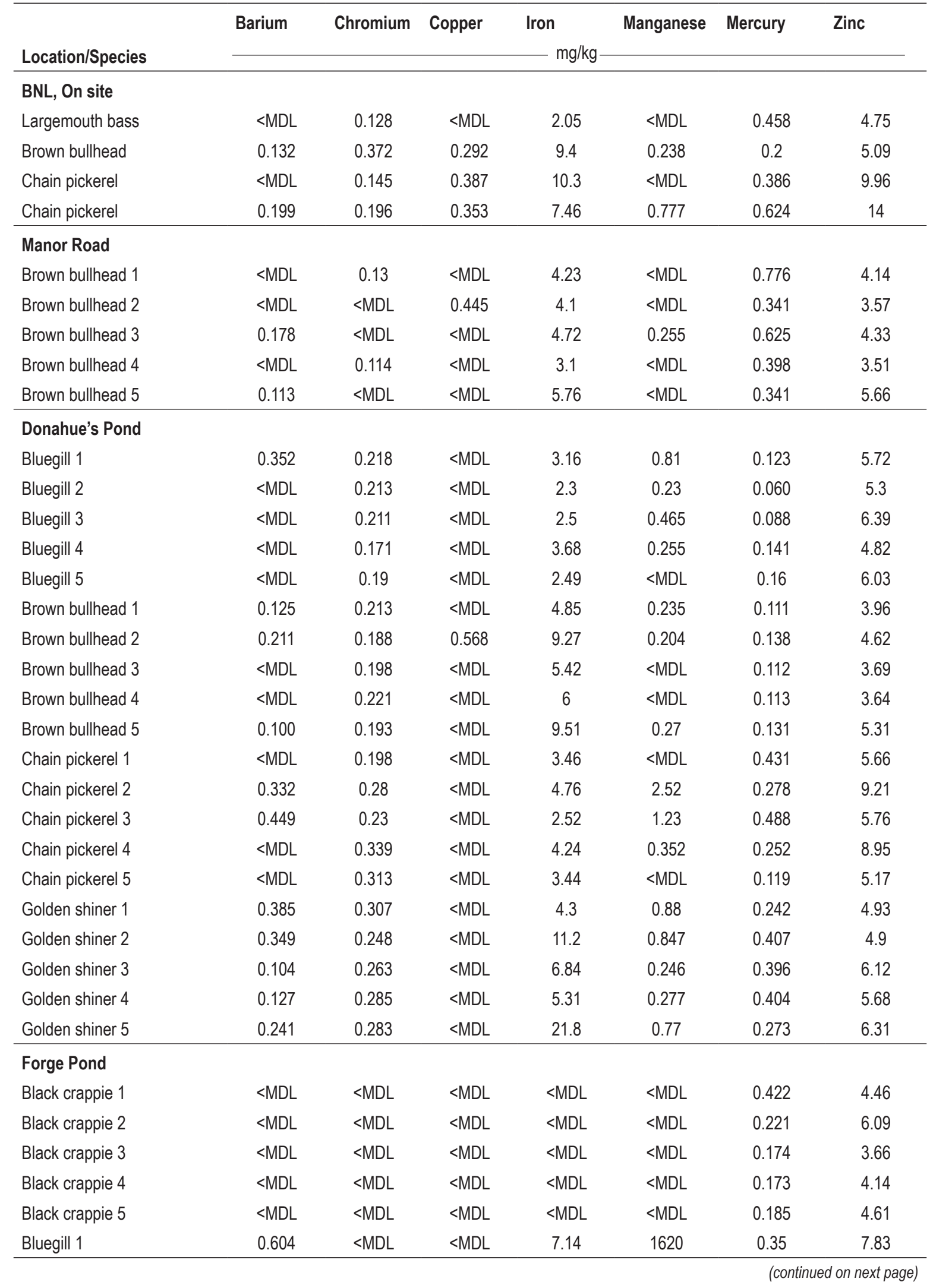


Table 6-5. Metals Analyses of Fish from the Peconic River System and Carmans River, Lower Lake(continued).

\begin{tabular}{|c|c|c|c|c|c|c|c|}
\hline \multirow[b]{2}{*}{ Location/Species } & Barium & Chromium & Copper & \multirow{2}{*}{$\begin{array}{l}\text { Iron } \\
\quad \mathrm{mg} / \mathrm{kg}\end{array}$} & Manganese & Mercury & \multirow[t]{2}{*}{ Zinc } \\
\hline & & & & & & & \\
\hline \multicolumn{8}{|c|}{ Forge Pond (continued) } \\
\hline Bluegill 2 & $<\mathrm{MDL}$ & $<M D L$ & $<\mathrm{MDL}$ & $<\mathrm{MDL}$ & 916 & 0.133 & 5.03 \\
\hline Bluegill 3 & 5.41 & 0.487 & $<\mathrm{MDL}$ & 6.67 & 39.7 & 0.123 & 17.4 \\
\hline Bluegill 4 & 0.369 & $<M D L$ & $<M D L$ & $<M D L$ & 0.834 & 0.332 & 8.96 \\
\hline Bluegill 5 & 0.926 & $<M D L$ & $<\mathrm{MDL}$ & 3.94 & 3.54 & 0.181 & 6.88 \\
\hline Largemouth bass 1 & $<M D L$ & 0.269 & $<M D L$ & $<M D L$ & 0.486 & 0.147 & 5.93 \\
\hline Largemouth bass 2 & $<M D L$ & $<M D L$ & $<\mathrm{MDL}$ & 3.81 & $<\mathrm{MDL}$ & 0.285 & 3.31 \\
\hline Largemouth bass 3 & $<M D L$ & $<M D L$ & $<M D L$ & $<M D L$ & $<M D L$ & 0.181 & 4.33 \\
\hline Chain pickerel 1 & $<\mathrm{MDL}$ & $<\mathrm{MDL}$ & $<\mathrm{MDL}$ & 3.43 & 1.47 & 0.347 & 7.08 \\
\hline Chain pickerel 2 & $<M D L$ & $<M D L$ & $<M D L$ & $<M D L$ & $<M D L$ & 0.123 & 7.58 \\
\hline Chain pickerel 3 & $<M D L$ & $<M D L$ & $<M D L$ & 16 & 0.843 & 0.257 & 4.05 \\
\hline Chain pickerel 4 & $<M D L$ & $<M D L$ & $<M D L$ & $<M D L$ & 0.976 & 0.209 & 5.75 \\
\hline Chain pickerel 5 & $<M D L$ & $<M D L$ & $<M D L$ & $<M D L$ & $<M D L$ & 0.16 & 7.66 \\
\hline Golden shiner 1 & 0.188 & 0.137 & $<M D L$ & 9.3 & 0.374 & 0.129 & 6.57 \\
\hline Golden shiner 2 & 0.586 & 0.109 & $<\mathrm{MDL}$ & $<M D L$ & 0.992 & 0.086 & 9.91 \\
\hline Golden shiner 3 & 0.767 & 0.118 & $<M D L$ & 5.07 & 3.77 & 0.057 & 10.4 \\
\hline Golden shiner 4 & 1.09 & 0.099 & $<M D L$ & 5.97 & 4.32 & 0.122 & 8.26 \\
\hline Golden shiner 5 & 0.458 & $<M D L$ & $<\mathrm{MDL}$ & 2.43 & 1.26 & 0.105 & 8.39 \\
\hline \multicolumn{8}{|l|}{ Swan Pond } \\
\hline Bluegill 1 & 0.614 & 0.471 & $<M D L$ & 4.06 & 3.33 & 0.042 & 8 \\
\hline Bluegill 2 & $<M D L$ & 0.172 & $<M D L$ & 2.27 & 3.57 & 0.041 & 6.17 \\
\hline Bluegill 3 & $<M D L$ & 0.115 & $<M D L$ & 2.69 & 0.619 & 0.246 & 7.23 \\
\hline Bluegill 4 & $<M D L$ & 0.134 & $<M D L$ & 2.12 & 1.73 & 0.025 & 5.61 \\
\hline Bluegill 5 & $<M D L$ & 0.117 & $<M D L$ & $<M D L$ & 0.253 & 0.036 & 5.25 \\
\hline Brown bullhead 1 & 0.174 & 0.123 & 0.288 & 5.57 & 0.887 & 0.039 & 4.29 \\
\hline Largemouth bass 1 & $<M D L$ & 0.121 & $<M D L$ & 2.65 & $<M D L$ & 0.203 & 4.43 \\
\hline Largemouth bass 2 & $<M D L$ & 0.132 & $<M D L$ & $<M D L$ & $<M D L$ & 0.139 & 3.96 \\
\hline Largemouth bass 3 & $<M D L$ & 0.132 & 1.64 & 3.51 & 0.237 & 0.115 & 4.34 \\
\hline Largemouth bass 4 & $<M D L$ & 0.205 & $<M D L$ & $<M D L$ & 0.408 & 0.169 & 4.49 \\
\hline Largemouth bass 5 & $<M D L$ & 0.113 & $<\mathrm{MDL}$ & 1.92 & $<M D L$ & 0.121 & 5 \\
\hline Chain pickerel 1 & $<M D L$ & 0.141 & $<\mathrm{MDL}$ & 2.11 & 0.386 & 0.053 & 7.23 \\
\hline Chain pickerel 2 & $<\mathrm{MDL}$ & 0.159 & $<\mathrm{MDL}$ & 3.28 & 0.434 & 0.082 & 5.62 \\
\hline Chain pickerel 3 & $<M D L$ & 0.204 & $<M D L$ & 4.36 & 0.876 & 0.11 & 11.4 \\
\hline Golden shiner 1 & 1.03 & 0.565 & 383 & 8.9 & 6.68 & 0.023 & 12.7 \\
\hline Golden shiner 2 & 0.411 & 0.133 & $<\mathrm{MDL}$ & 3.27 & 0.465 & 0.030 & 6.49 \\
\hline Golden shiner 3 & 2.17 & 0.158 & $<\mathrm{MDL}$ & 6.21 & 21.7 & 0.041 & 11.4 \\
\hline Golden shiner 4 & 0.264 & 0.107 & $<\mathrm{MDL}$ & 4.58 & 2.38 & 0.045 & 7.4 \\
\hline Golden shiner 5 & 0.677 & 0.114 & 0.349 & 2.93 & 1.24 & 0.049 & 8.74 \\
\hline
\end{tabular}


Table 6-5. Metals Analyses of Fish from the Peconic River System and Carmans River, Lower Lake.(concluded).

\begin{tabular}{|c|c|c|c|c|c|c|c|}
\hline \multirow[b]{2}{*}{ Location/Species } & Barium & Chromium & Copper & \multirow{2}{*}{$\begin{array}{l}\text { Iron } \\
\quad \mathrm{mg} / \mathrm{kg}\end{array}$} & Manganese & Mercury & \multirow[t]{2}{*}{ Zinc } \\
\hline & & & & & & & \\
\hline \multicolumn{8}{|c|}{ Lower Lake, Carmans River (control location) } \\
\hline Largemouth bass 1 & 0.289 & 0.154 & $<M D L$ & 6.74 & 0.57 & 0.094 & 5.02 \\
\hline Largemouth bass 2 & 0.143 & 0.128 & $<\mathrm{MDL}$ & 1.88 & $<\mathrm{MDL}$ & 0.093 & 4.47 \\
\hline Brown bullhead 1 & 0.24 & 0.215 & $<M D L$ & 6.04 & 0.258 & 0.034 & 5.56 \\
\hline Brown bullhead 2 & 0.362 & 0.142 & $<M D L$ & 5.9 & 0.559 & 0.013 & 5.7 \\
\hline Brown bullhead 3 & 0.272 & 0.16 & $<M D L$ & 9.93 & 0.888 & 0.012 & 5.55 \\
\hline Brown bullhead 4 & 0.36 & 0.13 & $<M D L$ & 4.44 & 0.249 & 0.018 & 4.08 \\
\hline Brown bullhead 5 & 0.345 & 0.123 & $<M D L$ & 3.99 & 0.484 & 0.010 & 4.19 \\
\hline Brown trout 1 & 0.196 & 0.147 & $<M D L$ & 4.58 & 0.591 & 0.010 & 6.37 \\
\hline Brown trout 2 & $<M D L$ & 0.114 & 0.409 & 2.31 & $<M D L$ & 0.006 & 4.78 \\
\hline Bluegill 1 & 0.295 & 0.415 & $<M D L$ & 3.83 & 0.529 & 0.031 & 6.2 \\
\hline Bluegill 2 & $<M D L$ & 0.115 & $<M D L$ & $<M D L$ & 0.27 & 0.029 & 6.24 \\
\hline Bluegill 3 & $<\mathrm{MDL}$ & 0.115 & $<M D L$ & $<\mathrm{MDL}$ & $<\mathrm{MDL}$ & 0.023 & 5.59 \\
\hline Bluegill 4 & $<M D L$ & 0.116 & $<M D L$ & $<\mathrm{MDL}$ & $<M D L$ & 0.018 & 6.25 \\
\hline Bluegill 5 & 0.579 & 0.121 & $<M D L$ & $<\mathrm{MDL}$ & 3.07 & 0.040 & 7.97 \\
\hline \multicolumn{8}{|c|}{$\begin{array}{l}\text { Notes: } \\
\text { See Figure 5-8 for sampling locations. } \\
\text { All fish were analyzed as edible portions (fillets) except golden shiners, which were analyzed as whole body-composite samples. } \\
\text { MDL = Minimum Detection Limit }\end{array}$} \\
\hline
\end{tabular}

capable of affecting the health of consumers of such fish. Due to the fact that values for arsenic, beryllium, cadmium, cobalt, silver, thallium, selenium, and vanadium were near or less than the MDL for the analytical procedure, they were not included in Table 6-5. Other metals tested but not included in the table include aluminum, antimony, lead, and nickel, as most values reported for these metals were less than the MDL. Values that were above the MDL are discussed below.

Due to its known health effects, mercury is the metal of highest concern. Mercury in on-site Peconic River samples ranged from $0.46 \mathrm{mg} / \mathrm{kg}$ to $0.62 \mathrm{mg} / \mathrm{kg}$. Off-site Peconic River samples ranged from $0.02 \mathrm{mg} / \mathrm{kg}$ in bluegill and golden shiner to $0.78 \mathrm{mg} / \mathrm{kg}$ in a brown bullhead taken from the Manor Road area. The highest mercury value in the control location on the Carmans River was $0.09 \mathrm{mg} / \mathrm{kg}$. All mercury values were less than the $1.0 \mathrm{mg} / \mathrm{kg}$ consumption standard set by the U.S. Food and Drug Administration.

Values for metals not shown in Table 6-5 because they were at or near MDL were as follows: antimony was found in a various species in levels between 0.40 and $1.7 \mathrm{mg} / \mathrm{kg}$ throughout the Peconic River; arsenic was found in three fish samples between $0.46 \mathrm{mg} / \mathrm{kg}$ in the Peconic River and $0.56 \mathrm{mg} / \mathrm{kg}$ in trout from the Carmans River; cadmium was found at 0.33 $\mathrm{mg} / \mathrm{kg}$ in bluegill taken at Forge Pond; lead was found in a brown bullhead and golden shiners from Donahue's Pond at levels of 0.11 and 0.15 $\mathrm{mg} / \mathrm{kg}$, respectively; nickel was recorded in fish in Peconic River fish at levels between 0.01 and $0.22 \mathrm{mg} / \mathrm{kg}$; selenium was found in two bluegills taken from the Carmans River at 0.49 and $0.56 \mathrm{mg} / \mathrm{kg}$; and silver was found in a chain pickerel from Donahue's Pond at $0.29 \mathrm{mg} / \mathrm{kg}$. These reported values and those presented in Table 6-5 are not considered to pose any health risks to humans or other animals that might consume fish.

Table 6-6 shows the results of pesticide and PCB analyses in fish. Only samples and compounds with detectable results are presented. Concentrations of DDE and DDD, which are breakdown products of the pesticide DDT, were found in low levels in both on- and off-site fish 
Table 6-6. Pesticide and РСВ Analyses of Fish from the Peconic River System and Carmans River, Lower Lake.

\begin{tabular}{|c|c|c|c|c|c|c|}
\hline \multirow[b]{2}{*}{ Location/Species } & 4,4'-DDE & 4,4'-DDD & 4,4'-DDT & Aroclor-1242 & Aroclor-1254 & Aroclor- 1260 \\
\hline & \multicolumn{6}{|c|}{$-\mu g / k g$} \\
\hline \multicolumn{7}{|l|}{ Donahue's Pond } \\
\hline Bluegill 3 & $<M D L$ & $<M D L$ & $<M D L$ & 48.6 & 37.5 & $13.9^{*}$ \\
\hline Bluegill 5 & $<M D L$ & $<\mathrm{MDL}$ & $6.15^{*}$ & $<M D L$ & $<\mathrm{MDL}$ & $<\mathrm{MDL}$ \\
\hline Brown bullhead 1 & $3.49^{*}$ & $<M D L$ & $<M D L$ & $<M D L$ & $<M D L$ & $<\mathrm{MDL}$ \\
\hline Brown bullhead 2 & $3.59^{*}$ & $<M D L$ & $<\mathrm{MDL}$ & $<M D L$ & $<M D L$ & $<M D L$ \\
\hline Brown bullhead 3 & 10.7 & $4.21^{*}$ & $<\mathrm{MDL}$ & $<M D L$ & $<M D L$ & $<\mathrm{MDL}$ \\
\hline Brown bullhead 4 & $<M D L$ & $<M D L$ & $<M D L$ & 51.2 & 26.8 & $11.3^{*}$ \\
\hline Chain pickerel 1 & 17.9 & $<M D L$ & $<\mathrm{MDL}$ & $<M D L$ & $<M D L$ & $<\mathrm{MDL}$ \\
\hline Chain pickerel 5 & $<M D L$ & $<\mathrm{MDL}$ & $<M D L$ & 91.3 & 52.4 & 23.3 \\
\hline \multicolumn{7}{|l|}{ Forge Pond } \\
\hline Bluegill 2 & 15.2 & $<M D L$ & $<\mathrm{MDL}$ & $<M D L$ & $<M D L$ & $<\mathrm{MDL}$ \\
\hline \multicolumn{7}{|l|}{ Swan Pond } \\
\hline Largemouth bass 5 & $<M D L$ & $<\mathrm{MDL}$ & $<\mathrm{MDL}$ & $<M D L$ & $17.3^{*}$ & $<\mathrm{MDL}$ \\
\hline Chain pickerel 3 & $2.61^{*}$ & $<M D L$ & $<M D L$ & $<M D L$ & $<M D L$ & $<\mathrm{MDL}$ \\
\hline Golden shiner 1 & 15.7 & $<M D L$ & $<\mathrm{MDL}$ & $<M D L$ & $<M D L$ & $<M D L$ \\
\hline Golden shiner 2 & 13.4 & $<\mathrm{MDL}$ & $<M D L$ & $<\mathrm{MDL}$ & 308 & $<\mathrm{MDL}$ \\
\hline Golden shiner 3 & 12.9 & $<M D L$ & $<M D L$ & $<M D L$ & $<M D L$ & $<M D L$ \\
\hline \multicolumn{7}{|c|}{ Lower Lake, Carmans River (control location) } \\
\hline Brown bullhead 3 & 22.6 & 12.4 & 11.1 & $<M D L$ & $<M D L$ & $<\mathrm{MDL}$ \\
\hline \multicolumn{7}{|c|}{$\begin{array}{l}\text { Notes: } \\
\text { Only locations with samples showing detectable levels of pesticides and PCBs are presented. } \\
\text { All fish analyzed as edible portions (fillets) except for golden shiner, which were analyzed as whole body-composite samples. } \\
\text { MDL = Minimum Detection Limit } \\
\text { PCB = Polychlorinated biphenyls }\end{array}$} \\
\hline
\end{tabular}

sampled in 2006. DDT was reported for only two samples: the larger amount was from the control location outside BNL influence, and the other was a low concentration estimated by the contract analytical laboratory. The levels of pesticides detected did not exceed any established health standards for the consumers of such fish and thus are not considered harmful. DDT was commonly used on Long Island before 1970.

PCBs were found at levels above the MDL in three fish samples taken from Donahue's Pond and one sample taken from Swan Pond. Aroclor-1242 ranged from $48.6 \mu \mathrm{g} / \mathrm{kg}$ in bluegill to $91.3 \mu \mathrm{g} / \mathrm{kg}$ in chain pickerel taken from Donahue's Pond. Aroclor-1254 ranged from an esti- mated value of $17.3 \mu \mathrm{g} / \mathrm{kg}$ in a largemouth bass taken in Swan Pond to $308 \mu \mathrm{g} / \mathrm{kg}$ in a golden shiner from Swan Pond. Aroclor-1260 ranged from and estimated $11.3 \mu \mathrm{g} / \mathrm{kg}$ in a brown bullhead to $23.3 \mu \mathrm{g} / \mathrm{kg}$ in a chain pickerel, both from Donahue's Pond. Historically, PCBs have been found in both fish and sediment at BNL and periodically at other locations in the Peconic River. The cleanup of the Peconic River that was completed in 2005 removed most PCBs within the sediments.

\subsubsection{Aquatic Sampling}

6.3.5.1 Radiological Analysis

Annual sampling of sediment, vegetation, and 
Table 6-7. Radiological Analyses of Aquatic Vegetation and Sediment from the Peconic River and Carmans River System, Lower Lake.

\begin{tabular}{|c|c|c|}
\hline \multirow{2}{*}{$\begin{array}{l}\text { Location } \\
\text { /Sample type }\end{array}$} & $\mathrm{K}-40$ & Cs-137 \\
\hline & \multicolumn{2}{|c|}{$\ldots$ pCi/g Dry Sediment } \\
\hline \multicolumn{3}{|c|}{ Donahue's Pond } \\
\hline Sediment ${ }^{* *}$ & $2.58 \pm 0.67$ & $0.31 \pm 0.06$ \\
\hline Vegetation* & $1.04 \pm 0.18$ & $0.03 \pm 0.01$ \\
\hline \multicolumn{3}{|l|}{ Forge Pond } \\
\hline Sediment ${ }^{* *}$ & $2.42 \pm 0.76$ & $0.29 \pm 0.06$ \\
\hline Lilypad* & $2.75 \pm 0.36$ & $0.03 \pm 0.02$ \\
\hline \multicolumn{3}{|l|}{ Swan Pond } \\
\hline Sediment ${ }^{* *}$ & $3.86 \pm 1.11$ & ND \\
\hline Lilypad & $3.74 \pm 0.53$ & ND \\
\hline \multicolumn{3}{|c|}{ Lower Lake, Carmans River (control location) } \\
\hline Sediment ${ }^{* *}$ & $1.68 \pm 1.02$ & ND \\
\hline Vegetation & $1.82 \pm 0.63$ & ND \\
\hline \multicolumn{3}{|c|}{$\begin{array}{l}\text { Notes: } \\
\text { Cs- } 137=\text { cesium- } 137 \\
\text { K-40 = potassium- } 40 \\
\text { ND }=\text { Not detected } \\
{ }^{*} \text { Cs- } 137 \text { values estimated based on contract analytical laboratory qualifiers. } \\
{ }^{*} \text { Sediment values reported in } \mathrm{pCi} / \mathrm{g} \text { dry weight. }\end{array}$} \\
\hline
\end{tabular}

freshwater in the Peconic River and a control location on the Carmans River was conducted in 2006. See Chapter 5 for a discussion on water quality and monitoring, and Figure 5-8 for sampling stations. Additionally refer to Section 6.3.6 for a discussion of sediment and water analysis related to monitoring post-cleanup of the Peconic River. Because significant numbers of samples are now taken under this monitoring program, fewer samples are being taken through routine surveillance monitoring, to reduce duplication of effort.

Table 6-7 summarizes the radiological data. Low levels of Cs-137 were documented in sediments and vegetation at Donahue's and Forge Ponds, while samples taken at Swan Pond and Lower Lake on the Carmans River lacked detectable levels.

\subsubsection{Metals in Aquatic Samples}

Metals analyses (Table 6-8) were conducted on aquatic vegetation and sediments from the Peconic River and Carmans River. Most of the data indicate metals at background levels. The standard used for comparison of sediments is the soil cleanup objectives for heavy metals supported by SCDHS. Vegetation results are compared to soil cleanup standards, because metals in vegetation may accumulate via uptake from sediment. In general, metals are seen in vegetation at levels lower than in associated sediment.

Off site, levels of arsenic were detected in sediments at Forge pond at $764 \mathrm{mg} / \mathrm{kg}$ (not shown in Table 6-8). Additionally, lead was found above SCDHS action levels at Swan Pond and Forge Pond. No other metals were found above action levels or cleanup objectives in off-site portions of the Peconic River or Lower Lake on the Carmans River.

\subsubsection{Pesticides and PCBs in Aquatic Samples}

Pesticides and PCBs were found in only three aquatic samples taken in 2006 during routine surveillance; therefore, no table is necessary for reporting. Aroclor-1254 and Aroclor-1260 were detected in lilypads taken from Forge Pond at 27.8 and $9.9 \mu \mathrm{g} / \mathrm{kg}$, respectively. The $9.9 \mu \mathrm{g} / \mathrm{kg}$ value is an estimated value based on laboratory qualifiers. Aroclor-1254 was detected at an estimated level of $9.70 \mu \mathrm{g} / \mathrm{kg}$ in sediments taken from Swan Pond. The pesticide DDT and one of its breakdown products, DDE, were found in sediments from Donahue's Pond at levels of 90.1 and $59.7 \mu \mathrm{g} / \mathrm{kg}$, respectively. The value for DDE $(59.7 \mu \mathrm{g} / \mathrm{kg})$ was an estimated value based on laboratory qualifiers. In general, DDT and its breakdown products appear to be slowly declining. Routine vegetation and sediment samples were not taken from on-site portions of the Peconic River, due to extensive post-cleanup monitoring associated with cleanup efforts.

\subsubsection{Peconic River Post-Cleanup Monitoring}

Sediment from the Peconic River was remediated in 2004 and 2005 to remove mercury and associated contaminants from the river. The cleanup of sections of the river on site focused on sediment in known depositional areas. The goal of the cleanup was to reduce the average mercury concentrations on site to less than 


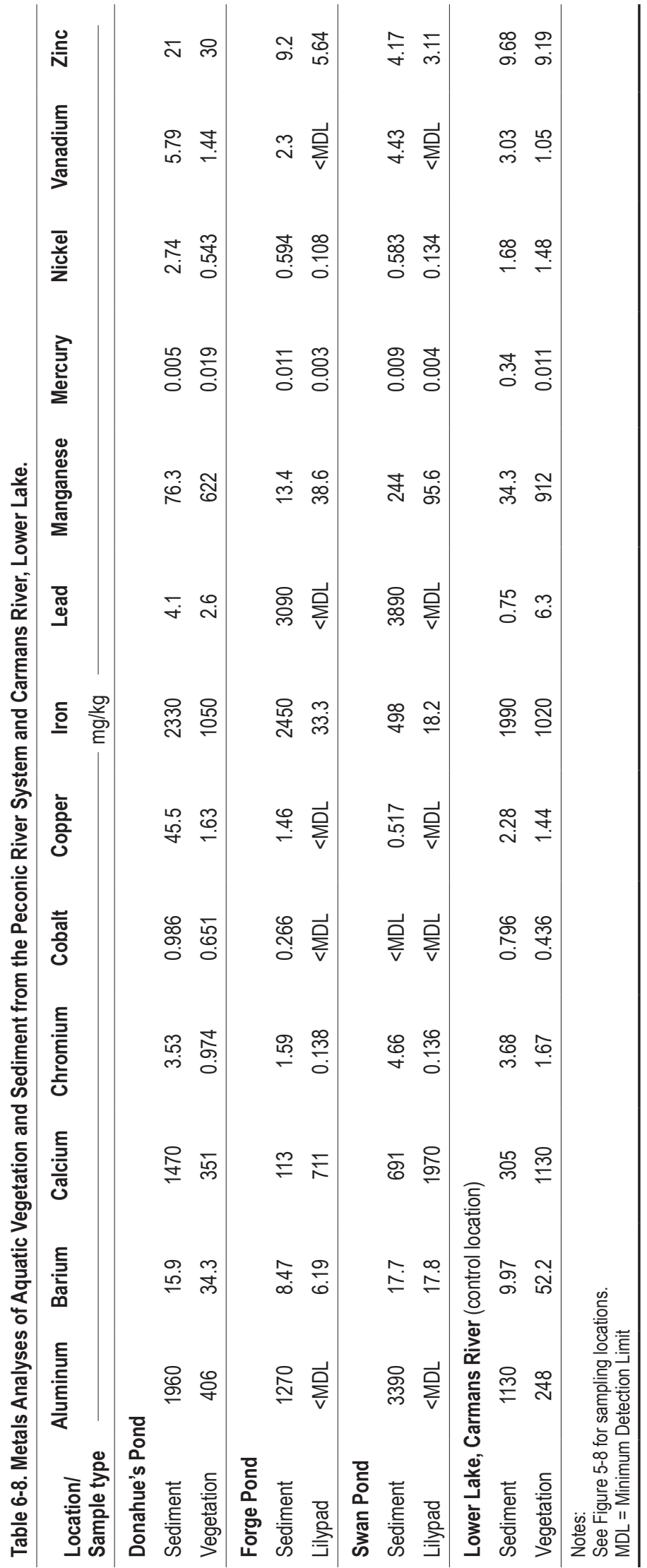

$1 \mathrm{mg} / \mathrm{kg}$, with an overall goal to reduce mercury concentrations in the remediated areas, both on site and off site, to less than $2 \mathrm{mg} / \mathrm{kg}$. Onsite remediation efforts resulted in a 96 percent reduction in average mercury concentrations in river sediments, from approximately $4.6 \mathrm{mg} / \mathrm{kg}$ to $0.2 \mathrm{mg} / \mathrm{kg}$ (Envirocon, 2005).

Cleanup of off-site locations focused on a more stringent cleanup target that would allow the greatest flexibility for use as County parkland or for potential development. Sediment was removed from ponded areas where methylation leading to bioaccumulation is most likely to occur, as well as other areas containing higher concentrations of contamination east of the BNL property line to Connecticut Avenue. The cleanup goal was to reduce mercury concentrations within the sediment to less than $0.75 \mathrm{mg} / \mathrm{kg}$, with an overall goal of mercury concentrations to less than $2 \mathrm{mg} / \mathrm{kg}$ following the cleanup. Off-site remediation efforts resulted in a 95 percent reduction in average mercury concentrations in river sediments downstream of the BNL property line, from approximately $1.8 \mathrm{mg} / \mathrm{kg}$ to $0.09 \mathrm{mg} / \mathrm{kg}$, excluding the Manor Road area, which had an 83 percent reduction, from $1.08 \mathrm{mg} / \mathrm{kg}$ to $0.19 \mathrm{mg} / \mathrm{kg}$ (Envirocon, 2005).

The Laboratory and DOE are committed to a multi-year post-cleanup sampling of sediment, surface water, fish, and wetland restoration. Sampling results for 2006 are summarized below. Detailed information on 2006 sampling results can be found in the 2006 Peconic River Monitoring Report (BNL, 2007).

\subsubsection{Sediment Sampling}

Sediment was sampled in June at 16 Peconic River sampling stations on site and 14 sampling stations off site. Ninety-three percent of samples analyzed for mercury met the cleanup goal of $2.0 \mathrm{mg} / \mathrm{kg}$. Two samples exceeded the $2.0 \mathrm{mg} / \mathrm{kg}$ goal and another sample was close to the goal. The sample results were shared with NYSDEC, EPA, and SCDHS. In August 2006, five additional sediment samples were taken from the three stations where concentrations had been higher than $2.0 \mathrm{mg} / \mathrm{kg}$. The August sample results were substantially lower than those obtained in 
June, although several of the samples surrounding each of the three stations still exceeded 2.0 $\mathrm{mg} / \mathrm{kg}$. Additional sampling procedures to characterize the nature and extent of contamination were prepared for implementation in 2007.

\subsubsection{Water Column Sampling}

Surface water was analyzed for total mercury and methylmercury at 20 Peconic River sampling stations and one reference station on the Connetquot River (see Figure 6-5). Samples were taken in both June and August. Concentrations of total mercury were generally less than the 2005 concentrations upstream of Schultz Road, but generally greater than the 2004 mercury concentrations downstream of Schultz Road. In each of the sampling events, the mercury concentration increased from upstream of the Sewage Treatment Plant (STP) outfall to downstream of the STP outfall, then generally decreased continuing downstream from the STP. August samples were generally greater than the June 2006 levels upstream of Schultz Road, with concentrations less than the June concentrations downstream of Schultz Road. In August, low water levels prevented samples from being taken at stations both upstream and downstream of the east boundary off site. Effluent from the STP is a potential low-level mercury source that may contribute to the elevation of mercury concentrations in the Peconic River surface water between stations PR-WC-12 (upstream of the STP outfall) and PR-WC-11 (downstream of the STP outfall). Additional surface water monitoring of the STP effluent will be conducted to evaluate its potential contribution of mercury, methylmercury, and total suspended solids (TSS) to mercury concentrations in the Peconic River.

\subsubsection{Fish Sampling}

In 2006, fish were collected from three sampling stations; Area D near North Street, the Manor Road area, and Donahue's Pond. Comparing 1997 and 2006 data indicated that the average mercury concentrations in fish were very similar at the BNL site boundary at North Street $(0.36 \mathrm{mg} / \mathrm{kg}$ and $0.42 \mathrm{mg} / \mathrm{kg}$, respectively). At Manor Road, the 2006 concentration $(0.50 \mathrm{mg} /$ $\mathrm{kg})$ was higher than the 1997 concentration $(0.32$ $\mathrm{mg} / \mathrm{kg}$ ). At Donahue's Pond, the 2006 mercury concentrations in fish tissue were substantially lower $(0.22 \mathrm{mg} / \mathrm{kg})$ than in $1997(0.32 \mathrm{mg} / \mathrm{kg})$. The average concentration of mercury in all fish caught at North Street, Manor Road, and Donahue's Pond was $0.3 \mathrm{mg} / \mathrm{kg}$. The EPA criterion for methyl mercury concentration in fish tissue is $0.3 \mathrm{mg} / \mathrm{kg}$.

The average PCB concentration in fish in 2006 for all three locations was below the detection limit; this was a substantial improvement over the 1997 concentration of PCBs found in fish. All 2006 samples analyzed for cesium-137 were also substantially lower than values found in fish in 1997.

\subsubsection{Wetland Sampling}

The wetland monitoring results for 2006 are summarized in Section 5 of the 2006 Peconic River Monitoring Report (BNL, 2007) and detailed in Attachment B of that report. BNL's success at meeting the DEC permit equivalency conditions detailed in the On-Site Peconic River Restoration Program Permit Equivalency Application (Louis Berger, 2004a) and the OffSite Peconic River Restoration Program Permit Equivalency Application (Louis Berger, 2004b) are discussed below.

As of September 2006, the Laboratory met and exceeded the DEC Equivalency Permit requirements for "cover" growth in on-site marshy areas. A target percent cover of 65 percent in the low marsh was achieved, with an overall average for all 64 transects of 92 percent. No low marsh cleanup area had less than 79 percent cover, and percent cover of invasive species was less than the permit limit of 10 percent in any one wetland restoration. This was achieved with an average percent cover (for permit-specified invasive wetlands plants) of less than 1 percent across all cleanup areas.

In 2007, DEC will tour the Peconic River wetlands and evaluate whether the Permit Equivalency conditions have been met there. Monitoring of invasive species will continue until 2008, at which time DEC will evaluate whether BNL has met the Permit Equivalency requirement for less than 10 percent cover by invasive species in any one remediated area. 
CHAPTER 6: NATURAL AND CULTURAL RESOURCES

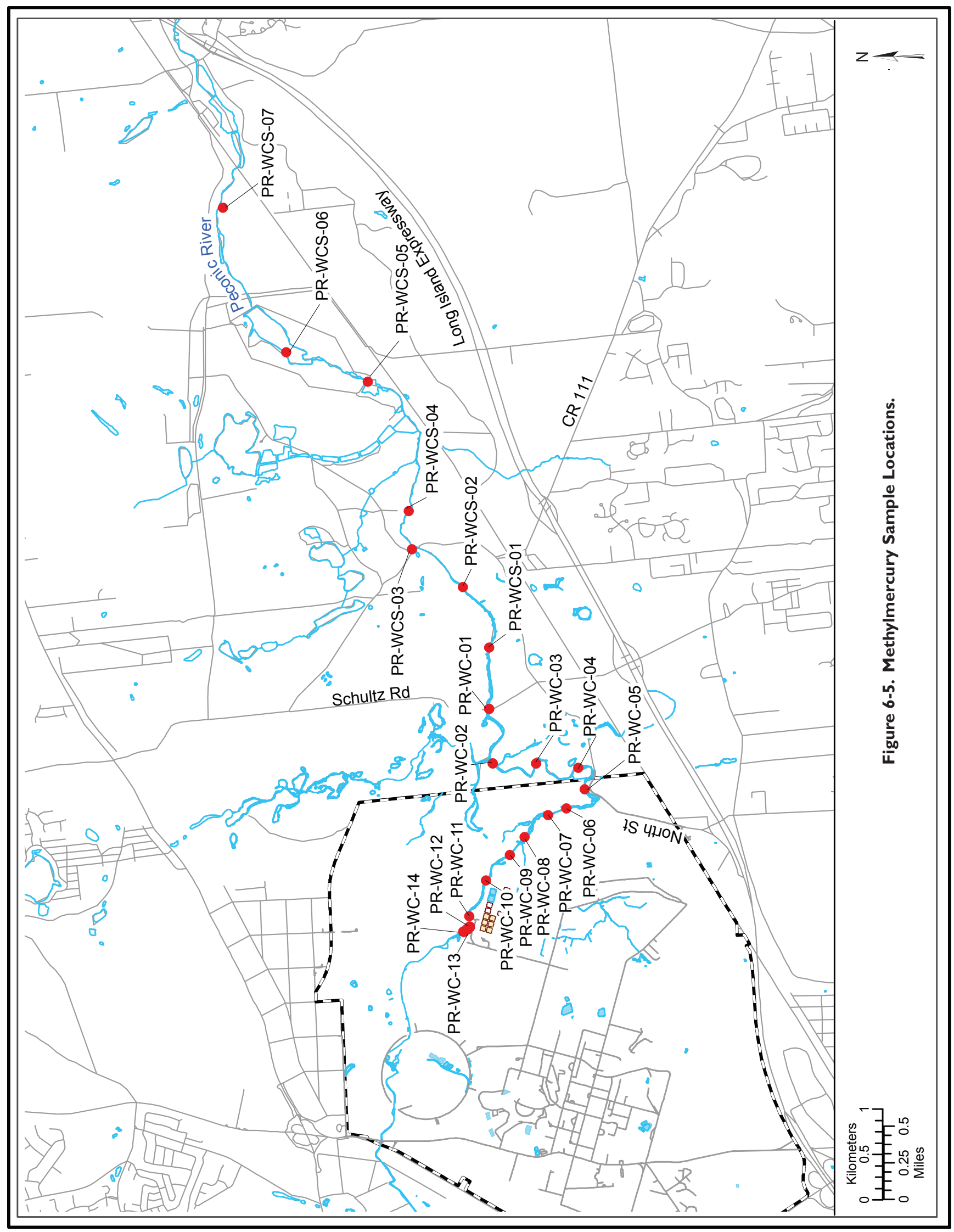




\subsubsection{Vegetation Sampling}

6.3.7.1 Garden Vegetables

On-site sampling of garden vegetables continued in 2006. Samples of zucchini, cucumber, tomato, pepper, and eggplant were analyzed for Cs-137 content. The radionuclide was not detected in any vegetable sample, but was detected in soils at very low levels $(0.23 \mathrm{pCi} / \mathrm{g})$. Sampling of off-site farm vegetation was discontinued in 2003 because historical data have consistently indicated the absence of BNL-related radionuclides in off-site vegetation. Periodic confirmatory sampling (approximately every five years) will be conducted off site to obtain data on farm vegetables.

\subsubsection{Grassy Plants}

In 2003, grassy vegetation sampling was converted to a graded approach and was linked to other sampling programs. As an example of this approach, vegetation sampling would be conducted only if routine air sampling indicated that radionuclides had been released and deposited on soil and vegetation. Periodic confirmatory sampling of grassy vegetation will be conducted approximately every five years. Grassy vegetation will be sampled on site in 2007.

As part of post-cleanup monitoring for the former Hazardous Waste Management Facility, five terrestrial and two aquatic vegetation samples were acquired. Cs-137 was detected at an estimated value of $0.14 \mathrm{pCi} / \mathrm{g}$ dry weight in one of the aquatic vegetation samples. It was not detected in any of the other six samples.

\subsection{OTHER MONITORING}

\subsection{Soil Sampling}

Soil sampling uses the same graded approach as that used for grassy vegetation sampling and was removed from the basic monitoring protocols in 2003. Confirmatory soil sampling will be conducted every five years. Confirmatory soil sampling will be conducted on site in 2007, in association with vegetation sampling.

\subsubsection{Basin Sediments}

A five-year testing cycle for basin sediment samples was established in 2003. There are 14 basins associated with outfalls that receive dis- charges permitted under the State Pollutant Discharge Elimination System (SPDES) permit (see Figure 5-6 for outfall locations). The next round of basin sampling will occur in 2007 in order to stagger periodic five-year sampling.

\subsubsection{Chronic Toxicity Tests}

Under the SPDES discharge permit, BNL conducted chronic toxicity testing of the STP effluents. Results of this testing are discussed in Chapter 3, Section 3.6.1.1. Testing will continue in 2007.

\subsubsection{Radiological Monitoring of Precipitation}

As part of the BNL Environmental Monitoring Program, precipitation samples were collected quarterly at air monitoring Stations P4 and S5 (see Figure 4-3 for station locations), and were analyzed for radiological content. Four samples were taken from each of these two stations in 2006. Gross alpha activity measurements above the MDL at $0.91 \mathrm{pCi} / \mathrm{L}$ were detected at the $\mathrm{S} 5$ station in the fourth quarter sample only.

Gross beta activity was measured in samples in all four quarters from both stations. In general, radioactivity in precipitation comes from naturally occurring radionuclides in dust and from activation products that result from solar radiation. Location $\mathrm{P} 4$ had a maximum gross beta activity level of $4.5 \mathrm{pCi} / \mathrm{L}$, with an average of $3.6 \mathrm{pCi} / \mathrm{L}$. Location $\mathrm{S} 5$ had a maximum gross beta activity level of $4.9 \mathrm{pCi} / \mathrm{L}$, with an average of $3.9 \mathrm{pCi} / \mathrm{L}$. Gross beta activity values were within the range of values historically observed at these two locations. No radionuclide-specific analyses indicated values above MDL.

\subsection{WILDLIFE PROGRAMS}

BNL sponsors a variety of educational and outreach activities involving natural resources. These programs are designed to help participants understand the ecosystem and to foster interest in science. Wildlife programs are conducted at BNL in collaboration with DOE, local agencies, colleges, and high schools. Ecological research is also conducted on site to update the current natural resource inventory, gain a better understanding of the ecosystem, and guide management planning. 
In 2006, the Environmental and Waste Management Services Division (EWMSD) and FERN hosted a total of 24 interns and two faculty members. Interns consisted of one high school intern, 13 undergraduate interns, and four school teachers during the summer. FERN also hosted six undergraduate interns for their Forest Health Monitoring Program. Seven of the undergraduate interns worked with faculty members from North Carolina Agricultural and Technical University and Southern University at New Orleans, as part of the Faculty and Student Teams Program. Interns worked on a variety of projects: surveying dragonflies and damselflies, radio tracking turtles, analyzing the water chemistry of coastal plain ponds, investigating turtle and amphibian diseases, investigating the loss of the southern leopard frog on Long Island, genetics of resident gray and red fox at BNL, effects of insect damage on chlorophyll production in oak trees, and studying various ecological aspects of forest health. Teachers also participated in preparing and carrying out a week-long workshop in environmental monitoring under a new program, the Open Space Stewardship Program, which is managed by the BNL Office of Education Programs. A limited discussion concerning each project is presented below.

An intern in the Community College Internship (CCI) program continued work on the identification and distribution of dragonflies and damselflies (Order Odonata) that was started in 2003 and expanded the project to study the feasibility of using simple mark-recapture techniques for determining population estimates of dragonflies. These aquatic insects are common around the ponds and Peconic River on site. The distribution of aquatic invertebrates may be useful for monitoring the health of aquatic systems. In addition, results from the Odonate surveys will supplement the New York State Odonate Atlas. The intern increased the number of species identified from 55 to 60 . The state atlas project will continue for another year, as will the Laboratory's surveys for Odonates.

In 2005, three eastern box turtles were found in one of BNL's many ponds. All three turtles had a fairly common infection of the ear. The turtles were taken to a wildlife rehabilitator for treatment and care. Two of the turtles subsequently died of their infections and their tissues were sent for analysis. In the analysis, an iridovirus implicated in amphibian declines was isolated. This resulted in a summer intern project in which samples from eastern box turtles were taken for virus identification and a radio telemetry study was conducted to look at range overlap. Range overlap is important to determine the potential for infected turtles to encounter non-infected turtles and transmit the virus. The study was conducted by an intern from Maine and provided indication of significant territorial overlap between individual turtles within a given area. This poses a potential problem if any of the turtles is carrying a virus.

In the Science Undergraduate Laboratory Intern (SULI) program, two interns from Wesleyan College and the University of Maryland looked at the distribution of the southern leopard frog and chytrid fungus on Long Island. The southern leopard frog has had precipitous population declines, and the focus was to attempt to find existing populations of this frog and to document whether or not chytrid fungus is present in other frog species across Long Island. Unfortunately, there were no southern leopard frogs found in any of the water bodies investigated, and no clear connection as to what may have caused the loss of this species on Long Island.

The two Faculty and Student Teams (FaST) conducted tests of four on-site ponds and the upper reaches of the Peconic River to look at chemical differences of soil and sediments as it relates to water quality variations among ponds and different portions of the Peconic River. Documentation of differences between various ponds on site is used to understand their use by various amphibian species, especially the endangered eastern tiger salamander. Differences in the various areas of the Peconic River is important in understanding the dynamics of this system and the potential effects of acid rain on the greater Pine Barrens ecosystem.

Associated with this study was a continuing effort by three teachers in the Lab Science Teacher Professional Development (LSTPD) program. This project involves obtaining water quality data from all ponds on site. In 2006, 
the teachers continued working with the FaST teams to use GPS and GIS to enhance their data. They also developed a week-long workshop under the Open Space Stewardship Program (OSSP) called "Gaining Research Experience in the Environment (GREEN) Institute," where they shared their expertise with approximately 20 teachers participating in OSSP so they could discuss the program within their home schools. The OSSP is expected to grow throughout Suffolk County to foster a sense of stewardship in students and to gather much-needed environmental data on numerous open space parcels throughout the county.

A fourth teacher working in the LSTPD program studied the effects of insect damage on leaves and the production of chlorophyll. This study helps ecologists understand the impacts of insect defoliators that have repeatedly been infesting oak trees at BNL. Insect defoliation has resulted in high tree mortality in hundreds of acres of oak forest in the Central Pine Barrens.

A student from the University of Rhode Island worked on a project to isolate genetic material from fox droppings. This non-invasive genetic technique is being utilized to look at the interrelatedness of numerous fox families living on site, and to try to distinguish between red and gray fox. The gray fox is known to live on site, but is rarely seen. Once thought to be extirpated from Long Island, a gray fox that had been struck by a car was found on site in 2005. Using non-invasive genetics techniques may also allow researchers to estimate population size and distribution of these two species.

Tiger salamanders continue to be a topic for research at the Laboratory. In 2006, a student from the Community College of Rhode Island spent the spring and summer months at BNL looking at various characteristics of ponds and vernal pools. The pond characteristics were compared to juvenile recruitment of metamorphic tiger salamanders. The work is part of a larger project being carried out as a dissertation project by a graduate student from Binghamton University.

As part of the tiger salamander research, a high school student completed a project on the distribution of small mammals around one of the more productive tiger salamander ponds, due to documentation of a relatively high mortality in tiger salamanders that appears to be related to small mammals. The documentation of small mammals around the pond can be compared to the use of small mammal burrows by tiger salamanders, perhaps increasing an understanding of the relationship and the resulting mortality.

FERN hosted six summer students who conducted Forest Health Monitoring in the Long Island Central Pine Barrens. The students were able to establish an additional 41 permanent monitoring plots throughout the pine barrens, gather data, analyze it, and produce five separate projects. Their scientific posters, forest health monitoring protocols, and the associated database are available on the FERN website at www.fern-li.org. The various projects dealt with different aspects of forest health or the ability to gather accurate information. Students evaluated differences in leaf litter among forest types, differences in understory composition and age class structure of the various forest types, differences in soil $\mathrm{pH}$ among different forest types, differences in snag (dead limb) density among forest types, and effects of overstory canopy on understory density. The final report on this project is expected to provide significant information resulting in recommendations for forest management throughout the Pine Barrens.

Members of EWMSD and other BNL departments volunteered as speakers for schools and civic groups and provided on-site ecology tours. EWMSD also hosted several environmental events in association with Earth Day. In October, BNL hosted the Eleventh Annual Pine Barrens Research Forum for ecosystems researchers to share and discuss their results.

The Laboratory also hosted the annual Wildland Fire Academy, offered by NYSDEC and the Central Pine Barrens Commission. Using the Incident Command System of wildfire management, this academy trains fire fighters in the methods of wildland fire suppression, prescribed fire, and fire analysis. BNL has developed and is implementing a Wildland Fire Management Plan. In October 2006, a second 
prescribed fire was conducted on site. This fire treated approximately 15 acres to improve germination and recruitment of oak seedlings. It also reduced fine-textured forest fuels that tend to increase the severity of wildfires. Pre-fire monitoring was conducted before the fire was started, and post-fire monitoring indicated the fire was conducted properly for its intended purpose. Additional post-fire monitoring in 2007 will be conducted to determine the effectiveness of the fire in promoting oak recruitment. The Laboratory intends to continue the use of prescribed fire for fuel and forest management in the future, and is working with NYSDEC and The Nature Conservancy to prepare additional prescriptions for a larger portion of the northern and eastern sections of the BNL property.

\subsection{CULTURAL RESOURCE ACTIVITIES}

The BNL Cultural Resource Management (CRM) Program ensures that the Laboratory fully complies with the numerous cultural resource regulations. The Cultural Resource Management Plan (CRMP) for Brookhaven National Laboratory (BNL, 2005), which guides the management of all of BNL's historical resources, was approved by DOE in March 2005. Along with achieving compliance with applicable regulations, one of the major goals of the CRM program is to fully assess both known and potential cultural resources. The range of the Laboratory's cultural resources includes buildings and structures, World War I (WWI) earthwork features, the Camp Upton Historical Collection, scientific equipment, archives of photos, audio, and video, and institutional records. As various cultural resources are identified, plans for their long-term stewardship are developed and implemented. Achieving these goals ensures that the contributions BNL and the site have made to our history and culture are documented and available for interpretation. The Laboratory has three structures or sites that have been determined to be eligible for listing on the National Register of Historic Places: the Brookhaven Graphite Research Reactor complex, the High Flux Beam Reactor complex, and the WWI training trenches associated with Camp Upton. The BNL trenches are examples of the few sur- viving WWI earthworks in the United States.

Compliance activities performed in 2006 included completing a National Historic Preservation Act (NHPA) Section 106 review of the remaining Camp Upton-era buildings at BNL. The review determined that none of the structures were eligible for listing on the National Register. An NHPA Section 106 Determination of Effects was performed to address decommissioning of the High Flux Beam Reactor (HFBR). The decommissioning action was determined to have "Adverse Effects" for its historical status, as defined by the NHPA regulations. Therefore, the Laboratory and DOE will be entering into consultation with the New York State Historic Preservations Officer (SHPO) to discuss ways of mitigating the adverse effects to this historic resource.

In accordance with the guidelines prescribed in the BNL CRMP, an archaeological survey of the proposed site of NSLS-II was performed in December 2006. A total of 356 shovel test pits were dug over the 24-acre area. Based on the results of the survey, no further archaeological investigations were recommended (Merwin and Manfra 2007).

Cultural resource management concepts were strengthened by integrating specific strategies into the Laboratory's maintenance planning and scheduling programs.

Outreach activities consisted of providing presentations on Laboratory cultural resources and tours of the WWI trenches to several small groups, and participating in local fairs. An article featuring BNL cultural resources was published in the DOE newsletter 'Partners In Preservation', April 2006 edition.

\section{REFERENCES AND BIIBLIOGRAPHY}

BNL. 1999. Record of Decision: Operable Unit I and Radiologically Contaminated Soils. BNL/OUI/I2.I/I-57 05-OCT-99. Brookhaven National Laboratory, Upton, NY.

BNL. 2000. 1999 Site Environmental Report. BNL-52553. Brookhaven National Laboratory, Upton, NY.

BNL. 2003a. Natural Resource Management Plan for Brookhaven National Laboratory. BNL-7 I 870-2003. Brookhaven National Laboratory, Upton, NY.

BNL. 2003b. Wildland Fire Management Plan for Brookhaven National Laboratory. BNL-7I 629-2003. Brookhaven National Laboratory, Upton, NY.

Louis Berger, 2004a. On-Site Peconic River Restoration Program: 
NYSDEC Permit Equivalency Application. Brookhaven National Laboratory, Upton, NY. July 2004.

Louis Berger, 2004b. Off-Site Peconic River Restoration Program: NYSDEC Permit Equivalency Application. Brookhaven National Laboratory, Upton, NY. July 2004.

BNL. 2005. Cultural Resource Management Plan for Brookhaven National Laboratory. BNL-73839-2005. Brookhaven National Laboratory, Upton, NY. March 2005.

BNL 2007. 2006 Peconic River Monitoring Report. Brookhaven National Laboratory.

DOE-FWS. 2000. Interagency Agreement Number AlO2OICHI 107 Between the U.S. Department of Interior, U.S. Fish \& Wildlife Service, Long Island National Wildlife Refuge Complex, and the U.S. Department of Energy Chicago Operations Office Brookhaven Group.

Dwyer, Norval. 1966. Brookhaven National Laboratory. Long Island Forum (reprint), West Islip, NY.

Florendo, Esperanza. 2004. "Seasonal food intake affecting Cs- 137 levels in white-tailed deer at Brookhaven National Laboratory." CCl Paper. Brookhaven National Laboratory.

IAEA. 1992. Effects of lonizing Radiation on Plants and Animals at Levels Implied by Current Radiation Protection Standards. Technical Report Series No. 332. International Atomic
Energy Agency, Vienna.

LMS. 1995. Phase II Sitewide Biological Inventory Report, Final. Lawler, Matusky \& Skelly Engineers. Pearl River, NY.

Merwin, D, Manfra, A. 2007. A Stage I Archaeological Survey for the Proposed NSLS-II at Brookhaven National Laboratory. The Institute for Long Island Archaeology, Department of Anthropology, State University of New York at Stony Brook. NYSDOH. 1996. Radioactive Contamination in the Peconic River. Bureau of Environmental Radiation Protection, New York State Department of Health, Albany, NY.

NYSDOH. 1999. Deer Meat Contaminated with Cesium- I 37 at Brookhaven National Laboratory. Bureau of Environmental Radiation Protection, New York State Department of Health, Albany, NY.

QEA. 2004a. Peconic River 2003 Data Summary Report. Quantitative Environmental Analysis, LLC. Montvale, New Jersey.

QEA. 2004b. 2004 Methylmercury Sampling Program Results: Addendum to the Peconic River 2003 Data Summary Report. Quantitative Environmental Analysis, LLC. Montvale, New Jersey.

QEA. 2006. 2005 Peconic River Water Column Sampling Data Summary Report. Quantitative Environmental Analysis, LLC. Montvale, New Jersey. 


\section{Groundwater Protection}

Brookhaven National Laboratory's Groundwater Protection Management Program is made up of four elements: prevention, monitoring, restoration, and communication. The Laboratory has implemented aggressive pollution prevention measures to protect groundwater resources. An extensive groundwater monitoring well network is used to verify that prevention and restoration activities are effective. In 2006, BNL collected groundwater samples from 852 monitoring wells during 2,337 individual sampling events. Eleven groundwater remediation systems removed 372 pounds of volatile organic compounds and returned approximately 1.5 billion gallons of treated water to the Upper Glacial aquifer. Since the beginning of active groundwater remediation in December 1996, the Laboratory has removed 5,592 pounds of volatile organic compounds by treating nearly 11.6 billion gallons of groundwater. During 2006, two additional groundwater treatment systems removed approximately 5.3 millicuries of strontium-90 while remediating approximately 14 million gallons of groundwater. Since 2003, BNL has removed approximately 11.6 millicuries of strontium-90 while remediating 24.5 million gallons of groundwater.

\section{I THE BNL GROUNDWATER PROTECTION MANAGEMENT PROGRAM}

The primary goal of BNL's Groundwater Protection Management Program is to ensure that plans for groundwater protection, management, monitoring, and restoration are fully defined, integrated, and managed in a manner that is consistent with federal, state, and local regulations. The program helps to fulfill the environmental monitoring requirements outlined in DOE Order 450.1, Environmental Protection Program, and is described in the BNL Groundwater Protection Management Program Description (Paquette et al. 2002). The program consists of four interconnecting elements: 1) preventing pollution of the groundwater, 2) monitoring the effectiveness of engineered and administrative controls at operating facilities and groundwater treatment systems, 3) restoring the environment by cleaning up contaminated soil and groundwater, and 4) communicating with stakeholders on groundwater protection issues. The Laboratory is committed to protecting groundwater resources from further chemical and radionuclide releases, and to remediating existing contaminated groundwater.

\section{I.I Prevention}

As part of BNL's Environmental Management System, the Laboratory has implemented a number of pollution prevention activities that are designed to protect groundwater resources (see Chapter 2). BNL has established a work control program that requires the assessment of all experiments and industrial operations to determine their potential impact on the environment. The program enables the Laboratory to integrate pollution prevention and waste minimization, resource conservation, and compliance into planning and decision making. Efforts have been implemented to achieve or maintain compliance with regulatory requirements and to implement best management practices designed to protect groundwater (see Chapter 3). Examples include upgrading underground storage tanks, closing cesspools, and adding engineered controls (e.g., barriers to prevent rainwater infiltration that could move 
contaminants out of the soil and into groundwater) and administrative controls (e.g., reducing the toxicity and volume of chemicals in use or storage). Samples from groundwater monitoring wells are used to confirm that these controls are working.

\section{I.2 Monitoring}

The Laboratory's groundwater monitoring network is designed to evaluate the impacts of groundwater contamination from former and current operations and to track cleanup progress (see Table 7-1). Results from groundwater monitoring are used to verify that protection and restoration efforts are working. Groundwater monitoring is focused on two general areas: 1) Environmental Surveillance (ES) monitoring, designed to satisfy DOE and New York State monitoring requirements for active research and support facilities, and 2) Environmental Restoration (ER) monitoring related to BNL's obligations under the Comprehensive Environmental Response, Compensation and Liability Act. This monitoring is coordinated to ensure completeness and to prevent duplication of effort in the installation, monitoring, and abandonment of wells. The monitoring program elements have been integrated and include data quality objectives; plans and procedures; sampling and analysis; quality assurance; data management; and the installation, maintenance, and abandonment of wells. These elements were integrated to create a cost-effective monitoring system and to ensure that water quality data are available for review and interpretation in a timely manner.

\section{I.3 Restoration}

BNL was added to the National Priorities List in 1989 (see Chapter 2 for a discussion of BNL's ER Program). To help manage the restoration effort, 30 separate Areas of Concern were grouped into six Operable Units (OUs). Remedial Investigation/Feasibility Studies have been conducted for each OU, and the focus is on installing and operating cleanup systems. Contaminant sources (e.g., contaminated soil and underground storage tanks) are being removed or remediated to prevent further
Table 7-1. Summary of BNL Groundwater Monitoring Program, 2006.

\begin{tabular}{lcc}
\hline & $\begin{array}{c}\text { Environmental } \\
\text { Restoration } \\
\text { Program }\end{array}$ & $\begin{array}{c}\text { Environmental } \\
\text { Surveillance } \\
\text { Program }\end{array}$ \\
\hline $\begin{array}{l}\text { Number of wells } \\
\text { monitored }\end{array}$ & 727 & 125 \\
$\begin{array}{l}\text { Number of sampling } \\
\text { events }\end{array}$ & 2,097 & 240 \\
$\begin{array}{l}\text { Number of analyses } \\
\text { performed }\end{array}$ & 4,381 & 656 \\
$\begin{array}{l}\text { Number of results } \\
\begin{array}{l}\text { Percent of } \\
\text { nondetectable } \\
\text { analyses }\end{array}\end{array}$ & 81,382 & 6,001 \\
$\begin{array}{l}\text { Number of new } \\
\text { wells installed (a) }\end{array}$ & 92 & 92 \\
$\begin{array}{l}\text { Number of wells } \\
\text { abandoned }\end{array}$ & 4 & 0 \\
\hline $\begin{array}{l}\text { Notes: } \\
\text { (a) Permanent wells only. Single-use temporary wells used for } \\
\text { characterization are not included. }\end{array}$ & 0 \\
\hline
\end{tabular}

contamination of groundwater. All remediation work is carried out under an Interagency Agreement involving EPA, the New York State Department of Environmental Conservation (NYSDEC), and DOE.

\section{I.4 Communication}

BNL's Community Education, Government and Public Affairs Program ensures that BNL communicates with its stakeholders in a consistent, timely, and accurate manner. A number of communication mechanisms are in place, such as press releases, web pages, mailings, public meetings, briefings, and roundtable discussions. Specific examples include routine meetings with the Community Advisory Council and the Brookhaven Executive Roundtable (see Chapter 2, Section 2.4.2). Quarterly and annual technical reports that summarize data, evaluations, and program indices are prepared. In addition, the Laboratory has developed a Groundwater Protection Contingency Plan (BNL 2003) that provides a formal process to communicate offnormal or unusual monitoring results to BNL's management, DOE, regulatory agencies, and other stakeholders, including the public and employees, in a timely manner. 


\subsection{GROUNDWATER PROTECTION PERFORMANCE}

Under the BNL Groundwater Protection Management Program, the Laboratory began tracking progress in 1998 toward preventing new contamination of the aquifer system. BNL has made significant investments in environmental and groundwater protection, and is making progress in achieving its goal of preventing new groundwater impacts. A new groundwater impact is defined as the detection and confirmation of unusual or off-normal groundwater monitoring results. The Groundwater Protection Contingency Plan (BNL 2003), mentioned earlier as a communications too, also is designed to ensure that appropriate and timely actions are taken if unusual or off-normal results are observed. The contingency plan provides guidelines for evaluating the source of the problem, notifying stakeholders, and implementing appropriate corrective actions.

Since 1998, BNL has installed several hundred permanent and temporary monitoring wells following a comprehensive evaluation of known or potential contaminant source areas. Using this enhanced monitoring system, BNL identified 10 new groundwater impacts during 1998 through 2001 (see Figure 7-1). No additional impacts have been identified since 2001. Five of the 10 identified impacts were determined to be from historical (or "legacy") contaminant releases, and five were related to active science operations and environmental protection activities. In all 10 cases, BNL thoroughly investigated the cause of the contamination and took corrective actions as necessary to eliminate or limit the scale of the impacts. The Laboratory will continue efforts to prevent new groundwater impacts, and is vigilant in measuring and communicating its performance.

\subsection{GROUNDWATER MONITORING}

Elements of the groundwater monitoring program include installing monitoring wells; planning and scheduling; developing and following quality assurance procedures; collecting and analyzing samples; verifying, validating, and interpreting data; and reporting. Monitoring wells (which are not used for the drinking water supply) are used to evaluate BNL's progress in restoring groundwater quality, to comply with regulatory permit requirements, to monitor active research and support facilities, and to assess the quality of groundwater entering and leaving the site.

The Laboratory monitors research and support facilities where there is a potential for environmental impact, as well as areas where past waste handling practices or accidental spills have already degraded groundwater quality. The groundwater beneath the site is classified by New York State as Class GA groundwater, which is defined as a source of potable water supply. Federal drinking water

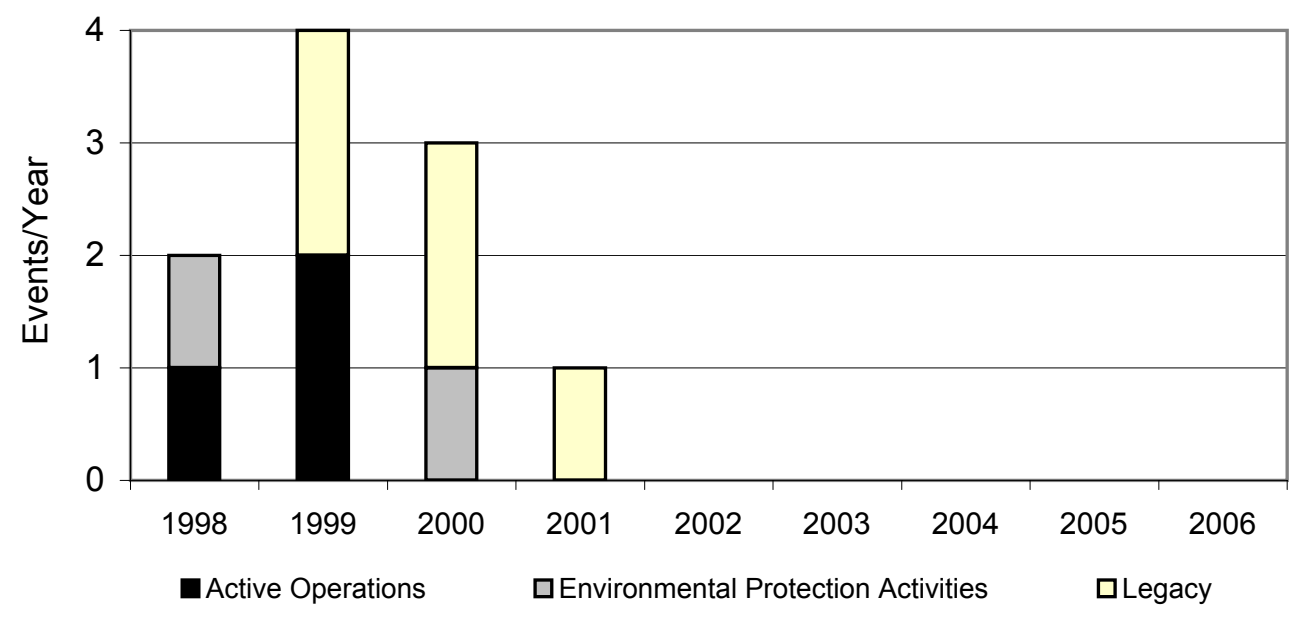

Figure 7-I. Groundwater Protection Performance, I 998 - 2006. 
standards (DWS), New York State DWS, and New York State Ambient Water Quality Standards (NYS AWQS) for Class GA groundwater are used as goals for groundwater protection and remediation. BNL evaluates the potential impact of radiological and nonradiological contamination by comparing analytical results to the standards. Contaminant concentrations that are below the standards are also compared to background values to evaluate the potential effects from facility operations. The detection of low concentrations of facility-specific volatile organic compounds (VOCs) or radionuclides may provide important early indications of a contaminant release and allow for timely identification and remediation of the source.

Groundwater quality at BNL is routinely monitored through a network of approximately 860 on- and off-site wells (see SER Volume II, Groundwater Status Report, for details). In addition to water quality assessments, water levels are routinely measured in more than 875 on- and off-site wells to assess variations in the direction and velocity of flow. Groundwater flow directions in the vicinity of the Laboratory are shown in Figure 7-2.

The following active facilities have groundwater monitoring programs: the Sewage Treatment Plant area, Waste Management Facility, Central Steam Facility and adjacent Major Petroleum Facility, Alternating Gradient Synchrotron, Relativistic Heavy Ion Collider, Waste Concentration Facility, and several vehicle maintenance and petroleum storage facilities. Inactive facilities include the former Hazardous Waste Management Facility, two former landfill areas, the Brookhaven Graphite Research Reactor (BGRR), High Flux Beam Reactor (HFBR), and the Brookhaven Medical Research Reactor (BMRR). As a result of detailed groundwater investigations conducted over the past 15 years, six significant VOC plumes and eight radionuclide plumes have been identified (see Figures 7-3 and 7-4).

\subsection{SUPPLEMENTAL MONITORING OF WATER SUPPLY WELLS}

As discussed in Chapter 3, BNL is classified as a public water purveyor and maintains water supply wells and associated treatment facilities for the distribution of potable water on site. This water is also used for cooling water purposes at a number of facilities. Most of BNL's water supply is obtained from a network of six large-capacity wells (wells 4, 6, 7, 10, 11, and 12). A seventh well, number 9, is a smallcapacity well that supplies process water to a facility where biological research is conducted. This well is not routinely monitored. The locations of the supply wells are shown in -2 .

The quality of the BNL potable water supply is monitored as required by the Safe Drinking Water Act (SDWA), and the analytical results are reported to the Suffolk County Department of Health Services. As required by SDWA, the Laboratory also prepares an annual Water Quality Consumer Confidence Report (BNL 2006) that is distributed to all employees and guests. Results of the SDWA-required monitoring are described in Chapter 3.

All of BNL's supply wells are screened within the Upper Glacial aquifer. Because of the proximity of the potable supply wells to known or suspected groundwater contamination plumes and source areas, the Laboratory conducts a supplemental potable supply well monitoring program that includes testing for VOCs, anions, metals, and radiological parameters. During 2006, the BNL potable water system fully complied with all drinking water requirements. To better understand the geographical source of the Laboratory's drinking water and to identify potential sources of contamination within these geographical areas, BNL prepared the Source Water Assessment for Drinking Water Supply Wells (Bennett et al. 2000). In 2003, the New York State Department of Health (NYSDOH) prepared a source water assessment for all potable water supply wells on Long Island (NYSDOH 2003). The source water assessments are designed to serve as management tools in further protecting Long Island's sole source aquifer system.

\subsection{Radiological Results}

During 2006, samples collected from six supply wells were analyzed for gross alpha and gross beta activity, tritium, and strontium-90 


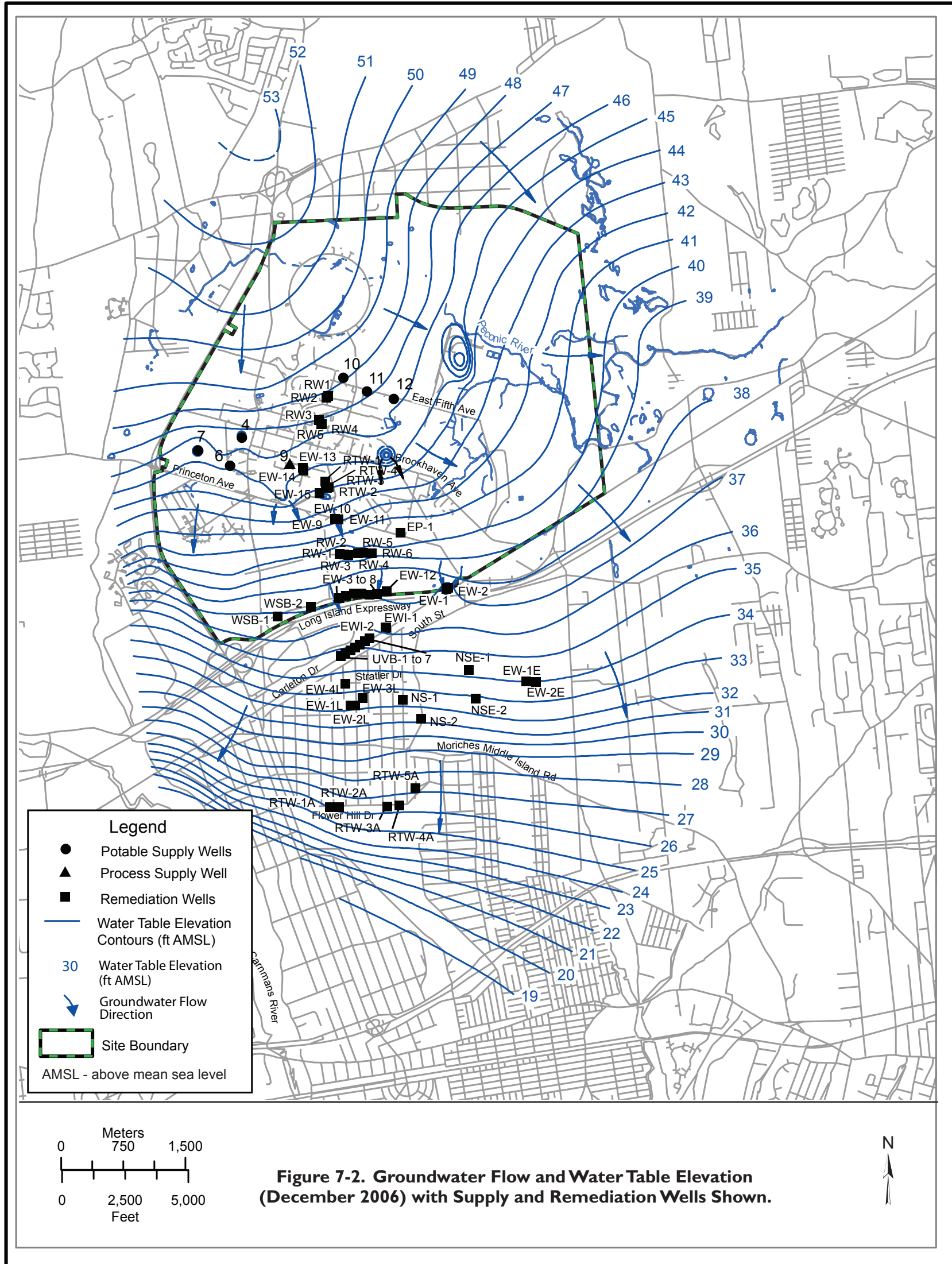




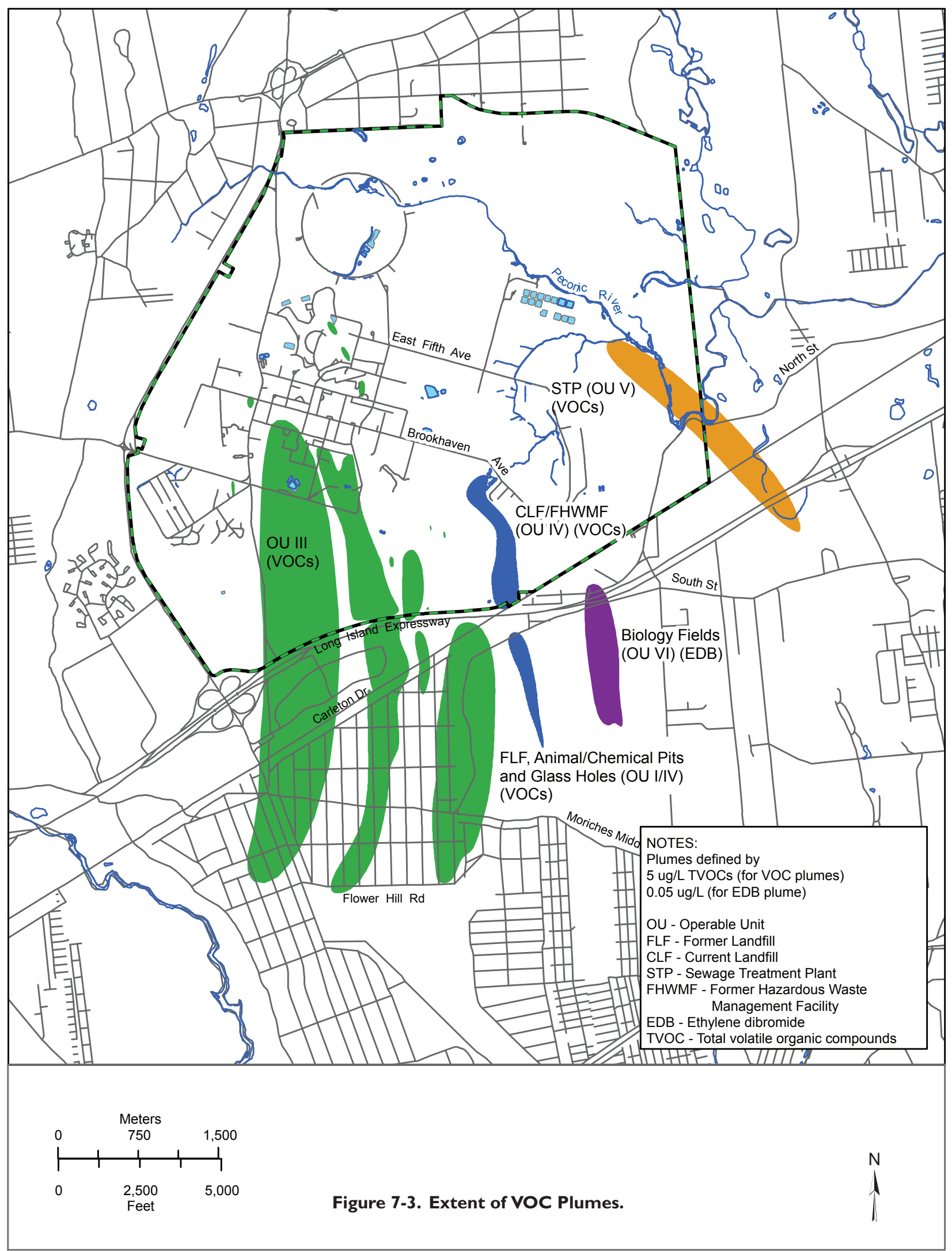




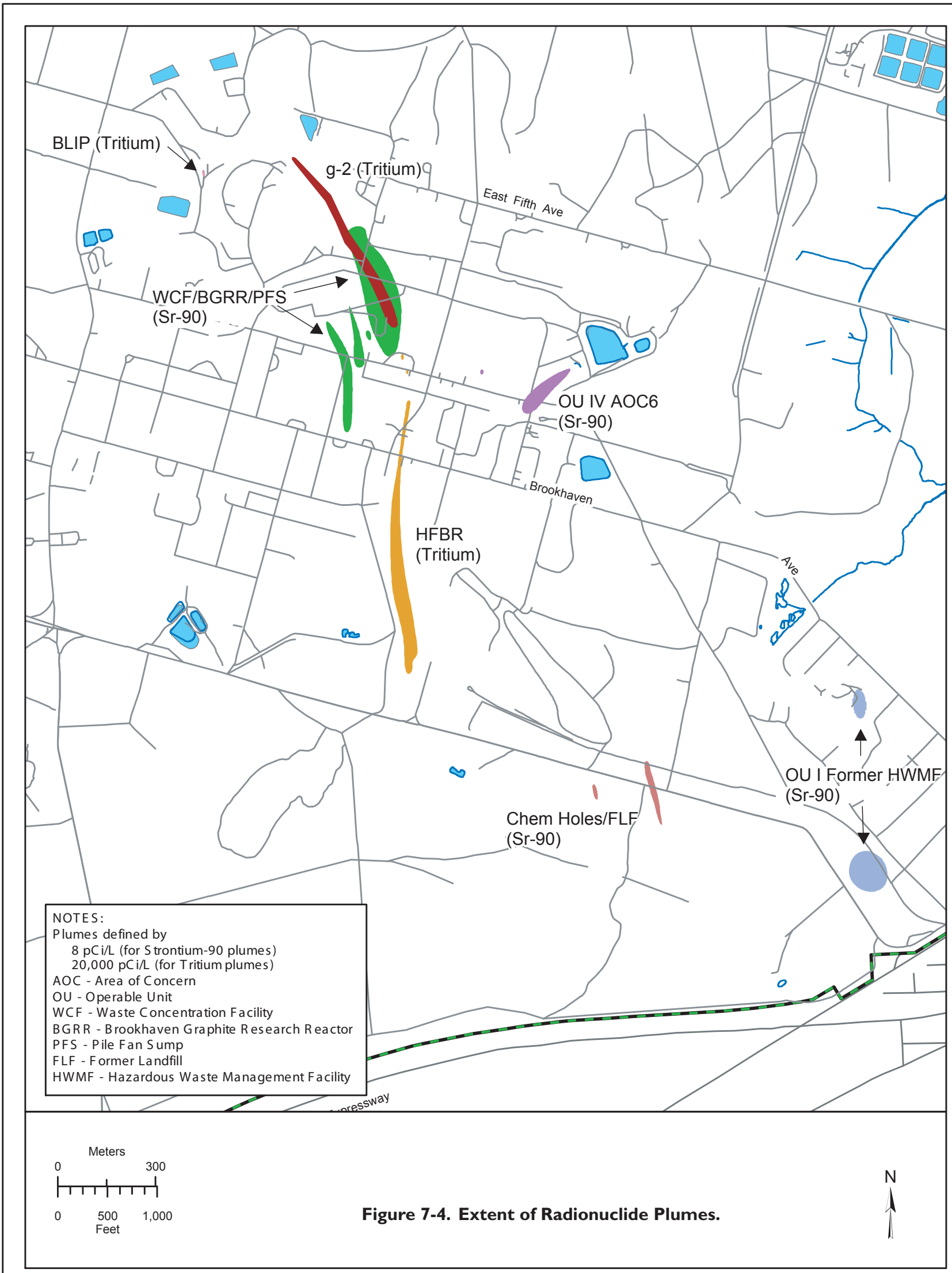


Table 7-2. Potable Well Radiological Analytical Results.

\begin{tabular}{|c|c|c|c|c|c|}
\hline \multicolumn{2}{|l|}{$\begin{array}{l}\text { Potable } \\
\text { Well ID }\end{array}$} & \multirow{2}{*}{$\begin{array}{c}\text { Gross } \\
\text { Alpha } \\
1\end{array}$} & \multirow{2}{*}{$\begin{array}{c}\text { Gross } \\
\text { Beta }\end{array}$} & \multirow{2}{*}{$\frac{\text { Tritium }}{1}$} & \multirow{2}{*}{$\frac{\text { Sr-90 }}{1}$} \\
\hline Well 4 & Samples & & & & \\
\hline & Max. & $<1.07$ & $1.69+0.44$ & $<547$ & $<0.41$ \\
\hline & Avg. & $N / A$ & $\mathrm{~N} / \mathrm{A}$ & $\mathrm{N} / \mathrm{A}$ & $\mathrm{N} / \mathrm{A}$ \\
\hline \multirow[t]{3}{*}{ Well 6} & Samples & 4 & 4 & 4 & 4 \\
\hline & Max. & $<1.2$ & $<2.65$ & $<653$ & $<0.69$ \\
\hline & Avg. & $0.45 \pm 0.31$ & $1.24 \pm 0.37$ & $-30.5 \pm 220.14$ & $-0.11 \pm 0.37$ \\
\hline \multirow[t]{3}{*}{ Well 7} & Samples & 4 & 4 & \pm & 4 \\
\hline & Max. & $<1.7$ & $<2.54$ & $<553$ & $<0.69$ \\
\hline & Avg. & $0.61 \pm 0.63$ & $1.42 \pm 0.54$ & $29.65 \pm 29.94$ & $-0.4 \pm 0.09$ \\
\hline \multirow[t]{3}{*}{ Well 10} & Samples & 1 & 1 & 1 & 1 \\
\hline & Max. & $<0.88$ & $<0.64$ & $<544$ & $<0.34$ \\
\hline & Avg. & $\mathrm{N} / \mathrm{A}$ & $N / A$ & $\mathrm{~N} / \mathrm{A}$ & $\mathrm{N} / \mathrm{A}$ \\
\hline \multirow[t]{3}{*}{ Well 11} & Samples & 2 & 2 & 2 & 2 \\
\hline & Max. & $<1.94$ & $<3.33$ & $<549$ & $<0.68$ \\
\hline & Avg. & $-0.21 \pm 0.63$ & $0.65 \pm 0.74$ & $209 \pm 78.4$ & $0.03 \pm 0.11$ \\
\hline \multirow[t]{3}{*}{ Well 12} & Samples & 3 & 3 & 3 & 3 \\
\hline & Max. & $<1.7$ & $<2.69$ & $<554$ & $<0.76$ \\
\hline & Avg. & $-0.3 \pm 0.5$ & $0.99 \pm 0.14$ & $168.7 \pm 149.3$ & $-0.6 \pm 0.26$ \\
\hline \multicolumn{2}{|c|}{$\begin{array}{l}\text { SDWA Limit } \\
(\mathrm{pCi} / \mathrm{L})\end{array}$} & $15(a)$ & 4 mrem (b) & 20,000 & 8 \\
\hline \multicolumn{6}{|c|}{$\begin{array}{l}\text { Notes: } \\
\text { See Figure } 7-2 \text { for well locations. } \\
\text { All values presented with a } 95 \% \text { confidence interval. } \\
\text { Potable Well \#10 was shut down most of the year due to its possible effect on groundwater } \\
\text { flow direction in the vicinity of the } g-2 \text { Tritium Plume. } \\
\text { WS = Well shut down due to operational problems } \\
\text { (a) Excluding radon and uranium. } \\
\text { (b) The drinking water standards were changed from } 50 \mathrm{pCi} / \mathrm{L} \text { (concentration based) } \\
\quad \text { to (dose based) in late } 2003 \text {. Because gross beta activity does not identify specific } \\
\text { radionuclides, a dose equivalent cannot be calculated for the values in the table. }\end{array}$} \\
\hline
\end{tabular}

(Sr-90) (see Table 7-2). Nuclide-specific gamma spectroscopy was also performed for potable well samples. All radioactivity levels in the potable water wells were consistent with those of typical background water samples.

\subsubsection{Nonradiological Results}

In addition to the quarterly SDWA compliance samples described in Section 3.7 of Chapter 3, BNL collected supplemental VOC samples from active supply wells during the year. The samples were analyzed for VOCs fol- lowing either EPA Standard Method 524 or 624. As in past years, low levels of chloroform continued to be routinely detected in samples from most wells, with a maximum concentration of $12.9 \mu \mathrm{g} / \mathrm{L}$ observed in 2006. The DWS for chloroform is $80 \mu \mathrm{g} / \mathrm{L}$. Trace levels of several other VOCs (e.g., 1,1,1-trichloroethane [TCA], bromodichloromethane, and dibromochloromethane) were occasionally detected, but at concentrations well below applicable DWS. Samples were also analyzed for metals and anions one time during the year from wells 6, 7, 11, and 12 (see Tables 7-3 and 7-4). As in previous years, iron was the only parameter detected at concentrations greater than the DWS, which is $0.3 \mathrm{mg} / \mathrm{L}$. The iron levels in wells 6 and 7 were $2.8 \mathrm{mg} / \mathrm{L}$ and $2.2 \mathrm{mg} / \mathrm{L}$, respectively. Because high levels of iron are naturally present in some portions of the Upper Glacial aquifer on the western side of the Laboratory site, water obtained from wells 4,6 , and 7 is treated at the BNL Water Treatment Plant to reduce iron levels before it is distributed.

\subsection{ENVIRONMENTAL SURVEILLANCE PROGRAM}

BNL's Environmental Surveillance Program includes groundwater monitoring at 10 active research facilities (e.g., accelerator beam stop and target areas) and support facilities (e.g., fuel storage facilities). During 2006, 125 groundwater wells were monitored during 240 individual sampling events. Detailed descriptions and maps related to the ES groundwater monitoring program can be found in SER Volume II, Groundwater Status Report.

Although no new impacts to groundwater quality were discovered during 2006, groundwater quality continues to be impacted at four facilities: continued high levels of tritium at the g-2/VQ-12 area of the Alternating Gradient Synchrotron (AGS) facility; tritium at the Brookhaven Linac Isotope Producer (BLIP) facility; low levels of VOCs at the Motor Pool/Facility Maintenance area; and low levels of VOCs at the Service Station. Monitoring results for these areas are described below.

- Although tritium continues to be detected at concentrations above the 20,000 pico-curies 
per liter ( $\mathrm{pCi} / \mathrm{L}) \mathrm{DWS}$ in wells immediately downgradient of the g-2/VQ-12 source area in the AGS facility, the levels are much lower than those observed in 2002 and 2003. Tritium concentrations reached a maximum of 3,440,000 pCi/L in 2002 and have shown a steady decline, remaining less than $100,000 \mathrm{pCi} / \mathrm{L}$ since July 2005 . Tritium concentrations in the source area wells dropped to less than $45,000 \mathrm{pCi} / \mathrm{L}$ by the end of 2006 .

- In January 2006, tritium concentrations exceeded the 20,000 pCi/L DWS in one well immediately downgradient of BLIP, with a concentration of $31,400 \mathrm{pCi} / \mathrm{L}$. Tritium concentrations declined to less than the DWS limit for the remainder of the year.

- At the Motor Pool/Site Maintenance area, the solvents TCA and 1,1-dichloroethane (DCA) continued to be detected at concentrations greater than the NYS AWQS of 5 $\mu \mathrm{g} / \mathrm{L}$. TCA was detected at concentrations up to $18 \mu \mathrm{g} / \mathrm{L}$, and DCA was detected at concentrations up to $6.6 \mu \mathrm{g} / \mathrm{L}$. Methyl tertiary butyl ether (MTBE), a gasoline additive, was also detected, with a maximum observed concentration of $1.8 \mu \mathrm{g} / \mathrm{L}$. The NYS AWQS for MTBE is $10 \mu \mathrm{g} / \mathrm{L}$.

- At the Service Station, VOCs associated with petroleum products and solvents continued to be detected at concentrations greater than the NYS AWQS of $5 \mu \mathrm{g} / \mathrm{L}$. Petroleum-related compounds detected in groundwater included $\mathrm{m} / \mathrm{p}$ xylene at $480 \mu \mathrm{g} / \mathrm{L}, \mathrm{o}-x y l e n e$ at $210 \mu \mathrm{g} / \mathrm{L}, 1,2,4$-trimethylbenzene at $360 \mu \mathrm{g} / \mathrm{L}$, and 1,3,5-trimethylbenzene at $110 \mu \mathrm{g} / \mathrm{L}$. The solvent tetrachloroethylene (TCE) was detected in several wells with a maximum concentration of $25 \mu \mathrm{g} / \mathrm{L}$. Trace levels of MTBE were also detected, at a maximum concentration of $0.34 \mu \mathrm{g} / \mathrm{L}$.

Although the engineered stormwater controls appeared to be effectively protecting the g-2/ VQ-12 and BLIP source areas, monitoring data suggested that the continued release of tritium in both areas appeared to be caused by the flushing of residual tritium from the vadose (or unsaturated) zone following significant natural periodic rises in the local water table. The amount of
Table 7-3. Potable Water Supply Wells Water Quality Data.

\begin{tabular}{|c|c|c|c|c|}
\hline \multicolumn{2}{|l|}{$\begin{array}{l}\text { Potable } \\
\text { Well ID }\end{array}$} & \multirow{2}{*}{$\begin{array}{c}\text { Chlorides } \\
\text { NS }\end{array}$} & \multirow{2}{*}{$\begin{array}{c}\text { Sulfates } \\
\text { - mg/L } \\
\text { NS }\end{array}$} & \multirow{2}{*}{$\begin{array}{c}\begin{array}{c}\text { Nitrate and } \\
\text { Nitrite }\end{array} \\
\text { NS }\end{array}$} \\
\hline Well 4 & $\mathrm{~N}$ & & & \\
\hline & Value & - & - & - \\
\hline \multirow[t]{2}{*}{ Well 6} & $\mathrm{~N}$ & 1 & 1 & 1 \\
\hline & Value & 25.3 & 8.98 & 0.26 \\
\hline \multirow[t]{2}{*}{ Well 7} & $\mathrm{~N}$ & 1 & 1 & 1 \\
\hline & Value & 23.6 & 10.1 & 0.29 \\
\hline \multirow[t]{2}{*}{ Well 11} & $\mathrm{~N}$ & 1 & 1 & 1 \\
\hline & Value & 21.1 & 9.24 & 0.34 \\
\hline \multirow[t]{2}{*}{ Well 12} & $\mathrm{~N}$ & 1 & 1 & 1 \\
\hline & Value & 23.2 & 10.9 & 0.55 \\
\hline NYS DWS & & 250 & 250 & 10 \\
\hline Typical MDL & & 4 & 4 & 1 \\
\hline \multicolumn{5}{|c|}{$\begin{array}{l}\text { Notes: } \\
\text { See Figure } 7-2 \text { for well locations. } \\
\text { Potable Well \#10 was shut down most of the year due to its possible } \\
\text { effect on groundwater flow direction in the vicinity of the g- } 2 \text { Tritium } \\
\text { Plume. } \\
\text { N = Number of samples } \\
\text { NYS DWS = New York State Drinking Water Standard } \\
\text { MDL = Minimum Detection Limit } \\
\text { NS = Well was not in operation during sample period }\end{array}$} \\
\hline
\end{tabular}

tritium remaining in the vadose zone close to the water table is expected to decline over time, due to this flushing mechanism and by natural radioactive decay (the half-life of tritium is 12.3 years).

Monitoring of the leak detection systems at both vehicle maintenance facilities indicated that the gasoline storage tanks and associated distribution lines were not leaking. Furthermore, BNL's ongoing evaluation of vehicle maintenance operations indicates that all waste oils and used solvents are being properly stored and recycled. Therefore, it is believed that the contaminants detected in groundwater at these facilities originated from past vehicle maintenance activities, and are not related to current operations.

\subsection{ENVIRONMENTAL RESTORATION GROUNDWATER MONITORING PROGRAM}

The mission of the Laboratory's Environmental Restoration Groundwater Monitoring 


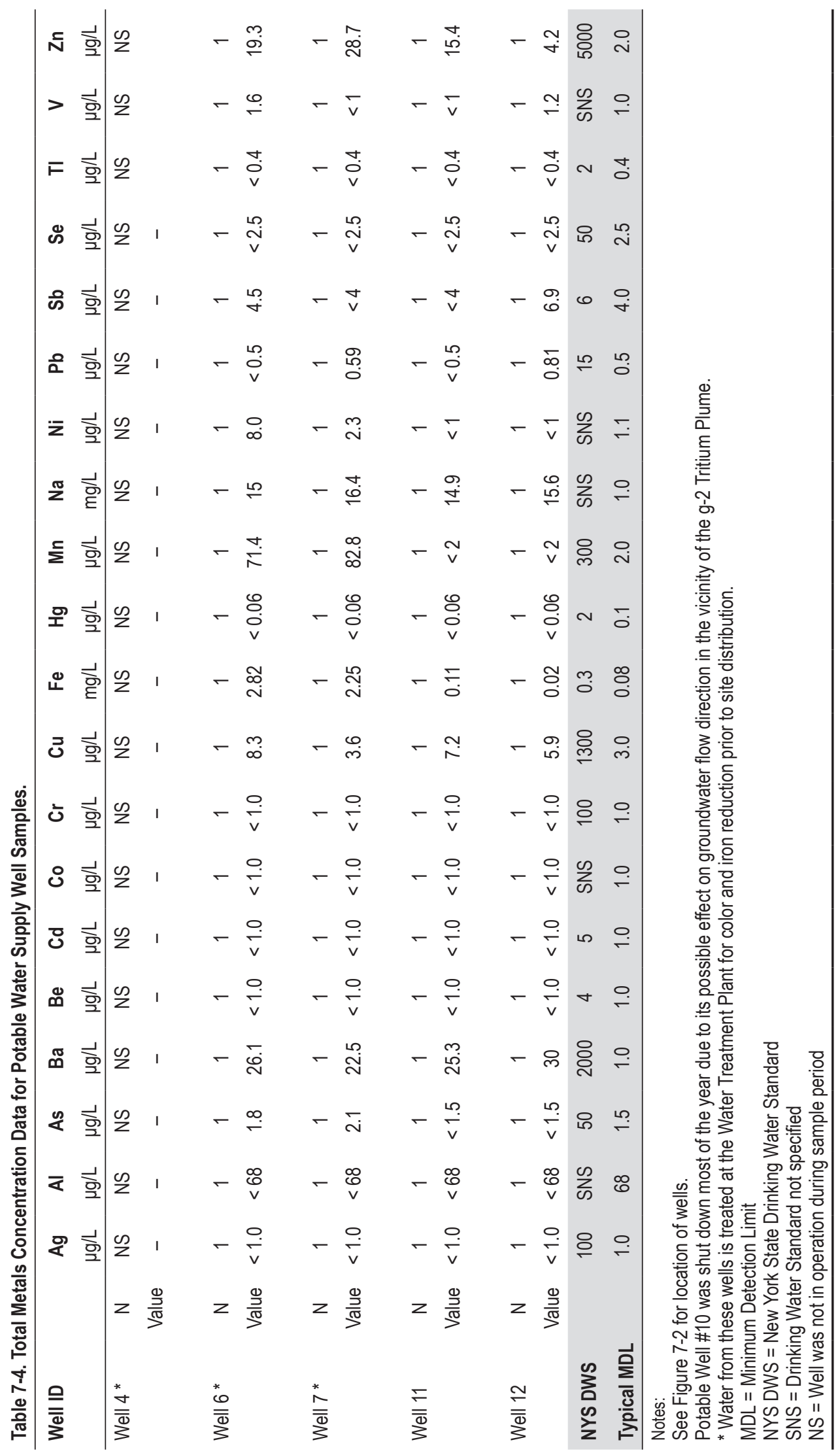


Program is to monitor the contaminant plumes on and off site. The monitoring results are used to track the progress that the groundwater treatment systems are making toward plume remediation. In 2006, a total of 727 groundwater wells were monitored, during 2,097 individual sampling events.

Maps showing the main VOC and radionuclide plumes are provided as Figures 7-3 and 74 , respectively. Detailed descriptions and maps related to the ER Groundwater Monitoring Program can be found in SER Volume II, Groundwater Status Report. Highlights of the program are described below.

- The OU III Record of Decision (ROD) contingency of $20,000 \mathrm{pCi} / \mathrm{L}$ tritium at Weaver Drive was triggered with a detection of $21,000 \mathrm{pCi} / \mathrm{L}$ in a temporary well on November 2, 2006. A fourth extraction well (EW) will be installed to address the plume in the vicinity of Weaver Drive. It is anticipated that the new extraction well, along with EW-11 (and possibly EW-10), will be operational during the third quarter of 2007. A complete discussion of the triggering of the OU III ROD contingency and plans for the restart of the system are included in Volume II, Groundwater Status Report.

- Based on the results of monitoring well data collected since the last injection of potassium permanganate in the Building 96 source area in January 2006, it appears that additional remedial action will be required to reduce high VOC concentrations in the source area. An engineering study will be completed by the end of 2007 to evaluate remedial alternatives. Extraction well RTW1 will be re-started to maintain hydraulic control of the source area.

- Additional characterization of the downgradient portion of the Chemical/Animal Holes Sr-90 plume was conducted in 2006 . Two additional extraction wells will be needed to achieve the cleanup goal of meeting MCLs in the Upper Glacial aquifer by 2040. These wells will be operational by the end of 2007.

- Elevated levels of VOCs were observed in Airport perimeter well 800-96, which is outside the capture zone of the treatment system. Groundwater characterization was performed to determine the location of the plume in this area, and an additional extraction well will be installed to allow for complete capture of the plume. The new extraction well will be operational during the third quarter of 2007.

- OU III South Boundary system extraction wells EW-6 and -7 will be placed in standby mode in October 2007, due to low VOC concentrations in these wells. EW-8 and EW-12, which are also part of this system, are currently in standby mode.

- Industrial Park system well UVB-4 will be placed in standby beginning in October 2007, based on the low VOC concentrations being observed in this well over the past year. Well UVB-1, which is also part of this system, is currently in standby mode.

- Pulse pumping of the Industrial Park system will be implemented in 2007, due to low VOC concentrations (all wells are less than the capture goal of $50 \mu \mathrm{g} / \mathrm{L}$ total VOCs [TVOCs]). LIPA system extraction wells EW-1L and -3L will be placed in standby mode, as both of these wells have shown TVOC concentrations well below the 50 $\mu \mathrm{g} / \mathrm{L}$ capture goal throughout 2006 . In addition, all of the monitoring wells in this area have concentrations less than $50 \mu \mathrm{g} / \mathrm{L}$ TVOC.

\subsection{GROUNDWATER TREATMENT SYSTEMS}

The primary mission of the Laboratory's Environmental Restoration Program is to operate and maintain treatment systems that remediate groundwater contamination and prevent additional contamination from migrating off site. Groundwater remediation activities are expected to continue until approximately 2030 to meet the cleanup objectives for the plumes. The specific goals are as follows:

- Achieve maximum contaminant levels (MCLs) for VOCs in the Upper Glacial aquifer by 2030

- Achieve MCLs for VOCs in the Magothy aquifer by 2065 


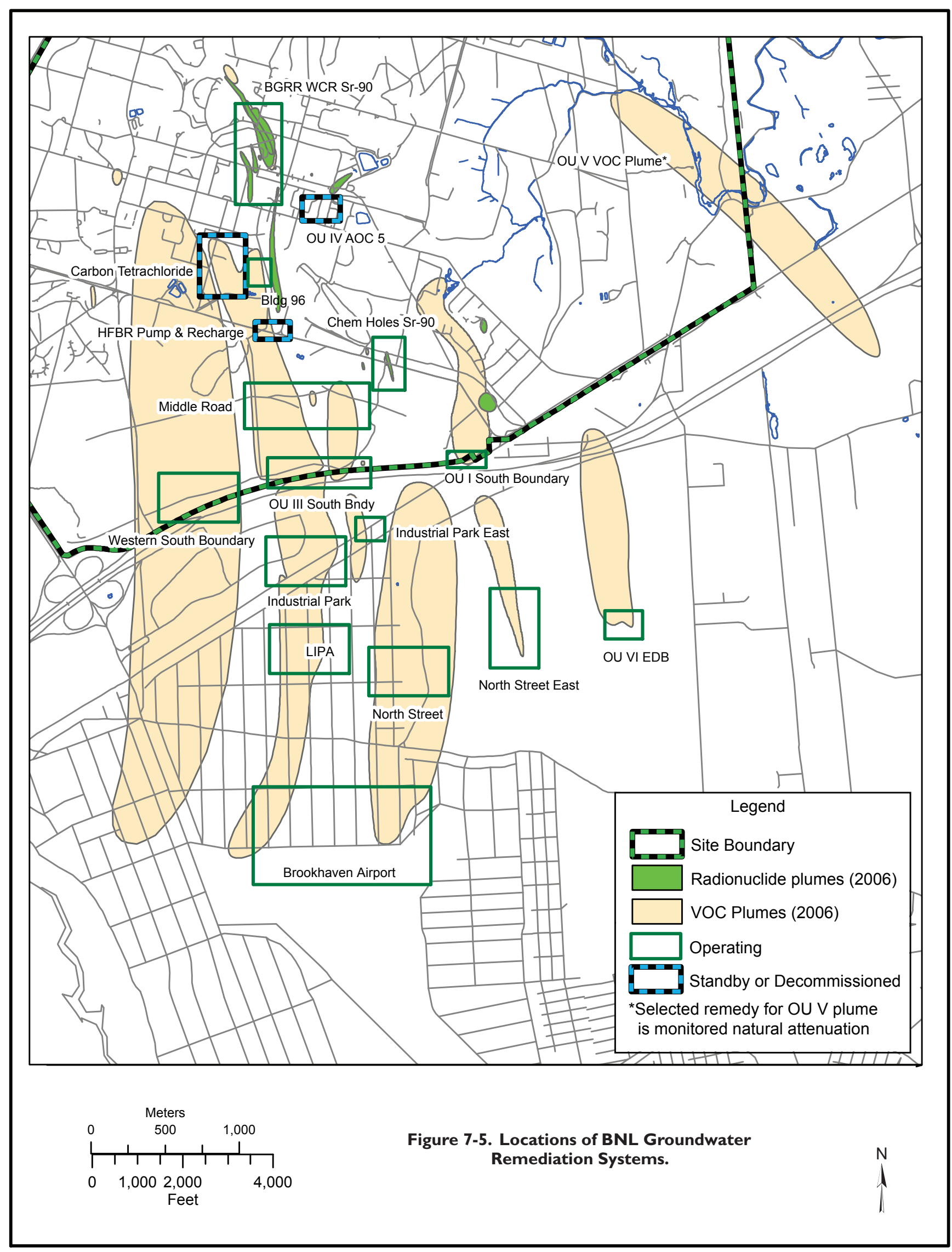


Table 7-5. BNL Groundwater Remediation Systems Treatment Summary for 1997 through 2006.

\begin{tabular}{|c|c|c|c|c|c|}
\hline \multirow[b]{2}{*}{ Remediation System } & \multirow[b]{2}{*}{ Start Date } & \multicolumn{2}{|c|}{$1997-2005$} & \multicolumn{2}{|c|}{2006} \\
\hline & & $\begin{array}{l}\text { Water Treated } \\
\text { (Gallons) }\end{array}$ & $\begin{array}{c}\text { VOCs } \\
\text { Removed } \\
\text { (Pounds) (e) }\end{array}$ & $\begin{array}{l}\text { Water Treated } \\
\text { (Gallons) }\end{array}$ & $\begin{array}{l}\text { VOCs Removed } \\
\text { (Pounds) (e) }\end{array}$ \\
\hline OU I South Boundary & 12/1996 & $2,893,249,000$ & 323 & $154,065,000$ & 8 \\
\hline OU III HFBR Tritium Plume (a) & 05/1997 & $241,528,000$ & 180 & Not in Service & 0 \\
\hline OU III Carbon Tetrachloride (d) & 10/1999 & $153,538,075$ & 349 & Not in Service & 0 \\
\hline OU III Building 96 & 02/2001 & $132,557,416$ & 70 & $2,940,000$ & 1 \\
\hline OU III Middle Road & $10 / 2001$ & $965,650,550$ & 608 & $173,761,000$ & 81 \\
\hline OU III South Boundary & 06/1997 & $2,813,099,850$ & 2,409 & $235,853,000$ & 102 \\
\hline OU III Western South Boundary & 09/2002 & $477,163,000$ & 39 & $54,484,000$ & 6 \\
\hline OU III Industrial Park & 09/1999 & $1,083,298,330$ & 901 & $151,180,000$ & 66 \\
\hline OU III Industrial Park East & 05/2004 & $143,598,000$ & 24 & $82,574,000$ & 5 \\
\hline OU III North Street & 06/2004 & $345,841,000$ & 187 & $157,281,000$ & 45 \\
\hline OU III North Street East & 06/2004 & $247,786,000$ & 11 & $111,076,000$ & 5 \\
\hline OU III LIPA/Airport & 06/2004 & $437,682,000$ & 145 & $238,205,000$ & 53 \\
\hline OU IV AS/SVE (b) & 11/1997 & (c) & 35 & Decommissioned & 0 \\
\hline OU VI EDB & 08/2004 & $178,142,000$ & $(f)$ & $156,059,000$ & (f) \\
\hline \multicolumn{2}{|l|}{ Total } & $10,113,133,221$ & 5,220 & $1,517,478,000$ & 372 \\
\hline & & \multicolumn{2}{|c|}{ 2003-2005 } & \multicolumn{2}{|c|}{2006} \\
\hline Remediation System & Start Date & $\begin{array}{l}\text { Water Treated } \\
\text { (Gallons) }\end{array}$ & $\begin{array}{c}\text { Sr-90 } \\
\text { Removed } \\
(\mathrm{mCi})\end{array}$ & $\begin{array}{l}\text { Water Treated } \\
\text { (Gallons) }\end{array}$ & $\begin{array}{c}\text { Sr-90 Removed } \\
(\mathrm{mCi})\end{array}$ \\
\hline OU III Chemical Holes Sr-90 & $02 / 2003$ & $6,612,826$ & 2.08 & $3,392,000$ & 0.24 \\
\hline OU III BGRR/WCF Sr-90 & 06/2005 & $3,576,000$ & 4.15 & $10,975,000$ & 5.1 \\
\hline Total & & $10,188,826$ & 6.23 & $14,367,000$ & 5.34 \\
\hline \multicolumn{6}{|c|}{$\begin{array}{l}\text { Notes: } \\
\text { (a) System was shut down and placed in standby mode on September } 29,2000 . \\
\text { (b) System was shut down on January 10,2001 and decommissioned in } 2003 . \\
\text { (c) Air Sparging/Soil Vapor Extraction (AS/SVE) system performance is measured by pounds of VOCs removed per cubic feet of air treated. } \\
\text { (d) System was shut down and placed in standby mode in August } 2004 . \\
\text { (e) Values are rounded to the nearest whole number. } \\
\text { (f) Because EDB has only been detected perodically at trace levels in the treatment systems influent, no removal of VOCs is reported. }\end{array}$} \\
\hline
\end{tabular}

- Achieve MCLs for Sr-90 at the BGRR in the Upper Glacial aquifer by 2070

- Achieve MCLs for Sr-90 at the Chemical Holes in the Upper Glacial aquifer by 2040

The cleanup objectives will be met by a combination of active treatment and natural attenuation. The previously described comprehensive groundwater monitoring program is used to measure the remediation progress.

In 2006, BNL continued to make significant progress in restoring groundwater quality on site, with 13 groundwater remediation systems in active operation. Figure 7-5 shows the locations of the groundwater treatment systems. Table 7-5 provides a summary of pounds of VOCs and curies of radioactivity removed, and gallons of water treated during 1997-2005. During 2006,372 pounds of VOCs and $5.3 \mathrm{mCi}$ of $\mathrm{Sr}-$ 90 were removed from the groundwater, and more than 1.5 billion gallons of treated ground- 
water were returned to the aquifer. To date, 5,592 pounds of VOCs have been removed from the aquifer. Since the start of the first groundwater treatment system in 1996, noticeable improvements in groundwater quality are already evident in the OU I South Boundary, OU III South Boundary, OU III Industrial Park, OU III Industrial Park East, OU III North Street, OU IV, Building 96, and Carbon Tetrachloride areas. The Chemical Holes Strontium-90 System has removed $2.3 \mathrm{mCi}$ of $\mathrm{Sr}-90$ out of a projected 19.6 mCi total. The BGRR/Waste Concentration Facility Strontium-90 System, which started operation in June 2005, has removed $9.3 \mathrm{mCi}$ of Sr-90 out of a projected total of $63.8 \mathrm{mCi}$. Detailed information on the groundwater treatment systems can be found in SER Volume II, Groundwater Status Report.
REFERENCES AND BIBLIOGRAPHY

Bennett, D., D. Paquette, K. Klaus, and W. Dorsch. 2000. Brookhaven National Laboratory, Source Water Assessment for Drinking Water Supply Wells. BNL-52608. Brookhaven National Laboratory, Upton, NY. December 27, 2000.

BNL 2003. Groundwater Protection Contingency Plan. Brookhaven National Laboratory, Upton, NY. Standards Based Management System Subject Area. September 2003.

BNL 2006. 2006 BNL Water Quality Consumer Confidence Report. Brookhaven National Laboratory Bulletin - Bulletin Special Edition. Upton, NY. May 3I, 2006.

DOE 2003. DOE Order 450.I, Environmental Protection Program. U.S. Department of Energy, Washington, DC.

NYSDOH. 2003. Long Island Source Water Assessment Summary Report. New York Sate Department of Health June 23, 2003.

Paquette, D.E., D.B. Bennett, and W.R. Dorsch. 2002.

Brookhaven National Laboratory, Groundwater Protection Management Program Description. BNL Report 52664. Brookhaven National Laboratory, Upton, NY. May 31, 2002. 


\section{Radiological Dose Assessment}

Brookhaven National Laboratory routinely evaluates site operations and new projects to ensure that the overall radiological dose impact to members of the public, BNL workers, and the environment is "As Low As Reasonably Achievable." All scientific and operational processes that can in any way impact the health and safety or may contribute to radiological dose are reviewed for their individual impacts on the people and environment. The potential radiological dose to the public is calculated as the maximum dose to a hypothetical Maximally Exposed Individual (MEI) at the BNL site boundary. Doses are calculated for all direct and indirect pathways, such as air immersion dose, inhalation of particulates and gases, ingestion of deer meat and fish, and any immersion dose. In 2006, the radiation dose calculations showed that the total Effective Dose Equivalent (EDE) from Laboratory activities was well below the EPA and DOE regulatory dose limits for the public, workers, and the environment.

The average annual external dose from all potential ambient sources was $68 \pm 11$ mrem $(680 \pm$ $110 \mu \mathrm{Sv})$ on site and $63 \pm 9 \mathrm{mrem}(630 \pm 90 \mu \mathrm{Sv})$ at off-site locations. Both measurements include the contribution from natural background and cosmic radiation. A statistical comparison of the average doses measured at 47 on-site and 15 off-site locations using thermoluminescent dosimeters (TLDs) showed that there was no additional external dose contribution from BNL operations above the natural background radiation dose. Additionally, nine TLDs were used to measure areas with slightly elevated radiation dose on the BNL site. The results of these measurements are described in Section 8.1.2.

The EDE from air emissions was calculated as $8.14 E-02 \mathrm{mrem}(0.81 \mu \mathrm{Sv})$ to the MEI. The ingestion pathway dose was estimated as 2.96 mrem (30 $\mu \mathrm{Sv})$ from consumption of deer meat and 0.07 mrem (0.7 $\mu S v)$ from consumption of fish caught in the vicinity of the BNL site. The total annual dose to the MEI from all pathways was estimated as $3.11 \mathrm{mrem}(31 \mu \mathrm{Sv})$. The $B N L$ dose from the air inhalation pathway was less than 1 percent of EPA's annual regulatory dose limit of $10 \mathrm{mrem}(100 \mu \mathrm{Sv})$, and the total dose was less than 4 percent of DOE's annual dose limit of $100 \mathrm{mrem}(1,000 \mu \mathrm{Sv})$ from all pathways.

Doses to aquatic and terrestrial biota were also evaluated and found to be well below the DOE regulatory limits. Other short-term projects conducted in 2006, such as remediation work and waste management disposal activities, were evaluated for radiological emissions and their potential dose impact; there was no radiological risk to the public, BNL employees, or the environment from these activities. In conclusion, the overall dose impact from all Laboratory activities in 2006 was indistinguishable from the natural background radiation levels.

\section{I DIRECT RADIATION MONITORING}

Direct, penetrating beta and gamma radiation is measured using thermoluminescent dosimeters. The principle of TLD operation is that when certain crystals are exposed to radiation, impurities in the crystals' low-temperature trapping sites are excited to higher energy states.

These electrons remain in a high-energy state at 
normal ambient temperature. When the TLDs are heated (annealed), the electrons return to the lower energy state, emitting photon energy (light), which is measured with a photomultiplier tube; the light intensity is directly proportional to the absorbed radiation dose. The environmental TLDs used at the Laboratory are composed of calcium fluoride and lithium fluoride crystals. Accuracy is verified by exposing the TLD to a known and characterized radiation source. BNL participates in the inter-comparison proficiency testing programs sponsored by DOE, as a check of its ability to measure radiation doses accurately.

A direct radiation-monitoring program is used to measure the external dose contribution to members of the public and workers from radiation sources at BNL. This is achieved by measuring direct penetrating radiation exposures both on and off site. The direct measurements taken at the off-site locations are with the premise that off-site exposures are true natural background radiation (contribution from cosmic and terrestrial) exposures and represent no contribution from Laboratory operations. On- and off-site external dose measurements were averaged, then compared with each other using the statistical t-test to measure any variations in the averages and thus the contribution, if any, from BNL operations.

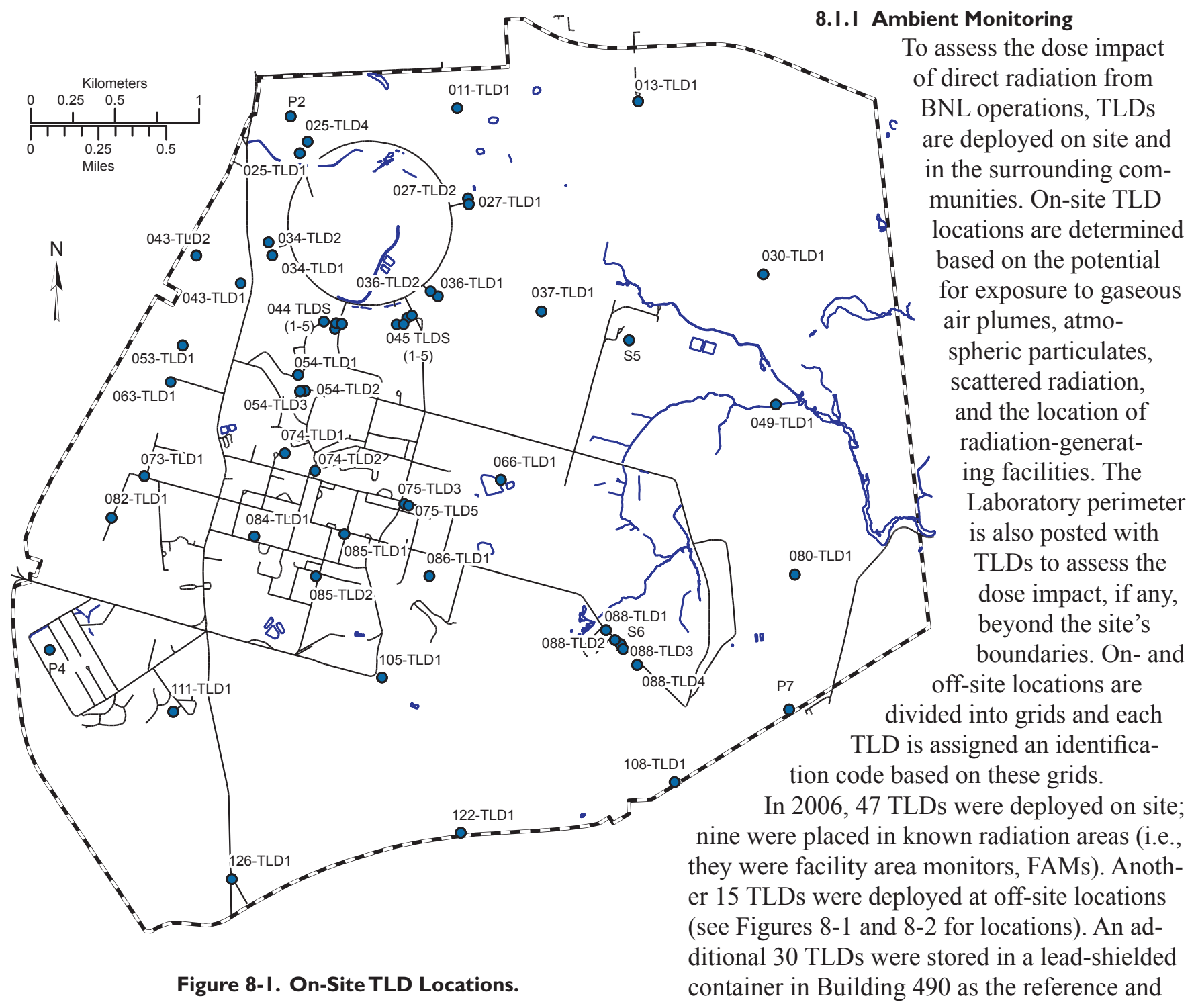




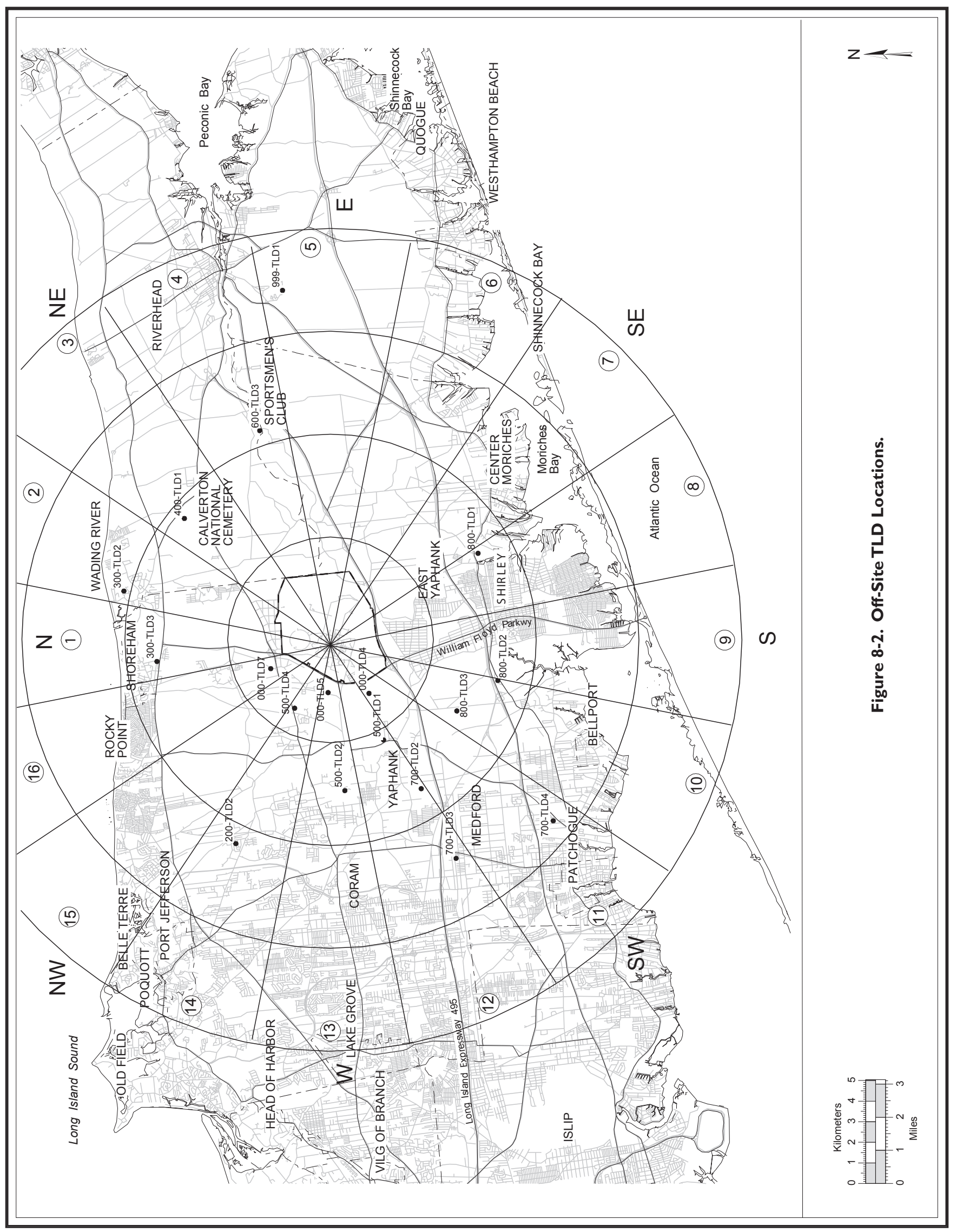


control TLDs for comparison purposes. The average of the control TLD values was reported as "075-TLD4" in Tables 8-1 and 8-2. Note that a small "residual" dose was reported for the control TLDs when they were annealed, because it is not possible to completely shield TLDs from all natural background and cosmic radiation sources. The on- and off-site TLDs were collected and read quarterly to determine the external radiation dose measured.

Table 8-1 shows the quarterly and yearly onsite radiation dose measurements for 2006. The on-site average external doses for the first, second, third, and fourth quarters were $18.4 \pm 3.6$, $16.0 \pm 3.0,15.6 \pm 3.3$, and $18.0 \pm 3.0 \mathrm{mrem}$, respectively. The on-site average annual external dose from all potential environmental sources, including cosmic and terrestrial radiation sources, was $68 \pm 11$ mrem $(680 \pm 110 \mu \mathrm{Sv})$.

Table 8 -2 shows the quarterly and yearly offsite radiation dose measurements. The off-site average external doses for the first, second, third, and fourth quarters were $17.1 \pm 2.4,14.9$ $\pm 2.5,14.6 \pm 3.6$, and $16.2 \pm 2.5 \mathrm{mrem}$, respectively. The off-site average annual ambient dose from all potential environmental sources, in- cluding cosmic and terrestrial radiation sources, was $63 \pm 9$ mrem $(630 \pm 90 \mu \mathrm{Sv})$.

To determine the BNL contribution to the external direct radiation dose, a statistical t-test between the measured on- and off-site external dose averages was conducted. The t-test showed no significant difference between the off-site dose $(63 \pm 9 \mathrm{mrem})$ and on-site dose $(68 \pm 11$ mrem) at the 95 percent confidence level. From the measured TLD doses, it can be safely concluded that there was no measurable external dose contribution to on- and off-site locations from Laboratory operations in 2006.

\subsubsection{Facility Area Monitoring}

Nine on-site TLDs were designated as facility area monitors because they were posted in known radiation areas. Table 8-3 shows the external doses measured with the FAM-TLDs. The environmental TLDs 088-TLD1 through 088TLD4 are posted at the S- 6 blockhouse location and on the fence of the former Hazardous Waste Management Facility (HWMF). These TLDs measured slightly higher external doses than the normal natural background radiation doses measured in other areas of BNL. The elevated ex-

\begin{tabular}{|c|c|c|c|c|c|c|c|}
\hline & & $\begin{array}{c}\text { 1st } \\
\text { Quarter }\end{array}$ & $\begin{array}{c}\text { 2nd } \\
\text { Quarter }\end{array}$ & $\begin{array}{c}\text { 3rd } \\
\text { Quarter }\end{array}$ & $\begin{array}{c}\text { 4th } \\
\text { Quarter }\end{array}$ & $\begin{array}{c}\text { Avg./Qtr. } \\
\pm 2 \sigma(95 \%)\end{array}$ & $\begin{array}{c}\text { Annual Dose } \\
\pm 2 \sigma(95 \%)\end{array}$ \\
\hline TLD\# & Location & & & 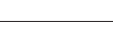 & em) & & \\
\hline 011-TLD1 & North firebreak & 16.3 & 12.6 & 12.8 & 15.5 & $14 \pm 4$ & $57 \pm 15$ \\
\hline 013-TLD1 & North firebreak & 17.1 & 14.4 & 14.7 & 16.7 & $16 \pm 3$ & $63 \pm 11$ \\
\hline 025-TLD1 & Bldg. 1010 beam stop 1 & 17.6 & 15.7 & 13.7 & 16.8 & $16 \pm 3$ & $64 \pm 13$ \\
\hline 025-TLD4 & Bldg. 1010 beam stop 4 & 19.8 & 14.2 & 14.6 & 17.2 & $16 \pm 5$ & $66 \pm 20$ \\
\hline 027-TLD1 & Bldg. 1002A South & 14.8 & 15.0 & 14.1 & 16.5 & $15 \pm 2$ & $60 \pm 8$ \\
\hline 027-TLD2 & Bldg. 1002D East & 17.7 & 14.5 & 13.2 & 17.0 & $16 \pm 4$ & $62 \pm 17$ \\
\hline 030-TLD1 & NE Firebreak & 18.4 & 16.5 & 15.6 & 17.5 & $17 \pm 2$ & $68 \pm 10$ \\
\hline 034-TLD1 & Bldg. 1008 collimator 2 & 18.6 & 16.2 & 15.7 & 17.7 & $17 \pm 3$ & $68 \pm 10$ \\
\hline 034-TLD2 & Bldg. 1008 collimator 4 & 18.5 & 15.1 & 15.6 & 17.6 & $17 \pm 3$ & $67 \pm 13$ \\
\hline 036-TLD1 & Bldg. 1004B East & 16.8 & 13.5 & 13.5 & 15.7 & $15 \pm 3$ & $60 \pm 13$ \\
\hline 036-TLD2 & Bldg. 1004 East & 18.6 & 16.1 & 17.3 & 19.5 & $18 \pm 3$ & $72 \pm 12$ \\
\hline 037-TLD1 & S-13 & 17.3 & 14.6 & 15.2 & 19.2 & $17 \pm 4$ & $66 \pm 16$ \\
\hline 043-TLD1 & North access road & 19.0 & 18.1 & 18.2 & 18.6 & $18 \pm 1$ & $74 \pm 3$ \\
\hline 043-TLD2 & North of Meteorology Tower & 18.4 & 16.3 & 16.4 & 17.7 & $17 \pm 2$ & $69 \pm 8$ \\
\hline
\end{tabular}


Table 8-1. On-Site Direct Radiation Measurements (concluded).

\begin{tabular}{|c|c|c|c|c|c|c|c|}
\hline & & $\begin{array}{c}\text { 1st } \\
\text { Quarter }\end{array}$ & $\begin{array}{l}\text { 2nd } \\
\text { Quarter }\end{array}$ & $\begin{array}{c}\text { 3rd } \\
\text { Quarter }\end{array}$ & $\begin{array}{l}\text { 4th } \\
\text { Quarter }\end{array}$ & $\begin{array}{l}\text { Avg./Qtr. } \\
\pm 2 \sigma(95 \%)\end{array}$ & $\begin{array}{c}\text { Annual Dose } \\
\pm 2 \sigma(95 \%)\end{array}$ \\
\hline TLD\# & Location & & & & rem)- & & \\
\hline 044-TLD1 & Bldg. 1006 & 17.4 & 17.2 & 16.4 & 17.4 & $17 \pm 1$ & $68 \pm 4$ \\
\hline 044-TLD2 & South of Bldg. 1000E & 18.0 & 17.6 & 14.7 & 17.2 & $17 \pm 3$ & $68 \pm 12$ \\
\hline 044-TLD3 & South of Bldg. 1000P & 16.8 & 15.2 & 13.7 & 19.8 & $16 \pm 5$ & $66 \pm 20$ \\
\hline 044-TLD4 & NE of Bldg. 1000P & 20.1 & 17.0 & 15.6 & 18.1 & $18 \pm 4$ & $71 \pm 15$ \\
\hline 044-TLD5 & $\mathrm{N}$ of Bldg. 1000P & 17.2 & 16.7 & 15.2 & 18.5 & $17 \pm 3$ & $68 \pm 11$ \\
\hline 045-TLD1 & Bldg. 1005S & 20.4 & 15.9 & 16.2 & 17.5 & $18 \pm 4$ & $70 \pm 16$ \\
\hline 045-TLD2 & East of Bldg. 1005S & 21.2 & 18.2 & 16.8 & 17.1 & $18 \pm 4$ & $73 \pm 16$ \\
\hline 045-TLD3 & SE of Bldg. 1005 S & 18.0 & 16.2 & 14.8 & 17.3 & $17 \pm 3$ & $66 \pm 11$ \\
\hline 045-TLD4 & SW of Bldg. 1005 S & 17.4 & 15.5 & 16.4 & 16.9 & $17 \pm 2$ & $66 \pm 6$ \\
\hline 045-TLD5 & WSW of Bldg. $1005 \mathrm{~S}$ & 14.4 & 13.7 & 13.5 & 15.2 & $14 \pm 2$ & $57 \pm 6$ \\
\hline 049-TLD1 & East firebreak & 16.3 & 16.2 & 14.6 & 17.1 & $16 \pm 2$ & $64 \pm 8$ \\
\hline 053-TLD1 & West firebreak & 22.6 & 17.2 & 18.3 & 20.7 & $20 \pm 5$ & $79 \pm 19$ \\
\hline 054- TLD1 & Bldg. 914 & 19.7 & 14.6 & 13.0 & 16.0 & $16 \pm 6$ & $63 \pm 22$ \\
\hline 063-TLD1 & West firebreak & 20.2 & 18.4 & 18.4 & 20.4 & $19 \pm 2$ & $77 \pm 9$ \\
\hline 066-TLD1 & Waste Management Facility & 16.5 & 14.0 & 14.2 & 15.7 & $15 \pm 2$ & $60 \pm 9$ \\
\hline 073-TLD1 & Meteorology Twr. /Bldg. 51 & 19.5 & 17.1 & 17.6 & 19.0 & $18 \pm 2$ & $73 \pm 9$ \\
\hline 074-TLD1 & Bldg. 560 & 18.7 & 18.3 & 18.5 & 19.2 & $19 \pm 1$ & $75 \pm 3$ \\
\hline 074-TLD2 & Bldg. 907 & 17.6 & 15.8 & 16.3 & 19.5 & $17 \pm 3$ & $69 \pm 13$ \\
\hline 080-TDL1 & East firebreak & 20.9 & 17.5 & 16.1 & 20.0 & $19 \pm 4$ & $75 \pm 17$ \\
\hline 082-TLD1 & West firebreak & 22.6 & 18.4 & 17.3 & 20.9 & $20 \pm 5$ & $79 \pm 19$ \\
\hline 084-TLD1 & Tennis courts & NP & 16.4 & 15.2 & 18.0 & $17 \pm 3$ & $66 \pm 11$ \\
\hline 085-TDL2 & Upton gas station & 19.0 & 17.1 & 17.0 & 19.4 & $18 \pm 2$ & $73 \pm 10$ \\
\hline 085-TLD1 & Diversity Office & 19.9 & 17.8 & 15.9 & 19.3 & $18 \pm 3$ & $73 \pm 14$ \\
\hline 086-TLD1 & Baseball fields & 20.9 & 19.3 & 19.3 & 20.6 & $20 \pm 2$ & $80 \pm 7$ \\
\hline 105-TLD1 & South firebreak & 19.0 & 15.5 & 16.5 & 19.1 & $18 \pm 4$ & $70 \pm 14$ \\
\hline 108-TLD1 & Water tower & 16.1 & 15.3 & 14.7 & 16.8 & $16 \pm 2$ & $63 \pm 7$ \\
\hline 111-TLD1 & Trailer park & 18.7 & 16.5 & 17.2 & 18.5 & $18 \pm 2$ & $71 \pm 8$ \\
\hline 122-TLD1 & South firebreak & 17.7 & 15.2 & 14.9 & 17.9 & $16 \pm 3$ & $66 \pm 13$ \\
\hline 126-TLD1 & South gate & 21.0 & 16.9 & 18.0 & 20.4 & $19 \pm 4$ & $76 \pm 15$ \\
\hline P2 & & 16.3 & 12.8 & 13.0 & 15.2 & $14 \pm 3$ & $57 \pm 13$ \\
\hline P4 & & 16.6 & 15.2 & 14.4 & 16.7 & $16 \pm 2$ & $63 \pm 9$ \\
\hline P7 & & 17.9 & 16.1 & 16.2 & 17.3 & $17 \pm 2$ & $68 \pm 7$ \\
\hline S5 & & 16.7 & 15.1 & 14.0 & 17.8 & $16 \pm 3$ & $64 \pm 13$ \\
\hline On-site average & & 18.4 & 16.0 & 15.6 & 18.0 & $17 \pm 3$ & $68 \pm 11$ \\
\hline $\begin{array}{l}\text { Standard Deviation } \\
(2 \sigma)\end{array}$ & & 3.6 & 3.0 & 3.3 & 3.0 & & \\
\hline 075-TLD4 & Control TLD average & 9.0 & 8.6 & 9.3 & 8.9 & $8.9 \pm 1$ & $36 \pm 2$ \\
\hline $\begin{array}{l}\text { Notes: } \\
\text { See Figure 8-1 for TLD } \\
\text { NP = TLD not posted }\end{array}$ & & & & & & & \\
\hline
\end{tabular}


Table 8-2. Off-Site Direct Radiation Measurements.

\begin{tabular}{|c|c|c|c|c|c|c|c|}
\hline TLD\# & Location & $\begin{array}{c}\text { 1st } \\
\text { Quarter }\end{array}$ & $\begin{array}{l}\text { 2nd } \\
\text { Quarter }\end{array}$ & $\begin{array}{c}\text { 3rd } \\
\text { Quarter }\end{array}$ & $\begin{array}{c}\text { 4th } \\
\text { Quarter } \\
\text { (mrem) }\end{array}$ & $\begin{array}{l}\text { Avg./Qtr. } \\
\pm 2 \sigma(95 \%)\end{array}$ & $\begin{array}{l}\text { Annual Dose } \\
\pm 2 \sigma(95 \%)\end{array}$ \\
\hline 000-TLD4 & Private property & 15.7 & 13.7 & 13.5 & 15.6 & $15 \pm 2$ & $59 \pm 9$ \\
\hline 000-TLD5 & Longwood Estate & 17.2 & 15.9 & $\mathrm{~L}$ & 16.2 & $16+/-1$ & $66 \pm 5$ \\
\hline 000-TLD7 & Mid-Island Game Farm & 17.2 & 15.1 & 15.6 & 16.4 & $16 \pm 2$ & $64 \pm 7$ \\
\hline 300-TLD3 & Private property & 17.2 & NP & 14.8 & 14.8 & $16 \pm 3$ & $62 \pm 11$ \\
\hline 400-TLD1 & Calverton Nat. Cemetary & 19.1 & 17.8 & 19.2 & 19.7 & $19 \pm 2$ & $76 \pm 6$ \\
\hline 500-TLD2 & Private property & 16.7 & 13.7 & 12.7 & 15.4 & $15 \pm 3$ & $59 \pm 14$ \\
\hline 500-TLD4 & Private property & 17.2 & 14.5 & 14.5 & 17.2 & $16 \pm 3$ & $63 \pm 12$ \\
\hline 600-TLD3 & Sportsmen's Club & 16.1 & 14.9 & 15.2 & 16.2 & $16 \pm 1$ & $62 \pm 5$ \\
\hline 700-TLD2 & Private property & 15.7 & 13.0 & 12.7 & 16.2 & $14 \pm 0$ & $58 \pm 0$ \\
\hline 700-TLD3 & Private property & 19.2 & 15.6 & 13.1 & 15.4 & $16 \pm 5$ & $63 \pm 20$ \\
\hline 700-TLD4 & Private property & 17.2 & 14.8 & 14.1 & 16.8 & $16 \pm 3$ & $63 \pm 12$ \\
\hline 800-TLD1 & Private property & 18.8 & 14.4 & 15.3 & 15.6 & $16 \pm 4$ & $64 \pm 15$ \\
\hline 800-TLD3 & Suffolk County CD & 17.4 & 16.2 & 16.3 & 17.5 & $17 \pm 1$ & $67 \pm 5$ \\
\hline 900-TLD2 & Private property & NP & NP & NP & 14.8 & $15 \pm 0$ & $59 \pm 0$ \\
\hline 999-TLD1 & Private property & 15.2 & 14.0 & 13.0 & 15.2 & $14 \pm 2$ & $57 \pm 8$ \\
\hline \multicolumn{2}{|c|}{ Off-site average } & 17.1 & 14.9 & 14.6 & 16.2 & $16 \pm 2$ & $63 \pm 9$ \\
\hline \multicolumn{2}{|c|}{ Standard Deviation $(2 \sigma)$} & 2.4 & 2.5 & 3.6 & 2.5 & & \\
\hline 075-TLD4 & Control TLD average & 10.1 & 9.2 & 9.3 & 9.1 & $9.4 \pm 1$ & $38 \pm 4$ \\
\hline \multicolumn{8}{|c|}{$\begin{array}{l}\text { Notes: } \\
\text { See Figure 8-2 for TLD locations. } \\
C D=\text { Correctional Department } \\
N P=\text { TLD not posted for the quarter } \\
L=\text { TLD lost }\end{array}$} \\
\hline
\end{tabular}

ternal dose measured at the former HWMF can be attributed to the presence of small amounts of soil contamination. However, a comparison of the 2006 dose rates to doses from previous years show that the dose rates have declined significantly since the removal of most of the radioactive soil. As Table 8-3 shows, the dose is currently just slightly above natural background levels. The former HWMF is fenced, access is controlled, and only qualified staff members are allowed inside the facility.

Two TLDs (075-TLD3 and 075-TLD5) near Building 356 showed higher than normal quarterly averages: $22 \pm 4$ mrem $(220 \pm 40 \mu \mathrm{Sv})$ and $25 \pm 4$ mrem $(250 \pm 40 \mu \mathrm{Sv})$, respectively. The yearly doses were measured at $89 \pm 14 \mathrm{mrem}$ $(890 \pm 140 \mu \mathrm{Sv})$ for $075-\mathrm{TLD} 3$, and $101 \pm 16$ mrem $(1010 \pm 160 \mu \mathrm{Sv})$ for 075-TLD5. The direct doses are higher than the on-site annual average because Building 356 houses a cobalt$60(\mathrm{Co}-60)$ source, which is used to irradiate materials, parts, and electronic circuit boards. The elevated dose from Building 356 is attributed to the "sky-shine" phenomenon. Although it is conceivable that individuals who use the parking lot adjacent to Building 356 could receive a dose from this source, the dose would be minimal due to the limited time an individual spends in the parking lot.

In previous years, two FAM-TLDs placed on the fence northeast and northwest of Building 913-B (the Alternating Gradient Synchrotron tunnel access) showed higher than normal ambient external dose. In 2006, the dose was just barely above normal background radiation.

\subsection{DOSE MODELING}

EPA regulates radiological emissions from 
Table 8-3. Facility Area Monitoring.

\begin{tabular}{|c|c|c|c|c|c|c|c|}
\hline \multirow[b]{2}{*}{ TLD\# } & \multirow[b]{2}{*}{ Location } & $\begin{array}{c}\text { 1st } \\
\text { Quarter }\end{array}$ & $\begin{array}{c}\text { 2nd } \\
\text { Quarter }\end{array}$ & $\begin{array}{c}\text { 3rd } \\
\text { Quarter }\end{array}$ & $\begin{array}{c}\text { 4th } \\
\text { Quarter }\end{array}$ & $\begin{array}{c}\text { Average } \\
\pm 2 \sigma(95 \%)\end{array}$ & $\begin{array}{c}\text { Annual } \\
\text { Dose } \\
\pm 2 \sigma(95 \%)\end{array}$ \\
\hline & & \multicolumn{6}{|c|}{ (mrem) - } \\
\hline 054-TLD2 & N/E of Bldg. 913-B & 19.7 & 17.5 & 15.6 & 17.9 & $18 \pm 3$ & $71 \pm 13$ \\
\hline 054-TLD3 & N/W of Bldg. 913-B & 21.4 & 18.0 & 13.7 & 16.4 & $17 \pm 6$ & $70 \pm 25$ \\
\hline S6 & & 20.9 & 17.6 & 17.6 & 18.8 & $19 \pm 3$ & $75 \pm 12$ \\
\hline 088-TLD1 & FWMF-50' East of S-6 & 19.9 & 16.6 & 17.3 & 18.9 & $18 \pm 3$ & $73 \pm 12$ \\
\hline 088-TLD2 & FWMF-50' West of S-6 & 21.8 & 19.2 & 19.6 & 21.5 & $21 \pm 3$ & $82 \pm 10$ \\
\hline 088-TLD3 & FWMF-100' West of S-6 & 20.8 & 18.1 & 18.0 & 20.3 & $19 \pm 3$ & $77 \pm 11$ \\
\hline 088-TLD4 & FWMF-150' West of S-6 & 19.8 & 17.8 & 18.5 & 19.4 & $19 \pm 2$ & $76 \pm 7$ \\
\hline 075-TLD3 & Bldg. 356 & 21.0 & 20.3 & 24.2 & 23.2 & $22 \pm 4$ & $89 \pm 14$ \\
\hline 075-TLD5 & North Corner of Bldg. 356 & 25.0 & 22.5 & 25.8 & 27.5 & $25 \pm 4$ & $101 \pm 16$ \\
\hline $\begin{array}{l}\text { Notes: } \\
\text { See Figure } 8 \\
\text { FWMF = For }\end{array}$ & $\begin{array}{l}\text { TLD locations. } \\
\text { Vaste Management Facility }\end{array}$ & & & & & & \\
\hline
\end{tabular}

DOE facilities under the requirements set forth in 40 CFR 61, Subpart H, National Emission Standards for Hazardous Air Pollutants (NESHAPs). This regulation specifies the compliance and monitoring requirements for reporting the radiation doses received by members of the public from airborne radionuclides. The regulation mandates that no member of the public shall receive a dose from DOE operations that is greater than $10 \mathrm{mrem}(100 \mu \mathrm{Sv})$ in a year. The emission monitoring requirements are set forth in Subpart H, Section 61.93(b) and include the use of a reference method for continuous monitoring at major release points (defined as those with a potential to exceed 1 percent of the $10 \mathrm{mrem}$ standard), and a periodic confirmatory measurement for all other release points. The regulations also require DOE facilities to submit an annual NESHAPs report to EPA that describes the major and minor emission sources and dose to the MEI. The dose estimates from various facilities are given in Table 8-4, and the emissions are discussed in detail in Chapter 4.

As a part of the NESHAPs review process at BNL, any source that has the potential to emit radioactive materials is evaluated for regulatory compliance. Although the activities conducted under the Environmental Restoration (ER) Program are exempt under the Comprehensive Environmental Response, Compensation and
Liability Act (CERCLA), these activities are monitored and assessed for any potential to release radioactive materials, and to determine their dose contribution, if any, to the environment. In 2006, any new processes or activities were evaluated for compliance with NESHAPs regulations using EPA's approved dose modeling software (see Section 8.2.1 for details). Because this model was designed to treat all radioactive emission sources as continuous over the course of a year, it is not well suited for estimating short-term or acute releases. Consequently, it overestimates potential dose contributions from short-term projects and area sources. For that reason, the results are considered to be "conservative"- that is, erring on the side of caution.

\subsection{Dose Modeling Program}

Compliance with NESHAPs regulations is demonstrated through the use of EPA dose modeling software, the Clean Air Act Assessment Package-1988 (CAP88-PC), Versions 2.1 and 3.0. This computer program uses a Gaussian plume model to estimate the average dispersion of radionuclides released from elevated stacks or diffuse sources. It calculates a final value of the projected dose at the specified distance from the release point by computing dispersed radionuclide concentrations in air, rate of deposition on ground surfaces, and intake via the food path- 
Table 8-4. MEl Effective Dose Equivalent From Facilities or Routine Processes.

\begin{tabular}{|c|c|c|c|c|}
\hline Building No. & Facility or Process & Construction Permit No. & $\begin{array}{l}\text { MEI Dose } \\
\text { (mrem) (a) }\end{array}$ & Notes \\
\hline 348 & Radiation Protection & None & ND & (b) \\
\hline 463 & Biology Facility & None & $1.59 \mathrm{E}-11$ & (b) \\
\hline 490 & Medical Research & BNL-489-01 & $8.46 \mathrm{E}-9$ & (b) \\
\hline $490 \mathrm{~A}$ & Energy and Environment National Security & None & ND & (b) \\
\hline 491 & Brookhaven Medical Research Reactor & None & ND & (e) \\
\hline 510 & Calorimeter Enclosure & BNL-689-01 & ND & (f) \\
\hline $510 \mathrm{~A}$ & Physics & None & ND & (b) \\
\hline 535 & Instrumentation & None & ND & (b) \\
\hline 555 & Chemistry Facility & None & ND & (b) \\
\hline 725 & National Synchrotron Light Source & None & $5.57 \mathrm{E}-10$ & (b) \\
\hline 750 & High Flux Beam Reactor & None & $2.61 \mathrm{E}-5$ & (c) \\
\hline 801 & Target Processing Lab & None & $3.47 \mathrm{E}-5$ & (b), (c) \\
\hline $802 \mathrm{~B}$ & Evaporator Facility & BNL-288-01 & NO & (e) \\
\hline 820 & Accelerator Test Facility & BNL-589-01 & ND & (d) \\
\hline 830 & Environmental Science Department & None & ND & (d) \\
\hline 865 & Reclamation Building & None & ND & (c) \\
\hline 906 & Medical-Chemistry & None & ND & \\
\hline 925 & Accelerator Department & None & ND & (b) \\
\hline 931 & Brookhaven Linac Isotope Producer & None & 8.13E-2 & (c) \\
\hline 938 & REF/NBTF & BNL-789-01 & ND & (g) \\
\hline 942 & Alternate Gradient Syncrotron Booster & BNL-188-01 & ND & (h) \\
\hline--- & Relativistic Heavy Ion Collider & BNL-389-01 & ND & (d) \\
\hline \multicolumn{2}{|c|}{ Total Potential Dose from BNL Operations } & \multicolumn{3}{|c|}{ 8.14E-2 } \\
\hline EPA Limit & & \multicolumn{3}{|c|}{10.0 mrem } \\
\hline \multicolumn{2}{|c|}{$\begin{array}{l}\text { Notes: } \\
\text { Diffuse, Fugitive, and Other sources are not included in this table since they } \\
\text { are short-term emissions. } \\
\text { MEI = Maximally Exposed Individual } \\
\text { NBTF = Neutron Beam Test Facility } \\
\text { REF = Radiation Effects Facility } \\
\text { (a) "Dose" in this table means effective dose equivalent to MEI. } \\
\text { (b) Dose is based on emissions calculated using } 40 \text { CFR } 61 \text {, } \\
\text { Appendix D methodology. } \\
\text { (c) Emissions are monitored at the facility. }\end{array}$} & \multicolumn{3}{|c|}{$\begin{array}{l}\text { (d) ND = No dose from emissions source in } 2006 \text {. } \\
\text { (e) NO = Not operational in } 2006 \text {. } \\
\text { (f) This has become a zero-release facility since original permit } \\
\text { application. } \\
\text { (g) This facility is no longer in use; it produces no radioactive } \\
\text { emissions. } \\
\text { (h) Booster ventilation system prevents air release through } \\
\text { continuous air recirculation. }\end{array}$} \\
\hline
\end{tabular}

way (where applicable). CAP88-PC calculates both the EDE to the MEI and the collective population dose within a 50-mile radius of the emission source. In most cases, the CAP88-PC model provides conservative doses. For the purpose of modeling the dose to the MEI, all emission points are located at the center of the developed portion of the BNL site. The dose calculations are based on very low concentrations of the environmental releases and on chronic, continuous intakes in a year. The input parameters used in the model include radionuclide type, emission rate in curies (Ci) per year, stack parameters such as height and diameter, and emission exhaust velocity. Site-specific weather and population data are factored into the dose assessment. Weather data are supplied by measurements from the Laboratory's meteorological tower, which include the wind speed, direction, frequency, and air temperature (see 
Chapter 1 for details). Population data used in the model are based on the Long Island Power Authority population survey (LIPA 2000). Because visiting researchers and their families may reside at the BNL on-site apartment area for extended periods, these residents are also included in the population file used for dose assessment.

\subsubsection{Dose Calculation Methods and Pathways} 8.2.2.1 Maximally Exposed Individual

The MEI is defined as a hypothetical person who resides at the site boundary and has a lifestyle such that no other member of the public could receive a higher dose. This person is assumed to reside 24 hours a day, 365 days a year at the BNL site boundary in the downwind direction, and to consume significant amounts of fish and deer containing radioactivity attributable to Laboratory operations based on projections from the New York State Department of Health (NYSDOH). In reality, it is highly unlikely that such a combination of "maximized dose" to any single individual would occur, but the concept is useful for evaluating maximum potential risk and dose.

\subsubsection{Effective Dose Equivalent}

The EDE to the MEI for low levels of radioactive materials dispersed into the environment was calculated using the CAP88-PC dose modeling program, Versions 2.1 and 3.0. Site meteorology data were used to calculate annual dispersions for the midpoint of a given wind sector and distance. Facility-specific radionuclide release rates $(\mathrm{Ci} / \mathrm{yr})$ were used for continuously monitored facilities. For small sources, the emissions were calculated using the method set forth in 40 CFR 61, Subpart H, Appendix D. The Gaussian dispersion model calculated the EDE at the site boundary and the collective population dose values from immersion, inhalation, and ingestion pathways. These dose and risk calculations to the MEI are based on low emissions and chronic intakes.

\subsubsection{Dose Calculation: Fish Ingestion}

To calculate the EDE from the fish consumption pathway, the intake is estimated. Intake is the average amount of fish consumed by a person engaged in recreational fishing in the Peconic River. Based on a NYSDOH study, the consumption rate is estimated at 15 pounds (7 kg) per year (NYSDOH 1996). For each radionuclide of concern for fish samples, the dry weight activity concentration was converted to picocuries per gram $(\mathrm{pCi} / \mathrm{g})$ wet weight, since "wet weight" is the form in which fish are caught and consumed. A dose conversion factor was used for each radionuclide to convert the activity concentration into the EDE. For example, the committed dose equivalent factor for cesium-137 (Cs-137) is 5.0E-02 $\mathrm{rem} / \mu \mathrm{Ci}$, as set forth in DOE/EH-0071. The dose was calculated as: $\boldsymbol{d o s e}(\mathrm{rem} / \mathrm{yr})=$ intake $(\mathrm{kg} / \mathrm{yr}) \times$ activity in flesh $(\mu \mathrm{Ci} / \mathrm{kg}) \times$ dose factor $(\mathrm{rem} / \mu \mathrm{Ci})$.

\subsubsection{Dose Calculation: Deer Meat Ingestion}

The dose calculation for the deer meat ingestion pathway is similar to that for fish consumption. The Cs-137 radionuclide dose conversion factor was used to estimate dose, based on the U.S. Environmental Protection Agency Exposure Factors Handbook (EPA 1996). The total quantity of deer meat ingested during the course of a year was estimated as 64 pounds $(29 \mathrm{~kg})$

(NYSDOH 1999).

\subsection{SOURCES: DIFFUSE, FUGITIVE, “OTHER”}

Diffuse sources are described as releases of radioactive contaminants to the atmosphere that do not have a well-defined emission point such as a stack or vent. Such sources are also known as nonpoint or area sources. Fugitive sources include releases to the air not through an actively ventilated air stream (i.e., leaks from vents). As a part of the NESHAPs review process, in addition to stack emissions, any fugitive or diffuse emission source that could potentially emit radioactive materials to the environment is evaluated. Although CERCLA-prompted actions, such as remediation projects, are exempt from the procedural requirements to obtain federal, state, or local permits, any BNL activity or process with the potential to emit radioactive material must be evaluated and assessed for dose impact to members of the public. The following radiological sources were evaluated in 2006 for potential contribution to the overall site dose. 


\subsection{Brookhaven Graphite Research Reactor}

The decontamination activities for removal of the Brookhaven Graphite Research Reactor (BGRR) belowground duct (BGD) liner and graphite pile were continued in 2006. The BGRR facility was shut down in 1969 and all fuel was removed from the site by June of 1972. As a result of previous operations at the BGRR, the BGD liner and graphite pile were both activated and contaminated. The following radionuclides were identified as potential contaminants: Am-241, C-14, Co-60, Cs-137, Eu-152, Eu-154, H-3, I-129, Ni-63, Pu-238, $\mathrm{Pu}-239, \mathrm{Pu}-240, \mathrm{Sr}-90$, and Th-232.

Two remote manipulators were used for the liner removal work. One manipulator was fitted with standard demolition tools, while the other manipulator had a clamshell bucket for loading the liner waste into a transport cart. When the transport cart was full, it was moved to the filter access opening and the liner waste was removed with a gantry crane, for placement into sealant-type waste transport containers. Once the primary liner was removed, the secondary liner was exposed; this was left in place until final disposition of the BGRR is determined. Debris and loose surface contamination were removed via vacuuming or other physical or mechanical means. After loose surface contamination was removed, a light-colored industrial coating of paint was applied to affix any remaining contamination. The newly painted surface also is more visible during inspections. The primary liner radionuclides concentration was used for development of the source term were based on BGRR-SE-04-03 document During the primary liner removal operation, the BGD was connected with Building 708-T, the Duct Service Building (DSB), to minimize the potential for any airborne contamination. Both buildings were maintained at a slightly negative pressure with respect to the outside atmosphere. Two self-contained, skid-mounted 6,000-cfm HEPA-filtered ventilation units were tested and installed in the DSB. They exhausted to the outside via a single, 26-inch diameter duct.

A NESHAPs evaluation showed that the total dose to the MEI resulting from the BGRR BGD primary liner removal operation was estimated to be $1.5 \mathrm{E}-05 \mathrm{mrem} / \mathrm{yr}$. The potential dose was below the $10 \mathrm{mrem} / \mathrm{yr}$ annual limit as specified in $40 \mathrm{CFR}$ 61, subpart $\mathrm{H}$, and below the $0.1 \mathrm{mrem} / \mathrm{yr}$ limit that triggers the NESHAPs continuous monitoring requirements. Although continuous monitoring was not required, a sampling probe was installed in the HEPA-filtered ventilation system of the DSB to ensure that the nearby environment was not exposed to levels of radioactive materials exceeding the established regulatory limits, and also to verify that the engineering controls were effective. In addition, emissions monitoring was implemented to assess non-routine incident consequences, and specify appropriate corrective action that might be needed if such an event were to happen. The monitoring was performed in accordance with ANSI/HPS N13.11999 standards. The samples collected from the ducts were routinely analyzed for gross alpha/beta, gamma, and other radiological parameters, when deemed necessary. The results showed that there was no radioactivity released above the detection limit.

\subsubsection{Former Hazardous Waste Management Facility}

The objective of the dose assessment was to evaluate the potential dose impact to the MEI (in this case, a firefighter) in the event of an accidental fire at the former HWMF (Area of Concern I). The former HWMF covers about 12 acres; two acres are radiologically controlled and will be used to support planned Waste Loading Area operations for the BGRR and HFBR remediation projects. The main portion of the former HWMF was cleaned up under the Operable Unit I technical specifications and applicable design criteria for soil removal and remediation. The remedial cleanup goal was based on $15 \mathrm{mrem} / \mathrm{yr}$ dose above natural background after 50 years of institutional control of the site. However, if there were a fire in the controlled area, firefighters and other personnel could receive radiation dose from residual radionuclide contamination in the soils and via airborne particulates. There is no dose modeling program specifically for an accidental fire incident; the RESRAD dose modeling program 
(Version 6.3) was deemed more appropriate for the scenario being evaluated than CAP88-PC.

For the dose assessment, it was assumed that firefighting equipment, water trucks, fire retardants, and shovels were used to control and mitigate the accidental fire. This assessment did not evaluate access to certain contaminated areas, the availability of fire hydrants, the use of firebreaks to control the fire, and the potential for fire to spread to other vulnerable buildings. Also, structural hazard factors, slope hazard, and fuel type and loading were not assigned values. The radiological contamination beneath paved roads/surfaces was not considered in the dose assessment, because fixed contamination underneath the asphalt has a low probability of becoming airborne. Additionally, engineering controls such as containment structures and HEPA filters were not used as mitigating measures in the dose assessment.

The highest residual contamination present in the hotspot areas was assumed to be the concentrations of radionuclides distributed evenly throughout the former HWMF. The concentrations were taken from Appendix A of the closeout report prepared by Envirocon, Inc., dated September 29, 2005. The Multi Agency Radiation Survey and Site Investigation Manual (MARSSIM) suggests using the Derived Concentration Guideline Level (DCGL) as the investigation level. However, if the residual activity appears as small areas of elevated activity within a larger area, MARSSIMS considers the results of individual measurements. In a worstcase scenario, the highest likely concentrations of the radionuclides in unit K-4 for Cs-137 (96 $\mathrm{pCi} / \mathrm{g})$, unit D-4 for $\mathrm{Sr}-90$ (81.10 pCi/g), and unit A for Ra-226 (1.27 pCi/g) were taken as the source terms. The concentration of the radionuclides present in the vegetation, plants, and grass was assumed to be in equilibrium with the remediation radioactivity present in the soil. In the model, air pollutant emissions are directly related to the intensity and direction (relative to wind) of the accidental fire. An assumption for this study was that fire personnel and equipment would be upwind of the fire scene. The dose evaluation did not consider factors that affect the spread of fire such as weather conditions, fuel type, fuel array, and topography. The particle size was also not taken into consideration in the dose assessment. The fugitive dust source was assumed to be controlled by watering the contaminated area. Also, the quantities of natural primordial radionuclides present in the air and soil from nuclear tests fallout were not taken into consideration, because the quantities were treated as natural background radiation. Another assumption was that the accidental fire was a surface fire, which favors the grassy "available fuel" (i.e., loose, combustible material), rather than a crown fire, which causes sufficient heat to burn the deep soil. Therefore, the modeling factor for the intensity of fires greater than 400 degrees Celsius, which could affect the volatility of cesium-137, was not included in the dose assessment.

The radiological dose and risk assessment to the MEI (firefighter) was estimated using RESRAD, Version 6.3. The pathways analyzed for dose assessment were the external gamma dose, inhalation along with radon, and soil particles ingested during the exposure period. The maximum dose was calculated to be 16.63 mrem for a year if the individual had resided in the former HWMF. However, because a firefighter would likely only be in the area for a number of hours, the "total equivalent dose estimate" (TEDE) was corrected using an occupancy correction factor. Taking that into account, the TEDE to the firefighter was calculated to be $1.90 \mathrm{E}-03 \mathrm{mrem} /$ $\mathrm{hr}$, and the dose for two hours of work would be $3.80 \mathrm{E}-3$ mrem.

In summary, the TEDE from the accidental wildfire scenario to a firefighter MEI was estimated to be $1.90 \mathrm{E}-03 \mathrm{mrem} / \mathrm{hr}$ under the worstcase scenario using the highest radionuclide concentration of the hot spots in the former HWMF area.

\subsubsection{High Flux Beam Reactor}

Since the permanent shutdown in November 1999 of the HFBR, it has been stabilized and maintained under a surveillance and maintenance program. When the reactor operated, it used heavy water $\left(\mathrm{D}_{2} \mathrm{O}\right)$ as a neutron moderator and fuel coolant. When $\mathrm{D}_{2} \mathrm{O}$ was exposed to the neutron fields generated inside the reactor ves- 
Table 8-5. BNL Site Dose Summary.

\begin{tabular}{c|c|c|c}
\hline Pathway & $\begin{array}{c}\text { Dose to Maximally } \\
\text { Exposed Individual }\end{array}$ & $\begin{array}{c}\text { Percent of DOE } \\
100 \text { mrem/year Limit }\end{array}$ & $\begin{array}{c}\text { Estimated Population } \\
\text { Dose per year }\end{array}$ \\
\hline Inhalation & & & 0.30 person-rem \\
\hline Air & $0.08 \mathrm{mrem}(0.81 \mu \mathrm{Sv})$ & None & None \\
\hline Ingestion & None & $<1 \%$ & Not tracked \\
\hline Drinking water & $0.07 \mathrm{mrem}(0.7 \mu \mathrm{Sv})$ & $<3 \%$ & Not tracked \\
\hline Fish & $2.96 \mathrm{mrem}(30 \mu \mathrm{Sv})$ & $<4 \%$ & 0.30 person-rem \\
\hline Deer Meat & $3.11 \mathrm{mrem}(31 \mu \mathrm{Sv})$ & &
\end{tabular}

sel, the deuterium became activated, producing radioactive tritium (half-life: 12.3 years). While most of the liquid sources of tritium have been removed, residual tritium is present in the confinement atmosphere and in the structures and equipment; this allows the potential for a small source of tritium emissions. After 2000, a number of actions were taken to remove contaminated structures, systems, and components from the HFBR complex. Most of the reactor systems have been put into a lay-up condition; the building's heating, ventilation, and cooling (HVAC) system is one of the few that remain in service.

Planned activities include demolition of numerous HFBR ancillary structures, including demolition of the 100-meter exhaust stack used for ventilation. Due to the potential release of minor amounts of tritium from the concrete and other systems into the atmosphere within the HFBR, a best management practice was established to provide ventilation prior to routine inspection of the facility. The proposed ventilation system will consist of a 4,000-cfm centrifugal exhaust fan with inline roughing and HEPA filters. The exhaust system will be operated for up to 5 days in a calendar quarter, just prior to and during the building surveillance inspections. The ventilation will also be operated during any necessary maintenance of the building. A technically acceptable and cost-effective option for the reactor is to leave the facility in a safe storage condition. This condition has the potential to generate fugitive emissions from the presence of residual tritium and low-level contamination on structures, systems, and the floor. Comprehensive sampling and analysis and multiple surveys were per- formed to characterize the HFBR complex. The nature and extent of radiological contamination and residual inventory were described in a series of characterization studies performed at the reactor. Most radioactivity was determined to be within the activated structures and components, which consists of the control-rod blades, reactor internals, reactor vessel, thermal shield, and biological shield. These activated materials are not dispersible radioactive materials, under normal conditions.

The source term is defined as the amount of radioactive material in grams or curies that can be released to the environment. For the NESHAPs assessment, the source term was based on the Assessment of HFBR Airborne Tritium Test Results, which gives the residual contamination within the confinement of the building. The potential source term was based on the materialat-risk (MAR) that can become airborne due to an exchange of tritium with water vapor in the confinement. MAR is defined as the maximum amount of radionuclides available to be acted upon by a given physical stress (maintenance activities, ventilation, etc.) or any other means (exchange) with certain probability for the radioactive materials to be released to the environment. The MAR values used in the calculations represent the maximum quantity of dispersible radionuclides present in the structures, components, and systems of the HFBR that were identified as activated or contaminated during the characterization activities. For the purpose of this assessment, the source term was assumed to be 5.3E-08 Ci of Cs-137, 8.3E-10 Ci of Co-60, and 1,000 $\mathrm{Ci}$ of tritium. 
The effective dose equivalent to the MEI as a result of safe storage condition of the HFBR was estimated to be $6.13 \mathrm{E}-05 \mathrm{mrem} / \mathrm{yr}$ at the southeast location. The potential dose was well below the $10 \mathrm{mrem} / \mathrm{yr}$ annual limit as specified in 40 CFR 61, subpart $\mathrm{H}$, and was below the $0.1 \mathrm{mrem} / \mathrm{yr}$ limit that triggers the requirement for a NESHAPs permit.

Although, the dose estimates are well below the NESHAPs regulatory requirements, periodic stack emissions monitoring was recommended to record any airborne particulate activity that may get released during the inspection/maintenance periods or during an unplanned release scenario. Periodic sampling frequency will include the annual collection of a representative sample of the aerosol particulates and tritium during any one of the quarterly inspection periods.

\subsubsection{National Synchrotron Light Source II} The National Synchrotron Light Source II (NSLS-II) is a newly proposed facility at BNL. A pre-NESHAPs evaluation was completed for NEPA compliance and documentation in 2006. During normal accelerator operations at the NSLS-II, it is possible to generate short-lived activation products such as C-11 (half-life: 20 minutes), N-13 (half-life: 10 minutes), and O-15 (half-life: 2.1 minutes). Theses radioactive gases would be produced within the accelerator enclosure and decay quickly, due to their short halflives. A preliminary calculation showed that the dose impact to workers and members of the public would be less than one-tenth of the NESHAPs permit requirements (40 CFR 61.93 [b] 4[i]). A NESHAPs evaluation will be conducted prior to startup of NSLS-II operations.

\subsection{Dose from Point Sources}

\subsection{Brookhaven Linac Isotope Producer}

Source term descriptions for the point sources are given in Chapter 4. The Brookhaven Linac Isotope Producer (BLIP) facility is the only emission source with any potential to contribute dose to members of the public greater than 1 percent of the EPA limit (i.e., $0.1 \mathrm{mrem}$, or 1.0 $\mu \mathrm{Sv})$. The BLIP facility uses the excess beam capacity of the Linear Accelerator (Linac) to produce short-lived radioisotopes for medical diagnostic procedures, medical imaging, and scientific research. During the irradiation process, the targets are cooled continuously by water recirculating in a 16-inch-diameter shaft. The principal gaseous radionuclides produced as a result of activation of the cooling water are $\mathrm{O}$ 15 and C-11. Because the BLIP facility has the potential to exceed 1 percent of the EPA emission limit $(0.1 \mathrm{mrem} / \mathrm{yr})$, the facility emissions are directly measured using a low-resolution gamma spectrometer with an in-line sampling system connected to the air exhaust, to measure the short-lived gaseous products that cannot be sampled and analyzed by conventional methods. Particulates and radioiodine are monitored with paper and granular activated charcoal filters, which are exchanged weekly for analysis by a contract analytical laboratory. A tritium sampler also operates continuously, with weekly sample collection and analyses.

In 2006, the BLIP facility operated over a period of 22 weeks. During the year, 1,284 Ci of $\mathrm{C}-11$ and 3,122 $\mathrm{Ci}$ of O-15 were released from the BLIP facility. Tritiated water vapor (6.78E$02 \mathrm{Ci}$ ) was also released, due to activation of the targets' cooling water. The annual EDE to the MEI from BLIP operations was calculated to be 8.13E-02 mrem $(0.81 \mu \mathrm{Sv})$.

An analysis of BLIP operating data for the past four years and the real-time emissions data collected to date show that BLIP emissions have been effectively reduced by approximately 30 percent since the installation of a sealed Lucite cover to enclose the cooling water surface, which was the source of most BLIP emissions.

\subsubsection{High Flux Beam Reactor}

In 2006, the HFBR facility was in a cold shutdown mode and was downgraded from a nuclear facility to a radiological facility. Tritium samples were taken on a monthly frequency and the dose contribution was determined to be $2.61 \mathrm{E}-5 \mathrm{mrem}(26 \mathrm{nSv})$ in a year.

\subsubsection{Brookhaven Medical Research Reactor}

In 2006, the Brookhaven Medical Research

Reactor (BMRR) facility was in a cold shutdown mode. During the year, all the primary 
coolant was drained and the reactor internals were removed. There was no dose contribution from the BMRR.

\subsubsection{Unplanned Releases}

There were no unplanned releases in 2006.

\subsection{DOSE FROM INGESTION}

Because deer and fish bioaccumulate radionuclides in their tissues and organs, tissue samples were analyzed to evaluate the dose contribution to humans from the ingestion pathway. As discussed in Chapter 6, deer meat samples collected off site and less than 1 mile from the BNL boundary were used to assess the potential dose impact to the MEI. Nine samples of deer meat (flesh) were used to calculate the "off site and less than 1 mile" average for the purpose of dose calculations. Potassium-K (K-40) and Cs-137 were the two radionuclides detected in the tissue samples. K-40 is a naturally occurring radionuclide and is not related to BNL operations. The average $\mathrm{K}-40$ concentrations in tissue samples were $3.7 \pm 1.3 \mathrm{pCi} / \mathrm{g}$ (wet weight) in the flesh and $2.6 \pm 1.6 \mathrm{pCi} / \mathrm{g}$ (wet weight) in the liver. The average Cs-137 concentrations were $2.0 \pm 0.3 \mathrm{pCi} / \mathrm{g}$ (wet weight) in the flesh and 0.4 $\pm 0.1 \mathrm{pCi} / \mathrm{g}$ (wet weight) in the liver (see Table 6-2). The potential dose from consuming deer meat with the average Cs- 137 concentration was estimated as $2.96 \mathrm{mrem}(30 \mu \mathrm{Sv})$ in a year. This is less than 30 percent of the health advisory limit of $10 \mathrm{mrem}(100 \mu \mathrm{Sv})$ established by NYSDOH.

In collaboration with the New York State Department of Environmental Conservation (NYSDEC) Fisheries Division, BNL maintains an ongoing program of collecting and analyzing fish from the Peconic River and surrounding freshwater bodies. In 2006, brown bullhead samples collected in the Peconic River at the Manorville Road site had the highest concentration of Cs-137, at $0.21 \pm 0.1 \mathrm{pCi} / \mathrm{g}$; this was used to estimate the EDE to the MEI. The potential dose from consuming 15 pounds of these brown bullhead annually was calculated to be 0.07 mrem $(0.7 \mu \mathrm{Sv})$ - far below the NYSDOH health advisory limit of $10 \mathrm{mrem}$.

\subsection{DOSE TO AQUATIC AND TERRESTRIAL BIOTA}

DOE-STD-1153-2002, A Graded Approach

for Evaluating Radiation Doses to Aquatic and Terrestrial Biota, provides the guidelines for screening methods to estimate radiological doses to aquatic animals, terrestrial plants, and terrestrial animals, using environmental surveillance data. The RESRAD-BIOTA 1.0 biota dose screening program was used to evaluate compliance with the requirements for protection of biota specified in DOE Order 5400.5 (1990), Radiation Protection of the Public and the Environment, and proposed Rule 10 CFR 834, Subpart F (66 FR 25380). The terrestrial animal and plant doses were evaluated based on 0.25 $\mathrm{pCi} / \mathrm{L}$ of strontium-90 (Sr-90) in surface waters at the Donahue Pond sampling location on the Peconic River (see Figure 5-8 for sampling stations). Soil samples were not collected this year due to a graded approach used for soil sampling (see Chapter 6 for more information). The dose was based on the surface water concentrations, and calculated to be $5.00 \mathrm{E}-09$ Gy/day to terrestrial animals and 1.22E-10 Gy/day to terrestrial plants. The doses to terrestrial animals and plants were well below the biota dose limit of $1 \mathrm{mGy} /$ day.

For calculating dose to aquatic animals, radionuclide concentration values from Donahue's Pond were used for both the surface water and sediment samples from the same location. The Cs-137 sediment concentration was 0.31 $\mathrm{pCi} / \mathrm{g}$, and the $\mathrm{Sr}-90$ concentration in surface water was $0.25 \mathrm{pCi} / \mathrm{L}$. The aquatic animal dose was estimated to be $2.39 \mathrm{E}-06 \mathrm{~Gy} /$ day and the estimated dose to riparian animals was $5.05 \mathrm{E}$ 06 Gy/day. Therefore, the dose to aquatic and riparian animals was also well below the $10 \mathrm{mGy} /$ day limit specified by the regulations.

\subsection{CUMULATIVE DOSE}

Table 8-5 summarizes the potential cumulative dose from the BNL site. The total dose to the MEI from air and ingestion pathways was estimated to be $3.11 \mathrm{mrem}(31 \mu \mathrm{Sv})$. In comparison, the EPA regulatory limit for the air pathway is $10 \mathrm{mrem}(100 \mu \mathrm{Sv})$ and the DOE limit from all pathways is $100 \mathrm{mrem}(1,000 \mu \mathrm{Sv})$. 
The cumulative population dose would be 0.30 person-rem ( 3 person-mSv) in a year. The effective dose was well below the DOE and EPA regulatory limits, and the ambient TLD dose was within normal background levels seen at the Laboratory site. The potential dose from drinking water was not estimated, because most of the residents adjacent to the BNL site get their drinking water from the Suffolk County Water Authority rather than private wells.

To put the potential dose impact into perspective, a comparison was made with other sources of radiation. The annual dose from all natural background sources and radon is approximately 300 mrem (3.0E-3 $\mu \mathrm{Sv})$. A diagnostic chest $\mathrm{x}-$ ray would result in 5 to $20 \mathrm{mrem}(50-200 \mu \mathrm{Sv})$ per exposure. Using natural gas in homes yields approximately 9 mrem $(90 \mu \mathrm{Sv})$ per year, cosmic radiation yields $26 \mathrm{mrem}(260 \mu \mathrm{Sv})$, and natural potassium in the body yields approximately 39 mrem $(390 \mu \mathrm{Sv})$ of internal dose. Even with worst-case estimates of dose from the air pathway and ingestion of local deer meat and fish, the cumulative dose from BNL operations was well below the dose that could be received from a single chest $\mathrm{x}$-ray.

\section{REFERENCES AND BIBLIOGRAPHY}

40 CFR 6I, Subpart H. National Emissions Standard for Hazardous Air Pollutants. U.S. Environmental Protection Agency, Washington, DC. 1989.

66 FR 25380. May 14, 200 I. U.S. Department of Energy. 10 CFR 834, Radiation Protection of the Public and the Environment. Federal Register.
ANSI/HPS. 1999. Sampling and Monitoring Releases of Airborne Radioactive Substances from the Stacks and Ducts of Nuclear Facilities. NI 3. I - 1999.

BNL 2006. Assessment of the High Flux Beam Reactors Airborne Tritium Test Results. January 2006.

BNL 2004. Brookhaven Graphite Research Reactor -SE-0403, Removal of BGRR-DP Canal and Contaminated Deep Soil. 2004.

DOE. 2002. A Graded Approach for Evaluation of Radiation Doses to Aquatic and Terrestrial Biota. DOE-STD-I I 53-2002. U.S. Department of Energy, Washington, DC. July 2002.

DOE Order 5400.5. 1990. Radiation Protection of the Public and the Environment. U.S. Department of Energy, Washington, DC. Change 2: 1-7-93

DOE/EH-007I. Internal Dose Conversion Factors for Calculations of Dose to the Public. July 1988.

EML-DOE. 2000. 12th International Intercomparison of Environmental Dosimeters. New York, NY.

EPA. 1992. User's Guide for CAP88-PC, Version 2.1.1 EPA 402B92001. U.S. Environmental Protection Agency, Washington, DC.

EPA. 1996. Food Ingestion Factors, Exposure Factors HandbookVolume II. EPA600P95002FB. U.S. Environmental Protection Agency, Washington, DC.

LIPA. 2000. Population Survey 1999: Current Population Estimates for Nassau and Suffolk Counties and the Rockaway Peninsula. Long Island Power Authority, Uniondale, NY. October 1999.

NCRP. 1987. Exposure of the Population of the United States and Canada from Natural Background Radiation. NCRP Report No. 94. National Council on Radiation Protection and Measurements, Bethesda, MD.

NYSDOH. 1993. Environmental Radiation in New York State. Bureau of Environmental Radiation Protection, New York State Department of Health, Albany, NY.

NYSDOH. 1996. Radioactive Contamination in the Peconic River. Bureau of Environmental Radiation Protection, New York State Department of Health, Albany, NY.

NYSDOH. 1999. Deer Meat Contaminated With Cs- 37 at Brookhaven National Laboratory. Bureau of Environmental Radiation Protection, New York State Department of Health, Albany, NY. 


\section{Quality Assurance}

Quality assurance is an integral part of every activity at Brookhaven National Laboratory. A comprehensive Quality Assurance/Quality Control (QA/QC) Program is in place to ensure that all environmental monitoring samples are representative and that data are reliable and defensible. QC in the contract analytical laboratories is maintained through daily instrument calibration, efficiency and background checks, and testing for precision and accuracy. Data are verified and validated as required by project-specific quality objectives before being used to support decision making. The multilayered components of QA monitored at BNL ensure that all analytical data reported for the 2006 Site Environmental Report are reliable and of high quality.

\section{I QUALITY PROGRAM ELEMENTS}

As required by DOE Order 450.1, Environmental Protection Program, BNL has established a QA/QC Program to ensure that the accuracy, precision, and reliability of environmental monitoring data are consistent with the requirements of Volume 10 of the Code of Federal Regulations, Section 830 (10 CFR 830), Subpart A, Quality Assurance Requirements (2005) and DOE Order 414.1C, Quality Assurance. The responsibility for quality at BNL starts with the Laboratory director, who approves the policies and standards of performance governing work, and extends throughout the entire organization. The purpose of the BNL Quality Management (QM) System is to implement QM methodology throughout the various Laboratory management systems and associated processes, in order to:

- Plan and perform BNL operations in a reliable and effective manner to minimize any impact on the health and safety of the public, employees, and the environment

- Standardize processes and support continual improvement in all aspects of Laboratory operations

- Enable the delivery of products and services that meet customers' requirements and expectations

For environmental monitoring, QA is deployed as an integrated system of management activities. These activities involve planning, implementation, control, reporting, assessment, and continual improvement. QC activities measure each process or service against the QA standards. QA/QC practices and procedures are documented in manuals, plans, and a comprehensive set of standard operating procedures (SOPs) for environmental monitoring (EMSOPs). Staff members who must follow these procedures are required to document that they have reviewed and understand them.

The ultimate goal of the environmental monitoring and analysis QA/QC program is to ensure that results are representative and defensible, and that data are of the type and quality needed to verify protection of the public, employees, and the environment. Figure 9-1 depicts the flow of the QA/QC elements of BNL's Environmental Monitoring Program and indicates the sections of this chapter that discuss each element in more detail.

Laboratory environmental personnel determine sampling requirements using the EPA Data Quality Objective (DQO) process (EPA 2000) or its equivalent. During this process, the project manager for each environmental program determines the type, amount, and quality of data needed to support decision making, legal requirements, and stakeholder concerns. An environmental monitoring plan or project-specific sampling plan is then prepared, specifying the 


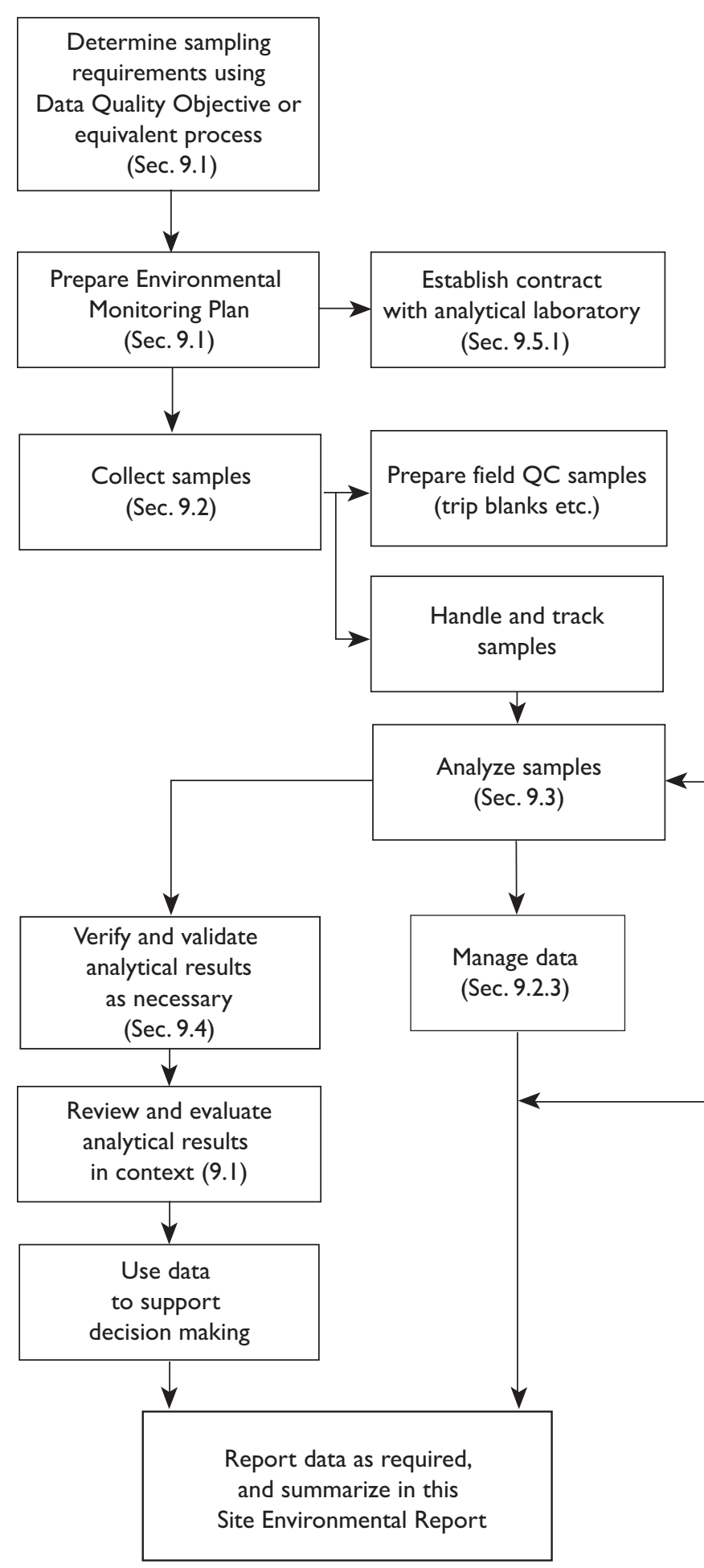

Figure 9-I. Flow of Environmental Monitoring QA/QC Program Elements.

location, frequency, type of sample, analytical methods to be used, and a sampling schedule. These plans and the EM-SOPs also specify data acceptance criteria. Contracts with off-site analytical laboratories are established for sampling analysis. The EM-SOPs direct sampling technicians on proper sample collection, preservation, and handling requirements. Field QC samples are prepared as necessary. Samples are analyzed in the field or at certified contract analytical laboratories in accordance with EM-SOPs. The results are then validated or verified in accordance with published procedures. Finally, data are reviewed and evaluated by environmental professionals and management in the context of expected results, related monitoring results, historical data, and applicable regulatory requirements (e.g., drinking water standards, permit limits, etc.). Data are then used to support decision making. Data are also reported as required and summarized in this annual report.

(Sec. 9.5)

\subsection{SAMPLE COLLECTION AND HANDLING}

In 2006, environmental

Test Laboratory

Proficiency (Sec. 9.6)

and Audit (Sec. 9.7) monitoring samples were collected as specified by EM-SOPs, the BNL Environmental Monitoring Plan Update January 2006 (BNL 2006), and project-specific work plans, as applicable. For example, the BNL Groundwater Monitoring Program Quality Assurance Project Plan (QAPP) (BNL 1999) describes the QA program and $\mathrm{QC}$ requirements that must be followed for groundwater monitoring. This plan documents organizational structure, documentation requirements, sampling requirements, field QA/QC sample collection, acceptance criteria, sample custody requirements, data validation procedures, and general data handling and database procedures.

BNL has sampling SOPs for all environmental media, including groundwater, surface water, soil, sediment, air, flora, and fauna. These procedures contain detailed information on how to prepare for sample collection; what type of field 
equipment to use and how to calibrate it; how to properly collect, handle, and preserve samples; and how to manage any wastes generated during sampling. The procedures ensure consistency between samples collected by BNL sampling personnel and outside contractors in support of the environmental restoration, compliance, and surveillance programs.

QC checks of sampling processes include the collection of field duplicates, matrix spike samples, field blanks, trip blanks, and equipment blanks. For example, field readings of water quality parameters are taken until all parameters are within acceptable limits. Also, specific sampling methodologies include QC checks. An example of this is the low-flow groundwater sampling technique, which includes checks to ensure that monitoring wells are properly purged before readings are taken.

All wastes generated during sampling (contaminated equipment, purge water from wells, etc.) are managed in accordance with applicable requirements. A factor considered during sample collection is minimizing the amount of waste generated, consistent with the Pollution Prevention Program described in Chapter 2.

\subsection{Field Sample Handling}

To ensure the integrity of samples, chain-ofcustody (COC) was maintained and documented for all samples collected in 2006. A sample is considered to be in the custody of a person if any of the following rules of custody are met: 1) the person has physical possession of the sample, 2) the sample remains in view of the person after being in possession, 3 ) the sample is placed in a secure location by the custody holder, or 4) the sample is in a designated secure area. These procedures are outlined in EM-SOP 109, "Chainof-Custody, Storage, Packaging, and Shipment of Samples" (BNL 2006a). All environmental monitoring samples in 2006 maintained a valid COC from the time of sample collection through sample disposal by the contract analytical laboratories.

\subsubsection{Custody and Documentation}

Field sampling technicians are responsible for the care and custody of samples until they are transferred to a receiving group or contract analytical laboratory. Samples requiring refrigeration are placed immediately into a refrigerator or a cooler with cooling media, and kept under custody rules. The technician signs the COC form when relinquishing custody, and contract analytical laboratory personnel sign the COC form when accepting custody.

As required by EM-SOP-201 (BNL 2004), the field sampling technician is also required to maintain a bound, weatherproof field logbook, which is used to record sample ID number, collection time, description, collection method, and COC number. Daily weather conditions, field measurements, and other appropriate sitespecific observations also are recorded in the logbook.

\subsubsection{Preservation and Shipment}

Before sample collection, the field sampling technicians prepare all bottle labels and affix them to the appropriate containers, as defined in the QA program plan or applicable EM-SOPs. Appropriate preservatives are added to the containers before or immediately after collection; in appropriate cases, samples are refrigerated. For example, samples collected for methylmercury are cooled immediately and shipped to the contract analytical laboratory on the day of collection. After samples arrive at the laboratory, they are preserved with hydrochloric acid.

Sample preservation is maintained as required throughout shipping. If samples are sent via commercial carrier, a bill-oflading is used. COC seals are placed on the shipping containers; their intact status upon receipt indicates that custody was maintained during shipment. These procedures are outlined in EM-SOP 109.

\subsubsection{Field Quality Control Samples}

Field QC samples collected for the environmental monitoring program include equipment blanks, trip blanks, field blanks, field duplicate samples, and ma- 
trix spike/matrix spike duplicate samples. The rationale for selecting specific field QC samples, and minimum requirements for their use in the environmental monitoring program, are provided in the BNL EM-SOP 200 series. Equipment blanks and trip blanks (see below) were collected for all appropriate media in 2006.

An equipment blank is a volume of solution (in this case, laboratory-grade water) that is used to rinse a sampling tool after decontamination. The rinse water is collected and tested to verify that the sampling tool is not contaminated. Equipment blank samples are collected, as needed, to verify the effectiveness of the decontamination procedures on nondedicated or reusable sampling equipment.

A trip blank is provided with each shipping container of samples to be analyzed for volatile organic compounds (VOCs). Analysis of trip blanks shows whether a sample bottle was contaminated during shipment from the manufacturer, while in bottle storage, in shipment to a contract analytical laboratory, or during analysis at a lab. Trip blanks consist of an aliquot of laboratory-grade water sealed in a sample bottle, usually prepared by the contract analytical laboratory prior to shipping the sample bottles to BNL. If trip blanks were not provided by the lab, then field sampling technicians prepare trip blanks before they collect the samples. Trip blanks were included with all shipments of aqueous samples for VOC analysis in 2006.

Field blanks are collected to check for crosscontamination that may occur during sample collection. For the Groundwater Monitoring Program, one field blank is collected for every 20 samples, or one per sampling round, whichever is more frequent. Field blanks are analyzed for the same parameters as the groundwater samples. For other programs, the frequency of field blank collection is based on their specific DQOs.

In 2006 (as in other years), the most common contaminants detected in the trip, field, and equipment blanks included methylene chloride, toluene, and chloroform. These compounds are commonly detected in blanks and do not pose significant problems with the reliability of the analytical results. Several other compounds were also detected, such as acetone and strontium-90 (Sr-90), at low levels. When these contaminants are detected, validation or verification procedures are used, where applicable, to qualify the associated data as "nondetects," (see Section 9.4). The results from blank samples collected during 2006 did not indicate any significant impact on the quality of the results.

Field duplicate samples are analyzed to check the reproducibility of sampling and analytical results, based on EPA Region II guidelines (EPA 2001). For example, in the Groundwater Monitoring Program, duplicates are collected for 5 percent of the total number of samples collected for a project per sampling round. During 2006, 123 duplicate samples were collected for nonradiological analyses, and 74 duplicate samples were collected for radiological analyses. All duplicate samples were acceptable for input into BNL's Environmental Information Management System (EIMS) database, which is used to manage the Laboratory's environmental data. Duplicates were analyzed only for the parameters relevant to the program they monitored. Of the 6,803 nonradiological parameters analyzed in 2006, 98.7 percent of the analyses met QA criteria. Of the 298 radiological parameters monitored, 98.7 percent met QA criteria. These results indicate consistency between the contract analytical laboratory and field sampling technicians.

Matrix spike and matrix spike duplicates are performed to determine whether the sample matrix (e.g., water, soil, air, vegetation, bone, or oil) adversely affected the sample analysis. A spike is a known amount of analyte added to a sample. Matrix spikes are performed at a rate specified by each environmental program's DQOs. The rate is typically one per 20 samples collected per project. No significant matrix effects were observed in 2006 for routine matrices such as water and soil. Nonroutine matrices, such as oil, exhibited the expected matrix issues.

\subsubsection{Tracking and Data Management}

Most environmental monitoring samples and analytical results were tracked in the EIMS. The small number of environmental samples that were not tracked in the EIMS were from 
Chemtex Lab, which cannot produce the electronic data deliverables needed to enter the data into BNL's EIMS. Tracking was initiated when a sample was recorded on a COC form. Copies of the COC form and supplemental forms were provided to the project manager or the sample coordinator and forwarded to the data coordinator to be entered into the EIMS. Each contract analytical laboratory also maintained its own internal sample tracking system.

Following sample analysis, the contract analytical laboratory provided the results to the project manager or designee and, when applicable, to the validation subcontractor, in accordance with their contract. Once results of the analyses are entered into the EIMS, reports can be generated by project personnel and DOE Brookhaven Site Office staff using a web-based data query tool.

\subsection{SAMPLE ANALYSIS}

In 2006, environmental samples were analyzed by one of five contract laboratories, whose selection is discussed in Section 9.3.1. All samples were analyzed according to EPA-approved methods, where such methods exist, and by standard industry methods where there are no EPA methods. In addition, field sampling technicians performed field monitoring for parameters such as conductivity, dissolved oxygen, $\mathrm{pH}$, temperature, and turbidity.

\subsection{Qualifications}

BNL used the following contract analytical laboratories for analysis of environmental samples in 2006:

- General Engineering Lab (GEL) in Charleston, South Carolina, for radiological and nonradiological analytes

- H2M Lab in Melville, New York, for nonradiological analytes

- Severn-Trent Lab (STL), based in St. Louis, Missouri, for radiological and nonradiological analytes

- Chemtex Lab in Port Arthur, Texas, for select nonradiological analytes

- Brooks Rand in Seattle, Washington, for mercury and methylmercury analyses

The process of selecting off-site contract ana- lytical laboratories involves a number of factors: 1) their record on performance evaluation (PE) tests, 2) their contract with the DOE Integrated Contract Procurement Team, 3) pre-selection bidding, and 4) their adherence to their own QA/QC programs, which must be documented and provided to BNL. Routine QC procedures that laboratories must follow, as discussed in Section 9.5, include daily instrument calibrations, efficiency and background checks, and standard tests for precision and accuracy. All the laboratories contracted by BNL in 2006 were certified by the New York State Department of Health (NYSDOH) for the relevant analytes, where such certification existed. The laboratories also were subject to PE testing and DOEsponsored audits (see Section 9.7).

\subsection{VERIFICATION AND VALIDATION OF ANALYTICAL RESULTS}

Environmental monitoring data are subject to data verification and, in certain cases, data validation, when the data quality objectives of the project require this step. For example, as per the BNL Groundwater Monitoring Program Quality Assurance Project Plan (BNL 1999), a significant portion of the groundwater samples analyzed for environmental restoration projects underwent data validation in addition to verification.

The data verification process involves checking for common errors associated with analytical data. The following criteria can cause data to be rejected during the data verification process:

- Holding time missed - The analysis is not initiated or the sample is not extracted within the time frame required by EPA or by the contract.

- Incorrect test method - The analysis is not performed according to a method required by the contract.

- Poor recovery - The compounds or radioisotopes added to the sample before laboratory processing are not recovered at the recovery ratio required by the contract.

- Insufficient $Q A / Q C$ data - Supporting data received from the contract analytical laboratory are insufficient to allow validation of results. 
- Incorrect minimum detection limit (MDL). The contract analytical laboratory reports extremely low levels of analytes as "less than minimum detectable," but the contractually required limit is not used.

- Invalid chain-of-custody - There is a failure to maintain proper custody of samples, as documented on COC forms.

- Instrument failure - The instrument does not perform correctly.

- Preservation requirements not met - The requirements identified by the specific analytical method are not met or properly documented.

- Contamination of samples from outside sources - These possible sources include sampling equipment, personnel, and the contract analytical laboratory.

- Matrix interference - Analysis is affected by dissolved inorganic/organic materials in the matrix.

Data validation involves a more extensive process than data verification. Validation includes all the verification checks as well as checks for less common errors, including instrument calibration that was not conducted as required, internal analyte standard errors, transcription errors, and calculation errors. The amount of data checked varies, depending on the environmental media and on the DQOs for each project. Data for some projects, such as long-term groundwater monitoring, may require only verification. Data from initial investigations receive the more rigorous validation testing, performed on 20 to 100 percent of the analytical results. The results of the verification or validation process are entered into the EIMS.

\subsection{Checking Results}

Nonradiological data analyzed in 2006 were verified and/or validated, when project DQOs required, using BNL EM-SOPs in the 200 Series and EPA contract laboratory program guidelines (EPA 1992, 2001). Radiological packages were verified and validated using $\mathrm{BNL}$ and DOE guidance documents (BNL 2002, DOE 1994). During 2006, the verifications were conducted using a combination of manually checking the hard copy data packages and the use of a computer program developed at BNL to verify the information reported electronically and stored in the EIMS.

\subsection{CONTRACT ANALYTICAL LABORATORY QA/QC}

In 2006, procedures for calibrating instruments, analyzing samples, and assessing QC were consistent with EPA methodology. QC checks performed included: analyzing blanks and instrument background; using Amersham Radiopharmaceutical Company or National Institute for Standards and Technology (NIST) traceable standards; and analyzing reference standards, spiked samples, and duplicate samples. Analytical laboratory contracts specify analytes, methods, required detection limits, and deliverables - which include standard batch QA/QC performance checks. As part of the laboratory selection process, candidate laboratories are required to provide BNL with copies of their QA/QC manuals and QA program plans.

When discrepancies were found in field sampling designs, documented procedures, $\mathrm{COC}$ forms, data analyses, data processing systems, and QA software, or when failures in PE testing occurred, nonconformance reports were generated. Following investigation into the root causes, corrective actions were taken and tracked to closure.

\subsection{PERFORMANCE OR PROFICIENCY EVALUATIONS}

Four of the contract analytical laboratories (GEL, STL, H2M, and Brooks Rand) participated in several national and state PE testing programs in 2006. The fifth contractor, Chemtex Laboratory, did not participate in PE testing because there is no testing program for the specific analytes Chemtex analyzed: tolytriazole, polypropylene glycol monobutyl ether, and 1,1hydroxyethylidene diphosphonic acid. Each of the participating laboratories took part in at least one testing program, and several laboratories participated in multiple programs. Results of the tests provide information on the quality of a laboratory's analytical capabilities. The testing was conducted by Environmental Resource Associates (ERA), the National Voluntary Laboratory 
Accreditation Program (NVLAP), the voluntary Mixed Analyte Performance Evaluation Program (MAPEP), and NYSDOH Environmental Laboratory Accreditation Program (ELAP). The results from these tests are summarized in Section 9.6.1. Because Brooks Rand analyzed samples only for mercury and methylmercury, their PE results are not summarized. Brooks Rand maintained the required certification when performing analyses for BNL in 2006.

\subsection{Summary of Test Results}

In Figures 9-2 and 9-3, results are plotted as percentage scores that were "Acceptable," "Warning (But Acceptable)," or "Not Acceptable." A Warning (But Acceptable) is considered by the testing organization to be "satisfactory." An "average overall satisfactory" score is the sum of results rated as Acceptable and those rated as Warning (But Acceptable), divided by the total number of results reported. A Not Acceptable rating reflects a result that is greater than three standard deviations from the known value - a criterion set by the independent testing organizations.

Figure 9-2 summarizes radiological performance scores in the ERA and MAPEP programs. During 2006, the New York State ELAP did not provide radiological samples for PE testing, so there were no ELAP scores as there have been in past years. GEL and STL had average overall satisfactory scores of 95 and 93 percent, respectively. More details about the radiological assessments are in Section 9.6.2.1.

Figure 9-3 summarizes the nonradiological performance results of the three participating laboratories (GEL, H2M, and STL) in the ERA, MAPEP, and ELAP tests. For nonradiological tests, the average overall satisfactory results ranged from 93.1 to 100 percent. Additional details on nonradiological evaluations are in Section 9.6.2.2.

\subsubsection{Radiological Assessments}

In 2006, STL participated in the ERA radiological program. GEL participated in the ERA and MAPEP programs. NYSDOH ELAP provided no samples for radiological testing in 2006.
Both GEL and STL participated in the ERA radiological PE studies. For GEL's tests on radiological samples, 95.7 percent were in the acceptable range; 92.9 percent of STL's tests were acceptable. GEL participated in the MAPEP evaluations: 88.1 percent of GEL's tests on radiological samples were in the acceptable range, and 6.7 percent were in the warning (but acceptable) range.

\subsubsection{Nonradiological Assessments}

During 2006, H2M and GEL participated in the NYSDOH ELAP evaluations of performance on tests of nonpotable water, potable water, and solid wastes. NYSDOH found 98.1 percent of H2M's nonradiological tests to be in the acceptable range and 92.1 percent of GEL's nonradiological tests to be in the acceptable range. STL, which is certified through the National Environmental Laboratory Accreditation Conference (NELAC), was not required to participate in ELAP evaluations.

H2M, STL, and GEL voluntarily participated in the ERA water supply and water pollution studies, although this evaluation is not required for New York State certification. ERA found that 96.2 percent of H2M's tests were in the acceptable range and 94.7 percent of STL's tests were in the acceptable range, as were 95.1 percent of GEL's tests.

GEL also voluntarily participated in MAPEP evaluations. These evaluations showed that 98.8 percent of GEL's nonradiological tests were in the acceptable range.

$\mathrm{H} 2 \mathrm{M}$ also voluntarily participated in NISTNVLAP evaluations. These evaluations showed that 98.0 percent of H2M's nonradiological tests were in the acceptable range.

\subsection{AUDITS}

As part of DOE's Integrated Contract Procurement Team Program, STL and GEL were audited during 2006 (DOE 2006a, b). During the audits, errors are categorized into Priority I and Priority II findings. Priority I status indicates a problem that can result in unusable data or a finding that the contract analytical laboratory cannot adequately perform services for DOE. Priority II status indicates problems 


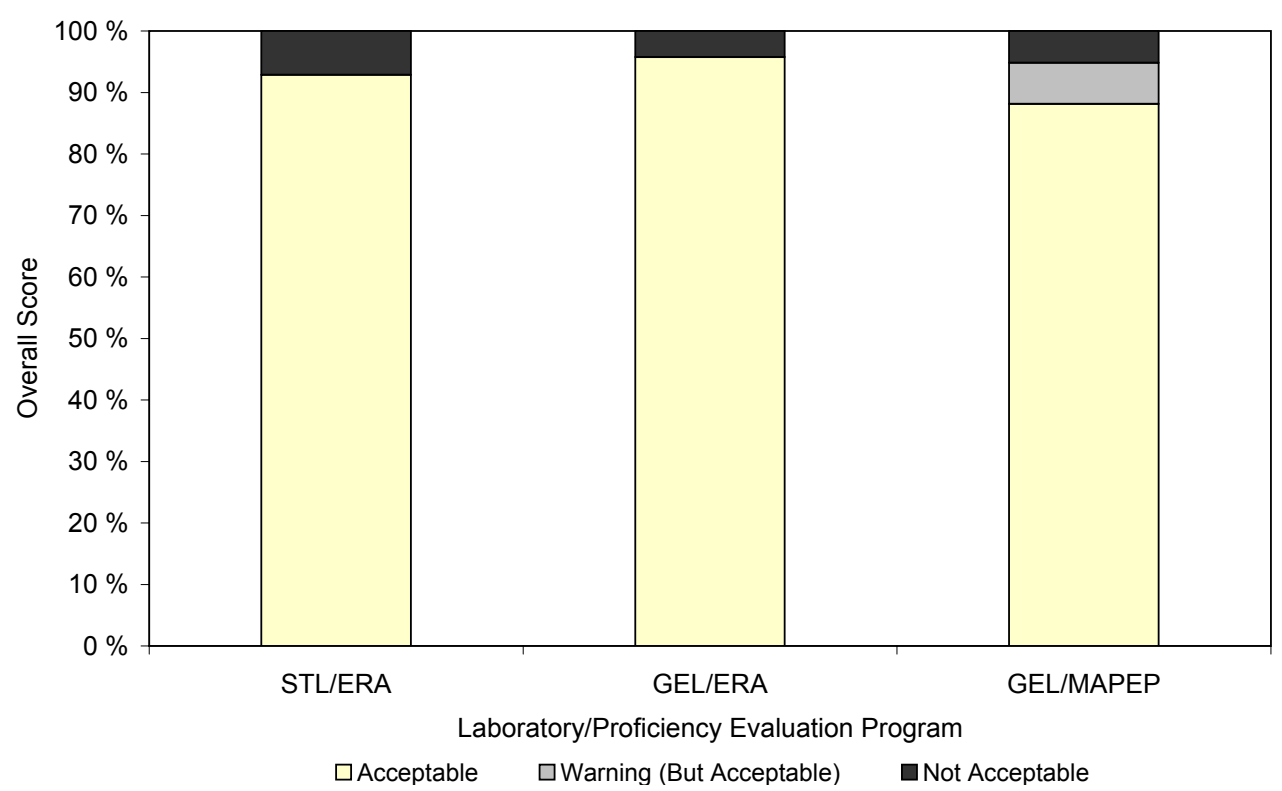

Note that the Acceptable scores and the Warning (But Acceptable) scores combined constitute the "overall satisfactory" category referred to in the text of this chapter.

Figure 9-2. Summary of Scores in the Radiological Proficiency Evaluation Programs.

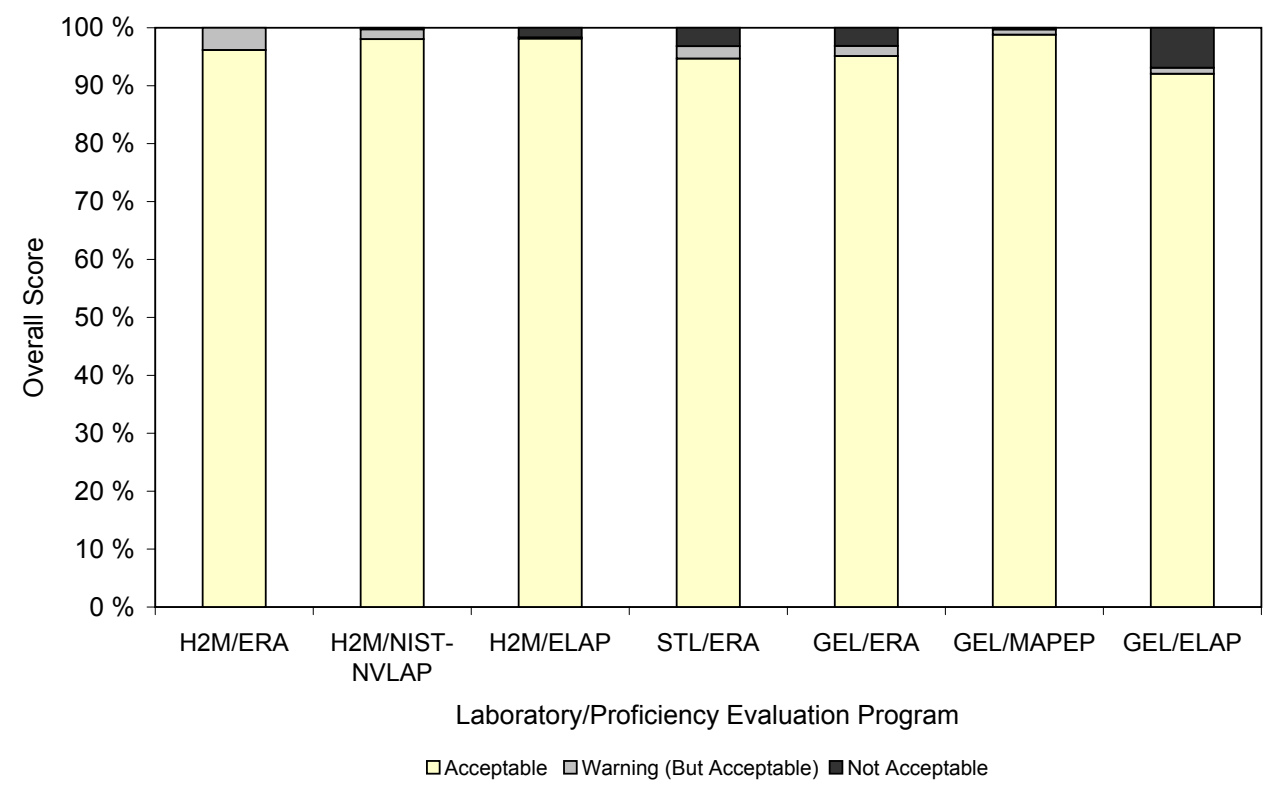

Note that the Acceptable scores and the Warning (But Acceptable) scores combined constitute the "overall satisfactory" category referred to in the text of this chapter.

Figure 9-3. Summary of Scores in the Nonradiological Proficiency Evaluation Programs.

that do not result in unusable data and do not indicate that the contract analytical laboratory cannot adequately perform services for DOE (DOE 2002). There were no Priority I findings for STL and GEL.
The results of the STL audit included 14 Priority II findings: five radiological findings, three QA management system findings, one waste management finding, three organic findings, one inorganic finding, and one labora- 
tory information management system (LIMS) finding. The results of the GEL audit included seven Priority II findings: two QA management system findings, two organic findings, one inorganic finding, one radiological finding and one waste management finding. Corrective action plans were submitted to DOE by both contract analytical laboratories to document that procedures were put in place to correct these findings. Based on the audits, the analytical data met DOE's criteria for acceptable status.

\subsection{CONCLUSION}

Based on the data validations, data verifications, and results of the independent Performance Evaluation assessments, the chemical and radiological results reported in this 2006 Site Environmental Report are of acceptable quality.

\section{REFERENCES AND BIBLIOGRAPHY}

10 CFR 830 Subpart A. U.S. Department of Energy. Quality Assurance Requirements. U.S. Code of Federal Regulations. 2000.

BNL. 1999. BNL Groundwater Monitoring Program Quality Assurance Project Plan (QAPP). Brookhaven National Laboratory. Upton, NY. August 31, 1999.

BNL. 2002. EM-SOP 209. "Radiochemical Data Validation." Brookhaven National Laboratory, Upton, NY.

BNL 2004. EM-SOP-20 I "Documentation of Field Activities." Brookhaven National Laboratory, Upton, NY. Revision I.
BNL. 2006a. EM-SOP 109. "Chain-of-Custody, Storage, Packaging, and Shipment of Samples." Brookhaven National Laoratory. Upton, NY. Revision 3.

BNL. 2007. Brookhaven National Laboratory Environmental Monitoring Plan Update January 2007. BNL-52676-2006. Brookhaven National Laboratory, Upton, NY.

DOE. 1994. RD-4 Guidance for Radiochemical Data Validation. Draft. Report EM-73. U.S. Department of Energy, Washington, DC.

DOE. 2006a. Continuing Qualification Audit of Severn Trent Laboratories, Inc. Earth City, Mo. May 30, 2006.

DOE. 2006b. Continuing Qualification Audit of General Engineering Laboratories, Inc. Charleston, South Carolina. July 19,2006

DOE. Order 4I 4. I C. 2005. QualityAssurance. U.S. Department of Energy. Washington, DC. November 24, 1998.

DOE. Order 450.I. 2003. Environmental Protection Program. U.S. Department of Energy. Washington, DC. I - I5-03.

DOE. 2002. Environmental Management Consolidated Audit Program EMCAP Procedure Number 1.0 Revision 2. October I, 2002.

EPA. 1992. Evaluation of Metals Data for the Contract Laboratory Program. EPA Region-II SOP HW-2. U.S. Environmental Protection Agency, Washington, DC.

EPA. 1998. EPA Requirements for Quality Assurance Project Plans for Environmental Data Operations. Report QA/R-5. U.S Environmental Protection Agency, Washington, DC.

EPA. 2000. "Guidance for the Data Quality Objectives Process (QA/G-4)." U.S. Environmental Protection Agency, Washington, DC.

EPA. 200 I. CLP Organic Data Review and Preliminary Review. EPA Region-II SOP HW-6. U.S. Environmental Protection Agency, Washington, DC. Revision 12, March 2001. 


\section{Acronyms and Abbreviations}

These acronyms and abbreviations reflect the typical manner in which terms are used for this specific document and may not apply to all situations. Items with an asterisk $(*)$ are described in the glossary of technical terms, which follows this list.

\begin{tabular}{|c|c|c|c|}
\hline AEC & Atomic Energy Commission & CRM & Cultural Resource Management \\
\hline AGS & Alternating Gradient Synchrotron & CRMP & Cultural Resource Management Plan \\
\hline ALARA* & "As Low As Reasonably Achievable" & Cs & cesium \\
\hline AMSL & above mean sea level & CSF & Central Steam Facility \\
\hline AOC* & area of concern & CTN & Center for Transitional Neuroimaging \\
\hline APG & Analytical Products Group & CWA* & Clean Water Act \\
\hline \multirow[t]{2}{*}{ ARARs } & \multirow{2}{*}{$\begin{array}{l}\text { Applicable, Relevant, and Appropriate } \\
\text { Requirements }\end{array}$} & $\mathrm{CY}$ & calendar year \\
\hline & & $\mathrm{D}_{2} \mathrm{O} *$ & heavy water \\
\hline ARPA* & Archeological Resource Protection Act & DAC & Derived Air Concentration \\
\hline AS/SVE* & air sparging/soil vapor extraction & DCA & I,I-dichloroethane \\
\hline AST & aboveground storage tank & DCE & I, I-dichloroethylene \\
\hline AWQS & Ambient Water Quality Standards & DCG* & derived concentration guide \\
\hline BAF & Booster Applications Facility & $D \& D$ & decontamination and decommissioning \\
\hline BGD & belowground duct & DDD & dichlorodiphenyldichloroethane \\
\hline BGRR & Brookhaven Graphite Research Reactor & DDE & dichlorodiphenyldichloroethylene \\
\hline $\mathrm{BHSO}$ & DOE Brookhaven Site Office & DDT & dichlorodiphenyltrichloroethane \\
\hline BLIP & Brookhaven Linac Isotope Producer & DMR & Discharge Monitoring Report \\
\hline BMRR & Brookhaven Medical Research Reactor & DOE* & U.S. Department of Energy \\
\hline BNL & Brookhaven National Laboratory & $\mathrm{DOE} \mathrm{CH}$ & DOE Chicago Operations Office \\
\hline BOD* & biochemical oxygen demand & DQO & Data Quality Objective \\
\hline $\mathrm{Bq}^{*}$ & becquerel & DSB & Duct Service Building \\
\hline $\mathrm{Bq} / \mathrm{g}$ & becquerel per gram & DUV - FEL & Deep UltraViolet - Free Electron Laser \\
\hline $\mathrm{Bq} / \mathrm{L}$ & becquerel per liter & DWS & Drinking Water Standards \\
\hline BRAHMS & Broad Range Hadron Magnetic Spectrometer & $\mathrm{EA}^{*}$ & Environmental Assessment \\
\hline BSA & Brookhaven Science Associates & EDB* & ethylene dibromide \\
\hline Btu & British thermal units & EDE* & Effective Dose Equivalent \\
\hline CAA* & Clean Air Act & EDTA & ethylenediaminetetraacetic acid \\
\hline CAAA* & CAA Amendments (1990) & $\mathrm{EE} / \mathrm{CA}$ & Engineering Evaluation/Cost Analysis \\
\hline CAC & Community Advisory Council & EIMS* & Environmental Information Management \\
\hline CAP & Clean Air Act Assessment Package & & System \\
\hline CBS & chemical bulk storage & ELAP & Environmental Laboratory Approval Program \\
\hline CEGPA & Community, Education, Government and & EML & Environmental Measurements Laboratory \\
\hline & Public Affairs & EMP & Environmental Monitoring Plan \\
\hline CERCLA* & Comprehensive Environmental Response, & EMS* & Environmental Management System \\
\hline & & EPA* & U.S. Environmental Protection Agency \\
\hline CFC-II & an ozone-depleting refrigerant & EPCRA* & Emergency Planning and \\
\hline $\mathrm{cfm}, \mathrm{cfs}$ & cubic feet per minute, per second & & Community Right-to-Know Act \\
\hline CFN & Center for Functional Nanomaterials & ER & environmental restoration \\
\hline CFR & U.S. Code of Federal Regulations & ERA & Environmental Resource Associates \\
\hline $\mathrm{Ci}^{*}$ & curie & ERD & Environmental Restoration Division \\
\hline $\mathrm{CO}$ & certificate to operate & ES* & environmental surveillance \\
\hline $\mathrm{COC}^{*}$ & chain-of-custody & ESR & Experimental Safety Review \\
\hline
\end{tabular}




\begin{tabular}{|c|c|c|c|}
\hline $\begin{array}{l}\text { ES\&H } \\
\text { ESA* }\end{array}$ & $\begin{array}{l}\text { Environment, Safety, and Health } \\
\text { Endangered Species Act }\end{array}$ & LSTPD & $\begin{array}{l}\text { Laboratory Science Teacher Professional } \\
\text { Development }\end{array}$ \\
\hline ESH\&Q & $\begin{array}{l}\text { Environment, Safety, Health, and } \\
\text { Quality Directorate }\end{array}$ & $\begin{array}{l}\text { MACT } \\
\text { MAPEP }\end{array}$ & $\begin{array}{l}\text { Maximum Available Control Technology } \\
\text { Mixed Analyte Performance Evaluation }\end{array}$ \\
\hline $\mathrm{ESSH}$ & Environmental Safety, Security and Health & & Program \\
\hline EWMSD & $\begin{array}{l}\text { Environmental and Waste Management } \\
\text { Services Division }\end{array}$ & $\begin{array}{l}\text { MAR } \\
\text { MCL }\end{array}$ & $\begin{array}{l}\text { Materials-at-risk } \\
\text { maximum contaminant level }\end{array}$ \\
\hline FFCA* & Federal Facilities Compliance Act & MDL* & minimum detection limit \\
\hline FIFRA* & $\begin{array}{l}\text { Federal Insecticide, Fungicide, and } \\
\text { Rodenticide Act }\end{array}$ & $\begin{array}{l}\mathrm{MEI} * \\
\mathrm{MeV}\end{array}$ & $\begin{array}{l}\text { maximally exposed individual } \\
\text { million electron volts }\end{array}$ \\
\hline FRP & Facility Response Plan & MGD & million gallons per day \\
\hline FWS* & U.S. Fish \& Wildlife Service & $\mathrm{mg} / \mathrm{L}$ & milligrams per liter \\
\hline FY & fiscal year & MMBtu & million British thermal units \\
\hline GBq & giga (billion or $\mathrm{E}+09$ ) becquerel & MOA & Memorandum of Agreement \\
\hline GAB & gross alpha and beta & MPF & Major Petroleum Facility \\
\hline GC/ECD & $\begin{array}{l}\text { gas chromatography/electron capture } \\
\text { detector }\end{array}$ & $\begin{array}{l}\text { MPN } \\
\text { mrem }\end{array}$ & $\begin{array}{l}\text { most probable number } \\
\text { milli (thousandth of a) rem }\end{array}$ \\
\hline GC/MS & gas chromatography/mass spectrometry & MRI & Magnetic Resonance Imaging \\
\hline GDS & Groundwater Discharge Standard & MRC & Medical Research Center \\
\hline GEL & General Engineering Laboratory, LLC & MSL* & mean sea level \\
\hline $\mathrm{GeV}$ & giga (billion) electron volts & $\mathrm{mSv}$ & millisievert \\
\hline gge & gas gallon equivalent & MTBE & methyl tertiary butyl ether \\
\hline GIS & Geographical Information System & MW & megawatt \\
\hline GWh & gigawatt hour & $\mu g / L$ & micrograms per liter \\
\hline $\mathrm{H} 2 \mathrm{M}$ & H2M Labs, Inc. & NA & not analyzed \\
\hline $\begin{array}{l}\text { HEPA } \\
\text { HFBR }\end{array}$ & $\begin{array}{l}\text { high efficiency particulate air } \\
\text { High Flux Beam Reactor }\end{array}$ & NCRP & $\begin{array}{l}\text { National Council on Radiation Protection } \\
\text { and Measurements }\end{array}$ \\
\hline HTO & tritiated water (liquid or vapor) & ND & not detected \\
\hline HVAC & heating/ventilation/air conditioning & NEAR & Neighbors Expecting Accountability and \\
\hline HWMF & Hazardous Waste Management Facility & & Remediation \\
\hline I & lodine & NELAC & $\begin{array}{l}\text { National Environmental Laboratory } \\
\text { Accreditation Conference }\end{array}$ \\
\hline $\begin{array}{l}\text { IAEA } \\
\text { IAG }\end{array}$ & $\begin{array}{l}\text { International Atomic Energy Agency } \\
\text { Interagency Agreement }\end{array}$ & NELAP & $\begin{array}{l}\text { National Environmental Laboratory } \\
\text { Accreditation Program }\end{array}$ \\
\hline IC & ion chromatography & NEPA* & National Environmental Policy Act \\
\hline ICP/MS & $\begin{array}{l}\text { inductively coupled plasma/mass } \\
\text { spectrometry }\end{array}$ & NESHAPs* & $\begin{array}{l}\text { National Emission Standards for Hazardous } \\
\text { Air Pollutants }\end{array}$ \\
\hline ISMS & Integrated Safety Management System & $\mathrm{ng} / \mathrm{J}$ & nano (one-billionth) gram per Joule \\
\hline ISO* & $\begin{array}{l}\text { International Organization for } \\
\text { Standardization }\end{array}$ & NHPA* & National Historic Preservation Act \\
\hline K & potassium & NIST & $\begin{array}{l}\text { National Institute for Standards and } \\
\text { Technology }\end{array}$ \\
\hline $\mathrm{kBq}$ & kilobecquerels (I,000 Bq) & $\mathrm{NO}_{2}$ & nitrogen dioxide \\
\hline $\mathrm{KeV}$ & kilo (thousand) electron volts & NOV & Notice of Violation \\
\hline $\mathrm{Kr}$ & kryptonite & $\mathrm{NO}_{x}^{*}$ & nitrogen oxides \\
\hline $\mathrm{kwH}$ & kilowatt hours & NOEC & no observable effect concentration \\
\hline LDR & Land Disposal Restriction & NPDES & National Pollutant Discharge Elimination \\
\hline LED & light emitting diode & & System \\
\hline LEED & $\begin{array}{l}\text { Leadership in Energy and Environmental } \\
\text { Design }\end{array}$ & $\begin{array}{l}\text { NR } \\
\text { NRMP }\end{array}$ & $\begin{array}{l}\text { not required } \\
\text { Natural Resource Management Plan }\end{array}$ \\
\hline LIE & Long Island Expressway & NS & not sampled \\
\hline Linac & Linear Accelerator & NSF-ISR & NSF-International Strategic Registrations, Ltd. \\
\hline LIPA & Long Island Power Authority & NSLS & National Synchrotron Light Source \\
\hline
\end{tabular}




\begin{tabular}{|c|c|c|c|}
\hline $\begin{array}{l}\text { NSRL } \\
\text { NT }\end{array}$ & $\begin{array}{l}\text { NASA Space Radiation Laboratory } \\
\text { not tested }\end{array}$ & SCDHS & $\begin{array}{l}\text { Suffolk County Department of Health } \\
\text { Services }\end{array}$ \\
\hline NYCRR* & New York Codes, Rules, and Regulations & SCSC & Suffolk County Sanitary Code \\
\hline NYPA & New York Power Authority & SDL & Source Development Laboratory \\
\hline NYS & New York State & SDWA* & Safe Drinking Water Act \\
\hline NYSDEC & $\begin{array}{l}\text { NYS Department of Environmental } \\
\text { Conservation }\end{array}$ & $\begin{array}{l}\text { SER } \\
\text { SI }\end{array}$ & $\begin{array}{l}\text { Site Environmental Report } \\
\text { International System (measurement units) }\end{array}$ \\
\hline NYSDOH & NYS Department of Health & SNS & standard not specified \\
\hline NYSHPO & NYS Historic Preservation Office & $\mathrm{SO}_{2}$ & sulfur dioxide \\
\hline $\mathrm{O}_{3}^{*}$ & ozone & SOP & standard operating procedure \\
\hline ODS & ozone-depleting substances & SPCC & Spill Prevention Control and \\
\hline OHSAS & $\begin{array}{l}\text { Occupational Health and Safety Assessment } \\
\text { Series }\end{array}$ & SPDES* & $\begin{array}{l}\text { Countermeasures } \\
\text { State Pollutant Discharge Elimination System }\end{array}$ \\
\hline OMC & Occupational Medical Clinic & $\mathrm{Sr}$ & strontium \\
\hline ORC & oxygen-releasing compound & STAR & Solenoid Tracker at RHIC \\
\hline ORPS* & $\begin{array}{l}\text { Occurrence Reporting and Processing } \\
\text { System }\end{array}$ & $\begin{array}{l}\text { STEM } \\
\text { STL }\end{array}$ & $\begin{array}{l}\text { Scanning Transmission Electron Microscope } \\
\text { Severn Trent Laboratories, Inc. }\end{array}$ \\
\hline OSHA & $\begin{array}{l}\text { Occupational Health and Safety } \\
\text { Administration }\end{array}$ & $\begin{array}{l}\text { STP } \\
\text { SU }\end{array}$ & $\begin{array}{l}\text { Sewage Treatment Plant } \\
\text { standard unit }\end{array}$ \\
\hline OU* & operable unit & SUNY & State University of New York \\
\hline $\mathrm{P} 2 *$ & pollution prevention & Sv* & sievert; unit for assessing radiation dose risk \\
\hline PAAA* & Price-Anderson Act Amendment & SVE* & soil vapor extraction \\
\hline PAF & Process Assessment Form & SVOC* & semivolatile organic compound \\
\hline $\mathrm{Pb}$ & lead & $\mathrm{t}_{1 / 2} *$ & half-life \\
\hline PBT & persistent, bioaccumulative, and toxic & TAG & Technical Advisory Group \\
\hline PCBs* & polychlorinated biphenyls & $\mathrm{TBq}$ & tera (trillion, or $\mathrm{E}+12$ ) becquerel \\
\hline PCE & tetrachloroethylene (or perchloroethylene) & TCA & I, I, I-trichloroethane \\
\hline $\begin{array}{l}\mathrm{pCi} / g \\
\mathrm{PE}\end{array}$ & $\begin{array}{l}\text { picocuries per gram } \\
\text { performance evaluation }\end{array}$ & TCAP & $\begin{array}{l}\text { Transportation Safety and Operations } \\
\text { Compliance Assurance Process }\end{array}$ \\
\hline PET & positron emission tomography & TCE* & trichloroethylene \\
\hline ppb & parts per billion & TCLP & toxicity characteristic leaching procedure \\
\hline Ppm & parts per million & TKN & Total Kjeldahl nitrogen \\
\hline QA* & quality assurance & TLD* & thermoluminescent dosimeter \\
\hline QAPP & Quality Assurance Program Plan & TPL & Target Processing Laboratory \\
\hline QC* & quality control & TRE & Toxic Reduction Evaluation \\
\hline QM & Quality Management & TRI & Toxic Release Inventory \\
\hline R-II (etc.) & ozone-depleting refrigerant & TSCA* & Toxic Substances Control Act \\
\hline $\mathrm{RA}^{*}$ & removal action & TVDG & Tandem Van de Graaff \\
\hline RACT & Reasonably Available Control Technology & TVOC* & total volatile organic compounds \\
\hline RCRA* & Resource Conservation and Recovery Act & UIC* & underground injection control \\
\hline RF & resuspension factor & UST* & underground storage tank \\
\hline RHIC & Relativistic Heavy lon Collider & VOC* & volatile organic compound \\
\hline ROD* & Record of Decision & VUV* & very ultraviolet \\
\hline RPD & relative percent difference & WAC & waste acceptance criteria \\
\hline RSB & Research Support Building & WCPP & Waste Certification Program Plan \\
\hline RWMB & Radioactive Waste Management Basis & WCF & Waste Concentration Facility \\
\hline RWP & Radiological Work Permit & WET & Whole Effluent Toxicity \\
\hline SARA* & $\begin{array}{l}\text { Superfund Amendments and Reauthorization } \\
\text { Act }\end{array}$ & $\begin{array}{l}\text { WM } \\
\text { WMF }\end{array}$ & $\begin{array}{l}\text { Waste Management } \\
\text { Waste Management Facility }\end{array}$ \\
\hline SBMS* & Standards Based Management System & WTP & Water Treatment Plant \\
\hline
\end{tabular}




\section{Technical Terms}

These definitions reflect the typical manner in which the terms are used for this specific document and may not apply to all situations. Bold-face words in the descriptions are defined in separate entries.

\section{A}

AA (atomic absorption) - A spectroscopy method used to determine the elemental composition of a sample. In this method, the sample is vaporized and the amount of light it absorbs is measured.

accuracy - The degree of agreement of a measurement with an accepted reference or true value. It can be expressed as the difference between two values, as a percentage of the reference or true value, or as a ratio of the measured value and the reference or true value.

activation - The process of making a material radioactive by bombardment with neutrons, protons, or other high energy particles.

activation product - A material that has become radioactive by bombardment with neutrons, protons, or other high energy particles.

activity - Synonym for radioactivity.

Administrative Record - A collection of documents established in compliance with CERCLA. Consists of information the CERCLA lead agency uses in its decision on the selection of response actions. The Administrative Record file should be established at or near the facility and made available to the public. An Administrative Record can also be the record for any enforcement case.

aerobic - An aerobic organism is one that lives, acts, or occurs only in the presence of oxygen.

aerosol - A gaseous suspension of very small particles of liquid or solid.

ALARA (As Low As Reasonably Achievable) - A phrase that describes an approach to minimize exposures to individuals and minimize releases of radioactive or other harmful material to the environment to levels as low as social, technical, economic, practical, and public policy considerations will permit. ALARA is not a dose limit, but a process with a goal to keep dose levels as far below applicable limits as is practicable.

alpha radiation - The emission of alpha particles during radioactive decay. Alpha particles are identical in makeup to the nucleus of a helium atom and have a positive charge. Alpha radiation is easily stopped by materials as thin as a sheet of paper and has a range in air of only an inch or so. Despite its low penetration ability, alpha radiation is densely ionizing and therefore very damaging when ingested or inhaled. Naturally occurring radioactive sources such as radon emit alpha radiation. air stripping - A process for removing VOCs from contaminated water by forcing a stream of air through the water in a vessel. The contaminants evaporate into the air stream. The air may be further treated before it is released into the atmosphere.

ambient air - The surrounding atmosphere, usually the outside air, as it exists around people, animals, plants, and structures. It does not include the air immediately adjacent to emission sources.

analyte - A constituent that is being analyzed.

anneal - To heat a material and then cool it. In the case of thermoluminescent dosimeters (TLDs), this is done to reveal the amount of radiation the material had absorbed.

anion - A negatively charged ion, often written as a superscript negative sign after an element symbol, such as $\mathrm{Cl}^{-}$.

anthropogenic - Resulting from human activity; anthropogenic radiation is human-made, not naturally occurring

AOC (area of concern) - Under CERCLA, this term refers to an area where releases of hazardous substances may have occurred or a location where there has been a release or threat of a release of a hazardous substance, pollutant, or contaminant (including radionuclides). AOCs may include, but need not be limited to, former spill areas, landfills, surface impoundments, waste piles, land treatment units, transfer stations, wastewater treatment units, incinerators, container storage areas, scrap yards, cesspools, tanks, and associated piping that are known to have caused a release into the environment or whose integrity has not been verified.

aquifer - A water-saturated layer of rock or soil below the ground surface that can supply usable quantities of groundwater to wells and springs. Aquifers can be a source of water for domestic, agricultural, and industrial uses.

ARPA (Archaeological Resources Protection Act) This law, passed in 1979, has been amended four times. It protects any material remains of past human life or activities that are of archaeological interest. Known and potential sites of interest are protected from uncontrolled excavations and pillage, and artifacts found on public and Indian lands are banned from commercial exchange. (source: http:// www.cr.nps.gov/linklaws.htm, accessed 3-7-05)

AS/SVE (air sparging/soil vapor extraction) - A method of extracting volatile organic compounds from the groundwater, in place, using compressed air. (In contrast, air stripping occurs in a vessel.) The vapors are typically collected using a soil vapor extraction system. 
$\mathrm{B}$

background - A sample or location used as reference or control to compare BNL analytical results to those in areas that could not have been impacted by BNL operations.

background radiation - Radiation present in the environment as a result of naturally occurring radioactive materials in the Earth, cosmic radiation, or human-made radiation sources, including fallout.

beta radiation - Beta radiation is composed of charged particles emitted from a nucleus during radioactive decay. A negatively charged beta particle is identical to an electron. A positively charged beta particle is called a positron. Beta radiation is more penetrating than alpha radiation, but it may be stopped by materials such as aluminum or Lucite ${ }^{\mathrm{TM}}$ panels. Naturally occurring radioactive elements such as potassium-40 emit beta radiation.

blank - A sample (usually reagent-grade water) used for quality control of field sampling methods, to demonstrate that cross contamination has not occurred.

blowdown - Water discharged from either a boiler or cooling tower in order to prevent the build-up of inorganic matter within the boiler or tower and to prevent scale formation (i.e., corrosion).

BOD (biochemical oxygen demand) - A measure of the amount of oxygen in biological processes that breaks down organic matter in water; a measure of the organic pollutant load. It is used as an indicator of water quality.

Bq (becquerel) - A quantitative measure of radioactivity. This alternate measure of activity is used internationally and with increasing frequency in the United States. One Bq of activity is equal to one nuclear decay per second.

bremsstrahlung - Translates as "fast braking" and refers to electromagnetic radiation produced by the sudden retardation of a charged particle in an intense electric field.

\section{$\mathrm{C}$}

CAA (Clean Air Act), CAA Amendments (CAAA) - The original Clean Air Act was passed in 1963, but the U.S. air pollution control program is based on the 1970 version of the law. The 1990 Clean Air Act Amendments (CAAA) are the most far-reaching revisions of the 1970 law. In common usage, references to the CAA typically mean to the 1990 amendments. (source: EPA's "Plain English Guide to the Clean Air Act” glossary @ http://www.epa.gov/oar/oaqps/ peg_caa/pegcaain.html, accessed 3-7-05)

caisson - A watertight container used in construction work under water or as a foundation.

cap - A layer of natural or synthetic material, such as clay or gunite, used to prevent rainwater from penetrating and spreading contamination. The surface of the cap is generally mounded or sloped so water will drain off.

carbon adsorption/carbon treatment - A treatment system in which contaminants are removed from groundwater, surface water, and air by forcing water or air through tanks containing activated carbon (a specially treated material that attracts and holds or retains contaminants).

carbon tetrachloride - A poisonous, nonflammable, colorless liquid, $\mathrm{CCl}_{4}$.

CERCLA (Comprehensive Environmental Response, Compensation and Liability Act) - Pronounced "sir-klah" and commonly known as Superfund, this law was enacted by Congress on December 11, 1980. It created a tax on the chemical and petroleum industries and provided broad federal authority to respond directly to releases or threatened releases of hazardous substances that may endanger public health or the environment. CERCLA established prohibitions and requirements concerning closed and abandoned hazardous waste sites; provided for liability of persons responsible for releases of hazardous waste at these sites; and established a trust fund to provide for cleanup when no responsible party could be identified

The law authorizes two kinds of response actions: shortterm removals, where actions may be taken to address releases or threatened releases requiring prompt response, and long-term remedial response actions that permanently and significantly reduce the dangers associated with releases or threats of releases of hazardous substances that are serious, but not immediately life threatening. These actions can be conducted only at sites listed on EPA's National Priorities List (NPL). CERCLA was amended by the Superfund Amendments and Reauthorization Act (SARA) on October 17, 1986. (source: EPA web site http://www.epa.gov/superfund/action/law/cercla.htm, accessed 03-7-05)

CFR (Code of Federal Regulations) - A codification of all regulations developed and finalized by federal agencies in the Federal Register. The CFR is arranged by "title," with Title 10 covering energy- and radiation-related issues, and Title 40 covering protection of the environment. Subparts within the titles are included in citations, as in " 40 CFR Subpart H." The CFR is available online at http://www. gpoaccess.gov/cfr/index.html (acessed 3-7-05).

characterization - Facility or site sampling, monitoring, and analysis activities to determine the extent and nature of contamination. Characterization provides the basis of necessary technical information to select an appropriate cleanup alternative.

Ci (curie) - A quantitative measure of radioactivity. One $\mathrm{Ci}$ of activity is equal to $3.7 \mathrm{E}+10$ decays per second. One curie has the approximate activity of 1 gram of radium. It is named after Marie and Pierre Curie, who discovered radium in 1898 .

Class GA groundwater - New York State Department of Environmental Conservation classification for high quality groundwater, where the best intended use is as a source of drinking water supply.

closure - Under RCRA regulations, this term refers to a hazardous or solid waste management unit that is no longer operating and where potential hazards that it posed have been addressed (through clean up, immobilization, capping, etc.) to the satisfaction of the regulatory agency. 
COC (chain-of-custody) - A method for documenting the history and possession of a sample from the time of collection, through analysis and data reporting, to its final disposition.

cocktail - a mixture of chemicals used for scintillation counting.

collective Effective Dose Equivalent - A measure of health risk to a population exposed to radiation. It is the sum of the EDEs of all individuals within an exposed population, frequently considered to be within 50 miles ( 80 kilometers) of an environmental release point. It is expressed in personrem or person-sievert.

Committed Effective Dose Equivalent - The total EDE received over a 50-year period following the internal deposition of a radionuclide. It is expressed in rems or sieverts.

composite sample - A sample of an environmental medium containing a certain number of sample portions collected over a period of time, possibly from different locations. The constituent samples may or may not be collected at equal time intervals over a predefined period of time, such as 24 hours.

confidence interval - A numerical range within which the true value of a measurement or calculated value lies. In the SER, radiological values are shown with a 95 percent confidence interval: there is a 95 percent probability that the true value of a measurement or calculated value lies within the specified range. See also "Uncertainty" discussion in Appendix B.

conservative - Estimates that err on the side of caution because all possibly deleterious components are included at generous or high values.

contamination - Unwanted radioactive and/or hazardous material that is dispersed on or in equipment, structures, objects, air, soil, or water.

control - See background.

cooling water - Water used to cool machinery and equipment. Contact cooling water is any wastewater that contacts machinery or equipment to remove heat from the metal; noncontact cooling water has no direct contact with any process material or final product. Process wastewater cooling water is water used for cooling that may have become contaminated through contact with process raw materials or final products.

cover boards - Sheets of plywood placed on the ground near ponds to serve as attractive habitat for salamanders, as part of a population study.

curie - See Ci.

CWA (Clean Water Act) - Growing public awareness and concern for controlling water pollution led to enactment of the Federal Water Pollution Control Act Amendments of 1972. As amended in 1977, this law became commonly known as the Clean Water Act. It established the basic structure for regulating discharges of pollutants into the waters of the United States, giving EPA the authority to implement pollution control programs such as setting wastewater standards for industry. The CWA also continued requirements to set water quality standards for all contaminants in surface waters and made it unlawful for any person to discharge any pollutant from a point source into navigable waters unless a permit was obtained. The CWA also funded the construction of sewage treatment plants and recognized the need for planning to address the critical problems posed by nonpoint source pollution.

Revisions in 1981 streamlined the municipal construction grants process. Changes in 1987 phased out the construction grants program. Title I of the Great Lakes Critical Programs Act of 1990 put into place parts of the Great Lakes Water Quality Agreement of 1978, signed by the U.S. and Canada; the two nations agreed to reduce certain toxic pollutants in the Great Lakes. Over the years many other laws have changed parts of the CWA. (source: http://www.epa.gov/region5/water/cwa.htm, accessed 03-7-05)

\section{$\mathrm{D}$}

\section{$\mathbf{D}_{2} \mathbf{O}-$ See heavy water.}

daughter, progeny - A given nuclide produced by radioactive decay from another nuclide (the "parent"). See also radioactive series.

DCG (derived concentration guide) - The concentration of a radionuclide in air or water that, under conditions of continuous exposure for one year by a single pathway (e.g., air inhalation, absorption, or ingestion), would result in an effective dose equivalent of $100 \mathrm{mrem}(1 \mathrm{mSv})$. The values were established in DOE Order 5400.5

decay product - A nuclide resulting from the radioactive disintegration of a radionuclide, being formed either directly or as a result of successive transformations in a radioactive series. A decay product may be either radioactive or stable.

decontamination - The removal or reduction of radioactive or hazardous contamination from facilities, equipment, or soils by washing, heating, chemical or electrochemical action, mechanical cleaning, or other techniques to achieve a stated objective or end condition.

disposal - Final placement or destruction of waste.

DOE (Department of Energy) - The federal agency that promotes scientific and technical innovation to support the national, economic, and energy security of the United States. DOE has responsibility for 10 national laboratories and for the science and research conducted at these laboratories, including Brookhaven National Laboratory.

DOE Order 231.1A - This order, Environment, Safety, and Health Reporting, is dated 8/19/03. It replaces the 1995 version, Order 231.1, as well as the "ORPS" order, DOE Order 232.1A, Occurrence Reporting and Processing of Operations Information, dated 7/21/97, and Order 210.1, Performance Indicator..., dated 9/27/95. It can be found at http://www.directives.doe.gov (accessed 3/7/05). 
DOE Order 450.1 - This order, Environmental Protection Program, is dated $1 / 15 / 03$. It replaces DOE Order 5400.1, General Environmental Protection Program, dated 11/9/88. It can be found at http://www.directives.doe.gov (accessed 3/7/05).

DOE Order 5400.5 - This order, Radiation Protection of the Public and the Environment, was first published by DOE in 1990 and was modified in 1993. It established the standards and requirements for operations of DOE and DOE contractors with respect to protecting the public and the environment against undue risk from radiation. It can be found at http://www.directives.doe.gov (accessed 3/7/05).

dose - See EDE.

dosimeter - A portable detection device for measuring exposure to ionizing radiation. See Chapter 8 for details.

downgradient - In the direction of groundwater flow from a designated area; analogous to "downstream."

DQO (Data Quality Objective) -The Data Quality Objective (DQO) process was developed by EPA for facilities to use when describing their environmental monitoring matrices, sampling methods, locations, frequencies, and measured parameters, as well as methods and procedures for data collection, analysis, maintenance, reporting, and archiving. The DQO process also addresses data that monitor quality assurance and quality control.

drift fence - A stretch of temporary fencing to prevent an animal population from leaving the area, used at BNL as part of a population study.

dry weight - The dry weight concentration of a substance is after a sample is dried for analysis. Dry weight concentrations are typically higher than wet weight values.

D-waste - Liquid waste containing radioactivity.

\section{E}

EA (Environmental Assessment) - A report that identifies potentially significant effects from any federally approved or funded project that might change the physical environment. If an EA identifies a "significant" potential impact (as defined by NEPA), an Environmental Impact Statement (EIS) must be researched and prepared.

EDB (ethylene dibromide) - A colorless, nonflammable, heavy liquid with a sweet odor; slightly soluble in water. Although the U.S. Department of Health and Human Services has determined that ethylene dibromide may reasonably be anticipated to be a carcinogen, it is still used to treat felled logs for bark beetles; to control wax moths in beehives; as a chemical intermediary for dyes, resins, waxes, and gums; to spot-treat milling machinery; and to control Japanese beetles in ornamental plants.

EDE (Effective Dose Equivalent) - A value used to express the health risk from radiation exposure to tissue in terms of an equivalent whole body exposure. It is a "normalized" value that allows the risk from radiation exposure received by a specific organ or part of the body to be compared with the risk due to whole-body exposure. The EDE equals the sum of the doses to different organs of the body multiplied by their respective weighting factors. It includes the sum of the EDE due to radiation from sources external to the body and the committed effective dose equivalent due to the internal deposition of radionuclides. EDE is expressed in rems or sieverts.

effluent - Any liquid discharged to the environment, including stormwater runoff at a site or facility.

EIMS (Environmental Information Management System) - A database system used to store, manage, verify, protect, retrieve, and archive BNL's environmental data.

EM (environmental monitoring) - Sampling for contaminants in air, water, sediment, soil, food stuffs, plants, and animals, either by directly measuring or by collecting and analyzing samples.

emissions - Any gaseous or particulate matter discharged to the atmosphere.

EMS (Environmental Management System) - The BNL EMS meets the requirements of the ISO 14001 EMS standard, with emphasis on compliance assurance, pollution prevention, and community outreach. An extensive environmental monitoring program is one component of BNL's EMS.

environment - Surroundings (including air, water, land, natural resources, flora, fauna, and humans) in which an organization operates, and the interrelation of the organization and its surroundings.

environmental aspect - Elements of an organization's activities, products, or services that can interact with the surrounding air, water, land, natural resources, flora, fauna, and humans.

environmental impact - Any change to the surrounding air, water, land, natural resources, flora, and fauna, whether adverse or beneficial, wholly or partially resulting from an organization's activities, products, or services.

environmental media - Includes air, groundwater, surface water, soil, flora, and fauna.

environmental monitoring or surveillance - See EM.

EPA (U. S. Environmental Protection Agency) - The federal agency responsible for developing and enforcing environmental laws. Although state or local regulatory agencies may be authorized to administer environmental regulatory programs, EPA generally retains oversight authority.

EPCRA (Emergency Planning and Community Right-toKnow Act) - Also known as Title III of SARA, EPCRA was enacted by Congress as the national legislation on community safety, to help local groups protect public health, safety, and the environment from chemical hazards. To implement EPCRA, Congress required each state to appoint a State Emergency Response Commission (SERC). The SERCs were required to divide their states into Emergency Planning Districts and to name a Local Emergency Planning Committee for each district

Broad representation by fire fighters, health officials, government and media representatives, community groups, in- 
dustrial facilities, and emergency managers ensures that all necessary elements of the planning process are represented. (source: http://www.epa.gov/region5/defs/html/epcra.htm, accessed 3-7-05)

ES (environmental surveillance) - Sampling for contaminants in air, water, sediment, soil, food stuffs, plants, and animals, either by directly measuring or by collecting and analyzing samples.

ESA (Endangered Species Act) - This provides a program for conserving threatened and endangered plants and animals and their habitats. The FWS maintains the list of 632 endangered species (326 are plants) and 190 threatened species ( 78 are plants). Species include birds, insects, fish, reptiles, mammals, crustaceans, flowers, grasses, and trees. Anyone can petition FWS to include a species on this list. The law prohibits any action, administrative or real, that results in a "taking" of a listed species or adversely affects habitat. Likewise, import, export, interstate, and foreign commerce of listed species are all prohibited. EPA's decision to register pesticides is based in part on the risk of adverse effects on endangered species as well as environmental fate (how a pesticide will affect habitat). Under FIFRA, EPA can issue emergency suspensions of certain pesticides to cancel or restrict their use if an endangered species will be adversely affected. (source: http://www.epa. gov/region5/defs/html/esa.htm, accessed 3-7-05)

evapotranspiration - A process by which water is transferred from the soil to the air by plants that take the water up through their roots and release it through their leaves and other aboveground tissue.

exposure - A measure of the amount of ionization produced by $\mathbf{x}$-rays or gamma rays as they travel through air. The unit of radiation exposure is the roentgen $(\mathbf{R})$.

\section{$\mathrm{F}$}

fallout - Radioactive material, made airborne as a result of aboveground nuclear weapons testing, that has been deposited on the Earth's surface.

FFCA (Federal Facility Compliance Act) - Formerly, the federal government maintained that it was not subject to fines and penalties under solid and hazardous waste law because of the doctrine of "sovereign immunity." The State of Ohio challenged this in Ohio v. the Department of Energy (1990). The U.S. Circuit Court of Appeals found in favor of the State (June 11, 1990), writing that the federal government's sovereign immunity is waived under both the CWA sovereign immunity provision and RCRA's citizen suit provision. The Circuit Court decision was overturned by the Supreme Court on April 21, 1992, in DOE v. Ohio, which held that the waiver of sovereign immunity in RCRA and CWA is not clear enough to allow states to impose civil penalties directly. After the high court's ruling, the consensus among lawmakers was that a double standard existed: the same government that developed laws to protect human health and the environment and required compliance in the private sector, was itself not assuming the burden of compliance. As a result, Congress enacted the FFCA (October 6,
1992, Pub. Law 102-386), which effectively overturned the Supreme Court's ruling. In the legislation Congress specifically waived sovereign immunity with respect to RCRA for federal facilities.

Under section 102, FFCA amends section 6001 of RCRA to specify that federal facilities are subject to "all civil and administrative penalties and fines, regardless of whether such penalties or fines are punitive or coercive in nature." These penalties and fines can be levied by EPA or by authorized states. In addition, FFCA states that "the United States hereby expressly waives any immunity otherwise applicable to the United States." Although federal agents, employees, and officers are not liable for civil penalties, they are subject to criminal sanctions. No departments, agencies, or instrumentalities are subject to criminal sanctions. Section 104 (1) and (2) require EPA to conduct annual RCRA inspections of all federal facilities. (source: http://tis.eh.doe. gov/oepa/laws/ffca.html, accessed 3-7-05)

FIFRA (Federal Insecticide, Fungicide, and Rodenticide Act) - The primary focus of this law was to provide federal control of pesticide distribution, sale, and use. EPA was given authority under FIFRA not only to study the consequences of pesticide usage but also to require users (farmers, utility companies, and others) to register when purchasing pesticides. Through later amendments to the law, users also must take exams for certification as applicators of pesticides. All pesticides used in the U.S. must be registered (licensed) by EPA. Registration assures that pesticides will be properly labeled and that if used in accordance with specifications, will not cause unreasonable harm to the environment. (source: http://www.epa.gov/region5/defs/html/ fifra.htm, accessed 3-7-05)

FS (feasibility study) - A process for developing and evaluating remedial actions using data gathered during the remedial investigation. The FS defines the objectives of the remedial program for the site and broadly develops remedial action alternatives, performs an initial screening of these alternatives, and performs a detailed analysis of a limited number of alternatives that remain after the initial screening stage.

FWS (U.S. Fish \& Wildlife Service) - The U.S. Fish and Wildlife Service is the principal federal agency responsible for conserving, protecting, and enhancing fish, wildlife, plants, and their habitats for the continuing benefit of the people of the United States. FWS manages the 95million-acre National Wildlife Refuge System, which encompasses 544 national wildlife refuges, thousands of small wetlands, and other special management areas. It also operates 69 national fish hatcheries, 64 fishery resources offices, and 81 ecological services field stations. The agency enforces federal wildlife laws, administers the Endangered Species Act, manages migratory bird populations, restores nationally significant fisheries, conserves and restores wildlife habitat such as wetlands, and helps foreign and Native American tribal governments with their conservation efforts. It also oversees the Federal Assistance Program, which distributes hundreds of 
millions of dollars in excise taxes on fishing and hunting equipment to state fish and wildlife agencies. (source: http://northeast.fws.gov/ameel/petition.html, accessed 3/7/05)

fugitive source - Unanticipated sources of volatile hazardous air pollutants due to leaks from valves, pumps, compressors, relief valves, connectors, flanges, and various other pieces of equipment.

\section{G}

gamma radiation - Gamma radiation is a form of electromagnetic radiation, like radio waves or visible light, but with a much shorter wavelength. It is more penetrating than alpha or beta radiation, capable of passing through dense materials such as concrete.

gamma spectroscopy - This analysis technique identifies specific radionuclides. It measures the particular energy of a radionuclide's gamma radiation emissions. The energy of these emissions is unique for each nuclide, acting as a "fingerprint."

geotextile - A product used as a soil reinforcement agent and as a filter medium. It is made of synthetic fibers manufactured in a woven or loose manner to form a blanket-like product.

grab sample - A single sample collected at one time and place.

Green Building - Construction that adheres to guidelines established by the Green Building Council, a coalition of leaders from across the building industry working to promote structures that are environmentally responsible, profitable, and healthy places to live and work.

groundwater - Water found beneath the surface of the ground (subsurface water). Groundwater usually refers to a zone of complete water saturation containing no air.

gunite - A mixture of cement, sand, and water sprayed over a mold to form a solid, impermeable surface. Formerly a trademarked name, now in general usage.

\section{$\mathrm{H}$}

half-life $\left(\mathbf{t}_{1 / 2}\right)$ - The time required for one-half of the atoms of any given amount of a radioactive substance to disintegrate; the time required for the activity of a radioactive sample to be reduced by one half.

halon - An ozone-depleting fire suppressant; suffixes (-1301, etc.) indicate variants.

hazardous waste - Toxic, corrosive, reactive, or ignitable materials that can injure human health or damage the environment. It can be liquid, solid, or sludge, and include heavy metals, organic solvents, reactive compounds, and corrosive materials. It is defined and regulated by RCRA, Subtitle C.

heat input - The heat derived from combustion of fuel in a steam generating unit. It does not include the heat from preheated combustion air, recirculated flue gases, or the exhaust from other sources. heavy water $\left(\mathbf{D}_{2} \mathbf{O}\right)$ - A form of water containing deuterium, a nonradioactive isotope of hydrogen.

herpetofaunal - Relating to the study of reptiles.

hot cell - Shielded and air-controlled facility for the remote handling of radioactive material.

hydrology - The science dealing with the properties, distribution, and circulation of natural water systems.

\section{I}

inert - Lacking chemical or biological action.

influent - Liquid (such as stormwater runoff or wastewater) flowing into a reservoir, basin, or treatment plant.

intermittent river - A stream that dries up on occasion, usually as a result of seasonal factors or decreased contribution from a source such as a wastewater treatment plant.

ionizing radiation - Any radiation capable of displacing electrons from atoms or molecules, thereby producing ions. High doses of ionizing radiation may produce severe skin or tissue damage. See also alpha, beta, gamma radiation; $\mathrm{x}$-rays.

ISO 14001 EMS standard - The International Organization for Standardization (ISO) sets standards for a wide range of products and management operations. Following the success of the ISO 9000 Standards for quality management, ISO introduced the 14000 series for environmental management. BNL was the first DOE Office of Science laboratory to obtain third-party registration to this globally recognized environmental standard.

isotope - Two or more forms of a chemical element having the same number of protons in the nucleus (the same atomic number), but having different numbers of neutrons in the nucleus (different atomic weights). Isotopes of a single element possess almost identical chemical properties.

\section{$\mathrm{L}$}

leaching - The process by which soluble chemical components are dissolved and carried through soil by water or some other percolating liquid.

light water - As used in this document, tap water, possibly filtered.

liquid scintillation counter - An analytical instrument used to quantify tritium, carbon-14, and other beta-emitting radionuclides. See also scintillation.

\section{$\mathrm{M}$}

matrix, matrices - The natural context (e.g., air, vegetation, soil, water) from which an environmental sample is collected.

MDL (minimum detection limit) - The lowest level to which an analytical parameter can be measured with certainty by the analytical laboratory performing the measurement. While results below the MDL are sometimes measurable, they represent values that have a reduced statistical confidence associated with them (less than 95 percent confidence). 
MEI (maximally exposed individual) - The hypothetical individual whose location and habits tend to maximize his/ her radiation dose, resulting in a dose higher than that received by other individuals in the general population.

metamorphic - In the state of changing from larval to mature forms.

mixed waste - Waste that contains both a hazardous waste component (regulated under Subtitle C of RCRA) and a radioactive component.

monitoring - The collection and analysis of samples or measurements of effluents and emissions for the purpose of characterizing and quantifying contaminants, and demonstrating compliance with applicable standards.

monitoring well - A well that collects groundwater for the purposes of evaluating water quality, establishing groundwater flow and elevation, determining the effectiveness of treatment systems, and determining whether administrative or engineered controls designed to protect groundwater are working as intended.

MSL (mean sea level) - The average height of the sea for all stages of the tide. Used as a benchmark for establishing groundwater and other elevations.

\section{$\mathrm{N}$}

NEPA (National Environmental Policy Act) - Assures that all branches of government give proper consideration to the environment before any land purchase or any construction projects, including airports, buildings, military complexes, and highways. Project planners must assess the likely impacts of the project by completing an Environmental Assessment (EA) and, if necessary, an Environmental Impact Statement (EIS). (source: http:/www.epa.gov/region5/defs/html/nepa.htm, accessed 3-7-05)

NESHAPs (National Emissions Standards for Hazardous Air Pollutants) - Standards that limit emissions from specific sources of air pollutants linked to serious health hazards. NESHAPs are developed by EPA under the CAA. Hazardous air pollutants can be chemical or radioactive. Their sources may be human-made, such as vehicles, power plants, and industrial or research processes, or natural, such as radioactive gas in soils. (source: www.epa.gov/radiation/ neshaps, accessed 3-7-05)

neutrino - A small, neutral particle created as a result of particle decay. Neutrinos were believed to be massless, but recent studies have indicated that they have small, but finite, mass. Neutrinos interact very weakly.

NHPA (National Historic Preservation Act) - With passage of the National Historic Preservation Act in 1966, Congress made the federal government a full partner and a leader in historic preservation. The role of the federal government is fulfilled through the National Park Service. State participation is through State Historic Preservation Offices. "Before 1966, historic preservation was mainly understood in one-dimensional terms: the proverbial historic shrine or Indian burial mound secured by lock and key-usually in a national park-set aside from modern life as an icon for study and appreciation. NHPA largely changed that approach, signaling a much broader sweep that has led to the breadth and scope of the vastly more complex historic preservation mosaic we know today." (source: http://www.achp. gov/overview.html, accessed 3-7-05)

nonpoint source pollution - Nonpoint source pollution occurs when rainfall, snowmelt, or irrigation water runs over land or through the ground, picks up pollutants, and deposits them into rivers, lakes, and coastal waters or introduces them into groundwater. Nonpoint source pollution also includes adverse changes to the hydrology of water bodies and their associated aquatic habitats. After Congress passed the Clean Water Act in 1972, the nation's water quality community emphasized point source pollution (coming from a discrete conveyance or location, such as industrial and municipal waste discharge pipes). Point sources were the primary contributors to the degradation of water quality then, and the significance of nonpoint source pollution was poorly understood. Today, nonpoint source pollution remains the largest source of water quality problems. It is the main reason that approximately 40 percent of surveyed rivers, lakes, and estuaries are not clean enough to meet basic uses such as fishing or swimming. (source: http://www. epa.gov/owow/nps, accessed 3-7-05)

$\mathbf{N O}_{\mathbf{x}}$ - Nitrogen oxides are gases consisting of one molecule of nitrogen and varying numbers of oxygen molecules. Nitrogen oxides are produced, for example, by the combustion of fossil fuels in vehicles and electric power plants. In the atmosphere, $\mathrm{NO}_{\mathrm{x}}$ can contribute to the formation of smog, impair visibility, and have health consequences. $\mathrm{NO}_{\mathrm{x}}$ are considered "criteria air pollutants" under the CAA.

nuclide - A species of atom characterized by the number of protons and neutrons in the nucleus.

NYCRR (New York Codes, Rules, and Regulations) The NYCRR primarily contains state agency rules and regulations adopted under the State Administrative Procedure Act. There are 22 Titles: one for each state department, one for miscellaneous agencies and one for the Judiciary. Title 6 addresses environmental conservation, so many references in the SER are to "6 NYCRR."

\section{$\mathrm{O}$}

$\mathbf{O}_{3}-$ See ozone.

on site - The area within the boundaries of a site that is controlled with respect to access by the general public.

opacity - Under the Clean Air Act (CAA), a measurement of the degree to which smoke (emissions other than water vapor) reduces the transmission of light and obscures the view of an object in the background.

ORPS (Occurrence Reporting and Processing System) A system for identifying, categorizing, notifying, investigating, analyzing, and reporting to DOE events or conditions discovered at the BNL site. It was originally established by 
DOE Order 232.1, which has been replaced by DOE Order 231.1A.

OU (operable unit) - Division of a contaminated site into separate areas based on the complexity of the problems associated with it. Operable units may address geographical portions of a site, specific site problems, or initial phases of an action. They may also consist of any set of actions performed over time, or actions that are concurrent, but located in different parts of a site. An OU can receive specific investigation and a particular remedy may be proposed. A Record of Decision (ROD) is prepared for each OU.

outfall - The place where wastewater is discharged.

oxides of nitrogen $\left(\mathrm{NO}_{\mathrm{x}}\right)$ - See $\mathrm{NO}_{\mathrm{x}}$.

ozone $\left(\mathbf{O}_{3}\right)$ - A very reactive type of oxygen formed naturally in the upper atmosphere which provides a shield for the earth from the sun's ultraviolet rays. At ground level or in the lower atmosphere, it is pollution that forms when oxides of nitrogen and hydrocarbons react with oxygen in the presence of strong sunlight. Ozone at ground level can lead to health effects and cause damage to trees and crops.

\section{$\mathrm{P}$}

P2 (pollution prevention) - Preventing or reducing the generation of pollutants, contaminants, hazardous substances, or wastes at the source, or reducing the amount for treatment, storage, and disposal through recycling. Pollution prevention can be achieved through reduction of waste at the source, segregation, recycle/reuse, and the efficient use of resources and material substitution. The potential benefits of pollution prevention include the reduction of adverse environmental impacts, improved efficiency, and reduced costs.

PAAA (Price-Anderson Act Amendments) - The PriceAnderson Act (PAA) was passed in 1957 to provide for prompt compensation in the case of a nuclear accident. The PAA provided broad financial coverage for damage, injury, and costs, and required DOE to indemnify contractors. The amended act of 1988 (PAAA) extended indemnification for 15 years and required DOE to establish and enforce nuclear safety rules. The PAAA Reauthorization, passed in December of 2002, extended current indemnification levels through 2004. 10 CFR 820 and its Appendix A provide DOE enforcement procedure and policy. (source: http://tis. eh.doe.gov, accessed 3-24-04)

Parshall flume - An engineered channel used to measure the flow rate of water. It was named after the inventor, who worked for the U.S. government as an irrigation research engineer.

PCBs (polychlorinated biphenyls) - A family of organic compounds used from 1926 to 1979 (when they were banned by EPA) in electrical transformers, lubricants, carbonless copy paper, adhesives, and caulking compounds. PCBs are extremely persistent in the environment because they do not break down into different and less harmful chemicals. PCBs are stored in the fatty tissues of humans and animals through the bioaccumulation process.

percent recovery - For analytical results, the ratio of the measured amount, divided by the known (spiked) amount, multiplied by 100 .

permit - An authorization issued by a federal, state, or local regulatory agency. Permits are issued under a number of environmental regulatory programs, including CAA, CWA, RCRA, and TSCA. Permits grant permission to operate, to discharge, to construct, and so on. Permit provisions may include emission/effluent limits and other requirements such as the use of pollution control devices, monitoring, record keeping and reporting. Also called a "license" or "certificate" under some regulatory programs.

pH - A measure of hydrogen ion concentration in an aqueous solution. Acidic solutions have a $\mathrm{pH}$ less than 7, neutral solutions have a $\mathrm{pH}$ of 7 , and basic solutions have a $\mathrm{pH}$ greater than 7 and up to 14 .

plume - A body of contaminated groundwater or polluted air flowing from a specific source. The movement of a groundwater plume is influenced by such factors as local groundwater flow patterns, the character of the aquifer in which groundwater is contained, and the density of contaminants. The movement of an air contaminant plume is influenced by the ambient air motion, the temperatures of the ambient air and of the plume, and the density of the contaminants.

point source - Any confined and discrete conveyance (e.g., pipe, ditch, well, or stack) of a discharge.

pollutant - Any hazardous or radioactive material naturally occurring or added to an environmental medium, such as air, soil, water, or vegetation.

potable water - Water of sufficient quality for use as drinking water without endangering the health of people, plants, or animals.

precision - A statistical term describing the dispersion of data around a central value, usually represented as a variance, standard deviation, standard error, or confidence interval.

putrescible waste - Garbage that contains food and other organic biodegradable materials. There are special management requirements for this waste in 6 NYCRR Part 360.

\section{Q}

QA (quality assurance) - In environmental monitoring, any action to ensure the reliability of monitoring and measurement data. Aspects of QA include procedures, inter-laboratory comparison studies, evaluations, and documentation.

QC (quality control) - In environmental monitoring, the routine application of procedures to obtain the required standards of performance in monitoring and measurement processes. QC procedures include calibration of instruments, control charts, and analysis of replicate and duplicate samples. 
qualifier - A letter or series of letter codes in a graph or chart indicating that the associated value did not meet analytical requirements or was estimated.

quenching - Anything that interferes with the conversion of decay energy to electronic signal in the photomultiplier tubes of detection equipment, usually resulting in a reduction in counting efficiency.

\section{$\mathrm{R}$}

$\mathbf{R}$ (roentgen) - A unit of exposure to ionizing radiation. It is the amount of gamma or $\mathrm{x}$-rays required to produce ions carrying one electrostatic unit of electrical charge in one cubic centimeter of dry air under standard conditions. It is named after the German scientist Wilhelm Roentgen, who discovered x-rays.

RA (removal actions, "removals") - Interim actions that are undertaken to prevent, minimize, or mitigate damage to the public health or environment that may otherwise result from a release or threatened release of hazardous substances, pollutants, or contaminants pursuant to CERCLA, and that are not inconsistent with the final remedial action. Under CERCLA, EPA may respond to releases or threats of releases of hazardous substances by starting an RA to stabilize or clean up an incident or site that immediately threatens public health or welfare. Removal actions are less comprehensive than remedial actions. However, removal actions must contribute to the efficiency of future remedial actions.

radiation - Some atoms possess excess energy, causing them to be physically unstable. Such atoms become stable when the excess energy is released in the form of charged particles or electromagnetic waves, known as radiation.

radiation event $-A$ single detection of a charged particle or electromagnetic wave.

radioactive series - A succession of nuclides, each of which transforms by radioactive disintegration into the next until a stable nuclide results. The first member of the series is called the parent and the intermediate members are called daughters or progeny.

radioactivity - The spontaneous transition of an atomic nucleus from a higher energy to a lower energy state. This transition is accompanied by the release of a charged particle or electromagnetic waves from the atom. Also known as "activity."

radionuclide - A radioactive element characterized by the number of protons and neutrons in the nucleus. There are several hundred known radionuclides, both artificially produced and naturally occurring.

RCRA (Resource Conservation and Recovery Act) Pronounced "rick-rah," this act of Congress gave EPA the authority to control the generation, transportation, treatment, storage, and disposal of hazardous waste. RCRA also set forth a framework for the management of nonhazardous wastes. The 1986 amendments to RCRA enabled EPA to address environmental problems that could result from underground tanks storing petroleum and other hazardous substances. RCRA focuses only on active and future facilities and does not address abandoned or historical sites (see CERCLA). In 1984, amendments to RCRA called the Hazardous and Solid Waste Amendments (HSWA, pronounced "hiss-wa") required phasing out the land disposal of hazardous waste. Some other mandates of this strict law include increased enforcement authority for EPA, more stringent hazardous waste management standards, and a comprehensive underground storage tank (UST) program. (source: http://www.epa.gov/region5/defs/html/rcra.htm, accessed 3-7-05)

recharge - The process by which water is added to a zone of saturation (aquifer) from surface infiltration, typically when rainwater soaks through the earth to reach an aquifer.

recharge basin - A basin (natural or artificial) that collects water. The water will infiltrate to the aquifer.

release - Spilling, leaking, pumping, pouring, emitting, emptying, discharging, injecting, escaping, leaching, dumping, or disposing of a hazardous substance, pollutant, or contaminant into the environment. The National Contingency Plan also defines the term to include a threat of release.

rem - Stands for "roentgen equivalent man," a unit by which human radiation dose is assessed (see also $\mathbf{S v}$ ). The rem is a risk-based value used to estimate the potential health effects to an exposed individual or population. 100 rem $=1$ sievert.

remedial (or remediation) alternatives - Options considered under CERCLA for decontaminating a site such as an operable unit (OU) or area of concern (AOC). Remedial actions are long-term activities that prevent the possible release, or stop or substantially reduce the actual release, of substances that are hazardous but not immediately lifethreatening. See also feasibility study (FS) and Record of Decision (ROD).

residual fuel - Crude oil, Nos. 1 and 2 fuel oil that have a nitrogen content greater than 0.05 weight percent, and all fuel oil Nos. 4, 5, and 6, as defined by the American Society of Testing and Materials in ASTM D396-78, Standard Specifications for Fuel Oils, (c. 2001).

riparian - An organism living on the bank of a river, lake, or tidewater.

ROD (Record of Decision) - A document that records a regulatory agency's decision for the selected remedial action. The ROD also includes a responsiveness summary and a bibliography of documents that were used to reach the remedial decision. When the ROD is finalized, remedial design and implementation can begin.

roentgen - See $\mathrm{R}$.

RPD (relative percent difference) - A measure of precision, expressed by the formula: $\mathrm{RPD}=[(\mathrm{A}-\mathrm{B}) /(\mathrm{A}+\mathrm{B})] \mathrm{x}$ 200 , where $A$ equals the concentration of the first analysis and $\mathrm{B}$ equals the concentration of the second analysis. 
runoff - The movement of water over land. Runoff can carry pollutants from the land into surface waters or uncontaminated land.

\section{$\mathrm{S}$}

sampling - The extraction of a prescribed portion of an effluent stream or environmental media for purposes of inspection or analysis.

SARA (Superfund Amendments and Reauthorization Act) - This Act of Congress in 1986 reauthorized CERCLA to continue cleanup activities around the country. Several site-specific amendments, definitions clarifications, and technical requirements were added to the legislation, including additional enforcement authorities. Title III of SARA also authorized EPCRA. (source: http://www.epa. gov/region5/defs/html/sara.htm, accessed 3-7-05)

SBMS (Standards-Based Management System) - A document management tool used to develop and integrate systems, and to demonstrate BNL's conformance to requirements to perform work safely and efficiently.

scintillation - Flashes of light produced in a phosphor by a radioactive material.

SDWA (Safe Drinking Water Act) - The Safe Drinking Water Act was established to protect the quality of drinking water in the United States. It focuses on all waters actually or potentially designed for drinking use, whether from above ground or underground sources. The SDWA authorized EPA to establish safe standards of purity and required all owners or operators of public water systems to comply with health-related standards. State governments assume regulatory power from EPA. (source: http://www.epa.gov/ region $5 / \mathrm{defs} / \mathrm{html} / \mathrm{sdwa} \cdot \mathrm{htm}$, accessed 3-7-05)

sediment - The layer of soil and minerals at the bottom of surface waters, such as streams, lakes, and rivers.

sensitivity - The minimum amount of an analyte that can be repeatedly detected by an instrument.

sievert - See $\mathbf{S v}$.

skyshine - Radiation emitted upward from an open-topped, shielded enclosure and reflected downward, resulting in the possibility that flora and fauna (including humans) outside the shielded enclosure can be exposed to radiation.

sludge - Semisolid residue from industrial or water treatment processes.

sole source aquifer - An area defined by EPA as being the primary source of drinking water for a particular region. Includes the surface area above the sole source aquifer and its recharge area.

SPDES (State Pollutant Discharge Elimination System) This permit program is delegated to the states, but the effluent limitations and other requirements are set by the federal government. 6 NYCRR Section 750-1.11(a) concerns the provisions of SPDES permits and lists the citations for the various effluent limitations from the Federal Register and the CFR. (source: www.dec.state.ny.us/website/dcs/spdes/ spdes02.html, accessed 3-7-05) stable - Nonradioactive.

stakeholder - People or organizations with vested interests in BNL and its environment and operations. Stakeholders include federal, state, and local regulators; the public; DOE; and BNL staff.

stripping - A process used to remove volatile contaminants from a substance (see also air stripping).

sump - A pit or tank that catches liquid runoff for drainage or disposal.

Sv (sievert) - A unit for assessing the risk of human radiation dose, used internationally and with increasing frequency in the United States. One sievert is equal to 100 rem.

SVE (soil vapor extraction) - An in situ (in-place) method of extracting VOCs from soil by applying a vacuum to the soil and collecting the air, which can be further treated to remove the VOCs, or discharged to the atmosphere.

SVOC - A general term for volatile organic compounds that vaporize relatively slowly at standard temperature and pressure. See also VOC.

synoptic - Relating to or displaying conditions as they occur over a broad area.

$\mathrm{T}$

$\mathbf{t}_{1 / 2}$ (half-life) - The time required for one-half of the atoms of any given amount of a radioactive substance to disintegrate; the time required for the activity of a radioactive sample to be reduced by one half.

TCE (trichloroethylene, also known as trichloroethene) A stable, colorless liquid with a low boiling point. TCE has many industrial applications, including use as a solvent and as a metal degreasing agent. TCE may be toxic when inhaled or ingested, or through skin contact, and can damage vital organs, especially the liver. See also VOC.

Tier III reports - Reports, required by SARA, that are prepared to document annual emissions of toxic materials to the environment. These are also known as TRI Section 313 reports.

TLD (thermoluminescent dosimeter) - A device used to measure radiation dose to occupational workers or radiation levels in the environment.

tritium - The heaviest and only radioactive nuclide of hydrogen, with a half-life of 12.3 years and a very-low-energy radioactive decay (tritium is a beta emitter).

TSCA (Toxic Substances Control Act) - Enacted by Congress in1976, TSCA empowers EPA to track the 75,000 industrial chemicals produced or imported into the United States. EPA repeatedly screens these chemicals and can require reporting or testing of any that may pose an environmental or human health hazard. EPA can ban the manufacture or import of chemicals that pose an unreasonable risk. (source: http://www.epa.gov/region5/defs/html/tsca.htm, accessed 3-7-05) 
TVOC (total volatile organic compounds) - A sum of all individual VOC concentrations detected in a given sample.

\section{$\mathrm{U}$}

UIC (underground injection control) - A hole with vertical dimensions greater than its largest horizontal dimensions; used for disposal of wastewater.

UST (underground storage tank) - A stationary device, constructed primarily of nonearthen material, designed to contain petroleum products or hazardous materials. In a UST, 10 percent or more of the volume of the tank system is below the surface of the ground.

upgradient/upslope - A location of higher groundwater elevation; analogous to "upstream."

\section{$\mathrm{V}$}

vadose - Relating to water in the ground that is above the permanent groundwater level.

vernal pool - A small, isolated, and contained basin that holds water on a temporary basis, most commonly during winter and spring. It has no aboveground outlet for water and is extremely important to the life cycle of many amphibians (such as the tiger salamander), as it is too shallow to support fish, a major predator of amphibian larvae.

VOC (volatile organic compound) - A general term for organic compounds capable of a high degree of vaporization at standard temperature and pressure. Because VOCs readily evaporate into the air, the potential for human exposure is greatly increased. Due to widespread industrial use, VOCs are commonly found in soil and groundwater.

VUV - Stands for "very ultraviolet" and refers to a beamline at the NSLS with wavelengths at the far ultraviolet end of the spectrum.

\section{W}

waste minimization - Action that avoids or reduces the generation of waste, consistent with the general goal of minimizing current and future threats to human health, safety, and the environment. Waste minimization activities include recycling, improving energy usage, reducing waste at the source, and reducing the toxicity of hazardous waste. This action is associated with pollution prevention, but is more likely to occur after waste has been generated.

water table - The water-level surface below the ground where the unsaturated zone ends and the saturated zone begins. It is the level to which a well that is screened in the unconfined aquifer will fill with water.

watershed - The region draining into a river, a river system, or a body of water.

weighting factor - A factor which, when multiplied by the dose equivalent delivered to a body organ or tissue, yields the equivalent risk due to a uniform radiation exposure of the whole body. See also EDE.

wet weight - The wet weight concentration of a substance is before a sample is dried for analysis (in other words, in its "natural" state), and is the form most likely to be consumed. Wet weight concentrations are typically lower than dry weight values.

wind rose - A diagram that shows the frequency of wind from different directions at a specific location.

\section{$\mathrm{X}$}

x-rays - A form of electromagnetic radiation with short wavelength, generated when high-energy electrons strike matter or when lower-energy beta radiation is absorbed in matter. Gamma radiation and x-rays are identical, except for the source.

\section{Z}

zeolite - A naturally occurring group of more than 100 minerals, formed of silicates and aluminum, with unique and diverse crystal properties. Zeolites can perform ion exchange, filtering, odor removal, and chemical sieve and gas absorption tasks. Synthetic zeolites are now used for most applications. 


\section{Understanding Radiation}

This section introduces the general reader to some basic concepts of radioactivity and an understanding of the radiation emitted as radioactive materials decay to a stable state. To better comprehend the radiological information in the Site Environmental Report (SER) it, is important to remember that not all radiations are the same and that different kinds of radiation affect living beings differently.

This appendix includes discussions on the common sources of radioactivity in the environment, types of radiation, the analyses used to quantify radioactive material, and how radiation sources contribute to radiation dose. Some general statistical concepts are also presented, along with a discussion of radionuclides that are of environmental interest at BNL. The discussion begins with some definitions and background information on scientific notation and numerical prefixes used when measuring dose and radioactivity. The definitions of commonly used radiological terms are found in the Technical Topics section of the glossary, Appendix A, and are indicated in boldface type here only when the definition in the glossary provides additional details.

\section{RADIOACTIVITY AND RADIATION}

All substances are composed of atoms that are made of subatomic particles: protons, neutrons, and electrons. The protons and neutrons are tightly bound together in the positively charged nucleus (plural: nuclei) at the center of the atom. The nucleus is surrounded by a cloud of negatively charged electrons. Most nuclei are stable because the forces holding the protons and neutrons together are strong enough to overcome the electrical energy that tries to push them apart. When the number of neutrons in the nucleus exceeds a threshold, then the nucleus becomes unstable and will spontaneously "decay," or emit excess energy ("nuclear" energy) in the form of charged particles or electromagnetic waves. Radiation is the excess energy released by unstable atoms. Radioactivity and radioactive refer to the unstable nuclear property of a substance (e.g., radioactive uranium). When a charged particle or electromagnetic wave is detected by radiation-sensing equipment, this is referred to as a radiation event.

Radiation that has enough energy to remove electrons from atoms within material (a process called ionization) is classified as ionizing radiation. Radiation that does not have enough energy to remove electrons is called nonionizing radiation. Examples of nonionizing radiation include most visible light, infrared light, microwaves, and radio waves. All radiation, whether ionizing or not, may pose health risks. In the SER, radiation refers to ionizing radiation.

Radioactive elements (or radionuclides) are referred to by name followed by a number, such as cesium-137. The number indicates the mass of that element and the total number of neutrons and protons contained in the nucleus of the atom. Another way to specify cesium-137 is Cs-137, where Cs is the chemical symbol for cesium in the Periodic Table of the Elements. This type of abbreviation is used in the SER.

\section{SCIENTIFIC NOTATION}

Most numbers used for measurement and quantification in the SER are either very large or very small, and many zeroes would be required to express their value. To avoid this, scientific notation is used, with numbers represented in multiples of 10. For example, the number two million five hundred thousand (two and a half million, or 2,500,000) is written in scientific notation as $2.5 \times 10^{6}$, which represents " 2.5 multiplied by (10 raised to the power of 6)." Since even " $2.5 \times 10^{6 "}$ " can be cumbersome, the capital letter E is substituted for the phrase " 10 raised to the power of ...." Using this format, $2,500,000$ is represented as $2.5 \mathrm{E}+06$. The " +06 " refers to the number of places the decimal point was moved to the left to create the shorter version. Scientific notation is also used to represent numbers smaller than zero, in which case a 


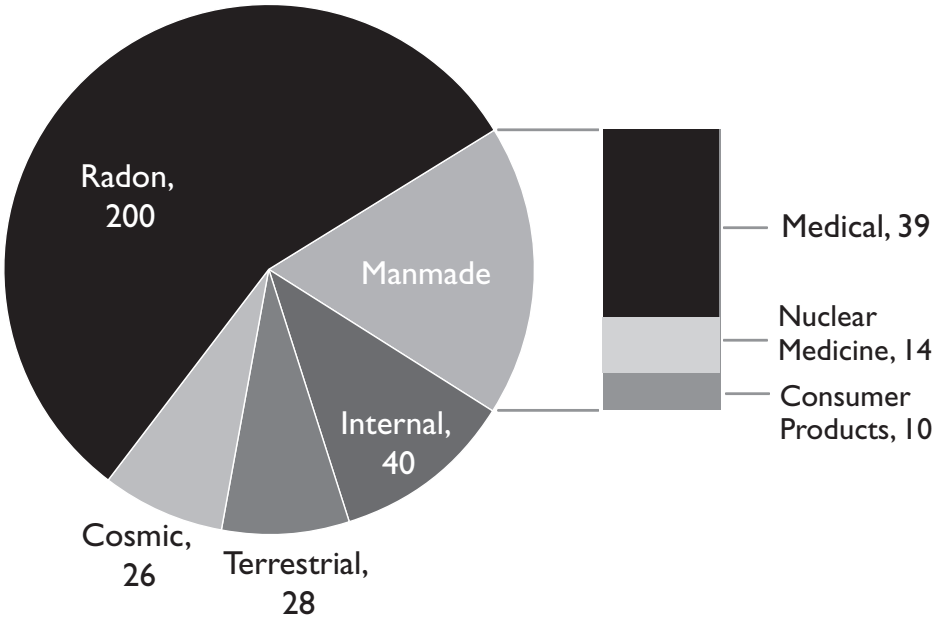

Figure B-I. Typical Annual Radiation Doses from Natural and Man-Made Sources (mrem). Source: NCRP Report No. 93 (NCRP 1987)

minus sign follows the E rather than a plus. For example, 0.00025 can be written as $2.5 \times 10^{-4}$ or $2.5 \mathrm{E}-04$. Here, "- 04 " indicates the number of places the decimal point was moved to the right.

\section{NUMERICAL PREFIXES}

Another method of representing very large or small numbers without using many zeroes is to use prefixes to represent multiples of ten. For example, the prefix milli (abbreviated $\mathrm{m}$ ) means that the value being represented is one-thousandth of a whole unit; $3 \mathrm{mg}$ (milligrams) is 3 thousandths of a gram or E-03. See Appendix $\mathrm{C}$ for additional common prefixes, including pico $(\mathrm{p})$, which means trillionth or E-12, giga $(\mathrm{G})$, which means billion or $\mathrm{E}+09$, and tera $(\mathrm{T})$, which means trillion, $\mathrm{E}+12$.

\section{SOURCES OF IONIZING RADIATION}

Radiation is energy that has both natural and manmade sources. Some radiation is essential to life, such as heat and light from the sun. Exposure to high-energy (ionizing) radiation has to be managed, as it can pose serious health risks at large doses. Living things are exposed to radiation from natural background sources: the atmosphere, soil, water, food, and even our own bodies. Humans are exposed to ionizing radiation from a variety of common sources, the most significant of which follow.

Background Radiation - Radiation that occurs naturally in the environment is also called background activity. Background radiation consists of cosmic radiation from outer space, radiation from radioactive elements in soil and rocks, and radiation from radon and its decay products in air. Some people use the term background when referring to all non-occupational sources commonly present. Other people use natural to refer only to cosmic and terrestrial sources, and background to refer to common man-made sources such as medical procedures, consumer products, and radioactivity present in the atmosphere from former nuclear testing. In the SER, the term natural background is used to refer to radiation from cosmic and terrestrial radiation.

Cosmic - Cosmic radiation primarily consists of charged particles that originate in space, beyond the earth's atmosphere. This includes ionizing radiation from the sun, and secondary radiation generated by the entry of charged particles into the earth's atmosphere at high speeds and energies. Radioactive elements such as hydrogen-3 (tritium), beryllium-7, carbon-14, and sodium-22 are produced in the atmosphere by cosmic radiation. Exposure to cosmic radiation increases with altitude, because at higher elevations the atmosphere and the earth's magnetic field provide less shielding. Therefore, people who live in the mountains are exposed to more cosmic radiation than people who live at sea level. The average dose from cosmic radiation to a person living in the United States is approximately 26 mrem per year. (For an explanation of dose, see effective dose equivalent in Appendix A. The units rem and sieverts also are explained in Appendix A.)

Terrestrial - Terrestrial radiation is released by radioactive elements that have been present in the soil since the formation of the earth. Common radioactive elements that contribute to terrestrial exposure include isotopes of potassium, thorium, actinium, and uranium. The average dose from terrestrial radiation to a person living in the United States is approximately 28 mrem per year, but may vary considerably depending on the local geology.

Internal - Internal exposure occurs when radionuclides are ingested, inhaled, or absorbed through the skin. Radioactive material may be incorporated into food through the uptake of terrestrial radionuclides by plant roots. People can 
ingest radionuclides when they eat contaminated plant matter or meat from animals that have consumed contaminated plants. The average dose from food for a person living in the United States is about 40 mrem per year. A larger exposure, for most people, comes from breathing the decay products of naturally occurring radon gas. The average dose from breathing air with radon byproducts is about 200 mrem per year, but that amount varies depending on geographical location. An EPA map shows that BNL is located in one of the regions with the lowest potential radon risk.

Medical - Every year in the United States, millions of people undergo medical procedures that use ionizing radiation. Such procedures include chest and dental x-rays, mammography, thallium heart stress tests, and tumor irradiation therapies. The average doses from nuclear medicine and $\mathrm{x}$-ray examination procedures are about 14 and 39 mrem per year, respectively. Anthropogenic - Sources of anthropogenic (man-made) radiation include consumer products such as static eliminators (containing polonium-210), smoke detectors (containing americium-241), cardiac pacemakers (containing plutonium-238), fertilizers (containing isotopes from uranium and thorium decay series), and tobacco products (containing polonium-210 and lead-210). The average dose from consumer products to a person living in the United States is 10 mrem per year (excluding tobacco contributions).

COMMON TYPES OF IONIZING RADIATION

The three most common types of ionizing radiation are described below.

Alpha Radiation - An alpha particle is identical in makeup to the nucleus of a helium atom, consisting of two neutrons and two protons. Alpha particles have a positive charge and have little or no penetrating power in matter. They are easily stopped by materials such as paper and have a range in air of only an inch or so. However, if alpha-emitting material is ingested, alpha particles can pose a health risk inside the body. Naturally occurring radioactive elements such as uranium emit alpha radiation.

Beta Radiation - Beta radiation is composed of particles that are identical to electrons. Therefore, beta particles have a negative charge. Beta radiation is slightly more penetrating than alpha radiation, but most beta radiation can be stopped by materials such as aluminum foil and plexiglass panels. Beta radiation has a range in air of several feet. Naturally occurring radioactive elements such as potassium-40 emit beta radiation. Some beta particles present a hazard to the skin and eyes.

Gamma Radiation - Gamma radiation is a form of electromagnetic radiation, like radio waves or visible light, but with a much shorter wavelength. Gamma rays are emitted from a radioactive nucleus along with alpha or beta particles. Gamma radiation is more penetrating than alpha or beta radiation, capable of passing through dense materials such as concrete. Gamma radiation is identical to $\mathrm{x}$-rays except that $\mathrm{x}$-rays are more energetic. Only a fraction of the total gamma rays a person is exposed to will interact with the human body.

\section{TYPES OF RADIOLOGICAL ANALYSES}

The amount of radioactive material in a sample of air, water, soil, or other material can be assessed using several analyses, the most common of which are described below.

Gross alpha - Alpha particles are emitted from radioactive material in a range of different energies. An analysis that measures all alpha particles simultaneously, without regard to their particular energy, is known as a gross alpha activity measurement. This type of measurement is valuable as a screening tool to indicate the total amount but not the type of alpha-emitting radionuclides that may be present in a sample.

Gross beta - This is the same concept as that for gross alpha analysis, except that it applies to the measurement of gross beta particle activity.

Tritium - Tritium radiation consists of low-energy beta particles. It is detected and quantified by liquid scintillation counting. More information on tritium is presented in the section Radionuclides of Environmental Interest, later in this appendix.

Strontium-90 - Due to the properties of the radiation emitted by strontium-90 (Sr-90), a special analysis is required. Samples are 
chemically processed to separate and collect any strontium atoms that may be present. The collected atoms are then analyzed separately. More information on Sr-90 is presented in the section Radionuclides of Environmental Interest.

Gamma - This analysis technique identifies specific radionuclides. It measures the particular energy of a radionuclide's gamma radiation emission. The energy of these emissions is unique for each radionuclide, acting as a "fingerprint" to identify it.

\section{STATISTICS}

Two important statistical aspects of measuring radioactivity are uncertainty in results, and negative values.

Uncertainty - Because the emission of radiation from an atom is a random process, a sample counted several times usually yields a slightly different result each time; therefore, a single measurement is not definitive. To account for this variability, the concept of uncertainty is applied to radiological data. In the SER, analysis results are presented in an $\mathrm{x} \pm \mathrm{y}$ format, where " $x$ " is the analysis result and " $\pm y$ " is the 95 percent "confidence interval" of that result. That means there is a 95 percent probability that the true value of $x$ lies between $(x+y)$ and $(\mathrm{x}-\mathrm{y})$.

Negative values - There is always a small amount of natural background radiation. The laboratory instruments used to measure radioactivity in samples are sensitive enough to measure the background radiation along with any contaminant radiation in the sample. To obtain a true measure of the contaminant level in a sample, the background radiation level must be subtracted from the total amount of radioactivity measured. Due to the randomness of radioactive emissions and the very low concentrations of some contaminants, it is possible to obtain a background measurement that is larger than the actual contaminant measurement. When the larger background measurement is subtracted from the smaller contaminant measurement, a negative result is generated. The negative results are reported, even though doing so may seem illogical, because they are essential when conducting statistical evaluations of data.
Radiation events occur randomly; if a radioactive sample is counted multiple times, a spread, or distribution, of results will be obtained. This spread, known as a Poisson distribution, is centered about a mean (average) value. Similarly, if background activity (the number of radiation events observed when no sample is present) is counted multiple times, it also will have a Poisson distribution. The goal of a radiological analysis is to determine whether a sample contains activity greater than the background reading detected by the instrument. Because the sample activity and the background activity readings are both Poisson distributed, subtraction of background activity from the measured sample activity may result in values that vary slightly from one analysis to the next. Therefore, the concept of a minimum detection limit (MDL) was established to determine the statistical likelihood that a sample's activity is greater than the background reading recorded by the instrument.

Identifying a sample as containing activity greater than background, when it actually does not have activity present, is known as a Type I error. Most laboratories set their acceptance of a Type I error at 5 percent when calculating the MDL for a given analysis. That is, for any value that is greater than or equal to the MDL, there is 95 percent confidence that it represents the detection of true activity. Values that are less than the MDL may be valid, but they have a reduced confidence associated with them. Therefore, all radiological data are reported, regardless of whether they are positive or negative

At very low sample activity levels that are close to the instrument's background reading, it is possible to obtain a sample result that is less than zero. This occurs when the background activity is subtracted from the sample activity to obtain a net value, and a negative value results. Due to this situation, a single radiation event observed during a counting period could have a significant effect on the mean (average) value result. Subsequent analysis may produce a sample result that is positive. When the annual data for the SER are compiled, results may be averaged; therefore, all negative values are retained for reporting as 
well. This data handling practice is consistent with the guidance provided in the Handbook of Radioactivity Measurements Procedures (NCRP 1985) and the Environmental Regulatory Guide for Radiological Effluent Monitoring and Environmental Surveillance (DOE 1991). Average values are calculated using actual analytical results, regardless of whether they are above or below the MDL, or even equal to zero. The uncertainty of the mean, or the 95 percent confidence interval, is determined by multiplying the population standard deviation of the mean by the $\mathrm{t}_{(0.05)}$ statistic.

\section{RADIONUCLIDES OF ENVIRONMENTAL INTEREST}

Several types of radionuclides are found in the environment at BNL due to historical operations.

Cesium-137-Cs-137 is a fission-produced radionuclide with a half-life of 30 years (after 30 years, only one half of the original activity level remains). It is found in the worldwide environment as a result of past aboveground nuclear weapons testing and can be observed in near-surface soils at very low concentrations, usually less than $1 \mathrm{pCi} / \mathrm{g}(0.004 \mathrm{~Bq} / \mathrm{g})$. Cs-137 is a beta-emitting radionuclide, but it can be detected by gamma spectroscopy because its decay product, barium-137m, emits gamma radiation.

Cs-137 is found in the environment at BNL mainly as a soil contaminant, from two main sources. The first source is the worldwide deposition from nuclear accidents and fallout from weapons testing programs. The second source is deposition from spills or releases from BNL operations. Nuclear reactor operations produce Cs-137 as a byproduct. In the past, wastewater containing small amounts of Cs-137 generated at the reactor facilities was routinely discharged to the Sewage Treatment Plant (STP), resulting in low-level contamination of the STP and the Peconic River. In 2002/2003, under the Environmental Restoration Program, sand and its debris containing low levels of Cs-137, Sr-90, and heavy metals were removed, assuring that future discharges from the STP are free of these contaminants. Soil contaminated with
Cs-137 is associated with the following areas that have been, or are being, addressed as part of the Environmental Remediation Program: former Hazardous Waste Management Facility, Waste Concentration Facility, Building 650 Reclamation Facility and Sump Outfall Area, and the Brookhaven Graphite Research Reactor (BGRR).

Strontium-90 - Sr-90 is a beta-emitting radionuclide with a half-life of 28 years. Sr-90 is found in the environment principally as a result of fallout from aboveground nuclear weapons testing. Sr-90 released by weapons testing in the 1950s and early 1960s is still present in the environment today. Additionally, nations that were not signatories of the Nuclear Test Ban Treaty of 1963 have contributed to the global inventory of fission products (Sr-90 and Cs-137). This radionuclide was also released as a result of the 1986 Chernobyl accident in the former Soviet Union.

Sr-90 is present at BNL in the soil and groundwater. As in the case of Cs-137, some Sr-90 at BNL results from worldwide nuclear testing; the remaining contamination is a byproduct of reactor operations. The following areas with Sr-90 contamination have been or are being addressed as part of the Environmental Remediation Program: former Hazardous Waste Management Facility, Waste Concentration Facility, Building 650 Reclamation Facility and Sump Outfall Area, the BGRR, Former and Interim Landfills, Chemical and Glass Holes Area, and the STP.

The information in SER tables is arranged by method of analysis. Because $\mathrm{Sr}-90$ requires a unique method of analysis, it is reported as a separate entry. Methods for detecting Sr-90 using state-of-the-art equipment are quite sensitive (detecting concentrations less than $1 \mathrm{pCi} / \mathrm{L}$ ), which makes it possible to detect background levels of Sr-90.

Tritium - Among the radioactive materials that are used or produced at BNL, tritium has received the most public attention. Approximately 4 million $\mathrm{Ci}(1.5 \mathrm{E}+5 \mathrm{TBq})$ per year are produced in the atmosphere naturally (NCRP 1979). As a result aboveground weapons testing in the 1950s and early 1960s in the United 
States, the global atmospheric tritium inventory was increased by a factor of about 200 . Other human activities such as consumer product manufacturing and nuclear power reactor operations have also released tritium into the environment. Commercially, tritium is used in products such as self-illuminating wristwatches and exit signs (the signs may each contain as much as $25 \mathrm{Ci}$ [925 GBq] of tritium). Tritium also has many uses in medical and biological research as a labeling agent in chemical compounds, and is frequently used in universities and other research settings such as BNL and the other national laboratories.

Of the sources mentioned above, the most significant contributor to tritium in the environment has been aboveground nuclear weapons testing. In the early 1960 s, the average tritium concentration in surface streams in the United States reached a value of 4,000 pCi/L (148 Bq/ L; NCRP 1979). Approximately the same concentration was measured in precipitation. Today, the level of tritium in surface waters in New York State is less than one-twentieth of that amount, below $200 \mathrm{pCi} / \mathrm{L}$ (7.4 Bq/L; NYSDOH 1993). This is less than the detection limit of most analytical laboratories.

Tritium has a half-life of 12.3 years. When an atom of tritium decays, it releases a beta particle, causing transformation of the tritium atom into stable (nonradioactive) helium. The beta radiation that tritium releases has a very low energy, compared to the emissions of most other radioactive elements. In humans, the outer layer of dead skin cells easily stops the beta radiation from tritium; therefore, only when tritium is taken into the body can it cause an exposure. Tritium may be taken into the body by inhalation, ingestion, or absorption of tritiated water through the skin. Because of its low energy radiation and short residence time in the body, the health threat posed by tritium is very small for most exposures.

Environmental tritium is found in two forms: gaseous elemental tritium, and tritiated water or water vapor, in which at least one of the hydrogen atoms in the $\mathrm{H}_{2} \mathrm{O}$ water molecule has been replaced by a tritium atom (hence, its shorthand notation, HTO). Most of the tritium released from BNL sources is in the form of HTO, none as elemental tritium. Sources of tritium at BNL include the reactor facilities (all now non-operational), where residual water (either heavy or light) is converted to tritium via neutron bombardment; the accelerator facilities, where tritium is produced by secondary radiation interactions with soil and water; and facilities like the Brookhaven Linac Isotope Producer (BLIP), where tritium is formed from secondary radiation interaction with cooling water. Tritium has been found in the environment at BNL as a groundwater contaminant from operations in the following areas: Current Landfill, BLIP, Alternating Gradient Synchrotron, and the High Flux Beam Reactor. Although small quantities of tritium are still being released to the environment through BNL emissions and effluents, the concentrations and total quantity have been drastically reduced, compared with historical operational releases as discussed in Chapters 4 and 5.

\section{REFERENCES AND BIBLIOGRAPHY}

DOE Order 5400.5. 1993. Radiation Protection of the Public and the Environment. U.S. Department of Energy, Washington, DC. Change 2: 1-7-93.

DOE. 1991. Environmental Regulatory Guide for Radiological Effluent Monitoring and Environmental Surveillance. DOE/EH0173T. U.S. Department of Energy, Washington, DC.

NCRP. 1979. Tritium in the Environment. NCRP Report No. 62. National Council on Radiation Protection and Measurements. Bethesda, MD.

NCRP. 1985. Handbook of Radioactivity Measurements Procedures, NCRP Report No. 58. National Council on Radiation Protection and Measurements, Bethesda, MD.

NCRP. 1987. Ionizing Radiation Exposure of the Population of the United States. NCRP Report No. 93. National Council on Radiation Protection and Measurements. Bethesda, MD.

NYSDOH. 1996. Radioactive Contamination in the Peconic River. Bureau of Environmental Radiation Protection, New York State Department of Health, Albany, NY.

NYSDOH. 1993. Environmental Radiation in New York State. Bureau of Environmental Radiation Protection, New York State Department of Health, Albany, NY.

Radiochemistry Society Online. www.radiochemistry.org/ nomenclature/index/html, accessed 3-25-04. 
APPENDIX C

\section{Units of Measure and Half-Life Periods}

UNITS OF RADIATION MEASUREMENT AND CONVERSIONS

\begin{tabular}{|l|c|c|}
\hline U.S. System & International System & Conversion \\
\hline curie $(\mathrm{Ci})$ & becquerel $(\mathrm{Bq})$ & $\mathrm{I} \mathrm{Ci}=3.7 \times 10^{10} \mathrm{~Bq}$ \\
\hline $\mathrm{rad}$ & gray $(\mathrm{Gy})$ & $\mathrm{I}$ rad $=0.0 \mathrm{I} \mathrm{Gy}$ \\
\hline $\mathrm{rem}$ & sievert $(\mathrm{Sv})$ & $\mathrm{I} \mathrm{rem}=0.0 \mathrm{I} \mathrm{Sv}$ \\
\hline
\end{tabular}

APPROXIMATE METRIC CONVERSIONS

\begin{tabular}{|c|c|c|c|c|c|}
\hline When you know & multiply by & to obtain & When you know & multiply by & to obtain \\
\hline centimeters $(\mathrm{cm})$ & 0.39 & inches (in.) & in. & 2.54 & $\mathrm{~cm}$ \\
\hline meters $(\mathrm{m})$ & 3.28 & feet $(\mathrm{ft})$ & $\mathrm{ft}$ & 0.305 & $\mathrm{~m}$ \\
\hline kilometers (km) & 0.62 & miles (mi) & $\mathrm{mi}$ & 1.61 & $\mathrm{~km}$ \\
\hline kilograms (kg) & 2.20 & pounds (lb) & $\mathrm{lb}$ & 0.45 & $\mathrm{~kg}$ \\
\hline liters (L) & 0.264 & gallons (gal) & gal & 3.785 & $\mathrm{~L}$ \\
\hline cubic meters $\left(\mathrm{m}^{3}\right)$ & 35.32 & cubic feet $\left(\mathrm{ft}^{3}\right)$ & $\mathrm{ft}^{3}$ & 0.03 & $\mathrm{~m}^{3}$ \\
\hline hectares (ha) & 2.47 & acres & acres & 0.40 & ha \\
\hline square kilometers $\left(\mathrm{km}^{2}\right)$ & 0.39 & square miles $\left(\mathrm{mi}^{2}\right)$ & $\mathrm{mi}^{2}$ & 2.59 & $\mathrm{~km}^{2}$ \\
\hline degrees Celcius $\left({ }^{\circ} \mathrm{C}\right)$ & $1.8\left({ }^{\circ} \mathrm{C}\right)+32$ & degrees Fahrenheit $\left({ }^{\circ} \mathrm{F}\right)$ & ${ }^{\circ} \mathrm{F}$ & $\left({ }^{\circ} \mathrm{F}-32\right) / 1.8$ & ${ }^{\circ} \mathrm{C}$ \\
\hline
\end{tabular}

\section{SCIENTIFIC NOTATION USED FOR MEASUREMENTS}

\begin{tabular}{|c|c|c|c|c|}
\hline Multiple & Decimal Equivalent & Notation & Prefix & Symbol \\
\hline $1 \times 10^{12}$ & $\mathrm{I}, 000,000,000,000$ & $E+12$ & Tera- & $\mathrm{T}$ \\
\hline $1 \times 10^{9}$ & $1,000,000,000$ & $E+9$ & giga- & G \\
\hline $1 \times 10^{3}$ & 1,000 & $E+03$ & kilo- & k \\
\hline $1 \times 10^{-2}$ & 0.01 & $\mathrm{E}-02$ & centi- & c \\
\hline $1 \times 10^{-3}$ & 0.001 & $\mathrm{E}-03$ & milli- & $\mathrm{m}$ \\
\hline $1 \times 10^{-6}$ & 0.000001 & E-06 & micro- & $\mu$ \\
\hline $1 \times 10^{-9}$ & 0.000000001 & E-09 & nano- & $\mathrm{n}$ \\
\hline $1 \times 10^{-12}$ & 0.000000000001 & $\mathrm{E}-12$ & pico- & $P$ \\
\hline
\end{tabular}

\section{CONCENTRATION CONVERSIONS}

\begin{tabular}{|l}
$\mathrm{I} \mathrm{ppm}=1,000 \mathrm{ppb}$ \\
$\mathrm{I} \mathrm{ppb}=0.001 \mathrm{ppm}=1 \mathrm{\mu g} / \mathrm{L}^{*}$ \\
$\mathrm{I} \mathrm{ppm}=1 \mathrm{mg} / \mathrm{L}=1000 \mu \mathrm{g} / \mathrm{L}^{*}$
\end{tabular}

* For aqueous fractions only. 


\begin{tabular}{|l|c|}
\hline & HALF-LIFE PERIODS \\
\hline Am-24I & $432.7 \mathrm{yrs}$ \\
\hline C-1I & $\sim 20 \mathrm{~min}$ \\
\hline Co-60 & $5.3 \mathrm{yrs}$ \\
\hline Cs-137 & $30.2 \mathrm{yrs}$ \\
\hline $\mathrm{N}-13$ & $\sim 10 \mathrm{~min}$ \\
\hline $\mathrm{N}-22$ & $2.6 \mathrm{yrs}$ \\
\hline O-15 & $\sim 2 \mathrm{~min}$ \\
\hline PU-238 & $87.7 \mathrm{yrs}$ \\
\hline Pu-239 & $24,100.0 \mathrm{yrs}$ \\
\hline Pu-240 & $6,560.0 \mathrm{yrs}$ \\
\hline Sr-90 & $29.1 \mathrm{yrs}$ \\
\hline tritium & $12.3 \mathrm{yrs}$ \\
\hline U-234 & $247,000.0 \mathrm{yrs}$ \\
\hline U-235 & $\sim 700$ million yrs \\
& $(7.0004 \mathrm{EE} 8)$ \\
\hline U-238 & $87.7 \mathrm{yrs}$ \\
\hline
\end{tabular}


APPENDIX D

\section{Federal, State, and Local Laws and Regulations Pertinent to BNL}

\section{DOE DIRECTIVES, REGULATIONS, AND STANDARDS}

DOE O 231.1-A Order: Environment, Safety and Health Reporting 08/19/03

DOE O 414.1 Order: Management Assessment and Independent Assessor's Guide 05/31/2001

DOE O 435.1 Order, Change 1: Radioactive Waste Management 08/28/2001

DOE O 450.1 Order: Environmental Protection Program 01/15/2003

DOE P 450.5 Policy: Line Environment, Safety, and Health Oversight 06/26/1997

DOE O 5400.5 Order: Change 2, Radiological Protection of the Public and the Environment 01/07/1993

\section{FEDERAL LAWS AND REGULATIONS}

Executive Order

$13148 \quad$ Greening of the Government Through Leadership in Environmental Management

10 CFR $1021 \quad$ National Environmental Protection Act, Implementing and Procedures

10 CFR 1022 Compliance with Floodplain/Wetlands Environmental Review Requirements

10 CFR 830 Subpart A: Quality Assurance Requirements

10 CFR $834 \quad$ Radiation Protection of the Public and the Environment

16 USC $470 \quad$ National Historic Preservation Act

36 CFR $60 \quad$ National Register of Historic Places

36 CFR 63 Determination of Eligibility for Inclusion in the National Register of Historic Places

36 CFR 79 Curation of Federally Owned and Administered Archaeological Collections

36 CFR $800 \quad$ Protection of Historic Properties

40 CFR 50-0 National Primary and Secondary Ambient Air Quality Standards

40 CFR $82 \quad$ Protection of Stratospheric Ozone

40 CFR 109 Criteria for State, Local and Regional Oil Removal Contingency Plans

40 CFR $110 \quad$ Discharge of Oil

40 CFR 112 Oil Pollution Prevention Act

40 CFR $113 \quad$ Liability Limits for Small Onshore Storage Facilities

40 CFR 116 Designation of Hazardous Substances

40 CFR 117 Determination of Reportable Quantities for Hazardous Substances

40 CFR 121 State Certification of Activities Requiring a Federal License or Permit 
APPENDIX D: FEDERAL, STATE, AND LOCAL LAWS

AND REGULATIONS PERTINENT TO BNL

40 CFR $122 \quad$ National Pollution Discharge Elimination System (NPDES)

40 CFR $123 \quad$ State Program Requirements

40 CFR $124 \quad$ Procedures for Decision-making

40 CFR 125 Criteria and Standards for the National Pollutant Discharge Elimination System

40 CFR 129 Toxic Pollutant Effluent Standards

40 CFR $130 \quad$ Water Quality Planning and Management

40 CFR $131 \quad$ Water Quality Standards

40 CFR $132 \quad$ Water Quality Guidance for the Great Lakes System

40 CFR 133 Secondary Treatment Regulation

40 CFR 135 Prior Notice of Citizen Suits

40 CFR $136 \quad$ Guidelines Establishing Test Procedures for the Analysis of Pollutants

40 CFR $141 \quad$ National Primary Drinking Water Regulations

40 CFR $142 \quad$ National Primary Drinking Water Regulations Implementation

40 CFR $143 \quad$ National Secondary Drinking Water Regulations

40 CFR $144 \quad$ Underground Injection Control (UIC) Program

40 CFR $146 \quad$ Underground Injection Control (UIC) Program: Criteria and Standards

40 CFR $148 \quad$ Hazardous Waste Injection Restrictions

40 CFR 149 Sole Source Aquifers

40 CFR 167 Submissions of Pesticide Reports

40 CFR $168 \quad$ Statements of Enforcement Policies and Interpretations

40 CFR 169 Books and Records of Pesticide Production and Distribution

40 CFR $170 \quad$ Worker Protection Standard

40 CFR $171 \quad$ Certification of Pesticide Applicators

40 CFR 260 Hazardous Waste Management Systems: General

40 CFR 261 Identification and Listing of Hazardous Waste

40 CFR 262 Standards Applicable to Generators of Hazardous Waste

40 CFR 263 Standards Applicable to Transporters of Hazardous Waste

40 CFR 264 Standards for Owners and Operators of Hazardous Waste Treatment, Storage, and Disposal Facilities

40 CFR 265 Interim Status Standards for Owners and Operators of Hazardous Waste Treatment, Storage, and Disposal Facilities

40 CFR 266 Standards for the Management of Special Hazardous Wastes and Specific Types of Hazardous Waste Management Facilities

40 CFR $268 \quad$ Land Disposal Restrictions 
40 CFR 270

40 CFR 271

40 CFR 272

40 CFR 273

40 CFR 279

40 CFR 280

40 CFR 300

40 CFR 302

40 CFR 355

40 CFR 370

40 CFR 372

40 CFR 700

40 CFR 702

40 CFR 704

40 CFR 707

40 CFR 710

40 CFR 712

40 CFR 716

40 CFR 717

40 CFR 720

40 CFR 721

40 CFR 723

40 CFR 725

40 CFR 745

40 CFR 747

40 CFR 749

40 CFR 750

40 CFR 761

40 CFR 763

40 CFR 1500

40 CFR 1501
EPA Administered Permit Program: The Hazardous Waste Permit Program

Requirements for Authorization of State Hazardous Waste Mgmt Programs

Approved State Hazardous Waste Management Programs

Standards for Universal Waste Management

Standards for the Management of Used Oil

Technical Standards and Corrective Action Requirements for Owners and Operators of Underground Storage Tanks (USTs)

National Oil and Hazardous Substances Pollution Contingency Plan

Designation, Reportable Quantities, and Notification

Emergency Planning and Notification

Hazardous Chemical Report: Community Right-to-Know

Toxic Chemical Release Report: Community Right-to-Know

Toxic Substances Control Act [TSCA]

Toxic Substances Control Act: General Practices and Procedures

Toxic Substances Control Act: Reporting and Recordkeeping Requirements

Chemical Imports and Exports

Inventory Reporting Regulations

Chemical Information Rules

Health and Safety Data Reporting

Records and Reports of Allegations that Chemical Substances Cause Significant Adverse Reactions to Health or the Environment

Premanufacture Notification

Significant New Users of Chemical Substances

Premanufacture Notification Exemptions

Reporting Requirements and Review Processes for Microorganisms

Lead-Based Paint Poisoning Prevention in Certain Residential Structures

Metalworking Fluids

Water Treatment Chemicals

Procedures for Rulemaking Under Section 6 of TSCA

PCBs Manufacturing, Processing, Distribution in Commerce, and Use Prohibitions

Asbestos

Council on Environmental Quality: Purpose, Policy, and Mandate

NEPA and Agency Planning 


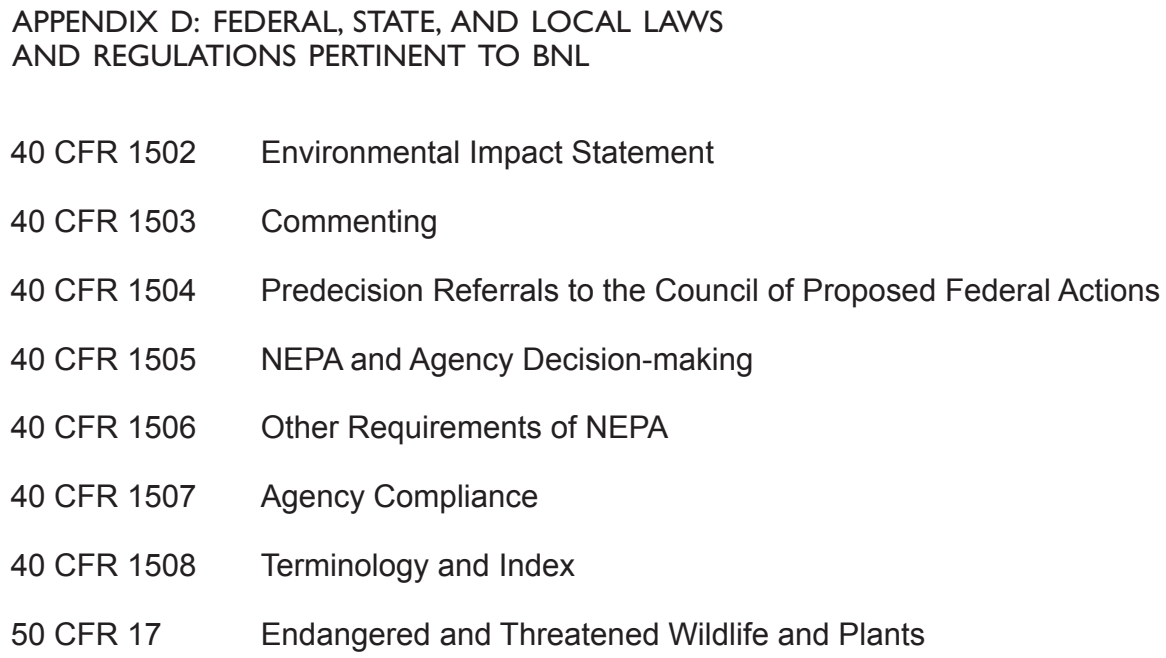

6 NYCRR 182 Endangered and Threatened Species of Fish and Wildlife, Species of Special Concern

6 NYCRR 200 Environmental Conservation Law

6 NYCRR 201 Subpart 201-1: General Provisions

6 NYCRR 202 Subpart 202: Emissions Verification

6 NYCRR 203 Indirect Sources of Air Contamination

6 NYCRR $204 \quad$ NO Budget Training Program

6 NYCRR 205 Architectural and Maintenance (AIM) Coatings

6 NYCRR 207 Control Measures for an Air Pollution Episide

6 NYCRR 208 Landfill Gas Collection and Control System for Certain Municipal Solid Waste Landfills

6 NYCRR 211 General Prohibitions

6 NYCRR 212 General Process Emission Sources

6 NYCRR 215 Open Fires

6 NYCRR 217 Environmental Conservation Rules and Regulations [Exhaust and Emission Standards]

6 NYCRR 218 Subpart 218-1 [More on Vehicle Exhaust]

6 NYCRR 221 Asbestos-Containing Surface Coating Material

6 NYCRR 225 Subpart 225-1: Fuel Composition and Use - Sulfur Limitations

6 NYCRR 227 Solvent Metal Cleaning Processes

6 NYCRR 228 Surface Coating Processes

6 NYCRR 229 Petroleum and Volatile Organic Liquid Storage and Transfer

6 NYCRR 230 Gasoline Dispensing Sites and Transport Vehicles

6 NYCRR 231 New Source Review in Nonattainment Areas and Ozone Transport Regions

6 NYCRR 234 Graphic Arts

6 NYCRR 237 Acid Deposition Reduction NO Budget Training Program 
6 NYCRR 238 Acid Deposition Reduction $\mathrm{SO}_{2}$ Budget Training Program

6 NYCRR 239 Portable Fuel Container Spillage Control

6 NYCRR 240 Conformity to State or Federal Implementation Plans

6 NYCRR 250 Miscellaneous Orders

6 NYCRR 256 Air Quality Classification System

6 NYCRR 257 Air Quality Standards

6 NYCRR 307 [Air Quality in] Suffolk County

6 NYCRR 320 Pesticides - General

6 NYCRR 325 Application of Pesticides

6 NYCRR 326 Registration and Certification of Pesticides

6 NYCRR 327 Use of Chemicals for the Control or Elimination of Aquatic Vegetation

6 NYCRR 328 Use of Chemicals for the Extermination of Undesirable Fish

6 NYCRR 329 Use of Chemicals for the Control or Elimination of Aquatic Insects

6 NYCRR 360-1 General Provisions: Solid Waste Management Facilities

6 NYCRR 361 Siting of Industrial Hazardous Waste Facilities

6 NYCRR 364 Waste Transporter Permits

6 NYCRR 370 Hazardous Waste Management Regulations

6 NYCRR 371 Identification and Listing of Hazardous Waste

6 NYCRR 372 Hazardous Waste Manifest System and Related Standards for Generators, Transporters and Facilities

6 NYCRR 373 Hazardous Waste Management Facilities

6 NYCRR 374 Standards for the Management of Specific Hazardous Wastes

6 NYCRR 376 Land Disposal Restrictions

6 NYCRR 595 Release of Hazardous Substances

6 NYCRR 596 Hazardous Substance Bulk Storage Regulations

6 NYCRR 597 List of Hazardous Substances

6 NYCRR 611 Environmental Priorities and Procedures in Petroleum Cleanup and Removal

6 NYCRR 612 Registration of Petroleum Storage Facilities

6 NYCRR 613 Handling and Storage of Petroleum

6 NYCRR 663 Freshwater Wetlands Permit Requirements

6 NYCRR 666 Regulation for Administration and Management of the Wild, Scenic, and Recreational Rivers System in New York State Excepting Private Land in the Adirondack Park

6 NYCRR 700 Part 700 Water Quality Regulations 
APPENDIX D: FEDERAL, STATE, AND LOCAL LAWS

AND REGULATIONS PERTINENT TO BNL

6 NYCRR 701 Classification - Surface Waters and Groundwaters

6 NYCRR 702 Derivation and Use of Standards and Guidance Values

6 NYCRR 703 Surface Water and Groundwater Quality Standards and Groundwater Effluent Limitations

6 NYCRR 750 Obtaining a SPDES Permit

10 NYCRR 5 State Sanitary Code - Part 5

SUFFOLK COUNTY RULES, REGULATIONS, AND STANDARDS

SCSC Art. 12 Toxic and Hazardous Material Storage, Handling and Control 


\section{Site Environmental Report Reader Response Form}

The 2006 Site Environmental Report (SER) was written to inform outside regulators, the public, and BNL employees of the Laboratory's environmental performance for the calendar year. The report summarizes BNL's on-site environmental data; environmental management performance; compliance with applicable regulations; and environmental, restoration, and surveillance monitoring programs.

BNL welcomes your comments, suggestions for improvements, or any questions you may have. Please fill in the information below, and mail your response form to:

Brookhaven National Laboratory

Environmental and Waste Management Services Division

Attention: SER Project Coordinator

Building 120

P.O. Box 5000

Upton, NY 11973-5000

Name

Address

Phone

Email

Comments, Suggestions, or Questions

I would like to be added to your Environmental Issues mailing list. 


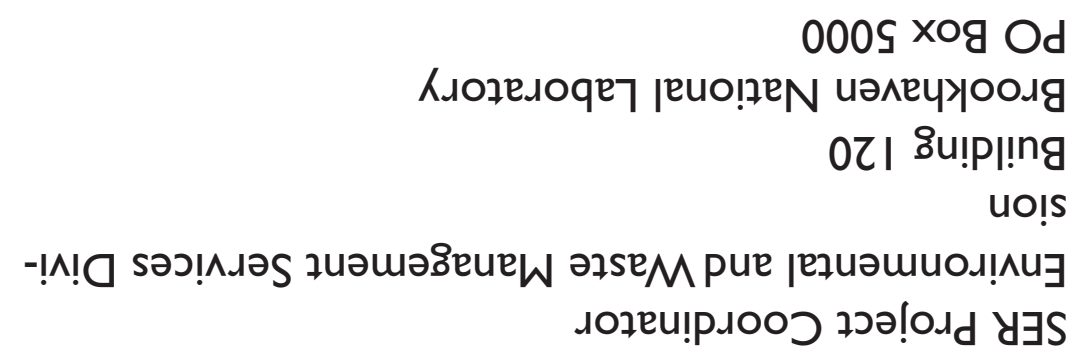

